\title{
Modelling executive powers in the Indonesian constitution
}

Citation for published version (APA):

Ristawati, R. (2017). Modelling executive powers in the Indonesian constitution: a comparative study of constitutions. [Doctoral Thesis, Maastricht University]. Maastricht University. https://doi.org/10.26481/dis.20171208rr

Document status and date:

Published: 01/01/2017

DOI:

10.26481/dis.20171208rr

Document Version:

Publisher's PDF, also known as Version of record

\section{Please check the document version of this publication:}

- A submitted manuscript is the version of the article upon submission and before peer-review. There can be important differences between the submitted version and the official published version of record.

People interested in the research are advised to contact the author for the final version of the publication, or visit the DOI to the publisher's website.

- The final author version and the galley proof are versions of the publication after peer review.

- The final published version features the final layout of the paper including the volume, issue and page numbers.

Link to publication

\footnotetext{
General rights rights.

- You may freely distribute the URL identifying the publication in the public portal. please follow below link for the End User Agreement:

www.umlib.nl/taverne-license

Take down policy

If you believe that this document breaches copyright please contact us at:

repository@maastrichtuniversity.nl

providing details and we will investigate your claim.
}

Copyright and moral rights for the publications made accessible in the public portal are retained by the authors and/or other copyright owners and it is a condition of accessing publications that users recognise and abide by the legal requirements associated with these

- Users may download and print one copy of any publication from the public portal for the purpose of private study or research.

- You may not further distribute the material or use it for any profit-making activity or commercial gain

If the publication is distributed under the terms of Article $25 \mathrm{fa}$ of the Dutch Copyright Act, indicated by the "Taverne" license above, 
Rosa Ristawati: Modelling Executive Powers in the Indonesian Constitution: A comparative Study

Modelling Executive Powers in the Indonesian Constitution A Comparative Study of Constitutions

\section{DISSERTATION}

to obtain the degree of Doctor at the Maastricht University, on the authority of the Rector Magnificus, Prof dr. Rianne M. Letschert on accordance with the decision of the Board of Deans, to be defended in public

on Friday, 8 December, 2017, at 12.00

by

Rosa Ristawati 
Rosa Ristawati: Modelling Executive Powers in the Indonesian Constitution: A comparative Study

Supervisor:

Prof.dr. A.W. Heringa

Co Supervisor:

Dr. Sascha Hardt

Assessment Committee:

Prof. mr. G.R. de Groot (Chair)

Dr. Fokke Fernhout

Prof. dr. Saldi Isra, S.H., MPA., University of Andalas, Indonesia

Prof. dr. Yuliandri, S.H., M.H., University of Andalas, Indonesia

Maastricht University 2017

Under project

Directorate of Higher Education, Ministry of Education, Indonesia, 2011 - 2014 
Rosa Ristawati: Modelling Executive Powers in the Indonesian Constitution: A comparative Study

\section{Table of Content}

\section{Table of Content}

Acknowledgements

List of glossary

List of tables

List of figures

\section{Chapter 1: Introduction}

1. Background of Study $\quad 1$

2. Concept and scopes $\quad 3$

3. Research questions $\quad 4$

4. Scientific relevance $\quad 4$

5. Methods and approach $\quad 5$

$\begin{array}{lr}\text { 6. The structure of book } & 6\end{array}$

\section{Chapter 2: Executive Power in a Theoretical and Comparative Reflection}

2.1. The Executive in the Constitutional System of Government 7

1. The term and nature of the executive branch

2. The Executive and its power in a democratic regime of parliamentary, presidency, and hybrid system

a. Executive power in a presidency

b. Executive power in a premiership

c. Executive power in a hybrid system

The concept of a Hybrid system of government: a combination and deviance 17

3. Executive power: scopes, sources, features and limits 19

$\begin{array}{lr}\text { a. The sources and categories of the power } & 19\end{array}$

b. The limits of executive power $\quad 23$

c. Other mechanisms to constrain executive power $\quad 24$

4. Executive powers: a-z $\quad 25$

$\begin{array}{lr}\text { a. Law making powers } & 26\end{array}$

b. Appointment powers $\quad 27$

c. Administrative powers: internal state administration affairs, budget and spending, and other affairs of $\begin{array}{lr}\text { state government } & 28\end{array}$

d. Emergency powers $\quad 29$

e. Military powers $\quad 31$

f. Foreign affairs power $\quad 32$

g. War powers $\quad 33$

h. Pardoning powers $\quad 35$

2.2. Executive power in a comparative study: Different Models of constitution of government system and Experiences 
Rosa Ristawati: Modelling Executive Powers in the Indonesian Constitution: A comparative Study

a. a comparison of constitutional modelsin different government systems

b. Executive power: reflections on countries with a parliamentary system (a fusion of power: executive and legislative)

1. Germany

- The Federal Government and executive powers: the Federal Chancellor and the federal ministers

2. South Africa

- The National Executive 44

c. Executive powers - experiences from presidential constitution countries (presidential system: a separation of power between the executive and the legislative)

1. US

2. The Philippines

d. Executive power in the hybrid system of government

1. France: Executive power under the Fifth Republic Constitution $\quad 74$

The President of the Republic under the Constitution of the Fifth Republic 75

Prime Minister and the Government $\quad 79$

2. Poland $\quad 81$

$\begin{array}{ll}\text { The Polish President } & 81\end{array}$

The Council of Ministers, the Prime Minister, and Government

Administration

\subsection{Closing Remarks}

Chapter 3: The Development of Executive Power in Indonesian Constitutional History

\subsection{Introduction: sequences of Constitution regimes in Indonesia}

3.2. Executive power in the Indonesian constitution (from the post-Dutch colonial period to Indonesian independence)

- The annotations to the constitutional provisions on executive power

3.3. Indonesian executive power in the Constitution of the Republic of Indonesia Federalism (the KRIS "Konstitusi Republik Indonesia Serikat"): a short experience of executive power in Indonesian parliamentary system

$\begin{array}{ll}\text { The executive under the KRIS Constitution } & 101\end{array}$

- Presidential duties and power $r$

- Government power $r$

- $\quad$ The DPR and the Senate check against government power 106

- Executive immunity $\quad 106$

3.4. Indonesian executive power under the Temporary Constitution of the Republic of Indonesia (the "UUDS 1950") 
Rosa Ristawati: Modelling Executive Powers in the Indonesian Constitution: A comparative Study

3.5. The Indonesian Constitution under the UUD 1945 (the period of reinstatement of the UUD 1945 after the temporary Constitution of 1950)

a. Executive power under the UUD 1945: the Soekarno administration $(1959$ - 1968)

b. Executive power under UUD 1945: the Soeharto administration $(1968$ - 1998)

c. Executive power under the UUD 1945 (the Habibieadministration) (1998 - 1999)

d. Abdulrahman Wahid administration (1999 - 2001)

3.6. Executive power under the $1^{\text {st }}, 2^{\text {nd }}$ and $3^{\text {rd }}$ Amendments of the UUD 1945 Executive power under the UUD 1945: Megawati administration (2001 - 2004)

3.7. The democratic era of executive powers under the Amended Constitution: the President SBY administration (the 1st, $2004-2009$ and the 2nd term office, 2009 2014)

3.8. Closing remarks

4.1. The Amendment of the constitution: a spirit of constraining presidential power in a constitutional framework

a. The law-making powers

1. The President in the Legislative process

2. The power to make the Emergency Law

3. The Power to issue Government Directive (Peraturan Pemerintah) 155

4. The Power to issue Presidential Regulation(Peraturan Presiden) 156

5. The power to issue Presidential Decree(Keputusan Presiden) 158

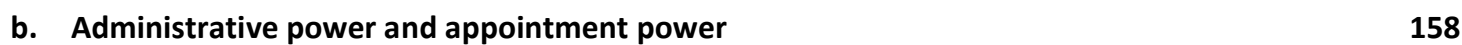

1. Forming and reshuffling the cabinet: the Constitutionality of the state Ministerial Department

2. The Presidential cabinet formation: establishment, nomination, selection, and appointment

3. Changing and Reshuffling the Cabinet

4. Cabinet Dissolution $\quad 167$

5. Presidential Cabinet, coalition, and Checks against the appointment power of the cabinet 167

6. The President, the Ministers, and policy making $\quad 169$

7. President's authority to issue other administrative regulations $\quad 171$

8. The Establishment of the President's Advisory Council, President's office, independent agencies/ commission, and state agencies in supporting the role and duties of the President as the head of government and state administration 
Rosa Ristawati: Modelling Executive Powers in the Indonesian Constitution: A comparative Study

9. The Presidential Office and other state agencies 172

10. The state intelligence agency 174

11. Appointment power: the judges, the chief of constitutional agency and the executive officers (the chief police, the chief of Military, the chief of supreme public prosecutor, and other chiefs of executive officers)

12. Local government autonomous government supervision

c. State budgetary and spending Power

- Constitutionality of the state budgeting and spending power

d. Foreign affairs power

1. War and peace power

2. Treaty power

The nature of the Treaty making power: constitutional perspective

Treaties, the DPR's approval, and the process of transforming into the domestic legal framework

3. Diplomacy powers

Emergency power

199

$\begin{array}{lr}\text { f. Military power } & 208\end{array}$

\begin{tabular}{ll} 
- & The Presidential Duties to protect \\
\hline
\end{tabular}

- The Presidential Military Power: the TNI's roles in supporting the state Government

g. The Presidential pardoning power

- The pardoning power in the Constitution: judiciary power for the President? 212

4.3. Checks and balances over the executive powers of the President

a. Who and how checks and/ or constrains presidential power

1. MPR

2. The DPR

3. The DPD

4. The Constitutional Court and the Supreme Court

b. Checks and balances of the Presidential power: constraint, limitation, control of government? 223

- The Legislative checks and balances power constraints to the Presidential treaty power 223

The Judiciary and the treaty making power 225

- $\quad$ Are treaties subject to Judicial Review? $\quad 225$

- $\quad$ The DPR's Consideration for diplomatic powers $\quad 227$

- $\quad$ Checks and balances against the President's administration: Legislative Scrutiny (Oversight) 229

- The Legislature and the Presidential Law Making Power 230

- The Court and the Presidential Law Making Power 231

- Legislative check on the Presidential pardoning power 232

- Judicial check against the Presidential pardoning power 233

- The legislative check on Presidential Military Power: the DPR function in constraining the President's military power

Legislative, the budgeting and spending power

- Judicial review of the state budget and spending power 
Rosa Ristawati: Modelling Executive Powers in the Indonesian Constitution: A comparative Study

4.5. The 2014 Presidential Election

4.6. Insights into President Jokowi's administration: brief remarks on the Executive powers during one year of President Jokowi

4.7. The Assessment of thelndonesian Executive Powers under the Amended Constitution

1. Problems in presidential power as a result of the Amendment 256

a. Law- making powers 256

$\begin{array}{lr}\text { b. Foreign affairs powers } & 259\end{array}$

$\begin{array}{lr}\text { c. Emergency powers } & 261\end{array}$

d. Pardoning, accessories, and administrative powers $\quad 262$

2. Electoral bargaining and the Indonesia Presidential election $\quad 264$

3. Presidential immunity $\quad 268$

$\begin{array}{ll}\text { The Constitution and Presidential Immunity } & 271\end{array}$

\section{\begin{tabular}{ll} 
4.8. & Closing remarks \\
\hline
\end{tabular}}

Chapter 5: The Indonesian Presidency: the Ideas and the Proposal 274

1. Introduction: from President Soekarno to President Susilo Bambang Yudoyono 274

2. Indonesian presidency and the executive powers: idea for future executive powers in Indonesia

a. A choice of presidency: from hypo-presidential system to an original style of presidential system

b. Model of checks and balances of the executive powers for Indonesia 279

c. Design of constitutional text for future Indonesian executive power 285

Chapter 6: Conclusion and General remarks $\quad 300$

Bibliography

Appendix Excerpt Constitutions and Legislations 


\section{Rosa Ristawati: Modelling Executive Powers in the Indonesian Constitution: A comparative Study}

\section{ACKNOWLEDGEMENTS}

Above all, I would like to thank Allah SWT for granting me the wisdom, health and strength to undertake this PhD project and Whose guidance let me be courageous at every moment.

My very first meeting with Prof AW. Heringa was the most important meeting ever in my academic journey, and was the decisive encounter to start my "runaway-impossible journey of PhD project". Prof. Heringa's first impression signaled a trust and an opportunity for me. These signals continued throughout my PhD journey and have strengthened me. For making everything happen, I would like to acknowledge and extent my very-humble and deepest appreciation to my highly-distinguished supervisor, my most respected mentor, Prof. Aalt Willem Heringa, who always put trust in me and always give the opportunity to conduct, continue and finally accomplish a PhD project under his wings. I would never have been able to make it all come true without his trust, moral support, and his patience in guiding me through this project. He has been a constant source of inspiration to me. His precious advise, ideas, instructions, and knowledge of the subject helped me immensely.

I would also like to acknowledge my co-supervisor, Dr. S. Hardt, who kindly offered me guidence in my final stages of PhD. His careful comments regarding my final manuscript helped me to improve the manuscript.

I extend my sincere gratitude to Prof. Dr. Saldi Isra, S.H., MPA, my mentor during the last stage of writing my PhD thesis. His strong commitment to guide me during the crucial stage of my PhD candidacy had helped me to build my confidence. When I started doubting myself, his continueos support and guidance in the years that followed keep me motivated throughout the last stage of writing my manuscript.

For the completion of this PhD project, I would like to send my sincere gratitude to my reading and degree committee: Prof. Mr.G.R. de Groot (Chairman), Prof. Dr. Yuliandri, S.H., M.H., Prof. Dr. Saldi Isra, S.H., MPA, Dr. F. Fernhout for their time, interest, helpful comments, insightful questions, and for taking me to the final approval of my manuscript.

I am hugely indebted and thoroughly grateful to Ms. Poll Liccette for all her help and for always having solutions for me. I am grateful also to Ms. Eva Rongen, Ms. Tilllie Noelle, and Ms. Monique Laenen who were always helpful with administrative and technical matters. 


\section{Rosa Ristawati: Modelling Executive Powers in the Indonesian Constitution: A comparative Study}

During my PhD program, I had valuable academic experiences by joining the lus Commune Research School. I would like to send my deep appreciation to Mrs. Marina Jodogne and Mrs. Marjo Muellers for their kind help to facilitate me in all lus Commune conferences, classes, workshops, and other academic activities during my three years of complishing my PhD training program. All the conferences and trainings have finally brought me a certification of a researcher. Indeed, it have helped me to build my confidence to be a PhD researcher as well as helped me to shape and improve my PhD thesis. To Dr. Mr. Michael Milo (Utrecht University), Prof Dr. Tom Zwart (Utrecht University), Dr. J.H. (Jan-Herman) Reestman (University van Amsterdam), Prof. Stefan Sottiaux (KU Leuven), I was honored to have them all as my papers discussants. Their time to read and thoroughly review my works and their valuable comments have indeed enriched and improved my PhD research.

In my early stage of PhD program, I also acquired valuable knowledge about EU comparative constitutional law, constitutional court, and judicial review from Prof. Monica Claess (Maastricht University) who also welcomed me for any discussions and who gave opportunity to sit in her EU constitutional law and comparative constitutional law classes. I also got opportunities to observe comparative constitutional law classes from Dr. Phillip Kiiver who at the time was also very helpful sharing materials related to comparative constitutional law.

During my second year of PhD, I got valuable opportunity to participate in a PhD English writing program and during the three months program, I really gained benefit from attending the program, especially since at the end of every class, all the participants had an individual opportunity to be guided by the mentor, Gabriel Campbell, to write a PhD proposal in English.

On July 2012, I had been fortunate to be granted a summer-school scholarship by the Central European University. During the two weeks of my summer school on comparative regionalism, I got valuable knowledge and experiences in sharing ideas with all the participants from all over the world. The most important thing is that the course has broaden my perspectives about how other states have their regional constitutionalism values. I would also like to extent my sincere gratitude to Prof. Renata Uitz (Central European University) for giving me opportunity to be a visiting researcher at CEU Budapest in October 2012. Prof. Renata Uitz was very welcoming. She gave me the opportunity to sit in all classes she taught and share valuable knowledge on all subjects relating to comparative constitutional law. During that time also, I had been given the opportunity to use all the facilities at the CEU library including unlimited access to its e-library. All the staffs were so welcoming and helpful to me. I had been 


\section{Rosa Ristawati: Modelling Executive Powers in the Indonesian Constitution: A comparative Study}

given an opportunity to attend a weekly PhD seminar by Prof. Tibor Tajti (CEU). It was such a valuable opportunity for me to experience the PhD atmosphere at the CEU.

Writing a PhD dissertation in English would have been impossible for me without both of my English mentors: Mr. Gaspar Besin and Mr. Graham Sedgley. As my first English teacher, Mr. Gaspar had helped me to do a preliminary check on my rough draft. During my last stage of PhD, Mr. Graham Sedgley who had great commitment and available time had helped me to do the English editing on my manuscript, and from him I learnt valuable English lessons. I am greatly indebted for his passion in guiding me step by step during the proof-reading and final editing process. My deep appreciation also goes out to Associate Prof. Dr. Johan Shamsuddin bin Hj. Sabbaruddin, the Dean of Faculty of Law, Malaya University, who has read and given valuable comments on my first-rough draft.

I owe a debt of gratitude to my mother $\mathrm{Hj}$. Liliek Suyatmiatun and my sister, my very best friend, Dian Fitriana, M.H., MKn for the unconditional love and support. Their never-ending support and optimism always give me motivation to stand, move on, and never give up. They have both always had their two hands to help me survive all the ups and downs, good times and bad times year by year of my PhD. They never let me give up. This dissertation is dedicated to both of them.

During my PhD program, I have shared the tears and the happiness of the journey with my big family: Mba Nining (Akbarningrum Fatmawati, ST. M.Sc), mba ifa, mba ninis, dek Nanda and dek Moon, Raffa, Jasmine, and Adzriel. My special thanks go to all my friends all over the world, especially to Amira Paripurna, LL.M, PhD and Mas Yanto (Gert-Jan van Westerlaak). Last but not least, Tante Siska and Oom Simon (my parent in Maastricht), I am extremely thankful for their care, and guardianship during my 4 wonderful years in Maastricht.

Maastricht, December 8, 2017 
Rosa Ristawati: Modelling Executive Powers in the Indonesian Constitution: A comparative Study

\section{LIST OF GLOSSARY}

\begin{tabular}{|c|c|}
\hline ABRI & Angkatan Bersenjata Republik Indonesia: The Republic of Indonesia Armed Forces \\
\hline ASEAN & The Association of Southeast Asian Nations \\
\hline BI & Bank Indonesia: Indonesian Bank (the Indonesian Central Bank) \\
\hline BLBI & Bantuan Likuiditas Bank Indonesia: the Liquidity Aids from Bank of Indonesia \\
\hline BPK & Badan Pemeriksa Keuangan: State Financial Auditor \\
\hline BPUPKI & $\begin{array}{l}\text { Badan Penyelidik Usaha Persiapan Kemerdekaan Indonesia: the Investigation } \\
\text { Committee on the Preparation of the Indonesian Independence (established by the } \\
\text { Japanese government on March 1945) }\end{array}$ \\
\hline DOM & Daerah Operasi Militer (the Military Operation Area) \\
\hline DP & Dewan Pertimbangan (the Advisory Council) \\
\hline DPA & Dewan Pertimbangan Agung: the Supreme Advisory Council \\
\hline DPD & Dewan Perwakilan Daerah: the Council of Local Representative \\
\hline DPR & Dewan Perwakilan Rakyat: the Council of Peoples Representative \\
\hline DPRD & Dewan Perwakilan Rakyat Daerah: the Representative Council in local government \\
\hline DPRGR & $\begin{array}{l}\text { Dewan Perwakilan Rakyat Gotong Royong: the Council of "Gotong Royong" of the } \\
\text { People Representative }\end{array}$ \\
\hline GAM & Gerakan Aceh Merdeka (the Aceh Independence Movement) \\
\hline GBHN & Garis Besar Haluan Negara: the Guidelines of the State Policy \\
\hline GOLKAR & Golongan Karya: the Political Party of Functional Group \\
\hline IGGI & Inter Government Group on Indonesia \\
\hline Inpres & Instruksi Presiden: the Presidential Instruction \\
\hline KEPPRES & Keputusan Presiden: the Presidential Decision \\
\hline KMB & Konferensi Meja Bundar: the Hague Roundtable Conference 1949 in Scheveningen \\
\hline KNIP & Komite Nasional Indonesia Pusat: the National Committee of Central Indonesia \\
\hline KRIS & $\begin{array}{l}\text { Konstitusi Republik Indonesia Serikat: the Constitution of Federal Republic of } \\
\text { Indonesia }\end{array}$ \\
\hline KY & Komisi Yudisial (the Judicial Commission) \\
\hline MA & Mahkamah Agung: the Supreme Court \\
\hline MK & Mahkamah Konstitusi: the Constitutional Court \\
\hline MP & Maklumat Pemerintah: the Government Decree \\
\hline MPR & Majelis Permusyawaratan Rakyat: the People Deliberation Assembly \\
\hline MPRS & $\begin{array}{l}\text { Majelis Permusyawaratan Rakyat Sementara: the Temporary Assembly of People } \\
\text { Representative }\end{array}$ \\
\hline OPM & Organisasi Papua Merdeka: the Papua Independence Organization \\
\hline PDI & Partai Demokrasi Indonesia: the Indonesian Democratic Party \\
\hline Perpu & $\begin{array}{l}\text { Peraturan Pemerintah Pengganti Undang-Undang: the Government Rules substitute } \\
\text { Legislation }\end{array}$ \\
\hline Perpres & Peraturan President ( the Presidential Rules) \\
\hline
\end{tabular}


Rosa Ristawati: Modelling Executive Powers in the Indonesian Constitution: A comparative Study

\begin{tabular}{|c|c|}
\hline PKB & Partai Kebangkitan Bangsa: the National Revival Party \\
\hline PP & Peraturan Pemerintah: the Government Rules \\
\hline PPKI & $\begin{array}{l}\text { Panitia Persiapan Kemerdekaan Indonesia: the Preparatory Committee on the } \\
\text { Indonesia Independence }\end{array}$ \\
\hline POLRI & Polisi Republik Indonesia: the Police of Republic Indonesia \\
\hline PROLEGNAS & Program Legis/asi Nasional: the National Legislation Program \\
\hline PRRI & $\begin{array}{l}\text { Pemerintah Revolusioner Republik Indonesia: the Revolutionary Government of } \\
\text { Republic Indonesia }\end{array}$ \\
\hline $\mathbf{R I}$ & Republik Indonesia: the Republic of Indonesia \\
\hline RIS & Republik Indonesia Serikat: the Federal Republic of Indonesia \\
\hline SUPERSEMAR & Surat Perintah Sebelas Maret: the Presidential Order of 11 March 1966 \\
\hline SBY & Susilo Bambang Yudhoyono: The Sixth Indonesian President \\
\hline TNI & Tentara National Indonesia: the Indonesian National Army \\
\hline UU & Undang-Undang: Legislation \\
\hline UUD 1945 & Undang-Undang Dasar 1945: the Constiitution of Republic Indonesia 1945 \\
\hline UUD NRI 1945 & $\begin{array}{l}\text { Undang-Undang Dasar Negara Republik Indonesia 1945: the Amendment } \\
\text { Constitution }\end{array}$ \\
\hline UUDS 1950 & Undang-Undang Dasar Sementara 1950: the Temporary Constitution 1950 \\
\hline
\end{tabular}


Rosa Ristawati: Modelling Executive Powers in the Indonesian Constitution: A comparative Study

\section{LIST OF TABLES}

Table 2.1 Executive

Table 2.2 Executive under three models of democratic government systems

Table 2.3 Features of three model government systems

Table 2.4 Summary of general characteristic of three models of government systems

Table 3.1 Executive power under the first Indonesian Constitution of UUD 1945

Table 3.2 Executive power under the KRIS 1949 Constitution

Table 3.3 Executive power under the UUDS 1950 Constitution

Table 4.1 The Indonesian Presidential Power before and after Amendment

Table 4.2 The Presidential Law-making Power under the Indonesian Amendment Constitution

Table 4.3 The Cabinet appointment power of the Indonesian President

Table 4.4 The Indonesian Presidential cabinet formation and reshuffle in practices

Table 4.5 Example of the Department agencies and the Non-department agencies

Table 4.6 The presidential appointment power under the Indonesian Amendment Constitution

Table 4.7 Example of treaties transformed by the Presidential Rules (2004 - 2011)

Table 4.8 Example Treaties transformed by Law

Table 4.9 Presidential Diplomacy Power based on Law No. 37/1999 on the International

Relations

Table 4.10

Table 4.11

Table 4.12

Examples of Emergency Law in Indonesia

Table 4.13

The Indonesian Presidential Military Power

Table 4.14

Military operation in Indonesia conducted by the TNI ordered by the President

Duties of the DPR

Table 4.15

the DPR vis a vis the executive power

Table 4.16

the Jokowi's vissions

Table 4.17

the Jokowi's NAWACITA missions

Table 4.18

the Jokowi's agendas

Table 4.19

Projects signed under Jokowi's administration

Table 4.20

The legislative power

Problems occurred as a result of Article 20 before and after the Amendment Constitution

Table 4.21 Problems of foreign affairs power of the Indonesian President before and after the Amendment Constitution

Table 4.22 Problems of Emergency power before and after the Amended Constitution

Table 4.23 Problems of pardoning, accessories, and administrative power before and after the Amended Constitution

Table 4.24

Table 5.1

Problems of the presidential election before and after the Amendment

Model for Indonesian executive power 
Rosa Ristawati: Modelling Executive Powers in the Indonesian Constitution: A comparative Study

\section{LIST OF SCHEMES}

Scheme 1 Summary of the Executive Powers

Scheme 2 System of government

Scheme 3 The Presidential institutions within the Indonesian presidential system

Scheme 4 The DPR procedures based on Part III of the DPR's Rules of Procedures: approval for particular treaties in article 11 section 2 UUD NRI 1945

Scheme 5 Treaty making process and its transformation into the domestic legal system

Scheme 6 Procedures of ambassadors and consuls appointment based on Law No. 27/2009 on MPR, DPR, DPD, and DPRD

Scheme 7 Procedures of the ambassadors and consuls appointment based on the DPR Rules of Procedures

Scheme 8 The Impeachment: the constitutional process based on Article 7B of the Constitution

\section{LIST OF FIGURES}

Figure 1 The period of the Indonesian executive powers according to the enactment of the Constitution

Figure 2 The executive powers in historical timeline of the Presidential office

Figure 3 The hierarchicy of the Laws based on the Legislation No. 12/2011

Figure 4 Design Institutional Choices under the Presidential government system

Figure 5 The DPR Consideration for the Ambassador's nomination based on Article 196 of the DPR's Rules of Procedures

Figure 6 The DPR consideration of the prospective ambassador from foreign countries to Republic Indonesia (during the session) based on Article 194 of the DPR's Rules of Procedures

Figure $7 \quad$ The DPR's consideration for the prospective ambassadors from foreign countries to Republic Indonesia (during the recess) based on Article 195 of the DPR's Rules of Procedures 


\section{Chapter 1}

\section{Introduction}

\section{Background of the study}

The Executive is a very important branch of government. It becomes the center point in constitutional systems mostly because in a modern government system, the concentration of government powers is on the Executive. The branch plays its significant roles in any government system. Indonesia, which has developed as a modern constitutional state, has experienced many changes of executive powers. Historically, the executive power in Indonesia has grown under different Constitutional and government regimes. By a series of constitutional amendments (the First Amendment of the Constitution of 1999 - the Fourth Amendment of the Constitution of 2001), the Amended Constitution reduced and limited the executive powers of the President. A significant change was implied by Article 5 of the First Amended Constitution, shifting the law-making power away from the President to the DPR. ${ }^{1}$ In general, the amendment of the Constitution has created protective mechanisms for the Indonesian executive powers in many ways.

The Amended Constitution does not give latitude to the President anymore. ${ }^{2}$ In almost all the executive powers, the President should rely on the DPR to obtain its authorization to

\footnotetext{
${ }^{1}$ The DPR (Dewan Perwakilan Rakyat) is the Council of Peoples Representatives. Before the First Amendment Constitution, Article 5 of the Constitution granted the President the power to make Law with approval from the DPR. Article 5 of the First Amendment Constitution changed the power of the President. The Article says that the President has no power to make law but only has the right to initiate law. However, According to Article 20, the President has the same power as the DPR to jointly discuss and jointly approve Bills of Legislation to become the Legislation in the legislation process.

${ }^{2}$ With regard to Cabinet appointments, the President is bound by the constitutional and legal framework. Unlike before the Amendment Constitution, the President no longer has full power to establish and name a ministerial department. He has no discretion to form, name, or establish a ministry that he might think important to support his programs. The name and design of a ministry is defined and limited by the Law. However, even though the President has the right to nominate, select, reshuffle and dismiss a minister; practice shows that the President can't do it freely. The President is also bound by the pre-political coalition deals during the presidential candidacy.
} 
Rosa Ristawati: Modelling Executive Powers in the Indonesian Constitution: A comparative Study

exercise the executive powers. ${ }^{3}$ Furthermore, the Amended Constitution gives real and substantial executive powers to the Legislature; whereas, the President is given the residual and formal executive powers. ${ }^{4}$ For example, with most of the appointment powers, the Indonesian President acts more like a King or Queen by just formalizing the appointment.

After more than a decade, although many changes had been made as a result of the Amendment process, it seems that the Amended Constitution functions as a curb on the executive power of the President. However, it fails to provide a balanced constitutional framework for the allocation of powers and institutional system for Indonesia. What is written in the Constitution has not yet been consistently implemented in practice. There are still missing links and loopholes in particular issues of the executive powers. The Amended Constitution provides much ambiguity and vagueness in most of the text. ${ }^{5}$ The process of amendment that was predominantly inspired by a strong spirit to reduce the executive powers of the President seems contradictory to the purpose of the amendment process. It even undermines the equlibrium among branches within the constitutional system. It creates more branch dominancy and represses the President as the Executive.

The Amended Constitution has succesfully introduced a limited presidency under a presidential system by setting limits and interventions to the executive powers of the President. The framers of the Amended Constitution missed the point that a presidency in a presidential system is an independent and a strong branch in running the state administration. Ideally, the President should be allocated a proportional amount of powers to run state administration. In addition, the framers had even made some of the constitutional provisions more ambigous and obscure. Such a situation may trigger an unsolved conflict of powers between executive and

\footnotetext{
${ }^{3}$ The DPR (Dewan Perwakilan Rakyat) is the Peoples Representative Council, one of the parliaments, and has functions similar to the House of Representatives, elected directly by the people, representing the people and public opinion. It has the budget, legislative, and oversight functions.

${ }^{4}$ The executive powers for the purposes of this research are divided into the primary and residual power to explain the actual power which is given to the DPR while the residual or the rest of the power is given to the President. The executive power can also be divided into the substantive and formal power in order to distinguish that in the substantive power, the legislative is actually the decision maker while the President has the formal power to formalize the decision made by the Legislature.

${ }^{5}$ Many ambiguities and vague areas occur with regard to the constitutional concept in the constitutional provisions. The overlapping of constitutional concepts can be determined in the Constitutional text. Such provisions, for example the treaty clause and the emergency clause encounter difficulties in practices.
} 
other branches. The institutional framework that has been made to equalize the government branches even gives the legislature more powers to control the President. On the other hand, the Court, particularly the Constitutional Court, came up with some of its decisions that seem to indirectly overrule and intervene in the executive powers of the President. ${ }^{6}$ It has even acted beyond its competence by setting alternative mechanisms that may potentially be contradictory to the government's mechanisms in order to indirectly control the President's exercise of power. ${ }^{7}$

In the future of modern democratic government, Indonesia does need a modern Constitution that gives a proportional framework for the Indonesian government system. This is intended to minimize the conflicts of power between state institutions, to anticipate unsolved conflicts, to stabilize the government system, and to reconcile the global international challenges. To this extent, this study has a main goal to come up with an alternative design for a constitutional framework of the executive powers. In general, the purpose of this study is to review the theory of the governmental system, the executive and its power, to reflect on a comparative perspective of practices of other states, to reveal the history on how actually the Indonesian framers figured out the Indonesia presidency, to analyze the existing presidency and determine the problems, and finally to design a proposal for the future Indonesian presidency.

\section{Concept and scopes}

There are many studies on the executive powers which have been conducted. However, this research on "Modelling Executive Powers in the Indonesian Constitution: A comparative Study" is more specifically concerned with the executive powers of the Indonesian President as explicitly written in the Constitution. Since this research will offer a more appropriate constitutional design for the Indonesian executive powers, it will deal with theory and

\footnotetext{
${ }^{6}$ The Law No. 12/ 2011 on the Establishment of Laws, Article 10 stipulates that the President as well as the DPR has duties to follow up the Court's decision. The following up is intended to anticipate any legal vacuum in Indonesia.

${ }^{7}$ In one of the cases of budgetary power, the Court was acting beyond its competence by its decision on setting a method confronting the calculation method that the government had set. It has created another conflict between the President and the Court, but ended up with the government's compliance with the Court's decision.
} 
Rosa Ristawati: Modelling Executive Powers in the Indonesian Constitution: A comparative Study

constitutional frameworks of the executive power in some other states. In this research, the term "power" will mostly be used to refer to the executive powers of the President.

The executive powers in this research will be mostly referred to 8 areas, namely: the law-making power, the appointment power, the foreign affairs power (including the treaty power and the diplomacy power), the administrative power (including the budget and expenditure power), the emergency power, the military power, the war power (which in modern times is called the self-defense power), and the pardoning power. In general, those executive powers are commonly mentioned in the Constitution.

The last chapter offers a framework of the executive powers for the future Indonesian Constitution. The main idea of the framework will be that the executive power should be exercised as either a shared power, a dependent power, or an independent power. The indication depends on the fact that an executive needs to be vested with independent and unilateral power in certain situations; on the other hand, it is constitutionally important to preserve the checks and balances among branches. The framework will also introduce some new concepts to Indonesia such as executive immunity which may be relevant for the executive power, and some modern models of executive power that may be compatible to the global development of international law.

\section{Research questions}

Based on the background of the study, there are two major issues to be addressed in this research:

a. Description of the existing constitutional framework for the executive powers based on the historical and comparative perspective, and the effect of the Amendment to the Constitution on its implications for the executive power in Indonesia

b. An idea of solution of constitutional design on how the Indonesian executive powers should be organized in order to improve the Indonesian presidency

In order to resolve those issues, the study will mainly focus on the Constitution, its practice, and theory, and rely upon a comparative approach. 
Rosa Ristawati: Modelling Executive Powers in the Indonesian Constitution: A comparative Study

\section{Scientific relevance}

The research conducted for this dissertation is relevant to the development of constitutional law, in particular the subject of the executive and its powers in Indonesia. It will enrich the perspective on how the executive and its powers should be established within the Indonesian Constitution. Furthermore, the use of comparative constitutional law in this work may be beneficial for understanding the global context of constitutional values, theory, and common practices. For the specific purposes, the scientific result in this research may help in developing the Indonesian Constitution, the Indonesian government system, and particularly the development of the executive power. By using the method of constitutional comparative law, studying constitutional concepts from other states experiences, the dissertation will deliver some recommendations for an alternative design of the future Indonesian Amended Constitution related to the executive powers. The Indonesian Constitution should give the President, as the chief of the executive, appropriate portions of executive powers, most importantly substantive and accountable powers.

\section{Methods and approach}

This research is supported by a comparative constitutional method. The output of a comparative constitutional study commonly plays a central role by bringing into focus similarities and contrasts among states; that in the end, helps to learn from experiences from other Constitutions and states practice. For the comparative approach, one would be expected to enhance a capacity for self-reflection on a system in order to develop a better understanding of it. ${ }^{8}$

The main sources of this research are the Constitutions, Legislations, treaties, judicial decisions, and doctrines. In general, legal sources will be interpreted systematically, based on the hierarchy, the original intent, the purpose of the Laws, and the coherency of laws. Furthermore, the political practice, historical experiences, political phenomena, and social political culture will also be briefly analysed.

\footnotetext{
${ }^{8}$ Vicky C. Jackson, "Methodological Challenges in Comparative Constitutional Law", Penn State International Law Review, Vol. 28/2010, pp. 319- 326, accessed from http://ssrn.com/abstract=1739756, 28/07/2011, p. 320.
} 
Rosa Ristawati: Modelling Executive Powers in the Indonesian Constitution: A comparative Study

There are two groups of Constitutions in the comparative constitutional section in this study, namely: the primary Constitutions and the secondary Constitutions. The primary Constitutions are the Constitution of the Philippines, the US Constitution and the French Constitution. The Constitution of the Philippines and the US Constitution will represent "the most similar Constitutions" to the Constitution of Indonesia, within the same system of government (presidential system); whereas, the French Constitution represents "the most different Constitution"from the Constitution of Indonesia since it is a different system of government (the semi-presidential system). The three Constitutions selected for comparison have some points in common: they are pluralistic democracies with free elections, and claiming to be democratic in the system of government. Moreover, the secondary Constitutions are these of Germany, the Poland and South Africa. The second group will be used only for comparing some relevant issues. The selection of Constitutions in both groups in this thesis is mostly intended to permit an inquiry into whether there are some functional, recurrent similarities in terms and practices of executive power in comparable government systems. The different experiences of the constitutional history, the post-colonial experience (the Philippines), the political turbulence (the US), and the regime transition from authoritarian to the more democratic system of government (South Africa) in the Constitutions chosen are also very interesting from a comparative point of view.

The focus of this research is limited to the executive branch and its power specifically in a presidential system. To be more specific, it will only focus on the head of the executive, the President.

\section{The structure of the book}

The following Chapter 2 will contain general theory and comparison. It will present the general theory of the executive powers and government systems. Moreover, the Chapter will briefly depict the executive powers in 6 Constitutions (the US Constitution, the Philippines Constitution, the French Constitution, the Polish Constitution, the German Constitution, and the South African Constitution). Chapter 3 will be achapter about the constitutional history of Indonesia. It will describe how the Indonesian constitution has developed the executive power 
Rosa Ristawati: Modelling Executive Powers in the Indonesian Constitution: A comparative Study

in different regimes. Chapter 4 will provide an analysis for the current issues of the executive powers under the Fourth Amended Constitution. Chapter 5 will offer a design of constitutional provisions for a future framework of the Indonesian executive powers. Chapter 6 will be the concluding and general remarks chapter.

\section{Chapter 2}

\section{Executive Power in a Theoretical and Comparative Reflection}

This chapter is a descriptive chapter of executive powers from a theoretical and comparative perspective. First, it deals with literatures about executive branches; then the powers, and the powers in different systems of government. The following section deals with the comparative perspectives and a reflection on how executive powers have developed in presidential systems, parliamentary systems, and in hybrid systems of government. This comparative perspective will give insight on how each government system works with executive powers and this will be used as a basis for the constitutional design of the proposedfuture Indonesian executive power in chapter 5.

\subsection{The Executive in the Constitutional System of Government: the General Theory}

\section{The term and nature of the executive branch}

The word executive has long been recognized from the Latin words "ex sequi", which means "follow out or carrying out" in English, and then in practice refers to the executive's roles to carry out the political system's policies, laws, or directives. ${ }^{9}$ The Executive becomes the more significant branch in a political and government system since the branch is the key to implementing laws and running the state administration as a whole. Duncan Watts clarifies the role of the executive branch as the branch which is charged with the responsibility for the state

\footnotetext{
${ }^{9}$ Duncan Watts, British Government and Politics: a Comparative Guide, Edinburgh University Press, 2006, p. 111.
} 
administration and the implementation of laws made by the legislature. ${ }^{10}$ The role is mainly as political leadership to take decisions and assume overall responsibility for the direction and coordination of government policy. ${ }^{11}$ Furthermore, as the policy maker and political leader, the roles of the executive include initiation, formulation, articulation, and implementation of policy with the responsibility of ceremonial tasks, control of policy making, political leadership, management of the bureaucracy, and crisis management. ${ }^{12}$ In daily administration, the executive branch of government performs three main functions, namely: 1. Decision-making: initiating government action and formulating public policy; 2. Implementation: executives implement (apply) the laws, which means they must also run the main departments and bureaucracies of a state; 3. Coordination: coordination and integration of the complex affairs of state. ${ }^{13}$ From this point of view, the executive is not just a decision maker but also an executor in all matters of state administration.

In practice, there are several models of executive branches: a single chief executive of a president, a prime minister, a chief minister, a supreme leader or a monarch and a dual executive of two offices, which consists of the president and prime minister or a ruling juntaexercising shared leadership. ${ }^{14}$ While a single executive enjoys all the executive powers, a dual executive has to share the powers. In literatures, writers commonly refer the executive to the phrase "core executive" to describe the complexity of integrated institutions which are in charge of daily state government affairs. ${ }^{15}$ Meanwhile, Will Storey considered that independent regulatory commissions could also be considered as the executive branch, since these commissions are empowered to establish for the policy area they regulate rules which have the force of law, and to enforce these rules. ${ }^{16}$

\footnotetext{
${ }^{10}$ Duncan Watts, Understanding US/UK Government and Politics: a Comparative Guide, Manchester University Press, 2003, p. 66.

${ }^{11}$ ld. at p. $67-69$.

${ }^{12}$ Duncan Watts, Op.Cit., p. 115-116.

${ }^{13}$ Ken Newton and Jan W. Van Deth, Foundations of Comparative Politics: Democracies of the Modern World, Cambridge University Press, 2005, p. 45.

${ }^{14}$ Duncan Watts, Op. Cit., p. 111.

${ }^{15}$ Duncan Watts, Op. Cit., p. 111: They are the first minister, the cabinet and its committees, the office that serves the first minister and cabinet, and the departments headed as they are by senior ministers and senior civil servants.

${ }^{16}$ William Storey, US Government and Politics, Edinburgh University Press, 2007, p. 289.
} 
Rosa Ristawati: Modelling Executive Powers in the Indonesian Constitution: A comparative Study

In political constitutional history, the executive branch found its roots as the concept of the state had been introduced. In the late medieval transformations, John Locke proposed that the executive branch is a branch that necessarily exists to execute and enforce laws. ${ }^{17}$ However, in a special case, John Locke confirmed that where the public good is concerned, the executor of the laws may be given discretion to perform his powers in specific terms. ${ }^{18}$ Accordingly, the main executive area is to execute laws, but, it could be possible to be broader than just executing laws in the development. In a more current study, Andraz Sajo emphasized that the executive branch is important as an institution because it has a monopoly on coercion. ${ }^{19}$ The executive has the right to influence decisions. ${ }^{20}$ In current and global development, the executive branch finds its area to be broader as the scope of state administration is also broader. The roles are moving forward even more from just performing state administration to the key-centre of deciding the path of the state.

Table 2.1 Summary: Executive term and definition, roles and functions, and Model

\begin{tabular}{|l|l|}
\hline \multicolumn{2}{|l|}{ The executive } \\
\hline $\begin{array}{l}\text { Term and } \\
\text { definition }\end{array}$ & The executor of laws \\
\hline $\begin{array}{l}\text { Roles and } \\
\text { functions }\end{array}$ & Run the state administration and government affairs, execute the laws, \\
\hline Model & $\begin{array}{l}\text { A single executive of A Monarch, a President, a Prime Minister, a Chief of Minister, } \\
\text { A dual executive of President and Prime Minister } \\
\text { A collective executive of a Prime Minister and Ministers }\end{array}$ \\
\hline
\end{tabular}

6. The Executive and its power in a democratic regime of parliamentary, presidency, and hybrid system

In modern democratic regimes, there are three models of government system: a parliamentary system, a presidential system, and a mixed system. Donald S. Lutz stated that in a parliamentary system, the executive usually refers to the prime minister who is selected and

\footnotetext{
${ }^{17}$ The Founders' Constitution Volume 1, Chapter 10, Document 3, the University of Chicago Press, John Locke: Second Treatise Edited by Peter Laslett. New York: Mentor Books, New American Library, 1965, p. 143, 144, 150, 159, paragraph 144, accessed on http://press-pubs.uchicago.edu/founders/documents/v1ch10s3.html, at $12 / 12 / 2012$.

${ }^{18} \ddot{I d}$. at paragraph 159.

${ }^{19}$ Andraz Sajo, Limiting Government: An Introduction to Constitutionalism, English Translation, Central European University Press, 1999, Budapest, p. 174.

${ }^{20}$ ld. at p. 175
} 
is part of the legislative; where in a presidential system, the executive is popularly elected and is not part of the legislative. ${ }^{21}$ In a presidential constitution, the president is both the head of state and head of government, the president is directly elected, and both president and legislature serve for a fixed term; while in a semi presidential constitution, a president is directly elected or popularly elected and serves for a fixed term, there is a separate position of prime minister, and the prime minister and cabinet are collectively responsible to the legislature. ${ }^{22} \mathrm{~A}$ government system could also be determined by the executive-ministers (the cabinet) relationship. With respect to the Cabinet, a presidential cabinet consists of presidential cabinet officers who hold their posts purely on the decision of their chief (the president), while in contrast, parliamentary ministers are parliamentary colleagues; a president in a presidential system can protect his cabinet members from criticism much more effectively than a prime minister. ${ }^{23}$ Furthermore, the relationship between the executive is different in a parliamentary system and in a presidential system. In a parliamentary system, a prime ministeris much closer to being on an equal footing with their fellow ministers; while in a presidential system, a president will never be equal with cabinet appointees. ${ }^{24}$ The president in a presidential system has hierarchical relationships with the ministers in the cabinet, while in a parliamentary system, the prime minister as the chief executive has a collegial relationship with the ministers in the cabinet.

Moreover, Stepan and Skach argue that the minister in a cabinet can be more frequently changed in a presidential system rather than in a parliamentary system. ${ }^{25}$ This could indicate that the government in a presidential system is more flexible and exists within the authority of the President, but its relationship with the parliament is different, since the parliament does not have the power to change the cabinet. In a presidential system, if no coalition government is established as a result of the election process, representatives of the president's party may

\footnotetext{
${ }^{21}$ Donald S. Lutz, Principles of Constitutional Design, Cambridge University Press, 2006, p.118.

${ }^{22}$ Sophia Moestrup, Semi-Presidentialism and Democracy, Editors Elgie, R., Wu, Y., Palgrave Macmillan UK, 2011, p. 2.

${ }^{23}$ Juan Linz, "The Perils of Presidentialism", 1 Journal of Democracy 1 (Winter 1990), Published by The John Hopkins University Press pp. 51-69, p. 63.

${ }^{24}$ Id. at p. 62.

${ }^{25}$ Jose Antonio Cheibub, Presidentialism, Parliamentarism, and Democracy (Cambridge: Cambridge University Press, 2007), p. 54.
} 
be invited to fill all vacancies in the cabinet. On the other hand, in a parliamentary system, every portfolio within government, either minority or coalition, enjoys the support of a legislative majority. ${ }^{26}$

Besides being determined by the executive-cabinet relationship, the government systems could also be valued by the executive-legislature relationship. With regard to the executive-legislature relationship, Ken Newton and Jan W. Van Deth observed that even though presidential systems and parliamentary systems are theoretically different, in practice the two systems tend to converge since in practice both systems depend on a close working relationship between executive and legislature. ${ }^{27}$ To this extent, in a presidential system, the relationship between the executive and legislature also contributes to the stability of the state administration and support to the presidential survival. A good relationship between the executive and the legislature would contribute to the greater stability of the state administration.

\section{a. Executive power in a presidency}

A pure presidential system in a democracy has two fundamental characters that are: (1) the legislative power has a fixed electoral mandate which has its own source of legitimacy and (2) the chief executive power has a fixed electoral mandate which also has its own source of legitimacy. ${ }^{28}$ Moreover, Alfred Stepan and Cindy Skach argue that in a presidential system, the system may face the possibility of a political impasse between the executive and the legislature; a situation that may happen as a result of a president's and legislature's direct election that creates a mutual independence between both institutions. ${ }^{29}$ The situation occurs even more when a president-elect is from a minority political party sitting in the legislative. $\mathrm{S} /$ he will face difficulty in making policy when many of the parties sitting in the legislature are not supportive.

\footnotetext{
${ }^{26} / d$. at p. 55.

${ }^{27}$ Ken Newton and Jan W. Van Deth, Op. Cit., p. 64.

${ }^{28}$ Alfred Stepan and Cindy Skach, "Constitutional Frameworks and Democratic Consolidation: Parliamentarianism versus Presidentialism", World Politics, Vol. 46 No. 1, October 1993, pp. 1-22, published by Cambridge University Press, accessed online via: http://www.jstor.org/stable/2950664 on 12/08/2010, p. 4.

${ }^{29}$ Id. at p. 18.
} 
Rosa Ristawati: Modelling Executive Powers in the Indonesian Constitution: A comparative Study

A presidential system could have parliamentary tendencies. The tendencies may occur by combining elements of both presidential and parliamentary systems but still strongly bringing out the elements of the presidential system. ${ }^{30}$ In a presidential system with a tendency towards "parliamentarization", there is a mechanism of parliamentary control. ${ }^{31}$ Another mechanism of parliamentarization in a presidential system can be observed from the operational dynamics of executive-legislative relations when they exemplified the establishment of rules governing the attendance of members of the government in the legislative chambers, the obligation to be periodically present at the legislative's sessions, the power of the legislature to call for the ministers to appear before the assembly, soft control by the legislature (by interpellation or parliamentary question), and a vote of no confidence that translates into the censure of a minister or of the cabinet as a whole but not the president. ${ }^{32}$

The executive in a presidential system mostly has three essential features according to the position and powers being inherently logical in a presidential regime, namely: leadership power resources, leadership autonomy, and personalization of the electoral process. ${ }^{33}$ The first

\footnotetext{
${ }^{30}$ Héctor Fix-Fierro, Pedro Salazar-Ugarte, Presidentialism in: the Oxford Handbook of Comparative Constitutional Law edited by Michel Rosenfeld and Andras Sajo, Oxford University Press, 2012, p. 26.

${ }^{31}$ ld. at p. 23.

${ }^{32}$ Id. at p. 24: In some systems, ministers have the possibility of making use of the legislative rostrum (in Latin America, this is a possibility in Argentina, Brazil, Chile, Colombia, Costa Rica, Dominican Republic, Guatemala, Peru, and Venezuela). In others, they may appear only before legislative committees. In any case, the purpose is to transfer control over the executive to the legislative seat. Some of these controls are soft (eg interpellation or parliamentary questions). Others are hard (this is the case of the vote of no confidence). Interpellations and questions represent a soft form of control that may be expressed in written form, or directly (orally) in the parliamentary seat. Their essential purpose is to keep open channels of communication, as well as information exchanges between the parliament and the government. The vote of no confidence is a hard type of control (widely instituted in Latin American constitutions: eg in Argentina, Colombia, Costa Rica, Ecuador, El Salvador, Guatemala, Panamá, Paraguay, Peru, Uruguay, and Venezuela) that translates into the censure of a minister or of the cabinet as a whole. This latter hypothesis the censure of the government by the legislature may result in the removal of one or more ministers, or even the dismissal of the prime minister, but, in contrast to parliamentary systems, not of the president himself as the head of government.

${ }^{33}$ Thomas Poguntke and Paul Webb, The Presidentialization of Politics: A Comparative Study of Modern Democracies, Oxford University Press, 2005, p. 5: “1. Leadership power resources: The logic of presidentialism provides the head of government with superior executive power resources. This emanates directly from the fact that he or she is not responsible to parliament, is usually directly legitimated and has the power to form a cabinet without significant interference from other institutions. 2. Leadership autonomy: This is also a direct result of the separation of powers. While in office, the head of the executive is well protected against pressure from his own party. 3. Personalization of the electoral process: This follows directly from the natural focus on the highest elective office and implies that all aspects of the electoral process are decisively moulded by the personalities of the leading candidates."
} 
feature, thatof the leadership power resources, may be related to the executive-cabinet relationship where the president is the chief of the cabinet and other state administration institutions. On the other hand, the leadership's autonomy and personalization of the electoral process could be seen as a consequence of the fact that the executive in a presidential system being independently elected by the people. As a consequence of direct suffrage, a President has a personal democratic mandate. The personal mandate allows the President as the chief of executive to unilaterally make policy. ${ }^{34}$ An elected President has full authority to establish his government and be responsible for the state administration entirely. The president has full authority for cabinet appointments and dismissal; while ministers in the cabinet are accountable directly to the President. Furthermore, the President is an independent institution from the legislature and thus, has full authority and responsibility for his public affairs. The independent relationship between the President and the legislature is ensured by the real separation in which neither the president nor the ministers in the cabinet are members of the legislature. $^{35}$

In a presidential system, the executive power is vested in the hands of the president and commonly known as presidential power. Chiebub mentions three powers in which the President may have dominance over the budget process; the power to initiate budget laws, the power to amend the budget proposal, and the expenditure power in a situation where there is noapproval for a budget law. ${ }^{36}$ In most of the presidential constitutions, the President is given some legislative powers including veto, decree, and urgency powers, as well as the government's exclusive power to introduce certain legislation. ${ }^{37}$ Cheibub's view is that the President, as the executive, may dominate the legislative initiative in most crucial areas of policy-making since the President has the exclusive right to initiate legislation that concerns the budget, taxes, and public administration. ${ }^{38}$ In a presidential system, Cheibub defines that the veto power of the President is relevant to the power of the President to enact a bill to become

\footnotetext{
${ }^{34}$ Id. at p. 8.

${ }^{35}$ Ken Newton and Jan W. Van Deth, Op. Cit., p. 61.

${ }^{36}$ Cheibub, Op. Cit., p. 101.

${ }^{37}$ Jose Antonio Cheibub, "Reforming Presidential and Semi-Presidential Democracies", Instituto de Investigaciones Juridicas de la UNAM, accessed via www.juridicas.unam.mx , p. 10.

${ }^{38}$ Cheibub, Op. Cit., p. 129.
} 
Rosa Ristawati: Modelling Executive Powers in the Indonesian Constitution: A comparative Study

Law by appending his signature; the veto power may have meaning in the sense that the President can refuse the bill either entirely (identified as a complete or total veto power) or partly (a partial veto power); however, the legislature, by a majority vote, has the right to override such presidential power:

"The legislative majority required for veto override is usually larger than the majority required for the approval of the bill in the first place. Most presidential constitutions (including the U.S. Constitution and the majority of the Latin American presidential constitutions) require a two-thirds majority of the legislature in order to override a presidential veto. If such a majority exists, the president is required to sign the bill and it then becomes law". ${ }^{39}$

In some countries, the Constitution may give the president the power to make decrees. The presidential decree powers refer to a law-making power that exists in the Constitution both in presidential and parliamentary constitutions. The determination of decree power by Carey and Shugart states that decree power varies with respect to the areas where decrees may be issued:

"First, it varies with respect to the areas where decrees may be issued. Some constitutions allow only for presidential "executive orders" - that is, purely administrative proclamations pertaining to the implementation of laws already approved by the legislature. Others allow for presidential decrees under special circumstances, which are often sufficiently vague that presidential action is possible in virtually any area (e.g., "relevance," "urgency," "economic or financial matters when so required by the national". 40

In practice, decree powers are mostly used for special circumstances when there are urgent matters.

A presidential system may potentially lead to an autocratic regime. This is relevant in that in a presidential system, the power of the executive is mostly vested in the hands of a single-institution, the President. According to Héctor Fix-Fierro and Pedro Salazar-Ugarte there may be two mechanisms to stabilize and prevent the system from becoming an autocratic regime: 1 . by strengthening the president's ability to influence legislative work (strengthening the executive) and, 2 . by reinforcing the ability of the members of the legislature to influence the operation of the government (increasing the power of parliament). ${ }^{41}$ Moreover, the alternative measures to strengthen the Executive could be by strengthening the president's

\footnotetext{
${ }^{39} / d$. at p. 170.

${ }^{40}$ Id. at p. 170.

${ }^{41}$ Héctor Fix-Fierro, Pedro Salazar-Ugarte, Op. Cit., p. 21.
} 
veto power on legislation passed by the legislature; giving preference to the legislative bills introduced into the legislature by the President (any such bill must be passed or rejected within a limited time); giving the President more powers to issue decrees with legislative force, or, ultimately reserving the power of introducing legislative bills to the President. On the other hand, the mechanism to increase the power of parliament could be by increasing the involvement of the legislature in the appointment and removal of cabinet members, so it can strengthen its powers to make the government accountable; or broadening its powers to shape public policy. ${ }^{42}$

In history, the idea of the executive branch and its power in a presidential system could be traced down from the US Constitutional history. As the first written constitution and first presidential constitution, the US Constitution represents the standard on how the executive branch and its power established a presidential system. According to US Constitutional history, the executive branch in a presidency was intended to be a strong branch but with little independent power; the President is in a position to lead, influence, persuade, but rarely to command or order. ${ }^{43}$ In the beginning, the President was intended to be selected by the Congress. ${ }^{44}$ The US constitutional framers designed a mechanism to control as well as to empower the executive in 4 ways: 1 . Limited government, a reaction against the arbitrary, expansive powers of the king or state and a protection of personal liberty; 2 . Rule of law; the government could only act on the basis of legal and constitutional grounds; 3. Separation of power; each of the three branches of government would have a defined sphere of power; 4 . Checks and balances; each branch could limit or control the executive powers. ${ }^{45}$ To this extent, the feature of the US presidential system reflects that the president is not the dominant and central institution among other constitutional branches. The powers of the executive really depend on the Legislature (the US Congress).

\footnotetext{
${ }^{42}$ Id. at p. 21.

${ }^{43}$ Michael A. Genovese, Is the Presidency Dangerous to Democracy?, in: the Presidency and the challenge of Democracy edited by Michael A. Genovese and Lori Cox Han, Palgrave Macmillan, 2006, p. 8.

${ }^{44}$ Andrew Rudalevige, The New Imperial Presidency: Renewing Presidential Power After Watergate, the University of Michigan Press, 2005, p. 21.

${ }^{45}$ Michael A. Genovese, Op. Cit., p. 9.
} 
Rosa Ristawati: Modelling Executive Powers in the Indonesian Constitution: A comparative Study

\section{b. Executive power in a premiership}

The history of parliamentary systems started when the UK Bill of Rights 1689 left the executive power in the hands of the Monarch but imposed conditions upon the exercise of that power to protect the interests of Parliament. Thus, the emergence of the office of the Prime Minister in 1723 required the Queen to ensure the ministers were supported by the two houses of Parliament, in particular the House of Commons, and had the exclusive privilege to determinepolicies of the government that are conducted on behalf of the Monarch. ${ }^{46}$ The British Westminster Parliamentary system is the root model of a parliamentary system. It consists of and separates the three traditional branches of government powers. ${ }^{47}$ In general, the parliamentary system in the UK emphasizes two important elements as features in the parliamentary system model:

1. ministers must be members of Parliament mainly in the elected house, although in Britain a few ministers may sit in the House of Lords and may be granted peerages for this purpose;

2. ministers must account to Parliament for their policies and decisions, and are thus ultimately accountable to the electorate. ${ }^{48}$

The parliamentary system puts the UK in the situation where ministers belong to part of the government, and are able to exercise executive powers, whether acting in their own name or in the name of the head of state in whom the powers are vested, and are accountable to the parliament for their use of powers. ${ }^{49}$ This reflects that the relation between the legislative and executive powers is to be fused and does not follow a formal separation between legislative and executive. Furthermore, the system was mainly grounded on the relationship between the executive and the legislature; the legislature's powers and the confidence that the executive received from the legislature, might prevail over the other in the exercise of political power. ${ }^{50}$ The system entitles the Monarch to participate in the legislative process by giving the royal assent; the Monarch also has a discretionary power to dissolve the assembly whenever the

\footnotetext{
${ }^{46}$ Anthony W. Bradley, Cesare Pinelli, Parliamentarism, in: the Oxford Handbook of Comparative Constitutional Law edited by Michel Rosenfeld and Andras Sajo, Oxford University Press, 2012, p. 651.

${ }^{47}$ Richard Albert, "The Fusion of Presidentialism and Parliamentarism", Research Paper 190, March 1, 2010, Boston College Law School, Legal Studies Research Paper Series, available at: http://ssrn.com/abstract=1424084, p. 534.

${ }^{48}$ Anthony W. Bradley and Cesare Pinelli, Op. Cit., p.651.

${ }^{49}$ Id. at p.652.

${ }^{50}$ ld. at p.654.
} 
parliament is acting contrary to the state's interest. ${ }^{51}$ However, the Constitution generally does not designate the Monarch or the president in a parliamentary system as head of the executive; instead they have the position of the head of the state. Accordingly, a definite parliamentary majority only asserts the powers of appointing the prime minister and of dissolving parliament as a formal matter of the head of the state. Anthony W. Bradley and Cesare Pinelli argued that in a parliamentary system, the position of head of the state is maintained equally by the definite existence of parliamentary majority. ${ }^{52}$ Furthermore, a motion of confidence may be proposed by the government with the aim of ensuring that it has the support of a majority for its program, or for a single bill or policy. ${ }^{53}$ In principle, a government must resign whenever parliament approves a "no confidence" motion, or rejects a confidence motion. The parliamentary system in the UK, according to Anthony W. Bradley and Cesare Pinelli, recognizes the principle of ministerial individual accountability; the principle has the meaning that the ministers are responsible in the sense that they are answerable to the parliament for each of their departments; it reflects a chain of accountability. ${ }^{54}$

According to the UK and most of the parliamentary Constitutions, the existence of the executive branch (the government) depends generally on the motion of confidence of the legislature; whereas, in a presidential system model, a government is independent of the legislature as a result of a direct election. ${ }^{55}$ Anthony W. Bradley and Cesare Pinelli said that most parliamentary systems corresponded to federations. ${ }^{56}$

Commonly, the political executive in a parliamentary system (chancellor, premier, prime minister and their cabinet or council of ministers) is not directly elected but emerges from the

\footnotetext{
${ }^{51}$ ld. at p.654.

${ }^{52} / d$. at p. 655 .

${ }^{53}$ Id. at p. 664

${ }^{54}$ Id. at p. 664.

${ }^{55}$ Jose Antonio Chiebub, Op. Cit., p. 1.

${ }^{56}$ Anthony W. Bradley and Cesare Pinelli, Op. Cit.,p.659: "In some countries such as Australia, Germany, South Africa, as well as other forms of government, parliamentary systems, have increasingly corresponded to the federations; it has important consequences for the national decision-making process, including the fact that a second chamber representing the regional components of the federal state is usually established; federal systems are inter alia differentiated according to whether powers among the federation and regional territories are strictly separated or mostly shared".
} 
majority party or ruling coalition in the assembly. ${ }^{57}$ Ken Newton and Jan W. Van Deth state that the executive, in a parliamentary system usually consists of a prime minister and a cabinet or a council of ministers, in which, they share responsibilities among their members. ${ }^{58} \mathrm{~A}$ Prime Minister is not only the chairperson of the Cabinet but also responsible for the party organization. ${ }^{59}$ In addition, according to Stephen Buckley, in a parliamentary system, the executive branch is usually performed by two distinct groups of people who are politically appointed and serve as permanent officials such as the civil service in the United Kingdom. ${ }^{60}$

\section{c. Executive in a hybrid system}

\section{The concept of a Hybrid system of government: a combination and deviance}

The hybrid system of government (half-presidential, quasi-presidential, quasi parliamentary, premier presidentialism, or pseudo-presidential) emerges as a combination or deviation of traditional types of presidential and parliamentary systems. Maurice Duverger introduced and elaborated the hybrid system of a semi-presidential system as a combination system between a presidential system and parliamentary system and pointed out the French Constitution of 4 October $1958 .^{61}$ According to Robert Elgi's study, since 1920 the term has been used to describe a situation when there was either a powerful prime minister or a powerful president. ${ }^{62}$ Elgie noted that the dual executive may potentially provoke a conflict between the president and the prime minister. ${ }^{63}$ On the other hand, according to Pasquino, the system of semi presidentialism may run risks, such as:

"1. Turn out to be a hyper-presidentialism, when the President of the Republic is also recognized as the leader of the parliamentary majority and cumulates the executive and legislative power; 2 . create a constitutional crisis caused by a decision-making paralysis while this situation may be raised when the parliamentary majority is made of a coalition of parties that are opposing the president and a political and institutional clash between the prime minister and the president may ensue; 3 . the paralysis is a consequence of anytime the president put too much interference with the parliamentary decision-making

\footnotetext{
${ }^{57}$ Ken Newton and Jan W. Van Deth, Op. Cit., p.75.

${ }^{58}$ Id. Ken Newton and Jan W. Van Deth (2005), p. 62.

${ }^{59}$ Sir Ivor Jennings, Cabinet Government, Cambridge University Press, $3^{\text {rd }}$ edition, 1969, p. 24.

${ }^{60}$ Stephen Buckley, the Prime Minister and Cabinet, Edinburgh University Press, 2006, p. 2.

${ }^{61}$ Horst Bahro, Bernhard H. Bayerlein et al, "Duverger's concept: Semi-presidential government revisited", European Journal of Political Research, Kluwer Academic Publisher, the Netherlands, 1998, pp. 201-224, p. 202.

${ }^{62}$ Robert Elgie, Semi- Presidentialism: Sub Types and Democratic Performance, Oxford University Press, 2011, p. 20

${ }^{63}$ Id, Robert Elgie (2011), p. 22.
} 
Rosa Ristawati: Modelling Executive Powers in the Indonesian Constitution: A comparative Study

process and the power of the prime minister; the likely reaction of the prime minister and his attempt, one way or another, to legislate may also push to a situation of constitutional crisis." ${ }^{\prime 64}$

A hybrid system of government creates a framework where the President may hold considerable powers and a government. ${ }^{65}$ Unlike in a presidential system with the President as the single executive branch who has the full command in performing the executive power, a hybrid system allocates shared-executive powers to the President and other institutions. On the other hand, unlike in the Parliamentary system where the Monarch or the President cannot be brought down by the Parliament, in some hybrid systems of government, though the President is mostly elected by direct suffrage, the Parliament may have a significant role in removing the President; thus, this may make the President dependent on the Parliament.

In addition, Elgie observed that since the practice varies, the constitutional powers of the Presidents, Prime Ministers, and the Cabinets also multiply; sometimes the Presidents dominate Prime Ministers, or vice versa, the Prime Ministers have stronger power, or it may be that sometimes neither one dominates the other ${ }^{66}$ In general, a semi-presidential system has often been an easy system to choose for strategic reasons since the system offers the prospect of a strong president; while on the other hand it enables power sharing and facilitates coalition building. ${ }^{67}$

Table 2.2 Executive under three models of democratic government systems

\begin{tabular}{|c|c|c|}
\hline Parliamentary system & Presidential system & Hybrid system \\
\hline $\begin{array}{l}\text { Executive branch: } \\
\qquad \begin{aligned} \text { - } & \text { collective } \\
\text { - } & \text { headed by a Prime Minister } \\
\text { - } & \text { dependent to the parliament }\end{aligned}\end{array}$ & $\begin{array}{l}\text { Executive branch } \\
\qquad \begin{aligned} & \text { - } \text { single } \\
& \text { - } \text { headed by a President } \\
& \text { - } \quad \text { independent branch }\end{aligned}\end{array}$ & $\begin{array}{l}\text { Executive branch } \\
\text { - } \quad \text { dual } \\
\text { - } \quad \text { a President and a Prime Minister } \\
\text { - } \quad \text { independent branch }\end{array}$ \\
\hline $\begin{array}{l}\text { Executive power } \\
\qquad \quad \text { vest in a Prime Minister }\end{array}$ & $\begin{array}{l}\text { Executive power } \\
\text { - } \quad \text { mainly vest in a President }\end{array}$ & $\begin{array}{l}\text { Executive power } \\
\qquad \begin{array}{l}\text { shared between President and } \\
\text { Prime Minister }\end{array}\end{array}$ \\
\hline
\end{tabular}

\footnotetext{
${ }^{64}$ Pasquino, G., The Advantages and Disadvantages of Semi-Presidentialism: A West European Perspective, in: Elgie, R. And Moestrup, S. (eds) Semi-Presidentialism Outside Europe: A Comparative Study, London: Routledge, 2007, pp. 14-29, p. 24.

${ }^{65}$ Horst Bahro, Op. Cit., p. 214.

${ }^{66}$ Robert Elgie, Comparative European Politics: Semi-Presidentialism in Europe,New York: Oxford University Press, 2004, p. 14.

${ }^{67}$ Pasquino, Op. Cit., p. 24
} 
Rosa Ristawati: Modelling Executive Powers in the Indonesian Constitution: A comparative Study

\section{Executive power: scopes, sources, features and limits}

The scope of executive power has been increased in modern days. ${ }^{68}$ However, it has a tendency to be formally limited in order to preserve the power balance with other branches; namely, the legislature and the courts. ${ }^{69}$ Moreover, the features of the executive powers in most legal systems have evolved over time and are not fixed since they greatly fluctuate with the actual distribution of powers at any given moment shaped by social and political circumstances. ${ }^{70}$

\section{d. The sources and categories of the power}

The executive powers are derived from various sources, both constitutional and extraconstitutional, and they exist in two forms of formal and informal power. ${ }^{71}$ Michael $\mathrm{A}$. Genovese specified the formal and informal power of the President. The formal power is derived from the Constitution and extends beyond the strictly legalistic or specifically granted powers that find their sources in the literal reading of the words of the Constitution; while informal powers find their sources in the political as opposed to the constitutional. ${ }^{72}$ On the other hand, Sakrishna Prakash in his work "Taxonomy of the Presidential powers" proposed that the executive (presidential) powers may be sourced from the Constitution, or from other sources. Prakash proposed four categories of executive powers that can be viewed from its sources, namely: "specific powers,"'vesting clause powers," "structural powers," and "extra-

\footnotetext{
${ }^{68}$ Duncan Watts, Op. Cit., p. 69: "Much of their increase in power derives from the growth in governmental interventionism, but the globalization of economic and political concerns has also added to their responsibilities and recognition."

${ }^{69}$ Jenny S. Martinez, "Inherent Executive Power: a Comparative Perspective", the Yale Law Journal, Vol. 115, No. 9, the Most Dangerous Branch? Mayors, Governors, Presidents, and the Rule of Law: a Symposium on Executive Power, 2006, pp. 2480-2511, Published by the Yale Law Journal Company Inc, accessed at http://www.jstor.org/stable/20455703 on 26/06/2010, p. 2483.

${ }^{70}$ Id. at p. 2487.

${ }^{71}$ Michael A. Genovese, Op. Cit., p. 10.

${ }^{72}$ Id. at p. 11: Presidents have enumerated powers that the Constitution expressly grants; implied powers that may be inferred from power expressly granted, resulting powers that result when several enumerated powers are added together, inherent powers when the powers in the field of external affairs that the Supreme Court has declared do not depend upon constitutional grants but grow out of the existence of national government. The informal powers of the President rely upon his/her ability to engage in the personal part of politics. The informal powers require skill at persuasion, political manipulation, coalition building, self-dramatization, and mobilization. The formal powers are limited and often shared. The informal powers are a function of skill, situation, and the political circumstances. While the formal power of the president remains fairly constant over time, the president's informal powers are quite variable, dependent on the skill of each individual president."
} 
textual powers." ${ }^{73}$ The specific powers may be variously found in the constitutional provisions and are specific in the sense that the powers are particularly listed. ${ }^{74}$ The vesting clause powers are mentioned to be power of removal, power of executing laws, and power in accordance to the exercise of certain authority in emergency situations. ${ }^{75}$ The structural powers according to Prakash may refer to the constitutional structure; whereas, the extra-textual powers may arise from sources outside the Constitutional text and structure. ${ }^{76}$

Debates over the executive powers have come to the question of whether or not the powers are inherently attached. While in practice, the executive powers are not fixed but rather shaped by political context and the path dependent evolution of particular legal systems. ${ }^{77}$ The term Executive has been potentially misleading since it may create the impression that the executive power is like a fortress in which the leader does whatever he wants. ${ }^{78}$ The executive powers could be categorized based on the character of powers, namely: the regularable powers, residual powers, and absolute powers. ${ }^{79}$ The regularable powers are the powers that can be limited by the legislator through legislation; on the other hand, the residual powers are powers that are normally allocated to other branches, such as the legislature, or the judiciary, but where some remaining aspects are left to the President. ${ }^{80}$ In contrast with both powers, the absolute powers are the power that can be exercised without any checks. ${ }^{81}$ On the other hand, C.F. Strong viewed the executive powers from their functionsand asserted that the modern executive branch is more flexible rather than only executing laws. $^{82}$

\footnotetext{
${ }^{73}$ Saikrishna Bangalore Prakash, "a Taxonomy of Presidential Powers", Boston University Law Review, Vol. 88/2008, pp. 327- 340, accessed via Heinonline (http://heinonline.org, Citation 88 B.U. L. Rev. 327 2008) on 11/03/2010, p. 331.

${ }^{74}$ Id. at p. 331.

${ }^{75}$ Id. at p. 332

${ }^{76} / d$. at p. 332-333.

${ }^{77}$ Jenny S. Martinez, Op. Cit., p. 2483.

${ }^{78}$ Andraz Sajo, Op. Cit., p. 173-174.

${ }^{79}$ Prakash, Op. Cit., p. 334.

${ }^{80}$ Id. at p. $334-335$.

${ }^{81} / d$. at p. 336

${ }^{82}$ C.F. Strong, Op. Cit.,p. 234.
} 
Rosa Ristawati: Modelling Executive Powers in the Indonesian Constitution: A comparative Study

As the main executive powers commonly originate from the Constitution and are known asconstitutional powers, other powers are commonly known as delegated powers. Delegated powers are the powers that may not be derived from the Constitution since they may be given by legislation, made by the legislature or the Parliament. The powers are usually given because the executive runs the state administration and government activity. Those powers are necessary for the Legislature in case there is something urgent in the area of government. Therefore, the Legislature may delegate the power to the executive. Such powers may extendthe executive powers. In a presidential system, a modern President has even more executive powers from both the Constitution and political resources (the elections, political parties, interest groups, the media and public opinion). ${ }^{83}$ There are three factors that can influence the expansion of the executive power in a presidential system: the party, popular mobilization, and administration. ${ }^{84}$

Moreover, any kind of laws (such as: the executive orders, presidential decrees, presidential decisions, executive agreements, executive directives, etc) issued by the President are also known as the instruments that may contribute to the expansion of the executive power of the President. Such laws may be issued and implemented unilaterally; it will, then, justify any kind of presidential actions. However, such presidential law should be based on the Constitution, as the primary power source, and the Legislation as the source from which the power of the executive is derived from Parliament. Therefore, the Presidential law-making power is actually derivative and residual from the Constitutional power and the legislation (the delegated power from the parliament).

\section{Scheme 1: Summary of the Executive Powers}

\footnotetext{
${ }^{83}$ Benjamin Ginsberg et al, We the People: an introduction to American Politics, W.W. Norton \&Company, Eight Essential Edition, 2011, p. 304.

${ }^{84}$ Id. at p. 319: "In the first instance, presidents may construct or strengthen national partisan institutions with which to exert influence in the legislative process and through which to implement their programs. Second, presidents may use popular appeals to create a mass base of support that will allow them to subordinate their political foes. This tactic is called "going public." Third, presidents may seek to bolster their control of established executive agencies or to create new administrative institutions and procedures that will reduce their dependence on Congress and give them a more independent governing and policy-making capability. A Presidents' use of executive orders to achieve their policy goals in lieu of seeking to persuade Congress to enact legislation is, perhaps, the most obvious example."
} 


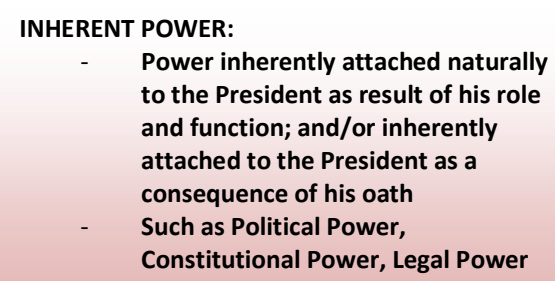

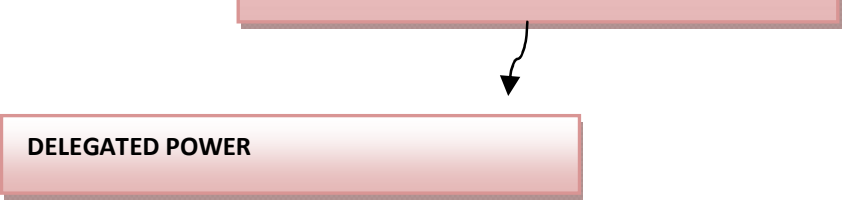

\section{e. The limits of the executive powers}

The exercise of the executive powers depends on other branches, in particular, the legislature and the Court. Therefore, executive power is not a power without check and balance from others. Mostly, none of the democratic countries give the executive broad and unchecked power even in the area of national security; all divide powers in this area between the executive and the legislature, often including a role for the courts as well. ${ }^{85}$ In general, contemporary democracies limit the executive powers and preserve a balance of political power with the legislature and the courts that protect liberty. ${ }^{86}$

In the US, the limitation over the executive branch is mainly by Congress: the Senate, by confirmation of presidential appointments and the ratification of treaties, and the House of Representatives by analyzing the budget and other forms of day-to-day scrutiny, shared by both chambers. ${ }^{87}$ The formal constitutional powers of the US President are originally the power that belongs to other branches. ${ }^{88}$ To this extent, the executive powers of the president are actually

\footnotetext{
${ }^{85}$ Martinez, Op. Cit., p. 2491.

${ }^{86} / d$. at p. 2510.

${ }^{87}$ William Storey, US Government and Politics, Edinburgh University Press, 2007, p. 236.

${ }^{88}$ Robert Singh, American Government and Politics: a Concise Introduction, Sage Publication, $1^{\text {ST }}$ publishing, 2003, p. 130: “..As Commander-in-Chief, for example, the president faces a Congress that possesses the exclusive responsibility to declare war and fund the armed forces. The Senate must ratify treaties that the president
} 
Rosa Ristawati: Modelling Executive Powers in the Indonesian Constitution: A comparative Study

not independent but depend on other branches.In a political sense, the executive power in the US may be checked by the Congress and Senate by some obvious political checks that can be used to restrain a president:

\begin{abstract}
"Congress has some obvious political checks it can use to restrain a president, such as refusing to pass key legislative proposals urged by the chief executive, overriding a presidential veto, or denying funding for presidential priorities. Congress may also pass legislation to reserve an executive order or to overturn administrative rules and regulations. Other tactics are Senate refusal to ratify treaties or attaching conditions and reservations to them, and, similarly, Senate failure to confirm a president's nominees for executive or judicial appointments. Upping the ante a bit is the practice of congressional oversight, both as a routine, ongoing activity to keep watch over executive branch agencies and departments, and, more pointedly, when claims of questionable executive branch conduct arise, where more specific congressional investigations may be warranted. This basic list of legislative checks against a president is, however, juxta-posed within an existing political context. Thus, in eras of divided government, it is reasonable, although not always correct, to presume a higher degree of contentiousness and confrontation between a president and Congress, while a period of unified party government presupposes fewer legislative checks and greater policy coordination and consensus. Even this rough generalization, to be more accurate, requires closer attention to the exact party make up in each chamber of Congress (and even to the relative strength of specific wings of each party in each house) and to the internal rules of each house". ${ }^{89}$
\end{abstract}

In most practice, the check from the Legislature may be imposed by a rejection of a legislative proposal or of state budget. Whereas, in order to balance the executive powers, the legislature may share the power with the executive branch, such as on the appointments, ministerial performance supervisory, and government policies review. Meanwhile, the Court may check the executive powers of the President. Nancy Kassop argued that the Court is a potent branch to limit the exercise of executive power and prevent the President from going beyond the boundaries. ${ }^{90}$ However, apart from all checks, there is always an opportunity for the President

negotiates and confirm presidential nominations. Although the president can recommend new legislative measures, Congress need not act on presidential recommendations and may even overturn a presidential veto of newly passed bills if two-thirds of both the House and Senate so vote. The Constitution, then, gives the president relatively few formal powers, other branches being accorded partial vetoes that limit even those it does confer."

${ }^{89}$ Nancy Kassop, The Constitutional Checks and Balances that Neither Check nor Balance in the Presidency and the challenge of Democracy edited by Michael A. Genovese and Lori Cox Han, Palgrave Macmillan, 2006, p. 75.

${ }^{90}$ Id. at p. 76: "The Courts can interpret Congress's statutory delegations of power to a president narrowly so as to reduce the president's range of action (as the Court did so notoriously to Franklin D. Roosevelt in the early 1930s in its interpretations of new deal legislation that delegated power to the executive branch), and they can declare unconstitutional the acts of a president, rejecting his interpretation of the scope of his constitutional powers, as the Supreme Court did to Truman in 1952 in Youngstown and to Nixon in 1974 in the Watergate tapes case.The Court did exercise its responsibility and determine the limits of executive power, and it did rebuke sitting presidents for going beyond those boundaries, though the Court was not willing to even enter the debate over war 
Rosa Ristawati: Modelling Executive Powers in the Indonesian Constitution: A comparative Study

to respond to all the checks and balances that other branches may invoke by, for example, using the veto power or wielding the appointment power. ${ }^{91}$

\section{f. Other mechanisms to constrain the executive power}

Besides the mechanism of checks and balances, some mechanisms are also significantly effective to restrain the executive powers. Jody C. Baumgartner argues that impeachment is the ultimate check on the power of a chief executive in a presidential system. ${ }^{92}$ Impeachment may be a signal that there is no perpetual branch existing with absolute power.

Other mechanisms to limit the executive powers may be taken by clarification and limitation of the application of the executive immunity in the Constitution. The idea of executive immunity is mostly beyond the doctrine that anyone is treated equally before the law. Commonly, immunity may be given conditionally in certain circumstances. In general, the ground of giving the immunity to the executive is mainly to encourage effective decision making and protect discretionary action from suits. ${ }^{93}$ However, according to some scholars, executive immunity may be granted to the executive as an absolute immunityor a qualified immunity. ${ }^{94}$ The chief executive is granted an absolute immunity when the immunity could shield him from all actions within the scope of his authority; on the other hand, a qualified immunity is given to the chief executive as a conditional immunity or a limited immunity

powers during the Vietnam War. The contrast was striking, given that membership of the Court was largely unchanged".

${ }^{91}$ Id. at p. 77: "Presidents can use their veto power to register their disagreement with legislative proposal with legislative proposals, and can wield their appointment power to nominate federal judges with the hope of trying to affect more favorably the outcome of future judicial decisions. The likelihood of success of either of these efforts, however, depends heavily on the political context in which presidents exert them. But the larger point is that this constant action reaction chain of events is a clear manifestation of Madison's handiwork and of Fisher's dialogue."

92 Jody C. Baumgartner, Introduction: Comparative Presidential Impeachment on Checking Executive power: Presidential Impeachment in Comparative Perspective Edited by Jody C. Baumgartner and Naoko Kada, Praeger Publishers, USA, 2003, p. 3: "Thus, although unwieldy, impeachment is the ultimate check on the power of a chief executive in a presidential system, and therefore, a fundamental democratic element of the system."

${ }^{93}$ See: Michael T. Matraia, "Presidential Immunity: Running For Cover Behind Presidential Immunity: the Oval Office as Safe Heaven From Civil Suits", Suffolk University Law Review, Vol. XXIX, 1995, pp. 195-231, p. 228 (accessed online from http://heinonline.org , 29/04/2012).

${ }^{94}$ See: Lyman G. Bullard, Jr," Absolute Presidential Immunity From Civil Damage Liability: Nixon v. Fitzgerald", Boston College Law Review, Vol. 24, Issue 3 No. 3, 1983, (accessed online from:

http://lawdigitalcommons.bc.edu/bclr/vol24/iss3/5 ). 
whenever he acts in good faith and reasonably in the circumstances. ${ }^{95}$ Furthermore, qualified immunity is about balancing the need to promote effective government and the interests of protecting citizens' constitutional rights; it provides fair protection for Presidents when there is a presidential function which does require absolute immunity. ${ }^{96}$

\section{Executive powers: $a-z$}

The executive powers include the whole state administration affairs; both in domestic and foreign areas. They cover all the strategic state affairs. The post-conflict organization has classified the executive powers into domestic affairs power and foreign affairs power. The domestic affairs power includes: (1) signing, promulgating, and executing laws, (2) vetoing legislation passed by the legislature, (3) declaring a state of emergency, (4) conferring titles, orders, and decorations, (5) granting individual pardons and amnesties, (6) appointing state officials and judges, (7) announcing elections, (8) calling referenda, and (9) dissolving the legislature. ${ }^{97}$ The foreign affairs power includes: (1) representing the state abroad; (2) negotiating the terms of treaties; (3) appointing ambassadors and envoys; and (4) accrediting and receiving foreign ambassadors and envoys. ${ }^{98}$ In general, there are at least 8 executive powers that are mostly found in the Constitutions, namely: the law-making power, the appointment power, the foreign affairs and treaty power, the administrative power, the emergency power, the military, war power, and the pardoning power.

\section{a. Law-making powers}

The law-making power may include the participation of the Executive in the legislative process, the power to make sub-ordinate laws, the power to make any executive rule, the power to make Emergency Laws (decree or executive order), and the power to make any other Executive Rules and Regulations. The legislative power, on the basis of separation of powers is commonly exercised by the Parliament or the Legislature; the Parliament has full authority over the whole legislative process, while the Constitutions confirm the right of the government to

\footnotetext{
${ }^{95}$ See: Michael T. Matraia, Op. Cit., p. 209.

${ }^{96}$ See: Id. p. 228.

${ }^{97}$ The Public International Law and Policy Group, Post-Conflict Constitution Drafter's Handbook, 2007, available online at: www.publicinternationallaw.org, p. 30.

${ }^{98}$ Id. at p. 32.
} 
submit draft bills. ${ }^{99}$ In some states like the US, the Executive does not have the right to formally submit a bill. By not having the right to submit a bill, it does not mean that the Executive has no power in the legislative process. The Constitution gives veto power to the executive. Veto power is more like a bridge in a divided government and veto bargaining is an essential part of a theory of divided government. Charles Cameron observed that under divided government, the probability of a veto increases dramatically with the significance of the legislation. ${ }^{100} \mathrm{~A}$ veto power in a legislative process will reflect the more democratic system of government. It gives an opportunity for the Executive to disagree with the Legislature and bring through the opportunity to bargain in a democratic sphere. According to Charles M. Cameron, the President can shape legislation through the vetoes:

\begin{abstract}
"There are three ways vetoes can shape legislation. First, an intransigentpresident can try to kill a bill. He uses the veto to force its re-passage,hoping outside events derail the legislation. Second, the president canforce Congress to craft a new, veto-proof version of the bill, one he maystill find objectionable but nonetheless preferable to the original version.Third, the president can force Congress to rewrite the vetoed bill, offeringenough concessions so he will sign the repassed bill. The presidentmay do this even though he would have been willing to sign the first billif it were a one-shot offer. In each of these cases the veto is a form ofstrategic holdout intended to shape the outcome of the inter-branch bargaining.Skillful presidents can use sequential veto bargaining to impresstheir preferences on policy much more than static conceptions of theveto would suggest". ${ }^{101}$
\end{abstract}

The veto does not always mean that a president can dominate the law-making power. Yet, it is not about a strong power since the veto could always be over-ridden by the legislature. However, a presidential system does not always provide the executive with veto power. Many presidential Constitutions do not have veto power for the executive; while some others give the veto power implicitly. The veto power cannot be used to assess whether the Executive has a significant and dominant power or whether it has weak power in a legislative process. The Executive with veto power may still be the dominant party when in the bargaining process $\mathrm{s} / \mathrm{he}$ can influence and raise support from the Legislature. On the other hand, veto power indeed appears as a weak power when it is over-ridden or waived. The Executive with the power to submit bills, on the other hand, may be weaker when there is lack of support from the

\footnotetext{
${ }^{99}$ Andraz Sajo, Op. Cit., p. 189.

${ }^{100}$ Charles M. Cameron, Veto Bargaining: Presidents and the Politics of Negative Power, Cambridge University Press, 2000, p. 125.

${ }^{101} / d$. at p. 20.
} 
majorityin the legislature. In general, the legislative power of the President does not depend on the veto power or the power to submit the bill. It mainly depends on the bargaining process between the President and the Legislature during the process, in the legislative session, or outside the legislative forum. The indicators for the legislative power of the Executive may be viewed from the portions of distributions between the executive and legislature. However, when the veto power is combined with the power to initiate a bill, the legislative power of the Executive may be dominant in the legislative process. Meanwhile, when the Executive has only the right to initiate or propose bills, the Executive has the ability to shape legislation and control the agenda by choosing a proposal. ${ }^{102}$ In this context, the President would have more portions of power than the legislature in the legislative process if the Constitution gives both legislative initiatives and a veto of the bills.

\section{b. Appointment powers}

In order to perform his roles and duties, the head of the executive branch has the power to appoint state officers. The appointment power may be only a formal power to appoint, or a real power acting as the final decision maker to nominate, to promote, to elect and to appoint including to dismiss and reshuffle. Commonly, the appointment powers include the power to appoint the executive officers and judges. The appointment powers are usually implied fromthe Constitution and from the laws. For example, in the US Constitution, the appointment clause in Article II explicitly vests the nomination power to the President and establishes three categories of federal officials namely: the non-inferior (or principal) officers, inferior officers, and nonofficers (employees). ${ }^{103}$

As the appointment power could be extended but not limited, usually, the power is exercised with checks and balances and is vested in the head of state or head of government. Some constitutions, such as the US Constitution and the Philippines Constitution, explicitly allow the appointment power to be exercised during the recess orduring the session. According

\footnotetext{
${ }^{102}$ Zachary Elkins, Tom Ginsburg, James Melton, Constitutional Constraints on Executive Making, accessed online at https://netfiles.uiuc.edu/melton/Files/melkinsburg executivepower.pdf, on January 6, 2012, p. 5.

103 Harvard Law Review, Appointment Clause and Longstanding Practice, The Harvard Law Association, Vol. 120, No. 7, 2007, pp. $1914-1935$, p. 1916.
} 
to the US Constitution, the appointment power may be exercised during the recess and has raised controversies since the power then is a unilateral power by the President without advice and consent from the legislature. ${ }^{104}$ The scopes of appointment are commonly clarified in the text of the Constitution as well as the mechanisms of appointment. It may include the judicial appointment (the appointment of judges), the executive appointment (the appointment of ministers, the appointment of state ambassadors and the Consuls, and other executive officers under the executive branch), the military appointment, and/or other political appointment.

\section{c. Administrative powers: internal state administration affairs,budget and expenditure, and other affairs of state government}

The administrative powers refer to the power to execute laws and to establish a state administration. The administrative powers also include the power to direct, control and supervise the ministerial cabinet and the executive departments as a whole, and state or local governments, issue executive regulations, the power to spend state budget that has been approved by the Legislature, establish any executive agencies and commission, and other state administrative affairs. In order to run the daily activities and state administration, the Executive usually has the privilege to submit budget bills. ${ }^{105}$ However, the power to approve the budget bill is vested in the Parliament.

\section{d. Emergency powers}

The emergency power is usually an extra-ordinary power to take any extraconstitutional actions in order to deal with a situation that cannot be dealt with by regular powers. The power may justify any actions deriving from discretionary powers and may allow suspension of rights. The exercise of emergency powers usually has a time limit so that any extra-ordinary actions may be applied only during an emergency situation. The emergency powers may be applied when the emergency situation cannot be sufficiently dealt with by regular powers set in the Constitution. Debates about the justification of such emergency

\footnotetext{
104 Jonathan Turley, Constitutional Adverse Possession: Recess Appointments and the Role of Historical Practice in Constitutional Interpretation, Winsconsin Law Review, 2013, pp. 965 - 1037, p. 967.

${ }^{105}$ Andraz Sajo, Op. Cit., p. 190: the Spanish Cadiz Constitution 1812 was the first Constitution giving the government the privilege to submit the budget proposal.
} 
Rosa Ristawati: Modelling Executive Powers in the Indonesian Constitution: A comparative Study

power, raised some pros and cons. However, it is believed that constitutionally and historically speaking, the power is not unlimited and unchecked. ${ }^{106}$ Within a constitutional framework, any institution attached with the emergency power is limited in itscoercive powers to deal with emergency situations. The emergency power is constrained by other branches which may check and balance the presidential emergency power. ${ }^{107}$

According to political and constitutional theory, the emergency powers have been discussed since the experience of dictatorship of the ancient Roman Republic right up to the modern democracy in the new era of global terrorism threats. ${ }^{108}$ According to John Ferejohn and Pasquale Pasquino, there are two main differences between the ancient classical Roman and the Constitution in modern era;

"In the Roman dictatorship the agency declaring the emergency (the Senate) is different from the agent appointing the official who can exercise the emergency powers (the Consuls), and is different from the agency exercising Emergency Powers (the dictator). Moreover, the dictator is not an active magistracy during the regular government. In the modern, or neo-Roman, model the head of the executive recognizes an emergency and the same agent exercises Emergency Powers. And, the executive is a regular (not a dormant) organ of the constitutional system. One can suspect immediately that the Romans were much more concerned with potential abuses of emergency powers than were the designers of the modern constitutions who perhaps put more faith in the fact that the executive had to stand for election." ${ }^{109}$

According to John Locke, the emergency power is an extra-legal power dictated by necessity that is given to the executive, and in nature was associated with the English doctrine of prerogative to deal with incidental necessities where the law-making power was excessive or too slow to be executed. On the other hand, it permits the executive to act with discretion for

\footnotetext{
${ }^{106}$ See: Louis Fisher, President's Game, Legal Times Vol. XXIX No. 49, 4 December 2006.

${ }^{107}$ Michael Freeman, Freedom or Security: The Consequences for the Democracies Using Emergency Powers to Fight Terror, Praeger Publisher, 2003, pp. 37: “..the power is constrained through the principle of state branches equality, liberty, and the concept of separation of power".

${ }^{108}$ John Ferejohn, Pasquale Pasquino, Emergency Power, in: The Oxford Handbook of Political Theory by John S. Dryzek, Bonnie Honig, and Anne Phillips, Printed from Oxford Handbooks Online (www.oxfordhandbooks.com), Oxford University Press, 2012, accessed online from Maastricht University Library Online on 30 January 2013, p. 1. ${ }^{109}$ Id. at p. 5.
} 
Rosa Ristawati: Modelling Executive Powers in the Indonesian Constitution: A comparative Study

the public good without prescription of the Law or even sometimes in contradiction with the Law, and it permits the disregard of even the direct letter of the Law. ${ }^{110}$

The emergency power is usually written in the Constitution. According to Bruce Ackerman, defining the scope of emergency power is a serious and sensitive concern. ${ }^{111}$ Ackerman considers that there are two kinds of emergency:

\begin{abstract}
"One kind is created by a terroristattack, an atomic blast, a killer epidemic, and another when the governmentis paralyzed and can't respond in a credible fashion. The first kind of emergency is an inevitability of twenty-first-centurylife and it will be a miracle if we can prevent all terrorist attacks, and I don'tbelieve in miracles. But the second kind is merely a product of an ostrich-likerefusal to confront the obvious inadequacies of our present arrangements.It doesn't take a rocket scientist to come up with a bettersolution; it just takes a little foresight and a bit of political will, not a lotsince there is little reason to expect significant political resistance" ${ }^{112}$
\end{abstract}

In common constitutional practice, the text of the Constitution usually provides certain circumstances that may be defined as an emergency, including International and internal conflict, direct military attack or military invasion, civil conflicts including internal disturbances, and is extended for other humanitarian catastrophes such as natural disasters, epidemics, famine, economic and political crisis, or any event which occurs and potentially contributes to the state's collapse, a threat to national security like terrorism. Such events may be an international or internal threat to the state and community. Modern Constitutions usually also provide checks and balances for such emergency powers. Courts have the main role to review any measure during the emergency, and to conduct post-checks against the constitutionality or legality of the use of emergency power. On the other hand, legislatures may have a role to set laws concerning the state emergency and put limits onthe use of emergency power. Modern Constitutions have attempted to set any measure that may be taken in time of emergency, and design certain limitations to the emergency power by providing strict and clear definitions of certain circumstances that may be classified as an emergency. The emergency powers are also restrained by international political and legal circumstances; while public participation would

\footnotetext{
${ }^{110} J u l e s$ Lobel, "Emergency Power and the Decline of Liberalism", the Yale Law Journal , Vol. 98, No. 7, May 1989, pp. 1385 - 1433, The Yale Law Journal Company, Accessed online athttp://www.jstor.org/stable/796748 on 20/03/2012, 12:13, p. 1392.

${ }^{111}$ Bruce Ackerman, Before the Next Attack: Preserving Civil Liberties in an Age of Terrorism, Yale University Press, 2006, p. 4.

${ }^{112}$ ld. at p. 168.
} 
reduce the power of the centralized government altogether with legal restraint provided horizontally within the national government by separation of powers and supplemented by vertical restraints imposed by international society and popular community pressures. ${ }^{113}$

The emergency powers include the power to determine certain circumstances as an emergency situation, the power to declare a state of emergency in part of the state or the state as a whole, the power to take any unilateral measures to deal with the emergency situation, and the power to issue and enact emergency laws. The emergency power is a temporary power. It may have a slightly unilateral character during the exercise of such power. However, the exercise of emergency power has a limited enforceability. After it has expired, such power may not be exercised unless it is authorized by the Legislature. However, according to Jules Lobel, the best response to anemergency situation is by forcing the President to immediately seek congressional and public ratification instead of putting a temporary limitation and allowing broad executive discretion. ${ }^{114}$

\section{e. Military powers}

The military power of the executive is commonly expressed in the Constitution as a consequence of the Commander in chief clause. Edward S. Corwin indicates divisions within the particular area of power:

- The power in the presence of domestic war, as shown by the events of the Civil War,

- The powers in the presence of conditions of violence, real, or threatened, that are less than war

- The powers in the establishment of martial law

- $\quad$ The power as the delegate of Congress when the country is involved in foreign war,

- The executive's organizational relations with the national forces. ${ }^{115}$

The power authorizes the executive to command the national forces in active service. Moreover, the military power also allows the executive to terminate hostilities and conduct peace negotiations. In peace situation, the power enables the executive to decide the mobilization of national military forces for peace-keeping or humanitarian intervention.

\footnotetext{
${ }^{113}$ Jules Lobel, Op. Cit., p. 1431.

${ }^{114}$ Jules Lobel, Op. Cit., p. 1428.

${ }^{115}$ Edward S. Corwin, The President Office and Powers: History and Analysis of Practice and Opinion, New York University Presss, p. 155.
} 
Rosa Ristawati: Modelling Executive Powers in the Indonesian Constitution: A comparative Study

\section{f. Foreign affairs power}

The foreign affairs power is generally derived as a consequence of the role of the executive as the head of state. According to Michael Genovese, the powers can be classified as the inherent power of the executive. However, since foreign affairs are also state affairs, the powers may also be executed by the executive as the head of the government. The powers are generally specified in the Constitution although the term foreign affairs power is not commonly written in the Constitution. Foreign affairs powers implied in the Constitution cover the treaty power, the diplomacy power, foreign policy making, conducting peace keeping operations, and other external affairs.

According to the British precedents, all the external affairs are assigned to the monarch including declaring wars, raising armies, making treaties, appointing ambassadors, and issuing letters of marque and reprisal (to authorize private citizens to engage in military actions. ${ }^{116}$ Prakash and Ramsey argued that the foreign affairs powers arose from the executive power of the Crown under a parliamentary system; while in a presidential system, the foreign affairs power is given to the President which implies that the President has the executive power including the foreign affair power. ${ }^{117}$ In some countries, like in the US, Louis Fisher observed that not all foreign affairs power was given to the President:

" the US Constitution grants not a single one of those powers to the president. The powers to declare war, mobilize armies, and issue letters of marque and reprisal are placed exclusively in Congress. The powers to make treaties and appoint ambassadors are given jointly to the president and the Senate" . ${ }^{118}$

The foreign affairs power of a President may be determined as enumerated powers that include the President's explicit power to make treaties (with the advice and consent of the senate),

\footnotetext{
${ }^{116}$ Louis Fisher, From Presidential Wars to American Hegemony: the Constitution: the Constitution After 9/11 in the Presidency and the challenge of Democracy edited by Michael A. Genovese and Lori Cox Han, Palgrave Macmillan, 2006, p. 24.

${ }^{117}$ Saikrishna B. Prakash and Michael D. Ramsay, "the Executive Power over Foreign Affairs", The Yale Law Journal, Vol. 111:231/2001, pp. $236-355$, p. 253.

${ }^{118}$ Louis Fisher, Op. Cit., p. 24.
} 
Rosa Ristawati: Modelling Executive Powers in the Indonesian Constitution: A comparative Study

appoint ambassadors (with the advice and consent), and to receive foreign ambassadors (considered in the context of a broader foreign affairs). ${ }^{119}$

With regard to the treaty power, Louis Henkin argued that the treaty making power is an important power not only as an occasional power; the appointment of ambassadors is an ordinary routine, not consequential, and even more infrequent; receiving ambassadors seems as a function and assigned duty, a ceremony that in many countries is performed by a figurehead. ${ }^{120}$ While the treaty making powers are explicitly laid down in the Constitution, most of the Constitutions are silent about the treaty termination power. Louis Henkin considered that the silence of the Constitution renders a textual analysis impossible, but the nature, character, and structure of the treaty-making power permits logical inference to determine the locus of the authority to terminate treaties. ${ }^{121}$

\section{g. War powers}

The war power is one of constitutional powers to empower the executive branch to act not above the law, but within the Constitution and in order to protect the state. ${ }^{122}$ The war powers include the power to declare war, the power to mobilize the military force and the power to order any military actions. The war power in a parliamentary system commonly requires parliamentary consent. Parliamentary consent for the performance of war power may have several beneficial effects: parliamentary consent in war power accords more legitimacy to, and consolidates popular support for, military operations, increasing their effectiveness, providing the public with a strong incentive to avoid unnecessary wars, keeping military forces anchored in a given society, in contrast to standing armies, which tend to embrace interests which differ from those of citizens. ${ }^{123}$

\footnotetext{
${ }^{119}$ Louis Henkin, Foreign Affairs and the United States Constitution, Clarendon Press, Oxford University Press, $2^{\text {nd }}$ edition, 1997, p. 35.

${ }^{120} / d$. at p. 38.

${ }^{121}$ David Gray Adler, the Constitution and the Termination of Treaties, Garland Publishing, Inc, New York \& London, 1986, p. 85.

122 Jeffrey A. Smith, War and Press Freedom: The Problem of Prerogative Power, Oxford University Press, 1999, p. 16.

${ }^{123}$ Yasuo Hasebe, War Power, in: The Oxford Handbook of Comparative Constitutional Law edited by Michel Rosenfeld and Andras Sajo, Oxford University Press, 2012, p. 456.
} 
Rosa Ristawati: Modelling Executive Powers in the Indonesian Constitution: A comparative Study

In the UK, the war powers are vested solely in the executive and it leaves the British Parliament having no formal role in the deployment of the armed forces. ${ }^{124}$ However, according to the Bill of Rights of 1689, a standing army within the Kingdom in time of peace, unless it be with consent of Parliament, is against the law; thus, while the Royal Navy may be maintained without authorization by virtue of prerogative, the authority of Parliament is required for the maintenance of the British Army, the Royal Air Force, and other land-based forces. ${ }^{125}$ The war power in the UK is proposed to require a parliamentary consent. ${ }^{126}$ However, the war power in a presidential system finds an ambiguity. In most of the presidential constitutions, the war power is formally vested in the executive but practically develops into more ambiguous ones since it mostly requires the authorization from the legislatures.

In general, the definition of war in the constitutions may be defined differently. Seth Weinberger observed that legal theorists and policy makers generally staked out two opposing views defining the constitutional meaning of a war declaration clause:

\begin{abstract}
"On one side are those who argue for the broadest understanding of the declare war clause and a very limited conception of executive power. In this formulation, war must be formally declared each and every time American troops are to be sent into battle (with the possible exception of a sudden attack on American soil in which the enemy must be met before deliberations over declaring war can be held). On the other side are those who read a very narrow definition of the declare war clause, and claim that declarations of war are only necessary in extreme cases and are used to transform the legal status of the nation from a peacetime to a wartime footing. This side tends to argue that such a transformation does not require a formal declaration of war, but can be achieved through various kinds of congressional authorizations. A declaration of war, in the narrow definition, is only necessary to activate certain domestic laws that are not part of the president's war powers, such as the power to seize private property or establish price controls or rationing patterns."127
\end{abstract}

In practice, declaring war could be by formally declaring war, claiming military confrontation to other states, or by launching a military operation against other states. However, some Constitutions, for example the US Constitution, give the war power to the Congress, while the formality to declare war has to be done by the President. Whereas, some constitutions, such as the Indonesian Constitution give the war power to the President.

\footnotetext{
${ }^{124} / d$. at p. 466.

${ }^{125}$ Id .at p. 466.

${ }^{126} / d$. at p. 467.

${ }^{127}$ Seth Weinberger, Restoring the balance : war powers in an age of terror, Greenwood Publishing Group, 2009, p. 22.
} 
Rosa Ristawati: Modelling Executive Powers in the Indonesian Constitution: A comparative Study

\section{h. Pardoning powers}

The pardoning power is the power to grant pardon, clemency, abolition, reprieve, amnesty, commutation and any kind of removing all or some of the monetary penalties (fines and forfeiture), or the punitive consequences of a criminal conviction. ${ }^{128} \mathrm{It}$ is a singular tool of governance that is intended to restore balance in the justice system and put important issues on the national agenda. ${ }^{129}$ The power may be exercised unconditionally or conditionally, given as full or partial pardon by the head of the state or the executive. It can be exercised by changing the punishment (in the case of death penalty to life imprisonment), reprieve the punishment, pardon or remit the punishment. The pardoning power comes from the British Crown which was vested in the Monarch in accordance with the Monarch's divine right to rule. $^{130}$

According to the US legal system, the pardoning power may be in the form of pardon, amnesty, reprieve, commutation and remission of fines; and may be exercised in an absolute, full, or unconditional pardon in which the pardon is granted without any conditions; or partial or conditional pardon which limit the pardon in time. Some scholars distinguish between amnesty and pardon by saying that amnesty is in the legislative area. ${ }^{131}$ In Russia, the Duma

\footnotetext{
${ }^{128}$ James N. Jorgensen, "Clemency and Pardons Note", University of Richmond Law Review, Vol. 27/1993, pp. 345 370, (accessed online from heinOnline http://heinonline.org on 01/04/2012), p. 347: "Amnesty typically is extended to individuals who are subject to trial but have not yet been convicted. Although amnesty has largely the same legal effect as a pardon, it does not eliminate from a person's record the offense for which punishment is being remitted. A reprieveon the other hand, the most limited form of clemency, is the temporary post-ponement of the execution of a sentence. Unlike other forms of clemency, a reprieve does not defeat the eventual imposition of judgment. It merely withdraws the sentence for a specified time period.Commutation also is within the president's clemency powers. Commutation is the substitution of a lesser sentence for the original punishment imposedby a court. Unlike a pardon, it does not disturb the legal consequencesthat may attach to a conviction. Finally, the authority to remit fines and forfeitures which accrue from offenses against the United States is also within the broad ambit of the president's clemency powers. The president's power to remit fines and forfeitures, however, is limited to monetary penalties which have not yet been paid to the United States".

${ }^{129}$ Leon Neyfakh, The Untapped Power of Pardons, Boston Globe, March, 17, 2013.

${ }^{130}$ Jonathan T. Menitove, "The Problematic Presidential Pardon: A Proposal for Reforming Federal Clemency", Harvard Law and Policy Review, Vol. 3, 2009, pp. 447 - 460, p. 499.

${ }^{131}$ See more on Jody C. Baumgartner and Mark H. Morris (Politics and Policy, Vol. 29, No. 2/June 2001), p. 214, about the distinguishes between the executive pardons and the legislative amnesty.
} 
may give amnesty and sometimes serves as a positive check on the presidential pardoning power. $^{132}$

In common practice, the pardoning power is given to the head of the state or generally to the executive with the rationale that the executive may give effect to widespread public opinion in favor of or against the sentence of a particular accused person. ${ }^{133}$ Naturally, the pardoning power is typically broad without significant constraints. ${ }^{134}$ Considering the nature of pardoning power as merely a prerogative power, without significant limitation, as well as to ensure the accountability of such power in modern democratic atmosphere, James $\mathrm{N}$. Jorgensen suggests that the pardoning power is exercised only after trial, conviction, and sentencing; and only in certain offences. ${ }^{135}$

\subsection{Executive Power in a Comparative Study: Different Models of Constitution of Government System and Experiences}

\section{a. A comparison of constitutional models in different government systems}

This section discusses the classic model of constitutional government systems in modern democracies commonly studied in most of literatures, namely: parliamentary constitutions, presidential constitutions, and hybrid/ intermediate constitutions. The focus of this part is on the executive branch and its powers. It provides a general overview on how executive powers are written in the text of the Constitution and how the Constitution prescribes the exercise of the powers. The Constitutions chosen represent different government systems: Germany, South Africa, the US, the Philippines, France and Poland. ${ }^{136}$ The US Constitution is a primary example of a presidential Constitution. ${ }^{137}$ France's hybrid system embeds the concept of

\footnotetext{
${ }^{132} / d$. at p. 226.

133 Parul Kumar, "The Executive Power to Pardon", NUJS Law Review, Vol. 2/2009, p. 12.

${ }^{134}$ Jody C. Baumgartner and Mark H. Morris, Op. Cit., p. 209.

${ }^{135}$ James N. Jorgensen, "Clemency and Pardons Note", University of Richmond Law Review, Vol. 27/1993, pp. 345 370, (accessed online from heinOnline http://heinonline.org on 01/04/2012), p. 368.

${ }^{136} \mathrm{All}$ the compared states are secular states since even though Indonesia is a muslim majority state, Indonesia is a secular state. None of the compared states is an Islamic state since an Islamic Constitution would have different constitutional values of government as a secular Constitution. The comparison is addressed to adopt the constitutional terms and constitutional mechanisms that may have been written in the compared constitutions.

${ }^{137}$ The US Constitution would be the most dominant comparison to be discussed. The US Constitution would be more compared since the US presidential system is the role model for Indonesia. It is also the real-nature of a presidential constitution.
} 
Rosa Ristawati: Modelling Executive Powers in the Indonesian Constitution: A comparative Study

executive powers and how they develop in modern days. The German post-war and Polish Constitution represent modern constitutions. On the other hand, South Africa with a progressive constitutional development, after being revived from constitutional crisis, has managed and developed the constitutional system progressively. The Constitution of the Philippines is chosen because the Phillippines is a state in South East Asia relevant for regional comparison. It may give a spectrum of development from an entrenched democracy and constitutionalism under a similar presidential system as Indonesia. Two Constitutions are chosen to represent a parliamentary system model: the German Constitution and the South African Constitution. Under the parliamentary system, both Constitutions provide a contrasting experience of an executive branch. The Philippines Constitution is chosen on the basis that it represents alternative aspects of the presidential system, namely, a low level presidential systemas the President has more weight and hassubstantial powers, but meanwhile, the parliament has less power to check on the president's powers. The French Constitution and the Polish Constitution are chosen since both Constitutions have been known as the first observed Constitutions with a hybrid or semi presidential system. The semi presidential system establishes a unique dual executive. The French Constitution may have some modern mechanisms that are relevant to be of inspiration for Indonesia. Poland, on the other hand, has developed its Constitution with more modern concepts and it has set a coherent-systematic framework for the executive and executive powers.

b. Executive power: reflections on countries with a parliamentary system (a fusion power: executive and legislative)

\section{Germany}

Germany is a republic with a parliamentary system as the system of government. It is a federal state. As a parliamentary system, the head of state and the head of government are separated. The head of state is the Federal President and the head of government is the Federal Chancellor. The Germany Constitution is the German Basic Law (Grungesetz fur die Bundesrepublik Deutschland) of 23 May 1949 as amended by federal statute of 29 July 2009 and incorporating the amendments resulting from the federal statute of 8 October 2008 which 
Rosa Ristawati: Modelling Executive Powers in the Indonesian Constitution: A comparative Study

entered into force with the Treaty of Lisbon on 1 December $2009 .{ }^{138}$ The German Basic Law does not explicitly clarify what are the executive powers, but instead implicitly refers to them in some of the provisions. The German Basic Law provisions indicate that the executive power belongs to the Federal Government which consists of the Federal Chancellor and the Federal Minister, and the Lander as a consequence that German is a federal state. The Lander has the executive power in a Land. It has also the power to execute federal laws in their own right. ${ }^{139}$

\section{The Federal president}

The German Basic Law determines the Federal President as the head of the state. The Federal President is absolutely not the Federal government. According to Article 55 section (1), the Federal President may not be a member of the Federal Government or of a legislative body of the Federation or of a State. In general, the Federal President is not a strong President; it is because the German Basic Law does not provide provisions to empower the Federal President with real powers and does not create a strong presidency; while also, the Federal President has a weak office because he is indirectly elected without strong popular support in order to make discretionary actions. ${ }^{140}$ In most of the powers, the Federal President has no real influence other than formal power on behalf of the Federation and acting as the Federation representation. The Federal President has limited powers in practice. Article 58 of the GermanBasic Law states that all instructions and orders (except for the appointment and dismissal of the Federal Chancellor, the dissolution of the Bundestag under Article 63 and the request to the Federal Chancellor or a federal minister to continue the affairs until the appointment of a successor under Article 69 (3)), made by the Federal President require the counter-signature of the Federal Chancellor or the competent federal minister for the validity. On the other hand, Heringa and Kiiver mention two presidential powers which stand out in the Federal President; firstly, the Federal President may, and in fact can, refuse to sign legislation

\footnotetext{
${ }^{138}$ Philipp Kiiver and N. Kornet, eds, the Maastricht Collection: Selected National European and International Provisions from Public and Private Law, Second Edition, Groningen, Europa Law Publishing, 2010.

${ }^{139}$ Deutscher Bundestag, Basic Law for the Federal Republic of Germany, Translated by Christian Tomuschat and David P. Currie, Donald P. Kommers in cooperation with the Language Service of the German Bundestag, Printed version at November 2012: Article 83 German Constitution.

${ }^{140}$ Aalt Willem Heringa and Philipp Kiiver, Constitutions Compared: An Introduction to Comparative Constitutional Law, $3^{\text {rd }}$ Edition, Intersentia, UK, 2012, p. 138.
} 
Rosa Ristawati: Modelling Executive Powers in the Indonesian Constitution: A comparative Study

that in his view violates the Basic Law when he promulgates bills adopted on the federal legislative process; while he may not veto legislation for political reasons; and secondly, the formal power to dissolve the Bundestag. ${ }^{141}$

The Federal President is indirectly elected by the Federal Convention (Bundesversammlung which consists of the members of the Bundestag and an equal number of members who are elected by the parliaments of the States on the basis of proportional representation. ${ }^{142}$ An absolute majority vote is required. Within the term of office, the Federal President can be impeached. Article 61 section (1) stipulates that the Bundestag or the Bundesrat (at least a quarter of the members of the Bundestag or a quarter of the votes of the Bundesrat for a motion to impeach and a majority of two-thirds of the members of the Bundestag or two thirds of the votes of the Bundesrat for the decision to impeach) may impeach the Federal President for an intentional violation of the Basic Law or another federal statute before the Federal Constitutional Court. Furthermore, Article 61 section (2) determines that the Federal Constitutional Court establishes the prosecution and decides whether the Federal President is guilty or not for having committed an intentional violation of the Basic Law or another federal statute and may declare the Federal President is removed from the office, and thus, may rule that he is prevented from exercising the functions as a Federal President.

On law-making power, the Federal President has the formal power to certify a bill into federal legislation according to Article 82 section (1) the German Basic Law. On the appointment power, the Federal President only has formal power to appoint and to dismiss the Federal Chancellor. However, he has the power to nominate a candidate for the Federal Chancellor. The Federal President also has the formal power to appoint and dismiss federal ministers according to Article 64 the German Basic Law. Article 60 Section (1) grants the Federal President the power to appoint and dismiss the federal judges, federal civil servants, officers and non-commissioned officers as far as statutory regulation does not provide to the contrary. The Federal President has the power to formally dissolve the Bundestag in a conditional situation according to Article 63 section (4) and Article 68 section (1) the German Basic Law.

\footnotetext{
${ }^{141} / d$. at p. 139.

${ }^{142}$ Deutscher Bundestag, Op. Cit., Article 54 section (3) the German Basic Law.
} 
On the foreign affairs power, as the head of the state, the Federal President, on behalf of the Federation has the treaty power. He represents the Federation in international law. According to Article 59 section (1), the Federal President has the power on behalf of the Federation to conclude treaties with foreign states and accredits and receives envoys. However, this power does not fully depend on the Federal President but is limited, particularly with regard to the treaties which regulate the political relations of the Federation, or which refer to objects of federal legislation; for this reason, the treaty power of the Federal President requires the consent or participation of the organs competent for such federal legislation in the form of a federal statute. Furthermore, for administrative agreements, the regulation regarding the federal administration is said to be applied as mutatis mutandis. ${ }^{143}$

On the emergency power, the Federal President in a particular situation, referring to Article 68, has the power to declare a legislative emergency with the consent of the Bundesrat. Furthermore, in terms of the state emergency, according to Article 115a section (1) the German Basic Law, it is the power of the Bundestag with the consent from the Bundesrat and on the request of the Federal Government, to declarea state of defense. However, the Federal President has the authority in accordance with section 3 of the Article to publish the pronouncement of the state of defense. Furthermore, section 4 and section 5 of the Article emphasize that the Federal President only has the formal power to publish the declaration of the state of defense; section 5 of the Article precisely stipulates that if the finding of a state of defense has been published and the territory of the Federation is being attacked by force of arms, the Federal President may with the consent of the Bundestag make a declaration under international law regarding the existence of a state of defense. Contrary to the publication of the declaration of the state of defense, if the state of defense is declared to be terminated by the Bundestag with the consent of the Bundesrat, the Federal President has the formal power to publish the declaration of the state of defense termination. ${ }^{144}$

\footnotetext{
${ }^{143}$ Id. Article 59 section (1) the German Basic Law .

${ }^{144} / d$. Article 115 I section (2) the German Basic Law.
} 
Rosa Ristawati: Modelling Executive Powers in the Indonesian Constitution: A comparative Study

On the pardoning power, although he may transfer the powers to other authorities ${ }^{145}$, Article 60 of the Germany Basic Law grants the Federal President the pardoning power in individual cases on behalf of the Federation. ${ }^{146}$ The pardoning power of the Federal President is as a consequence that he is the symbol of the Federation and formally gives the pardon as a personification of the Federation.

\section{The Federal Government and the executive powers}

The Federal chancellor is the executive who is subject to the parliamentary motion of censure. The federal chancellor can be brought down by qualified procedure in Bundestag (the lower chamber). Moreover, Chapter VI of the German Basic Law stipulates about the Federal Government. Article 62 of the German Basic Law defines the Federal Government as the Federal Chancellor (Bundeskanzler) and the federal ministers. According to Article 63 section (1) and (2) the German Basic Law, the Federal Chancellor is elected, on the proposal of the Federal President, by the Bundestag without debate by a majority vote of the members of the Bundestag. Like the Federal Chancellor, the Federal ministers according to Article 64 section (1) are appointed and dismissed by the Federal President on the proposal of the Federal Chancellor.

According to Article of 65 the German Basic Law, the Federal Chancellor has the power to (1) determine the guidelines of the policy and bear responsibility for that; (2) direct its affairs according to rules of procedures as adopted by the Federal Government and approved by the Federal President. However, in general, the German Constitution implies that the executive powers are mostly exercised by the Federal government. The Federal Chancellor can not exercise the powers individually. Accordingly, the Federal government consists of the Federal Chancellor and the Federal ministers.

On the area of law-making power, the Federal Government has the power to introduce Bills in the Bundestag according to Article 76 of the German Basic Law. Furthermore, Article 80 of the German Basic Law, the Federal Government, a federal minister or the State Governments has the power to adopt ordinances (Rechtsverordnungen) which require the consent of the

\footnotetext{
${ }^{145} / d$. Article 60 section (3) the German Basic Law.

${ }^{146} / d$. Article 60 section (2) the German Basic Law.
} 
Rosa Ristawati: Modelling Executive Powers in the Indonesian Constitution: A comparative Study

Bundesrat. In terms of the appointment power, the Federal Chancellor has the power to appoint a federal minister as his deputy according to Article 69 (1) of the German Basic Law. The German Basic Law vests the Chief Commander power of armed forces to the Federal Chancellor. $^{147}$

On the administration power, the Federal Government in particular the Minister of Finance has the expenditure power with the supervision of the Bundestag. ${ }^{148}$ In the end of the financial term, if by the end of a fiscal year the budget for the following year has not been established by a statute, the Federal Government is empowered, until its entry into force, to make all expenditures that are necessary to maintain statutory institutions and to carry out statutory measures, to fulfill the legal obligation of the Federation, and to continue constructions, acquisitions and other services, or to continue to grant benefits for these purposes, to the extent that amounts have already been approved in the budget of a previous year. ${ }^{149}$ Furthermore, the Federal Government has the power to mobilize the funds necessary for sustaining operational management up to a maximum of one quarter of the total amount of the previous budget by way of a credit. ${ }^{150}$

According to Article 84 the German Basic Law, the Federal government has the power to issue general administrative regulations with the consent from the Bundesrat. Section (4) of the Article authorizes the Federal Government with the power to issue individual instructions in particular cases with regard to the execution of the Federal statutes. Section (3) of the Article stipulates that the Federal Government has the power to supervise the federal statutes execution in accordance with the applicable law by the States and by this purpose, the Federal Government has the power to send agents to the highest State authorities also to subordinate authorities, with their consent, or if such consent is refused with the consent of the Bundesrat. As a result of the supervision, the Federal Government, according to section (4) of the Article may request to the Bundesrat that the State has violated the law while it may be challenged before the Federal Constitutional Court.

\footnotetext{
${ }^{147}$ Id. Article $115 \mathrm{~b}$ the German Basic Law.

${ }^{148} / d$. Article 112 - 114 section ( 1 the German Basic Law).

${ }^{149} / d$. Article 111 section (1) the German Basic Law.

${ }^{150}$ Id. Article 111 section (2) the German Basic Law.
} 
Rosa Ristawati: Modelling Executive Powers in the Indonesian Constitution: A comparative Study

On the emergency power, the Federal Government is also empowered with emergency power. Article $115 \mathrm{f}$ of the German Basic Law strengthened the Federal Government with some particular powers in times of state emergency in so far as the circumstances require. Those powers include the power to use the Federal Border Guard throughout the entire territory of the Federation and the power to give orders, both to the federal administration and to the State governments and, if it considers it to be urgent, to the State authorities and transfer the power to members of the State government to be determined by it. ${ }^{151}$ However, the execution of such powers should be notified to the Bundestag, the Bundesrat and the Joint Committee.

\section{South Africa}

The South African Constitution does not explicitly describe the choice of the government system. However, according to some provisions, the system of government is indicated as a parliamentary system. The Constitution designates a presidency and recognizes the President as both the head of the state and the head of government. The powers of the President are mostly the same as the President in presidential countries with a president and cabinet, and a bi-cameral legislature and a judiciary including a constitutional court. ${ }^{152}$

One of the parliamentary system characters is reflected from the President's appointment. The President is not directly elected but appointed by the parliament (National Assembly) from among its members and may be removed by a two-thirds vote of the National Assembly on the grounds of serious violation of Constitution or the Law, serious misconduct or inability to perform the function during his office. ${ }^{153}$ The South Africa Constitution designates a Presidency within a parliamentary Constitution. The President is the head of state and the head of government but he actually depends on the parliament. The Constitution distinguishes between two executive branches, namely: the national executive and the provincial executive. The national executive is in the hands of the President; while, the provincial executive is in the hands of the Premier.

\footnotetext{
${ }^{151} / d$. Article $115 f$ section (1) the German Basic Law.

${ }^{152}$ Robert L. Maddex, Constitution of the World, $3^{\text {rd }}$ Edition, Congressional Quarterly (CQ) Press, Washington D.C., 2008, p. 395.

${ }^{153}$ The Oxford Handbook of Comparative Constitutional Law, edited by Michel Rosenfield and Andras Sajo, Oxford University, 1st Edition, 2012, p. 557.
} 
Rosa Ristawati: Modelling Executive Powers in the Indonesian Constitution: A comparative Study

\section{- The National Executive}

The South African Constitution distinguishes the executive branch from the national executive and the provincial executive. It stipulates that the President as the head of the executive is elected from the National Assembly; the President has the power to appoint members of the government which are invested with their functions and are accountable collectively and individually to Parliament for the exercise of their powers and the performance of their functions. ${ }^{154}$ It reflects that the President and the government rely on the Parliament and in general are secured through motions of confidence or no confidence.

In general, the national executive branch and its powers are stipulated in Chapter 5 of the Constitution. Article 83a of the Constitution explicitly admits that the President has functions as the head of the State and the head of the national executive. According to the Article, the President has some constitutional obligations to uphold, defend, and respect the Constitution as the Supreme Law of the Republic and promote the unity of the nation that will advance the Republic. ${ }^{155}$ In order to perform the functions as head of state and head of the national executive, the President is said to have powers that are guaranteed in the Constitution and the legislation. ${ }^{156}$ According to Article 42 section (5) of the South African Constitution, the President has the power to summon Parliament to an extraordinary sitting at any time to conduct special business. Article 84 section (2) of the South African Constitution determines that the President is responsible for:

\footnotetext{
a. assenting to and signing Bills;

b. referring a Bill back to the National Assembly for reconsideration of the Bill's

c. referring a Bill to the Constitutional Court for a decision on the Bill's constitutionality;

d. summoning the National Assembly, the National Council of Provinces or

e. making any appointments that the Constitution or Legislation requires the President to make, other than as head of national executive;

f. appointing commissions of inquiry

g. calling a national referendum in terms of an Act of Parliament;

h. receiving and recognizing foreign diplomatic and consular representatives;
}

\footnotetext{
${ }^{154}$ Anthony W. Bradley and Cesare Pinelli, Op. Cit., p.663.

${ }^{155}$ Constituteproject.org, South Africa's Constitution of 1996 with Amendments through 2012, generated from excerpts of texts from the repository of the Comparatice Constitutions Project and distributed on constituteproject.org, Pdf generated 23 May 2016: Article 83b, Article 83c the Constitution of the Republic of South Africa.

${ }^{156} / d$. Article 84 section 1 the Constitution of the Republic of South Africa.
} 
i. appointing ambassadors, plenipotentiaries, and diplomatic and consular representatives;

j. pardoning or reprieving offenders and remitting any fines, penalties or forfeitures and

k. conferring honours. ${ }^{157}$

The Constitution confirms that the President is the executive authority in Article 85 of the South African Constitution. The President as the executive authority here is referred to as the one who exercises the executive power together with the other members of the Cabinet. The state administrative powers include the following:

a. powers to implement national legislation except where the Constitution or an Act of Parliament provides otherwise;

b. powers to develop and implement national policy;

c. powers to coordinate the functions of state departments and administrations;

d. powers to prepare and initiate legislation;

e. powers to exercise any other executive functions provided for in the Constitution or in national legislation.

On the law-making power, according to the South African Constitution, the President of South Africa has the power in the law-making process. The powers include assenting to and signing Bills, referring a Bill back to the National Assembly for reconsideration of the Bill and referring a Bill to the Constitutional Court for a decision on the Bill's constitutionality. Article 79 (1) states that the President must assent to the bill when the National Assembly passes a bill. ${ }^{158}$ However, he may refuse to assent to a bill only on the grounds of its unconstitutionality. ${ }^{159}$ In this case, the South African Constitution states that the President may refer a bill back to the National Assembly for reconsideration. ${ }^{160}$ If the bill after the reconsideration has accommodated the President's concern on the constitutionality, the President must assent to and sign the bill or refer the bill to the Constitutional Court for a decision about the constitutionality of the bill. ${ }^{161}$ The President must assent to and sign a bill if

\footnotetext{
${ }^{157} / d$. Article 84 section 2 the Constitution of the Republic of South Africa.

${ }^{158} / d$. Article 79 (1) the Constitution of the Republic of South Africa.

${ }^{159} / d$. Article 79 (1) the Constitution of the Republic of South Africa.

${ }^{160} / d$. Article 79 ( 1 the Constitution of the Republic of South Africa).

${ }^{161}$ Id. Article 79 (4) the Constitution of the Republic of South Africa.
} 
the Constitutional Court decides that the bill is constitutional. ${ }^{162}$ There is no veto power for the South African President. The Constitution protects the independence of the Legislature from the Executive by providing a check on the presidential power to block the passage of legislation. ${ }^{163}$

On the Cabinet and other appointment power, according to Article 91, the President has the power over the Cabinet. Article 91 section (1) points out that the President has the power to appoint the Deputy President (who will assist the President in the administration of the functions of government) and Ministers, assign the Deputy President and Ministers' powers, and dismiss them. In terms of the Deputy President's appointment, the President performs his power by selecting the candidate from among the members of the National Assembly. ${ }^{164}$ In exercising the minister appointment power, the President selects any number from among the members of the Assembly; and no more than two Ministers from outside the Assembly. ${ }^{165}$ Article 91 section (4) also clarifies that the President has the power to appoint a member of the Cabinet to be the leader of government business in the National Assembly. ${ }^{166} \mathrm{As}$ a result of the Presidential appointment power, the Deputy President and Ministers are responsible for the executive powers and functions assigned by the President; however, they are collectively and individually accountable to the Parliament. ${ }^{167}$

In order to assist the powers and functions of the Minister in the Cabinet, Article 93 gives the President the power to appoint and dismiss any number of Deputy Ministers from among the members of the National Assembly and no more than two Deputy Ministers from outside the Assembly; on the other hand, they will be responsible to the Parliament. ${ }^{168}$ Moreover, Annex B of the Constitution sets out in more detail on the Cabinet appointment by the President. As stated in the Constitution, the Cabinet of South Africa consists of the

\footnotetext{
${ }^{162} / d$. Article $79(5)$ the Constitution of the Republic of South Africa.

${ }^{163}$ Ndulo, Muna, "Presidentialism in the Southern African States and Constitutional Restraint on Presidential Power" (2002), Cornell Law Faculty Publications paper 62, p. 780, accessed online via: http://scholarship.law.cornell.edu/facpub/62.

${ }^{164}$ Constituteproject.org, Op. Cit., Article 91 Section 3a the Constitution of the Republic of South Africa.

${ }^{165} / d$. Article 91 section $3 b$ and $3 c$ the Constitution of the Republic of South Africa.

${ }^{166} / d$. Article 91 the Constitution of the Republic of South Africa.

${ }^{167} / d$. Article 92 the Constitution of the Republic of South Africa.

${ }^{168} / d$. Article 93 the Constitution of the Republic of South Africa.
} 
Rosa Ristawati: Modelling Executive Powers in the Indonesian Constitution: A comparative Study

President, the Executive Deputy Presidents and ministers as determined in Article $91 .{ }^{169}$ The executive deputy President is designated by the President among the members of the Assembly. ${ }^{170}$ On the other hand, the cabinet appointment and the President's power over the cabinet are based on the procedures as determined by Article 91 section 8 - section 15 .

The Constitution of South Africa allows the President to establish deputy ministerial posts. ${ }^{171}$ The procedures of the deputy ministerial appointment are set in Article 93 section 2 3. ${ }^{172}$ The Deputy of ministers has the duties to exercise and perform on behalf of the relevant minister any of the powers and functions assigned to that Minister in terms of legislation and subject to the directions of the President. ${ }^{173}$ Meanwhile, the President has the power over the deputy minister and can take any action during the deputy minister's absent. ${ }^{174}$ The ministers are accountable individually to the President and to the National Assembly for the administration of their portfolio. ${ }^{175}$ However, according to Article 102, the National assembly has the power to pass a motion of no confidence in the Cabinet but not including the President. In this situation, the President must reconstitute the Cabinet. ${ }^{176} \mathrm{By}$ a vote supported by a majority of its members, the National Assembly may pass a motion of no confidence in the President, and the President and the other members of the Cabinet and any Deputy Ministers must resign. ${ }^{177}$

On the other appointment power, the President, as the head of the National executive has the power to appoint the Judiciary officers. According to Article 174 section (3), the President has the power to appoint the Chief of Justice and the Deputy Chief Justice after consulting the Judicial Service Commission and the leaders of parties represented in the

\footnotetext{
${ }^{169} / d$. Article 91 the Constitution of the Republic of South Africa.

${ }^{170} / d$. Article 91 the Constitution of the Republic of South Africa.

${ }^{171} / d$. Article 93 Section (1) the Constitution of the Republic of South Africa.

${ }^{172}$ Id. Article 93 Section (2) the Constitution of the Republic of South Africa.

${ }^{173} / d$. Article 93 Section (4) the Constitution of the Republic of South Africa.

${ }^{174} / d$. Article 93 Section(5) the Constitution of the Republic of South Africa.

${ }^{175} / d$. Article 96 the Constitution of the Republic of South Africa.

${ }^{176} / d$. Article 102 the Constitution of the Republic of South Africa.

${ }^{177}$ Id. Article 102 Section(2) the Constitution of the Republic of South Africa.
} 
Rosa Ristawati: Modelling Executive Powers in the Indonesian Constitution: A comparative Study

National Assembly; and appoint the President and Deputy President of the Supreme Court of Appeal. ${ }^{178}$

Moreover, section 4 of the Article states that the President after consulting the Chief Justice and the leader of parties represented in the National Assembly has the power to appoint other judges of the Constitutional Court. ${ }^{179}$ In general, the President has the power to appoint the judges of all other courts with the advice of the Judicial Service Commission. ${ }^{180}$ In any special situation of a judge's absence, the President has the power, with the recommendation of the Cabinet approval by the Chief of Justice, to appoint a woman or a man to be a judge of the Constitutional Court. ${ }^{181}$ The Constitution clarifies that the President has the formal power of judicial removal by adopting a resolution calling for a judge to be removed. ${ }^{182}$

On the other issues of appointment power, the President also has the power, upon the advice of the Judicial Service Commission, to suspend a judge who is guilty of gross incompetence or guilty of gross misconduct and an in-capacity to act. ${ }^{183}$ The President, as the head of the national executive, may have the power to appoint some of the members of the Judicial Service Commission. According to Article 178 section 1f, the President appoints two members of the Judicial Service Commission from practising advocates nominated from within the advocate profession to represent the profession as a whole and after consulting the leaders of all the parties in the National Assembly, four members of Judiciary service commission. ${ }^{184}$ Another appointment power of the President as the national executive is to appoint the prosecuting authority. ${ }^{185}$

Article 193 the South African Constitution grants formal power to the President to appoint, based on the recommendation of the National Assembly, the public protector, the

\footnotetext{
${ }^{178}$ Id. Article 174 Section (3)(Sub-s. (3) substituted by s. 13 of Act No. 34 of 2001) the Constitution of the Republic of South Africa.

${ }^{179}$ Id. Article 174 Section (4)(Sub-s.(4) Substituted by S. 13 of Act No. 34 of 2001) the Constitution of the Republic of South Africa.

${ }^{180}$ Id. Article 174 Section (6) the Constitution of the Republic of South Africa.

${ }^{181}$ Id. Article 175 Section (1) (Sub-s. (1) substituted by s. 14 of Act No. 34o f 2001) the Constitution of the Republic of South Africa.

${ }^{182}$ Id. Constituteproject.org: Article 177 Section (1) and Section (2) the Constitution of the Republic of South Africa.

${ }^{183} \mathrm{Id}$. Article 177 Section ( 3 the Constitution of the Republic of South Africa).

${ }^{184} / d$. Article 178 Section 1(f); Section 1(j) the Constitution of the Republic of South Africa.

${ }^{185}$ Id. Article 179 Section (1a) the Constitution of the Republic of South Africa.
} 
Rosa Ristawati: Modelling Executive Powers in the Indonesian Constitution: A comparative Study

auditor-general and the member of the South African Human Rights Commission, the Commission for Gender Equality, and the Electoral Commission. ${ }^{186}$ On the other hand, according to Article 194 section 3, the President may suspend a person from office at any time after the start of the proceedings; the President also has the power to remove a person from office upon adoption by the Assembly of a resolution calling for that person's removal. ${ }^{187}$ On the other removal powers, Article 196 states that the President has the power to remove the relevant member of the public service commission upon the adoption by the Assembly of a resolution calling for the removal or written notification by the Premier that the provincial legislature has adopted a resolution calling for that commissioner's removal. ${ }^{188}$

Besides some of the executive appointment powers mentioned above, the President as the national executive also has the power to appoint the financial and fiscal commission and remove a member from office on the grounds of misconduct, incapacity or incompetence. The Premier, as the provincial executive, is also involved in the appointment process. ${ }^{189}$ The appointment power of the President is also covered in the area of the appointment of the National Commissioner of the police service, to control and manage the police service. ${ }^{190}$

On the foreign affairs and treaty power, Chapter 14, Article 231 section (1) of the South African Constitution stipulates that the National executive, the President, has the power to negotiate and sign all international agreements. ${ }^{191}$ However, some particular treaties bind the Republic only after it has been approved by a resolution in both the National Assembly and the National Council of Provinces. ${ }^{192}$ Some treaties do not require either ratification or accession, and are entered into force by the President and bind the Republic without approval by the

\footnotetext{
${ }^{186} / d$. Article 193 Section (4) the Constitution of the Republic of South Africa.

${ }^{187}$ Id. Article 194 the Constitution of the Republic of South Africa.

${ }^{188} / d$. Article 196 Section (12) the Constitution of the Republic of South Africa.

${ }^{189} / d$. Article 221 Section (1)Sub-s. ( 1 ) amended by s. 2 of Act No. 2 of 1999 and substituted by s. 7 ( a ) of Act No. 61 of 2001 the Constitution of the Republic of South Africa.

${ }^{190} / d$. Article 207 Section (1) the Constitution of the Republic of South Africa.

${ }^{191} / d$. Chapter 14, Article 231Section (1) the Constitution of the Republic of South Africa.

${ }^{192} / d$. Article 231 Section (2) the Constitution of the Republic of South Africa.
} 
National Assembly and the National Council of Provinces must be tabled in the Assembly and the Council within a reasonable time. ${ }^{193}$

On the special power of state intelligence, the Constitution also explicitly specifies the President's power over the intelligence service. According to Article 209, the President has the power to establish the intelligence service other than any intelligence division of the defense force or police service by terms of national legislation. ${ }^{194}$ The President's power over the intelligence service includes those items which are mentioned in Section 2 of the Article, namely: to appoint the head of each intelligence service, assume political responsibility for the control and direction of any of those services, designate a member of the Cabinet to assume the responsibility. ${ }^{195}$ Furthermore, Article 201 of the South Africa Constitution sets out that the President has the power to coordinate and monitor any intelligence division of the defense including police service. ${ }^{196}$ The Constitution ensures that the National legislation regulates the powers and functions of the intelligence service.

On a special power, the President has the power to proclaim that the Constitution comes into effect according to Article $243 .{ }^{197}$ While in particular affairs, the President has the power to transfer the functions and assign temporary functions. The transfer of functions can be made by the President, by proclamation, to a member of the Cabinet in terms of the administration of any legislation entrusted to another member or any power or function entrusted by legislation to another member. ${ }^{198}$ In terms of the temporary assignment of functions, the President may have the power to assign to a Cabinet member any power or function of another member who is absent from office or is unable to exercise that power or perform that function. ${ }^{199}$ The President has the power to proclaim the assignment of functions of a Cabinet member that assign power or function to be exercised or performed by a member

\footnotetext{
${ }^{193}$ Id. Article 231 Section (3), Section (4), Section (5) the Constitution of the Republic of South Africa.

${ }^{194} I d$. Article 209 Section (1) the Constitution of the Republic of South Africa.

${ }^{195}$ Id. Article 209 Section (2 the Constitution of the Republic of South Africa.

${ }^{196} / d$. Article 210 the Constitution of the Republic of South Africa.

${ }^{197}$ Id. Article 243 Section (1), Section (2) the Constitution of the Republic of South Africa.

${ }^{198} / d$. Article 97 the Constitution of the Republic of South Africa.

${ }^{199} / d$. Article 98 the Constitution of the Republic of South Africa.
} 
of a provincial Executive Council or a Municipal Council; by such proclamation, the assignment will take into effect. ${ }^{200}$

On the administration power, the President as the national executive has the power to intervene in the provincial administration by taking any appropriate steps to ensure the fulfillment of an executive obligation in terms of the Constitution or legislation as stipulated in Article 100 the South Africa Constitution. According to the Article, the President may perform such a power by (1) issuing a directive to the provincial executive and describing the extent of the failure to fullfil its obligations and stating any steps required to meet its obligations; (2) assuming responsibility for the relevant obligation in that province to the extent necessary to maintain essential national standards or meet established minimum standards for the rendering of a service, maintain economic unity, maintain national security, or prevent that province from taking unreasonable action that is prejudicial to the interests of another province or to the country as whole. ${ }^{201}$ Furthermore, the intervention of the President as the national executive should be submitted in the form of a written notification to the National Council of Provinces within 14 days after the intervention started. Article 101 implies that the President has the power to make executive decisions in the form of legislation, proclamation, regulation and other instruments of subordinate legislation that can have legal consequences. ${ }^{202}$

In terms of the state emergency, the South African Constitution states that the declaration of state emergency is by an act of parliament. ${ }^{203}$ However, Article 203 on the state of national defense stipulates that the President has the power to declare a state of national defense and must inform parliament promptly and in appropriate detail. ${ }^{204}$ While on the military power, the President of South Africa, as the head of the national executive holds the power as Commander in Chief of the defense force and has the power to appoint the military

\footnotetext{
${ }^{200} / d$. Article 99 the Constitution of the Republic of South Africa.

${ }^{201}$ Id. Article 100 on National intervention in provincial administration[Sub-s. (1) amended by s. 2 (b) of Act No. 3 of 2003 the Constitution of the Republic of South Africa.

${ }^{202} / d$. Article 101 the Constitution of the Republic of South Africa.

${ }^{203} / d$. Article 37 the Constitution of the Republic of South Africa.

${ }^{204}$ Id. Article 203 Section(1), Section (2), Section (3) the Constitution of the Republic of South Africa.
} 
command of the defense force. ${ }^{205}$ Furthermore, the President has the power to direct the Command of the defense force. ${ }^{206}$

Article 201 Section (2) clarifies that only the President, as the head of the national executive has the power to employ the defense force in cooperation with the police service, in defense of the Republic and in fulfillment of an international obligation. ${ }^{207}$ However, the President must inform the Parliament about the reasons for the employment of the defense force, any place where the force is being employed, the number of people involved, and the period for which the force is expected to be employed. ${ }^{208}$ If the Parliament does not sit during the first seven days after the defense force is employed as envisaged, the President must provide the information required to the appropriate oversight committee. ${ }^{209}$

In addition, the South African Constitution provides a check to the executive power of the President in Annex B on Government of National Unity of National section 84 Sub-Section (3) thatbefore executing the power, the President must consult the Executive Deputy President on the specific issues as follows:
a. the development and execution of the policies of the national government;
b. all matters relating to the management of the Cabinet and the performance of Cabinet business;
c. the assignment of functions to the Executive Deputy Presidents;
d. any appointment under the Constitution or any legislation including the appointment of ambassadors or other diplomatic representative;
e. appointment of commissions of inquiry;
f. calling a referendum;
g. the implementation of pardoning power; pardoning or reprieving offenders. ${ }^{210}$

\section{c. Executive powers:experiences from the presidential Constitutions (presidential system: a separation of power between the executive and the legislative)}

\section{US}

The US Constitution reflects a classic model for a presidential system; in which, the executive and legislature are selected independently. ${ }^{211}$ There are some points that can be

\footnotetext{
${ }^{205} / d$. Article 202 Section (1) the Constitution of the Republic of South Africa.

${ }^{206} / d$. Article 202 section(2) the Constitution of the Republic of South Africa.

${ }^{207}$ Id Article 201 section (2) the Constitution of the Republic of South Africa.

${ }^{208} / d$. Article 201 section(3) the Constitution of the Republic of South Africa.

${ }^{209} / d$. Article 201 section (4) the Constitution of the Republic of South Africa.

${ }^{210}$ Id. ANNEX B on GOVERNMENT OF NATIONAL UNITY: NATIONAL SPHERE the Constitution of the Republic of South Africa.
} 
Rosa Ristawati: Modelling Executive Powers in the Indonesian Constitution: A comparative Study

noted from the US presidential system according to Ken Newton, namely: 1 . The President has veto power and can veto legislation, on the contrary, the legislature (Congress) can override the veto by a majority of two-thirds in both houses; 2 . The President is head of the armed forces, but only Congress can declare war; 3 . The President makes political appointments, but they can be rejected by the Senate; 4 . Congress cannot remove the president, and the president cannot dissolve Congress. ${ }^{212}$ Moreover, the Constitution allows the Congress to impeach a President from office. The Congress also has the power to make and enact Laws and the President is responsible to execute Laws. The President is ultimately dependent on the Congress as the Legislature. ${ }^{213}$ To this extent, the presidential system in the US allows the president to have an independent branch but the Constitution gives some substantial-checked powers to the president.

However, the US President not only has constitutional powers and delegated powers but also gets executive powers from many sources. There are still numerous institutional resources that may be the justification of broad ranges of power for the executive. According to the US practice, the tendency shows that the President can always expand the power through the mechanism of spending and budget control. The US President may also control the legislation process and thus, it will indirectly make the President the key institution in the legislation process. The existence of the Office of Management and Budget (OMB) may contribute to the dominant power of the President to take control through the procedure over the entire executive branch; in particular on the area of the spending, budget process, legislation process before submitted to the Congress:

\footnotetext{
${ }^{211}$ The Oxford Handbook of Comparative Constitutional Law, Op. Cit., p. 553.

${ }^{212}$ Ken Newton and Jan W. Van Deth, Op. Cit., p. 62.

${ }^{213}$ /d. at p. 63: "It is said, for example, that the American president has little power over Congress other than the power of persuasion.Many in the White House have found this inadequate for the purposes of government, if Congress and the president are of a different political mind they may fight each other and get little done. One image likens the president, the House, and the Senate to participants in a three-legged race - difficult to move along unless they move together; and easy to fall over. The problem is heightened if, as sometimes happens, the presidency is controlled by one political party, and one or both houses by another. If, on top of this, party discipline is weak, the majority party may be unable to pass its legislation. The result is that apparently powerful presidents are sometimes immobilized by elected assemblies. For this reason, many presidential systems have failed the test of democratic stability and some experts believe that they do not make for effective government. The USA may be the only successful example, although Costa Rica has maintained its presidential system since 1949".
} 
Rosa Ristawati: Modelling Executive Powers in the Indonesian Constitution: A comparative Study

"In particular, the Office of Management and Budget (OMB) serves as a potential instrument of presidential control over federal spending and hence a mechanism through which the White House has greatly expanded its power. In addition to its power over the federal budget process, the OMB has the capacity to analyze and approve all legislative proposals, not only budgetary requests, emanating from all federal agencies before being submitted to Congress. This procedure, now a matter of routine, greatly enhances the president's control over the entire executive branch. All legislation emanating from the White House as well as all executive orders also go through the OMB. Thus, through one White House agency, the president has the means to exert major influence over the flow of money as well as the shape and content of national legislation". ${ }^{214}$

Another mechanism that may contribute to the expansion of the executive power of the US President is the mechanism of regulatory review:

"..that presidents have used to increase their power and reach is the process of regulatory review, through which presidents have sought to seize control of rule-making by the agencies of the executive branch implementation". 215

Meanwhile, the US Congress discretion in delegating to administrative agencies may also contribute to the expansion of the executive power; in practice, the President can always have full power to order the agencies:

"President Clinton believed the president had full authority to order agencies of the executive branch to adopt such rules as the president thought appropriate. During the course of his presidency, Clinton issued 107 directives to administrators ordering them to propose specific rules and regulations. In some instances, the language of the rule to be proposed was drafted by the White House staff; in other cases, the president asserted a priority but left it to the agency to draft the precise language of the proposal. President George W. Bush continued the Clinton-era practice of issuing presidential directives to agencies to spur them to issue new rules and regulations. In January 2009, President Obama affirmed the importance of regulatory review but said his administration would review the process to make certain that federal agency guidance by the president would be fair and would involve public participation" ${ }^{216}$

In the US, the executive power also has the power that comes from the people that may affect the President's capacity to govern on the basis of popularity as well as a consequence that the executive is an institution. ${ }^{217}$ However, the powers of the President do not always make the US President the decision maker. The right to override the veto power of the president puts the Congress as the final decision maker; on the other hand, the senate has the

\footnotetext{
${ }^{214}$ Benjamin Ginsberg, at all, Op. Cit., p. 323.

${ }^{215} / d$. at p. 323.

${ }^{216} / d$. at p. 324.

${ }^{217} / d$. at p. 314.
} 
last word in terms of cabinet and other major executive appointments; similar also for the treaty power, and the Presidential military power as the commander in chief. ${ }^{218}$

Donald S. Lutz argued that the President does not hold real power instead of the legislature; the President is dependent to the legislature in terms of the power performance, and he clarified that the President may depend on the legislature in terms of conducting war, fund approval for the use of force, and other funds for executive agents and agencies; Donald S. Lutz reflected his argument by describing the US presidential model:

"..war to make this power meaningful, and only Congress can appropriate funds to give the commander in chief a fighting force. In addition, Congress can impeach the president, investigate executive functions and actions, create and abolish executive agents and agencies, and set or alter executive branch salaries. The president can pardon on hisown, but he is left out of the amendment process completely. The president cannot affect the sitting of Congress through prorogue or calling sessions. If the electoral, college fails to select a president, Congress shall select one. If the president and vice president die, are removed, or are incapacitated, Congress determines who shall be the executive currently the Speaker of the House. No other elected president in the world has so many legislative checks and restrictions placed upon him. Even most symbolic presidents can prorogue or call the legislature into session". ${ }^{219}$

Constitutionally, the US executive branch mainly derives from Article II the US Constitution.It implies that the US President is only vested with the core power for an executive branch, namely: the military power, the pardoning power, the treaty power, the appointment power, the state administrative power and the power to faithfully execute the Laws. According to the text of the US Constitution, the US President very much depends on the Senate and/or the Congress. He has a little or almost has no independent power since all the power is authorized by the Senate and/or the Congress. The Constitution empowers the Congress with some powers mentioned in detail in Article I Section 8 of the US Constitution. ${ }^{220}$

Section 2 of the Article sets the constitutional basis for the Military, Cabinet, Pardon, and Appointment power for the President. Paragraph 1 Section 2 of Article II of the US Constitution attaches the military power to the President as the Commander in Chief of the US Army and Navy of the United States, and of the Militia of several States. ${ }^{221}$ On the law-making

\footnotetext{
${ }^{218}$ Donald S. Lutz, Principles of Constitutional Design, Cambridge University Press, 2006, p.121.

${ }^{219} / d$. at p.122.

${ }^{220}$ Constituteprojects.org, The United State of America's Constitution of 1789 with Amendments through 1992 , generated from excerpts of texts from the repository of the Comparative Constitutions Project, and distributed on constituteproject.org:Article I Section 8 of the US Constitution: Powers of Congress.

${ }^{221}$ Id. Article II Section 2 Paragraph 1 of the US Constitution.
} 
Rosa Ristawati: Modelling Executive Powers in the Indonesian Constitution: A comparative Study

power, the US President's law-making power includes the legislative powers of the executive in some area of legislative process. The US Constitution gives the veto power and legislative initiation power to the President. ${ }^{222}$ The veto power for saying "no" to legislative proposals is limited by the US Constitution which Congress can over-ride. ${ }^{223}$ The veto is merely just a written objection and the Congress may over-ride it. ${ }^{224}$ At this point, the legislative power is absolutely attached in both houses of Congress, while the formal power to sign the bill belongs to the President. To this extent, the veto power empowers the President and assigns the President with strong bargaining power. But, it does not mean that the President has dominated the legislative power since Congress has the power to over-ride it. However, in practice, the fear that veto power will be the most powerful tool for modern presidents is greater than the modern role of the President in initiating legislation. ${ }^{225}$

In addition to the law-making power, the executive is also given the power to make other laws, the executive order, in relation to the state administration affairs. Such laws usually have specific and technical characters. They are hierarchically under the legislation. Commonly, the executive order is a regulation issued by the president and simply as a normal tool for the state management, as the rules in setting procedures, commanding, and other functional responsibilities. ${ }^{226}$ In practice, the executive order had been significant and sometimes

\footnotetext{
${ }^{222}$ Benjamin Ginsberg et al, Op. Cit., p. 311: "Two constitutional provisions are the primary sources of the president's power in the legislative arena. The first of these is the provision in Article II, Section 3, providing that the president "shall from time to time give to the Congress Information of the State of the Union, and recommend to their Consideration such Measures as he shall judge necessary and expedient." The second of the president's legislative powers is of course the veto power assigned by Article I, Section 7.9 Delivering a "State of the Union" address does not at first appear to be of any great import".

${ }^{223}$ Sanford Levinson, Our Undemocratic Constitution, Oxford University Press, 2006, p. 40.

${ }^{224}$ Constituteprojects.org, Op. Cit., The United State of America's Constitution of 1789 with Amendments through 1992: Article 1Section 7 of the US Constitution - Revenue Bills, Legislative Process, Presidential Veto.

${ }^{225}$ Sanford Levinson, Op. Cit., p. $41-46$.

${ }^{226}$ Benjamin Ginsberg, et al, Op. Cit., p. 313: "Most of the executive orders of the president provide for the reorganization of structures and procedures or otherwise direct the affairs of the executive brancheither to be applied across the board to all agencies or applied in some important respect to a single agency or department. One of the most important examples is Executive Order No. 8248, September 8, 1939, establishing the divisions of the Executive Office of the President".
} 
Rosa Ristawati: Modelling Executive Powers in the Indonesian Constitution: A comparative Study

controversial in US history since it is the instrument for the US President to set a substantive policy. $^{227}$

On the appointment power, the Constitution vests the appointment power in the US President. The functionalist perspective views that the President has the ability to identify and verify a suitable individual to fill vacancies. ${ }^{228}$ According to the Constitution, the US President has the power to appoint and nominate ambassadors, other public ministers and consuls, Judges of the Supreme Court, and all other officers of the United States. ${ }^{229}$ The US Constitution restrains the appointment power of the US President by setting checks and balances from the Senate and Congress. On the other hand, the House of Representatives, even though it has no direct roles on the appointment, may indirectly check abuses of the appointment power. ${ }^{230}$

\footnotetext{
${ }^{227}$ Id. at p. 325: "For example, when President Truman ordered the desegregation of the armed services, he did so pursuant to his constitutional powers as commander in chief. In a similar vein, when President Johnson issued Executive Order No. 11246, he asserted that the order was designed to implement the 1964 Civil Rights Act, which prohibited employment discrimination. Where an executive order has no statutory or constitutional basis, the courts have held it to be void.President Clinton issued numerous orders designed to promote a coherent set of policy goals: protecting the environment, strengthening federal regulatory power, shifting America's foreign policy from a unilateral to a multilateral focus, expanding affirmative action programs, and helping organized labor in its struggles with employers.President George W. Bush also did not hesitate to use executive orders, issuing nearly 300 during his two terms. During his first months in office, Bush issued orders prohibiting the use of federal funds to support international family-planning groups that provided abortion-counseling services and placing limits on the use of embryonic stem cells in federally funded research projects. Throughout his administration, Bush made very aggressive use of executive orders in response to the threat of terrorism. In November 2001, for example, Bush issued a directive authorizing the creation of military tribunals to try non-citizens accused of involvement in acts of terrorism against the United States. In 2007, Bush issued controversial national security directives that gave the president sole responsibility for determining when and how constitutional government could be re-established in the event of a catastrophic attack on the United States. President Obama issued thirty-eight executive orders in his first year in office, using some of them to reverse executive orders of his predecessor (just as Bush reversed some of those of the Clinton years). Obama executive orders authorized stem cell research, restored funding for international family-planning organizations, opened access to presidential papers, and barred improper interrogation methods of detainees captured by the United States".

${ }^{228}$ Matthew Hunter, "Legislating Around the Appointments Clause", Boston University Law Review, Vol. 91 (2011) pp.753-788, p. 757.

${ }^{229}$ Constituteprojects.org, Op. Cit., The United State of America's Constitution of 1789 with Amendments through 1992: Article II Section 2 paragraph 2 of the US Constitution.

${ }^{230}$ Hannah Metchis Volokh, "The Two Appointments Clauses: Statutory Qualifications for Federal Officers", Journal of Constitutional Law, Vol. 10, May 2008, pp. 745 - 789, p. 784: "The Constitution gives the House numerous tools to check abuses of the appointment power. The House of Representatives is involved in creating offices by statute before anyone can be appointed to them, and in setting the powers, duties, and salary of each office. The House also has a role in deciding whether the appointment to an office will be through the confirmation appointments process or the vested appointments process. Finally, the House can initiate impeachment of any officer. When the available tools are understood, statutory qualifications seem much less important as a means of controlling the appointment power."
} 
Rosa Ristawati: Modelling Executive Powers in the Indonesian Constitution: A comparative Study

For certain appointment powers, the Constitution vests the power to the Senate to check and balance the President by giving advice and consent; however, the Constitution implies nothing about the qualification and it leaves it individually to the President and the Senate.On the other appointment power, the Congress as a whole has the role to set qualification by Law as a check over the President. ${ }^{231}$ According to the Constitution, the appointment of the Ambassador, other public Ministers and Consuls, Judges of the Supreme Court, and all other Officers of the US (or the principal officers) can only be made by and with the advice and consent from the Senate; while the Congress will prescribe by Law such appointment of inferior officers to be independently exercised by the President. ${ }^{232}$ The US appointment clause in the US Constitution implies two distinct appointments that may be exercised by the President; the first is the "confirmation appointment", the appointment of principal officers (Ambassadors, other public Ministers and Consuls, Judges of the Supreme Court, and all other Officers of the US whose appointments are not provided for and which should be established by Law) in which the President has the power to nominate by and with advice and consent from the Senate; and the second is "the vested appointment" for the appointment of lower ranking officers which the Congress may by Law vest the appointment in the President alone, in the Court of Law, or in the Heads of Departments. ${ }^{233}$ At this point, the appointment power of the President for certain officials namely Ambassador, other public Ministers and Consuls, Judges of the Supreme Court, and all other Officers of the US is a shared power since the President has to share the power with the Senate and depends on the Senate's advice and consent.

On Paragraph 3 Section 2 of the Article II the US Constitution, the Constitution gives independent appointment power during the legislature's recess. ${ }^{234}$ However, although it seems that the appointment power of the US President during the recess is an independent power; it

\footnotetext{
${ }^{231} / d$. at p. 789.

${ }^{232}$ See more on: Andrew Croner, "Morrison, Edmond, and the Power of Appointments", The George Washington Law Review, Vol 77, 2009, pp. 1002 - 1014, p. 1003.

${ }^{233}$ Hannah Metchis Volokh, Op. Cit., p.749.

${ }^{234}$ Constituteprojects.org, Op. Cit., The United States of America's Constitution of 1789 with Amendments through 1992: Article II Section 2 Paragraph 3 of the US Constitution.
} 
Rosa Ristawati: Modelling Executive Powers in the Indonesian Constitution: A comparative Study

does not mean that the power is without checks and balances. ${ }^{235}$ The US practices show that the exercise of appointment power during the recess usually generates some controversies and conflicts between the executive and legislative. ${ }^{236}$ It is frequently used extensively by the US President. ${ }^{237}$ On the other hand, there are some excuses given to affirm the recess appointment power of the President including the argument that the President has to prevent executive paralysis, and administrative inefficiency, and has to ensure the functioning of the government. ${ }^{238}$ Functionalism allows a degree of flexibility to accommodate modern governance:

"The functionalist defense of expanded use of the recess appointments power tends to emphasize flexibility and equity. Functionalists' arguments focus mainly on the changing character and size of the federal government, as well as on a modern political system that is wrought with deadlocks and delays". ${ }^{239}$

The appointment power of the President coincides with the power of removal. The argument to vest both powers is mainly grounded on the ability of the President to control the policy executed by his subordinates. ${ }^{240}$

As the US government is a presidential system, the President has the power to appoint ministers in order to exercise the state administration. The ministers together are the cabinet

\footnotetext{
${ }^{235}$ See more on: Jonathan Turley, "Constitutional Adverse Possession: Recess Appointments and the Role of Historical Practice in Constitutional Interpretation", Wisconsin Law Review, 2013, pp. 965 - 1037, p. 977 - 979.

${ }^{236}$ Jonathan Turley, Op. Cit., p. 966: “Four appointments made by President Obama in January 2012, however, pushed this conflict between the legislative and executive branches to a new and troubling level In theAppointments Clause, the Framers state twice that such appointments could only be made with "the Advice and Consent of the Senate." It is a critical check and balance provision that the two branches must agree on who should sit on federal courts and in federal offices."

${ }^{237}$ See more the experiences of the US President in exercising the recess appointment power extensively on: Patrick Hein, "In Defense of Broad Recess appointment power: the Effectiveness of Political Counterweights", California Law Review, Vol. 96, Issue 1, Article 5, 2008, pp. 235 - 282, available online at: http://scholarship.law.berkeley.edu/californialawreview/vol96/iss1/5.

${ }^{238}$ Todd Garvey and David H. Carpenter, "The Recess Appointment PowerAfter Noel Canning v. NLRB: Constitutional Implication", the CRS Report for Congress, March 27, 2013, p. 14 (accessible online at www.crs.gov) . ${ }^{239}$ Jonathan Turley, "Recess Appointments in the Age of Regulation", Boston University Law Review, Vol. 93, 2013, pp. $1523-1604$, p. 1564.

${ }^{240}$ Matthew A. Samberg,"Established by Law: Saving Statutory Limitations on Presidential Appointments from Unconstitutionality", New York University Law Review, Vol. 85, November 2010, pp. 1735 - 1765, p. 1743.
} 
Rosa Ristawati: Modelling Executive Powers in the Indonesian Constitution: A comparative Study

of the state. The Cabinet has no constitutional status and is not responsible to the parliament; however, the Cabinet is also a part of the popular support. ${ }^{241}$

On the foreign affairs power, the diplomatic power of the President is given on the basis that the President is the head of the state and the representative of the state. However, practice shows that the power is exercised by the consent of the US Senate. The US President diplomatic powers not only include the treaty power but expand beyond all the areas of state diplomacy including determination of the state attitudes against other states and the international community, the power to make executive agreements or other commitments between two states to arrange any affairs below the policy and such agreement does not need the consent of the US Senate. ${ }^{242}$

The US President makes treaties by and with the advice and consent of the Senate. It has the meaning that the treaty power is in the hands of the US President, upon advice of the Senate before negotiation, where in the end the President makes the treaty to which the Senate had consented. ${ }^{243}$ The treaty clause on the US Constitution clearly provides the mechanism for Senate consent since it implies a two-thirds Senate majority for the consent. Moreover, according to the Federalist No. 75, Hamilton argued that treaty making power

\footnotetext{
${ }^{241}$ Benjamin Ginsberg et al, Op. Cit., p. 314: "In the American system of government, the Cabinet is the traditional but informal designation for the heads (secretaries, or chief administrators), of all the major federal government departments. Cabinet secretaries are appointed by the president with the consent of the Senate. The Cabinet has no constitutional status. Unlike in England and many other parliamentary countries, where the cabinet isthe government, the American Cabinet meets but it makes no decisions as a group. The Senate must approve each appointment, but Cabinet members are not responsible to the Senate or to Congress at large. Cabinet appointments help build party and popular support, but the Cabinet is not a party organ. The Cabinet is made up of directors but is not a true board of directors."

${ }^{242}$ Id. at p. 310: "As head of state, the president has the power to make treaties for the United States (with the advice and consent of the Senate). And when President Washington received Edmond Genêt ("Citizen Genêt") as the formal emissary of the revolutionary government of France in 1793 and had his cabinet officers and Congress back his decision, he established a greatly expanded interpretation of the power to "receive Ambassadors and other public Ministers," extending it to the power to "recognize" other countries. That power gives the president the almost unconditional authority to review the claims of any new ruling groups to determine if they indeed control the territory and population of their country, so that they can commit it to treaties and other agreements.In recent years, presidents have expanded the practice of using executive agreements instead of treaties to establish relations with other countries. An executive agreement is exactly like a treaty because it is a contract between two countries that has the force of a treaty but does not require the Senate's "advice and consent."Ordinarily, executive agreements are used to carry out commitments already made in treaties or laws, or to arrange for matters well below the level of policy."

${ }^{243}$ Louis Henkin, Constitutionalism, Democracy, and Foreign Affairs, Columbia University Press, New York, 1990, pp. 49.
} 
Rosa Ristawati: Modelling Executive Powers in the Indonesian Constitution: A comparative Study

should be shared between the legislative and executive branches since its nature is neither wholly executive nor wholly legislative. ${ }^{244}$ However, in more recent US practice, the President as the treaty and international agreement's exclusive negotiator has been undermined even more by recent trade legislation, which caused Congress to offer the President a fast track legislative procedure for implementing trade agreements with other nations. ${ }^{245}$

On the administrative power, the US President is the chief of the executive departments, establishing the state administration. ${ }^{246}$ Accordingly, the President may have the power to require the opinion of all the executive departments. Section 3 of Article II of the US Constitution confirms that the President has the power to faithfully execute the Laws. ${ }^{247}$ Moreover, the administrative power of the US President also refers to the power to control his subordinates' departments, establish independent agencies, appointment and removal assigned by the Constitution. The President also has the power to control all the state agencies decisions, oversee the implementation of Laws, and as a consequence, the President has administrative responsibilities. ${ }^{248}$ In the area of the US state administration, the President may issue a regulation to give orders to state officials. In the US experience, the Congress gives the delegation powers to the President as the executive, in case the Congress itself cannot directly step in on the area of state administration while it is urgent for Congress to take action. ${ }^{249}$ According to experience, the US Presidents usually expand their administrative power by

\footnotetext{
${ }^{244}$ See: Curtis A. Bradley and Martin S. Flaherty, "Executive Power Essentialism and Foreign Affairs", Michigan Law Review, Vol. 102. No. 4, February 2004, p. 630 (accessed 14/11/2011).

${ }^{245}$ Id, at p. 226.

${ }^{246}$ Constituteprojects.org, Op. Cit., The United State of America's Constitution of 1789 with Amendments through 1992: Article II Section 2 Paragraph 1 of the US Constitution: “.... when called into the actual Service of the UnitedStates; he may require the Opinion, in writing, of the principal Officer in each of theexecutive Departments, upon any subject relating to the Duties of their respective Offices".

${ }^{247}$ Id, Section 3 - State of the Union, Convening Congress of the US Constitution.

${ }^{248}$ See more on: Mattew Hunter, Op. Cit., pp. 753-788.

${ }^{249}$ Benjamin Ginsberg et al, Op. Cit., p. 314: "Given the vast range of the federal government's responsibilities, Congress cannot execute and administer all the programs it creates and the laws it enacts. Inevitably, Congress must turn to the hundreds of departments and agencies in the executive branch or, when necessary, create new agencies to implement its goals. Thus, for example, in 2002, when Congress sought to protect America from terrorist attacks, it established a Department of Homeland Security and gave it broad powers in the realms of law enforcement, public health, and immigration. Similarly, in 1970, when Congress enacted legislation designed to improve the nation's air and water quality, it assigned the task of implementing its goals to the Environmental Protection Agency (EPA), which President Nixon created by an executive order. Congress gave the EPA substantial power to set and enforce air and water quality standards."
} 
Rosa Ristawati: Modelling Executive Powers in the Indonesian Constitution: A comparative Study

enhancing the power of the executive office, increasing the White House control over the federal bureaucracy, expanding the role of executive orders and other instruments of direct presidential governance, and using the signing statement to negate congressional actions to which they object:

\begin{abstract}
"the White House "administrative strategies" to expand the administrative power have given presidents a capacity to achieve their programmatic and policy goals even when they are unable to secure congressional approval. Indeed, some recent presidents have been able to accomplish quite a bit without much congressional, partisan, or even public support. The Executive Office of the President has grown from six administrative assistants in 1939 to today's 400 employees working directly for the president in the White House office along with some 1,400 individuals staffing the divisions of the Executive Office. The creation and growth of the White House staff gives the president an enormously enhanced capacity to gather information, plan programs and strategies, communicate with constituencies, and exercise supervision over the executive branch. The staff multiplies the president's eyes, ears, and arms, becoming a critical instrument of presidential power". ${ }^{250}$
\end{abstract}

On the emergency power, the US President is vested with the emergency power. The emergency power is related to the constitutional statutes of the President as the Commander in Chief of the Army and Navy of the United State and of the Militia of several states. It is usually expanded by the ground of Article 1 Section 9 (which is actually under the Legislative Branch), which constitutionally allows the exercise of the privilege of the Writ of Habeas Corpus be suspended in certain cases of rebellion or invasion affecting public safety. ${ }^{251}$ The text of the Constitution does not give any definition about the state of emergency. Bruce Ackerman proposes some alternatives to set a framework for the emergency powers, of which one of the proposals is considered on the basis that the state of emergency enables the government to take extraordinary measures in its life-and-death struggle for survival. ${ }^{252}$

On the Military power, the US President is the Commander in chief. The idea of granting the US President as the commander in chief is because the President who is also running the government administration and also has the access will take any command and action in time of emergency:

\footnotetext{
${ }^{250} / d .$, p. 322.

${ }^{251}$ Constituteprojects.org, Op. Cit., Article 1 Section 9 the US Constitution: "The privilege of the Writ of Habeas Corpus shall not be suspended, unless when in Cases of Rebellion or Invasion the public Safety may require it".

252 Read: Bruce Ackerman, "the Emergency Constitution", the Yale Law Journal, Vol. 113, 2004, pp. 1029 - 1091 , p. 1037.
} 


\title{
Rosa Ristawati: Modelling Executive Powers in the Indonesian Constitution: A comparative Study
}

“The president's position as commander in chief was also designed for a republic of notables. The Founders expected the same group who ran the civilian government to take command of the army at moments of crisis. $^{253}$

On the other hand, the use of military forces is actually in the hand of Congress. Although the President is the Commander in chief, constitutionally, the President is required to get approval from Congress and the Congress has the final decision on the use of force authorization:

\begin{abstract}
"The position of commander in chief (the power of the president as commander of the national military and the state national guardian units when called into service) makes the president the highest military authority in the executive branch. Final authority over military matters rests with Congress, which may direct the commander in chief as it chooses." 254
\end{abstract}

When the use of military force requires the Congress approval, the US practices show that approval from the Congress is frequently often waived by the US President. The practice shows that the experiences from President Truman to President Bush had shown that the exercise of the use of force and presidential military power was exercised without requiring Congress approval and declaration of war. ${ }^{255}$ The President could exercise the military power unilaterally and the Congress may generally pass a resolution in order to affirm the military and war power of the President. Practically speaking, in the US president's military power, the pattern for future congressional-executive relations in the military realm is based on the experience when Congress passed a resolution approving the presidential action after the President launched the military force. This may contradict the Constitution which orders the president to get the authorization of Congress before mobilizing the use of military force in any situation either abroad or when the US is under serious internal threat. There are still debatable issues about the US President's military power. However, according to the US Constitution text, the real

\footnotetext{
${ }^{253}$ Bruce Ackerman, The Decline and Fall of the American Republic, the Belknap Press of Harvard University Press, 2010, p. 44.

${ }^{254}$ Benjamin Ginsberg et al, Op. Cit., p. 307.

${ }^{255}$ Id. at p. 307: "In the nineteenth century, Congress normally directed the president's military actions and decisions. In the twentieth century, however, presidents have engaged the country in many military campaigns abroad without congressional approval. Congress has not declared war since December 1941, and yet since then American military forces have engaged in numerous campaigns throughout the world under orders of the president. When North Korean forces invaded South Korea in June 1950, Congress was actually prepared to declare war, but President Harry S. Truman decided not to ask for congressional action. Instead, Truman asserted the principle that the president and not Congress could decide when and where to deploy America's military might. Truman dispatched American forces to Korea without a congressional declaration."
} 
Rosa Ristawati: Modelling Executive Powers in the Indonesian Constitution: A comparative Study

military power actually belongs to the Congress. Without Congress authorization, if the US President exercises military power unilaterally, the use of military force must be revoked. Some practices show that some of the US Presidents had over-ridden Congress authorization and claimed that the exercise of mobilizing military forces is part of the constitutional duties and so, it is the inherent power of the President to protect the nation; even finally the Congress affirmed and passed a resolution approving the President's use of force. ${ }^{256}$

The roles of the US President as the Commander in Chief of the Navy, Army and Air Force have the meaning that the US President has the right to take any action including the use of military force. Since then, the US President has the highest command over the military force. As the highest of the command, the US President may be also considered as someone who knows exactly the best solution and the decision maker over the situation that is threatening the state. However, the role of the Congress is important as the branch which has the power to check whether the Presidential action abused power. Most importantly, the Congress approval and the Congress budgetary power are very crucial for financing military operations.

On the pardoning power, the US President's pardoning power includes the power to grant reprieves, pardons, and amnesties against the convicted person except in the cases of impeachment. The power is commonly exercised on behalf of the President individually as a consequence of his role as the head of the state. ${ }^{257}$ The US President's pardoning power is inherently flexible; allowing the President to grant limited or conditional pardons; however, the

\footnotetext{
${ }^{256}$ Id. at p. 308: "The wars in Vietnam, Bosnia, Afghanistan, Iraq, and a host of lesser conflicts all were fought without declarations of war. In 1973, Congress responded to presidential unilateralism by passing the War Powers Resolution over President Richard Nixon's veto. President George W. Bush responded to the 2001 attacks by Islamic terrorists by organizing a major military campaign to overthrow the Taliban regime in Afghanistan, which had sheltered the terrorists. In 2003, Bush ordered a major American campaign against Iraq, which he accused of posing a threat to the United States. U.S. forces overthrew the government of the Iraqi dictator, Saddam Hussein, and occupied the country."

${ }^{257}$ Id. at p. 310: "The presidential power to grant reprieves, pardons, and amnesties involves the power of life and death over all individuals who may be a threat to the security of the United States. Presidents may use this power on behalf of a particular individual, as did Gerald Ford when he pardoned Richard Nixon in 1974 "for all offenses against the United States which he . . . has committed or may have committed." Or they may use it on a large scale, as did President Andrew Johnson in 1868, when he gave full amnesty to all southerners who had participated in the "Late Rebellion," and President Carter in 1977, when he declared an amnesty for all the draft evaders of the Vietnam War. President Clinton created great controversy with a large number of last-minute pardons issued in the final days of his presidency in 2000. President George W. Bush, on the other hand, issued fewer pardons than any president in modern times".
} 
practices have shown that such pardoning power has been widely exercised by some of the US presidents. ${ }^{258}$ Although it is widely exercised and being constitutionally unrestricted, the US President pardoning power is actually not the power without checks and balances from other branches. Although in the US the Congress has no direct control over the pardoning power, it could amend the Constitution to restrict the President's authority to extend the pardoning power, and the Court may strike down pardons which may have unconstitutional conditions. ${ }^{259}$ The constitutional amendment is one fundamental way of eliminating pardons, placing the power in another hand (the legislature), limiting through the requirement of approval by other government bodies (Supreme Court or constitutional court), or setting conditions or qualifications for pardons. ${ }^{260}$ As the US does not have a constitutional court, the Supreme Court has a significant role to establish constitutional boundaries of pardoning power; however, in practice, judicial challenges over the pardoning power are commonly serving to expand rather than to limit the use and scope of pardoning power. ${ }^{261}$ According to research, some of the US Presidents have controversially used the pardoning power. ${ }^{262}$ The most controversial use of pardoning power came from President Ford who granted a pardon to Richard Nixon in the Watergate scandal case, President Clinton who used his last day in office to pardon both his half-brother and a wealthy donor's tax-evading husband, and President Bush who commuted Lewis Scooter Libby's prison sentence in the case of leaking the name of a CIA agent. ${ }^{263}$

\section{The Philippines}

The present Constitution of the Philippines is the 1987 Constitution of the Republic of the Philippines that was approved by the 1986 Constitutional Commission on October 12, 1986; presented to President Corazon C. Aquino on October 15, 1986; ratified on February 2, 1987 by

\footnotetext{
${ }^{258}$ Read: Vanessa K. Burrows (2009), p. 2: the case of President Ford issued a pardon to President Nixon on the Watergate scandal and the case that President Bush gave pardon on the case related to Iran contra affairs. See also: James N. Jorgensen, Clemency and Pardons Note, University of Richmond Law Review, Vol. 27/1993, pp. 345 -370, (accessed online from heinOnline http://heinonline.org on 01/04/2012), p. 345 .

${ }^{259}$ Id. at p. 361.

${ }^{260}$ Jody C. Baumgartner and Mark H. Morris, "Presidential Power Unbound: A Comparative Look at Presidential Pardon Power", Politics and Policy, Vol. 29, No. 2/June 2001, p. 217.

${ }^{261}$ See: Id. at p. 218.

${ }^{262}$ See: P.S. Ruckman, Jr, "Federal Executive Clemency in the Administration of George W. Bush (2001-2009): A Pardon Power Report" accessed online at www.pardonpower.com, p. 7.

263 Leon Neyfakh, "The Untapped Power of Pardons", Boston Globe, March, 17, 2013.
} 
Rosa Ristawati: Modelling Executive Powers in the Indonesian Constitution: A comparative Study

plebiscite; proclaimed in force on February 11, $1987 .{ }^{264}$ The enforcement of the 1987 Constitution of the Republic of the Philippines has marked the return of the presidential system of the 1935 Constitution with the presidential powers substantially clipped and a re-installed and strengthened bi-cameral legislature. ${ }^{265}$ The Philippines President is the head of the executive branch of the government heading the Cabinet and all executive departments. ${ }^{266}$ The President holds the executive powers.

On the law-making power, according to the Constitution, the Philippines President has the key role in the legislative process. Article VI Section 27 (1) stipulates that the President has the power to approve or veto bills. ${ }^{267}$ Furthermore, Section 27 (2) emphasizes that the President's veto power of any particular items in an appropriation, revenue, or tariff bill should not affect the other items which he does not object to. ${ }^{268}$ During, her administration, President Arroyo in 2006 used the law-making power, issuing presidential decrees to declare a state of emergency and direct the Armed Forces of the Philippines (she also issued a General Order commanding the armed forces of the Philippines to coordinate with the Philippines National Police to raid the "opposition" newspapers, confiscated news stories, documents, and even arrested an opposition legislator and denied him contact with his relatives during his detention and attempted to arrest five others. In other areas, the executive power had been exercised to issue the executive order to unilaterally reorganize government agencies without regard for functional objectives or the constitutional independence of other institutions (without prior legislative sanction and such executive orders were unreviewable by the Court). Not only that, the power to issue the executive order also had been used to invoke executive privilege, as an effort to shield her from checks and other oversight mechanisms in the case of a controversial government procurement contract. On the next presidential term, the President successor, President Aquino used the law-making power for issuing an executive order to block the path of

\footnotetext{
${ }^{264}$ http://www.gov.ph/the-philippine-constitutions/

${ }^{265}$ Jurgen Ruland, Clemen Jurgen meyer et al, Parliaments and Political Change in Asia, Institute of Southeast Asian Studies, Singapore, 2005, p. 29.

${ }^{266}$ Constituteproject.org, Philippines's Constitution of 1987, generated from excerpt of texts from the repository of the Comparative Constitutions Project, and distributed on constituteprojects.org: Article VII Section 1 the Philippines Constitution.

${ }^{267}$ Id. Article VI Section 27. (1) the Philippines Constitution.

${ }^{268} \mathrm{Id}$.
} 
a former President (who was then sitting in the legislature); the President Aquino issued the executive order to remove all of the President Arroyo's appointees. In terms of the law-making power, the Constitution actually has provided a mechanism to review the validity of any kind of legal products involving the President. ${ }^{269}$ In case the President is seriously ill, such power may be discharged by the members of the Cabinet. ${ }^{270}$

On the appointment power, the Philippines President has the appointment power. According to Article VII Section 16, the President has the power to nominate and appoint the heads of the executive departments, ambassadors, public ministers and consuls, officers of the armed forces, and other officers whose appointments are constitutionally vested in the President including the members of the Supreme Court. ${ }^{271}$ However, the power is exercised with the consent from the Commission on Appointments for the executive officers appointment or according to the list from the Judicial and Bar Council in terms of the appointment of the Supreme Court's members. It means that actually the President has formal appointment power but only relatively has real appointment power since the power is exercised by the consent from the Commission or according to the Council. Important conditions are mentioned in the Constitution with regard to the presidential appointment power. According to Section 15 of the Article, the President is permitted to exercise the appointment power except during two months before the next presidential elections and up to the end of the presidential term. ${ }^{272}$

\footnotetext{
${ }^{269} / d$. According to Article VIII Section 5 the Philippines Constitution, The Philippines Supreme Court shall have the following powers:

1) Exercise original jurisdiction over cases affecting ambassadors, other public ministers and consuls, and over petitions for certiorari, prohibition, mandamus, quo warrant, and habeas corpus.

(2) Review, revise, reverse, modify, or affirm on appeal or certiorari, as the law or the Rules of Court may provide, final judgments and orders of lower courts in:

(a) All cases in which the constitutionality or validity of any treaty, international or executive agreement, law, presidential decree, proclamation, order, instruction, ordinance, or regulation is in question.

(b) All cases involving the legality of any tax, impost, assessment, or toll, or any penalty imposed in relation thereto.

(c) All cases in which the jurisdiction of any lower court is in issue.

(d) All criminal cases in which the penalty imposed is reclusion perpetua or higher.

(e) All cases in which only an error or question of law is involved.

${ }^{270} / d$. Section 12 the Philippines Constitution In case of serious illness of the President, the public shall be informed of thestate of his health. The members of the Cabinet in charge of national security andforeign relations and the Chief of Staff of the Armed Forces of the Philippines shall notbe denied access to the President during such illness.

${ }^{271}$ Id. Section 16 the Philippines Constitution.

${ }^{272}$ Id. Section 15 the Philippines Constitution.
} 
Rosa Ristawati: Modelling Executive Powers in the Indonesian Constitution: A comparative Study

During the restrictive period, the President may only be permitted to exercise the power for temporary appointments for the special conditions of public safety. The appointments by the President during the permitted period of appointment may be extended by the President in office; on the other hand the successor President in office may revoke appointments made by former Presidents. ${ }^{273}$ In Philippines experience, the appointment power has been potentially used to give more benefits to the administration. The President had used the appointment power to appoint key public officers with the purpose to counterbalance the executive power. In practice, the President frequently exerted considerable influence over some independent agencies due to the vast and largely unchecked reach of the appointment power. The President appointed several independent officers, including the Monetary Board (which has authority to give recommendations on foreign loans) and the commission on audit (which has constitutional authority to audit the revenue, receipts, and expenditures of government); all the appointments actually are subject to the commission on appointments confirmation; but the confirmation is of little significance because the President can issue interim appointments pending the confirmation. That is why all the commissions of appointments are dominated by the President's relatives or allies sitting in Congress. The Philippines had experience of controversial appointments during the President Arroyo administration. President Arroyo used the appointment power to fill many significant positions during the constitutional restrictive period of appointment; such appointments allegedly gave benefit to her allies. ${ }^{274}$ The controversial appointments (the public called them "midnight appointments") included the appointment of 169 positions in the government owned and controlled corporations, and some positions in government agencies:

\footnotetext{
"Outgoing President Gloria Macapagal Arroyo has been churning out "midnight" appointments on a daily basis, all backdated before the constitutional ban on appointments during an election period. From March 1 to March 9 alone, Arroyo supposedly appointed 169 people to positions in Government-Owned and Controlled Corporations (GOCCS) in 10 government agencies, including those under the Office of the President (OP). The ban on appointments to executive positions started on March 10. All in all, Arroyo

${ }^{273} / d$. Section 14 the Philippines Constitution.

${ }^{274}$ Read: Ed Lingao on Philippine Center for Investigative Journalism, Day after P-Noy Proclaimed President Arroyo made 13 midnight appointments on June 10, Manila, July 11, 2010, available online on: http://pcij.org/stories/arroyo-made-13-\%E2\%80\%98midnight-appointments\%E2\%80\%99-on-june-10/ (accessed on January 6 2014).
} 
Rosa Ristawati: Modelling Executive Powers in the Indonesian Constitution: A comparative Study

appointed 250 persons via midnight appointments, a government source, who provided the documents, said. $^{275}$

The appointments were constitutionally controversial since they contravened Section 15 of Article VII. The public believed that the appointments were unconstitutional because the appointments were made during the restriction period that Section 15 of Article VII of the Constitution prescribed. It should be for two months immediately before the next presidential elections and up to the end of her term except for appointments which were temporary; President Arroyo should not perform the appointment power. The successor President, President Aquino, responded to such controversial appointments with revocation and invalidated some of the appointments. ${ }^{276}$

The Philippines Constitution grants a vice president in the same term of office as the President and permits the vice president to be appointed (without any confirmation) as a member of the cabinet. ${ }^{277}$ The Constitution also provides a comprehensive explanation about the anticipative position of a Vice President. Section 7 of the Article specifies the situation when the Vice President constitutionally acts as the President. According to the Section, the Vice President may act as the President in the situation if the President elected failed, if the President should not have been chosen, or if the President died or was permanently disabled. ${ }^{278}$ Furthermore, the Constitution clarifies that the Vice President will succeed as the President in the case where the President in office is dead, permanently unable to hold the powers, removed from the office, or resigned. ${ }^{279}$ Only in the case that the Vice President's office is vacant during the term of office, the President has the power to nominate a Vice

\footnotetext{
${ }^{275}$ Aries Rufo on abs-cbnNews.com, Arroyo issues midnight madness of appointments, June, 3 2010, available online at: http://www.abs-cbnnews.com/nation/06/03/10/arroyo-issues-midnight-madness-appointments (accessed on January 6 2014).

${ }^{276}$ Inquirer.net, the Court of Appeals junks Arroyo "midnight appointments", September 6, 2013, available online at: http://newsinfo.inquirer.net/482351/ca-junks-arroyo-midnight-appointments (accessed on January 6 January 2014).

${ }^{277}$ Constituteproject.org, Op. Cit., Article XII Section 3 the Philippines Constitution.

${ }^{278} / d$. Article XII Section 7 the Philippines Constitution.

${ }^{279}$ Id. Article XII Section 8 the Philippines Constitution.
} 
President from among the Members of the Senate and the House of Representatives. ${ }^{280}$ However, the appointment should be confirmed by a majority voting in Congress.

On the foreign affairs power, the President on behalf of the Philippines has the power (with limitations by laws) to make contracts or guarantee foreign loans with the consent from the Monetary Board and must be reported to the Congress. ${ }^{281}$

Moreover, with regard to the treaty power, the Phillippines President has treaty power with the consent from at least two-third of the Senate. ${ }^{282}$ According to the provision, the President can only exercise the power to make a treaty or any kinds of international agreement with the consent of at least two-thirds of all members of Senate. Additionally, according to Article XII, the President also has the power to make agreements with foreign-owned corporations on technical or financial assistance for large scale exploration, development, and utilization of minerals, petroleum, and other mineral oils. ${ }^{283}$ In exercising the power, the President does not need consent from either Congress or the Senate but the President has to notify the Congress all the contracts that have been made within 30 days.

On the administration power and the budgetary-expenditure powers, the President has the power to propose budget expenditure and sources of financing, including receipts from existing and proposed revenue measures, according to Article $22 .{ }^{284}$ The Congress may not increase the appropriations recommended by the President for the operation of the Government specified in the budget. ${ }^{285}$ However, the power to issue revenue or tariff bills, bills authorizing increase of the public debt, bills of local application and private bills is vested in the House of Representatives with the involvement of the Senate to propose any bills for amendment. ${ }^{286}$ The President, the President of the Senate, the Speaker of the House of Representatives, the Chief Justice of the Supreme Court, the heads of Constitutional

\footnotetext{
${ }^{280} / d$. Section 9 the Philippines Constitution.

${ }^{281} / d$. Section 20 L the Philippines Constitution

${ }^{282}$ Id. Section 21 the Philippines Constitution.

${ }^{283} \mathrm{Id}$. Article XII ection 2 para 4 and 5 the Philippines Constitution.

${ }^{284} / d$. Section 22 the Philippines Constitution: The President shall submit to the Congress, within thirty days from the opening of every regular session as the basis of the general appropriations bill, a budget of expenditures and sources of financing, including receipts from existing and proposed revenue measures.

${ }^{285} / d$. Section 25 the Philippines Constitution.

${ }^{286} / d$. Article VI Section 24 the Philippines Constitution.
} 
Rosa Ristawati: Modelling Executive Powers in the Indonesian Constitution: A comparative Study

Commission have the authorization to augment the general appropriations according to their respective office from savings in other items of their respective appropriations. ${ }^{287}$ In practice, during the President Arroyo administration in 2008, the budgeting power had been used to increase the state budget for some government projects. Most controversially, the power was allegedly used for other personal purposes, that is, for supporting the President's political allies. It was also reported that in 2009, the President funded some of her foreign travels with the government's emergency fund. The legislative significance about the spending priorities had less impact on actual public spending than might be expected from a review of budget documents; the President had claimed a legal right to redirect funds to their favored projects.

As the head of the executive, the President has the power to direct command and control all executive departments and government agencies. ${ }^{288}$ Some government agencies are under the direct command of the President such as the Philippines Council of Film Development, the Metropolitan Manila Development Authority and the Securities and Exchange Commission. Constitutionally, the President also heads the independent economic and planning agency established by the Congress which has the role to recommend to the Congress and implement continuing integrated and coordinated programs and policies for national development. ${ }^{289}$ The administrative power of the Philippines President also includes Article X section 4. According to Section 4 of the Article, the President of the Philippines has the power to exercise general supervision over local government. This is also in accordance with the Philippines as a unitary state; and thus, the President has a unitary power performing a Unitarian presidential power. For this purpose, the Constitution in section 14 of Article $\mathrm{X}$ also empowers the President to specify power related to the administration of local government. ${ }^{290}$ Under section 16 of the Article, the President has the power to exercise general supervision over autonomous regions to ensure that laws are faithfully executed. ${ }^{291}$

\footnotetext{
${ }^{287}$ Id. Article VI Section 25 (5) the Philippines Constitution.

${ }^{288}$ Id. Article VII Section 17 the Philippines Constitution: The President shall have control of all the executive departments, bureaus, and offices. He shall ensure that the laws are faithfully executed.

${ }^{289} / d$. Article XII Section 9 the Philippines Constitution.

${ }^{290} / d$. Article X Section 14 the Philippines Constitution.

${ }^{291}$ Id. Article X Section $16 \mathrm{~L}$ the Philippines Constitution
} 
Rosa Ristawati: Modelling Executive Powers in the Indonesian Constitution: A comparative Study

On the military power, the President of the Philippines is the Commander in Chief of the Philippines Armed Forces according to Article 7 Section 18 of the 1987 Constitution. Accordingly, the President has the power to call out the armed forces to prevent or suppress lawless violence, invasion or rebellion. At this point, the use of such power may also be against the private armies, paramilitary forces, civilian home defense forces and other armed groups which are not recognized by the authority and the Constitution as mentioned in Article XII Section 24. ${ }^{292}$ Practically, President Aquino used his military power as Commander in chief to command the Philippines armed forces to take any action against conflict in Zamboanga by the MILF rebels. ${ }^{293}$

On the emergency powers, as the Commander in Chief, the Constitution grants the President with the emergency power permitting the President to take any action for public safety including suspending the privilege of the writ of habeas corpus or declare martial law in any part or the whole part of the Philippines. ${ }^{294}$ Although the President seems to be granted a unilateral emergency power in time of state emergency, the Constitution also provides the mechanism of check and balance from the Congress and the Court against the presidential emergency power. Still according to Section 18, the Congress has the power to extend or suspend the proclamation of a state emergency in the interests of public safety; on the other hand, the Court has the power to review any appropriate proceeding filed by citizens with respect to the declaration of a state emergency. ${ }^{295}$ Furthermore, some measures may be taken during a state emergency including those mentioned in Article XII Section $17-19 .{ }^{296}$ The President, for the necessity or emergency, may certify the immediate enactment of the bill. ${ }^{297}$

On the war power, the real war power is vested in the Congress. According to Article VI Section 23, by a vote of two-thirds of both Senate and House of Representative, Congress has

\footnotetext{
${ }^{292} / d$. Article XII Section 24 the Philippines Constitution.

${ }^{293}$ BBC, Philippine clashes: President warns Muslim rebels in Zamboanga, September 3, 2013, available online at: http://www.bbc.com/news/world-asia-24082614 (accessed on January 6, 2014).

${ }^{294}$ Constituteproject.org, Op. Cit., Article 7 Section 18 the Philippines Constitution.

${ }^{295}$ Id. Article XII Section 18 the Philippines Constitution.

${ }^{296} / d$. Article XII section 17 - section 19 the Philippines Constitution.

${ }^{297}$ Id. Article VI Section 26 (2) the Philippines Constitution.
} 
the power to declare war. ${ }^{298}$ The Congress by law also has the power to authorize the President to exercise powers necessary and proper to carry out a declared national policy. ${ }^{299}$ The Congress has the power to pass the bill. ${ }^{300}$

On the pardoning power, the President has the pardoning power to grant reprieves, commutations, pardons, remit fines and forfeitures according to Article VII Section $19 .^{301}$ However, the power can only be exercised after conviction by the final judgment and does not apply to impeachment cases. The exercise of the presidential pardoning power in particular of granting an amnesty should be performed with the support of a majority of all the members of the Congress.

The President and the Vice President are directly elected by the people according to Article VII Section 4 paragraph 1. Accordingly, the voting system is based on the simple majority vote where a candidate with the highest votes is elected as the President. However, in case there are two or more candidates having the same votes, there will be an election by Congress. The voting system in the second round is also a simple majority vote by both Houses of the Congress separately. ${ }^{302}$ In the presidential election, the Court has a role as the sole judge for the qualification of the President or Vice-President and any issues related to the election. Section 11 of the Article emphasizes the right of the Vice President during the written declaration from the Congress (the Senate and the House of Representative) on the disability of the President to carry out the power and duties. In this situation, the President's executive power and duties will be diverted to the Vice President; and accordingly, the Vice President will have the executive power during the process of impeachment. ${ }^{303}$

The Philippines Constitution has provision in anticipating abuse of power by the President in any case of affiliation and relatives. Section 13 of the Article clarifies the prohibition and attitudes of the President, Vice President, and other executive officers during

\footnotetext{
${ }^{298}$ Id. Article VI Section 23 (1) the Philippines Constitution.

${ }^{299}$ Id. Article VI Section 23 (2) the Philippines Constitution.

${ }^{300} / d$. Article VI Section 26. (1) the Philippines Constitution.

${ }^{301} / d$. Section 19 the Philippines Constitution.

${ }^{302} / d$. Section 4 the Philippines Constitution.

${ }^{303} / d$. Section 11 the Philippines Constitution.
} 
their office. ${ }^{304}$ On the Presidential Impeachment, the Philippines Constitution clarifies that the President may be removed from office on particular criminal grounds. ${ }^{305}$ According to section 79 of Article VII, the President may be removed on the grounds of inability during his office, death, illness, permanent disability, resignation. According to Article XI on the accountability of public officers section 2, the President may be subject to be removed from office on impeachment for and on conviction of culpable violation of the Constitution, treason, bribery, graft and corruption, other high crimes, or betrayal of public trust. ${ }^{306} \mathrm{~A}$ series of mechanisms according to Article XI Section 3-8 are constitutionally taken as the impeachment process for the President. ${ }^{307}$ According to the Article, the House of Representative has the power to initiate the impeachment process. The process will democratically involve the Senate and Supreme Court and end up by the Congress promulgation of the presidential impeachment. In this case, the House of Representatives may have the exclusive power to initiate all cases of impeachment. $^{308}$

\section{d. Executive power in a hybrid system of government}

\section{France: Executive power under the Fifth Republic Constitution}

The French Constitution (the Fifth Republic Constitution) is the Constitution of 4 October 1958 as amended by constitutional statute 2008-724 of 23 July $2008 .{ }^{309}$ The Constitution establishes a dual executive, the President and Prime Minister. It requires the President and the Prime Minister to share some of the executive power. In some areas, the Constitution requires the exercise of executive power to be shared; at this point, both the President and the Prime Minister have the right to veto. Such mutual veto sometimes may trigger conflict and deadlocks. ${ }^{310}$ For many important acts, such as appointments and the

\footnotetext{
${ }^{304} / d$. Section 13 the Philippines Constitution.

${ }^{305} / d$. Article XI Section 2 the Philippines Constitution.

${ }^{306}$ Id. Article XI Section 2 the Philippines Constitution.

${ }^{307}$ Id. Article XI Section 3 the Philippines Constitution.

${ }^{308}$ Id. Section 3. (1) the Philippines Constitution.

${ }^{309}$ The Maastricht Collection, Op. Cit.

${ }^{310}$ See: Cole J. Harvey, The Double-Headed Eagle: Semi- Presidentialism and Democracy in France and Russia, Bachelor of Philosophy Thesis, Submitted to the Dean of the University Honors College, University of Pittsburgh,
} 
Rosa Ristawati: Modelling Executive Powers in the Indonesian Constitution: A comparative Study

promulgation of laws, the President should give mutual counter-signatures, while on the other important power such as the military power of Commander in chief and foreign policy, the President has to exercise the power with reference to the Prime Minister and national Assembly. ${ }^{311}$ For such as a fundamental act like constitutional amendment, the President, on the recommendation of the Prime Minister and Members of Parliament has the right to initiateamendments to the Constitution. ${ }^{312}$

Andrew Knapp and Vincent Wright observed that though both president and prime minister wield powers according to political circumstances, their powers reside mainly in the constitutional text. ${ }^{313}$ The Constitution provides both President and Prime Minister with equally strong and significant power and makes it possible to be exercised individually. It places the President as the final decision maker and the dominant figure in some of the executive power; on the other hand, it gives the Prime Minister dominance in the Government and the Parliament. It is assumed that such as foreign affairs and defense power are to be mostly exercised independently by the President. ${ }^{314}$

defended on 14 July 2008, p. 18: "While defense and foreign policy are largely controlled by the president, there are times when presidential decisions are subject to veto by the prime minister, and vice versa. This mutual veto increases the likelihood of friction and government gridlock, but also obliges the two executives to work more closely together, and encourages negotiation and compromise. For example, the president is empowered to call national referendums, but only on the proposal of the prime minister or a joint resolution of the houses of parliament (Article 11). Both players, then, have an effective veto over a proposed referendum. The president may decline to formalize a referendum proposed by the prime minister, and the prime minister may refuse to propose a referendum desired by the president. The appointment of the various ministers is another area of shared responsibility. It is the president who appoints and dismisses the government ministers, but only on the proposal of the prime minister himself (Article 8)."

${ }^{311}$ See more on Andrew Knapp and Vincent Wright, the Government and Politics of France, $4{ }^{\text {th }}$ Edition, Routledge, London, 2001, p. 113: "The prime minister, on the other hand, has no interest as a presidential aspirant in assaulting the institutions of which he hopes, eventually, to become the guarantor. The two heads of the executive remain political adversaries, even enemies, but they also need each other."

${ }^{312}$ Constituteproject.org, France's Constitution of 1958 with Amendments through 2008, generated from excerpt of texts from the repository of the Comparative Constitutions Project, and distributed on constituteproject.org: Article 89 of the Fifth Republic Constitution (the French Constitution).

${ }^{313}$ Andrew Knapp and Vincent Wright, Op. Cit., p. 82.

${ }^{314}$ See: Cole J. Harvey, Op. Cit., p. 17: "While the constitution places the armed forces at the disposal of the government, it also names the president as commander-in-chief (Article 15), proclaims him the guarantor of national independence and territorial integrity (Article 5), and places him at the head of "the higher national defense councils" (Article 15). Presidents have also been assertive in the area of foreign policy. The constitution 
Rosa Ristawati: Modelling Executive Powers in the Indonesian Constitution: A comparative Study

\section{- The President of the Republic under the Constitution of the Fifth Republic}

The Fifth Republic Constitution empowers the President with limited numbers and scope of discretionary powers. ${ }^{315}$ Some of the Presidential powers have to be exercised with reference to the Prime Minister's or National Assembly's counter-signature. During the Presidential term of office, the French President is shielded with the immunity given by the Constitution. ${ }^{316}$

According to Article 5 of the Constitution of the Fifth Republic, the President of the Republic has several symbolic powers as the guarantor of national independence, territorial integrity and (by his arbitration) the proper functioning of the public authorities as well as the continuity of the State, and observance of treaties. Furthermore, according to Article 64, he also acts as the guarantor of the independence of the Judicial Authority. ${ }^{317}$ As a consequence, according to Article 65 of the Fifth Republic Constitution, the French President presides over the High Judiciary Council.

The French President is considered to have control over the government. The President has some powers that can directly affect the government, such as, the power to determine the size and shape of the government; the power to appoint and dismiss the Prime Minister, the power to intervene directly in the choice of individual ministers, and the power to determine the political balance of the government. ${ }^{318}$ Moreover, the President is the chief of the nation's policy makers since in practice, the President has access to intervene in the policy making procedure at all stages. ${ }^{319}$

states that "The President shall negotiate and ratify treaties" (Article 52). However, any treaty which concerns a subject under parliament's normal legislative domain can only be approved by an act of parliament (Article 53)".

${ }^{315}$ Id. at p. 12.

${ }^{316}$ Constituteproject.org, Op. Cit., Article 67 the Fifth Republic Constitution.

${ }^{317} / d$. Article 64 of the Fifth Republic Constitution.

${ }^{318}$ Andrew Knapp and Vincent Wright, Op. Cit., 2001, p. 103

${ }^{319}$ Id. Andrew Knapp and Vincent Wright, 2001, p. 104: "the President fixes the agenda and time table of the Council of Ministers and determine the government programs, he has direct and indirect access to the ministers, he has access to act as a final court of appeal over the Prime Minister on the policy issues, the President signs decree for implementing government legislation, etc." 
Rosa Ristawati: Modelling Executive Powers in the Indonesian Constitution: A comparative Study

Article 11 paragraph 1 the Constitution of the Fifth Republic stipulates that the President of the Republic has the power to submit a referendum concerningany government bills, in particular issues of the organization of public authorities, reforms relating to the economic, social or environmental policy of the nation and the public services which contribute to it; the power to propose the authorization of the ratification of a treaty which, while not being contrary to the Constitution, would have an effect on the functioning of the institution. ${ }^{320}$ In practice, the power to call a referendum has some political purposes such as establishing a direct line of communication between president and the people, reinforcing the unity of the governmental coalition, and dividing the political opposition. ${ }^{321}$

On the law-making power, the President of the Republic has the important role. He has the power according to Article 10 of the Fifth Republic Constitution to promulgate statute and ask the parliament to deliberate a newStatute or certain provisions. ${ }^{322} \mathrm{He}$ has no veto power but has a real indirect role in the legislative process. ${ }^{323}$ Moreover, the President has the right to refer any bills, Institutional Acts, Rules of Procedure of the Houses of Parliament (Article 61) to the Constitutional Council for their conformity to the Constitution.

\footnotetext{
${ }^{320}$ Constituteproject.org, Op. Cit., Article 11 paragraph 1 the Constitution of the Fifth Republic.

${ }^{321}$ See more: Andrew Knapp and Vincent Wright, Op. Cit., p. 84 - 85: “Article 11 may be invoked without the prime minister's countersignature; the constitutional requirement that a referendum should be proposed to the president by the government or parliament has meant in practice that the Council of Ministers is notified of the presidential decision. Of the nine referenda since 1958, the first four - ratifying the constitution itself in 1958 and amending it in 1962, as well as agreeing first the 'self-determination' of Algeria (in 1961) and then its independence (in 1962) - may be rated successes, with turn-outs of at least 75 per cent and yes votes of at least 61 per cent. The other five were less kind to their initiators: the voters rejected proposals to reform the Senate and the regions in April 1969, provoking de Gaulle's immediate resignation; a wafer-thin majority ratified the Maastricht Treaty on European Union in September 1992; high abstention rates greeted referenda on the enlargement of the European Community in April 1972, on the future of the troubled Pacific territory of New Caledonia in November 1988, and above all on the five-year presidential term in September 2000, when barely a quarter of the electorate cast a valid vote."

${ }^{322}$ Constituteproject.org, Op. Cit., Article 10 of the Constitution of the Fifth Republic.

${ }^{323}$ Andrew Knapp and Vincent Wright, Op. Cit., p. 86: "The president does not set foot in parliament and, unlike his American counterpart, has no legislative veto. Nevertheless, he has a real if indirect role in the legislative process. He chairs the Council of Ministers (Article 9), like his predecessors of the Third and Fourth Republics, and may do so more actively than they. He may request the 'reconsideration' of laws passed by the parliament (Article 10), though as a simple majority remains sufficient to carry any resulting vote, this right is rarely invoked. He may put a legislative proposal to referendum. He signs ordonnances (that is, primary legislation delegated to the government by parliament) and decrees (which implement primary legislation) under Article 13, though the constitution does not state whether he may refuse to do so."
} 
On the appointment power, Article 8 of the Constitution of the Fifth Republic stipulates that the French President has the power to appoint and dismiss the Prime Minister. He also has the power to appoint other members of the Government, as well as, terminate their functions. Following up, according to Article 9 of the Constitution of the Fifth Republic, the President of the Republic has the power to preside over the Council of Ministers. According to Article 13, the President has the appointment power of some civil and military posts of the state. ${ }^{324}$ According to the Article, the appointment is made by an Institutional Act and should be exercised after public consultation with the relevant standing committee in each House, and the President is bound by the votes in each committee. In practice, Andrew Knapp and Vincent Wright observed that the appointment power of the President is exercised in a wide range of other public sector posts. ${ }^{325}$ Furthermore, the President has the appointment power of the three members of the Constitutional Council. ${ }^{326}$

On the foreign affairs and treaty power, the President has significant power in the foreign policy making and European affairs. ${ }^{327}$ Article 14 indicates the diplomacy power of the President including the power to accredit ambassadors and envoys with extraordinary foreign power and vice versa. ${ }^{328}$ On the treaty power, the President has the power to negotiate and ratify treaties. ${ }^{329}$ However, it does not mean that the treaty power of the President is exercised as unchecked and unbalanced power. According to Article 53, there are certain treaties or international agreements that must be ratified or approved only by an Act of Parliament. ${ }^{330}$ The Constitutional Council, according to Article 54 also may have a role on the treaty process. It may determine that an international undertaking contains a clause contrary to the Constitution and

\footnotetext{
${ }^{324}$ Constituteproject.org, Op. Cit., Article 13 of the Fifth Republic Constitution.

${ }^{325}$ Andrew Knapp and Vincent Wright, Op. Cit.,p. 86:"This list, though, is not exhaustive, and in practice the president may propose candidates for a wide range of other public-sector posts, for example secret service chiefs, senior broadcasting chiefs or heads of nationalized industries."

${ }^{326}$ Constituteproject.org, Op. Cit., Article 56 of the Fifth Republic Constitution.

${ }^{327}$ See more on: Andrew Knapp and Vincent Wright, Op. Cit., p. 105.

${ }^{328}$ Id. Article 14 of the Fifth Republic Constitution.

${ }^{329} / d$. Article 52 of the Fifth Republic Constitution.

${ }^{330} / d$. Article 5 of the Fifth Republic Constitution 3.
} 
Rosa Ristawati: Modelling Executive Powers in the Indonesian Constitution: A comparative Study

the authorization to ratify or approve the international undertaking involved may be given after the Constitution is amended. ${ }^{331}$

On the military power, the President has the power as the Commander in Chief and the power to preside over the higher national defence councils and committees. ${ }^{332}$ In terms of the emergency power, the Constitution states that the President has to share the power with the Prime Minister. Article 16 determines the state of emergency as situations where the institutions of the Republic, the independence of the Nation, the integrity of its territory or the fulfillment of its international commitments are under serious and immediate threat; and the situation where the proper functioning of the constitutional public authorities is interrupted. ${ }^{333}$ In such an emergency situation, the President has the emergency power to take measures but only after formal consultation with the Prime Minister, the Presidents of the Houses of Parliament, and the Constitutional Council. To an extent, Article 16 of the Constitution indicates that the emergency power of the President is not a unilateral power that the President can exercise independently. Furthermore, the Article also indicates that there is term limit of the emergency power application. It orders that after thirty days of operation of the emergency power, the President of the National Assembly, the President of the Senate, sixty Members of the National Assembly or sixty Senators, may refer to the Constitutional Council to decide whether or not the emergency situation should be renewed.

On the pardoning power, the French President has the power to grant individual pardons. ${ }^{334}$

\section{- Prime Minister and the Government}

Title III of the Fifth Republic Constitution is the constitutional basis for the French government. In general, the Constitution implies that the Prime Minister is a significant figure in the government affairs and enjoys significant executive power. Andrew Knapp and Vincent Wright observed that some of the French Prime Minister's power can be exercised

\footnotetext{
${ }^{331} / d$. Article 54 of the Fifth Republic Constitution.

${ }^{332} / d$. Article 15 of the Fifth Republic Constitution.

${ }^{333}$ Id. Article 16 of the Fifth Republic Constitution.

${ }^{334} / d$. Article 17 of Fifth Republic Constitution.
} 
Rosa Ristawati: Modelling Executive Powers in the Indonesian Constitution: A comparative Study

independently under the President's intervention and support from a loyal parliamentary majority; however, some power such as appointment and defense power have to be shared with the President. ${ }^{335}$ As the Prime Minister is the actual director of the Government, he automatically enjoys the whole government powers. Article 20 of the Constitution declares that the government has the power to determine and conduct the policy of the Nation, and has the power, at its disposal, over the administration of the civil service and the armed forces. ${ }^{336}$ However, some articles specifically express the Prime Minister's power exclusively. Article 21 of the Fifth Republic Constitution implies that the Prime Minister has the power to direct the actions of the Government. It specifies that the Prime Minister has some powers in the following areas:

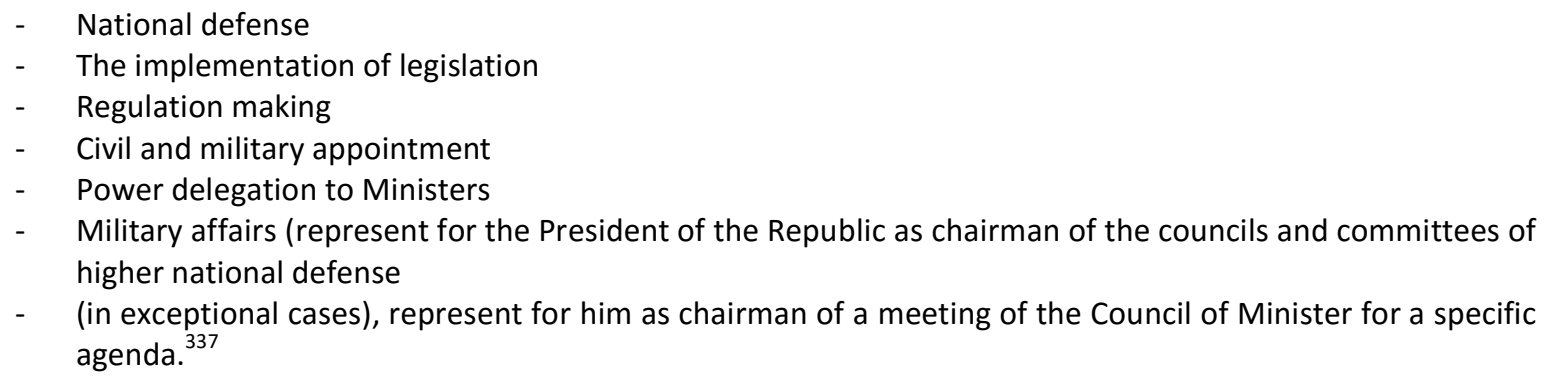

- Military affairs (represent for the President of the Republic as chairman of the councils and committees of higher national defense

- (in exceptional cases), represent for him as chairman of a meeting of the Council of Minister for a specific agenda. $^{337}$

The Prime Minister has the power to propose the appointment and to recommend the termination of the members of the Government to the President. ${ }^{338}$ Moreover, the Prime Minister also has the power to require an extra-ordinary session of parliament for a specific agenda. 339

On the law-making power, Article 39 of the Fifth Republic Constitution confirms that the Prime Minister has the right to initiate legislation. ${ }^{340}$ In some of constitutional articles, the Prime Minister has significant power in law-making. Article 61 allows the Prime Minister to refer the Institutional Acts, the Private Members' Bills, and the Rule of Procedures of the Houses of Parliament, before their promulgation, to the Constitutional Council for their

\footnotetext{
${ }^{335}$ Andrew Knapp and Vincent Wright, Op. Cit., p. 83.

${ }^{336}$ Constituteproject.org, Op. Cit., Article 20 of the Fifth Republic Constitution.

${ }^{337}$ Id. Article 21 of the Fifth Republic Constitution.

${ }^{338} / d$. Article 8 of the Fifth Republic Constitution.

${ }^{339}$ Id. Article 29 of the Fifth Republic Constitution.

${ }^{340} / d$. Article 39 of the Fifth Republic Constitution.
} 
conformity with the Constitution. ${ }^{341}$ On the treaty power, the Prime Minister has the right to refer any treaty and International agreement to the Constitutional Council on its conformity to the Constitution before it is ratified or approved. ${ }^{342}$

Article 49 constitutes some other significant powers of the Prime Minister. According to the Article, the Prime Minister, after deliberation by the Council of Ministers, has the power to ask the National Assembly for a vote of no-confidence against the government concerning the issue of government's program or possibly a general policy statement. ${ }^{343}$

Andrew Knapp and Vincent Wright argued that the Prime Minister, as the head of government, may also dominate the parliamentary activities which may be done by requesting delegated legislation or the procedure of the blocked vote; he also can control the complex procedure to deal with legislative dead lock in the parliament:

"It is the prime minister, as head of the government, who wields the battery of constitutional provisions designed to curb the activities of parliament: the request for delegated legislation under Article 38, for example, or the procedure of the vote bloque under Article 44, under which parliament may be obliged to vote on the government's version of a bill. It is the prime minister, finally, who controls the complex procedure under which bills are shuttled between the two houses of parliament (National Assembly and Senate) for successive readings before an agreed version (or failing that, the Assembly's version) is passed". 344

With regard to war power, Article 35 of the Constitution of the Fifth Republic implies that the Parliament holds the real power to authorize war. On the other hand, it lays down the other power to decide the mobilization of armed forces on the purpose of international intervention to the Government. ${ }^{345}$

\section{Poland}

The Polish semi-presidential system is regulated under the Polish Constitution 1997.The Polish 1997 Constitution recognizes a dual executive and places the Polish President as part

\footnotetext{
${ }^{341} / d$. Article 61 of the Fifth Republic Constitution.

${ }^{342} / d$. Article 54 of the Fifth Republic Constitution.

${ }^{343}$ Id. Article 49 of the Fifth Republic Constitution.

${ }^{344}$ Andrew Knapp and Vincent Wright, Op. Cit., p. 83.

${ }^{345}$ Constituteproject.org, Op. Cit., Article 35 of the Fifth Republic Constitution.
} 
ofthe dual executive. ${ }^{346}$ Generally, according to the Constitution, the executive power is jointly conferred upon the President and the Council of Ministers. ${ }^{347}$

\section{The Polish President}

The Polish President constitutionally performs duties as the head of the state and is not inherently strong, but constitutional practices can make him a powerful figure. ${ }^{348}$ The Polish President is elected in universal, equal, directelections conducted by secret ballot. ${ }^{349}$ According to Article 145, the President may be held accountable before the Tribunal of State for an infringement of the Constitution or Statute, or for commission of an offence. ${ }^{350}$

Certain symbolic powers are given to the Polish President in Article 126 of the Poland Constitution. The powers include the power as the supreme representative of the Republic of Poland and the power as the guarantor of the continuity of State authority, the power to ensure the observance of the Constitution, and the power to safeguard the sovereignty and security of the State as well as the inviolability of its territory. ${ }^{351}$

The President may have the power to recall a minister in whom a vote of no confidence has been passed by the Sejm. ${ }^{352}$ The President also has the power to affect changes in the composition of the Council of Minister on the application of Prime Minister. ${ }^{353}$ The Prime Minister has to submit the resignation of the Council of Ministers in certain situations. ${ }^{354}$

On the law-making power, Article 142 determines that the President has the power to issue regulations and executive orders as well as the power to issue decisions within the scope

\footnotetext{
${ }^{346}$ Miroslaw Wyrzykowski and Agnieszka Ciele, "Presidential Elements in Government Poland - semi presidentialism or rationalized parliamentarism?", European Constitutional Law Review, TMC Asser Press, Cambridge Journal, 2: 2006, pp. 253 - 267, p. 253 (accessed online athttp://journals.cambridge.org on 09/11/2011).

${ }^{347}$ Id. at p. 258.

${ }^{348}$ Id.

${ }^{349}$ Constituteproject.org, Poland's Constitution of 1997 with Amendments through 2009, generated from excerpts of texts from the repository of the Comparative Constitutions Projects, and distributed on constituteproject.org: Article 127 the Polish Constitution.

${ }^{350} / d$, Article 145 section 1 of the Polish Constitution, Article 145 section 2 of the Polish Constitution, Article 145 section 3 of the Polish Constitution.

${ }^{351} / d$. Article 126 of the Polish Constitution.

${ }^{352} / d$. Article 159 Section 1, Article 159 section 2 of the Polish Constitution.

${ }^{353} / d$. Article 161 of the Polish Constitution.

${ }^{354} / d$. Article 162 of the Polish Constitution.
} 
of the discharge of his other authorities. ${ }^{355}$ Furthermore, except for certain issues that are stipulated in Article 144 section 3, ${ }^{356}$ according to Article 144 of the Polish Constitution, the President has the power to issue Official Acts to exercise his constitutional and statutory authority. ${ }^{357}$ The Official Acts of the President have to be validated by the Prime Minister's signature. $^{358}$

On the appointment power, according to the Constitution, the President has the power to nominate a Prime Minister and appoint a Prime Minister together with other members of a Council of Ministers and accept the oaths of office of members of such newly appointed Council of Ministers. ${ }^{359}$ The President assists by a Presidential Chancellery. He has the power to establish the statute of the Presidential Chancellery including to appoint and dismiss its Chief. $^{360}$

On the foreign affairs power, the Polish President, as the representative of the state in foreign affairs, according to Article 133 section 1 of the Polish Constitution, has the power to ratify and renounce international agreements, appoint and recall the pleni-potentiary representatives of the Republic of Poland to other states and to international organization, to receive the Letters of Credence and recall of diplomatic representatives of other states and international organizations accredited to him. ${ }^{361}$ Moreover, section 2 of the Article allows the President, before ratifying an international agreement, to refer to the Constitutional Court and request it to adjudicate upon the conformity of the international agreement to the Constitution. ${ }^{362}$ In general, with regard to foreign policy power, the Constitution requires the President to cooperate with the Prime Minister and the appropriate minister. ${ }^{363}$

\footnotetext{
${ }^{355}$ Id. Article 142 section 1, Article 142 section 2 of the Polish Constitution.

${ }^{356} / d$. Article 144 section 3 of the Polish Constitution.

${ }^{357} / d$. Article 144 section 1 of the Polish Constitution.

${ }^{358} \mathrm{Id}$. Article 144 section 2 of the Polish Constitution.

${ }^{359} / d$. Article 154 section 1 of the Polish Constitution.

${ }^{360} / d$. Article 143 of the Polish Constitution.

${ }^{361} / d$. Article 133 section 1 of the Polish Constitution.

${ }^{362} / d$.Article 133 section 2 of the Polish Constitution.

${ }^{363} / d$. Article 133 section 2 of the Polish Constitution.
} 
On the military power, the Polish President has the military power as the Supreme Commander of the Armed Forces of the Republic of Poland. ${ }^{364}$ Furthermore, the Constitution also specifies the power of the President as the Supreme Commander into two different situations: the power in times of peace and the power in a period of war. According to Article 134 section 2, in times of peace, the Polish President has the power of command over the Armed Forces through the Minister of National Defence. ${ }^{365}$ In times of war, the President has the power to appoint the Commander in Chief of the Armed Forces on request of the Prime Minister. ${ }^{366}$ At the administrative level, the President as the Supreme Commander has the power to appoint the Chief of the General Staff and commanders of branches of the Armed Forces for a specified period of time. ${ }^{367}$ He has also the power to confer military ranks on the request of the Minister of National Defence and as specified by statute. ${ }^{368}$ On the national security issues, the National Security Council is the advisory organ to the President of Poland Republic. ${ }^{369}$ On the special issue of a direct external threat to the State, at the request of the Prime Minister, the President has the power to order a general or partial mobilization and deployment of the Armed Forces in defence of the state. ${ }^{370}$

On the civic power, the Polish President has the power to grant Polish citizenship and has the power to give consent for renunciation of Polish citizenship. ${ }^{371}$

On the pardoning power, as the head of the state, the President of Poland has the power to confer orders and decorations. ${ }^{372}$ With regard to the pardoning power, according to Article 139, the President has the power to grant pardon which may not be extended to individuals convicted by the Tribunal of State. ${ }^{373}$ On the cabinet council, According to Article

\footnotetext{
${ }^{364} / d$. Article 134 section 1 of the Polish Constitution.

${ }^{365} / d$. Article 134 section 2 of the Polish Constitution.

${ }^{366} / d$. Article 134 section 4 of the Polish Constitution.

${ }^{367} / d$. Article 134 section 3 of the Polish Constitution.

${ }^{368} / d$. Article 134 section 5, Article 134 section 6 of the Polish Constitution.

${ }^{369} / d$. Article 135 of the Polish Constitution.

${ }^{370} / d$. Article 136 of the Polish Constitution.

${ }^{371} / d$. Article 137 of the Polish Constitution.

${ }^{372} / d$. Article 138 of the Polish Constitution.

${ }^{373} / d$. Article 139 of the Polish Constitution.
} 
141, the President may have the power, on particular matters, to convene the Cabinet Council and to preside over the Council of Ministers debates. ${ }^{374}$

\section{The Council of Ministers, the Prime Minister, and Government Administration}

The 1997 Polish Constitution confirms that the Council of Ministers and the Prime Minister are the dominant and central part of the executive $\cdot{ }^{375}$ Article 146 clarifies that the Council of Ministers conducts the internal and foreign affairs. ${ }^{376}$ It consists of the Prime Minister as the President of the Council of Ministers and ministers; ${ }^{377}$ and may also include the Deputy Prime Minister who may be appointed as the vice president of the Council of Ministers. ${ }^{378}$ It also has the duty to manage the government administration. ${ }^{379}$ Furthermore, Article 146 section 4 specifies the duties of the Council of Ministers, which are mainly to perform government affairs. ${ }^{380}$ As Poland recognizes a dual executive, the Constitution clarifies the Prime Minister's power. According to the Polish Constitution, the powers of the Prime minister are specified in Article $148 .{ }^{381}$ The Prime Minister has also the power to allocategovernment administration tasks to the ministers. ${ }^{382}$ He has the power to request to revoke a regulation or order of a minister. ${ }^{383}$ In general, the Prime Minister has the power of control over the body of civil servants. ${ }^{384}$ The Prime Minister, within 14 days after his appointment, has to submit a program of activity of the Council of Ministers to the Sejm. ${ }^{385}$

The Polish Constitution does clarify that the member of the Council of Ministers is accountable to the Tribunal of State for an infringement of the Constitution or Statutes. ${ }^{386}$ The motion may be passed by the President or at least 115 Deputies. ${ }^{387}$

\footnotetext{
${ }^{374} / d$. Article 141 section 1 of the Polish Constitution.

${ }^{375}$ George Sanford, Democratic Government in Poland, Palgrave Macmillan, 2002, p. 151.

${ }^{376}$ Constituteproject.org, Op. Cit., Article 146 section 1, Article 146 section 2 the Polish Constitution.

${ }^{377} / d$. Article 147 section 1 of the Polish Constitution.

${ }^{378} / d$. Article 147 section 2 of the Polish Constitution.

${ }^{379} / d$. Article 146 section 3 of the Polish Constitution

${ }^{380} / d$. Article 146 section 4 of the Polish Constitution.

${ }^{381} \mathrm{Id}$. Article 148 of the Polish Constitution.

${ }^{382}$ Id. Article 149 section 1 of the Polish Constitution.

${ }^{383}$ Id. Article 149 section 2 of the Polish Constitution.

${ }^{384} / d$. Article 153 section 2 of the Polish Constitution.

${ }^{385} / d$. Article 154 section 2 of the Polish Constitution.

${ }^{386} / d$. Article 156 section 1 of the Polish Constitution.
} 
Rosa Ristawati: Modelling Executive Powers in the Indonesian Constitution: A comparative Study

\subsection{Closing remarks}

There is a general feature of the constitutions in terms of the Executive and its powers. ${ }^{388}$ They recognise the Executive as one of the constitutional branches which has the power to execute the Laws and the power of the state administration. All the constitutions under different systems provide checks and balances systems among three branches. There are similarities among the three models of constitutions in terms of preventing abuse of power by the Executive. However, In terms of the actual executive powers, there is a degree of difference among countries depending on different systemsof government in terms on how the powers are given. From the comparisons of the 6 Constitutions, some of following points may be considered by Indonesia in order to improve the executive powers ${ }^{389}$ :

1. Most of the 6 Constitutions have been set in more modern and up to date terminology, such as the German Constitution that uses modern terms of state defence instead of using the war terms, and the South African Constitution that uses modern terms of state of national defence to replace the term of war power. The French Constitution, on the other hand, has set a modern frameworkof a fixed definition for the state emergency. It definesthe emergency as the situation where the institution of the Republic, the independence of the Nation, the integrity of its territory or the fulfillment of its international commitments are under serious and immediate threat, and where the proper functioning of the constitutional public authorities is interrupted.The French Constitution has even more modern ideas in adopting a specific issue of international intervention which has been developed by International law.

2. Most of the 6 Constitutions give more clarity, such as the South African Constitution that gives more clarity about the President as the Commander in Chief. It also provides the determination of the scopes of the administrative power of the President as the national executive in its Article 85. On the other hand, the French Constitution

\footnotetext{
${ }^{387}$ Id. Article 156 section 2 of the Polish Constitution.

${ }^{388}$ See: table 2.3 .

${ }^{389}$ Adopting modern and up to date terminologies in the Constitution would help Indonesia develop as a modern state, adaptive to the global development problems nationally and internationally. It is also to help the Indonesian Constitution to be a living constitution that could answer any problems which may arise in the modern world.
} 
providesclarity of the role of the President and the scope of a treaty. It gives the President of the Republic the power to negotiate and ratify treaties. The Constitution also provides the scopes of treaties namely the peace treaties, trade agreements, treaties or agreements relating to international organizations, those committing the finances of the State, those modifying provisions which are the preserve of statute law, those relating to the status of persons, and those involving the ceding, exchanging or acquiring of territory; those treaties may be ratified or approved only by an Act of Parliament.

3. Most of the 6 Constitutions provide a mechanism of checks and balances to prevent abuse of power, for example, the Polish Constitution sets a mechanism for the President to refer to the constitutional tribunal for adjudication upon a bill's conformity to the Constitution; and based on the Constitutional tribunal's judgement, the President may refuse to sign the bill. It also sets a mechanism for the President to refer to the Constitutional tribunal before the ratification of an international agreement to adjudicate upon its conformity to the Constitution.

4. Most of the 6 Constitutions provide special powers that are relevant to the state and to the Executive; for example, the South African Constitution sets an article for the presidential power on the specific issue of the state intelligence service. On the other hand, the Polish Constitution also empowers the President with the consent from the Senate for a special power to call a referendum which gives the possibility for the President to invoke a referendum, in respect of matters of particular importance to the State.

5. Most of the 6 Constitutions provide a clear limitation to the Executive power, such as the US constitution which provides a firm limitation that the President may have pardoning power except for impeachment cases. On the other hand, the Philippines Constitution also makes the limitation for the pardoning power. It clearly says that except in cases of impeachment, the President has pardoning powers, including the power to grant reprieves, commutation, and pardons, and remit fines and forfeitures, after conviction by final judgment. 
Rosa Ristawati: Modelling Executive Powers in the Indonesian Constitution: A comparative Study

Table 2.3 Features of three government systems

\begin{tabular}{|c|c|c|c|c|}
\hline $\begin{array}{l}\text { Constitution: Systems of } \\
\text { government }\end{array}$ & \multirow[t]{2}{*}{$\begin{array}{l}\text { Parliamentary } \\
\text { Constitution }\end{array}$} & \multirow[t]{2}{*}{$\begin{array}{l}\text { Presidential } \\
\text { Constitution }\end{array}$} & \multirow[t]{2}{*}{ Mixed Constitution } & \multirow[t]{2}{*}{ Other Constitution } \\
\hline Features & & & & \\
\hline $\begin{array}{l}\text { Head of State } \\
\text { - Appointment } \\
\text { - } \quad \text { Removal }\end{array}$ & $\begin{array}{c}\bullet \\
\text { (direct-indirect } \\
\text { elected) }\end{array}$ & (direct elected) & (direct elected) & $\begin{array}{c}\bullet \\
\text { (direct elected/indirect } \\
\text { elected) }\end{array}$ \\
\hline Head of Government & (indirect elected) & (direct elected) & (direct elected) & (direct/indirect elected) \\
\hline $\begin{array}{l}\text { Relationship executive- } \\
\text { legislative }\end{array}$ & $\begin{array}{l}\text { Fusion of executive- } \\
\text { legislative }\end{array}$ & $\begin{array}{l}\text { Separation of executive- } \\
\text { legislative }\end{array}$ & $\begin{array}{l}\text { Fusion of executive- } \\
\text { legislative }\end{array}$ & $\begin{array}{l}\text { Separation executive- } \\
\text { legislative }\end{array}$ \\
\hline Executive branch & Prime minister & President & $\begin{array}{l}\text { President-prime } \\
\text { minister }\end{array}$ & $\begin{array}{l}\text { President/prime } \\
\text { minister/cabinet }\end{array}$ \\
\hline Government formation & $\begin{array}{l}\text { Mutual Dependent to } \\
\text { parliament } \\
\text { Coalition government }\end{array}$ & $\begin{array}{l}\text { Mutual Independent } \\
\text { from legislative } \\
\text { Non-coalition/coalition } \\
\text { government }\end{array}$ & $\begin{array}{l}\text { Mutual Dependent to } \\
\text { the parliament and to } \\
\text { elected President }\end{array}$ & \\
\hline
\end{tabular}

Table 2.4 Summary of general characteristic of three models of government systems

\begin{tabular}{|c|c|}
\hline \multicolumn{2}{|c|}{ Models of system of government } \\
\hline & $\begin{array}{l}\text { Parliamentary system } \\
\text { - Separation of head of state and head of government } \\
\text { The executive branch: Prime minister and the cabinet - collective executive branch } \\
\text { Head of executive: the Prime minister; can be changed anytime } \\
\text { - Relationship executive-legislative: Fusion of executive and legislative (mutual dependent) } \\
\text { - } \text { Appornment depends on and is responsible to the parliament } \\
\text { Removal: the executive, the prime minister can be brought down, subject to a political reason of vote no confidence } \\
\text { - Toring term office } \\
\text { The government is formed by the parliament; coalition government is established during and after the election } \\
\text { - Single legitimacy (direct election for parliament) } \\
\text { - Relationship between head of executive (Prime Minister) and the Cabinet: Horizontal (Collegial) } \\
\text { Ministerial responsibility: collectively and individually (both) to the parliament }\end{array}$ \\
\hline Presidential sys & $\begin{array}{l}\text { tem } \\
\text { The executive branch: President and the cabinet (single executive) } \\
\text { The head of executive branch: President; constitutionally fixed term office } \\
\text { Relationship executive-legislative: Separation of executive and legislative (mutual independent) } \\
\text { To exist, government does not need support from legislative majority } \\
\text { Appointment of head of the executive branch: directly by the people } \\
\text { Removal: the President, the executive cannot be politically subject of vote of confidence during term office; but subject } \\
\text { to impeachment on the criminal grounds } \\
\text { The government is formed by the President; the formation of coalition government is unnecessary and relatively small } \\
\text { The government is independently exist and responsible to the President; the President can unilaterally replace the } \\
\text { government either partially or completely } \\
\text { Direct presidential election mechanism } \\
\text { - } \text { hexibility of the ministerial composition depends on the President; rigidity of the ministerial because the parliament } \\
\text { Dual legitimacy (legislature direct election and presidential direct election) } \\
\text { - Cabinet character: Strong and independent minded member (professional) } \\
\text { Relationship between head of executive (President) and the Cabinet: Vertical (supervisory) } \\
\text { Ministerial responsibility: individually to the President }\end{array}$ \\
\hline Mixed $\mathrm{s}$ & $\begin{array}{l}\text { The executive: President and Prime minister (dual executive - power sharing) - a multiply executive branch } \\
\text { To exist, government depend on both on a legislative majority assembly and on elected president (dual responsibility } \\
\text { and mutual dependent) } \\
\text { The government can be removed during term office by either the assembly or the directly elected President } \\
\text { The President can dissolve the assembly and call early elections }\end{array}$ \\
\hline
\end{tabular}


Rosa Ristawati: Modelling Executive Powers in the Indonesian Constitution: A comparative Study

- Direct presidential election mechanism

- Indirect elected of head of government by the President applied in combination with assembly confidence

- Dual legitimacy (Presidential direct election and legislative direct election) + indirect election of prime minister

- Ministerial responsibility: collectively and individually to the parliament and to the elected President 
Rosa Ristawati: Modelling Executive Powers in the Indonesian Constitution: A comparative Study

\section{Scheme 2: Government Systems}
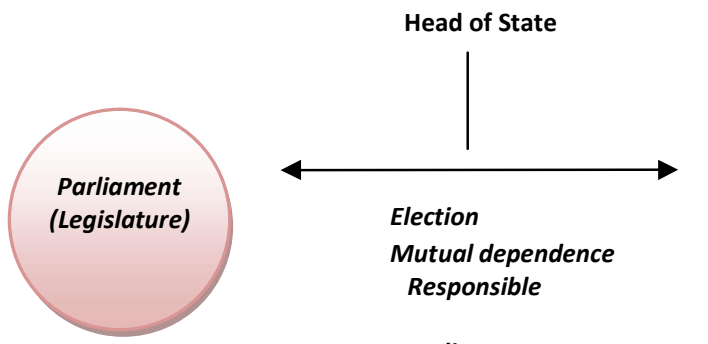

Prime

Minister

(Executive)

Responsible

Parliamentary system

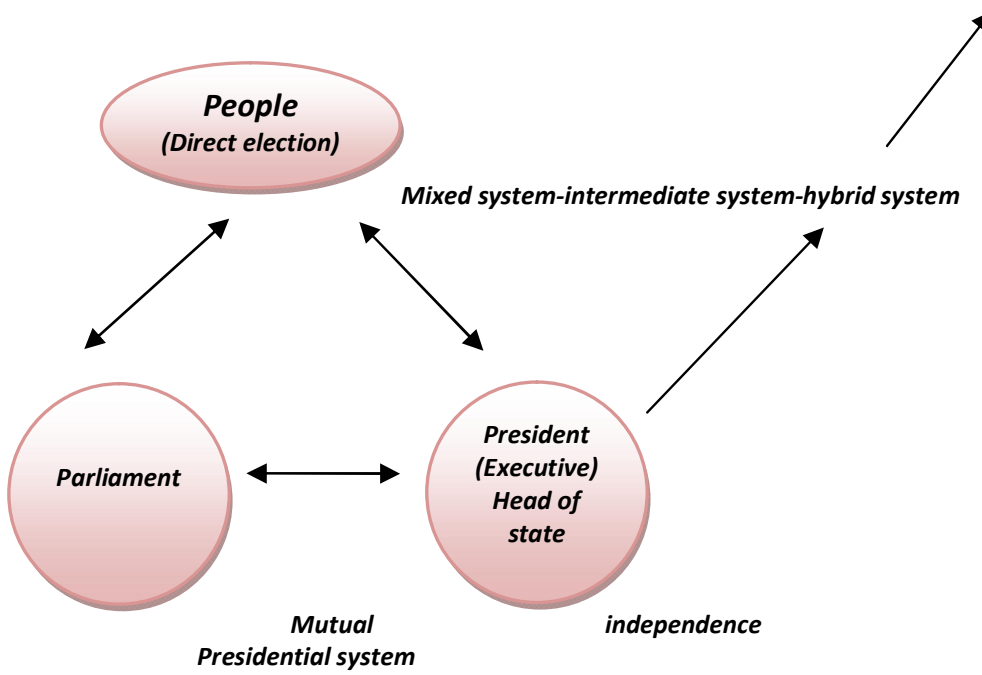

Conclusion

Parliamentary Constitutions:

Germany

Weak executive power: President-weak, Chancellor-weak

South Africa

Strong executive power: the President-considerable powers but could be brought down by the Parliament vote of no-confidence

Presidential constitutions:

US

Limited executive power: President-shared powers, strong legitimacy

The Philippines

Strong executive power: President-strong powers, strong legitimacy

Mixed constitutions:

France: dual executive powers between the President and the Prime Minister

Poland: dual executive powers between the President and the Prime Minister 


\section{Chapter 3}

\section{The Development of Executive Power in Indonesian Constitutional History}

This Chapter describes how the executive powers evolved in Indonesian constitutional history before the current Amended Indonesian Constitution. In this chapter, the development of the executive powers in Indonesia will be described in a chronological sequence of government regimes. The chapter is structured as follows. First, it will briefly introduce the sequence of constitutional regimes in Indonesia. Second, it will recount the executive powers under the period of the Indonesian constitution from the post-Dutch colonial period to Indonesian independence. Next, it will discuss a short experience of executive powers under the Indonesian parliamentary system when the Constitution of the KRIS (the Constitution of Federal Republic Indonesia) was enforced in 1949 in Indonesia. Following the discussion of the temporary Indonesian Constitution 1950, the chapter will address the problems of the return of the Indonesian presidential system with its implications for the executive powers. Moreover, it will also describe the practices of the executive powers under the period of re-instatement of the 1945 Indonesian Constitution. The final part of this chapter will briefly describe the executive powers during the process of the Amended Constitution.

\subsection{Introduction: sequences of Constitution regimes in Indonesia}

Indonesia experimented with Constitutions. The first Constitution (hereafter referred to as the UUD 1945) was in force during the period of 18 August 1945 to 27 December 1949. The Constitution was drafted the day after Indonesia's unilateral proclamation of independence and entered into force on 18 August 1945. The second Constitution, (hereafter referred to as the KRIS Constitution) was a very short-lived Constitution, enacted from 27 December 1949 to 17 August 1950. The third Constitution (hereafter referred to as the UUDS 1950) was in force temporarily for 9 years from 17 August 1950 to 5 July 1959. The following Constitution entered 
into force as a result of a Presidential Decree. By the 1959 Presidential Decree, the $1^{\text {st }}$ President of Indonesia, Soekarno reinstated the UUD 1945 (the $1^{\text {st }}$ Indonesian Constitution of 18 August 1945). It was in force from 5 July 1959 to 1999. The Constitution was therefore the longest living Constitution and had been enacted under different regimes of Indonesian governments; the Old Order ("orde lama") which was under the $1^{\text {st }}$ Indonesian President Soekarno, the New Order ("orde baru") which was under the authoritarian regime of President Soeharto, and the Reformation Era which was under the transition President of BJ. Habibie. During its existence, the Constitution was never ratified. Although it was said constitutionally in its provision that the MPR (the Majelis Permusyawaratan Rakyat) ${ }^{390}$ had the power to ratify the Constitution, the MPR never did so.

Under different Constitutions, the executive powers in Indonesia experienced lots of turbulence. Those experiences influenced significantly the constitutional systems and state practice. The most significant influence was the character of the executive powers.

\subsection{Executive power in Indonesian constitution making (from the post-Dutch colonial period to Indonesian independence)}

The development of the executive powers in Indonesia started as the Indonesian Constitution was drafted in 1945 (the UUD 1945). It consisted of a preamble, provisions, transitional provisions, additional provisions, and general and provisional annotations. ${ }^{391}$ It had embedded the first Indonesian executive powers. The preparation of the draft of the Indonesian Constitution started on 29 April 1945 by the Japanese government. ${ }^{392}$ For this

\footnotetext{
${ }^{390}$ The MPR (Majelis Permusyawaratan Rakyat) is the People's Representative Consultative Assembly. The members of the MPR were all members of the DPR and other representatives including the provinces representatives, military representatives, and minority groups. The MPR was at the time the parliament in Indonesia and had strong power including to elect and impeach the President. Currently, the MPR consists of all members of the DPR and all members of the DPD (the provinces representatives).

${ }^{391}$ Annotation to the Constitution was part of the Constitution that had legal consequences. It had content on the explanation and the elaboration. It consisted of two parts; the general explanation and the provisions explanation. The general explanation explained about the Constitution as a whole; whereas, the provisions explanations were about the explanation and elaboration of each of the provisions.

${ }^{392}$ Naskah Komprehensif Perubahan Undang-Undang Dasar Republik Indonesia Tahun 1945, Buku 1: Latar Belakang, Proses dan Hasil Perubahan UUD 1945, Edisi Revisi, Sekretariat Jenderal dan Kepaniteraan Mahkamah Konstitusi, 2012: "the Japanese government issued the Declaration of "Gunseikan" of the Japanese army commander No. 23 on the establishment of "Dokuritzu Zyunbi Tyoosakai" (in Indonesia: BPUPK (Badan Penyelidik
} 
reason the Japanese government established the "BPUPK". The BPUPK had a special committee namely, the committee of the basic law that mainly had special duties to draft the Constitution. On 11 July 1945, the Committee made some important decisions on the choice of the Unitary state (the Republic of the Unitary), and on the choice that a President in Indonesia is the head of the state. According to Provision III of the Transitional Provision of the first Indonesian Constitution (the UUD 1945), the first President and his vice President were elected by the PPKI (the Committee for the preparation of Indonesian Independence). ${ }^{393}$ There was no provision about a direct mechanism for the presidential election except that the President was indirectly elected by the people through the MPR as the Council of People Representatives. The President collegially worked with the Vice President, the ministers and the state secretary and was responsible to the MPR. According to Provision IV of the first Indonesian Constitution (the UUD 1945), the President had the power to exercise the MPR's power ${ }^{394}$, the DPR's powers ${ }^{395}$ and the DPA's powers ${ }^{396}$ before their establishment. ${ }^{397}$ With all the powers given by the Constitution, the Indonesian President constitutionally had exceptionally broad powers. The President exercises the three powers of the constitutional institutions (the MPR, the DPR, and the DPA). However, in exercising his constitutional powers, the Constitution assigned a national committee acting to assist the President, namely the Indonesian Central National Committee or "KNIP (Komite Nasional Indonesia Pusat)". Later on, the KNIP was the embryo of the DPR (the "Dewan Perwakilan Rakyat" as the council of people representatives).

According to the first Indonesian Constitution (UUD 1945), the executive power was under Chapter III, with the title "the power of the state government". Article 4 of the Constitution stipulated that "the President of the Republic of Indonesia shall hold the power of

\footnotetext{
Usaha Persiapan Kemerdekaan/the Committee on the investigation of the Indonesian Independence)." See further on page 19 to 43 .

${ }^{393}$ Provision III of the Transitional provision of the $1^{\text {st }}$ Indonesian Constitution, hereinafter is the "UUD 1945"(Appendix 1).

${ }^{394}$ The MPR 's power were the power to appoint and dismiss the President and the power to make and amend the Constitution.

${ }^{395}$ The DPR's powers were the powers to make laws.

${ }^{396}$ The DPA's power were the powers to give any advises and considerations to the President.

${ }^{397}$ Provision IV of the Transitional provision of the $1^{\text {st }}$ Indonesian Constitution (the "UUD 1945") (Appendix 1).
} 
government in accordance with the Constitution". Although the Constitution did not spell out explicitly the word "executive powers", it implied that the President institutionally possessed such powers. Furthermore, the following articles determined the power of the President as the government of the state.

According to the first Constitution, the President had various law-making powers. Article 5 section 1 of the Constitution confirmed that the President had the legislative power with the DPR's approval. ${ }^{398}$ The President had to share the legislative power with the DPR (the Council of People Representatives). However, the President was the main institution to make laws and the DPR was the sharing partner to give the bills approval. Thus, the President was the legislator and had the power to make and enforce laws. On the other law-making areas, Article 5 section 2 determined that the President also had other legislative powers to make government regulations as Legislation directives in order to implement the laws. ${ }^{399}$

Moreover, the President, according to the Constitution had the foreign affairs power. The foreign affairs powers were determined in Article 11 and Article 13 of the Constitution. ${ }^{400}$ The scope of powers included war power, peace power, treaty making powers, and diplomacy powers of appointing ambassadors, consuls, and receiving the credentials of foreign ambassadors. Article 10 affirmed that the President had the military power of commander in chief of the army, the navy and the air force. ${ }^{401}$ Article 12 gave the President the power to declare a state of emergency. ${ }^{402}$ Furthermore, according to Article 22, the President had the power to issue government regulations in lieu of laws in times of state emergency (the emergency law). However, such emergency laws had to be consented to by the DPR. ${ }^{403}$

As the head of the state, the Constitution gave the President the power to give pardon and the power to grant honors. The pardoning powers of the president included giving mercy,

\footnotetext{
${ }^{398}$ Article 5 section (1) the UUD 1945 (Appendix 1).

${ }^{399}$ Article 5 section (2) the UUD 1945 (Appendix 1).

${ }^{400}$ Article 11 (Appendix 1), Article 13 section (1)(Appendix); Article 13 section (2) the UUD 1945 (Appendix 1).

${ }^{401}$ Article 10 the UUD 1945 (Appendix 1).

${ }^{402}$ Article 12 of the UUD 1945 (Appendix 1).

${ }^{403}$ Article 22 Section (1), Section (2), Section (3) of the UUD 1945 (Appendix 1).
} 
amnesty, pardon and restoration of rights. ${ }^{404}$ The President also had the power to grant titles, decorations, and other distinctions of honours according to Article 15 of the Constitution. ${ }^{405}$ As the head of the government, the President had the power to preside over the Cabinet. Article 17 Section 3 of the Constitution gave the President the power to appoint and dismiss the ministers. ${ }^{406}$ Constitutionally, the ministers were the President's assistants and were responsible to the President. ${ }^{407}$ The President was granted the power to conduct the state administration. ${ }^{408}$ In order to establish the state administration, the Constitution assigned the state budgetary and spending power in the President's domain. The President had the power to make the state budget law. ${ }^{409}$ The budgeting power was also relevant to the legislative power of the President that was mentioned in Article 5 section (1) of the Constitution. In exercising the budgetary power, the President had to make the state budgetary Law and must have the DPR's approval. In relevance to that, the Constitution allowed the President to fully exercise spending power. However, the Constitution asserted that the President should be accountable for the performance of spending power. The accountability of the spending power was verified by the State Finance Auditor Council (BPK) and had to be reported to the DPR. ${ }^{410}$

While the Transitional Provision Clause IV of the Constitution gave extra power to the President to have the MPR's, the DPR's, and the DPA's power ${ }^{411}$; the additional provision of the Constitution authorized the President to take any preparatory steps and execute all the

\footnotetext{
${ }^{404}$ Article 14 of the UUD 1945 (Appendix 1).

${ }^{405}$ Article 15 of the UUD 1945 (Appendix 1).

${ }^{406}$ Article 17 section (2) of the UUD 1945 (Appendix 1).

${ }^{407}$ Article 17 section (1) (Appendix 1), Article 17 section (3) of the UUD 1945 (Appendix 1).

${ }^{408}$ It was shown on the original annotation that "concentration of power and responsibility upon the President.

${ }^{409}$ Chapter VII on State Finance, Article 23 section (1) of the UUD 1945 (Appendix 1).

${ }^{410}$ Article 23 section (5) of the UUD 1945 (Appendix 1).

${ }^{411}$ According to Article 3 the UUD 1945 (Appendix 1); Furthermore, the power of the MPR was also stipulated in Article 37 of the UUD 1945 (Appendix 1)that the MPR had the power to amend the Constitution. Meanwhile, the powers of the DPR according to the UUD 1945 was only providing counterbalance to the performance of the executive powers. The DPR had the power to approve a bill to become the law. The member of the DPR had also the right to purpose a bill. The DPR had also the power to give any other approval and recommendation to the performance of the executive power; for example, the DPR had the power to give approval for the Presidential emergency law, approve the declaration of war, the treaty making, the peace making by the President. While the DPA according to Article 16 section 2 had the power to propose any suggestion to the President.
} 
Constitutional duties. ${ }^{412}$ In practice, though the President was the decision maker, the Presidential power in that period was not really exercised absolutely by the President. The President was assisted by the KNIP (the National Committee). ${ }^{413}$

The intention of the framers to establish a limited government was reflected in the Constitutional provisions. The Constitution explicitly affirmed in theGeneral Annotations of the Constitution that Indonesia adopted the constitutional system with the government based on the Constitution and thus, the government,as a whole, had limited powers and could not haveabsolute power. The Constitution set down the highest power of the state in the hand of the MPR as articulated in the annotation of the Constitution as (Die gezamte staatgewalt lieght allein bei der Majelis). The framers personified the MPR as the representatives of the people and all at once manifested the sovereignty of the people. The MPR had the main power to determine the Constitution and the GBHN (the Outline of the State Policy) as well as to appoint the President and the Vice President. In this point, the Constitution implied that the President was dependent on the MPR. It was determined that the President had no equal position with the MPR, but he was sub ordinate to the MPR. The President was the mandator of the MPR. The President had to pursue state policy as outlined by the MPR. As consequence, the President was responsible and accountable to the MPR. ${ }^{414}$

To sum up, the first Constitution really reflected a parliamentary system. The fact was that the President was not directly elected by the people instead through amajority vote in the MPR's session; the constitutional duty of the President was to implement the Guidelines of the State policy set by the MPR; and the fact that the President was responsible to the MPR, implied that the President was really dependent on the MPR. The President could not independently exist without the MPR.

Unlike the hierarchical relationship between the President and the MPR, the relationship between the President and the DPR was constitutionally based on a mutual

\footnotetext{
${ }^{412}$ Additional Provisions of the Constitution imposed that "within six months after the end of the Great East Asia War, the President of Indonesia shall take preparatory steps and execute all the provisions of this Constitution.

${ }^{413}$ Transitional Provision Clause IV of the UUD 1945 (Appendix 1).

${ }^{414}$ Chapter IV of the Annotation to the Constitution of the UUD 1945 on the President is the Chief Executive of the State under the MPR.
} 
relationship. ${ }^{415}$ The President did not depend on the DPR; the President was not accountable to the DPR. The President had equally the same position as the DPR. The DPR acted as counterbalance to the President. The President should obtain the approval of the DPR to make laws (Gezetsgebung) and to determine the state budget. Technically, the President had to cooperate with the DPR. ${ }^{416}$ Moreover, the UUD 1945 strongly clarified that the executive powers of the President were not unlimited. Chapter VII of the General Annotation of the Constitution elaborated that "Although the President as the head of the state is not accountable to the DPR, the President is not a dictator since his power is not unlimited". The Chapter clearly implied that the Constitution did not intent to grant absolute powers to the President.

However, the Constitution gave the power to the President to establish a cabinet of ministers. According to Chapter VI, the General Annotation of the Constitution, the ministers were the President's assistants. They were not responsible and accountable to the DPR and the MPR. It was the President who appointed and dismissed the ministers of the state. Their status and position fully depended on the President. They mainly exercised day-to-day executive powers. The ministers were not just ordinary senior officials. They had a strategic position within the state. As the head of a ministerial department, a minister was obliged to have competence inspecific areas related to his duties. To this extent, the minister had great influence on the Presidential policy making. However, in determining the policy and for the purpose of state administration coordination, the ministers had to work in close cooperation with one-another under the leadership of the President.

\section{The annotation to the constitutional provisions on executive power}

According to the Constitutional Annotation of Chapter III, the President was the chief of the executive within the state and had the power to enforce laws by issuing government regulations. The Constitution also stressed that the President had the legislative power and shared the power with the DPR. Such kind of power sharing was also emphasized in the

\footnotetext{
${ }^{415}$ The Annotation provision of the UUD 1945 (the first Indonesia Constitution).

${ }^{416}$ Chapter VII of the Constitutional paragraph 2-4 of the UUD 1945 (Appendix 1).
} 
Rosa Ristawati: Modelling Executive Powers in the Indonesian Constitution: A comparative Study

constitutional explanation. Furthermore, Chapter VII of the Annotation of the Constitutionvested the oversight function in the DPR vis $a$ vis the President. The oversight function could be by sharing powers and checking the exercise of the Presidential power. In terms of the legislative power, according to the Annotation, the DPR had the power to approve all bills made by the President. However, the DPR was also granted the power to initiate the bills. Moreover, the DPR had the right to control the budget. The DPR could oversee the President and could invoke interpellations, investigations, and question the President's decisions and the government's policy. On the emergency power, the annotation of the Article 22 clarified that the President in exercising emergency power should obtain approval from the DPR to validate the emergency law. Therefore, all measures and actions taken by the President must be justified. ${ }^{417}$

In terms of state finance, Chapter VIII Article 23 Sections 1, 2, 3, 4, of the Annotation Constitution clarified that the DPR had the power to control the budget by giving approval or rejection to the bill of the state budget. The state budget was determined as the state expenditure and the state income. The rationality that the DPR should have the power to give approval or rejection was because the DPR represented the people. ${ }^{418}$ On the grounds that the people had the right to determine how to collect the revenue and the expenditure, any fields of the income in particularly taxes must be determined by law and most importantly approved by the DPR. The meaning of the DPR's approval actually implied that the role of the DPR was the key. The DPR had a stronger position than the government on the budget decision. ${ }^{419}$ If the DPR did not approve the state budget law, the government could not exercise the budgetary power. Therefore, on the budgeting area, the President was bound by the DPR's approval.

The President was granted exclusive and extra-ordinary powers by the transitional provision in the Constitution. The exclusive and extra-ordinary powers empowered the

\footnotetext{
${ }^{417}$ Article 22 of the constitutional explanation of the UUD 1945 (Appendix 1).

${ }^{418}$ The rationality of giving the power to the DPR was also in line with the spirit of the sovereignty of the people and democracy.

${ }^{419}$ The annotation to the constitutional provision 23 clarified that besides the DPR represented the people and whereas the people have the right to determine the state income and expenses, how the government spends the money that has been approved by the DPR must also conform to the decision on the budget.
} 
President with the MPR's power, the DPR's power and all institutional power that had not yet been established after the unilateral independence. However, Ismail Suni believed that although the President had been granted exclusive powers by the transitional provision, the President could not have all the MPR's power; especially the power to set the Constitution and the power to appoint the President and the Vice President. ${ }^{420}$ On the other hand, the President could temporarily restrain the enactment of part of the Constitution only to deal with the situation, overcome the perils and restore the situation and to exercise the power to establish the MPR and the DPR; but that did not mean that the President could amend the Constitution permanently. $^{421}$

In general observation of the constitutional text, the first Constitution actually gave limited powers to the President as the head of the executive although the President was occasionally vested with extra-ordinary power. The Constitution had explicitly intended that the executive powers were mostly shared between the President and the DPR. The President was bound by the DPR's approval in exercising the powers. The dependency and responsibility of the President to the MPR and the hierarchical relationship between the President and the MPR showed that the Constitution wanted the President to have limitedpower as a state institution.

In practice, after the appointment of the first Indonesian President and Vice President, the President dismissed the PPKI (Preparatory Committee on Indonesia Independence) on 29 August 1945 and established the KNIP (Indonesian Central National Committee). The establishment of the KNIP by the President was stated in Chapter IV of the transitional provisions. The KNIP had the duties to assist the President and not independently or collectively execute the Laws. ${ }^{422}$ The President had also appointed the Cabinet which consisted of ministers as the President's assistants. ${ }^{423}$ Two months after the Constitutional enactment, on 16 October 1945, the Vice President issued the "Maklumat No. X" (the Vice President Declaration No. X). This Vice President Declaration No.X stated that the KNIP, before the establishment of the MPR

\footnotetext{
${ }^{420}$ Ismail Suni, Pergeseran Kekuasaan Eksekutif, Aksara Baru, Jakarta, 1986, p. 35

${ }^{421}$ Id. at p. 35.

${ }^{422}$ Id. at p. 27. In establishing the Committee, the President was assisted by the Vice President. The President had appointed 135 members of KNIP, in which the KNIP members were including the members of the dismissed PPKI. ${ }^{423}$ Id. at p. 28.
} 
Rosa Ristawati: Modelling Executive Powers in the Indonesian Constitution: A comparative Study

and the DPR, had the legislative power and together with the President set the GBHN (guidelines to the state policy). ${ }^{424}$ It also decided that since it was in a crucial situation, the KNIP should delegate its power to a working committee that was appointed by and responsible to the KNIP. ${ }^{425}$ Ismail Suni observed that since 16 October 1945, the President had to share his power set by Article IV the transitional provisions; the power to set the guidelines of the state policy (the GBHN) and the power to make Laws with the KNIP. ${ }^{426}$ On the other hand, the President still had the power to supervise the Ministers until it was changed on 11 November 1945 when the working committee of the KNIP proposed to the President the ministerial responsibility to the Parliament (which in this period was the KNIP). Since the working Committee's proposal was approved by the President, the constitutional practice in Indonesia was said to be unconstitutional. ${ }^{427}$ The proposal of ministerial responsibility and the existence of the prime minister were not in accordance with the Constitution. However, the approval for the ministerial responsibility to the Parliament was given by the Government Declaration (Maklumat Pemerintah) on 14 November 1945 whereby the Ministers were the members of the Cabinet led by a Prime Minister, Sjahrir, and were not responsible to the President.In consequence, as it was observed by Ismail Suni, the executive powers had been shifted from the President to the Prime Minister. ${ }^{428}$ In effect, the power of President Soekarno was reduced to that only of figurehead. ${ }^{429}$ However, the appointment of the Prime minister had been

\footnotetext{
${ }^{424}$ Id. at p. 28.

${ }^{425}$ Id. at p. 29: "The powers of the working committee under the KNIP were determined as follows: a. set the guidelines of the state policy together with the President, however, the working committee had no right to intervene in the government's daily policy (dagelijks beleid), the President still had the power as the government daily maker; $b$. set the Legislation (concerning all kinds of government affairs) together with the President. However, to execute the Laws, it is the power of the government. The government was determined just as the President assisted by the minister and other state officials under the President."

${ }^{426}$ Id. at p. 29.

${ }^{427}$ Id. at p. 30: "the arguments that the working committee proposed the Ministerial responsibility to the Parliament were not only because the Constitution did not prohibit the ministerial responsibility but also on the basis that the ministerial responsibility to the Parliament reflected the people sovereignty. As a consequence of the President's approval to the ministerial responsibility, since 14 November 1945, the Presidential Cabinet was changed into the new parliamentary Cabinet with Sutan Sjahrir as the Prime Minister."

${ }^{428}$ Id. Ismail Suni (1986), p. 31.

${ }^{429}$ Colin Brown, a Short History of Indonesia: the Unlikely Nation?, Allen and Unwin, Australia, 2003, p. 163:"It is described that "in October-November 1945, the provisional government appointed Sjahrir as Prime Minister-a post not mentioned in the recently adopted Constitution-and in effect reduced Sukarno's status to that of
} 
challenged by Tan Malaka, his opponent, and politics were stalemated until President Soekarno intervened to reappoint Sjahrir. ${ }^{430}$

In January 1948, the government agreed to the Renville agreement. ${ }^{431}$ As a result, there was great division within Republican ranks; many of them were more radical political leaders. Both were Muslims and the left wing, claimed that the agreement was a sell-out to the Dutch; they forced the resignation ofthe government which had signed it. ${ }^{432}$ President Soekarno decided to appoint vice president, Hatta as the new prime minister. ${ }^{433}$ The political and economic situation was very difficult at the time, not only because of the government's tension with its opponents, but also as a result of a Communist party rebellion. In December, the Dutch launched a second military attack. ${ }^{434}$ However, in that period, external pressures and the rise of rebellion, communism and its guerilla warfare caused the Dutch to change their policy and overcome its unprepared military and policy. ${ }^{435} \mathrm{As}$ a result of the round table conference, the Dutch recognized Indonesian independence. However, that recognition was not given to the unitary Republic of Indonesia, but to the Federal Republic of the United States of Indonesia (the RIS) which consisted of 16 states. Further, this Round Table Conference caused the Parliamentary Constitution of RIS (KRIS 1949) to replace the first Constitution of UUD 1945. Thus, the government system in Indonesia changed froma presidential system to a parliamentary system.

Table 3.1 Executive power under the first Indonesian Constitution of UUD 1945

\begin{tabular}{|l|l|l|l|}
\hline Executive powers & Scopes & Checks and balances & \\
\hline \multirow{2}{*}{ Foreign affairs powers } & The power to make peace (Article 11) & With the DPR's approval & $*$ \\
\cline { 2 - 5 } & The power to make treaty between & With the DPR's approval & $*$ \\
\hline
\end{tabular}

figurehead. He was still head of state, but no longer head of government, making it more difficult for the Dutch to argue that the Republican government was in the hands of former collaborators with the Japanese. Although the Prime Ministership changed hands several times during the revolution, this political system was maintained; indeed, it was only replaced in 1957 when Sukarno reasserted Presidential authority."

${ }^{430}$ See: Id. at p. $164-165$.

${ }^{431}$ Under the agreement, the Republic conceded to the Dutch the territories that it had lost in the attack, in return for another Dutch promise of eventual independence.

${ }^{432}$ Colin Brown, Op. Cit., p. 167.

${ }^{433}$ Id. at p. 167.

${ }^{434} / d$. at p. 168.

${ }^{435}$ Id. at p. 169: "They restored Sukarno and Hatta toYogyakarta and began yet another round of negotiations at what wascalled the Round Table Conference, which led this time to a formal Dutch recognition of Indonesian independence in December 1949." 
Rosa Ristawati: Modelling Executive Powers in the Indonesian Constitution: A comparative Study

\begin{tabular}{|c|c|c|c|}
\hline & states (Article 11) & & \\
\hline & $\begin{array}{l}\text { The diplomacy power of appointing } \\
\text { the ambassadors and consuls (Article } \\
\text { 13) and receive the ambassadors of } \\
\text { other states (Article 13) }\end{array}$ & & $*$ \\
\hline \multirow[t]{3}{*}{ Emergency powers } & $\begin{array}{l}\text { The power to declare state emergency } \\
\text { (Article 12) }\end{array}$ & $\begin{array}{l}\text { The conditions and } \\
\text { consequences caused by the } \\
\text { state emergency is enacted by } \\
\text { legislation }\end{array}$ & $*$ \\
\hline & $\begin{array}{l}\text { The power to set emergency laws } \\
\text { (Article 22) }\end{array}$ & Approved by the DPR & $*$ \\
\hline & $\begin{array}{l}\text { The power to take any measures and } \\
\text { action promptly and appropriately } \\
\text { (Article } 22 \text { of the annotation to the } \\
\text { constitutional provisions) }\end{array}$ & Checked by the DPR & ** \\
\hline \multirow[t]{5}{*}{$\begin{array}{l}\text { Administrativeand } \\
\text { appointment powers }\end{array}$} & $\begin{array}{l}\text { The power to appoint and dismiss the } \\
\text { ministers (Article } 17 \text { section } 2 \text { ) }\end{array}$ & & $*$ \\
\hline & $\begin{array}{l}\text { The power to grant titles, decoration, } \\
\text { and other honorary signs (Article 15) }\end{array}$ & & $*$ \\
\hline & $\begin{array}{l}\text { The power to propose the state } \\
\text { budget (23) }\end{array}$ & & $*$ \\
\hline & $\begin{array}{l}\text { The power to set the political } \\
\text { government policy and direct the } \\
\text { ministers in the state government } \\
\text { (chapter VII paragraph } 3 \text { of the } \\
\text { general annotation of the } \\
\text { Constitution) }\end{array}$ & & $*$ \\
\hline & $\begin{array}{l}\text { The power to run the state } \\
\text { administration (Chapter IV of the } \\
\text { general annotation to the } \\
\text { Constitution) }\end{array}$ & & * \\
\hline \multirow[t]{2}{*}{ Law-making powers } & $\begin{array}{l}\text { The power to make Legislation } \\
\text { (Article } 5 \text { section } 1 \text { ) }\end{array}$ & With the DPR's approval & $*$ \\
\hline & $\begin{array}{l}\text { The power to set the government } \\
\text { regulation to exercise the Legislation } \\
\text { (Article } 5 \text { section } 2 \text { ) }\end{array}$ & & $*$ \\
\hline Pardoning powers & $\begin{array}{l}\text { the power to pardon, grant amnesty, } \\
\text { grant abolition and rehabilitation } \\
\text { (Article 14) }\end{array}$ & & * \\
\hline \multirow[t]{2}{*}{ Military powers } & $\begin{array}{l}\text { The power of Commander in chief of } \\
\text { the army, the navy, and the air force } \\
\text { (Article 10) }\end{array}$ & & $*$ \\
\hline & The power to declare war (Article 11) & With the DPR's approval & * \\
\hline \multirow[t]{2}{*}{ Other powers } & $\begin{array}{l}\text { The power to exercise the MPR's and } \\
\text { DPA's power before its establishment } \\
\text { (the provision IV of the transitional } \\
\text { provisions) }\end{array}$ & $\begin{array}{l}\text { Assisted by the National } \\
\text { Committee }\end{array}$ & * \\
\hline & $\begin{array}{l}\text { The power to organize and establish } \\
\text { the system as set by the Constitution } \\
\text { (Article } 1 \text { of the additional provision) }\end{array}$ & & $*$ \\
\hline
\end{tabular}

$* *$ the President on behalf of the government

3.3. Indonesian executive power under the Constitution of the Republic of Indonesia Federalism (the KRIS "Konstitusi Republik Indonesia Serikat"): a short experience of executive power under a parliamentary system

- The executive under the KRIS Constitution 
Rosa Ristawati: Modelling Executive Powers in the Indonesian Constitution: A comparative Study

The Constitution of the Republic of Indonesia federalism (hereafter referred to as the "1949 KRIS") was only in force during a one year period of 1949 to 1950. It was taken into force as a consequence of the Hague round table conference (the Konferensi Meja Bundar) on 23 August- 2 November $1949 .{ }^{436}$ The agreement was made on Saturday, 29 October 1949 in Scheveningen by the delegation of the Republic of Indonesia and the delegation of the Federal agreement (Bijeenkomst Federaal Overleg). As a result of the agreement, the Republic Federal of Indonesia had a Federal Constitution namely the Constitution of the Republic Federal of Indonesia (hereafter referred as the KRIS 1949 Constitution). The 1949 KRIS Constitution was in accordance with the main purpose of the agreement. It provided the real and unconditional transfer of sovereignty from the Kingdom of Nederland to the United States of Indonesia and the establishment of the Indonesian government. ${ }^{437}$ The 1949 KRIS Constitution was drafted by representatives from various states and provinces. It had 197 provisions plus an appendix and represented a mixture of concepts, principles, and institutions from several constitutional sources including the United States of America. ${ }^{438}$ The President of the Republic Federal Indonesia ratified the KRIS Constitution by Presidential Decree No. 48 in 31 January 1950. According to the Constitution, Indonesia had 6 main state institutions: the President, the ministers, the senate, the people's representatives (the DPR), the Indonesian Supreme Court,

\footnotetext{
${ }^{436}$ The Conference, which was addressed to resolve the conflict of the Dutch aggression I and II in 1947 and 1948 , had resulted in 3 main points: the establishment the state of Republic of Indonesia Federal, the transfer of sovereignty from the Dutch to the Republic of Federal Indonesia, and the establishment of Uni Republic of Federal Indonesia and the Kingdom of the Netherlands. As a consequence of the conference, the Constitution of KRIS was drafted to give constitutional basis to the transformation of the Unitarian state to a federal state. The Constitution was drafted on the Conference by the BFO delegation and was entered to force on 27 December 1949. It consists of a Preamble of 4 paragraphs, the body of 6 chapters and 197 provisions, and the annex.

${ }^{437}$ Charles Cheney, "The Status of the Republic of Indonesia in International Law", Colombia Law Review Vol. 49, No. 7, November 1949, pp. 955 - 966 965, Colombia Law Review Association, accessed 10/11/2012. “It was declared that "sovereignty will be transferred to the Provisional Federal Government of the United States of Indonesia which shall function on the basis of a provisional constitution," and that all "powers of the Netherlands supreme legislative body, of the Crown and of the Governor-General, including the title which the GovernorGeneral had held in consultation with the Volksraad (People's Council) or the Raad van Nederlands-Indie (Council for the Netherlands Indies) shall be vested in the Provisional Federal Government." It was announced that the Provisional Constitution should not contain any provision inconsistent with the Charter of Transfer of Sovereignty, and also that the Charter of Sovereignty should contain provisions".

${ }^{438}$ Homer G. Angelo, "Transfer of Sovereignty Over Indonesia", the American Journal of International Law, Vol. 44, No. 3 (July 1950), pp. 569 - 572, American Society of International Law, Accessed on 10/11/2012, p. 570.
} 
and the Council of financial supervision. ${ }^{439}$ Furthermore, based on Article 68 of the 1949 KRIS Constitution, the government of the state consisted of the President and the Ministers acting in collaboration. ${ }^{440}$ The Article implied that the executive power was in the hands of the President and the Ministers acting in collaboration.

According to Article 70 Section 1, the President and the Minister should not run any other general positions inside and outside the Federal Republic of Indonesia. They could not have dual positions while in office. Furthermore, Section 2 of the Article stipulated that the President and the Ministers should not be directly or indirectly involved or to be the underwriter of a profit company. Section (3) of the Article also stipulated that they could not have any claims against the Republic Federal of Indonesia apart from a general obligation letter. According to Section (4) of the Article, the constitutional conditions still bound the President and the Ministers three years after their resignation from the office.

In terms of a state of emergency, all the ministers and the special ministers acted together to make any decisions that had the same legal force to replace the Council of Ministers' decisions. ${ }^{441}$ In general, the Prime Minister (in case of the absence of the Prime Minister, will be replaced by the special Minister) conducted and satin the Council of Ministers session to discuss the public interest of the Federal Republic of Indonesia. ${ }^{442}$ The Council of Ministers should always notify all the important affairs to the President. The Ministers were responsible for all the government policy, both individually and collectively. ${ }^{443}$

\section{- Presidential duties and power}

Article 69 of the 1949 KRIS Constitution gave the position of the head of state to the President. Unlike a head of state in the parliamentary system under the monarchial system, the President as the head of State was elected by the state representatives who had the

\footnotetext{
${ }^{439}$ The 1949 KRIS Constitution (excerpted from www.ppid.kpuu.go.id , "Konstitusi Republik Indonesia Serikat", unofficial translated by the author): Chapter III on the state institutions of the Republic Federal of Indonesia (the 1949 KRIS Constitution) (Appendix 2).

${ }^{440}$ Article 68 section 1 of the 1949 KRIS Constitution, Article 68 Section 2 of the 1949 KRIS Constitution (Appendix 2).

${ }^{441}$ Article 75 section (1) of the 1949 KRIS Constitution.

${ }^{442}$ Article 76 section (1) of the 1949 KRIS Constitution.

${ }^{443}$ Article 118 section 2 of the 1949 KRIS Constitution.
} 
authorization to come together in agreement on the election of a head of state. In general, the main presidential duties were derived from the presidential oath. As the head of state and according to the constitutional oath, the President had duties to promote the welfare of the Federal Republic of Indonesia, protect and preserve the freedom and rights of all the citizens. ${ }^{444}$ According to the constitutional oath, the President also had duties to retain the laws and ensure the execution of laws in the Federal Republic of Indonesia. In case of presidential absence and in order to fulfill his constitutional duties, the President could order the Prime Minister to take over the daily work. ${ }^{445}$

The President had the power to order and appoint the Prime minister and the ministers. Before taking the office, the ministers were required to take the formal vow before the President. ${ }^{446}$ The appointment and dismissal of the minister was set by Government Decree. According to Article 74 section (1) KRIS Constitution, the President with the states representatives agreed to appoint a Cabinet Committee consisting of three members to establish a cabinet and appoint ministers. ${ }^{447}$ According to the advice of the Cabinet maker, the President appointed the Prime minister from one of the three members of the Cabinet and the other two would be appointed as the ministers. ${ }^{448}$ Furthermore, the President determined department ministers and non-department ministers. The determination should be in line with the advice and signed by the three members of the cabinet maker. The Ministers with a ministerial department included the Minister of Defense, the Minister of foreign affairs, the Minister of Home Affairs, Minister of Finance and economic affairs, and the Prime Minister. Besides appointing the ministers, Article 85 section (1) of the KRIS Constitution gave the power to the President to appoint the Chief of the Senate according to the advice of the Senate. ${ }^{449}$ In

\footnotetext{
${ }^{444}$ Article 71 of the 1949 KRIS Constitution of the Federal Republic of Indonesia.

${ }^{445}$ Article 72 section 1 of the 1949 KRIS Constitution.

${ }^{446}$ Article 77 of the 1949 KRIS Constitution.

${ }^{447}$ The cabinet maker was appointed by the President and the states representative to give advice to the President with regard to the minister appointment.

${ }^{448}$ Article 74 section (2) of the 1949 KRIS Constitution.

${ }^{449}$ Article 85 section 1 (Appendix 2) the 1949 KRIS Constitution.
} 
general, the position of the President according to the KRIS Constitution was fairly strong. Article 118 section (1) stipulated that the President had inviolability.

The President granted honorable decorations based on the Federal Laws. ${ }^{450}$ Furthermore, the President had the power to give pardon, and amnesty after asking the Supreme Court's advice. ${ }^{451}$ As the head of the state, in the field of diplomatic foreign affairs power, the Constitution stated that the President formally appointed the Republic Federal of Indonesia's representatives for other states and accepted other states' representatives for the Republic Federal of Indonesia. ${ }^{452}$ Furthermore, Article 182 (1) emphasized that the President was the highest commander as Chief in the Republic Federal of Indonesia. In formal procedures and according to the Federal Law, the President appoints, promotes and dismisses the officers of the state forces. ${ }^{453}$

\section{- Government ${ }^{454}$ power}

Chapter IV of the 1949 KRIS Constitution described the state administration and how the government's affairs were run. Article 117 section 2 emphasized that this main duty was addressed to the government's power as the purpose of establishing the state administration. ${ }^{455}$ Ministers signed Presidential Decrees. ${ }^{456}$ In general, under the KRIS Constitution, the Prime Minister's position was indeed enormously strong in the government system. ${ }^{457}$ The President played a small public role throughout 1949 and primarily only in a ceremonial capacity. ${ }^{458}$

\footnotetext{
${ }^{450}$ Article 126 the 1949 KRIS Constitution.

${ }^{451}$ Article 160 the 1949 KRIS Constitution Section (1) (Appendix 2), Article 160 Section (2) (Appendix 2), Article 160 Section (3) the 1949 KRIS Constitution (Appendix 2).

${ }^{452}$ Article 178 of the 1949 KRIS Constitution (Appendix 2).

${ }^{453}$ Article 181 (3) of the 1949 KRIS Constitution (Appendix 2).

${ }^{454}$ Government is the President and the ministers.

${ }^{455}$ Article 117 (2) of the 1949 KRIS Constitution (Appendix 2).

${ }^{456}$ Article 119 of the 1949 KRIS Constitution (Appendix 2).

${ }^{457}$ Herbert Feith, The Decline of Constitutional Democracy in Indonesia, Equinox Publishing, $1^{\text {st }}$ Edition, Jakarta, 2007, p. 49:"It was not that he towered over his colleagues in the way of leaders who choose men of markedly inferior ability as their associates and lieutenants. On the contrary, his ministers were men of a high order of both ability and prestige."

${ }^{458}$ Id, at p. 50
} 
In terms of the law-making power, the government had the power to make laws together with the DPR and the Senate. The government had the power in all areas of the lawmaking power. While on the other hand the President had a significant role in the whole lawmaking process. The proposal of a bill that was proposed by the government was sent through presidential message to the DPR. ${ }^{459}$ On the other hand, the DPR had the right to propose Legislation to the government. If the proposal came from the Senate, the President was informed and notified by a copy of the proposal. ${ }^{460}$ The President had significant roles in every stage of the legislation making process. The President had roles in the early process of proposing the legislation, the joint discussion session, and the validation of the legislation.

Besides the legislation making process, according to Article 139 the 1949 KRIS Constitution, the government had the power to authorize and be responsible for setting the emergency law. ${ }^{461}$ However, according to Article 140 section (1) of the 1949 KRIS Constitution, the Emergency Law should be passed to the DPR to be discussed further. If the DPR rejected and did not approve the Emergency Law, the Law was no longer valid and had no legal consequences. ${ }^{462}$ Furthermore, the Constitution empowered the government to make other laws; namely, Directives Law to implement the Legislation. ${ }^{463}$ By setting the Federal Legislation and the government regulation, the government could order state institutions to set further arrangements as determined in both Laws and the regulation. ${ }^{464}$

\section{- The DPR and the Senate check the government power}

The 1949 KRIS Constitution provided a check and balance mechanism for the government power. The DPR had the right of interpellation and right of inquiry ${ }^{465}$ and the rights

\footnotetext{
${ }^{459}$ Article 128 section(1) the 1949 KRIS Constitution.

${ }^{460}$ Article 128 section (2) the 1949 KRIS Constitution (Appendix 2). Article 128 Section (3) the KRIS Constitution (Appendix 2).

${ }^{461}$ Article 139 section (1) of the 1949 KRIS Constitution (Appendix 2), Article 139 Section (2) of the 1949 KRIS Constitution (Appendix 2).

${ }^{462}$ Article 140 section (2) of the1949 KRIS Constitution (Appendix 2), Article 140 section (3) of the 1949 KRIS Constitution (Appendix 2), Article 140 Section (4) of the 1949 KRIS Constitution.

${ }^{463}$ Article 141 of the 1949 KRIS Constitution Section (1) (Appendix 2), Article 141 of the 1949 KRIS Constitution Section (2) (Appendix 2).

${ }^{464}$ Article 142 (1) the 1949 KRIS Constitution.

${ }^{465}$ Article 120 section (1) the 1949 KRIS Constitution.
} 
to investigate (enquete) according to the federal law. ${ }^{466}$ On the other hand, according to Article 120 section (2) of the 1949 KRIS Constitution, the ministers had constitutional duties to counter balance the DPR's measures by giving written or oral explanations. ${ }^{467}$ However, the DPR could not force the Cabinet or Minister to step down from office. ${ }^{468}$ Besides the DPR, the 1949 KRIS Constitution also recognized the Senate. In a special session and important situation regardingthe relationship between states or the relationship between a state and the Republic Federal of Indonesia, the government should consider the Senate. The government should inform it of any decisions except for the Emergency Law. ${ }^{469}$

\section{- Executive immunity}

The 1949 KRIS Constitution did not give any privileges to particularly the President and other state officers and the executive in general. The President and other executive bodies could be prosecuted before the Court either during office or after resignation. Article 148 (1) of the 1949 KRIS Constitution stipulated that the President, Ministers, Chief and members of the Senate, the Chief and the members of the DPR, the Chief, Vice-Chief and members of the Supreme Court, the State Prosecutor of the Supreme Court, Chief and Vice Chief of the State Financial Supervisor, the President of the Bank, members of the high council, and other state officials as determined by the Federal Law might be prosecuted before the Supreme Court. The prosecution could also bestarted after resignation. They could be prosecuted because of crimes, official offences, and other violations as determined by the Federal Lawduring their office.

Article 174 of the 1949 KRIS Constitution stipulated that the Government held the power of foreign affairs. The President made and validated all the treaties and other agreements with other states. The treaty or other agreements were not ratified unless approved by the Legislation. ${ }^{470}$ However, in exercising the power to conclude and make treaties and other agreements, the President could only do it with the authorization from the

\footnotetext{
${ }^{466}$ Article 121 the 1949 KRIS Constitution.

${ }^{467}$ Article 120 section (2) of the 1949 KRIS Constitution (Appendix 2).

${ }^{468}$ Article 122 the 1949 KRIS Constitution.

${ }^{469}$ Article 123 Section (1) - Section (6) the 1949 KRIS Constitution (Appendix 2).

${ }^{470}$ Article 175 (1) of the 1949 KRIS Constitution.
} 
Federal Law. ${ }^{471}$ The executive power on the foreign affairs implied the power to decide the state participation in International Organizations. ${ }^{472}$ According to Article 177 of the 1949 KRIS Constitution, the Government undertook to solve the dispute with other states peacefully and also decided to ask or accept the International Court or International arbitration's decision. The Article implied that the Government also had the power to influence the decision making whether or not to ask, accept, or not accept the International Court or International arbitration's decision.

The government had the power in terms of the state defence affairs. ${ }^{473}$ Furthermore, the Government had the power to appoint (if necessary) the defence personnel under the general commander. The Minister of Defence could be appointed for the position. ${ }^{474}$ Article 183 Section (1) stipulated that the government declared war only if it was permitted by the DPR and the Senate. In this case, according toSection (2) of the article, the DPR and the Senate decided to give permission to declare war by holding a plenary session of the DPR and the Senate chaired by the chief of the DPR. On the other fields of the emergency power, Article 184 (1) mentioned that the government did hold the emergency power and had the power to declare that the state was in a state of war or in a war emergency. ${ }^{475}$ Further impact that comes as a consequence of the emergency declaration is regulated by the Federal Law. ${ }^{476}$

Instead of the power that had relevance to the state administration affairs, the Constitution implied that the government together with the Constituante had the power to set theConstitution. The government in this case also referred to the President. ${ }^{477}$ After setting the Constitution, the government had duties to make sure that the Constitution was implemented

\footnotetext{
${ }^{471}$ Article 175 (2) of the 1949 KRIS Constitution.

${ }^{472}$ Article 176 of the 1949 KRIS Constitution (Appendix 2).

${ }^{473}$ Article 181 (1) of the 1949 KRIS Constitution (Appendix 2).

${ }^{474}$ Article 181 (2) of the 1949 KRIS Constitution.

${ }^{475}$ Article 184 section (1) of the 1949 KRIS Constitution (Appendix 2).

${ }^{476}$ Article 184 section (2) of the 1949 KRIS Constitution (Appendix 2).

${ }^{477}$ Article 186 of the 1949 KRIS Constitution (Appendix 2), Article 187 Section (1) of the 1949 KRIS Constitution (Appendix 2), Article 187 Section (2), Article 188 (1), Article189 Section (1) - Section (4) the 1949 KRIS Constitution (Appendix 2).
} 
Rosa Ristawati: Modelling Executive Powers in the Indonesian Constitution: A comparative Study

and adjusted by the Legislation and other laws. ${ }^{478}$ In general, the annex of the Republic Federal of Indonesia Constitution, Article 51, determined the scope of the executive powers in state administration affairs. ${ }^{479}$

In practice, the Round Table Conference negotiations came to an agreement that the government of RIS recognized all the rights, concessions, and permission which had been granted by the colonial Dutch government. ${ }^{480}$ The negotiation also came to an agreement on the transfer of sovereignty from the Dutch to the new state namely the United States of Indonesia (RIS). ${ }^{481}$ However, the Dutch still influenced not only the area of politics but also all

\begin{abstract}
${ }^{478}$ Article 196 of the 1949 KRIS Constitution (Appendix 2).
${ }^{479}$ (a) Regulates the citizenship and residence of Republic Federal of Indonesia; (b) Immigration and emigration; (c) general affairs of colonization and transmigration; (d) pardoning: clemency, amnesty, and abolition; (e) the copy right, intellectual property rights, and kwekersrecht; (f) public law and civil law; (g) civil law and commercial law, on behalf of the social interest; economy, and other civil interest; ( $h$ ) criminal law; (i) Private law; (j) the organization of federal judiciary; ( $k$ ) land registration; (I) legal-economic nexus; $(\mathrm{m})$ the compensation as a consequence of war; $(n)$ Police and the principle of the state federal administration; the police official education; provide and promote the technical and empowerment of the republic federal of Indonesia's police; measures to promote the cooperation of the police; (o) currency, bank, and foreign exchange; (p) tax company; (q) tax property; $(r)$ income tax for the special affairs that is determined by the Federal Law; (s) import and export including the entry and exit custom and also the determination of the duty; ( $t$ ) stamp duty; ( $u$ ) custom; ( $v$ ) government monopoly; $(w)$ the foreign affairs, international relation, international rights and obligation of the government, international relation; $(x)$ state defense, including the criminal law and the military law, the judicial and the emergency law (declaring war and a war emergency); (y) Institute and science that benefit to the Republic Federal of Indonesia; $(z)$ maintenance of the monument and the natural protection that benefit to the Republic Federal of Indonesia; (A) collecting data statistic and documents that is important to the Republic Federal of Indonesia; (B) the arrangement and social measures that is important to the Republic Federal of Indonesia;(C) Guidelines of the state official; (D) education; (E) mass communication; (F) general rules of the import and movie industry's supervision; (G) the general guidelines of the agrarian politic; $(\mathrm{H})$ the endemic diseases; (I) commerce, industry, agriculture, keradjinan, pertanian, fishery, farm and economic affairs, and food; (J) the transportation; (K) aircraft and metereology; (L) Topography dan hidrography; (M) sea surveillance; (N) the harbor maintenance, river; $(\mathrm{O})$ the telecommunication affairs; $(\mathrm{P})$ mining arrangement; $(\mathrm{Q})$ water, electricity, the exploitation of the water company.
\end{abstract}

${ }^{480}$ Colin Brown, Op. Cit., p. 171: “..in effect, this meant that the Indonesian government agreed to honor all the agreements under which Dutch capital had been able to exploit the resources of Indonesia."

${ }^{481}$ L.C. Green, "Indonesia, the United Nations and Malaysia", Journal of Southeast Asian History, Vol. 6, No. 2, Modern Malaysia, Sept, 1965, pp. 71-86, Cambridge University Press on behalf of Department of History, National University of Singapore, Accessed: 10/11/2012, p. 73, "It was agreed that The Netherlands would surrender sovereignty over the areas not yet governed by the Republic, while the Republic would surrender its own 'sovereignty'. As a result of this dual surrender a new Federal sovereign would be established, of which the Republic would constitute but one part. At the same time, the Netherlands-Indonesian Union was pro claimed with the agreement of the Nationalist leaders. On the day of the transfer of sovereignty, December 27, 1949, the United States of Indonesia was recognized by the United Kingdom and most of the members of the Commonwealth. This 
Rosa Ristawati: Modelling Executive Powers in the Indonesian Constitution: A comparative Study

sectors such as military and economy and treated Indonesia as if it was still under Dutch control. ${ }^{482}$ This situation provoked mixed reactions among the Indonesian politicians. Some national leaders thought that the revolution was to be a change of regime, from the Dutch to Indonesia with a lot of changes in the details of the basis. ${ }^{483}$ They thought that the politics and government system should reflect Indonesian values and not those of the Dutch. They also had provoked the change of the new regime of changing into the presidential system. By this, they meant that the all unwanted foreign influence, including the Dutch influence, had to be driven out of Indonesia. Besides, in the period of the Constitution of 1949 KRIS there were major political issues faced by Indonesia. ${ }^{484}$ On 17 August 1950, President Soekarno announced the rejection of the federal systemand the restoration of the Unitarian Republic of Indonesia. ${ }^{485}$ As a consequence, the temporary Constitution was drawn up and adopted before the Constituante (Constituent Assembly) was elected to undertake the task for drafting a permanent Constitution.

Table 3.2 Executive power under the KRIS 1949 Constitution

\begin{tabular}{|l|l|l|}
\hline $\begin{array}{l}\text { Executive } \\
\text { powers }\end{array}$ & Scopes & Checks and balances \\
\hline $\begin{array}{l}\text { Foreign affairs } \\
\text { power }\end{array}$ & $\begin{array}{l}\text { Power of foreign affairs (Article 174) } \\
\text { Make, conclude, and validate all the treaties and other agreements } \\
\text { with other states (Article 175) } \\
\text { decide joining the international organization (Article 176) } \\
\text { Undertake to solve the dispute between other states with peaceful } \\
\text { and also decide to ask or accept the International court or } \\
\text { international arbitration's decision (Article 177) }\end{array}$ & $\begin{array}{l}\text { with the authorization } \\
\text { from federal law }\end{array}$ \\
Emergency & Hold the emergency power and had the power to declare the state & $*$ \\
\hline
\end{tabular}

act of recognition was followed the next day by similar action on behalf of the United States, Portugal and Formosa. Soviet recognition was delayed until well into January 1950, to be followed by that of Rumania in February. Unlike the recognition of the Republic of Indonesia earlier, recognition now was on a de jure basis, and as such regarded as irrevocable."

${ }^{482}$ Id, L. C. Green (1965), p. 73: "Soekarno had been President of the Republic and retained this position in the United States, with the Queen of the Netherlands as Head of the Union symbolizing the 'voluntary and lasting cooperation between the partners."

${ }^{483}$ Colin Brown, Op. Cit., p. 173.

${ }^{484}$ See more on: Colin Brown, Op. Cit., p. 175,.." the first major political issue that Indonesia faced after the recognition of its independence was its formal structure, specially, whether it would remain a federal state, with power shared between the central and provincial governments, or revert to a unitary format, in which the power of the central government was unchallenged."

${ }^{485}$ Colin Brown, Op. Cit., p. 186:.."Sukarno had never made anybones about the fact that he rejected parliamentary democracy, withits competing political parties and its emphasis on reaching decisionsby majority votes. To him, this system was inherently divisive, aliento Indonesian political culture and the prime cause of the country'spolitical instability. The political parties, in particular, were in hissights. In October 1956, he made a speech strongly critical of theparties, and calling for the establishment of a new form of democracy". 
Rosa Ristawati: Modelling Executive Powers in the Indonesian Constitution: A comparative Study

\begin{tabular}{|c|c|c|c|}
\hline power & $\begin{array}{l}\text { is under the war or under the emergency war (Article } 184 \text { section } \\
\text { 1) }\end{array}$ & & \\
\hline $\begin{array}{l}\text { Administrative } \\
\text { and } \\
\text { appointment }\end{array}$ & $\begin{array}{l}\text { grant the honorable sign (Article 126) } \\
\text { give the pardon, amnesty (Article 160) }\end{array}$ & $\begin{array}{l}\text { With the advice from the } \\
\text { Supreme Court }\end{array}$ & * \\
\hline power & to appoint three of the cabinet maker (Article 74) & $\begin{array}{l}\text { With the state } \\
\text { representatives }\end{array}$ & * \\
\hline & $\begin{array}{l}\text { to order and appoint the Prime minister and the ministers (Article } \\
\text { 74) }\end{array}$ & With the cabinet maker & \\
\hline & $\begin{array}{l}\text { to determine the department ministerial minister and the non- } \\
\text { department ministerial minister }\end{array}$ & & * \\
\hline & to appoint the Chief of the Senate (Article 85 section 1 ) & $\begin{array}{l}\text { With the advice of the } \\
\text { Senate }\end{array}$ & * \\
\hline & $\begin{array}{l}\text { the power to order and appoint the prime minister and the } \\
\text { ministers (Article 77) }\end{array}$ & $\begin{array}{l}\text { According to the cabinet } \\
\text { maker }\end{array}$ & * \\
\hline & $\begin{array}{l}\text { The power to order the Prime minister to take over the daily work } \\
\text { (Article 72) }\end{array}$ & & * \\
\hline & to dismiss the ministers & & \\
\hline & $\begin{array}{l}\text { to determine the department ministerial ministers and the non- } \\
\text { department ministerial ministers (Article }\end{array}$ & & * \\
\hline & $\begin{array}{l}\text { to appoint the chief of the senate (Article } 85 \text { ) - according to the } \\
\text { advice of the senate }\end{array}$ & & * \\
\hline & $\begin{array}{l}\text { appoint the Republic federal of Indonesia's representative for } \\
\text { other states and accepts other states representative for the } \\
\text { Republic Federal of Indonesia (Article 178) }\end{array}$ & & * \\
\hline & $\begin{array}{l}\text { appoints, promotes and dismiss the officer in the field of state } \\
\text { defense (Article } 181 \text { section } 3 \text { ) }\end{array}$ & & * \\
\hline & give the honorable sign (Article 126) & Based on the federal law & * \\
\hline $\begin{array}{l}\text { Law-making } \\
\text { power }\end{array}$ & the legislative power (Article 127) & $\begin{array}{l}\text { Joint power with the DPR } \\
\text { and the Senat }\end{array}$ & ** \\
\hline & validate the legislation & & * \\
\hline & $\begin{array}{l}\text { set the government regulation to directive legislation (Article } \\
\text { 141) }\end{array}$ & & $* *$ \\
\hline $\begin{array}{l}\text { Pardoning } \\
\text { power }\end{array}$ & $\begin{array}{l}\text { Set the emergency law (Article } 139 \text { section } 1 \text { ) } \\
\text { give pardon, amnesty (Article 160) }\end{array}$ & $\begin{array}{l}\text { after asking the supreme } \\
\text { court advice }\end{array}$ & $\begin{array}{l}* * \\
*\end{array}$ \\
\hline Military power & Power of the state defense affairs (Article 181 section 1 ) & & ** \\
\hline & $\begin{array}{l}\text { To appoint the defense personnel under the general commander/ } \\
\text { appoint the minister of defense to be in this position (Article } 181 \\
\text { section 2) }\end{array}$ & & * \\
\hline & Declare the war (Article 183 section 1 ) & $\begin{array}{l}\text { With the permission by } \\
\text { the DPR and the Senate }\end{array}$ & $* *$ \\
\hline & $\begin{array}{l}\text { hold the highest power of commander in chief (Article } 182 \text { section } \\
\text { (1)) }\end{array}$ & & * \\
\hline Other powers & Set the Constitution (Article 196) & With the Constituante & ** \\
\hline
\end{tabular}

*the President

**the government

\subsection{Indonesian executive power under the Temporary Constitution of Republic Indonesia (the "UUDS 1950")}

The Temporary Constitution of the UUDS 1950 (hereafter referred to as the UUDS 1950) was ratified in Jakarta on 15 August 1950 by the President of the Republic Federal of Indonesia (Soekarno), the Prime Minister (Mohammad Hatta), and the minister of justice (Soepomo). It was published at the same time by the minister of justice. The text of the temporary 
Rosa Ristawati: Modelling Executive Powers in the Indonesian Constitution: A comparative Study

Constitution was the 1949 KRIS Constitution text with some additional contents from the UUD 1945. The legal form of ratification of the temporary Constitution 1950 was Legislation, the Republic Federal Legislation No. 7/1950 on the conversion from the 1949 KRIS Constitution to the Temporary Constitution of Republic of Indonesia. The significant changes from the 1949 KRIS Constitution to the Temporary Constitution were mainly about the changes of the State, from the Federal State to the Unitarian State. The government system was thought to be a parliamentary democracy. Although it was said to be a parliamentary democracy, the text of the Constitution did not explicitly say so. Unlike the KRIS Constitution which specified clearly that the government was the President and the ministers in Article 68, the temporary Constitution 1950 did not explicitly specify thegovernment in any of the provisions. However, Chapter II on State institutions, Section 1 on the government (Article 45 - Article 55) recognized the position of the President, the Vice President, the cabinet, the Prime minister and the ministers.

According to Article II, the temporary Constitution of the UUDS RI 1950 entered into force on 17 August 1950. The Constitution determined that the state institutions consisted of: a. the President and the Vice President; b. Ministers; c. the DPR; d. the Supreme Court; e. the Financial supervisor Council. ${ }^{486}$ The President and the Vice President were to be categorized as the government of the state based on Article 45. There was no clarification provided about the holder of the executive power. However, it was stipulated that the President was the head of the state and was assisted by a Vice President. ${ }^{487}$

Unlike in the KRIS Constitution which did not recognize the position of a Vice President, the temporary Constitution 1950 reintroduced the position of the Vice President without including the Emergency Clause (that empowered the President in time of emergency to install a presidential cabinet not on the basis of the party strength). This would make possible the existence of a non-parliamentary cabinet. According to the Article, for the first time, the President had the power to appoint the Vice President who was recommended by the DPR. The

\footnotetext{
${ }^{486}$ The UUD 1950 (excerpted from www.reformasihukum.org , unofficial translated by the author), Article 44 of theUUDS 1950.

${ }^{487}$ Article 45 of the UUDS 1950 (Appendix 3).
} 
Rosa Ristawati: Modelling Executive Powers in the Indonesian Constitution: A comparative Study

Vice President, in the case of a presidential resignation, will constitutionally succeed the President. $^{488}$

The government had its office in the capital city and had the power to decide other places in an emergency. ${ }^{489}$ Before officially holding the position, the President and the vice President should make an oath according to their religion before the DPR to:

- Directly and indirectly not give any promise or give something to anyone

- $\quad$ not accept directly and indirectly any promises or gift from anyone

- $\quad$ Promote the welfare of the Republic of Indonesia, protect and preserve the freedom, general and particular rights of the residents of the state

- $\quad$ Faithfully execute the Constitution and maintain all the laws in the Republic of Indonesia, faithfully fulfill all the duties that are inherently imposed as the consequences of the office of the head of the state. ${ }^{490}$

In running the state government, the President had the power to establish the ministries. ${ }^{491}$ The procedures of the ministry establishment were mentioned in Article 51 of the Constitution as follows:

1. The President appoints a person or some person as the Cabinet Maker ${ }^{492}$

2. According to the advice of the Cabinet maker, the President appoints a Prime Minister and other Ministers

3. According to the Cabinet committee's (for appointing the ministers) advice, the President decides the ministers who have the duties to preside over a Ministry. The President may appoint ministers who do not need to lead a Ministry

4. The Presidential decision to appoint the Ministers was signed by the Cabinet Maker

5. The appointment and the dismissal of the Ministers office term and the resignation of the Cabinet was realized by the Presidential Decree

It was constitutionally confirmed that the ministers are responsible to parliament either individually or collectively. ${ }^{493}$ However, in contrast with the UUD 1945 Constitution, the

\footnotetext{
${ }^{488}$ Article 48 of the UUDS 1950 (Appendix 3).

${ }^{489}$ Article 46 of the UUDS 1950 (Appendix 3).

${ }^{490}$ Article 47 of the UUDS 1950.

${ }^{491}$ Article 50 of the UUDS 1950 (Appendix 3).

${ }^{492}$ According to Herbert Feith (Op. Cit, Herbert Feith, p. 147): "the form One measure of a formateur's power was the extent to which he was able to bring together a cabinet by compromises on policies and interests rather than by compromises between personal cliques whose demands were often not capable of being translated into a self consistent policy."

${ }^{493}$ Article 83 section 2 of the UUDS 1950 (Appendix 3).
} 
Rosa Ristawati: Modelling Executive Powers in the Indonesian Constitution: A comparative Study

ministers were not responsible to the President but to the legislative assembly. ${ }^{494}$ Furthermore, Article 52 clarified that the ministers by forming a council of ministers headed by the Prime Minister were responsible to discuss public and state interests in a joint discussion and should inform the President of all important affairs. ${ }^{495}$ The government policies were set by presidential decree which had to be signed by the minister or the minister in the area of the policy. ${ }^{496}$ With regard to government affairs, the cabinet was given enormous power. ${ }^{497}$ The ministers could act broadly. ${ }^{498}$ Besides establishing and appointing the ministers, the President had the power to appoint the chief, vice chief, members of the Supreme Court ${ }^{499}$ and in the area of the council of finance. ${ }^{500}$

In performing their duties, the President and the Vice President were constitutionally inviolable. ${ }^{501}$ Although the President was inviolable and was said in Article 84 to have the right to dissolve the House of Representatives by a presidential decree, the dissolution was only

\footnotetext{
${ }^{494}$ Herbert Feith, Op. Cit., p. 95. "The Republic's cabinet was responsible to its legislative assembly, this on the basis not of the Republic's written constitutionof August 1945, but of a convention dating back to November 1945."

${ }^{495}$ Article 52 of the UUDS 1950 (Appendix 3).

${ }^{496}$ Article 85 of the UUDS 1950 (Appendix 3).

${ }^{497}$ Herbert Feith, Op. Cit., p. 96, "In one respect the cabinet was given enormous power: the constitution prepared by the joint committee provided, as the RUSI constitution had, for the possibility of emergency laws which could be made by the government alone and would be valid until such time as they were specifically counter-manded by parliament. In other respects, however, the new constitution was tilted in parliament's favour. Parliament was placed in the position of being able to force the resignation of a cabinet or of individual ministers. On the other hand, the power of the cabinet to dissolve parliament was less clearly specified."

${ }^{498}$ Herbert Feith, Op. Cit., p. 147, "Cabinet members may have been in a weak position to effect the broad economic and social policies to which they were formally committed. But when their role is looked at without reference to considerations of long-term policy, it becomes clear that they were men of great influence. Particularly in the new and administratively fluid ministries but in some older ones too, ministers could play a virtuoso role, making important decisions without being closely checked by the cabinet as a whole, by the senior bureaucrats of their ministry, or by their respective parties. They could issue ministerial regulations on a wide range of subjects. Sometimes without anyone outside their ministries knowing that a particular regulation had been made or what it involved. They could exercise a broad degree of discretion as regards the distribution of funds and the How of patronage. And they had considerable freedom in the matter of appointments and transfers. In all these ways they could help not only their parties but also their own group of friends, associates, and followers. Thus it mattered a great deal who were the individual occupants of ministerial portfolios."

${ }^{499}$ Article 79 of the UUDS 1950 (Appendix 3).

${ }^{500}$ Article 81 of the UUDS 1950 (Appendix 3).

${ }^{501}$ Article 83 section 1 of the UUDS 1950 (Appendix 3).
} 
possible if the President was able to conduct an election of the new House of representatives within 30 days. ${ }^{502}$

In terms of law-making power, the Constitution implied that the President had significant power in the legislation-making process. It was stipulated in Article 89 that "the legislative power was held by the President (the government) jointly with the DPR."The President (the government) had the power to propose abill of legislation through presidential message to the DPR. On the other hand, the DPR had also the power to propose legislation to the government. ${ }^{503}$ On the President's bill, the DPR had the right to make changes. ${ }^{504}$ In further stages, whether the DPR accepted or rejected the proposal of legislation, the DPR should notify the President. ${ }^{505}$ If the process continued, the proposal would be sent to the President and validated by the President (the government). ${ }^{506}$ During the process, if the proposal of the legislation was not accepted by the DPR, the government could withdraw it. ${ }^{507}$

The legislation had the function to order state institutions and to regulate certain subjects. ${ }^{508}$ It was also an important instrument for the government in running the state administration. Article 113 stipulated that the budget of the state expenses and the state income can only be decided by legislation. The bill for the state budgetary legislation was proposed by the government to the DPR. ${ }^{509}$ The proposal of the legislation indicated that the calculation of the budget should be validated by the Council of the Financial Supervisor and in the end the government in spending the money should be responsible to the DPR. ${ }^{510}$ Besides

\footnotetext{
${ }^{502}$ Herbert Feith, Op. Cit., p. 96, "It was said in Article 84' of the Constitution that "the President has the right to dissolve the House of Representatives," but also, in the next sentence, that "the Presidential Decree announcing such dissolution shall also order the election of the new House of Representatives within 30 days." Thus it appeared, at least to one major school of constitutional interpretation, that dissolution was possible only in situations where it was feasible to elect a new House within 30 days."

${ }^{503}$ Article 90 of the UUDS 1950 (Appendix 3).

${ }^{504}$ Article 91 UUDS 1950 (Appendix 3).

${ }^{505}$ Article 92 of the UUDS 1950 (Appendix 3).

${ }^{506}$ Article 93 the UUDS 1950 (Appendix 3).

${ }^{507}$ Article 94 of the UUDS 1950 (Appendix 3).

${ }^{508}$ Article 99 section 1 UUDS 1950 (Appendix 3).

${ }^{509}$ Article 114 of the UUDS 1950 (Appendix 3).

${ }^{510}$ Article 116 of the UUDS 1950 (Appendix 3).
} 
being a tool to legitimise the state budget, the legislation was the instrument for the government to impose taxes and customs. ${ }^{511}$

Other presidential law-making power could be determined by Article 96. According to the Article, the government had the power to set Emergency Laws. ${ }^{512}$ During the next DPR's session, the Emergency Law should be proposed to the DPR. This way, the Emergency Law was based upon the proposal of legislation from the government. However, if it was rejected, the law would be legally invalid. ${ }^{513}$ However, the Article did not explicitly specify the presidential power in the process. It only generally referred to the government in general. ${ }^{514}$

The President as the head of the state had the right to give honorable decorations. ${ }^{515}$ In other area, still in the role as the head of the state, the President was granted the power of pardoning, amnesty, and abolition. ${ }^{516}$ The power could only be exercised after getting advice from the Supreme Court. The Constitution also determined that the government held the power in general financial affairs. ${ }^{517}$ On the other hand, the financial management power was constitutionally checked by a financial supervisory council and further, the result would be communicated to the DPR. ${ }^{518}$ In daily state management, the Constitution gave the right to the government to make any arrangement for the state's financial benefit. Article 118 Section 2 of the UUDS 1950 stipulated that the government had the right according to the laws to issue the currency and treasury promissory notes. In official daily management, Article 119 section 1 of the UUDS 1950 clarified that the government had the right to determine the salary and other incomes for state officials and members of state institutions according to the laws.

Chapter $V$ of the Constitution determined the constitutional basis for the foreign affairs power of the President and the government in general. According to Article 120 Section 1 of the Constitution, the President had the power to make and ratify treaties and other agreements

\footnotetext{
${ }^{511}$ Article 117 of the UUDS 1950 (Appendix 3).

${ }^{512}$ Article 96 section 1 and section 2 of the UUDS 1950 (Appendix 3).

${ }^{513}$ Article 97 of the UUDS 1950 (Appendix 3).

${ }^{514}$ Article 98 of the UUDS 1950 (Appendix 3).

${ }^{515}$ Article 87 of the UUDS 1950 (Appendix 3).

${ }^{516}$ Article 107 of the UUDS 1950 (Appendix 3).

${ }^{517}$ Article 109 section 4 of the UUDS 1950 (Appendix 3); Article 111 section 1 of the UUDS 1950 (Appendix 3)

${ }^{518}$ Article 112 section 1 of the UUDS 1950 (Appendix 3).
} 
between states. ${ }^{519}$ Furthermore, Section 2 of the Article emphasized that the President, through Legislation, also had the power to decide treaties and other agreements to be concluded. ${ }^{520}$ With regard to state participation in International organizations, Article 121 stipulated that according to the treaties and other agreements determined by Article 120, the government had the power to decide that the Republic of Indonesia shouldenter into an international organization. In other diplomatic affairs, Article 122 of the UUDS 1950 constitutionally empowered the government to undertake any measures in order to peacefully resolve a conflict with other states. In respect to that, the Constitution also provided constitutional options for the government to decide whether or not to ask for or accept the International Court or International arbitration. In term of international relations, the UUDS 1950 gave the president the power to appoint the representatives of the Republic of Indonesia to other states and to accept other states representatives to the Republic of Indonesia. ${ }^{521}$

With regard to the state defense, Article 126 section 1 of the UUDS 1950 stated that the government held the state defense affairs. Under the Constitution, in time of war, the President had the power as commander in chief. In general conditions, the President held the highest power of the Army of the Republic of Indonesia. ${ }^{522}$ The same as in the KRIS Constitution, the UUDS 1950 granted the President the power to declare war. However, this power could only be exercised with the permission of the DPR. ${ }^{523}$ In other situations of emergency, unlike the KRIS Constitution that explicitly mentioned that the government had the power to deal with the emergency situation, the UUDS 1950 indicated that the President had the power to declare that the Republic of Indonesia or part of the state territory was inan emergency situation. ${ }^{524}$ The declaration of the state emergency could be made with the assumption that the state security, public interest and international security in general was threatened by a dangerous situation.

\section{- Executive immunity}

\footnotetext{
${ }^{519}$ Article 120 Section 1 the UUDS 1950 section 1 (Appendix 3).

${ }^{520}$ Article 120 section 2 of the UUDS 1950 (Appendix 3).

${ }^{521}$ Article 123 of the UUDS 1950.

${ }^{522}$ Article 127 section 1 - section 3 of the UUDS 1950 (Appendix 3).

${ }^{523}$ Article 128 of the UUDS 1950 (Appendix 3).

${ }^{524}$ Article 129 section 1 of the UUDS 1950 (Appendix 3).
} 
The similarity between the KRIS Constitution and the UUDS 1950 could also be seen from the presidential immunity's provision. Article 106 Section 1 explicitly expressed that the President in office could be prosecuted before the first and the highest Supreme Court. The prosecution could also be started after the resignation of the President. The grounds of the prosecution could be crimes and other violations that had been committed by the President during his office. ${ }^{525}$

\section{- Check and balance against the presidential power under the UUDS 1950}

The Constitution recognized the DPR in Article 56 as the state institution representing all the Indonesians. Article 69 Section 1 stipulated that the DPR has the right of interpellation and right to question; each of the members had the right to do so. According to Article 70, the DPR had also the right to investigate (enquete right). In return, it was clearly stated that the ministers had the constitutional duty to give the DPR all written and unwritten explanations which were required by the DPR. ${ }^{526}$ However, the explanationshould not be contradictory to the public interest of the state. In case that the explanation contradicted the public and state interest, the ministers had the right to ignore the DPR inquiry. Unlike other Constitutions, the UUDS 1950 gave the power to the President to dissolve the DPR. ${ }^{527}$

In practice, the temporary Constitution of 1950 had replaced the parliamentary Constitution of KRIS 1949. Although the text of the Temporary Constitution was imported from the KRIS Constitution, the text gave a different power to the President. In general, the power of the President was not really strong. Since it was said that the system was parliamentary democracy, the President was said to be only a figurehead position. Article 52 implied that the ministers in the Ministerial council led by the Prime Minister had an important position in state administration. $^{528}$

\footnotetext{
${ }^{525}$ Article 106 section 1 of the UUDS 1950 (Appendix 3).

${ }^{526}$ Article 69 section 2 of the UUDS 1950.

${ }^{527}$ Article 84 of the UUDS 1950 (Appendix 3).

${ }^{528}$ Article 52 of the UUDS 1950 (Appendix 3).
} 
Rosa Ristawati: Modelling Executive Powers in the Indonesian Constitution: A comparative Study

Article 85 stipulated that all the Presidential Decrees including those regarding the performance of the Presidential military powers should be counter-signed by the ministers. ${ }^{529}$ The Article limited the presidential power for only formal powers concerning the appointment. With regard to the formal appointment, the President only acted formally and in accordance with the recommendation of the Cabinet Committee (a committee to establish the cabinet and appoint ministers) and the recommendation of the House of Representatives (on the appointment of the vice president). However, in practice, the position of President Soekarno during the period was stronger because of the support from the army commander and vice versa the President used his influence for the army organization. ${ }^{530}$ On the other hand, the cabinet did not really gain much support from the army. ${ }^{531}$ The relationship between the President and the cabinet could be seen in two perspectives. One perspective, though the President did not have direct power to establish the Cabinet instead of through the Cabinet maker, the President could still use his influence since the makers were appointed and associated with the President. ${ }^{532}$ Another perspective was that the Cabinet had a kind of mutual relation to the President in fact the existence of the Cabinet was greatly supported by the President. ${ }^{533}$ During the period of the Wilopo Cabinet, the Presidential dissolution power had been challenged by the situation of parliament and cabinet deadlock; however, it did not happen and was ended by a new Cabinet. ${ }^{534}$

\footnotetext{
${ }^{529}$ Article 85 of the UUDS 1950 (Appendix 3).

${ }^{530}$ Herbert Feith, Op. Cit, p. 250, "Many of the personnel changes which the army leaders had effectedin 1951 and the first half of 1952 had clearly lessened his influence within the army, and on at least one occasion in 1952 he had intervened against the army leaders' personnel policy by refusing to sign a decree.

${ }^{531}$ Herbert Feith, Op. Cit., p. 172, "in the months of January, February, and March 1951 Prime Minister Natsir obtained considerable support from the army leaders in his covert struggle with the President. It was an early manifestation of what was to become a characteristic situation of the politics of our period, the situation where the two chief extra parliamentary centers of power, the President and the army, were pulling the contenders in the cabinet-parliament arena in opposite directions. But, whether because of the army leaders' disinclination to use their influence too openly-perhaps the result of internal army divisionor because of a reluctance on Natsir's part to allow them to enter too far into civilian and constitutional politics, army support was not forthcoming on a scale sufficient to counter-balance the pressures exerted by the President."

${ }^{532}$ Herbert Feith, Op. Cit.,214, "Both of the formateurs were long-time associates of the President, and most of the principal figures in the cabinet, men such as Suwirjo, Iskaq, and Subardjo, had likewise long been tied to Soekarno as associates or supporters.

${ }^{533}$ Herbert Feith, Op. Cit., p. 214.

${ }^{534}$ Herbert Feith, Op. Cit., p. $262-270$.
} 
Rosa Ristawati: Modelling Executive Powers in the Indonesian Constitution: A comparative Study

As the issues at the time were about economic issues and capitalism, the Government had control over the economy and finance. During that period of 1950, Indonesia was suffering a deteriorating economic situation. To overcome the situation, the Government mostly used their power to reduce the number of people on the public payroll, raise efficiency and reduce the drain on the national budget, even though, it was unsuccessful. The Prime Minister at the time dominantly tried to overcome the government affairs. The crisis came from not only the economic situation but also from the territorial sovereignty dispute. For example, the territorial dispute issues of Irian Jaya. In this case, the Prime Minister had the role to politically negotiate. At the time, Prime Minister Ali Sastroamidjojo had a great influence in particular in foreign affairs. He initiated the establishment of the Asia-Africa bloc, the non-alliance states movement. On the other hand, in the spirit of revolution, President Soekarno introduced "guided democracy". 535

During the period of 1956-1957, after the election of 1955 and as a consequence of the election result (on the issues of the geographical division and the resignation of Vice President Hatta in 1956), a group of regional military commanders in Sumatera and Sulawesi seized power from the local civilian administrations appointed by Jakarta and set up their own administration. ${ }^{536}$ This situation called President Soekarno to declare a state of martial law across Indonesia. ${ }^{537}$ However, the effort taken had failed to overcome the rebels. ${ }^{538}$ This situation compelled President Soekarno to authorize the army to take military action.

\footnotetext{
${ }^{535}$ Colin Brown, Op. Cit., p. 190 - 191: “..the guided democracy was a system of government in which the parliament was to play a relatively small role, as were most political parties, with the increasingly important exception of the Communist party. It was a system that saw the Indonesian army consolidate its position as a major political force."

${ }^{536}$ Colin Brown, Op. Cit., p. 187.

${ }^{537}$ Colin Brown, Op. Cit., p. 188.

${ }^{538}$ See more: Colin Brown, Op. Cit., p. 188:“On 15 February 1958, the establishment of the Revolutionary government of the Republic of Indonesia (the PRRI: the Pemerintah Revolusioner Republik Indonesia) was proclaimed in West Sumatra. Two days later, the rebels from Sulawesi also joined the PRRI. They were not seeking separation from Indonesia but rather its reform. The situation provoked President Soekarno to authorize General Nasution (Army Commander) to take military action and resulted with victory for the central government. The victory strengthened the President Soekarno's position and brought him the opportunity to move forcefully against his opponents. In 1960, Soekarno had banned two of the political parties as his opponents (the Masjumi and the Indonesian Socialist Party), which had expressed the strongest opposition to his proposal for a reorganization of the Indonesia political system.
} 
Rosa Ristawati: Modelling Executive Powers in the Indonesian Constitution: A comparative Study

The executive power during the period was also challenged by foreign policy issues, particularly the effort to get International recognition for Indonesia. On the one hand, the president had to deal with the politics of nationalization of company affairs within the Indonesia territory by expelling foreign influence in domestic businesses. ${ }^{539}$ On the other hand, the presidential diplomatic power was challenged by the war with the West Irian territory. ${ }^{540}$

In general, according to the constitutional practices during this period, the power and the role of the President were merely within the scopes of nominal power rather than real power. However, there were many influences on state affairs by the President on the basis that the President was not only the symbol of the state but also a revolutionary leader. The situation sometimes provoked clashes between the President and the Cabinet. ${ }^{541}$ In the period ofthe Wilopo cabinet, the President indicated his reluctance to work with the cabinet. ${ }^{542}$

During the period, the situation was even more complicated since the Konstituante (the Constituent Assembly), established by the first election on 1955 had unsuccessfully drafted apermanent Constitution for Indonesia. This situation provoked Soekarno to formally propose the re-instatement of the first Constitution of 1945. Since the presidential proposal to re-adopt the Constitution was never agreed by the Konstituante, this situation prompted President

\footnotetext{
${ }^{539}$ Colin Brown, Op. Cit., p.191:“President Soekarno had decided to announce that Indonesia follow a new course of action in trying to recover the territory, putting direct pressure on the Dutch by a campaign against Dutch business interests in Indonesia. As a consequence, the major Dutch businesses were taken over in most instances by their employees, although all eventually came under government or military control. Dutch nationals were subjected to public harassment, and most were finally expelled from Indonesia. Mass rallies and parades were held in cities, towns, and villages across Indonesia, demanding that the Dutch get out of the territory."

${ }^{540}$ Herbert Feith, Op. Cit., p. 318:"At the same time the cabinets did not engage in dramatic foreign policy activities or attempt to evoke excited responses at home to their roles in the international arena. In handling the Irian question, they did their best, within the limits of their relationship to President Soekarno, to discourage agitational support of the claim."

${ }^{541}$ See more on Herbert Feith, Op. Cit., p. 217.

${ }^{542}$ Herbert Feith, Op. Cit., p. $244-245$, "The President had certain personal reasons to feel antagonistic toward the Wilopo cabinet. The cabinet contained a number of the men with whom he had come into conflict in the period of the Natsir cabinet, and it indicated as soon as it had taken office that it would insist, as the Natsir cabinet had (and the Sukiman cabinet had not ), on a sharp limitation of the President's prerogatives. The matter came to the fore at the very beginning of the Wilopo cabinet's period of office when the cabinet obliged the President to cancel arrangements made by him and the ex-Foreign Minister, Subardjo, for a presidential visit to Italy."
} 
Rosa Ristawati: Modelling Executive Powers in the Indonesian Constitution: A comparative Study

Soekarno to issue the unilateral presidential decree on the re-instatement of the first Constitution of the UUD $1945 .{ }^{543}$

Constitutionally, according to Article 134 of the temporary Constitution of UUDS 1950, the Konstituante together with the President would promptly set the Constitution. The Constitution was expected to replace the temporary Constitution of UUDS 1950. First after the 1955 general election for the Konstituante's members, on 10 November 1956, President Soekarno opened the first session of Konstitutante in Bandung. Since then, there were serious debates in drafting the state principles within the Konstituante. This situation led to a deadlock. On 19 February 1959, the Cabinet Djuanda took the position to decide the government mandate to re-instate the Constitution of UUD 1945. The mandate was stated in the Government Decree of 19 February 1959 with the argument that the debate within the Konstituante had a significant influence on the people and had potentially created conflict caused by the deadlock. On behalf of the government (the administration), President Soekarno delivered the president and government's recommendation to re-instate the Constitution of UUD 1945 on 22 April 1959. There were three points made by the President: 1 . the reinstatement of the Constitution of UUD 1945; 2. the re-instatement of the Constitution procedure; 3. the consolidation of the functional faction into the DPR. It was stated by the President that the Constitution of UUD 1945 was a democratic Constitution and reflected the identity of the nation. At this point, President Soekarno also introduced guided democracy, which was determined as a suitable democracy that should be adopted by Indonesia. It was based on the key principle of deliberation and wisdom. The President accordingly would appoint capable person as his assistants. However, the President and his assistants were responsible to the MPR. The presidential and government recommendation did not work at all since there were still debates within the Konstituante in the deal to re-instate the Constitution of UUD 1945. This deadlock had provoked President Soekarno to issue a presidential decree to impose the re-instatement of the Constitution of the UUD 1945. The grounds of the Presidential Decree were mostly because the Konstituante did not respond to the Presidential and

\footnotetext{
${ }^{543}$ Colin Brown, Op. Cit., p. 190.
} 
Rosa Ristawati: Modelling Executive Powers in the Indonesian Constitution: A comparative Study

government mandate to re-instate the Constitution of UUD 1945; On the other hand, the Konstituante had been considered to fail in performing their duty to set the new Constitution. To this extent, the President assumed that such constitutional problems would significantly impact the state emergency. On the main basis of protecting of the state and the people, President Soekarno delivered the Presidential Decree to re-instate the Constitution of UUD 1945, dismiss the Konstituante, and thus, dismiss the temporary Constitution of the UUDS 1950. Furthermore, the President also set the establishment of the temporary MPR and the temporary DPA.

Table 3.3 Executive power under the UUDS 1950 Constitution

\begin{tabular}{|c|c|c|c|}
\hline $\begin{array}{l}\text { Executive } \\
\text { powers }\end{array}$ & Scopes & $\begin{array}{l}\text { Check and } \\
\text { balance }\end{array}$ & \\
\hline \multirow{3}{*}{$\begin{array}{l}\text { Foreign affairs } \\
\text { power }\end{array}$} & $\begin{array}{l}\text { make and ratify treaty and other agreements between other states (Article } \\
120 \text { section 1) }\end{array}$ & & $*$ \\
\hline & $\begin{array}{l}\text { decide the treaties and other agreements to be concluded (Article } 120 \\
\text { section 2) }\end{array}$ & & * \\
\hline & enter into the international organization (Article 121) & & ** \\
\hline \multirow[b]{4}{*}{$\begin{array}{l}\text { Emergency } \\
\text { power }\end{array}$} & $\begin{array}{l}\text { undertake any measures in order to peacefully resolve the conflict } \\
\text { between other states (Article 122) }\end{array}$ & & ** \\
\hline & $\begin{array}{l}\text { make an option whether or not asking or accepting the International Court } \\
\text { or International arbitration (Article 122) }\end{array}$ & & ** \\
\hline & $\begin{array}{l}\text { appoint the representative of the Republic of Indonesia for other states } \\
\text { and accepts other states representative for the Republic of Indonesia } \\
\text { (Article 123) }\end{array}$ & & $*$ \\
\hline & $\begin{array}{l}\text { declare that the Republic of Indonesia or part of the state territory is } \\
\text { under emergency (Article } 129 \text { section } 1 \text { ) }\end{array}$ & & * \\
\hline \multirow{8}{*}{$\begin{array}{l}\text { Administrative } \\
\text { and } \\
\text { appointment } \\
\text { power }\end{array}$} & $\begin{array}{l}\text { The power to make government policies through the presidential decision } \\
\text { (Article 85) }\end{array}$ & & ** \\
\hline & $\begin{array}{l}\text { The power to appoint the chief, vice chief, and members of Supreme Court } \\
\text { (Article 79) }\end{array}$ & & $*$ \\
\hline & $\begin{array}{l}\text { The power to manage the state income by issuing the bilyet and promise } \\
\text { (Article } 118 \text { section } 2 \text { ) }\end{array}$ & & $* *$ \\
\hline & $\begin{array}{l}\text { The power to determine the salary and other incomes for state officials } \\
\text { and members of the state institution (Article } 119 \text { section } 1 \text { ) }\end{array}$ & & $* *$ \\
\hline & The power to give honorable sign (Article 87)- according to the laws & & $*$ \\
\hline & The power to establish the ministerial (Article 51) & & $*$ \\
\hline & Appoints and dismisses the army officers (Article 127 section 3 ) & & $*$ \\
\hline & The power of the general affairs of the financial (Article 111 section 1 ) & & ** \\
\hline \multirow{6}{*}{$\begin{array}{l}\text { Law-making } \\
\text { power }\end{array}$} & The power to propose the state budget legislation (Article 116) & & ** \\
\hline & The power to propose the bill of legislation & & ** \\
\hline & The legislative making power (Article 140) & $\begin{array}{l}\text { Joint approval with } \\
\text { the DPR }\end{array}$ & $* *$ \\
\hline & The power to set emergency law (Article 96) & & $* *$ \\
\hline & The power to make government rules (Article 98) & & $* *$ \\
\hline & The power to propose the tax and custom legislation (Article 117) & & $* *$ \\
\hline $\begin{array}{l}\text { Pardoning } \\
\text { power }\end{array}$ & The power of pardoning, give amnesty, abolition (Article 107) & $\begin{array}{l}\text { by the advice of } \\
\text { supreme court }\end{array}$ & $*$ \\
\hline \multirow[t]{3}{*}{ Military power } & $\begin{array}{l}\text { The power against the state defense affairs (Article } 126 \text { section 1)- } \\
\text { government }\end{array}$ & & $* *$ \\
\hline & Declare the war (Article 128) & with & $*$ \\
\hline & The power of commander in chief in time of war (Article 127 section 2) & & $*$ \\
\hline
\end{tabular}




\begin{tabular}{|c|c|c|}
\hline \multirow{3}{*}{ Other powers } & Highest commander of army in general situation (Article 127 section 1) & * \\
\hline & Dissolve the DPR (Article 84) & * \\
\hline & $\begin{array}{l}\text { Declare the dissolution and order to set the new DPR's election within } 30 \\
\text { days (Article 84) }\end{array}$ & * \\
\hline
\end{tabular}

\subsection{The Indonesian Constitution under the UUD 1945 (the period of reinstatement of the UUD 1945 after the temporary Constitution of 1950)}

\section{e. Executive power under the UUD 1945: Soekarno administration (1959 - 1968)}

Textually, the executive power under the Constitution of UUD 1945 that was re-instated by President Soekarno with the Presidential decree 1959 was the same as the executive powers in the Constitution of UUD 1945 that was enacted after the unilateral independence proclamation. However, during Soekarno's administration, the executive powers had been exercised unlawfully. Many constitutional violations were made by President Soekarno. The President used the power to appoint the Chairman of the MPRS, the Chairman of the DPRGR, the Vice Chairman of the DPA and the Chairman of the Council of National drafting committee as the main first vice minister. ${ }^{544}$ On the other hand, the Vice chairman of MPRS and the vice chairman of DPRGR were appointed as ministers. ${ }^{545}$ Another constitutional violation could be seen in the Decree of MPRS III/1963 concerning the presidential appointment for long-life tenure. These constitutional violations provoked a constitutional crisis in terms of the presidential leadership.

In practice, it was observed that President Soekarno was the sole interpreter of the revolution; he used his power to deal with the revolution era. ${ }^{546}$ The President had a strong

\footnotetext{
${ }^{544}$ The MPRS was the temporary MPR (the People Representative Assembly), the DPRGR was established by the President since the DPR (as a result of the first election 1955) did not approve the government's proposal on state budget. To this extent, the President established a new DPR which was named as DPRGR (the mutual aid of Council of people representative). All the members of the DPRGR were appointed by the President. The President also set all the rules with regard to the DPRGR.

${ }^{545}$ Ismail Suni, Op. Cit., p. 204-205.

${ }^{546}$ L.C. Green, Op. Cit., p. 71 "Soekarno calls for an abandonment of the rule of law at home when it appears that legal principles may hinder the personal ambitions of one who regards himself as the personification of a
} 
Rosa Ristawati: Modelling Executive Powers in the Indonesian Constitution: A comparative Study

influence on the Army. ${ }^{547}$ In this period, the presidential power also dealt with the rebellion movement. In 1962, the President used his emergency power to declare the end of martial law as the rebel leader of DI/TII, Kartasuwirjo had been captured and the end of the West Irian campaign had deprived the army of their intention to maintain martial law. ${ }^{548}$

Another constitutional crisis was also caused by political tension especially after the Indonesian Communist Party insurgency. In this period, Indonesia suffered from political and economic devastation, but President Soekarno ignored the political and economic crisis but was concernedby the conflict between Indonesia-Malaysia. As the tension was getting worse, the people demanded that President Soekarno overcome the conflicts and the crises. However, because of the political tension, the President was in a difficult position to determine the solutions. In general, Herbert Feith stated that during this period, the presidential power was dominantly agitational politics and characterized to be more progressive. ${ }^{549}$ Still according to Soekarno's concept of guided democracy, a democracy with leadership, President Soekarno revived the idea of the establishment of a new National Planning Board. ${ }^{550}$

revolution, and therefore of his people. It was also supported by the announcement from the Chairman of the Indonesian Supreme Court that the law may be broken if the interest of the revolution demanded."

${ }^{547}$ Herbert Feith, Op. Cit., President Soekarno, the Army and the Communists: the Triangle Changes Shape, Asian Survey, Vol. 4, No. 8 (August, 1964), University of California, pp. 969 - 980, Accessed on 10/11/2012, p. 969: “On June 23, 1962, Major-General Achmad Yani replaced General A. H. Nasution as Chief of Staff of the army, with Nasution assuming the new position of Chief of Staff of the armed services, as well as remaining Deputy First Minister for Defense and National Security. This represented a major increase in President Soekarno's influence within the army".

${ }^{548} / d$. at p. 971.

${ }^{549} / d$. at p. 978: "the President's power has always rested in large part on agitational skills and his moves to the left in the last two years can be explained partly as a requirement for the maintenance of agitational politics: forced to choose between economic stabilization and an ongoing struggle against neocolonialist Malaysia, he chose the latter, alienated the West and so had to align himself with the Communists. It may well be that Soekarno's actions in the last two years have been as much role-determining as role-determined, that he has been secure enough in his position in this recent period to be able to fashion policies partly on the basis of his ideas and attitudes about the future. It is often said that the President is deeply concerned with the question of how history will regard him. He certainly has considerable admiration for Communist regimes. And he is a man with a progressive and profoundly historicist view of history, consequently, a man who is likely to be unhappy about the possibility of being succeeded by any regime which he would see as reactionary."

${ }^{550}$ Justus M. van der Kroef, "Guided Democracy in Indonesia”, Far Eastern Survey Vol. 26 No. 8 (August 1957), pp. 113 - 124, Institute of Pasific Relations, accessed 02/11/2012, p. 115, "At that time the President also revived an earlier idea: the establishment of a new National Planning Board, to supersede the present National Planning Bureau, which has no "over all planning function." 
Rosa Ristawati: Modelling Executive Powers in the Indonesian Constitution: A comparative Study

In general practice, the executive powers used by President Soekarno also had to deal with the lack of international awareness specifically on the Indonesian position against the cold war. ${ }^{551}$ On a domestic level, crisis still came from the issue of the Indonesian territory in particular Irian Jaya. ${ }^{552}$ In other International issues, President Soekarno used the power to make a foreign affairs policy in confronting the Federation of Malaysia. ${ }^{553} \mathrm{He}$ continued to set a diplomatic foreign policy against Malaysia and proclaimed the Indonesian position against the establishment of the Federation of Malaysia. ${ }^{554}$ The confrontation provoked Soekarno to use his power to show the commitment of anti-colonialism and anti-communism to the International community. ${ }^{555}$ However, it changed as President Soekarno had his new doctrine about Indonesia's position in the world. ${ }^{556}$ In the other issues of international relations, still relevant to the Malaysian issue, President Soekarno used his power to withdraw from the UN in 1964. ${ }^{557}$ President Soekarno even issued foreign policy to break off the link with some International organizations. ${ }^{558}$ Soekarno also employed his executive power to express

\footnotetext{
${ }^{551}$ Colin Brown, Op. Cit., p. 192:"Under Sukarno, there seemed to Washington to be a real likelihood that Indonesia would throw in its lot with the communists, especiallyand most dangerouslywith China, with potentially disastrousconsequences for American strategy in Asia. Sukarno thus had to bediverted from the communists, to be shown that he had more to gainfrom friendly relations with Washington than with Beijing."

${ }^{552} / d$. at p. 193,..."with his new approach to the Irian Jaya issue, Soekarno had given the people the sense that they were participating in a great crusade against colonialism; a crusade not just national but also international in its reach. The campaign was also important in cementing the unity of the Indonesian nation, so recently under challenge in Sumatera and Sulawesi. Virtually no identifiable group in the community opposed it: communists, Muslims, military leaders and politicians of all persuasions participated in the struggle. The contrast with the divisive politics of the parliamentary democracy period was striking."

${ }^{553}$ Id. at p. $193-194$.

${ }^{554}$ Id., "in January 1963, Foreign Minister Subandrio announced Indonesia's opposition to the plan, proclaiming:

"The President has decided that henceforth we shall pursue a policy of confrontation against Malaya . . . we have always been pursuing a confrontation policy against colonialism and imperialism in all its manifestations. It is unfortunate that Malaya, too, has lent itself to become tools of colonialism and imperialism. That is why we are compelled to adopt a policy of confrontation."

${ }^{555}$ L.C.Green, Op. Cit., p. 77.

${ }^{556}$ Herbert Feith, Op. Cit., p. 974.

${ }^{557}$ Colin Brown, Op. Cit., p. 195, “At the end of 1964, Sukarno withdrew Indonesia from the United Nations in protest at Malaysia's election to a seat onthe Security Council. By the time the first major blow fell against the Sukarno regime in 1965, despite having been in progress for two yearsthe 'crush Malaysia' campaign was to all intents and purposes stymied".

${ }^{558}$ M.C. Ricklefs, A History of Modern Indonesia since c.1200, $3^{\text {rd }}$ Edition, Palgrave Macmillan, 2001, p. 338, In August 1965 Sukarno withdrew Indonesia from remaining links with the capitalist world (International Monetary Fund, Interpol, World Bank). When Lee Kuan Yew tearfully announced Singapore's separation from Malaysia on 9 August, Sukarno viewed this as confirmation of the righteousness of confrontation. But Singapore's separation also
} 
Indonesia's position on issues such as colonialism and imperialism and other issues related toAmerican's foreign policy and its interest to regional Asia. ${ }^{559}$ It implied that the presidential foreign affairs powers were used to indirectly secure the position of the President. ${ }^{560}$ On the treaty making power, the presidential power was exercised in accordance with the domestic policy on "friendly Chinese policy" that the President Soekarno had for ethnic Chinese in Indonesia. ${ }^{561}$ The regime of Soekarno administration came to an end as not only the conflict between the two political forces of army and Communist Party (PKI: Partai Komunis Indonesia) had risen but also from the guided democracy which he campaigned for and further resulted in the banning of the Communist Party in Indonesia. ${ }^{562}$ The conflict was marked by the 30 September movement of such a scenario of a coup d'etat and rendered what was called the transitional authority from the Soekarno administration to the Soeharto era. ${ }^{563}$

\section{f. Executive power under UUD 1945: Soeharto administration (1968 - 1998)}

In 1968, the transitional period of regime from the Soekarno to Soeharto administration was virtually complete by a mandate in which president Soekarno gave temporary authority to

removed most of the basis for the army leaders' fears of Malaysia and increased their inclination to end confrontation.

${ }^{559}$ Timothy P. Maga, "The New Frontier vs Guided Democracy: JFK, Sukarno, and Indonesia, 1961 - 1963 ", Presidential Studies Quarterly, Vol. 20, No. 1, Leadership and Crisis Management(WINTER 1990), pp. 91-102, Published by: Wiley-Blackwell on behalf of the Center for the Study of the Presidency and Congress, Accessed: 02/11/2012, p. 100.

${ }^{560}$ Herbert Feith, Op. Cit., p. 979, "President Soekarno is probably restrained from making moves in the direction of Cuba-like dependence on the Communist countries by fear that such moves could alarm powerful elements in the Indonesian army and add to their willingness to support some sort of coup against him".

${ }^{561}$ Colin Brown, Op. Cit., p. 196: “Indonesia's ethnic Chinese population experienced decidedly mixed fortunes during the guided democracy period. Sukarno himself was not anti-Chinese. Indeed, in a country where antiChinese outbursts from national leaders were distressingly commonplace, he stands out as having supported full membership of the Indonesian national community for citizens of ethnic Chinese descent. And the increasingly close relations between Indonesia and China, especially in the 1960s, meant that, at least at the public political level, being of ethnic Chinese descent was not a handicap. A Dual Nationality Treaty had been negotiated between China and Indonesia in 1955, the object of which was to resolve once and for all the question of the nationality of ethnic Chinese in Indonesia."

${ }^{562}$ Colin Brown: Op. Cit., p. 198, "the end for the Soekarno regime came in the mid-1960s, largely as a result of the rising conflict between the two political forces which apart from Soekarno himself had gained most from guided democracy: the communists and the military.

${ }^{563} / d$, Other troops seized control of the centre of Jakarta and broadcast a statement in the name of what they termed the '30th September Movement', saying that they had acted to protect the President from a coup d'état being planned by right-wing generals in the pay of the $\mathrm{CIA}$. 
Rosa Ristawati: Modelling Executive Powers in the Indonesian Constitution: A comparative Study

Soeharto. ${ }^{564}$ The new administration led by Soeharto was called the "New Order" era. Under the Constitution of UUD 1945, the Soeharto administration campaigned to implement the Constitution genuinely and consequently. The focus of the executive powers was addressed to set the achievement of political and economic stability, and further the economic development by its major broad policy objectives. ${ }^{565}$ In many issues, President Soeharto used the executive power under the Constitution as a tool to create his own political system and secured his political office. Even so, Soeharto had the same belief as Soekarno that Indonesia should have its own political system. ${ }^{566}$ With regard to the foreign affairs power, Soeharto used his power through his foreign policy which was rather different from that of Soekarno's. ${ }^{567}$ Unlike Soekarno's foreign affairs power that had already been used to raise international recognition of Indonesia's position as a state; the Soeharto's foreign affairs power aimed at promoting Indonesia in the regional forum. Not only regionally, Soeharto also expanded his foreign policy byestablishing a good diplomatic relationship with all states. ${ }^{568} \mathrm{He}$ had also a significant policy

\footnotetext{
564 It was called "SUPERSEMAR" of Surat Perintah 11 Maret, the mandate from President Soekarno to Soeharto to exercise temporary authority in Soekarno's name on 11 March 1966. Further on, Soeharto became the President replaced Soekarno in 1967.

${ }^{565}$ Colin Brown, Op. Cit., p. 200.

${ }^{566}$ Id. at p. 204, "While in political terms Suharto may have differed from Sukarno on many issues, one thing they shared was the belief that western political systems would not work in Indonesia. Suharto set out to create hisown political system, which maintained a fine balance between allowing a degree of public debate on political issues and at the same time ensuring that his government's control over political power was not threatened."

${ }^{567}$ Id. at p. 208, Sukarno's foreign policy had been activist and global in itsscope and, in the later years of guided democracy, increasingly aligned with China. Sukarno saw himself as a world figure, the leader of Southeast Asia.Suharto's foreign policy was much less visible, and regionally rather than globally directed. Suharto government ended confrontation with Malaysia. It also froze diplomatic relations with China, alleging that Beijing had supported the PKI's coup attempt. Relations with China were not normalized until August 1990. In 1967 Indonesia joined with Malaysia, Thailand, Singapore and the Philippines to form the Association of Southeast Asian Nations (ASEAN). Brunei, Burma, Cambodia, Laos and Vietnam subsquently joined the group.There is little doubt that most Indonesian politicians saw their country as the natural leader of ASEAN; nonetheless, the government went out of its way on most issues to avoid the appearance of dominating the association.

${ }^{568}$ M. C. Ricklefs, Op. Cit., p. 391: In 1989 he made a state visit to the USSR, already teetering on the brink of collapse. What he saw presumably enhanced his determination to avoid similar events in Indonesia. He also normalized Indonesia's relations with China that year. He and Chinese Premier Li Peng exchanged visits in 1990 and Jakarta received the first Palestinian ambassador to Jakarta, all steps enhancing Indonesia's standing in the Non-Aligned Movement. In September 1991 Indonesia was elected to the Movement's presidency and the following year its summit meeting was held in Jakarta.
} 
Rosa Ristawati: Modelling Executive Powers in the Indonesian Constitution: A comparative Study

to stopforeign financial aid from other states. ${ }^{569}$ During Soeharto's administration, Soeharto intervened in the independence of the Central Bank by directly steering its policy. ${ }^{570}$ Later on, the policy induced the scandal (known as "BLBI ${ }^{571}$ scandal"). ${ }^{572}$ On other fields of the political system, President Soeharto used his power to intervene in political parties by simplifying the political parties and merging the Islamic political parties into one party of PPP. ${ }^{573}$ Since then, there have only been three political parties in Indonesia, the PPP, Golkar, and PDI. This was done as an effort to consequently confirm the commitment of non-sectarianism and to genuinely implement "Pancasila", as the basic of the state. Furthermore, as he had a military background in his whole career, Soeharto was fully supported by the military (army police namely ABRI/ Angkatan Bersenjata Republik Indonesia/Republic Indonesia Armed forces). ${ }^{574}$ To

\footnotetext{
${ }^{569}$ Id. at p. 396, In early 1992 the Dutch government, which chaired the IGGIconsortium, made it clear that it thought aid to Indonesia should be linked toan improved human rights performance. Soeharto's response reflected hisestimation of his own and his nation's standing. He thereby effectively abolished the group that had channeled aid to Jakarta for 25 years.

${ }^{570}$ Kevin O'Rourke, Reformasi: The Struggle for Power in Post Soeharto Indonesia, Allen\&Unwin, 2002, p. 49, “The minister of finance, Mar'ie Muhammad visited parliament to fulfill a summons for testimony. Parliament had always been a rubber-stamp body, but occasionally it would exert its constitutional privilege to question policymakers-particularly when those policy-makers had fallen out of favor with Cendana. On this occasion Muhammad was questioned about rumors that BI had been quietly lending out large sums over the past two months-in contravention of its own tight monetary policy. In particular, parliamentarians questioned whether it was true, as they had 'heard', that BI had disbursed some Rp8 trillion (or around \$2.4 billion at prevailing exchange rates) to five large banks. Muhammad refused to answer. In a cabinet meeting on 3 September1997, Soeharto instructed the minister of finance Mar'ie Muhammad and the chief of bank central, Djiwandono to lend central bank funds to such cash-strapped banks, lest they default on their depositors.

${ }^{571}$ The BLBI was a scheme from the Indonesia Bank to give liquidity aid to 48 banks in Indonesia as a result of banks in Indonesia suffered from liquidity problems in 1998. The Scheme was given in accordance to the Indonesia-IMF agreement to overcome the economic crisis. However, the scheme was indicated as diverted and blown up as a scandal. The scandal had indicated the involvement of some state officers which led to the corruption.

${ }^{572}$ /d. at p. 60, "the instructions that Soeharto issued to $\mathrm{BI}$ on 27 Decemberwere sent by letter through State Secretary Moerdiono. The letter wasmarked confidential, but a parliamentary investigation later discoveredthat copies were leaked to certain bankers."

${ }^{573}$ Colin Brown, Op. Cit., p. 202, “In 1973, Suharto took explicit action against the four Muslim political parties then still in existence, including the long-standing Partai Sarekat Islam Indonesia and the Nahdatul Ulama. These four parties were required to amalgamate in the United Development Party, the Partai Persatuan Pembangunan (PPP), which was, however, denied the right to use Islamic symbols or even to call itself an Islamicparty: its philosophical base was to be the Pancasila with its non-sectarian commitment to belief in one supreme god."

${ }^{574}$ M.C. Ricklefs, Op. Cit., p. 372, The central pillar of the Soeharto regime was the military, known in Indonesia as ABRI (Angkatan Bersenjata Republik Indonesia, Armed forces of the Republic of Indonesia). ABRI consisted of four services: army, navy, airforce and police. Soeharto brought to the Presidency an understanding of military personnel and politics which he employed throughout his time.
} 
this extent, the simplification of the political party was also mainly to undermine potential nonmilitary opponents and control Golkar as a dominant political party which supported him. ${ }^{575}$ Moreover, his intervention to one of Golkar's party rivalswhom he assumed to be serious political challenges for his position was implicated through violence. An attack had been launched on one of political parties headquarter (the PDI's) by the Soeharto regime. ${ }^{576}$

During the administration, there were many cases of communal and religious conflicts. To overcome conflicts, Soeharto used his military power by mobilizing military forces. The executive powers during Soeharto's administration also faced challenges on particular issues of state territory and separatism. The territorial issues came from the East Timor integration. In 1975, under Soeharto's administration, there was a military operation called "Seroja operation". The military operation invaded East Timor in order to integrate East Timor under Indonesia rule. Eventually, in 1976 the loss of Fretellin as the political party that ruled in East Timor and support from the International community ended with the East Timor integration. During the invasion, it was believed that many human rights violations had occurred. Soeharto's administration was accused of responsibility for human rights violations during the Seroja military operation. Also, Soeharto used his power to deal with separatism in Aceh. Conflict against the issue of the Aceh Independence movement by GAM (Gerakan Aceh Merdeka) provoked Soeharto to mute the separatism movement. Soeharto proclaimed Aceh to be a Military Operations Area (Daerah Operasi Militer/DOM), proclaimed that part of the state (the province of Aceh) was under a state emergency, enforced the emergency/special law and gave a broad mandate to the Army. ${ }^{577}$ In economic development, Soeharto used the constitutional economic provision of Article 33 UUD 1945 to stir the economic sectors such as investment, production, taxes, mining, commercial agriculture, and other sectors. ${ }^{578}$ In many economic sectors, Soeharto used his powers widely to not only boost the Indonesia economy but also

\footnotetext{
${ }^{575}$ Id. at p. 397: "Soeharto sought tighter control of Golkar and to undermine potential non-military opponents."

${ }^{576}$ Kevin O'Rourke, Op. Cit., p. 1, "Raid PDI Headquarters" That simple command, issued by President Soeharto to his security forces in July 1996, triggered the extraordinary political power struggle that would consume Indonesia for years to come."

${ }^{577}$ Colin Brown, Op. Cit., p. 218.

${ }^{578}$ Article 33 of the UUD 1945 had been interpreted that all sectors that .... was dominated by the government.
} 
Rosa Ristawati: Modelling Executive Powers in the Indonesian Constitution: A comparative Study

abused his power to benefit his family and his cronies. ${ }^{579}$ In brief, the executive powers had been misused during the Soeharto administration. It had mostly led to some serious corruption cases in Indonesia. It weakened all the institutions under his administration. In practice, it was known that Soeharto had dominated all institutions. As the President, he controlled all state institutions and all state sectors. ${ }^{580}$ In January 1998, there was a great financial crisis followed by government collapse in Indonesia. Such a situation caused a constitutional crisis. ${ }^{581}$ Soeharto tried to maintain his position by creating a new Cabinet. ${ }^{582}$

\section{g. Executive power under the UUD 1945 (the Habibie administration) (1998 - 1999)}

The period of the Constitution of the UUD 1945 entered a new phase after the fall of the Soeharto administration. After the resignation of Soeharto, Vice President, Habibie, succeeded Soeharto as the Indonesian President. The executive power during the Habibie administration was still under the Constitution of UUD 1945 and was mainly used to support the reformation agenda in an interregnum. Unlike during the Soekarno administration and the Soeharto administration, during the Habibie administration, the executive powers were mainly used as a tool to appease the Indonesian people for a political change and new arrangements in all sectors. ${ }^{583}$ Habibie used his presidential pardoning power to grant amnesty and abolition for all

\footnotetext{
${ }^{579}$ Colin Brown, Op. Cit., p. 218-222.

${ }^{580} / d$. at p. 224: The primary reason for this was that the government, and specificallythe President, had a major hand in deciding who would sit in Parliament, both through the control of the electoral process and through the President's right to nominate half the members of the Upper House and, with the military, 20 per cent of the members of the Lower House. The press was no independent watchdog over government either."

${ }^{581}$ M.C., Ricklefs, Op. Cit., p. 405, "In January 1998 Soeharto announced an absurd budget which depended upon the plummeting Rupiah having the value it had six months before. He received phone calls from Bill Clinton in Washington, Helmut Kohl in Bonn and Hashimoto Ryutaro in Tokyo, and a visit from Singapore's Goh Chok Tong, all urging him to accept IMF reform proposals. On 15 January he seemed to do so, but in fact more conflict followed, with the IMF eventually threatening to withhold loans unless Soeharto adopted realistic reforms."

${ }^{582}$ Id. at p. 407, "He then announced that he would oversee a period of reform and step down after fresh elections were held. But no proposal which kept him asPresident was credible either domestically or overseas. His attempt to createa reform cabinet collapsed on 20 May when 14 ministers with responsibilityfor economic and financial affairs refused to serve under him."

${ }^{583}$ Colin Brown, Op. Cit., p. 231, "In taking on the Presidency Habibie was confronted with a Herculean task: to keep one step ahead of the reformist movement which had led the charge against Suharto, his former boss and political sponsor, and which was now demanding radical changes in the way in which Indonesia was run. For a while, against all the odds, it seemed that he might just be able to pull it off. His first few months as President saw the implementation of a raft of important policy initiatives, including the freeing of political prisoners, the almost complete removal of political censorship of the press, the lifting of restrictions on the formation of political parties
} 
Rosa Ristawati: Modelling Executive Powers in the Indonesian Constitution: A comparative Study

political prisoners prosecuted during Soeharto's administration. ${ }^{584}$ In all sectors, though Habibie was not really successful, Habibie used his presidential power to appease public demands to redress the state stability that was shattered by corruption, improve law enforcement, and reveal human rights violations during Soeharto's administration. Habibie used his power to terminate the state of emergency in Aceh including the abolishment of the application of the military operation and the emergency law that had been applied during the Soehartoadministration. ${ }^{585}$ One of the remarkable issues during Habibie's administration was the decision for a referendum to decide the East Timor independence or integration. However, there were also some human rights violation issues in which Habibie was strongly presumed to be a person who was responsible for the violations during the referendum in East Timor. This was because he was the president at that period, and constitutionally, he was the Commander in chief mobilizing the Indonesian military action with such terror, violence, and actions of the troops under the Indonesian military. On the basis that he was the Commander in chief, fingers were pointed that he knew all the actions addressed to undermine the referendum. With regard to the military relationship, Habibie fully relied on mutual dependence with the military forces. ${ }^{586}$ During Habibie's administration also, the ABRI (as the military forces in Indonesia) was

and trade unions and, the most important developments of all, planning for the holding of free general elections, which took place on 7 June 1999, and for a referendum on independence in East Timor, held on 30 August 1999."

${ }^{584}$ M.C. Ricklefs, Op. Cit., p. 414, "'Habibie began releasing political prisoners within weeks of becoming President, a vital step in the direction of both openness and reconciliation. Among them were regional separatists and elderly ex-PKI figures held for over thirty years. Amnesties were granted to H. Mohammad Sanusi and others arrested after the Tanjung Priok incident of 1984, including (post-humously) Hartono Dharsono."

${ }^{585}$ Steven Drakeley, Op. Cit., p. 171, Habibie ended the Military Operations Area (DOM) in Aceh and ordered the withdrawal of combat units, signaling his intention to pursue dialogue and reform in order to redress Acehnese grievances. But the most he was prepared to offer was autonomy within the parameters of his proposed national decentralization measures.

${ }^{586}$ Marcus Mietzner, The Politics of Military Reform in Post-Suharto Indonesia: Elite Conflict, Nationalism, and Institutional Resistance, the East-West Center, Washington, 2006, p. 10-11, "The new president relied on support from the armed forces to stabilize his rule, fend off societal challenges to his legitimacy, and prevent individual officers from undermining the reformist policies of his administration. The armed forces, on the other hand, needed the good will of the president, given his constitutional powers to appoint senior military leaders, distribute resources, and set the political agenda.This mutual dependence produced important policy compromises as far as military reform was concerned. Most important, the military was granted the right to formulate its own reform agenda. In return, however, the armed forces had to pledge their support for Habibie and refrain from interfering with the process of political reform. This trade-off was reflected in a number of political events throughout the 
separated from the Police.Under the appointment power, Habibie established his cabinet and tried to dismiss Soeharto's cronies. ${ }^{587}$

\section{h. Abdulrahman Wahid administration (1999-2001)}

After one year of his administration, Habibie's administration conducted a presidential election. The result of the election was Abdulrahman Wahid administration with his vice president, Megawati. Still under the Constitution of UUD 1945, Wahid used his presidential power to fulfill his promise of establishing ministries on behalf of political pluralism and political ally. With regard to the foreign affairs power, Wahid had a controversial vision to use his power to make commercial relations with Israel, which raised criticism from many Indonesian Islamic activists. ${ }^{588}$ On the issue of Aceh, Wahid used his power to open peace negotiations with the Aceh Independence movement (GAM). However, the situation in Aceh was even worse since the GAM proclaimed its independence on 4 December 2000 on the $24^{\text {th }}$ GAM's anniversary. Wahid persuaded Aceh about the referendum; however, the referendum was defined differently from Habibie's referendum on East Timor. Wahid proposed a referendum for Aceh to use the Shariah Islam (Islamic law) applied in Aceh and gavespecial autonomy to the administration of Aceh as a special province under Indonesia. The initiative for a peaceful dialogue with GAM was taken by Wahid in Geneva on 12 May 2000. The dialogue had generated an agreement that aimed to arrange a temporary halt to hostilities to allow the two parties some breathing space in which to seek some more permanent resolution of their dispute. Further on, Wahid allowed the enforcement of Shariah Islam in Aceh. Other crucial

second half of 1998. First, Habibie demanded in July 1998 that Wiranto assist in the election of his candidate for the chairmanship of Golkar, the former government party of the New Order."

${ }^{587}$ Michael Malley, "the $7^{\text {th }}$ Development Cabinet: Loyal to a Fault?, Indonesia", No. 65 (April, 1998), pp. $155-178$, Southeast Asia Program Publications at Cornell University, accessed: 02/11/2012, p.177, B. J. Habibie announced the formation of the Development and Reform Cabinet on May 22, just a day after he acceded to the presidency. The composition of the new cabinet reflects Habibie's own interests less than the exigencies of Soeharto's rapid exit. Major changes to the cabinet include: the replacement of ministers most closely linked to Suharto, including Bob Hasan, Tutut, Fuad Bawazier, and Subiakto Tjakwerdaya; the first appointment of non-Golkar political party members since the 1970s; removal of the central bank governor from the cabinet to enhance Bank Indonesia's independence; and the recreation of the two state minister portfolios Soeharto had entrusted to coordinating ministers. Of the thirty-seven officials with cabinet rank, sixteen were not members of Soeharto's last cabinet. Despite these changes, the views of cabinet ministers matter less to Indonesian politics now than under Soeharto, since the momentum for political changes comes almost entirely from outside the government.

${ }^{588}$ Muhaimin Iskandar, Gus Dur yang Saya Kenal: Catatan Transisi Demokrasi Kita, LKis, Yogyakarta, 2004, p. 14-18 
Rosa Ristawati: Modelling Executive Powers in the Indonesian Constitution: A comparative Study

issues during Wahid's administration were the separatism movement in Irian Jaya (the OPM) and some multi ethnic-religious conflicts in Maluku, Sulawesi, and Kalimantan. For these reasons, during his administration, Wahid had enforced a state of emergency in some of the affected provinces. As one of the reform agenda was eradicating corruption, Wahid had dedicated his executive power to make efforts on the corruption eradication progress. ${ }^{589}$

Ironically, in July, 23 2001, alleged corruption in the financial scandal of the Sultan Brunei Darussalam funds for Aceh, and his weaknesses in leading his cabinet, the MPR brought him down. Wahid refused to fulfill his obligation to deliver his accountability speech before theMPR. ${ }^{590}$ Wahid resisted and issued a presidential decree to freeze the MPR. ${ }^{591}$ However, it had been ignored and the MPR came to the decision of Wahid's impeachment. ${ }^{592}$

During his administration, Wahid faced challenges from the DPR while performing his presidential power. ${ }^{593}$ Not only often troubled with his policy in which he was always confronted by the DPR, Wahid was also troubled by the army. It was because Wahid came as a civilian to lead the military. ${ }^{594}$ Wahid even used his power to try to reduce the military influence within his office by appointing a non-military minister of defense (Matori Abdul Djalil) and tried

\footnotetext{
${ }^{589}$ Kevin O'Rourke, Op. Cit., p. 363:"The president established various anti-corruption commissions, sacked the Wiranto-era police chief and appointed credible figures to head the state oil and power monopolies, but these were only piecemeal steps. Wahid never presented a coherent strategy for comprehensive legal system reform which was a requisite for a sustainable economic recovery."

${ }^{590}$ Id. at p. 407, "When the MPR convened on Monday morning to hear his speech of accountability, he failed to appear. Wahid's absence simplified the MPR's task. In the afternoon, the assembly convened to vote on a measure that would reject the undelivered accountability speech; revoke Wahid's mandate; and install Vice-President Megawati as president, effective at once."

${ }^{591}$ Steven Drakeley, The History of Indonesia, Westport, Conn: Greenwood Press, 2005, p.159, "Ironically also in his last months and weeks, Wahid explored a number of desperate and undemocratic measures to cling to power such as suspending parliament and declaring a state of emergency with army support (which the army refused to give)." ${ }^{592}$ M.C. Ricklefs, Op. Cit., p. 421, "He attempted to suspend the nation's parliamentary institutions by decree to prevent this outcome, but no one paid any attention. The MPRgathered in a special session, removed Abdurrahman and installed MegawatiSukarnoputri as the nation's fifth President, to serve until the next generalelections scheduled for 2004".

${ }^{593}$ Steven Drakeley, Op. Cit., p. 156, "Wahid could rely on only around 10 percent of the votes in parliament and so experienced great difficulty securing parliamentary approval of his program. These problems were not solely a natural consequence of the balance of power within DPR."

${ }^{594}$ Id. at p. 157, "the biggest problem for Wahid was the army. It had begun the post-Soeharto era internally divided and unsure how much reform of itself and of the Indonesian political system it should allow. It was also rattled by the abrupt exposure of its unpopularity and consequently had difficulty gauging just how far it needed to retreat. By the time Wahid became president, however, the army had regained much of its composure and coherence."
} 
to make a radical reform within the military institution. ${ }^{595}$ On other issues of economics, Wahid used his power to intervene in state enterprises. ${ }^{596}$

\subsection{Executive powers under $1^{\text {st }}, 2^{\text {nd }}$ and $3^{\text {rd }}$ Amendment of the UUD 1945}

\section{Executive power under the UUD 1945: Megawati administration (2001 - 2004)}

Weatherbee characterizes the Megawati administration as merely about policy drift and bureaucratic stasis and only focused on personal political power and status that was confirmed by greatness ceremony. ${ }^{597}$ One important agenda in the Megawati administration was the continuation of the fourth Constitutional amendment process. The exercise of the executive powers during Megawati's administration was mostly for continuing and accelerating the reforms agenda and retaining her power and position as the Indonesian president. Megawati established her Cabinet mainly supposed to be different from the Cabinet during previous administrations and with more professional and competent characters. ${ }^{598}$ However, under her leadership, the cabinet was lacking coordination. ${ }^{599}$ On the other hand, Megawati was able to gain support from the military. ${ }^{600}$

\footnotetext{
${ }^{595}$ Marcus Mietzner, Op. Cit., p. 20: "In the first months of his administration, Wahid "took a series of measures to exert civilian control over the military and rein in the Army". Compensating key army officers like Wiranto, Yudhoyono, and Gumelar with cabinet posts, Wahid removed them from command positions and elegantly ended their military careers. He also appointed a widely respected civilian academic as minister of defense (the first since the early 1950s), disbanded amilitary-coordinated security agency notorious for its political surveillance activities, and abolished the socio-political offices at the Ministry of the Interior, a traditional military stronghold. Wahid, it appeared, was determined to initiate a radical process of military reform and enforce civilian supremacy over the political realm. The replacement of several army generals who had risen to prominence under Suharto's rule aimed at the very break with the New Order military that Habibie had not achieved. Wahid had identified Wiranto as the major obstacle to further military reform and consequently moved to destroy the latter's patronage network spread throughout the TNI hierarchy. In this context, he asked his personal confidant, Matori Abdul Djalil, the chairman of the NU-affiliated PKB (Partai Kebangkitan Bangsa, National Awakening Party), to come up with a list of military officers who could be expected to take the lead in revamping TNI's institutional structures."

${ }^{596}$ Id. at p. 27, Wahid intervened in legal proceedings and in the internal affairs of state enterprises, apparently in order to promote the political and economic interests of his major financial patrons. Moreover, he appeared increasingly erratic, threatening to arrest his political adversaries and producing headlines with controversial statements and policies on an almost daily basis.

${ }^{597}$ Donald E. Weatherbee, "Indonesia: Political Drift and State Decay", The Brown Journal of World Affairs, Spring 2002, Vol. IX, Issue 1, p. 25

${ }^{598}$ Steven Drakeley, Op. Cit., p. 161:"Weighted toward competent and respected reform-oriented technocrats rather than "political" appointments, it seemed to be a cabinet that would not be held hostage to the special interest groups that had hindered progress during the Habibie and Wahid administrations."

${ }^{599}$ Id. at p. 162:"Megawati lacked genuine commitment to reform seemed borne out by the experiences of the reform-minded cabinet ministers as they battled to effect change without the political backing needed to
} 
Rosa Ristawati: Modelling Executive Powers in the Indonesian Constitution: A comparative Study

As for appointments, Megawati used her power to appoint a state attorney general whose main duties were to deal with corruption issues, though it raised cynical views. ${ }^{601}$ During her administration, Megawati continued the agenda to deal with the issue of Aceh. She facilitated the peace agreement; however, the agreement collapsed and later on, she used her emergency powers to declare an Aceh emergency and enforced the emergency law in the territory. $^{602}$

\subsection{A democratic era of executive powers under the Amended Constitution: the President SBY administration (the 1st, 2004 - 2009 and the 2nd term office, 2009-2014)}

President Susilo Bambang Yudoyono (SBY) was the first President who was directly elected by the people and the first incumbent President who took office for two periods according to the limitation of the presidential term in the Amended Constitution. His first term in office was $2004-2009$ and his second term was 2009 - 2014. During both terms in office,

overcome resistance. Criticisms were also made of the lack of coordination among the various ministries and the lack of drive and leadership emanating from the top. While vice president, Megawati had remained glumly silent and inactive, keeping her political distance from Wahid lest she be tarnished by his failings. As president, she finally had the opportunity to pursue the noble political objectives she always intimated she had. It soon became apparent, however, that what many had long suspected was indeed the case. Her political silence and quietude had not been "Javanese" reticence hinting at strength and purity of purpose and unsuspected abilities. Instead, Megawati's "stillness" had merely obscured herweaknesses."

${ }^{600} / d$. at p. 163: "Unlike Wahid, she was not inclined to pursue the difficult issue of reforming the army and recasting the army-civilian relationship. In exchange for unobtrusive political support, her administration was content to allow the army to run its "own" affairs. Megawati was (in practice) also in broad sympathy with the army's hard-line attitude toward separatists. As expected, therefore, Megawati did not experience the lack of cooperation that Wahid had from the army in dealing with security problems."

${ }^{601}$ Id. at p. 161: "Megawati appointed M. A. Rachman, a senior career bureaucrat from within the department. More cynical political observers concluded that Megawati wanted somebody who could be relied upon to pursue only those prosecutions for corruption and humanrights abuses that met with her approval. According to this view, Rachman's appointment would mean that those members of the elite closely associated with PDI-P, Megawati, and her businessman- politician husband, Taufik Kiemas, would be immune from prosecution. It would also mean that other powerful and wealthy individuals could avoid justice unless it suited Megawati's administration to prevent them from doing so."

${ }^{602}$ Marcus Mietzner, Op. Cit., p. 39:“throughout 2002 and early 2003, Megawati allowed her coordinating minister for political and security affairs, Susilo Bambang Yudhoyono, to seek a peaceful settlement of the Aceh problem through negotiations. The efforts resulted in a "cessation of hostilities agreement" in December 2002, but most civilian politicians and the armed forces were unwilling to endorse it. The military was widely suspected of sabotaging the peace deal by engineering attacks on monitors of the cease-fire, and in May 2003 the agreement collapsed. Unanimously supported by Parliament and the vast majority of the public, Megawati declared martial law and launched one of the largest military campaigns in Indonesian history." 
Rosa Ristawati: Modelling Executive Powers in the Indonesian Constitution: A comparative Study

President SBY employed executive powers under the Amended Constitution which will be discussed in the following chapter. However, in general, the character of the executive powers during the SBY'S administration was relatively weak. It was not only because of the vagueness and ambiguity of the Amended Constitution but also because President SBY's administration was backed by weak coalition parties in the government. For example on the appointment of ministers, President SBY was restricted by the grand coalition parties which made it difficult for the President to exercise his prerogative right in nominating and appointing the ministers. ${ }^{603}$ The situation was more like there were political compromises on the Cabinet appointment and the President had to accommodate the different interests of each party in the coalition government. ${ }^{604}$ While in general, President SBY was much more active inforeign affairs to raise the role of Indonesia internationally. ${ }^{605}$ However, during the second term of his administration, President SBY had to deal with controversies such as Bank Century and the institutional scandals concerning the KPK (anti-corruption commission) and the National Police. ${ }^{606}$

\footnotetext{
${ }^{603}$ See: Aly Yusuf, "Evaluasi Pemerintahan SBY - KALLA, Policy Assessment", Juni 2005, The Indonesian Institute, www.theindonesianinstitute.com , p. $6-10$ : "There was great intervention from the political parties in the "grand coalition" supported SBY in the 2004 election. In general the Cabinet formation during the SBY's administration much more reflected the coalition of parties in the 2014 election rather than the meritocracy and profesionalists." ${ }^{604}$ Hanta Yuda AR, "Evaluating the First Year of the SBY Administration's Performance", The Indonesian Update, Volume V, No. 7, the Indonesian Institute, 2010, p. 6: On one side, the loyalty is to the President, but on the other side, they remain loyal to the parties. In situation like this, the performance of the cabinet is being hostage by the interest of the coalition parties. The government is also being held hostage by transactional coalition through the Secretariat of the Joint Coalition Parties.

${ }^{605}$ See: Marcus Mietzner, SBY's mixed legacy, www.indoupdate.com :President SBY put Indonesia back on the map of regional and global powers by leading ASEAN and admiting to the G20.

${ }^{606}$ See more about the scandal of the Bank Century and the institutional controversies between the KPK and the National Police on Christian von Luebke, the Politic of Reform: Political Scandals, Elite Resistance, and Presidential Leadership in Indonesia, Journal of Current Southeast Asian Affairs 1/2010, 79-94, www.CurrentSoutheastAsianAffairs.org.
} 
Rosa Ristawati: Modelling Executive Powers in the Indonesian Constitution: A comparative Study

Figure 1. The period of the Indonesian executive powers according to the enactment of the Constitution

\section{The Indonesian Executive powers in period}

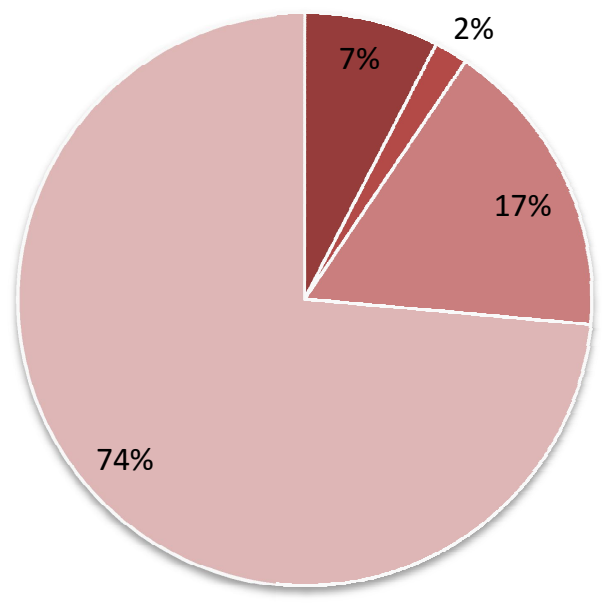

- Under the UUD 1945 Constitution (1945 - 1949)

- Under the KRIS 1949 Constitution (1949 - 1950)

- Under the Temporary 1950

Constitution (1950 - 1959)

- Under the UUD 1945 Constitution (After the Presidential Decree 1950 (1959 - 1999)

Notes:

1. Under the UUD 1945 Constitution (1945 - 1949); the system of government was a presidential system; the executive power was in the hands of the President. The President was granted broad powers not only executive powers but also other powers that should be held by other branches (the MPR, the DPR, and the DPA). The characters of the executive powers in this period were dominant, stronger than any other powers, unchecked, revolutionary. The President used the executive powers to mainly raise the International awareness over the existence of Indonesia as a state. The foreign affairs power in particular the diplomacy powers were often used by the President.

2. Under the KRIS 1949 Constitution (1950), the system of government was a parliamentary system; the executive power was shared by the President and the Prime Minister

3. Under the 1950 Temporary Constitution (1950 - 1959), the system of government was a presidential system, the executive power was in the hands of the President; however, there was a prime minister. But since the President introduced guided democracy, the prime minister was also under the control of the President. In this period, the emergency power was often used by the President in order to struggle and survive from not only the external but also the internal threats. 
Rosa Ristawati: Modelling Executive Powers in the Indonesian Constitution: A comparative Study

4. Under the UUD 1945 Constitution (after the Presidential Decree 1959), the system of government was a presidential system, the executive power was in the hands of the President. The characteristics of the executive powers can be not only viewed according to the constitutional text but also reflected from the state practices during each different presidential office. As originally the same as the first UUD 1945 Constitution, the text gave strong and broad executive powers to the President. However, the practices shown many unconstitutional power's performances. The President used the constitutional provision to abuse and to manipulate the powers.

Figure 2. The executive powers in historical timeline of the Presidential office

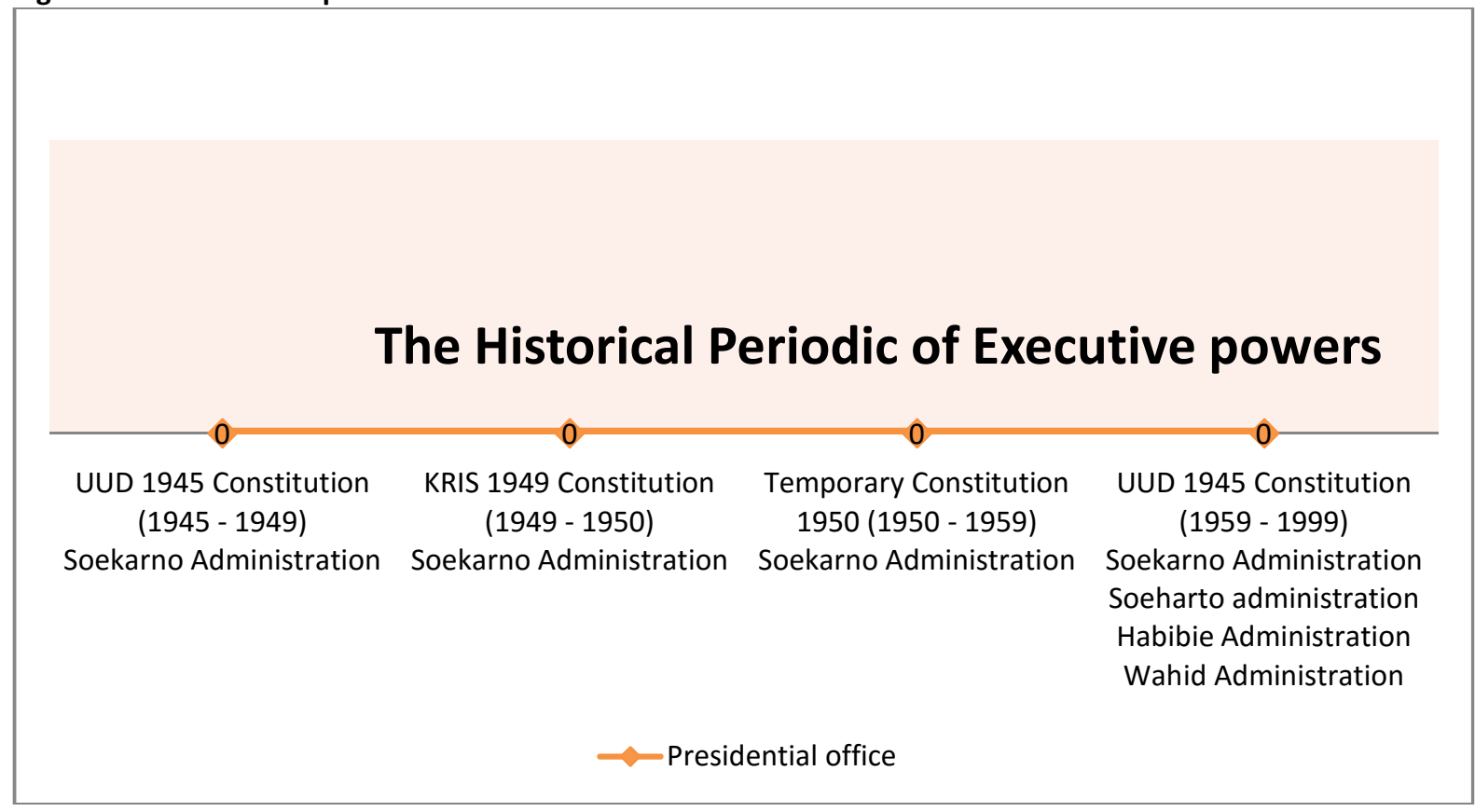

\subsection{Closing remarks}

The period of 1945-1949 was the period when Indonesia struggled against the formal institutional colonization. The executive powers during this period were constitutionally exercised by the President. The characteristics of the power were much more revolutionary with the main purpose to bring radical changes in politics, social, and economics. The powers were mostly attributed by the Constitution but had been unconstitutionally applied. Textually, according to the Constitution, the executive powers originally belonged to the MPR and the MPR would give the mandate and delegate powers to the President. This was because under the Constitution, the President was under, and responsible and accountable to the MPR. In this 
Rosa Ristawati: Modelling Executive Powers in the Indonesian Constitution: A comparative Study

context, the Constitution intended that the power of the executive was controlled by the MPR. Moreover, according to the Constitution, the MPR had the power to set the Guidelines of the State Policy (GBHN - Garis-Garis Besar Haluan Negara). It had the meaning that the exercise of the executive powers by the President was indeed under the MPR's authorization. In consequence, at the end of the Presidential office, the Constitution required the President to deliver an accountability speech about his responsibility for the exercise of executive powers during his office. However, in practice, what constituted the Constitutional text was not reflected in practice. It was not only because of many unconstitutional events but also because most of the state institutional organs including the MPR had not yet been established. In addition, the transitional provisions of the Constitution which was drafted just after Indonesia's unilateral declaration of independence, vested the MPR's, DPR's, and Advisory body's power to the President. It granted the President with multiple powers including extraordinary powers to enact the Constitution and GBHN/ the Guidelines of the State Policy, to make Laws and make any recommendations, and to establish a National Committee which would have the role to assist the President. Thus, during the period, the exercise of the executive powers reflected a hyperactive presidency since the President could act beyond the Constitution. The executive powers of the President in this period played out as a dominant power since the President had both executive and legislative powers. The first Indonesian President, Soekarno, appeared to have participated in all major governmental decisions, including the promulgation of any laws or decrees, which required signature from either the President or the Vice President and it was Soekarno's position that the signature was no mere formality but an indication of a presidential approval which he had the right to withhold when he disagreed. ${ }^{607}$ During this period, Indonesia also experienced many independent and unilateral executive powers of the President. It was noted that more than 3 times, the President had unilaterally exercised emergency powers on the grounds of state emergency. ${ }^{608}$ In general, theexecutive powers were

\footnotetext{
${ }^{607}$ Id. at p. 43.

${ }^{608}$ Id. at p. 47, from 29 June 1946 to 3 October 1946 as consequence of the prime minister, Sutan Sjahrir's abduction; from 27 June 1947 to 3 July 1947 as consequence of the crucial political situation because of the deadlock of the Indonesia- Netherlands negotiation; 15 September 1948 to 15 December 1948 as a consequence
} 
mostly for revolutionary purposes. Since the Constitution was enacted right after Indonesia's unilateral declaration of independence in 1945, the power of the executive was mainly used not only to support Indonesia externally as a state, to bring Indonesia in to the International community and raise international awareness, but also internally to restore security and maintain the sovereignty and the territory. For such purposes, the first Indonesian President had frequently used both his diplomacy powers and military powers. On other areas, the emergency powers were mainly used to deal with external threats, threats from other states, and to confront internal separatist movements that threatened state sovereignty, legitimate government, and territory.However, not more than 3 months after the enactment of the Constitution, the system of government practically shifted from a presidential system to a parliamentary system. Since then, the executive powers were shifted from the President to the Prime Minister, even though the position of the prime minister was not recognized by the Constitution. The introduction of a parliamentary system and a prime minister by practicesignificantly influenced the executive power. The executive powers were shifted from the President to the prime minister, while the President was mainly the head of state. To conclude, the Indonesian executive powers under the first Indonesian Constitution were really exercised beyond the Constitution. The executive powers grew as dominant and unilateral powers without checks and balances. Neither the Legislature nor the Courts could question and challenge the use of the executive powers during the period of $1945-1949$.

During the period of 1949 to 1950, Indonesia struggled with the aftermath of the influence of the Dutch government. Though Indonesia's independence had been recognized, Indonesia was still under Dutch colonization. One major political issue that Indonesia had to deal with was the Dutch idea on Indonesianfederalism. The Federal Constitution, the KRIS, was drafted with parliamentary characters. The Constitution determined that the executive power

of the power struggle in Madiun. It was stated that the first and the second of the unilateral presidential power was exercised by the Presidential Decree (Maklumat President) which stated that the President take over the full and unilateral power of the government temporary. The third unilateral presidential power had given to the President through Law that made by the Cabinet with the approval from the working committee of KNIP. It legally gave the President the full and unilateral power to take any measures and actions and to set the Laws that may deviate from the existing law. 
was vested in the President and the Prime Minister. As the Constitution had parliamentary characteristics, the President only had nominal formal executive power while the real executive power remained with the Prime Minister. However, the use of executive powers was not really significantly remarkable since the Constitution was only enforced forless than 1 year.

During the next period, Indonesia was under the Temporary Constitution of 1950. During the temporary Constitution, the system of the government was actually a parliamentary democracy. The Constitution not only recognized a Prime Minister but also reintroduced a Vice President. Thus, the Constitution implied that the government consisted of the President (as the head of the state), the Vice President (assisted the President), the Prime Minister and the Ministers. Under the Temporary Constitution 1950, the executive power still had to struggle with anti-colonization and anti-imperialism. It still, on the other hand, struggled with Indonesian foreign policy in order to deal with challenges of International awareness; in particular the Indonesian position as a State in International Communities. In this period, the role of the President was still dominant. The use of the executive powers in this period was mostly addressed to deal with political instability and economic crises. It had also dealt with the effort to restore security within the state and the struggle for the state territory. However, although the power of the President was not really strong since he only had nominal/ formal powers rather than substantive powers, the President still played a dominant executive figure among others. One of the remarkable uses of the power was the use of emergency power. The President issued a Presidential Decree to order some fundamental points including the dissolution of the Constitutional Assembly and the re-enactment of the first 1945 Indonesian Constitution.

In the following period, the executive branch was under the re-instated first Indonesian Constitution (UUD 1945). During the period, in most regimes of administration (the Soekarno administration, the Soeharto administration, the Habibie administration, the Wahid administration, and the Megawati administration), the executive powers were used mostly to strengthen the political position of the President. Although the Constitution stipulated that the President was under the MPR and was responsible and accountable to it, the President was 
extremely dominant with the position at the top of a steep hierarchy. In all particular areas the ministers as leaders in their area of planning, really depended on their relationship with the President. During Soeharto's administration, the executive powers had been used with widediscretion. However, the use of the executive powers during the period of the re-instatement of the First Indonesian Constitution (UUD 1945) varied according to different presidential regimes. Although the Constitution required the President to be responsible and accountable to the MPR, the practice during each presidential office showed different experiences. On the appointment power, each President had his own discretion to establish and appoint the Cabinet. In terms of foreign affairs, each President had specific focuses.In general, the characteristicsof the executive powers under the UUD 1945 were strong. In some cases, the President was granted full power with limited checks and balances from other institutions. There was no significant control of the executive powers. The mechanism of checks and balances did not really work. Most of the Presidents within their offices enjoyed wide executive powers and employed them frequently. The executive powers were mostly used to secure theiroffice position. Lastly, the first and the second regimes of SBY'S administrations may be now counted in the historical path. However, since the regimes were under the Amended Constitution, the regimes may represent a perfect picture to describe the Indonesian executive powers under the Amended Constitution. 


\section{Chapter 4}

\section{Indonesian Executive Power under the Amended Constitution}

This chapter analyses how the executive power in Indonesia is organised under the Amended Constitution. This chapter will build a perspective on how the executive power in Indonesia has been changed and evolved as the Constitution has been amended four times after the fall of the authoritarian regime and during the rise of the democratic system in Indonesia.

\subsection{The Amendment of the Constitution: a Spirit of Constraining the Presidential Power in a Constitutional Framework}

The Indonesian Constitution has been changed by a series of constitutional amendments. It has been amended four times (1999, 2000, 2001, and 2002) during the transition period of the state reformation and after the 1998 fall of the authoritarian regimes of the new period (orde baru). The period was marked by the end of the President Soeharto's administration and the beginning ofa more democratic regime of the so-called "reformasi" in 1999. After the new government had been installed, the agenda of the amended constitution was proposed on the basis of the purpose to weaken the President and limit executive powers. The aims of the amendment process were mainly:

- to curb and reduce Presidential power through the distribution of powers, vertically and horizontally

- to change the power from centralization to decentralization

- to increase the role of the DPR to oversee the executive power

- to change the structure of the MPR from a unicameral system to a bicameral system

- to restore sovereignty to the people through direct elections

- $\quad$ to establish the separation of power with a check and balances mechanism within the three branches of government

- to rearrange the judicial system and rule of law

- to guarantee human rights, state obligations and limitation of power in order to prevent the abuse of power. $^{609}$

\footnotetext{
${ }^{609}$ Mulyosudarmo, Soewoto, Pembaharuan Ketatanegaraan Melalui Perubahan Konstitusi, Asosiasi Pengajar HTNHAM Jatim-Intrans, Malang, 2004, pp. 40.
} 
Rosa Ristawati: Modelling Executive Powers in the Indonesian Constitution: A comparative Study

There were some basic weaknesses in the previous 1945 Constitution. It generated some misconceptions of the principles and norms. More importantly, in practice, the provisions had been abused and misused by the President in the "Orde Baru" administration. Most of the provisions had been used to strengthen the political position of the President. Throughout the transitional period, the process of the Amendment of the Constitution was expected to facilitate the transformation regime from authoritarian to a more democratic system. The Amended Constitution was mainly focussed on setting the mechanism of checks and balances, specifically to strengten the check over the executive power of the President, reduce, and limit the power of the President. According to Blair Andrew King, the Indonesian Amendment of Constitution was the best answer for the institutional presidency conflicts because the President acted as the most powerful branch without any control from other branches. ${ }^{610}$ The other arguments supporting the Constitutional amendment were based on the experience that the 1945 Constitution had given extraordinary emergency powers to the First Indonesian President. $^{611}$

Under the 1945 Constitution (before the Amended Constitution), the Indonesian presidency was applied in combination with some parliamentary elements. The President was not directly elected by the people but was appointed by the MPR (the Peoples Representative Assembly). To be appointed, the President of Indonesia must, in effect have a majority vote in parliament and must keep that majority to stay in office. Therefore, the MPR could directly dissolve the government, as parliaments could under a Westminster or parliamentary

\footnotetext{
${ }^{610}$ Blair Andrew King, Empowering the Presidency: Interest and Perceptions in Indonesia's Constitutional Reforms 1999-2002, Dissertation in Political Science, the Ohio State University, 2004, pp. 14: .."Philosophically, it was inspired by organic statism, one of the foundations of European Fascism; institutionally, it has been claimed to emulate the organs of the colonial Netherlands East Indies, the wartime Japanese fascist system, and the Chinese Nationalist government; as for a legal document, the constitution was vague and incomplete; in which, it was underspecified regarding many important political structures and the rules that govern them. Too many of its key clauses ended with an injunction for further specification in laws, opening the door to subsequent manipulation, and it lacked guarantees of basic civil and political rights. It also has a checkered history.

${ }^{611}$ Edward Schneier, The Role of Constitution-Building Processes in Democratization: Case Study Indonesia, International IDEA Democracy- building and Conflict Management (DCM), Sweden, 2005, pp. 8 (accessed at http://www.idea.int/conflict, 21/10/2011).
} 
system. ${ }^{612}$ The president was responsible to the MPR, but could not be deposed by the DPR (the legislative). ${ }^{613}$ The Constitution did not really give a good framework of checks and balances for the executive power. The provisions were too easily manipulated by the President. There were many loopholes to extensively expand the executive powers. The Constitution gave the opportunity to the president to constitutionally dominate the executive, legislative, and judicial powers in the government system. ${ }^{614}$ With an extensive interpretation, the President retained broader powers and had the power strengthened day by day. For example, in the emergency powers, the President enjoyed the power to declare a state of emergency and take any actions or even take any extra-constitutional actions (such as military action; whether it was constitutional or unconstitutional, whether it was legal or illegal) to overcome the situation without any checks. On the legislative power, Article 5 of the UUD 1945 (before the Amended Constitution) was the constitutional basis for the President to take control of the legislative process. The President was given the power to make legislation; while the DPR only formalized it. On the pardoning power, Article 14 of the 1945 Constitution gave the President unlimited power to grant pardon, amnesty, and abolition. Moreover, Article 33 of the 1945 Constitution had been misused in practice by the President, his cronies, family and the President's affiliated allies getting benefit by taking control of significant political patronage resources. ${ }^{615}$ In the lawmaking area, the Constitution granted the president the power to make government regulations in lieu of a law (the emergency law) and the presidential decision that had been usedby the President mostly to benefit his family and cronies. ${ }^{616}$ Indeed, the law-making power

\footnotetext{
${ }^{612}$ Stephen Sherlock, "Indonesia's New Government: Stability at Last?", Department of the Parliamentary Library: Current Issues Brief No. 4 2001-02, Australia, pp. 7 (accessed at: http://www.aph.gov.au/library on 23/10/2011).

${ }^{613}$ ICG International Crisis Group, "Indonesia's Presidential Crisis", ICG Asia Briefing Paper, Jakarta-Brussels, 21 February 2011, pp. 5: "The unusual system of the Indonesian presidential system before its amendment is in that the majority of the members of the MPR are also members of the DPR. While the latter cannot, in their capacity as members of the DPR vote the president out of office, their votes, in their capacity as members of the MPR, would be decisive if an attempt were made to impeach the president".

${ }^{614}$ Christopher Candland and Sity Nurjanah, "Indonesia after Wahid: the New Authoritarianism, The Royal Institute of International Affairs", Briefing Paper No. 28, December 2011, pp. 1: "From 1966, with the imposition of General Suharto's "new era", the president organized elections to the legislature so that he would be continuously reelected".

${ }^{615}$ See in Appendix 1: Article 33 of the UUD 1945 (the Constitution before it was amended).

${ }^{616}$ Blair Andrew King, Op. Cit., pp. 72.
} 
had empowered the president to legalize and justify all actions within both his official capacity and private capacity.

The explanatory draft of the 1945 Constitution emphasized that the president had the power and responsibility to conduct government affairs as the highest chief of government. ${ }^{617}$ As the head of the government, the President had a prerogative power to establish a cabinet. ${ }^{618}$ In practice, President Soeharto did fill his cabinet with his allies asministersand appointed ministers on the basis of personal relationship. This situation had been practised for almost 32 years and had been used to direct government policies that were mostly profitable to the President's allies, family and cronies. The president had full control over the cabinet and manipulated the government policies to strengthen his powers. Only one command from the president was needed to determine the government policy.

A series of amendments to the Constitution were focussed on changing provisions related to the executive branch, the President. Under the First Amended Constitution (1999), the executive powers in Indonesia were reduced in many ways. The First Amended Constitution still vested the executive powers in the hands of the President. According to Chapter III, Article 4, Section 1 of the First Amended Constitution, the President of the Republic of Indonesia should hold the power of government inaccordance with the Constitution. The provision set a constitutional basis that the executive power is vested in a single executive, the President, and reflects that there is no form of collective leadership within the state. Moreover, unlike before the First Amended Constitution which gave the president a broader sense of power without check by other branches ${ }^{619}$, the First Amended Constitution set sufficient constitutional control over the executive power by other branches.

\footnotetext{
${ }^{617}$ Annotation IV the UUD 1945 Constitution (Appendix 1).

${ }^{618}$ Annotation of the UUD 1945 Constitution, it stipulated that: "Although the positions of the Ministers of State depend upon the President, they are no ordinary senior officials since in practice it is primarily these ministers who exercise executive power (pouvoir executief). As head of a department, a minister knows all the matters related to his/her work domain. Hence a minister has great influence upon the President in deciding policy regarding his/her ministry. In fact, this means that these ministers are leaders of the state. In determining the government's policies and for the purpose of coordination in the administration of the state, ministers work in close cooperation with one another under the President.

${ }^{619}$ Deny Indrayana, Indonesian Constitutional Reform 1999-2002: an Evaluation of Constitution- Making in Transition, PhD Dissertation Centre for Comparative Constitutional Studies and the Asian Law, University of
} 
Rosa Ristawati: Modelling Executive Powers in the Indonesian Constitution: A comparative Study

Under the Third Amended Constitution, a direct process of presidential election was established. According to Article 6A section 1, the President and vice President should be elected directly by the people. This Article set a strong basis for a presidential system where an elected president has a strong legitimate position. The president is directly elected and thus, directly responsible to the people. During the campaign, a presidential candidate is already assumed to have political responsibility to fulfill his/her political commitments. The mechanism is expected to contribute to a more political independent executive. However, the mechanism still has some potential disadvantages specifically when the President comes from a nonpopular political party and raises weak support from the legislature. This situation, in the end may cause gridlock in a legislative-executive relationship in both the legislative process and the government policy-making. ${ }^{620}$ On the other hand, a direct election is expected to have more advantages to strengthen the character of the presidential system as such in Indonesia. The President has since not been elected through an indirect democracy mechanism such as what had been set in the UUD 1945. The president has more legitimacy from the people and in consequence, the president is constitutionally responsible to the people and not only to other branches. A direct election has to do with the Presidential position. It is mainly expected that the Presidential should survive during his office and is mainly expected to establish the government stability. Besides, it is addressed to give a more democratic atmosphere in Indonesia and it is intended to provide a constitutional protection for the presidential office. Unlike before the Amendment of Constitution, according to the Amended Constitution, it would be difficult for other branches to bring down the President since he is elected by the people.

Melbourne, Kompas Book Publishing, Jakarta, 2008, pp. 93-94: "The 1945 Constitution was an executive-heavy constitution; it provided the executive with enormous powers but lacked sufficient constitutional controls; none of the presidential powers except the power to declare war, make peace, and conclude treaties were subject to an agreement or confirmation of the other branches. In practice, these broad and largely uncontrolled powers were used by Suharto as the constitutional foundation for selecting key person in strategic position; therefore, the president managed to control the bureaucracy, the military, the legislative body and the judiciary; he basically became the one and only authority who had power to appoint and dismiss the strategic position in all institutions". ${ }^{620}$ Sebastian K. Braun, Indonesia's Presidential Democracy in Comparison with Malaysia's System, Friedrich Naumann Foundation, September 2008, http://www.fnfasia.org (accessed on 20/10/2011). 
However, the Third Amended Constitution also provides a constitutional mechanism to impeach the President. It clarifies the grounds of impeachment. According to the Third Amended Constitution, the president could only be brought down on specific grounds: criminal offences. According to theory, the impeachment mechanism in a presidential system is to be used to correct grave abuses by the executive and not as a routine means of unseating presidents. ${ }^{621}$ The Third Amended Constitution allows the DPR to invoke presidential impeachment whenever they indicate that the President has committed crimes or other constitutional impeachment grounds. The indication would then be submitted to the Constitutional Court to be affirmed. At this point, the Court may play a critical mediation role in this matter. ${ }^{622}$ However, there is no experience of presidential impeachment in Indonesia.

With regard to the presidential term, the First Amended Constitution has set term limits to the presidential office. It only allows a President to be re-elected once. The idea to limit the presidential term is mainly according to the bad experience that Indonesia had during the Soeharto administration. Since there was no limitation to the presidential term, it potentially puts Indonesia under an authoritarian regime. As the Indonesia presidency is expected to be more dynamic than before, the presidential term limit is even more necessary to help make the process even more dynamic and provide a more democratic atmosphere.

In the spirit of establishing a presidential government, the Amended Constitution provides articles that allow the executive powers to be jointly exercised by the President and the Legislature or the President and the Court or other institutions, for example, to exercise foreign affairs powers, the war powers, and the treaty powers, the President must jointly share the powers with the DPR. On the administrative power, the President has the power to establish the cabinet of ministers. The president is granted the power to appoint and dismiss ministers. However, by the Third Amended Constitution, such power is limited. The additional Section 4 of Article 17 stipulates that the formation, alteration and dissolution of ministers of

\footnotetext{
${ }^{621}$ Fukuyama Francis, Bjorn Dressel, et al, "Facing the Perils of Presidentialism?: Challenge and Change in East Asia", The Johns Hopkins University Press, Journal of Democracy, Vol. 16, No. 2, April, 2005 (pp.102-116), pp. 110. ${ }^{622}$ Fukuyama Francis et al, Op. Cit., p. 155.
} 
state shall be regulated by law. It implies that the presidential power to form the cabinet has been limited by the intervention of legislation.

On the legislative power, the First Amended Constitution shifted the legislative power from the President to the DPR. However, the Constitution still gives the President the right to jointly approve the Bill to become legislation in a joint approval session with the DPR. Once the President does not approve a bill, it would not be Law. Besides, the president still has the power to initiate any bills. The draft ofa bill should be jointly discussed and jointly approved by both the President and the DPR. To this extent, the Amended Constitution still places the President as the co-legislator who has an equal position and equal power in a legislative process as the DPR. Once the President rejects a bill in a joint session, there would not be a Law and the DPR could not override the President's rejection since all the Legislation is produced by a negotiation process between the President and the DPR in a joint session. On the judicial appointment power, the Amended Constitution reduces the executive intervention to the judicial branch. The powers of the executive are only to formally appoint judges in both the Supreme Court and Constitutional Court and nominate some judges in the Constitutional Court. However, the power is shared with the DPR and the Supreme Court for the constitutional court judges. On the other hand, the President has no power to appoint Supreme Court Judges since the power is now exercised by the Judicial Commission with approval from the DPR. On the pardoning power, the President could not unilaterally exercise the power anymore. The power has to be exercised with and by considering the Supreme Court's opinion for the power to give clemency and restoration of rights and the DPR's opinion for the power to give amnesty.

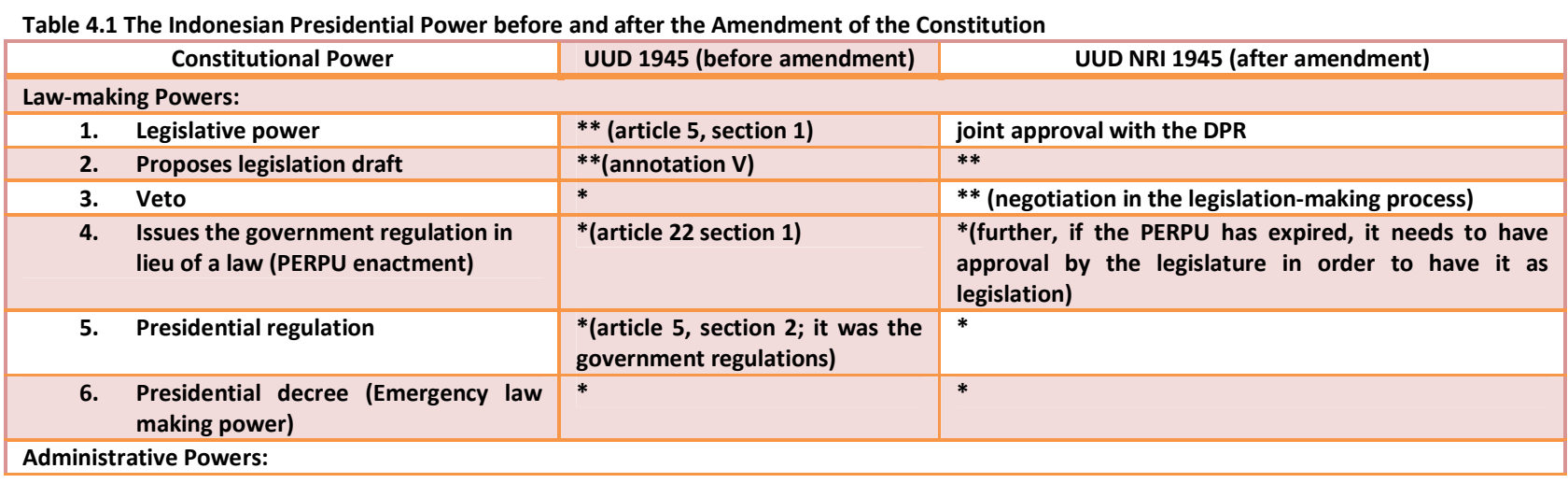


Rosa Ristawati: Modelling Executive Powers in the Indonesian Constitution: A comparative Study

\begin{tabular}{|c|c|c|c|}
\hline 1. & Cabinet formation & *(annotation para. VI) & *(article 17 , by legislation) \\
\hline 2. & Appoints ministers & *(article 17 section 2 ) & $*$ \\
\hline 3. & Cabinet dismissal & *(article 17 section 2 ) & $*$ \\
\hline 4. & Cabinet reshuffle & *(annotation para VI) & $*$ \\
\hline 5. & Convenes cabinet session & *(annotation para.VII) & $*$ \\
\hline 6. & $\begin{array}{l}\text { State agencies and state commissions } \\
\text { formation }\end{array}$ & NA & $* *$ \\
\hline 7. & $\begin{array}{l}\text { Office formation: advisory council } \\
\text { establishment }\end{array}$ & NA & *(article 16 , by legislation) \\
\hline 8. & $\begin{array}{l}\text { Civil servant (member of agencies and } \\
\text { commissions) appointment and } \\
\text { dismissal }\end{array}$ & $*$ & $* *$ and /or $* * *$ (by legislation) \\
\hline 9. & $\begin{array}{l}\text { Grants titles, decorations and other } \\
\text { distinction of honor }\end{array}$ & *(article 15) & *(article 15 , by legislation) \\
\hline \multicolumn{4}{|c|}{ Foreign Affairs Power: } \\
\hline 1. & Treaty power & ** (article 11) & $* *($ article 11, section 2$)$ \\
\hline 2. & $\begin{array}{l}\text { War power: declare war and make } \\
\text { peace }\end{array}$ & ** (article 11) & $* *($ article 11 , section 1$)$ \\
\hline 3. & Appoints the ambassador and consuls & ${ }^{*}$ (article 13, section 1$)$ & $* *$ (article 13 section 1,2 ) \\
\hline 4. & Receives foreign ambassadors & *(article 13 section 2 ) & **(article 13 section 3 ) \\
\hline 5. & Foreign policy & $*$ & $\begin{array}{l}* \text { and } * * \text { (article } 13 \text {, if significantly impact the people } \\
\text { and fundamentally relevant to state) }\end{array}$ \\
\hline \multicolumn{4}{|c|}{ Pardoning Power: } \\
\hline 1. & Clemency and restoration of rights & * (article 14) & $* * *$ (article 14 section 1 , the supreme court) \\
\hline 2. & Amnesty & *(article 14) & $* *$ (article 14 section 2 ) \\
\hline 3. & Pardon & *(article 14) & $* *$ (article 14 section 2 ) \\
\hline \multicolumn{4}{|c|}{ Military Power: } \\
\hline 1. & Commander in Chief & *(article 10) & *(article 10) \\
\hline 2. & State Intelligence & $*$ & NA (however, it's implied power) \\
\hline 3. & Appoints senior commanders & $*$ & $* *$ \\
\hline 4. & Commander National security & NA & NA \\
\hline 5. & Appoints the National Chief Police & $*$ & $* *$ \\
\hline \multicolumn{4}{|c|}{ Economic Power: } \\
\hline & $\begin{array}{l}\text { State budgeting (submitting state } \\
\text { budget) }\end{array}$ & **(annotation $\mathrm{V})$ & $* *$ \\
\hline 2. & Central bank coordinative & $*$ & $*$ \\
\hline 3. & Monetary and macro economy policy & $*$ & $*$ \\
\hline 4. & $\begin{array}{l}\text { Exploration and controlling the } \\
\text { resources }\end{array}$ & *(article 33 section 2 and 3 ) & $*$ \\
\hline \multicolumn{4}{|c|}{ Appointment Power: } \\
\hline 1. & Appoints chief of supreme court & $*$ & $* *, * * *$ \\
\hline 2. & Appoints constitutional court judges & $*$ & $* *, * * *$ \\
\hline 3. & $\begin{array}{l}\text { Appoints the supreme state } \\
\text { prosecutor }\end{array}$ & $*$ & $* *$ \\
\hline 4. & Appoints the central bank chief & $*$ & $* *$ \\
\hline & $\begin{array}{l}\text { Appoints the chief of state financial } \\
\text { supervisor } \\
\text { ( the BPK) }\end{array}$ & $*$ & $* *$ \\
\hline \multicolumn{4}{|c|}{ Emergency power } \\
\hline & 1. Declare the state emergency & *(article 12) & $* *$ \\
\hline & 2. Ending state emergency & NA & $* *$ \\
\hline
\end{tabular}

* The President

** checked and balanced by legislature (the DPR)

*** checked and balanced by Judicature (the Supreme Court and/or the Constitutional Court)

\subsection{Executive power under the Fourth Amended Constitution}


Rosa Ristawati: Modelling Executive Powers in the Indonesian Constitution: A comparative Study

\section{a. The Law-Making Power}

The law-making power is an instrument for government to legitimize substantial and procedural actions in reshaping and resolving public problems which are implemented and evaluated through rule and standard setting, administrative and executive interpretation, court decisions and petitions. ${ }^{623}$ The law-making process is a process of speculative, continuous, iterative and alternative, and informative inquiry in which making laws requires the power to look for facts in a deliberative, sequential, orderly, and declarative manner. ${ }^{624}$ The law-making power of an Indonesian President can be found in some articles of the Amended Constitution. ${ }^{625}$

Table 4.2 the Presidential Law-making Power under the Indonesian Amendment Constitution

\begin{tabular}{|c|c|c|c|c|}
\hline Law & $\begin{array}{l}\text { Legal Characteristics, legal effects and } \\
\text { mechanism }\end{array}$ & $\begin{array}{l}\text { The Presidential law } \\
\text { making powers }\end{array}$ & $\begin{array}{l}\text { Powers counter } \\
\text { balance by the } \\
\text { Legislative }\end{array}$ & $\begin{array}{l}\text { Powers counter } \\
\text { balance by the } \\
\text { Court }\end{array}$ \\
\hline Legislation & $\begin{array}{l}\text { Legal Characteristics } \\
\text { - General binding rules } \\
\text { made by a joint approval } \\
\text { between the DPR and the } \\
\text { President } \\
\text { - Legalized by the President } \\
\text { Substances: further and } \\
\text { detail regulations about a } \\
\text { constitutional provisions, } \\
\text { ordered by other legislations, } \\
\text { transformed international } \\
\text { treaties, as measures to } \\
\text { follow up the constitutional } \\
\text { court decisions, legal needs }\end{array}$ & $\begin{array}{l}\text { - Initiator } \\
\text { - Giving } \\
\text { approval in } \\
\text { the joint } \\
\text { approval } \\
\text { session } \\
\text { Legislation } \\
\text { draft } \\
\text { discussant } \\
\text { - Legalization: } \\
\text { Giving } \\
\text { signature to } \\
\text { the draft of } \\
\text { legislation }\end{array}$ & $\begin{array}{l}\text { Legislature is the real } \\
\text { law maker. } \\
\text { A democratic process } \\
\text { in a joint discussion } \\
\text { between the DPR and } \\
\text { the President } \\
\text { A democratic process } \\
\text { for a joint approval } \\
\text { between the DPR and } \\
\text { the President }\end{array}$ & $\begin{array}{l}\text { Constitutional } \\
\text { Court: the judicial } \\
\text { review of } \\
\text { constitutionality of } \\
\text { legislation }\end{array}$ \\
\hline $\begin{array}{l}\text { The } \\
\text { Government } \\
\text { Rules in lieu } \\
\text { Legislation }\end{array}$ & 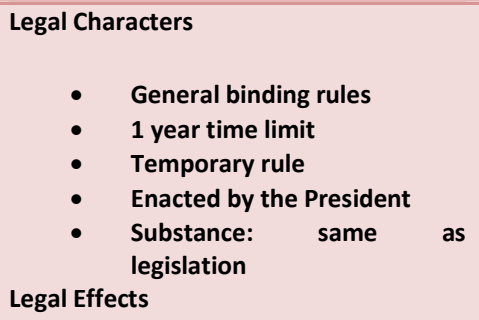 & $\begin{array}{ll}\text { - } & \text { Initiator } \\
\text { - } & \text { Rules maker } \\
\text { - } & \text { Enact }\end{array}$ & $\begin{array}{l}\text { The legislature may } \\
\text { come with its rejection } \\
\text { or approval }\end{array}$ & $\begin{array}{l}\text { The constitutional } \\
\text { court may revoke } \\
\text { the emergency law } \\
\text { on the ground that } \\
\text { the emergency law } \\
\text { is } \\
\text { unconstitutional. }\end{array}$ \\
\hline
\end{tabular}

\footnotetext{
${ }^{623}$ Charles O. Jones., The Presidency in a Separated System, Brookings Institution Press, Washington DC, $2^{\text {nd }}$ edition, 2005, p. 222.

${ }^{624}$ Id. at p. 223.

${ }^{625}$ See: Table 4.2 .
} 


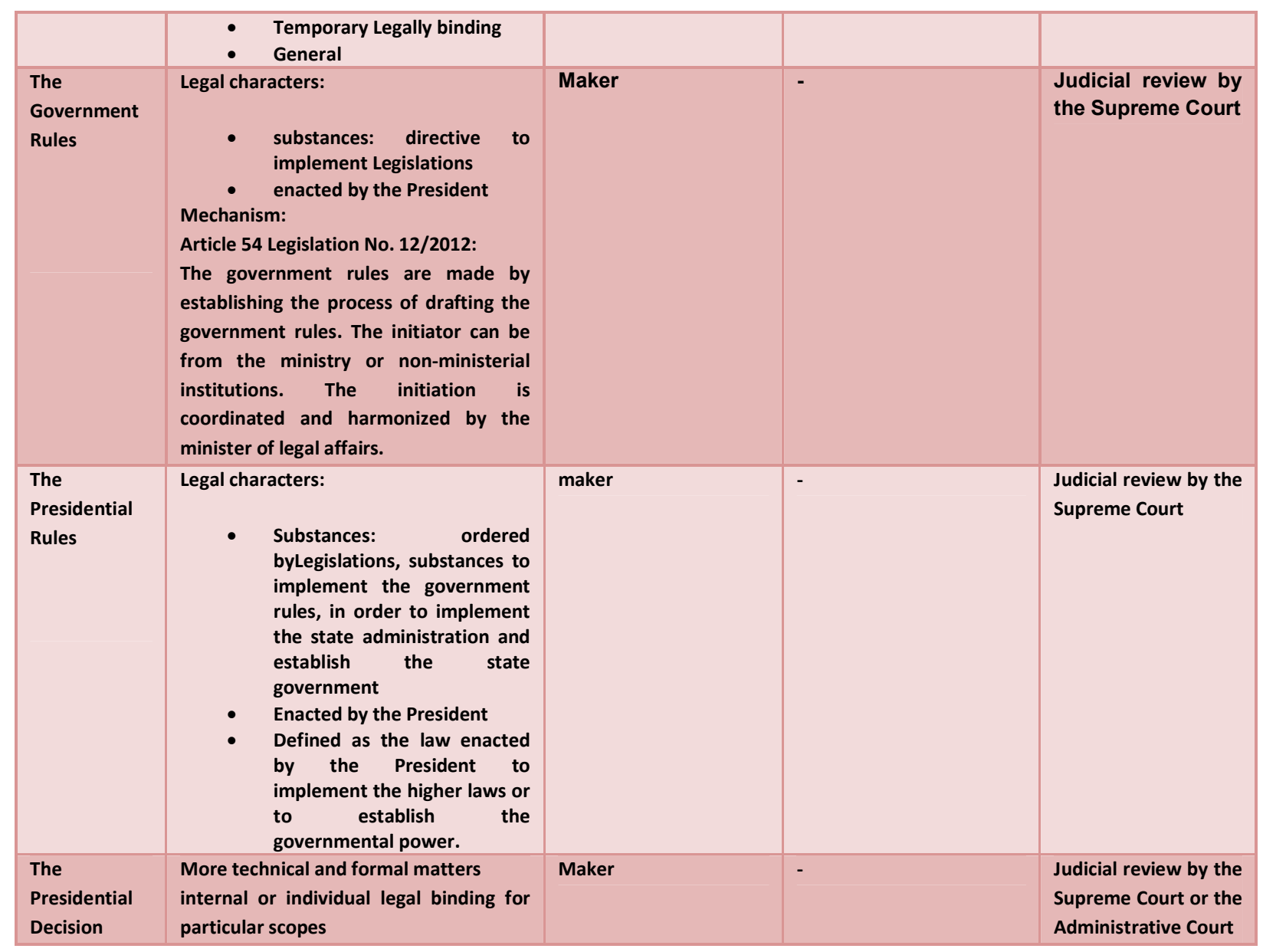

According to the articles in the Constitution, the law-making power of the President includes mainly the power in legislation-making, the Government Directive, and the government rules substituting the legislation (the Emergency Law). Article 5 section 1 of the Constitution explicitly states that the President has the right to initiate bills to the DPR. This article clarifies that the President is one of the initiators of the bill in the legislation-making process. ${ }^{626}$ Furthermore, Section 2 of Article 5 points out that the President sets the Government Directive (Peraturan Pemerintah), which is the Directive to implement the Legislation properly. In the case of urgency and state emergency, Article 22 grants the President the right to enact the Government Rules substituting the Legislation (PERPU as the Emergency Law).

\footnotetext{
${ }^{626}$ The UUD 1945 granted the President the full power as legislator. Article 5 before it was amended stipulated that the President holds the legislative power with the approval from the DPR.
} 
Rosa Ristawati: Modelling Executive Powers in the Indonesian Constitution: A comparative Study

Article 1, Legislation 12/2011 on the Establishment of Laws defines the law as the legal norms which have legal binding characteristics and are established or set by state institutions or state officials with authorization and competence through legal procedures as regulated in the laws. Moreover, Article 7 of the Legislation No. 12/2011 determines the hierarchy of Laws that may be applied in Indonesia. Those laws are described in the figure below:

Figure 3. The hierarchicy of the Laws based on the Legislation No. 12/2011

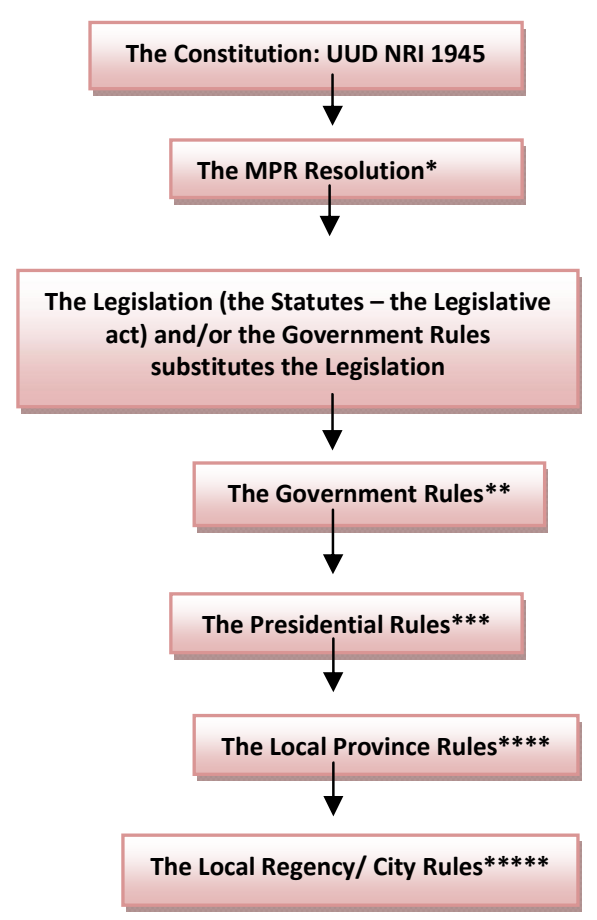

Other laws (determined as delegated by the higher laws and established under authority and competences); such other laws are including:

The MPR's Rules; the DPR's Rules, the DPD's Rules, the Supreme Court's Rules; the Constitutional Court's Rules; the BPK's Rules; the Judicial Commission Rules; the Indonesian Bank's Rules; the Minister's Rules; the Rules of the Institution/the Commission/the Agencies (established by the Legislation or government as ordered by the Legislation); the Province Local People Representative Rules; the Local Governor's Rules; the Regency/City Local People Representative's Rules, the Chief of Municipality's Rules, the Chief of Village's Rules

\footnotetext{
*The MPR Resolution refers to all the Resolutions that are still applicable based on Article 2 and Article 4 of the Resolution MPR RI No. I/MPR/2003, 7 August 2003 concerning the Review of the Substance and Legal Status of the MPRS and the MPR Resolution during the period from 1960 to 2002.

** The Government Directive for implementing Legislation. It is the law that is enacted by the President to execute the Legislation properly. In theory, the government rules is more likely as the statutory instrument, an instrument to implement the legislation

*** The Presidential Rules is the law that is enacted by the President to implement the order from the higher law or to perform the executive power in running the state administration.
} 
****The law that is made by the provincial representative body (the DPRD) in the joint approval session with the Governor in the provinces in Indonesia

*****The law that is made by the municipality/regency representative body (the DPRD) in the joint approval session with the regent/mayor in the municipality or the regency

According to above figure, the Law-making powers of the President include producing legislation, producing government rules as a substitute for legislation in times of an Emergency, and producing government and presidential regulations. In most of the Law making process, the President may directly be involved or may have significant powers over it.

In the legislation law-making process, the President has the power to initiate bills; also the President has the power as the co-law maker partner to the Legislature (the DPR). On the other hand, with the Provincial Regulations and the Municipality Regulation (the Local Laws), the President may have the power to conduct executive reviews of those Local Laws. Article 18 Section 6 of the Second Amended Constitution stipulates that the Local Government has the right to set any local laws and other local executive regulations in order to implement the autonomy and governmental duties to assist. The Article is relevant to Indonesia as a unitary state. In the unitary state of Indonesia, the President is the higher state executive and implicitly has the powerto conduct an executive review over the local laws and the power to supervise the implementation of Laws in local government.

\section{The President in the Legislative process}

Legislation is a legal product of the Legislature. The characters of legislation are as follows: it embodies a rule of conduct, sets norms or standards determining the manner in which rights are exercised and responsibilities are fulfilled; and a rule must be unilateral, legally binding, and apply to an undetermined number of persons. ${ }^{627}$ Legislation is mostly for the purpose of Constitutional directives, Treaty transformation and International agreements, following up the Constitutional Court's decision, and to meet any legal needs in the community. In practice, legislation is issued by a legislature, which has constitutional competences as stated

\footnotetext{
${ }^{627}$ Peter Wesley Smith, “Executive Order and the Basic Law”, Law Lectures for Practitioner, Hong Kong Law Journal Limited, 1998, pp. 187-209, p. 203 (accessed online at: Hong Kong Journals Online, www.hkjo.lib.hku.hk/exhibits/show/hkjo/browseArticle?book=b27720603\&issue=140020 , last accessed on January 15, 2015).
} 
in the Constitution. Article 5 section (1) the First Amended Constitution gives the President a Constitutional right to initiate the draft of a Bill to the DPR. However, the Constitution attaches the real legislative power to the DPR. Article 20 section 1 of the First Constitution clarifies that the power to make Laws belongs to the DPR. Accordingly, the main legislative branch is the DPR, whereas the President is the executive and the co-legislator. The Constitution still assigns the President to have an equal position and be a partner for the DPR in the legislative process. It is indicated in the Constitution that the President has the power to jointly discuss and jointly approve all the drafts of the bills to become Law (whether proposed by the DPR or the President) excluding the bill to transform a treaty into the domestic legal system, and the emergency laws. ${ }^{628}$ To this extent, there is a collaborative relationship between the President and the DPR in the law-making process. Together they should conclude joint approval for a draft bill to be a law. The President's power in the legislative process is very significant since every draft of the bill must also be approved not only by the DPR but also by the President. Without the approval from the President, a draft of the Bill will never be a Law, and vice versa, if the DPR does not approve the bill, it will not become Law. Theoretically, although the separation of power suggests the division of power between the executive and the legislative, the executive is involved and has power in the law-making process. According to the Indonesian Constitution, a joint approval from the DPR and the President is actually intended to maintain checks and balances. It is mostly because in the end, the President as the executive will have a constitutional duty to implement and execute the Legislation. To execute and implement the laws, the President should really understand the content and the purpose of the Bill. In a joint discussion, the President is given the right to give an opinion and deliver his idea on the lawmaking, whether or not the bill is reasonable and implementable.

In order to actualize the President's right to initiate the Bill, the President has also the power to propose the list of the legislation drafts into a National Legislation Program. The National Legislation Program is a list of guidelines for the priority of legislation making. It is arranged by both the DPR and the President.

\footnotetext{
${ }^{628}$ Article 20 section (2) of the Indonesian Amended Constitution.
} 
Rosa Ristawati: Modelling Executive Powers in the Indonesian Constitution: A comparative Study

\section{Veto power in Indonesia}

The Amended Constitution does not explicitly mention that the Indonesian President has veto power in the law-making process. Also there is no clarification about the mechanism to overrule the veto. However, the veto power of the President is actually in the joint discussion and in a joint approval session. In a joint approval, the President has the right to reject a bill. When the President does not approve a bill, it will not become the Law. To this extent, a strong veto is granted to the Indonesian President.

\section{The power to make Emergency Law}

Article 22 section (1) gives the President the power to issue Government Regulations to substitute Legislation in special cases of state emergency and urgent situations (the Emergency Law). However, as mentioned in section 2, the Emergency Law will become the law after it is submitted to the next DPR's session and approved by the DPR. If, however, the DPR rejects, such Law must be revoked by the President. The President may issue a government rule in lieu of the Legislation (the Emergency Law) only when the state is in an emergency situation or when there is an urgent situation. According to Bagir Manan, in issuing the emergency law, the power of the President is a conditional power and not an inherent power. ${ }^{629}$ To exercise the power, the President must have a strong argument that the state is vulnerable in an emergency situation and needs urgent protection. Unlike the theory on the presidential decree, the emergency law is mostly an extraordinary mechanism to bypass an uncooperative legislature in an unfavorable political environment ${ }^{630}$; the law can be made by the President in special conditions of state emergency and/or in an urgent situation.

\footnotetext{
${ }^{629}$ Bagir Manan, Teori dan Politik Konstitusi, FH UII Press, Yogyakarta, Cet. Kedua, 2004, p. 216:"The Presidential power in making emergency law should be regarded as a conditional power that is based on the argument of: 1 . Real emergency and urgent situation, 2 . A crisis that leads to a real obstacle and dangerous for the stability of the state government; 3 . The obstacle can come from the existing laws or because there are no laws that are urgent and need to be solved; 4 . The material condition that an emergency law made by the President should not refer to the constitutional matters, human rights, criminal matters, and state institutions; instead it should only regulate the state administration."

${ }^{630}$ Carlos Pereira , Timothy J. Power, Lucio Renno, "Under What Condition Do the Presidents Resort to Decree Power? Theory and Evidence from the Brazilian Case", The Journal of Politics, Vol. 67, No. 1, February 2005, pp. 178-200, accessed at 14 February 2012, p. 194.
} 
Rosa Ristawati: Modelling Executive Powers in the Indonesian Constitution: A comparative Study

The characters and contents of the Emergency Law are basically the same as Legislations. The argument for giving such power to the President is mainly that the president is the highest institution in state administration and acts as commander in chief. He has duties to protect and maintain state sovereignty, national security, enforce laws, and protect citizens. To deal with any emergency and urgent situation, the President is given discretion to take any measures.

\section{The Power to issue Government Directives (Peraturan Pemerintah)}

In order to execute the Legislation, Article 5 section (2) of the Constitution states that the President has the power to issue Government Directives as a legal product for the government's instrument to implement the Legislation. According to the President's constitutional oath in Article 7 of the Constitution, the President has to faithfully execute the Laws. A Government Directive is more like a presidential directive which has the purpose to implement the legislation properly. According to Article 26 of the legislation 12/2011, the making of a Government Directive is coordinated by the ministers. Moreover, Article 28 of the Legislation mentions that in certain situations, the ministry or the non-ministerial institution is allowed to initiate the draft of government rules that is a part of or not ordered by the legislation or a Supreme Court decision. The Article implies that in the government rulesmaking process, the discretion is allowed in urgent cases. A Government Directive is not only made as it is ordered by the legislation, but can be made as initiated by the ministry or a nonministerial institution. However, a government directive should remain an instrument to execute the legislation or be in the frame of the state administration. Under the Presidential Regulation No.68/2005, after discussing with the initiator and coordinating with the minister of Law, the draft of the Government Directive is submitted to the President and the President will enact it. In conclusion, the Presidential power in the Government Directive making can be valued broadly as it may be possible to have broad discretion.

\section{The Power to issue Presidential Regulation (Peraturan Presiden)}


The Constitution is not specific on the power of the President to issue Presidential Regulation. The constitutional basis for the President to issue presidential rules may be derived from Article 4 of the Constitution. The Article implies that the President has the power to conduct state administration and government affairs and gives a legal basis for the Presidential action to faithfully fulfill the constitutional duties based on the President's constitutional oath and promise not only faithfully to execute the laws, protect the people but also to maintain the sovereignty of the state. These powers imply that the President can issue Presidential Regulations. The regulations will also be the legal basis for presidential actions and also be a legal reference for government actions by state executive officials.

Article 1 section (3) of the Constitution stipulates that Indonesia is a state under the rule of law. As a consequence, all Presidential actions and government actions must be in accordance with a legal basis. According to the Legislation 12/2011 on the Establishment of Laws, the Presidential Regulation is one of the laws applied in the Indonesia legal system. The Presidential Regulation is defined as a law issued by the President in order to execute the higher laws or in order to conduct the administration and governmental power. ${ }^{631}$ It is said that the Regulations have a character of regulating (regeling).It can only be set by the order of Legislation or only in order to implement the Government Regulation, and has no autonomous character. The Presidential Regulations cannot exist without the order from the legislation or cannot be independently enacted ifthey are not in order to implement the Government Regulation. ${ }^{632}$ According to the legal definition, the Presidential Regulations have two purposes. Firstly, they are to execute the higher laws, and secondly to conduct the administration and government power. However, both purposes are translated into the presidential actions or/and the government actions. According to the Legislation 12/2011 Article 13, a Presidential Regulation has to execute the Legislation, to execute a Government Directive, or to conduct state administration power. At this point, the Presidential Regulations are the law that is made in order to implement Legislation. The Presidential Regulation is the legal form for any

\footnotetext{
${ }^{631}$ Article 1 of the Legislation No. 12/2011.

${ }^{632}$ Jimly Asshiddiqie, Perihal Undang-Undang, Konstitusi Press, 2006, p. 117.
} 
presidential actions to fulfill the duties to implement the Legislation. Such Presidential Regulations have similar characters as the legislation. They are generally applicable and not addressed to an individual subject.

As in an emergency law, where the President is commonly given unilateral power to enact legislation, ${ }^{63}$ the President is given more discretion to make a Presidential Regulation. The relationship between the legislation and the Presidential Regulation occurs from the idea that the legislation supplies a general standard or rule of conduct which empowers the President as the executive to apply, mobilize, operate and enforce it, whereas the executive act applies the general rule set in the legislation to execute it. The Presidential Regulation will have legal consequences but does not change the context of the legislation; however, it may be based on the Presidential discretion in order to implement it and in accordance with the legislation. ${ }^{634}$ In addition, the Presidential Regulations can also be issued in order to transform and legalize certain treaties. By transforming a treaty with a Presidential Regulation, the treaty can enter into force and have domestic legal effect. In terms of issuing Presidential Regulations, the President also acts in administering foreign affairs in the domestic jurisdiction and in fulfilling an international obligation. This is when a treaty requires a state to impose, change, harmonize, and to conform a mechanism within the state's jurisdiction. By a Presidential Regulation, the President can also set any rules that have not been regulated by the Legislation. However, this does not mean that the President can use the Presidential Regulations to override the Legislation because the Presidential Regulations should still be in conformity with the Legislation.

\section{The power to issue Presidential Decree (Keputusan Presiden)}

The Presidential Decree is defined as rules made by the President as a legal basis to set standards for daily state administration. Since the President has the power to administer and perform the state administration independently, the President has the power to set details and

\footnotetext{
${ }^{633}$ Zachary Elkins, Tom Ginsburg, James Melton, "Constitutional Constraint on Executive Law-Making", at https://netfiles.uiuc.edu/melton/Files/melkinsburg executivepower.pdf, accessed on 2 February 2012, p. 9.

${ }^{634}$ Peter Wesley, Op. Cit., p. 203.
} 
Rosa Ristawati: Modelling Executive Powers in the Indonesian Constitution: A comparative Study

guides in a more technical line to direct the institutions under the executive branch. The Presidential Decree has two different types: the presidential decision which has a general character and the presidential decision which has an individual character. When it has a general character, the Presidential Decree regulates the technical matters of the state administrative affairs either for home affairs or foreign affairs. The Presidential Decree that has individual character in order to establish, appoint, or dismiss, and other formal affairs. ${ }^{635}$

\section{b. Administrative power and the appointment power}

Article 4 (1) stipulates that the President of the Republic of Indonesia holds the governmental powers under the Constitution. As a consequence, the President is the highest organ to hold the authority and responsibility to conduct and manage the state government and administration. To carry out the powers, the President as the head of state and head ofgovernment is assisted by a Vice President, state ministers, other executive officers equal to ministers, heads of non-department government institutions, the state prosecutor, chief of military forces, and the chief of Police as part of the governmental system.

The Fourth Amended Constitution allows the President to have the power to establish a President's Advisory Council. ${ }^{636} \mathrm{~A}$ Presidential Advisory Council is aimed to replace one of the highest institutions, the Supreme Advisory Council (DPA: Dewan Pertimbangan Agung), which was established before the Amended Constitution. The power to establish an Advisory Council is an executive power for the President because such power is under Chapter III of the executive power of the Fourth Amended Constitution. Accordingly, the Advisory Council is inferior to the President.

\footnotetext{
${ }^{635}$ The Presidential decision that has individual character could be challenged before the administrative court. The presidential decision of Keppres No. 48/P/2012, 2 May 2012 on the dismissal of the Governor Agusrin and the validation of Junaidi as Governor of Bengkulu had been challenged before the administrative court (http://news.detik.com/read/2012/05/15/172100/1917766/10/sby-kalah-lawan-yusril-di-pengadilan-ini-jawabanistana?9922022). Against such individual characteristic, the Presidential Decision is addressed to an individual, has an impact to the individual and usually has formal administrative character. However, the President as acting in the office capacity should obey the Court's decision.

${ }^{636}$ Article 16 the Indonesian Amended Constitution (Appendix 4).
} 
As the head of the government, the President has the appointment powers. ${ }^{637}$ In practice, the appointment power of the President is the power which has a great potential for abuses of power. It allows the President to appoint his own people or allies and fill the key positions in bureaucratic agencies throughout the executive department on the grounds of individual consideration and personal interest. In practice, the appointment powers are often to be exercised in a very subjective way, which may create significant conflict of interests since it based only on personal opinion. It gives a chance to the President to appoint people who have a similar ideology or the same political interest.

As the head the executive branch, the President has the power as a manager to set policies, executive guidelines and government directives for state executive officers to be applied for daily technical practice. The President has the power to monitor the implementation of policies, directives and guidelines.

\section{Forming and reshuffling the cabinet: the Constitutionality of the state ministers}

According to the Amended Constitution, the ministers in a presidential system have very important and significant roles. ${ }^{638}$ Jimly Asshiddiqie determined ministry as one of the executive organs ${ }^{639}$ and one of the constitutional organs. ${ }^{640}$ The ministries are organized and given functions by the Constitution. Moreover, ministries are under an independent chapter which is separate from the Executive chapter in the Constitution. ${ }^{641}$ However, the Amended Constitution implies that the ministry of the State (the Cabinet) is an institution under and depends on the President. The Amended Constitution, Article 17 on Ministry of the State stipulates as follows:

Section (1) the President is assisted by the ministers

(2) The ministers are appointed and dismissed by the President

(3) Every minister is in charge of a particular affair in the government

\footnotetext{
${ }^{637}$ See: Table 4.3 the appointment power of the President.

${ }^{638}$ The term State Ministers refers to Chapter V on the State Ministers of the Indonesian Amended Constitution.

639 Jimly Asshiddiqie, Perkembangan dan Konsolidasi Lembaga Negara Pasca Reformasi, Sekretariat Jenderal dan Kepaniteraan Mahkamah Konstitusi RI, 2006, p. 27.

${ }^{640}$ Id. at p. 55.

${ }^{641}$ According to the Indonesian Amended Constitution, Chapter V on the State Ministerial is excluded from Chapter III on the executive.
} 
(4) The formation, change, and dissolution of a ministry is legislated by Legislation

Section 1 and 2 of the Article mean that the ministers are the President's assistant. The president has the power to appoint and dismiss the ministers. At this point, the Article confirms that the Ministers in the Cabinet are under, and responsible to, the President. They have the role to assist the President. The ministers are in charge of each particular government affair. A minister is responsible for leading and managing his ministerial department. However, the Third Amendment Constitution added section 4 to Article 17. It limits the ministerial powersof the President by stipulating that the procedure for forming, changing, and dissolving a ministry should be in accordance with the Law. It is implied from this section to have checks and balances of the President's power in establishing and managing state ministries with budget functions. $^{642}$

The ministers are in practice the daily executive. They run government affairs. In the executive organization, the ministers have the position to perform the government activities. The ministers have delegated powers from the President, as the chief of the government and responsible for all government affairs to act. According to Article 17 Section 3 of the First Amended Constitution, a minister is in charge of particular affairs of government. ${ }^{643}$ The minister is a chief of his/her department and in charge of public policy making. In special cases when the President and the Vice President simultaneously die or step down, are impeached, or are unable to perform their duties during their office, according to Article 8 section 3 of the Fourth Amended Constitution, the triumvirate of Ministers (the Minister of foreign affairs, Minister of home affairs, and Minister of state defense) will together exercise the presidential powers.

For ministerial appointments, the President is actually given independent powers to appoint and dismiss the ministers according to Article 17 section 2 the First Amended

\footnotetext{
${ }^{642}$ The Preparatory work of the amended constitution describes that the intention of the framers to legislate the formation, change and dissollution of state minister is based on the constitutional practice in the President Abdulrahman Wahid which was in the $1^{\text {st }}$ month of his period of administration; he had dissolved 2 state ministries.

${ }^{643}$ Before it is amended, the Constitution stipulated that "the Ministers lead the governmental department".
} 
Constitution. The ministerial appointments are always related to the Presidential programs. It may depend on the programs that the President had campaigned for during the election campaign. In office, the appointed ministers are the President's assistant to work on the President's programs. ${ }^{644}$ As the ministers are in charge of particular government affairs, each minister is responsible for his ministry. They are constitutionally responsible to the President and not responsible toparliament or other branches. In practice, the nomination, selection process, and formal appointment are in the hands of the President, but sometimes, political parties and the DPR put the President under great pressure during the ministerial nomination and reshuffle process.

According to the third Amended Constitution in Article 17 section (4), the ministers (the Cabinet) structure including the establishment, alteration, and dissolution of the state ministries is protected by the Legislation. The Article implies that there is an indirect intervention from the DPR in the establishment of a ministerial department. It limits the President's power to establish a ministerial department. The Law on the state ministers is jointly discussed and approved by the President and the DPR. To this extent, the DPR can indirectly control the establishment, change and dissolution of a state ministerial department. In accordance with Article 17 of the Constitution, the Legislation No. 39/2008 set a legal basis for the establishment of a state's ministerial department. The Legislation determines the name of ministerial departments and the establishment process. The scope of the government affairs for state ministers is classified in Article 4 section 2 of Legislation No. 39/2008. It includes all government affairs which are expressly mentioned in the Constitution and all government affairs which are intended to be focussed, coordinated, and synchronized. Furthermore, Article 5 determines that the scope of government affairs includes (1) government affairs referred to in article 4 section (1), which include foreign affairs, domestic affairs, and state defense; (2) government affairs referred to article 4 section (2) which are the areas of religion, law, finance, state security, human rights, education, culture, health, social, labor, industry, trade, mining, energy, public work, transmigration, transportation, information, communication, agriculture,

\footnotetext{
${ }^{644}$ Article 17 Section 1 of the Indonesian Amended Constitution (Appendix 4).
} 


\section{Rosa Ristawati: Modelling Executive Powers in the Indonesian Constitution: A comparative Study}

plantation, forestry, animal husbandry, marine and fisheries; (3) government affairs referred to inarticle 4 section $(2 \mathrm{C})$ concern the national development planning, state apparatus, state secretariat, state company, land, population, environment, science, technology, investment, cooperation, small and medium enterprises, tourism, woman empowering, sports, housing and construction area or disadvantages area.

Table 4.3 the Cabinet appointment power of the Indonesian President

\begin{tabular}{|c|c|c|}
\hline \multirow[b]{2}{*}{$\begin{array}{l}\text { Constitutional Power } \\
\text { (UUD NRI 1945) }\end{array}$} & Explicit power & Implied power \\
\hline & $\begin{array}{l}\text { - Article } 17 \text { section } 1 \text { : } \\
\text { to be chief ofthe state ministry and ministers } \\
\text { - Article } 17 \text { section 2: } \\
\text { to appoint and dissolve ministerial }\end{array}$ & $\begin{array}{ll}\text { - } & \text { to command } \\
\text { - } & \text { to manage } \\
& \text { and guidance direction } \\
\text { - } & \text { to nominate } \\
\text { - } & \text { to select } \\
\text { to formally } \\
\text { appoint or dismiss }\end{array}$ \\
\hline $\begin{array}{l}\text { Legal Power } \\
\text { (Law No. 38/2008) }\end{array}$ & $\begin{array}{l}\text { - Article 3: } \\
\text { To be chief and supervisor for state ministry and ministers } \\
\text { - Article 10: } \\
\text { - } \\
\text { - Article 11: } \\
\text { To map up duties, functions, and to make systematic the ministerial organization } \\
\text { with the Presidential decree } \\
\text { Article 12: } \\
\text { To establish the ministry of foreign affairs, ministry of domestic affairs, and } \\
\text { ministry of defence } \\
\text { Article 13: } \\
\text { To establish ministerial for government affairs of: religion, laws, financial, state } \\
\text { security, human rights, education, culture, health, social, labor, industry, trade, } \\
\text { mining, energy, public-work, transmigration, transportation, information, } \\
\text { communication, agriculture, plantation, forestry, animal husbandry, marine and } \\
\text { fisheries; and national development planning, state affairs, state secretariat, } \\
\text { state company, land, population, environmental, science, technology, } \\
\text { investment, cooperation, small and medium enterprises, tourism, woman } \\
\text { empowering, sports, housing and construction area or disadvantages area } \\
\text { Article 14: } \\
\text { To establish Ministry of Coordination for synchronization and coordination of } \\
\text { ministry } \\
\text { Article 18: } \\
\text { To change the ministry mentioned in article } 13 \\
\text { Article 21: } \\
\text { With the consideration from the DPR, to dissolve the ministerial department } \\
\text { mentioned in article } 13 \text {; andwith the approval from the DPR for particular } \\
\text { ministerialof the ministry of religion, Law, Financial, and defence } \\
\text { Article 22 section (1): } \\
\text { To appoint ministers } \\
\text { Article } \mathbf{2 4} \text { section (2) and (3): } \\
\text { To remove and suspend ministers }\end{array}$ & $\begin{array}{l}\text { - Nominate, select, } \\
\text { and appoint } \\
\text { Command, give } \\
\text { direction and } \\
\text { guidance } \\
\text { Coordinate, } \\
\text { supervise and } \\
\text { administer } \\
\text { - Assign, monitor, } \\
\text { and evaluate } \\
\text { - Facilitate and } \\
\text { support }\end{array}$ \\
\hline
\end{tabular}

2. The Presidential cabinet formation: establishment, nomination, selection, and appointment 
In the presidential system of Indonesia, the establishment of a cabinet is usually in accordance with a deal with the President's supporting parties and the coalition supporting the President. However, in specific circumstances, the appointment of ministers is based on merit. The ministers represent personal competences, technical qualifications and professional competences to implement the government affairs. ${ }^{645}$

To meet with the qualification and fit the President's requirements and according to his vision and mission and work program, the President conducts a fit and proper test that will be the grounds of the minister's appointment. Jimly Asshiddiqie argues that the appointment process of a minister has to be based on the meritocracy system where the President should make a priority for technical leadership qualifications rather than political support qualifications. ${ }^{646}$ In a meritocracy ministry, the Cabinet merely works on the professional ground and will be free from the political interest of the political party. ${ }^{647}$

However, in practice, the President could not be free to form the ministry in the cabinet even though it is said to fit in the President's program. ${ }^{648}$ According to Article 17 section (4) of the Third Amended Constitution, to establish the Cabinet and appoint ministers, the President must comply with the Law. The Law No. 38/2008 set the procedures of cabinet formation and limits the scope of ministry affairs. The Law gives a limit on the numbers of ministries at $34 .^{649}$

In terms of the ministerial title, the President has the prerogative power to name a ministry as long as the scopesare mentioned in the Legislation (Article 5 of Legislation No. 38/2008). Although the general qualifications are determined by Law, the President has prerogative power in the nomination and selection process. For the purposes of

\footnotetext{
${ }^{645}$ Jimly Asshidiqie, Pengantar IImu Hukum Tata Negara Jilid II, Mahkamah Konstitusi Republik Indonesia, 2006, p. 62.

${ }^{646}$ Jimly Asshiddiqie, Op. Cit., p.62.

${ }^{647}$ Jimly Asshiddiqie, Op. Cit., p. 175.

${ }^{648}$ See: Jakarta post, Analyst says health minister's resignation proves flaw in Cabinet selection, Jakarta Post, Thursday, 04/26/2012, http://www.thejakartapost.com/news/2012/04/26/analyst-says-health-minister-sresignation-proves-flaw-cabinet-selection.html.

${ }^{649}$ Article 15 of the Law No. 38/2008 has put a limit to the number of Ministries; the overall number is 34 ministries.
} 
Rosa Ristawati: Modelling Executive Powers in the Indonesian Constitution: A comparative Study

synchronization and coordination of government affairs between state ministers, the President appoints coordinator ministers. ${ }^{650}$ To establish state ministers, the Presidenthas tomakea Presidential Regulation. ${ }^{651}$

With regards to the ministers' nomination, the nominations come from the President. The President himself will conduct fit and proper tests for the minister candidates. He will confirm all the candidate qualifications and competences according to his personal requirement.

Table 4.4 The Indonesian Presidential cabinet formation and reshuffle in practices

\begin{tabular}{|c|c|c|}
\hline $\begin{array}{l}\text { President and } \\
\text { terms office }\end{array}$ & Cabinet Formation & Cabinet Reshuffle \\
\hline $\begin{array}{l}\text { Abdurahman Wahid } \\
(1999-2001)\end{array}$ & $\begin{array}{l}\text { Cabinet Formation: } \mathbf{2 0} \text { October } 1999 \\
32 \text { Ministers consist of: } \\
\text { - } 3 \text { Coordinating Ministers:Minister for Political Affairs } \\
\text { and Security, Minister for the Economy, Finance and } \\
\text { Industry, Minister for People's Welfare and Poverty } \\
\text { Eradication } \\
\mathbf{1 6} \text { Ministers: Minister of Home affairs, Minister of } \\
\text { Foreign Affairs, Minister of Defense, Minister of Law } \\
\text { and Legislation, Minister of Finance, Minister of Mines } \\
\text { and Energy, Minister of Industry and Trade, Minister of } \\
\text { Agriculture, Minister of Forestry and Plantation, } \\
\text { Minister of Communications, Minister of Maritime } \\
\text { exploration, Minister of Manpower, Minister of Health, } \\
\text { Minister of National Education, Ministry of Religious } \\
\text { Affairs, Minister of Settlement and Territorial } \\
\text { Development } \\
\mathbf{1 3 ~ S t a t e M i n i s t e r s : ~ M i n i s t e r ~ o f ~ R e s e a r c h ~ a n d ~} \\
\text { Technology, Minister of Cooperatives, Small and } \\
\text { Medium Enterprises, Minister of Environment, } \\
\text { Minister of Regional Autonomy, Minister of Tourism } \\
\text { and Arts, Minister of Investment and State Enterprises } \\
\text { Development, Minister of Youth Affairs and Sports, } \\
\text { Minister of Public Works, Minister of the } \\
\text { Empowerment of Women, Minister of Human Rights } \\
\text { Affairs, Minister of Transmigration and Population, } \\
\text { Minister of State Administrative Reform, Minister of } \\
\text { Social Affairs }\end{array}$ & $\begin{array}{l}\text { Cabinet Reshuffle: } 23 \text { August } 2000 \\
\text { 26 Ministers consist of: } \\
\text { 2 Coordinating Ministers: Minister for Political, } \\
\text { Social and Security Affairs, Minister for the } \\
\text { Economy } \\
\text { 17 Ministers: Minister of Home Affairs and } \\
\text { Regional Autonomy, Minister of Foreign Affairs, } \\
\text { Minister of Defense, Minister of Finance, } \\
\text { Minister of Religious Affairs, Minister of } \\
\text { Agriculture, Minister of National Education, } \\
\text { Minister of Health and Social Welfare, Minister } \\
\text { of Transportations and Telecommunications, } \\
\text { Minister of Manpower and Transmigration, } \\
\text { Ministry of Industry and Trade, Minister of } \\
\text { Energy and Mineral Resources, Minister of } \\
\text { Justice and Human Rights Affairs, Minister of } \\
\text { Settlement and Regional Infrastructure, Minister } \\
\text { of Culture and Tourism, Minister of Maritime } \\
\text { Affairs and Fisheries, Minister of Forestry and } \\
\text { Plantations Minsters: Minister for Women } \\
5 \text { State Ministers } \\
\text { Empowerment/Chairperson of the National } \\
\text { Family Planning Board, Minister of } \\
\text { administrative reforms, Minister for } \\
\text { Cooperatives and Small/Medium Enterprises, } \\
\text { Minister for the Environment, Minister for } \\
\text { Research and Technology } \\
2 \text { Junior Ministers: Minister of the Acceleration } \\
\text { of Development in Eastern Indonesia, Minister } \\
\text { of National Economic Restructuring } \\
\text { **in February } 2001 \text {, the Minister of Justice and Human } \\
\text { Rights affairs and the state minister of administrative } \\
\text { reforms were replaced; the same is for the Minister of } \\
\text { Forestry and Plantations in March } 2001 \text {. } \\
\text { Cabinet Reshuffle: } 1 \text { June } 2001 \text { whe the same as the Cabinet } \\
\text { The formation of Minister was the } \\
\text { formation of } 23 \text { August } 2000 ; 26 \text { Minister and consist of } 2 \\
\text { Coordinating minister, } 17 \text { Minister, } 5 \text { state minister, and } 2\end{array}$ \\
\hline
\end{tabular}

${ }^{650}$ Article 14 of the Legislation 38/2008 (Appendix 4)

${ }^{651}$ In the President SBY administration, the state ministry is established and organized in the Presidential Rules No. 47/2009. In line with the Legislation No. 38/2009, the President established 34 state ministries. 
Rosa Ristawati: Modelling Executive Powers in the Indonesian Constitution: A comparative Study

\begin{tabular}{|c|c|c|}
\hline & & $\begin{array}{l}\text { junior ministers. However, the President Wahid } \\
\text { reshuffling the person in charges as Minister. }\end{array}$ \\
\hline $\begin{array}{l}\text { Megawati } \\
\text { Soekarnoputri } \\
(2001-2004)\end{array}$ & $\begin{array}{l}\text { Cabinet Formation: } 23 \text { July } 2001 \text { (Cabinet "Gotong Royong") } \\
\mathbf{3 0} \text { Ministers consists of: } \\
\text { - } \\
\text { 3 Coordinating Ministers: Minister for Political and } \\
\text { Security Affairs, Minister for Economic Affairs, Minister } \\
\text { for People's Welfares } \\
\text { - } \mathbf{1 7} \text { Ministers: of Home Affairs, of Foreign Affairs, of } \\
\text { Justice and Human Rights, of Defense, of Religious } \\
\text { Affairs, of National Education, of Health, of Finance, of } \\
\text { Trade and Industry, of Manpower and Transmigration } \\
\text { Minister, Agriculture, Forestry, Transportation, of } \\
\text { Energy, of Fisheries and Maritime Affairs, for } \\
\text { Resettlement and Regional Infrastructure, of Social } \\
\text { Affairs } \\
\mathbf{1 0} \text { State Ministers: Minister for Culture and Tourism, } \\
\text { Minister Research and Technology, Minister for } \\
\text { Cooperatives and Small-Medium Enterprises, Minister } \\
\text { for the Environment, Minister for Women's } \\
\text { Empowerment Affairs, Minister for Administrative } \\
\text { Reforms, Minister for the Acceleration of Development } \\
\text { of Eastern Indonesia, Minister/Head of the National } \\
\text { Development Planning Board, Minister for Revenues } \\
\text { and State Companies, Minister for Communication and } \\
\text { Information }\end{array}$ & There was no Cabinet reshuffle \\
\hline $\begin{array}{l}\text { Susilo Bambang } \\
\text { Yudhoyono } \\
(2004-2009)\end{array}$ & $\begin{array}{l}\text { Cabinet Formation: } \mathbf{2 1} \text { October } 2004 \text { (United Cabinet I) } \\
\mathbf{3 2} \text { Ministers and } \mathbf{3} \text { state executive officer consist of: } \\
\text { - } 3 \text { Coordinating Ministers: Minister for Political, Legal } \\
\text { and Security Affairs, Minister for People's Welfare, } \\
\text { Minister for the Economy } \\
\text { 19 Ministers: Minister of Home Affairs, Minister of } \\
\text { Foreign Affairs, Minister of Defense, Minister of Justice } \\
\text { and Human Rights, Minister of Finance, Minister of } \\
\text { Energy and Natural Resources, Minister of Industry, } \\
\text { Minister of Trade, Minister of Agriculture, Minister of } \\
\text { Forestry, Minister of Transportation, Minister of } \\
\text { Maritime Affairs and Fisheries, Minister of } \\
\text { Cooperatives, Small and Medium Enterprises, Minister } \\
\text { of Manpower and Transmigration, Minister of Public } \\
\text { Work, Minister of National Education, Minister of } \\
\text { Social Service, Minister of Religious Affairs, Minister of } \\
\text { Culture and Tourism } \\
\text { 10 State Minister: Minister for Research and } \\
\text { Technology, Minister for Cooperatives and Small } \\
\text { and Medium Enterprises, Minister for the } \\
\text { Environment, Minister for Women Empowerment, } \\
\text { Minister for Administrative Reform, Minister for } \\
\text { Acceleration of Development in Backwards Regions, } \\
\text { Minister for State Enterprises, Minister for } \\
\text { Information and Communication, Minister for Public } \\
\text { Housing, Minister for Youth and Sports Affairs } \\
\mathbf{3} \text { state executive officer: State Secretary, Secretary } \\
\text { Cabinet, Chief of the National Development Planning } \\
\text { Agency (Bappenas) }\end{array}$ & $\begin{array}{l}\text { Cabinet Reshuffle: } 5 \text { December } 2005 \\
\text { 33 Ministers and } \mathbf{9} \text { Executive officer; the Cabinet } \\
\text { formation consist of } \mathbf{3} \text { Coordinating Ministers, } \mathbf{1 9} \\
\text { Ministers, } \mathbf{1 1} \text { state ministers. The President also replace } \\
\text { some name of minister. } \\
\text { 19 Minister: Minister of Home Affairs, Minister } \\
\text { of Foreign Affairs, Minister of Defense Minister, } \\
\text { Minister of Finance, Minister Religious Affairs, } \\
\text { Minister of Agriculture, Minister Education, } \\
\text { Minister of Health, Minister Social Services, } \\
\text { Minister of Transportation, Minister of } \\
\text { Manpower and Transmigration, Minister of } \\
\text { Industry, Minister of trade, Minister of energy } \\
\text { and mineral resources, Minister of justice and } \\
\text { human rights, Minister of oublic housing, } \\
\text { Minister of forestry, Minister of maritime affairs } \\
\text { and fisheries, Minister of public work } \\
\mathbf{1 1} \text { state ministers for:Minister of Culture and } \\
\text { Tourism, Minister for Women Empowerment, } \\
\text { Minister for Administrative Reforms, Minister } \\
\text { for State Enterprises, Minister of National } \\
\text { Development Planning/National Development } \\
\text { Planning Board chairman, Minister for } \\
\text { Cooperatives and Small and Medium } \\
\text { Enterprises, Minister for the Environment, } \\
\text { Minister Research and Technology, Minister for } \\
\text { Information and Communication, Minister for } \\
\text { Development of Disadvantaged Regions, } \\
\text { Minister of Youth and Sports Affairs. }\end{array}$ \\
\hline & & $\begin{array}{l}\text { Cabinet Reshuffle: } 7 \text { May } 2007 \\
\text { Cabinet formation was the same as previous formation. } \\
\text { However, the President reshuffle some ministers such as; } \\
\text { Ministry for coordinating economic, Ministry of home } \\
\text { affairs, ministry of Justice and Human rights, Minister of } \\
\text { Information and Communication, Minister for } \\
\text { Disadvantaged Regions }\end{array}$ \\
\hline
\end{tabular}




\begin{tabular}{|c|c|c|}
\hline $\begin{array}{l}\text { Susilo Bambang } \\
\text { Yudhoyono } \\
(2009-2014)\end{array}$ & $\begin{array}{l}\text { Cabinet Formation: } 21 \text { October } 2009 \text { (United Cabinet II)* } \\
34 \text { Ministers consist of } 3 \text { Coordinating Ministers, the State } \\
\text { Secretary, } 20 \text { Minister, and } 10 \text { State Minister** }\end{array}$ & $\begin{array}{l}\text { Cabinet Reshuffle: } 18 \text { October } 2011 \\
\text { The Cabinet formation is the same as previous formation. } \\
\text { However, the President replaced and substituted } 7 \\
\text { ministers. The President also changed } 2 \text { nomenclature and } \\
\text { function of the ministry; the Ministry of National education } \\
\text { into the Ministry of education and Cultural; the Ministry of } \\
\text { Tourism and Cultural into the Ministry of Tourism and } \\
\text { Economic Creative. }\end{array}$ \\
\hline
\end{tabular}

*The Cabinet Formation is based on the Law No. 38/2008 as it has been enacted.

**The Cabinet formation is confirmed by the Presidential Rules No. 47/2009 on the establishment and organization of state Ministry

\section{Changing and Reshuffling the Cabinet}

Article 17 section (4) of the Constitution stipulates that the establishment, alteration, and dissolution of the state ministries are set out in the Law. To this extent, the provision is a constitutional basis for the President to reshuffle and modify the formation of a cabinet. In accordance with the Constitution, the Legislation 38/2008 emphasizes that the President has the power to modify, reshuffle the ministry of the state or the cabinet as a whole. However, the Law has put a significant limit in how the President can reshuffle and modify the cabinet;

1. According to Article 17, the President could not change the three ministries as determined in Article 12 of the Law (the Ministry of foreign affairs, the ministry of home affairs, and the ministry of defense). However, the provision only implies the existence and the name of those three ministries but does not apply to the reshuffle of ministers. To this extent, the President can freely reshuffle ministers.

2. According to Article 18, the President could change and reshuffle the ministers as determined by article 13 and Article 5 section (2) and section (3). Those ministers are the minister of religion, law, financial, state security, human rights, education, culture, health, social, labor, industry, trade, mining, energy, public work, transmigration, transportation, information and communication, agriculture and plantation, forestry, animal husbandry, marine and fisheries, national development planning, state apparatus, state secretariat, state-owned company, land, population, environment, science, technology, investment, cooperation, small and medium enterprises, tourism, woman empowering, sports, housing and construction area or disadvantaged area. To 
an extent, the article implies that the President can reshuffle, replace, switch or modify the name of a ministry, the functions, and/or the ministers/ the person.

3. The president could reshuffle the cabinet only in certain considerations of efficiency and effectiveness, or on the basis of a change in the duties and functions and development, or on the basis of the scope of duties and workload proportions, implementation sustainability, equality, the integration of the scope of works, improvement of government performance, an urgent forward planning for government, or on the basis of synchronization and system adjustment.

4. A ministerial merger, is executed with the DPR's consideration. Consideration is given at least 7 days after the President's letter has been received by the DPR. In case the consideration is not given within 7 days, the DPR is assumed to have confirmed it.

\section{Cabinet and Ministry Dissolution}

Article 17 section (4) gives a constitutional basis for ministerial dissolution. This article does not focus on the dissolution of a whole cabinet but a ministerial department. In accordance with the constitution, Article 13 of the Law stipulates that the President's power to dissolve a ministry is only for certain ministeries. To dissolve a ministry, the President has to ask the DPR's consideration; instead of for the minister of religion, Justice, finance, and defense. ${ }^{652}$ Meanwhile, the President could not dissolve the three ministries of foreign affairs, home affairs, and defense since the three ministeries are the main ministries according to the Constitution. ${ }^{653}$

\section{Presidential Cabinet, coalition, and Checks against the cabinet appointment power}

In a presidential system, the Cabinet is in the executive branch. It is a significant element to support the President's program. The President is the supervisor of the ministers in the Cabinet. The President, as manager, is accountable for their performance by controlling the

\footnotetext{
${ }^{652}$ According to article 21 legislation 39/2008.

${ }^{653}$ According to article 20 legislation 39/2008 (Appendix 5).
} 
cabinet bureaucracy in order to influence public policy and meet public expectations. ${ }^{654}$ One of the mechanisms to control the cabinet bureaucracy is by conducting a fit and proper test to have the best, professionals, and ministers of integrity. A minister's appointment is a mechanism to design and create a bureaucracy that will support the President. ${ }^{655}$ Although it has a political sense, the ministers have to be independent from particular political interest. During the office, ministers are not representing political parties. The ministers are appointed according to their professionalism and their expertise.

To have a professional ministerial cabinet, the President is given a right to establish, nominate, and appoint ministers. However, although the constitutional text and practice in Indonesia gives rights to the President, it does not imply that the President could freely exercise the right. In Indonesia, the DPR is not in charge of the appointment and dismissal of a minister. However, in terms of ministerial appointment, the President should really pay attention to the DPR's opinion even though such opinion has no binding character and does not impose upon the President. The DPR may control the Cabinet only with regard to the ministerial state budget and number of ministers. ${ }^{656}$ To this extent, the DPR could be regarded as the co-state administrator in which the DPR has the right to confirm the President's power in establishment and dissolution of a ministry in the Cabinet. ${ }^{657}$

To this extent, the cabinet formation politics were therefore much more than a matter of devising acceptable compromises between parties on policies and interests. ${ }^{658}$ In fact, the political parties interest involved in the cabinet formation may potentially create a cabinet weakness and further, will lead to governmental instability. In almost all regimes of Indonesian

\footnotetext{
${ }^{654}$ David E. Lewis, Presidents and the politics of agency design: political insulation in the United States government Bureaucracy, Stanford California: Stanford University Press, 2003, p. 4.

${ }^{655}$ Nolan McCarty and Rose Razaghian, "Advice and Consent: Senate Responses to Executive Branch Nominations 1885- 1996", American Journal of Political Science, Vol. 43, No. 4 (Oct., 1999), pp. 1122-1143, p. 1122 (accessed 9/1/2012): "The strategy of centralization and politicization of the executive branch is designed to create a bureaucracy that is sympathetic and supportive of the president's agenda. One of the most important mechanisms used to this end is political appointment".

${ }^{656}$ Jimly Asshiddiqie, Konstitusi dan Konstitusionalisme, Jakarta: Konstitusi Press, 2005, p. 61.

${ }^{657}$ Id. at p. 180

${ }^{658}$ Herbert Feith, Op. Cit., p. 172.
} 
Presidents, the ministers' appointment always deals with political intrigues. The weakness factors so far are mostly because such an appointment is not merely a constitutional process but more about a political bargaining matter. The President is always under pressure by political parties and bound by parties' coalition commitments. At this point, the policy and the minister appointments may only be a moral duty for the President to give a significant position in the government system, in particular to the political parties which have supported the President in the coalition parties before, during, and after the election process.

\section{The President, the Ministers, and the policy making}

In Indonesian history, the ministers' roles have greatly influenced long term policy; not only in particular new and administratively fluid ministries but also in some older ones. Ministers could play a virtual role and make important decisions. ${ }^{659}$ Ministers could issue Minister Regulations on a wide range of subjects, sometimes without anyone outside their ministries knowing that a particular regulation had been made or what it involved. ${ }^{660}$ They could exercise a broad degree of discretion as regards the distribution of funds and the flows of patronage; they had considerable freedom in the matter of appointments and transfers. ${ }^{661}$ Accordingly, in the Indonesian presidential system, the actual chief executive is the minister and as a consequence, they are responsible to the President. ${ }^{662}$ The constitution sets a constitutional basis in Article 17 Section (3) that "a minister is in charge of a particular affair in the government". To this extent, in practical terms, the ministers are the highest chief of government in their particular domain. The ministers have authority to set policy in establishing government affairs particularly in their field even though their constitutional position is as the President's assistant. ${ }^{663}$

In elaborating the President's program for the five years of the President's office, the ministers have the authority to set policies. They should be separated from politics and should

\footnotetext{
${ }^{659} / d$. at p. 172.

${ }^{660} / d$. at p. 172

${ }^{661}$ Id. at p. 172.

${ }^{662}$ Jimly Asshiddiqie, Op. Cit., p. 172.

${ }^{663} / d$. at p. 174.
} 
not insert their political ideology into the policy they made. ${ }^{664}$ The policies are made in order to exercise the Law and administer government. In setting the policy, the ministers are empowered by legal competences to issue three products of legal regulation namely, the Ministerial Regulations (Peraturan Menteri/ Permen) ${ }^{665}$ which set technical guidelines in a particular field; the Ministerial Decree (Keputusan Menteri/Kepmen) which sets technical guidelines; and Ministerial instruction which sets particular technical and procedural guidelines for the institution internally. The argument of giving ministers the authority to issue legal products is that the ministers are in a very important position in administering government affairs; they are the chief in their department and exercise daily management in a particular sector. Another argument is that it is impossible and not efficient for the President to set a very detailed standard and guidelines with the Presidential Rules. It would lead to a concentration of powers in the hands of the President if every guideline should be set by the Presidential Rules. ${ }^{666}$ However, sometimes, practice shows some confusing contents between a Ministerial Regulation and a Ministerial Decree. ${ }^{667}$ It is assumed that both are laws with legal characteristics. However, as previously mentioned, all the technical policies must also be in line with the presidential policy. The President in this matter, as the chief of the ministers, sets guidelines through the Presidential Decree and the Presidential Directive that bind ministries.

In day-to-day administration, the ministers represent the President. On the other hand, the role of the ministers can also be very significant in the legislation process. ${ }^{668}$ Ministers are the key initiators for bills proposed by the President. In a joint discussion and a joint approval session of legislative process, a minister may be assigned by the President and represent him and execute his power to negotiate, bargain, and conclude the Bills. The Ministers are also in

\footnotetext{
${ }^{664} / d$. at p. 175.

${ }^{665}$ Article 8 section (2) Legislation 12/2011 stipulates that the Minister Rules, as long as ordered by the higher law or the law that was enacted under the authority are regarded as law and are legally binding (the law under the authority referred to particular government affairs based on law. In the explanation of article 8 of Legislation $12 / 2011$, the Minister Rules are defined as rules which are set by a Minister in order to administer particular government affairs.

${ }^{666}$ Jimly Asshiddiqie, Hukum Tata Negara dan Pilar-Pilar Demokrasi, Jakarta: Konstitusi Press, 2005, p. 119.

${ }^{667}$ Id. at p. 120

${ }^{668}$ Article 65 section 1 of the Legislation No. 12/2011.
} 
charge of framing the state development strategy for long-term, mid-term, and short-term state development planning. For this reason, also the ministers may initiate priority programs for the establishment of Legislation programs (PROLEGNAS) in the National Law System. In any case, the Ministers based on their specific subjects also have a significant role in drafting a Government Regulation as the Directive for implementing the Legislation. ${ }^{669}$ In certain situations, a Minister can propose a draft of Government Regulation aside from the Government Regulation that was set in the list plan.

\section{President's authority to issue other administrative regulations}

Beside the law-making power, the president also has authority to regulate by issuing a Presidential Decree and Presidential Directive. Both legal products of the President have administrative characteristics. Both are very technical in character. The legal scope of a Presidential Decree extends only for practical and formal procedures of the state administration. The substances of a Presidential Decree on particular formal issues cover the establishment of a government agency, the appointment of executive officers, the assignment of the vice president, and other practices and proceduresin running state administration and government affairs. ${ }^{670}$ On the other hand, the Presidential Directive is generally merely to give directions and guidelines to the government institutions under the President with the main purpose to conduct governmental affairs. ${ }^{671}$

8. The Establishment of the President's Advisory Council, President's office, independent agencies/ commission, and state agencies in supporting the role and duties of the President as the head of government and state administration

\footnotetext{
${ }^{669}$ Article 27 of the Legislation No. 12/2011 on the Establishment of the Laws.

${ }^{670}$ The Presidential Decree No. 3/2012 on Establishment of an evaluation team for synchronizing between the contract "karya" and the Mining contract; the Presidential Decree No. 1/2012 on the Membership of Indonesia government in the development centre-organization for economic cooperation and development; the Presidential Decree No. 2/2012 on the establishment of a state attorney in Tebing Tinggi, the state attorney in Negeri Lima Puluh and state attorney in Boroko. Those examples of the Presidential Decrees can be drawn that the legal characteristics of the Presidential Decrees are merely administrative in order to practically run the state administration and conduct governmental affairs; giving formally legal basis or establishment, dissolution, appointment, and other formal procedures.

${ }^{671}$ Examples for the Presidential Directive are the Presidential Directive No. 1/2012 on the Implementation and supervision on the Mining coal business; Presidential Directive No. 2/2012 on the Improvement of production of national petroleum; the Presidential Directive No. 17/2011 on the anticipation and the eradication action against corruption 2012; the controlling improvement in forest and land fires.
} 
The Amended Constitution grants the power of the President to establish an advisory council. Article 16 of the Constitution stipulates that the President may establish an Advisory Council which has duties to give advice and consideration to the President. Conversely, as the Council is under the President; it is responsible to the President. ${ }^{672}$

According to the Article, the Advisory Council has a constitutional role in the state administration by giving advice and consideration to the President. The advice and consideration is in terms of state administration power and the implementation of government affairs. ${ }^{673}$ Within the office, the advisory council consists of 8 members including the chief of the Advisory Council. ${ }^{674}$ To some extent, the Advisory Council consists of ex-ministers who have competences in their particular fields. In practice, each of the members has their own activities in order to give advice and consideration based on a particular field of expertise. However, unlike the ministers in the cabinet, the Advisory Council has no legal product and even though the advice has significance for the President, the advice and consideration have no binding character. The President is the decision maker. Although legally speaking the President should consider the advisers and recommendations given by the Council, the Council has a less significant role compared to ministers. According to Jimly Asshiddiqie, the Council functions seem to overlap with other state agencies' functions. ${ }^{675}$ However, the Council is expected to give the President a second opinion on government affairs. At this point, the Council should consist of members who have high experiences, capabilities, and high competences in their field.

\section{The Presidential Office and other state agencies}

The Constitution only explicitly mentions that the President is assisted by the state ministry and the advisory council. There are no provisions explicitly mentioning that the

\footnotetext{
${ }^{672}$ The Constitutional existence of the advisory council is emphasized by article 2 the Legislation No. $19 / 2006$.

${ }^{673}$ Article 4 and 5 of the Legislation No. 19/2006 gives a legal basis for the roles and functions the advisory council. In order to do so, the explanation of the Legislation is that the President may classify the area of the governmental affairs; including the political affairs, the defense and security affairs, the economic and financial affairs, and the state welfare.

${ }^{674}$ Article 7 the Legislation No. 19/2006.

${ }^{675}$ Jimly Asshiddiqie, Op. Cit., p. 184.
} 
President has the power to establish his office. However, in order to support the President's duties to cover all government affairs, according to the Presidential Regulation No. 3/2011, the President may create his own office. Article 2 of the Presidential Regulation emphasizes that the duty of the President's office is to carry out certain duties which are not covered by the ministerial organization and other governmental agencies. ${ }^{676}$

On the other hand, the President also has the powers that are delegated by Law, to establish state agencies. There are references to state agencies but no constitutional provision creating them or describing what they should look like. The framers may leave to the President the responsibility for designing the machinery of government, both what it would do and how it would do it. Article 4 of the Constitution may be a constitutional basis for the President to create agencies. ${ }^{677}$

It is not explicitly mentioned in which field the President may have the powers to set up an agency. However, the Constitution implicitly mentions the government affairs; which consist of foreign affairs and all domestic state administration including the local province administration (since Indonesia is a unitary state and the President is the highest and unilateral authority as the head of state and government). In order for the President to successfully carry out his administration, it is his responsibility to make sure the policies of the government are implemented effectively. To do so, he has the power to control the government administrative apparatus. He has the power to design administrative structures to maximize presidential duties whereas on the other hands the administrative bureau model should fit the budget.

The design of state agencies and their work can determine the success or failure of the President in running constitutional and electoral mandates; it reflects democratic impulses and pressures. ${ }^{678}$ The establishment of some state agencies requires the DPR's confirmation, which is usually by legislation; whereas, some agencies which are discretionally created by the

\footnotetext{
${ }^{676}$ The President's office consists of the President's private secretary, President's spokesman, International relations, Public relations, Political Communication, Law human rights and the corruption, collusion and nepotism eradication, social communication, food and energy, development and autonomy, climate change, publication and social aid and disaster documentation. Those President offices are coordinated and responsible to the Secretary Cabinet.

${ }^{677}$ Article 4 of the Indonesian Amended Constitution

${ }^{678}$ David E Lewis, Op. Cit., p. 4
} 
Rosa Ristawati: Modelling Executive Powers in the Indonesian Constitution: A comparative Study

President do not require the DPR's confirmation and were established by the Presidential Rules. Agencies created by the President are really under the President and function in supporting state administrative affairs. ${ }^{679}$

Figure 4. Design Institutional Choices under the Presidential government system
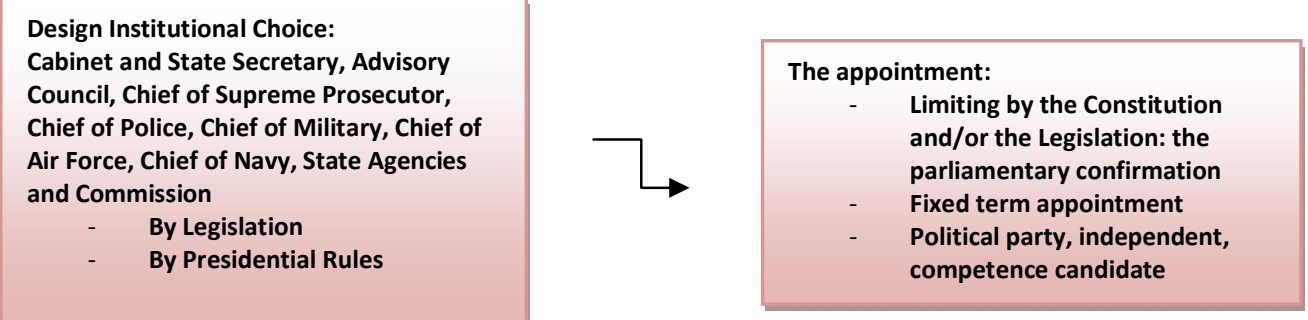

Table 4.5 Example of the Department agencies and the Non-department agencies

\begin{tabular}{|c|c|c|c|}
\hline $\begin{array}{l}\text { Executive } \\
\text { Agency }\end{array}$ & & Establishment & \\
\hline $\begin{array}{l}\text { Department } \\
\text { (under } \\
\text { ministerial } \\
\text { departments) }\end{array}$ & $\begin{array}{l}\text { - The Committee on the National Coordination on } \\
\text { the anticipation and the eradication of the Money } \\
\text { Laundering } \\
\text { - The National Committee on the transportation } \\
\text { safety } \\
\text { - The Committee on the defense industrial policy } \\
\text { - } \quad \text { The Commission on the bio safety product of the } \\
\text { genetic engineering } \\
\text { - The National Council and the Council of the special } \\
\text { economic } \\
\text { - National committee on the economic } \\
\text { - National committee on the innovation } \\
\text { - The National Council on information technology } \\
\text { and communication } \\
\text { The Committee on privatization of the company } \\
\text { The Committee on the direction development of } \\
\text { the special economic area in Batam, Bintan, and } \\
\text { Karimun Island }\end{array}$ & $\begin{array}{l}\text { - The Presidential Rule } \\
\text { No. } 6 / 2012 \\
\text { - } \quad \text { The Presidential Rule } \\
\text { No. } 2 / 2012 \\
\text { - The Presidential Rule } \\
\text { No. } 42 / 2010 \\
\text { - Presidential Decision } \\
\text { No. } 39 / 2010 \\
\text { The Presidential } \\
\text { Decision No. } 33 / 201 \\
\text { The Presidential } \\
\text { Decision No. } 31 / 2010 \\
\text { The Presidential } \\
\text { Decision No. } 32 / 2010 \\
\text { The Presidential Rule } \\
\text { No. } 20 / 2006 \\
\text { Presidential Decision } \\
\text { No. } 18 / 2006 \\
\text { Presidential Decision } \\
\text { No. } 12 / 2006\end{array}$ & $\begin{array}{l}\text { Consist of } \\
\text { the } \\
\text { Ministers } \\
\text { relevant to } \\
\text { and other } \\
\text { chief of } \\
\text { executive } \\
\text { agency } \\
\text { Consist of } \\
\text { the } \\
\text { ministers }\end{array}$ \\
\hline $\begin{array}{l}\text { Non- } \\
\text { department }\end{array}$ & $\begin{array}{l}\text { - The Geo-spatial Information Body } \\
\text { - The Commission of the state prosecutor } \\
\text { - } \quad \text { The National Coordination of the agricultural } \\
\text { consultation, fisheries, and forestry } \\
\text { - The National Drugs Body }\end{array}$ & $\begin{array}{l}\text { - The Presidential Rule } \\
\text { No. 94/2011 } \\
\text { - The Presidential Rule } \\
\text { No. } 18 / 2011 \\
\text { The Presidential Rule } \\
\text { No. } 10 / 2011\end{array}$ & $\begin{array}{l}\text { The non- } \\
\text { departmen } \\
\text { t agency } \\
\text { and } \\
\text { responsible } \\
\text { to the } \\
\text { President }\end{array}$ \\
\hline
\end{tabular}

${ }^{679}$ See: Table 4.5 


\begin{tabular}{|l|l|l||}
\hline$-\quad$ The National border management Body & $\begin{array}{l}\text { The Presidential Rule } \\
\text { No. } 23 / 2010 \\
\text { The Presidential Rule } \\
\text { No. } 12 / 2010\end{array}$ \\
\hline
\end{tabular}

\section{The state intelligence agency}

In Indonesia, the Law of 17/2011 on state intelligence makes clear the relationship between the President and the state intelligence office. Article 27 stipulates that the state intelligence is under and responsible to the President. ${ }^{680}$ The Legislation No. 17/2011 on the state intelligence clarifies that state intelligence is one of the important elements to support the Presidential emergency power. The state intelligence is an agency that supports the legitimate government in maintaining and running the state administration. Accordingly, the state benefits from its activities. The state intelligence provides a significant contribution to the President. The state intelligence agency may contribute to assess any threats; the agency can be the early warning for any threats against state security and state administration. The Legislation 17/2011 mentions the state intelligence agency as the first line in early detection and warning against any kind of threats, potential threats and actual threats. The agency is part of the integrated national security system, and is one of the elements in assessing and anticipating threats.

The hierarchical relationship between the President and the state intelligence agency can also be seen in Article 35 of the Legislation No. 17/2011. Article 35 of the Legislation stipulates that the chief of the state intelligence is appointed and dismissed by the President after receiving the consideration from the DPR. On the organization of the state intelligence agency, the DPR through the Legislation No. 17/2011 clearly has the function to check the intelligence activities. According to Article 41 of the Legislation, the DPR has supposedly approved and controlled the intelligence activities in the process of pre-approval of the state

\footnotetext{
${ }^{680}$ Article 27 the Law No. 17/2011, Article 42 of the Legislation stipulated that the state intelligence should make a written report to the President to report all the intelligence activities. However, against the activities of the state intelligence, the DPR as mentioned in Article 43 the Legislation No. 17/2011 has the power to over-see all activities of the agency. The check against the state intelligence can also be invoked as Article 41 of the legislation mentioned that the agency and all activities are financed by the state budget. By this means, the DPR has the power to approve or reject against the intelligence budget. Article 39 section of the Legislation also orders the state intelligence to report the coordinative activities to the President.
} 
budget proposed by the President. ${ }^{681}$ This means that the DPR needs to know all the state intelligence activities as the DPR has the power of the purse and approves the budget. The spending of the intelligence budget will be managed by the President through the minister of defense. However, not just controlling through the budgeting power, the DPR also has the authority to do external oversight. According to Article 43, the DPR has a special commission under its organization that has the duties to specially oversee the intelligence activities. Moreover, the DPR is also involved in the process of the appointment of the chief of the state intelligence. Article 36 of the Legislation has mentioned that the DPR has the authority to give consideration to the President in the process of appointment and dismissal of the chief of state intelligence. ${ }^{682}$ With regard to the Courts, the Indonesian Constitutional Court of decision no. 138/PUU-VII/2009 makes it possible for the Constitutional Court to review the executive order.

11. The appointment power: the judges, the chief of constitutional agency and the executive officers (the chief of police, the chief of Military, the chief of supreme public prosecutor, and other chiefs executive officers)

According to the Amended Constitution, the President has the power in theappointment of judges in the Supreme Court and in the Constitutional Court. ${ }^{683}$ For the Supreme Court's appointment, the President only has the power to formally appoint the Supreme Court judges while substantially, the power to nominate is in the hands of the Judicial Commission and the power to appoint is in the hands of the DPR. The formal appointment bythe President of the Supreme Court's judges reflects the function of the President as the head of state. It is also intended to preserve the Court's independence. With regard to theappointment of the Constitutional Court's judges, Article 24 A section 3, Article $24 \mathrm{C}$ section 3 mentions that the President not only has the power to formally appoint, but also has the power to nominate three judges among 9. ${ }^{684}$ The President in the appointment of the constitutional court judges represents the executive branch and reflects a democratic feature in the process. It also has the

\footnotetext{
${ }^{681}$ Article 41 of the Law 17/2011 (Appendix 5).

${ }^{682}$ Article 36 of the Law No. 17/2011 (Appendix 5).

${ }^{683}$ Article 24 A section 3 the Amended Constitution of Indonesia (Appendix 4).

${ }^{684}$ Article $24 \mathrm{C}$ section 3 the Amended Constitution of Indonesia (Appendix 4).
} 
purpose to maintain checks and balances between the three branches, the executive, the legislative, and the judiciary. The President, in the process does not just act as the head of state but acts as the executive branch.

Article 30 of the Constitution stipulates that the state defense and national security protection are established by means of the people's defense and security system with the National Military (the TNI) and the Republic of Indonesia Police as the main element and the people as a supporting element. The President has the power to appoint the chief of the Police with the DPR's approval. Article 11 the Legislation 2/2002 on the Republic of Indonesia Police legally stipulatesthat the President has the power to appoint and dismiss the chief of police. The appointment should be with the approval from the DPR. The proposal of appointment and dismissal together with the arguments and grounds of appointment are proposed by the President to the DPR. ${ }^{685}$ The formal procedure and formal appointment of the chief of the police is set by Presidential decision.

Moreover, the Article in section 3 and section 4 emphasizes the constitutional duties of the Indonesian National Military to defend, protect and maintain state integrity and sovereignty; while the Republic of Indonesia Police has duties to protect, serve, and enforce the law. According to both constitutional provisions, it is clear that both agencies have constitutional functions as the supporting agent for state interests and state affairs under the President's administration. According to Article 10 of the Constitution, the Constitution gives the President the highest power over the Army, the Navy, and the Air Force. The Constitution emphasizes that the military is under the command of the President. The President has the power to control and command the military and police. Furthermore, the President has the power to appoint and dismiss the chief of military force with approval from the DPR. ${ }^{686}$

In order to run the state administration, the state prosecutor as the government institution has the authority to represent the state before the Court. ${ }^{687}$ Since the function is part of the state administration, the President has the power to appoint and dismiss the chief

\footnotetext{
${ }^{685}$ Article 11 of the Law No. 2/2002 (Appendix 5).

${ }^{686}$ Article 13 of the Law No. 34/2004 on the Indonesian National Army (Appendix 5).

${ }^{687}$ Article 2 Law 16/2004 on the state prosecutor.
} 
Rosa Ristawati: Modelling Executive Powers in the Indonesian Constitution: A comparative Study

ofthe Supreme prosecutor. To this extent, the appointment brings the consequence that the state prosecutor is responsible to the President and the DPR. ${ }^{688}$

Table 4.6 The presidential appointment power under the Indonesian Amendment Constitution

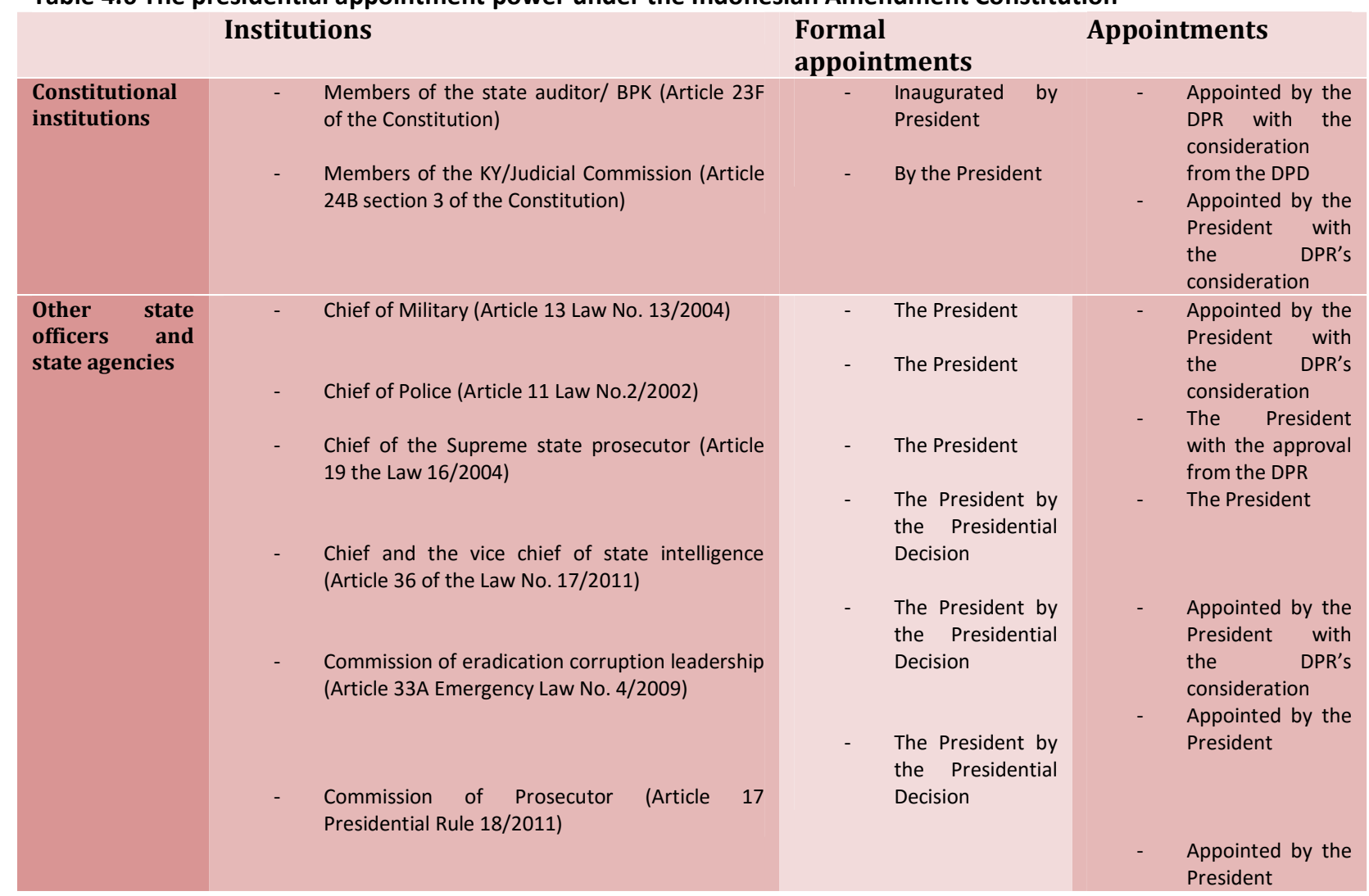

\section{Local government and autonomous government supervision}

Article 18 of the Amendment Constitution strongly confirms Indonesia as a unitary state. It means that the President is the national executive heading all executive departments including the local executive. However, there is no article in the Constitution clarifying that the President has the power to supervise and coordinate the local government since the Constitution only emphazises the autonomy and decentralization of the local government. The powers of the President as the head of government are implied in the Legislation on the Local Government. In practice, such powers are mostly delegated to the Minister of home affairs.

${ }^{688}$ Article 37 Law 16/2004 (Appendix 5). 
Scheme 3. The Presidential institutions within the Indonesian presidential system

\begin{tabular}{|c|c|c|c|}
\hline & THE PRESIDENT & & \\
\hline 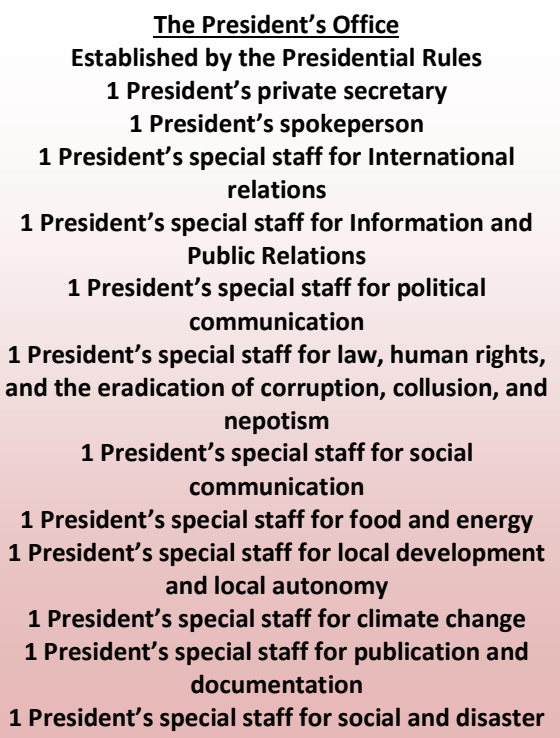 & $\begin{array}{c}\text { The Cabinet: Ministers } \\
\text { Established by the Legislation and the } \\
\text { Presidential Rules } \\
1 \text { Minister of State Secretary } \\
3 \text { Triumvirat Ministers of Minister of State } \\
\text { Defense, Minister of Foreign Affairs, } \\
\text { Minister of Home Affairs } \\
\text { Coordinator Ministers of Minister for } \\
\text { Political, legal and security affairs, } \\
\text { Minister for People's Welfare, Minister } \\
\text { for the Economy } \\
\text { Other Ministers and State Ministers }\end{array}$ & $\begin{array}{l}\text { The Advisory Council: } \\
\text { Established by the Legislation and the } \\
\text { Presidential Decision } \\
9 \text { Members of advisory expert on the } \\
\text { economic and environment, expert on } \\
\text { religions relationship, expert on the } \\
\text { education and cultural, expert on the } \\
\text { state development and autonomy, } \\
\text { expert on the International relation, } \\
\text { expert on governmental and } \\
\text { bureaucracy reform, expert on state } \\
\text { welfare, expert on legal and human } \\
\text { rights }\end{array}$ & $\begin{array}{c}\text { State Equipment and State } \\
\text { Apparatus } \\
\text { Established by the Legislation and } \\
\text { Presidential Decision } \\
\text { State equipment of Military } \\
\text { Force- Navy-Army-Air Force } \\
\text { State apparatus: the Republic of } \\
\text { Indonesia Police } \\
\text { Commission and Non-department } \\
\text { institution } \\
\text { State Agencies, Independent } \\
\text { Established by Legislation or } \\
\text { Presidential Decision } \\
\text { State Agencies - Independent } \\
\text { Commission - Non-department } \\
\text { institution - State Intelligence }\end{array}$ \\
\hline
\end{tabular}




\section{c. State budgetary and expenditure power}

\section{Constitutionality of the state budgetary and expenditure power}

Article 23 Section (1) the Third Amended Constitution stipulates that the state budget is annually set as Law and will be accountably and transparently implemented for the people's welfare. Moreover, Section (2) of the Article determines that the bill of state budget legislation is proposed by the President and discussed in a joint discussion with the DPR by also considering the opinion of the DPD.The President has the power to initiate the budget and make budget proposals to be submitted for joint discussion with the DPR. In joint discussion, the President and the DPR should also take the DPD's consideration. However, only the DPR has the power to give approval or disapproval of the state budget. Section 3 of the Article stipulates that in case the DPR does not approve the bill of state budget proposed by the President, the government should constitutionally refer to the previous state budget.

In general, the budgetary power is a shared and a dependent power. It is a shared power as the Article set in the Constitution explicitly stipulates that the President has the power to propose the state budget by proposing the bill of state budget to the DPR; while, the DPR as the decision maker, has the power to approve the budget. It shows that actually, the DPR is the actual holder of the power of the purse. This framework makes the President in the budget power depend on the DPR. Article 20A of the Second Amended Constitution emphasizes the DPR's functions over budgeting. Such a function is also confirmed by Articles 69 and 70 of the Legislation No. 27/2009. Article 70 Section 2 stipulates that the DPR's budgeting function covers the role of the DPR in a budgeting joint discussion and in giving approval or rejection to the budgetary Bill proposed by the President. Section 3 of the Article emphasizes that the DPR has oversight functions. The function of oversight is exercised in two mechanisms; the oversight of the law and the oversight of the budget usages (APBN). In addition, Article 71 of the Legislation No. 27/2009 specifies some of the DPR's duties and responsibilities in state budgetary:

1. Ask for the DPD's consideration of the bill of the state budgetary Legislation ${ }^{689}$

\footnotetext{
${ }^{689}$ Article 71 (f) Legislation No. 27/2009.
} 
2. Discuss in a joint session with the President by considering the DPD's comments ${ }^{690}$

3. Give approval to the bill of state budgetary Legislation proposed by the President ${ }^{691}$

4. Oversight of the implementation of the state budgetary (APBN) ${ }^{692}$

5. Discuss and follow up the result of this supervision (oversight) as reported by the DPD of the implementation of the state budget ${ }^{693}$

6. Discuss and follow up the result of the state budget management and the state budgetary responsibility completed by the $\mathrm{BPK}^{694}$

The President has the power to propose the draft of state budget law but, the Constitution is silent about the presidential expenditure power. The power to administer and manage the state administration implies that the President is given the expenditure power. The Law No. $17 / 2003$ is the legal basis for the expenditure power of the Indonesian president. It stipulates that the expenditure power and the power to manage the state finances belong to the President as the head of government; and such power is exercised for the state purpose and for the purpose of government functions. ${ }^{695}$ It is mentioned that the financial management and expenditure power are parts of the executive power in governmental affairs. In practice, according to Article 2 of the Legislation, the Presidential financial management and expenditure power is delegated to the Minister of Finances, other ministers and the chief of institution, the governor and local chief administration. The powers that are delegated do not include the authority to set monetary policy, such as issuing and circulating the money.

The power of the President is also confirmed in the explanation of the Legislation 17/2003. It is said that the budgetary power of the President as the head of government includes general authority and special authority. The budgetary power is partly delegated to the minister of finances. In this case, the minister of finances and other ministers are acting to assist the President in managing the fiscal policy and as the government representative in the

\footnotetext{
${ }^{690}$ Article 71 (g) Legislation No. 27/2009.

${ }^{691}$ Article 71 (g) Law No. 27/2009.

${ }^{692}$ Article 71 (h) Law No. 27/2009.

${ }^{693}$ Article 71 (i) Law No. 27/2009.

${ }^{694}$ Article 71 (n) Law No. 27/2009.

${ }^{695}$ Article 6 section 1 Law 17/2003 on the State Financial.
} 
state property ownership. The minister of finances is the assistant for the president, acting as a chief financial officer (CFO) of the Republic of Indonesia; while other ministers are acting as chief operational officer (COO) in particular government affairs. The fiscal affairs include functions to exercise a fiscal policy and the macro-economy, budget, tax administration, customs administration, the state treasury, and financial oversight. However, in local provincial government, the establishment of state administration is partially delegated from the President to the Governor.

Furthermore, the Law No. 1/2004 on the state treasury puts forward a legal basis for the establishment of state administration and management of the state budget and finances. Article 7 of the Law gives a position to the minister of finances as the state treasurer. According to the Law, there are 5 financial management tasks in the scope of spending; namely, management of the money, management of claims and debts, management of state investment, management of state property. With regard to state spending, the Minister on behalf of the state is legally responsible to organize state spending. Scopes in the area of state spending include that the government can spend the budget for (1) giving debts or grants to the local government, state corporations and/or local government corporations; ${ }^{696}$ (2) giving debts or grants to foreign foundations; ${ }^{697}$ (3) spending for state investment ${ }^{698}$ and spending of the state property management.

According to the Law, the Minister has the obligation to report the state budget spending to the President. ${ }^{699}$ The report from the minister of finances will be the basis for the President to deliver his accountability to exercise the spending power to the DPR. In exercising the expenditure power, although the President delegates the power to the Minister and the minister has daily delegation power to perform the state expenditure power, the President still acts to control and supervise the state expenditure budgetary. The President's supervision is

\footnotetext{
${ }^{696}$ Article 33 Law 1/2004 section (1).

${ }^{697}$ Article 33 Law 1/2004 section (2).

${ }^{698}$ Article 41 Law 1/2004 (Appendix 5).

${ }^{699}$ Article 55 section (1) of the Law No. 1/2004.
} 
through the government internal control system. ${ }^{700}$ However, the report should also be audited by the BPK.

\section{d. The Foreign affairs power}

There is no word of "foreign affairs" in the Amended Constitution. The framers did not clarify what is the scope of foreign affairs. However, the powers can be implied from Article 11 Section (1) and Section (2) and Article 13 Section (1) to Section (3) of the Third Amendment Constitution. According to these Articles, the powers include the power to declare war, to make peace, to conclude treaties with other countries, to make other international agreements, to appoint ambassadors and consuls, and to receive the accreditation of ambassadors of foreign nations. Furthermore, the powers can be classified into the war power, the treaty power, and the diplomatic power.

\section{War and peace power}

Article 11 Section (1) of the Third Amended Constitution grants the President the power to declare war on, and make peace with, other countries. ${ }^{701}$ According to this Article, the President should obtain the DPR's approval whenever he exercises the power. At this point, the war and peace power of the President are both shared powers since the President could not exercise the powers independently without any authorization from the DPR. The Constitution reflects that the President only has a formal power to decide and declare war or peace, but the real power is with the DPR since the DPR would be the decision maker. However, until now, there is still no experience of the war and peace power. The practice does not show any evidence on how the Indonesian President uses such power, how he invokes the DPR's approval, and how the DPR proceeds with its war/peace approval.

\section{Treaty power}

\section{The nature of the Treaty making power: constitutional perspective}

According to Chapter III, Article 11 Section (1) of the Third Amendment Constitution, the President has the power to conclude a treaty with other states by and with approval from the

\footnotetext{
${ }^{700}$ Article 58 section (1) of the Law No. 1/2004 (Appendix 5).

${ }^{701}$ Article 11 section (1) of the Amended Constitution of Indonesia (Appendix 4).
} 
DPR. ${ }^{702}$ Furthermore, section (2) of the article stipulates that the President in making other International agreements which have significant and fundamental impact for the people and an economic burden situation upon the state and International agreements which require an amendment to or the enactment of Law, should obtain approval from the DPR. ${ }^{703}$ From the systematic approach of constitutional interpretation, the Article explains that the treaty making power is basically in the boundary of executive power since article 11 is written in Chapter III, which deals with the executive power. Moreover, article 11 implies that the President, as the head of the state, is the sole institution representing the state to negotiate and conclude treaties. At this point, the President is the external representation since he constitutionally represents the state for external purposes of International relations. ${ }^{704}$ Such practice demonstrates that the President plays the main role in the treaty making process. However, inmore practical terms, the responsibility for the treaty making process rests in the hands of the government, particularly the foreign affairs minister, acting on behalf of the President. It is in accordance with international law where Article 7 (2a) of the VCLT stipulates that in virtue of their functions and without having produced full powers, the heads of state, heads of government and ministers for foreign affairs are considered as representing their State for the purpose of performing all acts relating to the conclusion of a treaty. ${ }^{705}$

According to political practice, the Indonesian foreign ministry has the duties to initiate and facilitate bilateral, regional and international agreements with other states and/or and International organizations. However, in doing so, the President may issue either a letter to delegate other parties in order to represent the government of the Republic of Indonesia in signing or accepting International agreements, declaring the state consent or consent to be bound or negotiating during the treaty making process. The President may also issue letters of accreditation to one or more persons in order to represent the government of the Republic of

\footnotetext{
${ }^{702}$ Article 11 section (1) of the Amended Constitution of Indonesia (Appendix 4).

${ }^{703}$ Article 11 section (2) the Amended Constitution of Indonesia (Appendix 4).

704 Luzius Wildhaber, Treaty-Making Power and Constitution: an International and Comparative Study, Schriftenreihe des Instituts fur Internationales Recht und Internationale Beziehungen, Helbig and Lichtenhahn, Basel und Stuttgart, 1971, pp. 15.

${ }^{705}$ Article 7 section (2a) VCLT.
} 
Indonesia to join, negotiate, and accept the result of an International agenda. ${ }^{706}$ According to Article 2 Law No. 24/2000 (Law on the International Agreement), the minister of the foreign affairs should have the competence to give advice, and political consideration. The foreign affairs minister also has legal competence to take any steps as needed in the treaty making process and the ratification process. However, such competency (in particularly treaty subject to the public interest) should be exercised only after consultation with the DPR. In practice, the minister of foreign affairs is the consultant and the coordinator of treaty initiatives. ${ }^{707}$

\section{Approval from the DPR}

Article 11 Section (1) of the Third Amended Constitution stipulates that the President, in the treaty making power, in particular treaties between states, should exercise the power by and with the DPR's approval. Meanwhile, Article 11 Section (2) mentions that the President should obtain the DPR's approval before making certain other international agreements (international agreements which potentially produce an extensive and fundamental impact on people's lives, influence the state financial burden, and/or international agreements which require an amendment to or enactment of a law. However, the Constitution does not clarify the mechanism for a treaty's approval. There is no article clarifying in what stages the mechanism of approval should be obtained (whether it is in the early stage of treaty negotiation or in the finalstage of the treaty making or whether it is applied in all stages of treaty-making process). The Article also lacks information about the specific issue of the treaty's transformation and how the treaty process relates to the dualistic nature of Indonesia.

A legislature's approval refers to the formal consent given by a legislature to an international agreement. Although, it is a necessary step in the procedure of treaty making, it does not inversely mean that without the approval, the treaty is not internationally binding. ${ }^{708}$

\footnotetext{
${ }^{706}$ The article 1 point 3 and 4 defines the full power letter and the credentials letter from the president in order to delegating the president's treaty power to one or some of civil servants to represent him in the treaty making process of negotiation, signature, and acceptance of the International agreement process.

${ }^{707}$ Article 5 section (1) the Law No. 24/2000 (Appendix 5): The article implies that though the President is the exclusive organ in the decision making of the treaty-making process, the initiative for making the treaty may come from other state organs or the central and local government organ (as Indonesia is a unitary state), as well as from the President.

${ }^{708}$ Luzius Wildhaber, Op. Cit., p. 79.
} 
To this extent, the DPR approval is a constitutional requirement for the treaty making power. In general, formal consent from the DPR is binding on the President. At this point the President cannot solely exercise the treaty power, but really needs the approval as an authorization to exercise the power.

The approval from the DPR is a constitutional requirement before the President exercises the treaty power. It means that the President could not conclude a treaty without the DPR's approval. The treaty making power appears to be a dependent power. The President could not independently exercise the power without the DPR's approval. Domestically, the word "approval" makes the DPR the key point in the treaty making power. To this extent, the President only acts as the state representation and has duties to negotiate in the treaty process. When strictly reading the treaty clause, it is clear that the Indonesian President will never make any treaty between states without the DPR's approval. Moreover, the Constitution confirms that the role of the DPR in treaty making power is not as a partner for the President. The relationship model between the President and the DPR is not a collaborative mode of action. Instead the Constitution actually vests the real treaty power to the DPR and the President depends on the DPR's approval. ${ }^{709}$ In practice there still often confusion between the DPR's approval and the mechanism to transform the treaty into domestic legal framework (as Indonesia adopts a dualism approach). The mechanism of approval that has been set in the DPR's Rules of Procedures (Part III, Article 197 - 199) implies that the approval or rejection may be given by a simple vote in a simple decision process. However, the rules do not give any direction on the indicators or reasonable grounds for the DPR to give approval or rejection since it is a matter of a policy decision.

While on the one hand obtaining the DPR's approval is a constitutional obligation for the President, the obscurity on the approval procedures creates loopholes for the exercise of the treaty power on the other hand. In practice, it made the President and the foreign minister dominate the whole treaty process. The Law even brought more confusion in practice since it is

\footnotetext{
${ }^{709}$ The preparatory work of amendment III of the constitution describes that the framers of the constitution intended to constrain the treaty making power of the president in order to minimize the possibility of abuses power by the President.
} 
contradictory to the Constitution. The Law No. 24/2000 contradicts the constitutional word "approval" in the treaty clause. The Law does not mention approval but only mentions the word "consideration" for certain treaties regarding the public interest. It sets a different term for a consultative role of the DPR in the treaty process and only the grounds of public interest. ${ }^{710}$ However, the Law has no explanation as to how the consultation should be and to what extent the consultation affects the President's decision to continue a treaty process. Ideally, if the treaty clause in the Amended Constitution is strictly read, the approval must be considered as a condition before the President ratifies a treaty. It is a constitutional requirement and has a binding character. The President should obtain the DPR approval before ratification. It is intended to anticipate a conflict between domestic law and international law and to avoid an incompatibility between treaties and the state's interest.

Scheme 4.

The DPR procedures based on Part III of the DPR's Rules of Procedures: approval for particular treaties in article 11 section 2 UUD NRI 1945

Article 197:

DPR gives approval on the transfer of

state assets andon the agreements

which have extensive and

fundamental impacts for the people

and relevant to the state finances
Article 199 Section (1):

The President submits the agreement through a letter to the Chief of DPR

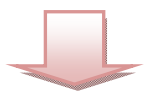

Article 199 Section (2):

The Chief of DPR reads the President's letter in the Plenary Session

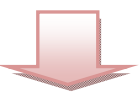

Article 199 Section (3):

The DPR deliberative body assigns the relevant committee to discuss with the government in terms of the given approval for the agreement

\footnotetext{
${ }^{710}$ Article 2, Law No. 24/2000 (Appendix 5): only mentions the consultative role of the DPR in case of the public interest that the treaty should be concluded.
} 
Treaties, the DPR's approval, and the process of transformation into the domestic legal framework

The Amended Constitution requires that all kinds of treaties between states concluded by the President should be approved by the DPR. As mentioned explicitly, the first section of article 11 of the UUD NRI 1945 must be interpreted that the President's treaty-making powers apply to all kinds of treaties, subject to public international law (treaties between states). At this point, section 1 clearly refers to a treaty between states subjected to public international law. In section 2, the constitution emphasizes the requirement of the DPR's approval for certain treaty categories including other international agreements between the state and International organizations. Certain treaties that require the DPR's approval are treaties which have extensive and fundamental impact for the state, treaties which require an amendment of Law, and treaties which may require a Law. ${ }^{711}$ According to the Article, the distinction between a treaty in section 1 and section 2 may refer to the parties which concluded the treaty. Section 1 refers to all treaties between states; whereas, section 2 refers to all treaties between the state and International organizations. However, such categorization seems to be excessive, ambiguous, and overlapping. Although both sections refer to specific treaties, both provisions potentially create an ambiguity. The Article only recognizes specific treaties and International agreements while it does not cover wide areas of other International agreements. A problem may occur when a treaty between states, with no significant priority for the public interest, needs to be concluded immediately; on the other hand, the DPR's approval must be required. According to the preparatory work of the Amended Constitution, the original intent of the treaty clause was to limit the Presidential power in treaty making. This is because before the Amendment Constitution, the President had quite often abused the treaty power, for example by making a bilateral treaty which actually contributed to the public debt. Practice shows that the President concluded a treaty without the DPR's approval. Moreover, the second section of the provision creates a potential conflict of interpretation. If a treaty between state and an

\footnotetext{
${ }^{711}$ Examples of the treaty, See: table 4.4.
} 
International organization does not meet the three criteria, the President may conclude such a treaty without approval from the DPR. At this point, the President may ignore the DPR and exercise the power independently. Furthermore, such a treaty will bind and impose Indonesia to implement thetreaty's obligations. However, when such a treaty is challenged because of being unconstitutional, it would not be easy for the President to withdraw from the treaty. From an International law perspective, once the President as the state representative has concluded a treaty, it would oblige the state to fulfill its obligations. The state could not easily waive its obligations, since the principle of "pacta sunt servanda" is applied for treaty compliance, and when the state does not fulfill the treaty obligation, it would be considered as an unlawful violation of the treaty's obligation. ${ }^{712}$ With regard to treaty compliance, the President and executive officials are largely responsible for abiding by treaties. ${ }^{713}$ It is the President's duty, as the head of government, to make sure that treaty obligations are implemented and executed. At this point, treaty implementation is the executive power of the President.

The adoption and transformation of a treaty into the domestic legal framework is one of the mechanisms to enable a treaty to be applied in the domestic legal system. Since Indonesia adopts a dualist system, a treaty cannot be automatically applied and cannot automatically have domestic legal effect. ${ }^{714}$ To this extent, treaty transformation and the treaty making power should be viewed as distinct mechanisms.

Moreover, when the treaty has been transformed into Legislation, the President as the executive has to make sure to implement the Legislation. For the Presidential Rules on treaty transformation, the President should submit such a Presidential rule to the DPR in order for it to be scrutinized. Treaties that should be transformed by Legislation are classified in Article 10 of Legislation No. 24/2000; those treaties are in certain areas of (1) political matters, peace, state security and defense, (2) territorial change or demarcation of state territory, (3) state

\footnotetext{
${ }^{712}$ Monica Claes, The National Court's Mandate in the European Constitution, Hart Publishing Oxford and Portland, Oregon, 2006, pp. 495.

713 Id. p. 239.

${ }^{714}$ It is the author's opinion to describe that Indonesia is a dualist system when it comes to treaties and International agreements.
} 
Rosa Ristawati: Modelling Executive Powers in the Indonesian Constitution: A comparative Study

sovereignty or state sovereignty rights, (4) human rights and the environment, (5) the establishment of new legal principles, and (5) International loans and grants. On the other hand, the explanatory annex to article 11 section (1) of the Legislation specifies treaty categories as (1) technical treaties that require a transformation; (2) have a procedural character and need to be urgently implemented without giving effect to the national legislation framework are transformed into the Presidential Rules. ${ }^{715}$ Such treaties are, e.g. treaties concerning science and technology, economic, trade, culture, the shipping and trade, taxation, investment cooperation, and other technical treaties.

\footnotetext{
${ }^{715}$ Examples of the treaty, see: table 4.7.
} 


\section{Scheme 5}

\section{Treaty making process and its transformation into the domestic legal system}

President
Power to negotiate
and to sign a Treaty

\section{$\underline{\text { DPR }}$ \\ Giving approval by simple vote after signing stage}
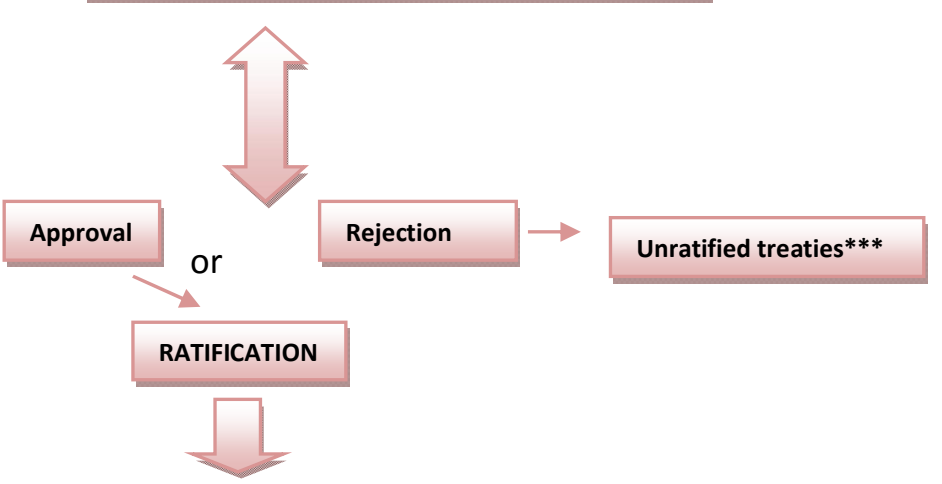

Ratified treaties****

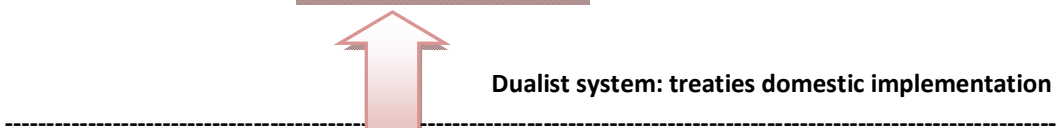

Transformation into domestic legal system

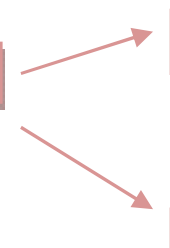

By Laws

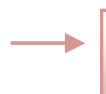

Legislation process

DPR - PRESIDENT

$\downarrow$

COLLABORATION RELATION

$\downarrow$

Joint approval

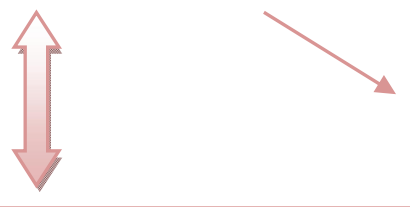

By Presidential

Law - making

process

JUDICIAL REVIEW*****

Constitutional Court ----- Laws transforming treaties

Supreme Court ---- Presidential Decree transforming treaties

\section{Note:}

*The President - the DPR relationship in treaty making power is a non-collaborative relationship. The President is a sole organ exercising his/her power in treaty making; the DPR only gives approval and does not need to be in session with the President in the treaty making process.

**Treaties between states and/or treaties between International organizations.

*** Treaties which have not been approved by the DPR should not be ratified. The President should guarantee that the treaties stage will not be continued to the ratification stage and thus, will never be at ratification stage. By this mean, the Presidential treaty power is constitutional

**** Treaties approved by the DPR will continue to the ratification stage. By this means, the Presidential treaty power is constitutional. However, for treaties rejected by the DPR if the process is still continued to the ratification process, the process will be unconstitutional. Therefore, the Presidential treaty making power in this case is unconstitutional.

$* * * * *$ The constitutional court will review the constitutionality of the Law contained in the draft of the ratified treaty. On the other hands, the Supreme Court will review the legality of the Presidential Decree containing the draft of a ratified treaty. 
Rosa Ristawati: Modelling Executive Powers in the Indonesian Constitution: A comparative Study

Table 4.7 Example of treaties transformed by the Presidential Rules (2004 - 2011)

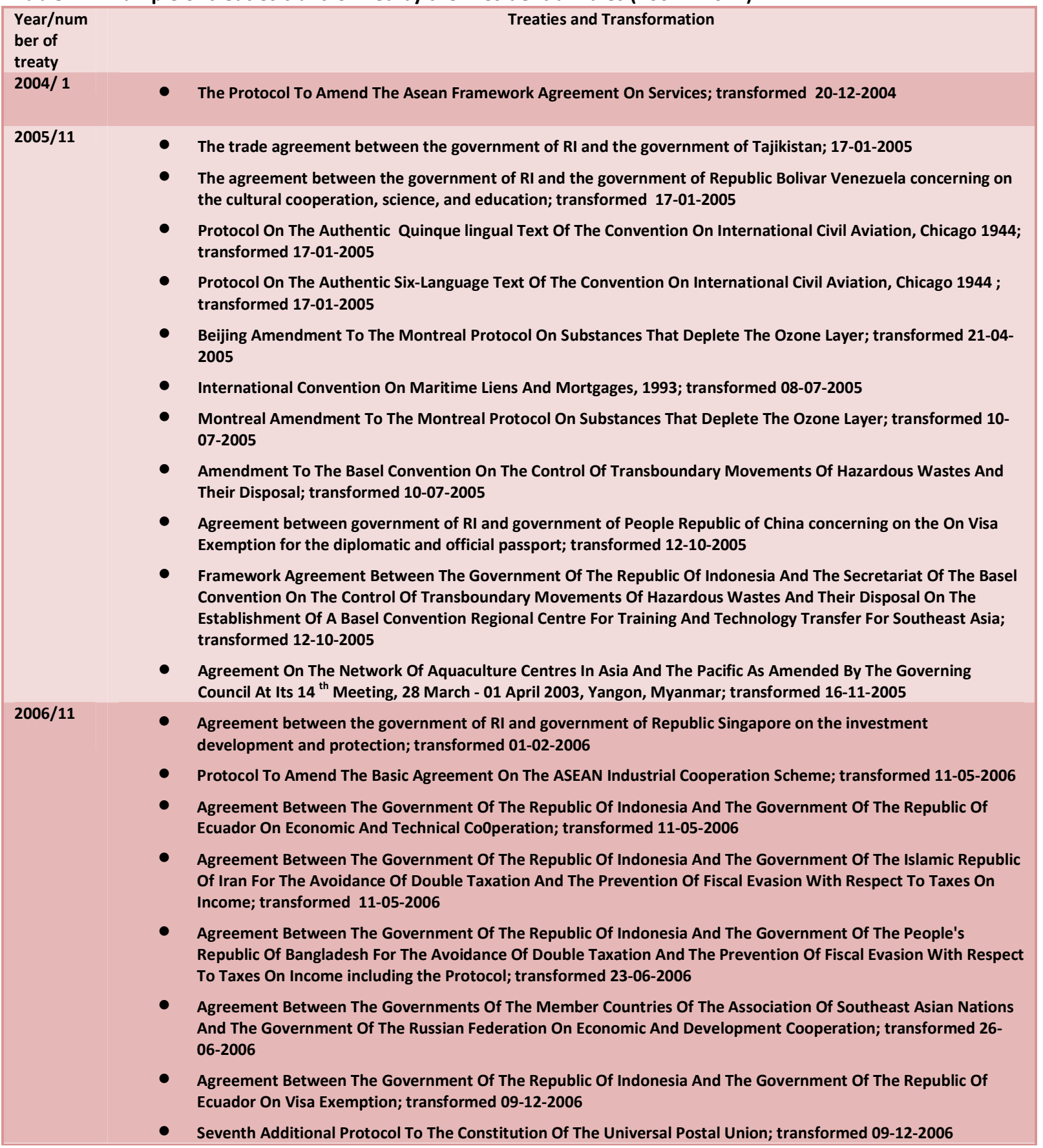




\section{Rosa Ristawati: Modelling Executive Powers in the Indonesian Constitution: A comparative Study}

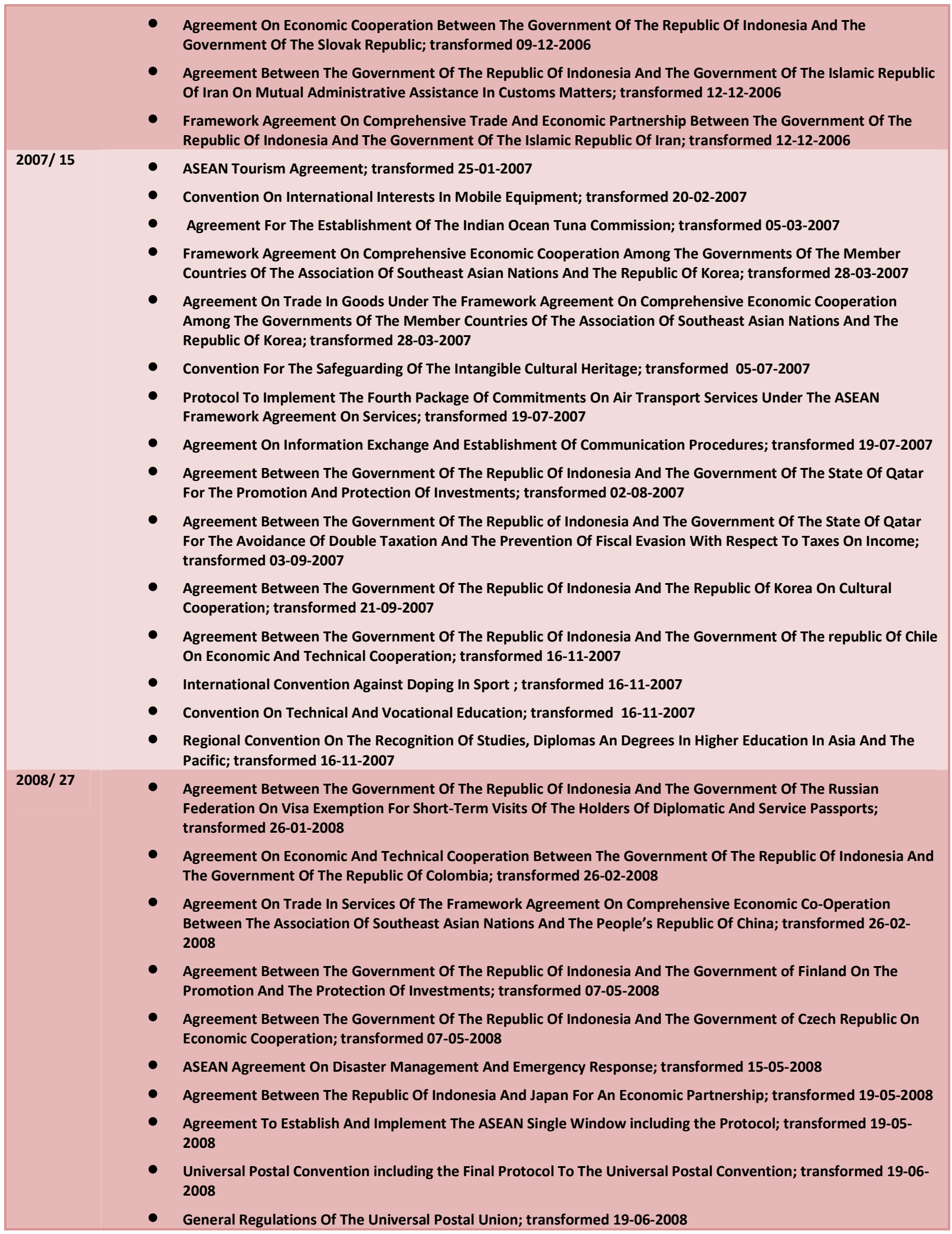




\section{Rosa Ristawati: Modelling Executive Powers in the Indonesian Constitution: A comparative Study}

- Postal Payment Services Agreement; transformed 19-06-2008

- Protocol To Implement The Third Package Of Commitments On Financial Services Under The ASEAN Framework Agreement On Services ; transformed 31-07-2008

- Protocol To Implement The Fourth Package Of Commitments Under The ASERAN Framework Agreement On Services; transformed 31-07-2008

- Multilateral Agreement Among D-8 Member Countries On Administrative Assistance In Custom Matters; transformed 28-08-2008

- Framework Agreement Between The Government Of The Republic Of Indonesia And The Government Of The Islamic Republic Of Pakistan On Comprehensive Economic Partnership; transformed 28-08-2008

- Statute Of The International Institute For The Unification Of Private Law; transformed 02-09-2008

- Agreement Between The Government of The Republic Of Indonesia And The Austrian Federal Government On Visa Exemption For Holders Of Diplomatic And Service Passports; transformed 02-09-2008

- International Coffee Agreement 2007; transformed 19-10-2008

- Agreement Between The Government Of Indonesia And The Government Of The Federation Republic Of Brazil On Visa Exemption For Diplomatic And Official Or Service Passports; transformed 19-10-2008

- Memorandum Of Understanding On Establishing The ASEAN-Korea Centre Between The Member Countries Of The ASEAN And The Republic Of Korea; transformed 21-10-2008

- Agreement On Promotion And Reciprocal Protection Of Investment Between The Government Of The Republic Of Indonesia And The Government Of The Islamic Republic Of Iran; transformed 21-10-2008

- Agreement Between The Republic Of Indonesia And The Kingdom Of The Netherlands On Mutual Administrative Assistance For The Proper Application Of Customs Law And For The Prevention, Investigation And Combating Of Custom Offences; transformed 21-10-2008

- Agreement Between The Government Of The Republic Of Indonesia And The Government Of The Hellenic Republic On Cultural And Educational Cooperation; transformed 06-11-2008

- Agreement Between The Government Of The Republic Of Indonesia And The Government Of The United Mexican States On Educational And Cultural Cooperation; transformed 13-11-2008

- Agreement On Dispute Settlement Mechanism Under The Framework Agreement On Comprehensive Economic Cooperation Among The Governments Of The Member Countries Of The Association Of Southeast Asia Nations And The Republic Of Korea; transformed 30-12-2008

- Memorandum Of Understanding On The ASEAN Power Grid; transformed 30-12-2008

- International Tropical Timber Agreement, 2006; transformed 30-12-2008

2009/ 16

- Protocol to Implement The Fourth Package Of Commitments On Financial Services Under The ASEAN Framework Agreement On Services; transformed 05-03-2009

- Agreement between the Government of the Republic of Indonesia and the Government of the Rusian Federation on the Promotion and Protection of Investments; transformed 05-03-2009

- Protocol Amending the Agreement and Protocol Between the Republic of Indonesia and the Swiss Confederation for The Avoidance of Double Taxation With Respect To Taxes ON Income; transformed 05-03-2009

- Agreement Between The Government Of The Republic Of Indonesia And The Government Of The Republic Of Tunisia On Visa Exemption For Diplomatic And Service Passport; transformed 22-05-2009

- ASEAN Framework Agreement On Visa Exemption; transformed 22-05-2009

- ASEAN Framework Agreement For The Integration Of Priority Sectors; transformed 11-06-2009

- Agreement Between The Government of The Republic of Indonesia And The Government of The Republic Of Azerbaijan On Economic And Technical Cooperation; transformed 23-06-2009

- Agreement Between The Government of The Republic Of Indonesia And The Government of The Kingdom Of Denmark Concerning The Promotion And Protection Of Investment; transformed 23-07-2009

- Amendments To The Agreement Establishing The ASEAN Promotion Center On Trade, Investment And Tourism; transformed 05-08-2009

- Trade Agreement Between The Government of The Republic of Indonesia and The Government of The Republic of Uzbekistan; transformed 28-08-2009

- Agreement Between The Government of Republic of Indonesia And The Government Of Paraguay On Visa 


\title{
Rosa Ristawati: Modelling Executive Powers in the Indonesian Constitution: A comparative Study
}

\author{
Exemption For Diplomatic Official And Service Passports; transformed 28-08-2009
}

- Agreement Between The Government of The Republic of Indonesia And The Government of Azerbaijan On Visa Exemption For Diplomatic Official And Service Passports; transformed 28-08-2009

- Amendment to the Convention on the Physical Protection of Nuclear Material; Transformed 29-10-2009

- Agreement Between The Government of The Republic Of Indonesia And The Government Of The DemocraticSosialist Republic Of Srilanka On Visa Exemption For Holders Of Diplomatic And Official/Service Passport; transformed 19-11-2009

- Agreement On Comprehensive Economic Partnership Among Member States Of The Association Of SouthEast Asian Nation And Japan; transformed 19-11-2009

- Final acts of the plenipotentiary conference, Antalya, 2006; transformed 12-12-2009

- Agreement Between The Government Of The Republic Of Indonesia And The Government Of The Russian Federation On Cooperation In The Field Of The Exploration And Use Outer Space For Peaceful Purposes; transformed 05-01-2010

- ASEAN trade In goods Agreement; transformed 05-01-2010

- Memorandum Of Understanding Between The Government Of The Republic Of Indonesia And The Government Of The Russian Federation On Cooperation In Combating Terrorism; transformed 05-01-2010

- Intergovernmental Agreement On The Asian Highway Network; transformed 22 - 01-2010

- Protocol To Implement The Fifth Package Of Commitments Under The ASEAN Framework Agreement On Service; transformed 22-01-2010

- Proposed Amendment Of The Articles Of Agreement Of The International Monetary Fund To Enhance Voice And Participation In The International Monetary Fund and Proposed Amendment Of The Articles Of Agreement Of The Investment Authority Of The International Monetary Fund; transformed 08-02-2010

- Instrument For The Amendment Of The Constitution Of The International Labor Organization, 1997; transformed 18-03-2010

- Agreement On Investment Under The Framework Agreement On Comprehensive Economic Cooperation Among The Governments Of The Member Countries Of The Association Of South East Asian Nations And The Republic Of Korea; transformed 18-03-2010

- Protocol To Implement The Sixth Package Of Commitments Under The Asian Framework Agreement On Services; transformed 18-03-2010

- Agreement Between The Government Of The State Of Kuwait On Economic And Technical Cooperation; transformed 18-03-2010

- Protocol Amending The Agreement Between The Government Of The Republic Of Indonesia And The Government Of Malaysia For The Avoidance Of Double Taxation and The Prevention Of Fiscal Evasion With Respect To Taxes On Income And Its Protocol Signed At Kuala Lumpur On 12 September 1991; transformed 17-05-2010

- Agreement On Trade In Goods Under The Framework Agreement On Comprehensive Economic Cooperation Between The Association Of Southeast Asian Nations And The Republic Of India; transformed 15-06-2010

- Agreement Between The Government Of The Republic Of Indonesia And The Government Of The Slovak Republic On Visa Exemption For Holders Of Diplomatic Passports And Service Passports; transformed 17-06-2010

- Agreement Between The Government Of The Republic Of Indonesia And The Government Of The Republic Of Bulgaria On Visa Exemption For Holders Of Diplomatic And Service Passports; transformed 17-06-2010

- Agreement Between The Government Of The Republic Of Indonesia And The Government Of The Republic Of Bulgaria On Economic Cooperation; transformed 21-06-2010

- Agreement Between The Government Of The Republic Of Indonesia And The Government Of The Republic Of Peru On Technical And Economic Cooperation; transformed 19-07-2010

- Investment Support Agreement Between The Government Of The Republic Of Indonesia And The Government Of The United States Of America including the Implementing Arrangement Between The Government Of The Republic Of Indonesia And The Government Of The United States Of America Regarding Notification Procedures; transformed 19-07-2010

- Agreement On Trade In Services Under The Framework Agreement On Comprehensive Economic Cooperation Among The Governments Of The Member Countries Of The Association Of Southeast Asian Nations And The Republic Of Korea; transformed 30-08-2010

- Agreement On Investment Of The Framework Agreement On Comprehensive Economic Co-Operation Between 


\section{Rosa Ristawati: Modelling Executive Powers in the Indonesian Constitution: A comparative Study}

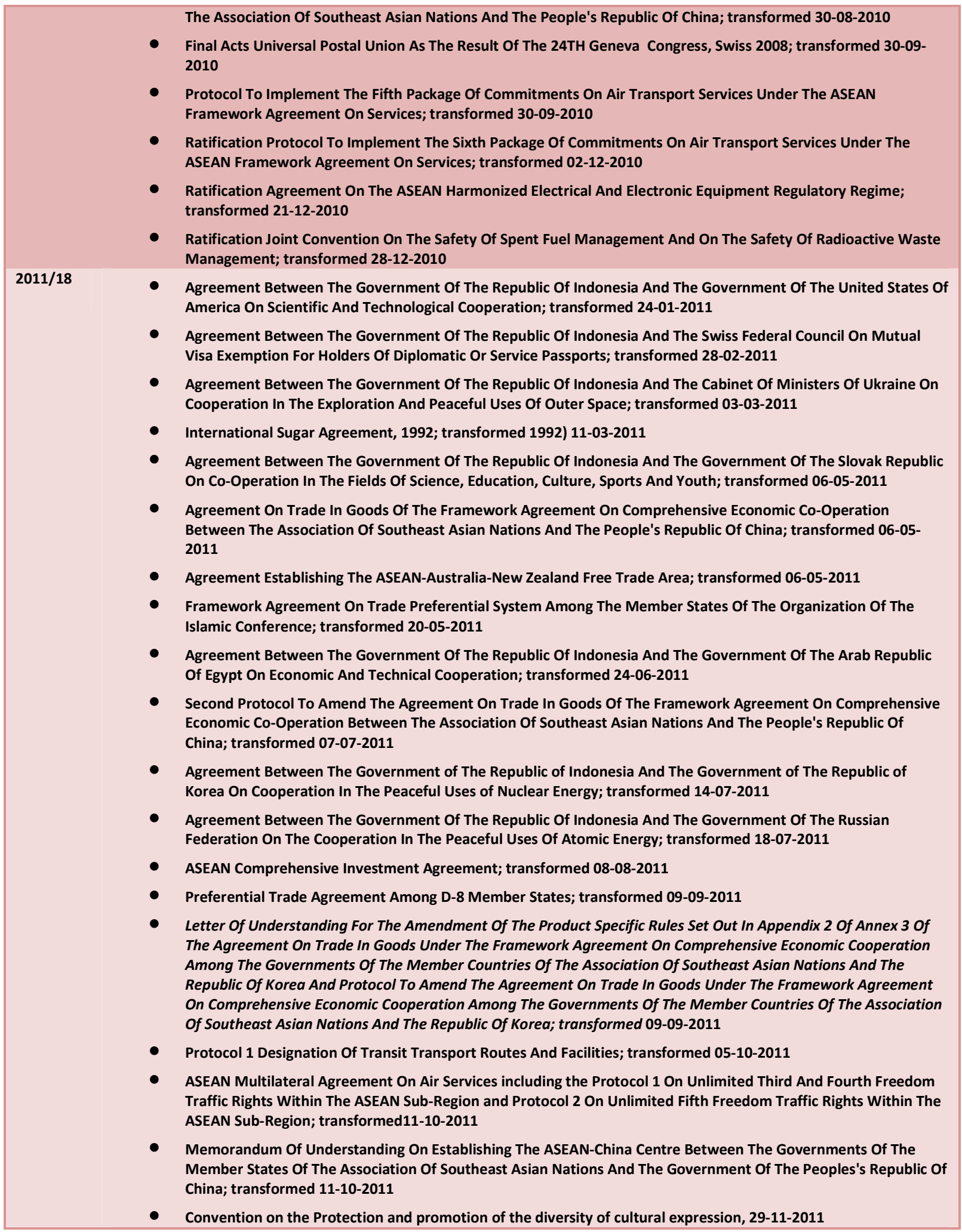


Rosa Ristawati: Modelling Executive Powers in the Indonesian Constitution: A comparative Study

- Agreement on recognizing the International Legal Personality of the International Rice Research Institute, 24-112011

- Third Protocol amending the treaty of amity and cooperation in Southeast Asia, 15-11-2011

- Agreement between the Republic of Indonesia and the ASEAN Inter-parliament on the speciality and immunity of the AIPA secretary in Jakarta, 5-12-2011

- Agreement between the Republic of Indonesia and Republic Islam Pakistan on the visa waiver for the official passport holder, 28- 12-2011

Table 4.8 Example Treaties transformed by Law

\begin{tabular}{|c|c|c|}
\hline $\begin{array}{l}\text { Year/number } \\
\text { of treaty }\end{array}$ & Treaties & Transformation \\
\hline $2004 / 2$ & $\begin{array}{l}\text { Kyoto Protocol To The United Nations Framework Convention On } \\
\text { Climate Change } \\
\text { Cartagena Protocol On Bio-safety To The Convention On Biological } \\
\text { Diversity }\end{array}$ & $\begin{array}{l}\text { Law No. } 17 / 2004,28-07-2004 \\
\text { Law No. } 21 . / 2004,16-08-2004\end{array}$ \\
\hline $2005 / 2$ & $\begin{array}{l}\text { - International Covenant On Economic, Social, And Cultural Rights } \\
\text { - International Covenant On Civil And Political Rights }\end{array}$ & $\begin{array}{l}\text { Law No. } 11 / 2005,28-10-2005 \\
\text { Law No. } 12 / 2005,28-10-2005\end{array}$ \\
\hline $2006 / 7$ & $\begin{array}{l}\text { - International Treaty On Plant Genetic Resources For Food And } \\
\text { Agriculture } \\
\text { - International Convention For The Suppression Of Terrorist } \\
\text { Bombings, } 1997 \\
\text { International Convention For The Suppression Of The Financing Of } \\
\text { Terrorism, } 1999 \\
\text { - United Nations Convention Against Corruption, } 2003 \\
\text { - Treaty Between The Republic Of Indonesia And The People } \\
\text { Republic Of China On Mutual Legal Assistance In Criminal Matters } \\
\text { Convention On The Prohibition Of The Use, Stockpiling, Production, } \\
\text { And Transfer Of Anti-Personnel, Mines, And Their Destruction } \\
\text { Agreement Between The Government Of The Republic Of } \\
\text { Indonesia And The Government Of The Republic Of India On } \\
\text { Cooperative Activities In The Field Of Defence }\end{array}$ & $\begin{array}{l}\text { Law No. 4/2006, 30-03-2006 } \\
\text { Law No. 5/2006, 05-04-2006 } \\
\text { Law No. 6/2006, 05-04-2006 } \\
\text { Law No. } 7 / 2006,18-04-2006 \\
\text { Law No. 8/2006, 18-04-2006 } \\
\text { Law No. 20/2006, 29-12-2006 } \\
\text { Law No. 21/2006, 29-12-2006 }\end{array}$ \\
\hline $2007 / 4$ & $\begin{array}{l}\text { - Agreement Between The Government Of The Republic Of } \\
\text { Indonesia And The Government Of The Socialist Republic Of } \\
\text { Vietnam Concerning The Delimitation Of The Continental Shelf } \\
\text { Boundary, } 2003 \\
\text { - Agreement between the government of RI and the government of } \\
\text { Republic Philippine on the cooperation defense and security } \\
\text { Treaty On Extradition Between The Republic of Indonesia And The } \\
\text { Republic Of Korea } \\
\text { Agreement Between The Republic Of Indonesia And Australia On } \\
\text { The Framework For Security Cooperation) }\end{array}$ & $\begin{array}{l}\text { Law No. } 18 / 2007,15-03-2007 \\
\text { Law No. 20/2007, 10-04-2007 } \\
\text { Law No. 42/2007, 23-10-2007 } \\
\text { Law No. 47/2007, 18-12-2007 }\end{array}$ \\
\hline $2008 / 3$ & $\begin{array}{l}\text { - } \quad \text { ILO Convention No. } 185 \text { Concerning Revising Seafarers' Identity } \\
\text { Documents Convention,1958 } \\
\text { - } \quad \text { Treaty On Mutual Legal Assistance In Criminal Matters } \\
\text { - } \quad \text { Charter Of The Association Of Southeast Asian Nations }\end{array}$ & $\begin{array}{l}\text { Law No. } 1 / 2008,04-01-2008 \\
\text { Law No. } 15 / 2008,30-04-2008 \\
\text { Law No. } 38 / 2008,06-11-2008\end{array}$ \\
\hline $2009 / 5$ & $\begin{array}{l}\text { - United Nations Convention Against Transnational Organized Crime } \\
\text { Protocol To Prevent, Suppress And Punish Trafficking In Persons, } \\
\text { Especially Women And Children, Supplementing The United } \\
\text { Nations Convention Against Transnational Organized Crime } \\
\text { Protocol Against The Smuggling Of Migrants By Land, Sea And Air, } \\
\text { Supplementing The United Nations Convention Against } \\
\text { Transnational Organized Crime } \\
\text { - Stockholm Convention On Persistent Organic Pollutants } \\
\text { Agreement For The Implementation Of The Provision Of The United } \\
\text { Nations Convention On The Law Of The Sea Of } 10 \text { December } 1982 \\
\text { Relating To The Conservation And Management Of Stradding Fish } \\
\text { Stocks And Highly Migratory Fish Stock }\end{array}$ & $\begin{array}{l}\text { Law No. 5/2009, 12-01-2009 } \\
\text { Law No. 14/2009, 05-03-2009 } \\
\text { Law No. 15/2009, 16-03-2009 } \\
\text { Law No. 19/2009, 11-06-2009 } \\
\text { Law No. 21/2009, 18-06-2009 }\end{array}$ \\
\hline
\end{tabular}




\begin{tabular}{|l|l|l|}
\hline 2010/ 2 Treaty Between The Republic Of Indonesia And The Republic Of & Law No. 4/2010, 22-06-2010 \\
Singapore Relating To The Delimitation Of The Territorial Seas Of & Law No. 6/2009, 27-08-2010 \\
The Two Countries In The Western Part Of The Strait Of Singapore, & Law \\
& 2009 \\
Memorandum Of Understanding Between The Government Of The & \\
Republic Of Indonesia And The Government Of His Majesty The & Sultan And Yang Di-Pertuan Of Brunei Darussalam On Defence \\
Cooperation &
\end{tabular}

\section{Diplomacy Power}

Article 13 section $(1)^{716}$ of the Amended Constitution stipulates that the President appoints ambassadors and consuls. Furthermore, section (3) of the Article states that the President receives the accreditation of ambassadors of other states. ${ }^{717}$ To exercise such powers, the President must take into account the consideration from the DPR. According to Law No. 31/1999 on the International Relations, the President has the power to establish International relations and to determine foreign policy. ${ }^{718}$ In practice, the President may delegate the powers to the minister of foreign affairs. ${ }^{719} \mathrm{He}$ may appoint state officials in addition to the foreign affairs minister, a government official, or others to maintain International relations in a particular field. ${ }^{720}$ In general, the diplomacy powers may be classified as an independent power. ${ }^{721}$ To exercise the power, the President only needs consideration from the DPR. The President is given an independent power to establish international relations.

On the other hand, the President has the power to establish and terminate diplomatic or consular relations with other states and an International organization membership. To exercise the power, the President is given an independent power as the decision maker but only after considering the opinion from the DPR. ${ }^{722}$ Furthermore, the President also has the

\footnotetext{
${ }^{716}$ Article 13 Section(1) the Indonesian Amended Constitution (Appendix 4); Article 13 section (2) the Amended Constitution of Indonesia (Appendix 4).

${ }^{717}$ Article 13 section(3) the Amended Constitution of Indonesia(Appendix 4).

${ }^{718}$ Article 6 section (1) Law No. 37/1999 (Appendix 5).

${ }^{719}$ Article 6 section (2) Law No. 37/1999(Appendix 5).

${ }^{720}$ Article 7 section (1) Law No. 37/1999 (Appendix 5).

${ }^{721}$ Diplomacy power of the President, , see: table 4.9.

${ }^{722}$ Article 9 section (1) Law No. 37/1999 (Appendix 5).
} 
Rosa Ristawati: Modelling Executive Powers in the Indonesian Constitution: A comparative Study

power to issue presidential rules to set up or shut down diplomatic or consular representative offices in other countries or a representative office for an international organization. ${ }^{723}$

Diplomacy powers may also relate to the power to appoint ambassadors and consuls. ${ }^{724}$ It may be grouped into the pre-appointment power which includes the selection, nomination, and formal appointment and the post-appointment power which includes ordering, commanding, and recommending the appointed ambassadors, controlling and monitoring the appointed ambassadors, or recalling the appointed ambassadors.

Procedures of Diplomacy power according to Article 165 the Law No. 27/2009

Scheme 6

Procedures of ambassadors and consuls appointment based on Law No. 27/2009 on MPR, DPR, DPD, and DPRD

Article 166 Section (1)

The President Submit names

of theambassador nominees

to the DPR
Article 166 Section (1):

The Chief of the DPR receives

the President nominees and

bring up to the Plenary

Session
Article 166 Section (2):

The Plenary Session will assign the Commission to discuss it confidentially
Article 168:

The DPR's consideration will be sent to the President confidentially by the Chief of DPR

\section{Scheme 7}

Procedures of the ambassadors and consuls appointment based on the DPR Rules of Procedures Part I: Propose, approve, or give consideration

Article 191 Section (1):

The DPR in giving consideration for a candidate, the plenary session assign the deliberative body to scheduling and assign the relevant Committee to discussing.
Article 193:

In order to giving the consideration/consultative the consideration/consultative are given by the

e Chief of the DPR together with the Chief of relevant

Committee and the chief of faction; instead of the

deliberative body determining differently. 

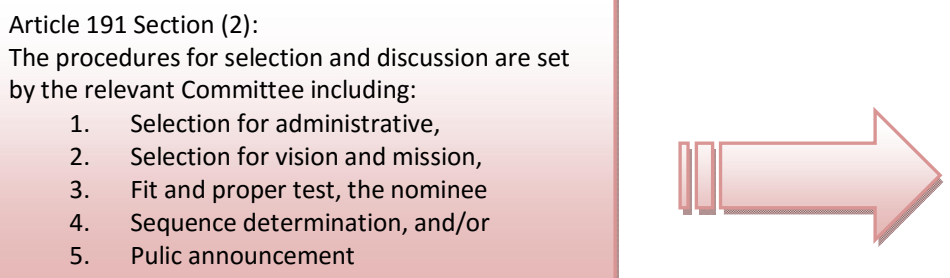

Article 192 Section (2):

The results of the Committee selection are reported to the deliberative body in order to be decided in the Plenary Session

Diplomacy powers also come from the Law. It allows the President (with the consideration of the DPR) to decide to send troops abroad or to join a peace keeping mission. ${ }^{725}$ The power also relates to the President's duty to protect the state and the people who are within the territory or who are outside Indonesia. The diplomacy power enables the president to assign a minister or state officer to coordinate and protect state security and its citizens. ${ }^{726}$ Moreover, the Indonesian President has the power to grant asylum to asylum seekers with the minister's consideration. ${ }^{727}$ He may issue a Presidential decision as a legal basis of asylum. With regard to refugees, the President, with consideration from the minister, has the power to make policy in order to deal with refugees from foreign states. ${ }^{728} \mathrm{He}$ may assign, through a presidential decision, another state officer who will have the same level as the state ambassadors. ${ }^{729}$ In special cases, the President has the power to give a credential letter to the special ambassador with the full power of the Republic of Indonesia for a country or international organization. In return, the President may receive a credential letter from another Head of state to appoint a special ambassador with full power for Indonesia. ${ }^{730}$ Moreover, the President signs the "Tauliah" letter for the Consulate General or Republic of Indonesia Consuls, who are appointed for consular duties in a certain territory in other countries; vice versa, the President receives the "tauliah" letter and issues the "ekse kuatur" of a Consulate General or a

\footnotetext{
${ }^{725}$ Article 10 Law No. 37/1999 (Appendix 5).

${ }^{726}$ Article 22 Law 37/1999; (Appendix 5).

${ }^{727}$ Article 25 section (1) and section (2) Law No. 37/1999 (Appendix 5).

${ }^{728}$ Article 27 section (1) Law No. 37/1999 (Appendix 5).

${ }^{729}$ Article 30 section (1) and section (2) Law No. 37/1999.

${ }^{730}$ Article 35 section (1) and section (2) Law No. 37/1999.
} 
Rosa Ristawati: Modelling Executive Powers in the Indonesian Constitution: A comparative Study

Consul who has consular duties in Indonesia. ${ }^{731}$ It also applies to honorary Consulate Generals or honorary Consuls of Republic Indonesia. ${ }^{732}$

Table 4.9 Presidential Diplomacy Power based on Law No. 37/1999 on the International Relations

\begin{tabular}{|c|c|c|c|c|}
\hline \multicolumn{2}{|c|}{ Diplomacy Powers } & \multirow{2}{*}{$\begin{array}{l}\text { PROVISION } \\
\text { Article } 6 \text { section (1) }\end{array}$} & \multirow{2}{*}{$\begin{array}{l}\text { DPR } \\
-\end{array}$} & \multirow{2}{*}{$\begin{array}{l}\text { PRESIDENT } \\
\text { Full power for the President }\end{array}$} \\
\hline • & $\begin{array}{l}\text { Establish the International } \\
\text { relations } \\
\text { perform the Republic Indonesia } \\
\text { political foreign policy }\end{array}$ & & & \\
\hline$\bullet$ & $\begin{array}{l}\text { appoint the state official in } \\
\text { addition to the foreign affairs } \\
\text { minister, the government } \\
\text { official, or others in order to } \\
\text { establish the foreign affairs } \\
\text { relation in particular field }\end{array}$ & Article 8 section (1) & - & Full power for the President \\
\hline • & $\begin{array}{l}\text { Establish and terminate the } \\
\text { diplomatic or consular relation } \\
\text { with other states; } \\
\text { membership and membership } \\
\text { withdrawal from the } \\
\text { international organization }\end{array}$ & Article 9 section (1) & Giving views & $\begin{array}{l}\text { President decides with the view from the } \\
\text { DPR }\end{array}$ \\
\hline - & $\begin{array}{l}\text { establish and; } \\
\text { shutdown the diplomatic or } \\
\text { consular representative office in } \\
\text { other countries or the } \\
\text { representative office in the } \\
\text { international organization }\end{array}$ & Article 9 section (2) & - & $\begin{array}{l}\text { Presidential decides with the Presidential } \\
\text { decree }\end{array}$ \\
\hline$\bullet$ & $\begin{array}{l}\text { send troops or } \\
\text { send the peace keeping mission }\end{array}$ & Article 10 & Giving views & \\
\hline - & $\begin{array}{l}\text { in terms of war or the } \\
\text { termination of the diplomatic } \\
\text { relation with other countries, } \\
\text { assigns the minister or the state } \\
\text { officer } \\
\text { coordinate effort for secure and } \\
\text { protect national interest } \\
\text { including the citizen }\end{array}$ & Article 22 & & Full power \\
\hline$\bullet$ & $\begin{array}{l}\text { grant asylum for foreigner with } \\
\text { the consideration }\end{array}$ & Article 25 & & $\begin{array}{l}\text { With consideration from the minister; the } \\
\text { President has such power from the } \\
\text { Presidential decree }\end{array}$ \\
\hline$\bullet$ & $\begin{array}{l}\text { decides the policy against the } \\
\text { refugees from outside countries }\end{array}$ & Article 27 section (1) & & $\begin{array}{l}\text { with the consideration from the minister; } \\
\text { the main principle of refugee will regulated } \\
\text { by the Presidential Decree }\end{array}$ \\
\hline
\end{tabular}

\section{e. Emergency power}

The emergency powers and its consequences are implicitly stipulated in some articles of the Amended Constitution. However, there is no explicit provision clarifying the definitions and

\footnotetext{
${ }^{731}$ Article 37 section (1) and section (2) Law No. 37/1999.

${ }^{732}$ Article 38 sectio (1) and section (2) Law No. 38/1999.
} 
scopes of a state of emergency. Article 12 of the Amended Constitution grants the President the power to declare a state of emergency. Furthermore, the Constitution states that the emergency's conditions and its consequences will be set by legislation. The Constitution does not imply that the President also has the power to take any action to encounter and restore a normal state situation from any intimidation and threats. According to the preparatory work of the amendment of the Constitution, the framer wanted to grant the power to declare the state of emergency to the President on the basis that the President is the head of the state.

Article 22 of the Constitution clarifies further the emergency powers of the Indonesian President. ${ }^{733}$ Under the state of emergency, if the situation needs urgent and emergency measures, the President is given (by the Constitution) the power to issue an Emergency Law (the government rules in lieu of Legislation/PERPU). The Constitution implies that the President can unilaterally issue the emergency law without seeking the DPR's approval. The state of emergency may also refer to war. In the case of war, the President as the commander in chief (army, navy, and the air force according to Article 10 of the Constitution) may allow any measures, to command the employment of armed forces, or any unconstitutional actions.To declare the state of emergency, the President has the power to determine any grounds of emergency declaration.

The provision implies that the emergency powers of the President cover broad scopes of emergency situations that need extraordinary and urgent measures. Additionally, Article 12 implies that the Constitution allows the President to take any measures to deal with the situations. In practice, a situation of state emergency can be declared if it meets one of the following situations: unexpected, unforeseen, and of unknown duration, dangerous and a threat for state and the people. It may also be a situation that in terms of government roles and authority is a matter of perception by those who discern the phenomenon. ${ }^{734}$

There are two different situations that potentially threaten the state: the physical threats for the whole population and the political threat for the existing regime. It is argued

\footnotetext{
${ }^{733}$ Article 22 Section 1 and Section 2 of the Amended Constitution of Indonesia (Appendix 5).

${ }^{734}$ Harold C. Relyea, National Emergency Powers. CRS Report for Congress, Congressional Research Service, 2007, p. 4.
} 
Rosa Ristawati: Modelling Executive Powers in the Indonesian Constitution: A comparative Study

that a president has formal powers that can be used unilaterally either with minimal input or without the consent of other institutional or non-institutional actors such as public opinion; though in the end, such powers can be overturned by other branches, such presidential power allows the President to make policy quickly and decisively. ${ }^{735}$

The rationale of the emergency powers is that an imminent threat to the very existence of the state may occur accidentally. It is a necessity to empower the executive, as a branch which is able to take extraordinary measures or extra-constitutional actions which may be unconstitutional or contra-constitutional. In such situations, the emergency powers may be justified as the first response to an emergency situation. The power is commonly exercised during a limited period before other constitutional mechanisms are taken.

Some cases showed that the continuity of state emergency and the termination of state emergency were declared by Presidential Rules. In 1999, when conflict occurred in the Province of Timor-Timur, President Habibie issued the Presidential Decision No. 107/1999 on the Military emergency in the province of Timor Timur. In the following period, President Megawati declared a partial state of emergency on the grounds of a military emergency level in Nanggroe Aceh Darussalam by the Presidential Decision. ${ }^{736}$ In other cases, the President

\footnotetext{
${ }^{735}$ Colin Provost and Paul Teske, President George W. Bush's influence over Bureaucracy and Policy: Extraordinary Times, Extraordinary Powers, $1^{\text {st }}$ Edition, Palgrave Macmillan, New York, 2009, p. 154.

${ }^{736}$ The Presidential Decision No. 28/2003 on the declaration of the state in danger with the level of the military emergency (martial law) in the province of Nanggroe Aceh Darussalam: The Decision emphasized that the supreme commander in chief who is responsible in the endangered situation with the level of military emergency is the President. Therefore, the President will take any responsibilities. It was also said in the Presidential Decision that the continuity of the status will be extended by the Presidential decision. The enactment of the Presidential decision was followed by the some of the integrated operations consisting of humanitarian operations, the economic restoration operation, the law enforcement operations, the stabilization of government operation, the security restoration. The status of emergency military (martial law) was changed into the declaration of the civil emergency by the Presidential Decision No. 43/2004 on the declaration of the changes of the status from the military emergency to the endangered situation of the civil emergency status in Aceh.Article 2 of the Presidential Decision stipulated that the President is the supreme authority in the endangered situation. Therefore, the President is responsible for any actions and should take any measures. The President had also issued the Presidential Decision No. 43/2003 on Ruling the foreign citizen activities, the NGo and the Journalists in the Province of Nanggroe Aceh Darussalam during the military emergency. The status of the civil emergency in the province of NAD had been extended by President Yudhoyono with the Presidential Rule No. 2/2004 on the extension of the civil emergency situation in the NAD. However, unlike other previous emergency situations thatwere terminated by the Presidential Decision, the emergency situation in the province of NAD was terminated
} 
Rosa Ristawati: Modelling Executive Powers in the Indonesian Constitution: A comparative Study

declared the state under civil emergency with a Presidential Decision to deal with the situation in the province of Maluku and the province of North Maluku. ${ }^{737}$

The practice after the Amended Constitution may be different since there are still no specific legislations setting the details about state emergency. However, Law No. 24/ 2007 on the counter-measures disaster may give reference about a state of emergency. It clarifies some part of the incident that can be determined as the situation of a state of emergency including the disasters. A Disaster according to Article 1 of the Law 24/2007 is defined as incidents or the whole incidents that threaten and distract the public community, and are caused by nature and/or other causes or human factors with human victims, environmental damages, property loss, and psychological loss. The Law has distinguished three types of disaster; natural disaster, caused by natural incidents such an earthquakes, tsunamis, volcano eruptions, floods, drought, hurricanes/storms, landslides; Non-natural disasters, such as technology failures, modernization failures, epidemic, disease endemic; social disaster, a disaster caused by humans, covering a social conflict between a social groups or between the public community and terror. The Law explicitly states that the government, clearly addressed the President, and he constitutionally holds the executive power based on Article 4 of the Constitution and is responsible to take countermeasures against such disasters as determined in the Law.

In the state of emergency of a natural disaster, besides the fact that the status may be proposed by a Governor with the approval from the local representative body (the DPRD), the President has unilateral power to declare a state of emergency and take measures to deal with natural disasters. The President can also mobilize the military for any humanitarian operations. With regard to the state of civil emergency, the President must have approval from the DPR to extend the duration of the status with at least 6 months. In any case of the state emergency of

by President Yudhoyono with the Presidential Rule 38/2005 on the invalidation of the danger situation with the level of civil emergency in the province of NAD.

${ }^{737}$ The Presidential Decision No. 88/ 2000 on the civil emergency in the province of Maluku and in the province of North Maluku. Article 2 of the Presidential Decision stipulates that the President has the power as supreme authority for civil emergency in the territorial of Maluku and North Maluku. The declaration of the civil emergency had been revoked by Presidential Decision No. 27/2003 on the revocation of the civil emergency in the North Maluku and the Presidential Decision No. 71/2003 on the revocation of the civil emergency in the province of Maluku. 
military emergency, the President has the power to declare the state of emergency based on military emergency as proposed by the Governor. The declaration must have approval from the DPR at least 72 hours after the declaration. If the DPR rejects the Presidential declaration, the President must revoke the declaration. However, if the Governor does not propose it, the President can't unilaterally declare the state military emergency. Instead, the President must take the consideration of the state security council and seek the DPR's approval. As the commander in chief, the President has extra ordinary powers to take any measures dealing with a military emergency. The President has legal responsibility as the commander in chief and takes resposibility for any actions taken by the subordinate officers. The President has the power to mobilize the military force and all security components and issue any rules to deal with technical matters during the military campaign. The President directs strategies to deal with the situation and decides any substantial measures. However, on the continuity of the situation, the President should have approval from the DPR at least after 6 months. If the DPR rejects it, the President must revoke the status of military emergency. In delivering his responsibility during the military endangered situation, the President should make a report which should be submitted to the DPR.

In conclusion, the scope of emergency can be determined from at least the characters of the extraordinary incidents that threaten the security of the state, public interest and the sovereignty of the state. It has to be anticipated, and has the balance of the extraordinary effort that categorized the emergency situation. The argument to grant the President the emergency power is because:

- the President as the head of the state acting as the commander in chief has the authority to respond and mobilize any measure

- the President as the head of government has the duties to maintain and protect public security and the stability of the government

- the President with the constitutional power can take any ordinary measure to deal with extraordinary incidents. 
Rosa Ristawati: Modelling Executive Powers in the Indonesian Constitution: A comparative Study

The emergency law has a limited duration and may only be enacted temporily. For example when terrorism attacks occurred some years ago, the President enacted the emergency law No. 1/2002 on the eradication of terrorism without declaring the state to be indanger situation. The President issued the emergency law as a response to the Bali terrorism attack.

According to the state practice, in the period of $2000-2009$, the President issued an emergency law not because the situation was factually in danger. Most of the emergency laws were issued on the ground that there was no Legislation which actually applied. Therefore, the President decided to set a regulation by issuing the PERPU (the government rules in lieu of legislation). Most of the substances in the emergency law were addressed to matters related to the administration and government affairs. The extraordinary incident that occurred as the consequence of the terrorist attack on 2002 forced the President to issue an emergency law in order to deal with the factual situation and the legal vacuum of counter-measures against terrorism. However, the emergency laws were not connected to the declaration of the endangered state situation. Even when there was a terrorism attack, the President did not invoke the power to declare the state endangered but only issued an emergency Law. Some of the emergency laws were connected to the presidential power in declaring the state endangered. The emergency law No. 2/2005 on the zone of rehabilitation and reconstruction and society in the province of Nanggroe Aceh Darussalam and the Island of Nias in the Province of North Sumatra and the emergency law No. 2/2007 on the counter-measures of legal problems in order to implement the rehabilitation and reconstruction of the area and the society in the Province of Nanggroe Aceh Darussalam and the Islands of Nias in the Province of North Sumatra had a connection with the declaration and revocation of the state under an emergency situation.

The emergency situation covers broad areas. The emergency may occur in an economic and financial crisis, the public welfare caused by a natural disaster, endemic disease, disaster that was caused by humans, the incidents that threaten public order, society, the incidents against state security, and international affairs, the incidents against the armed conflict. 
Rosa Ristawati: Modelling Executive Powers in the Indonesian Constitution: A comparative Study

Moreover, in exercising the power, the President is supported by the state instrument, the military force, police, and the intelligence agency. The Law No. 17/2011 on state intelligence defines the threat that potentially put the state in an emergency situation. ${ }^{738}$ The Legislation also considers that the threats are not only traditional threats but also non-traditional threats. In the Legislation, the argument to rule the state's intelligence activities is that the term of "threat" has also developed globally. The threats do not include only internal threats and external threats that conventionally have been recognized but also global threats that are more sophisticated, unrecognized, uncategorized, multi-dimensional, unidentified. The need to deal with those kinds of threats also needs to be synchronized with the principle of human rights, good government governance, and the rule of law make it necessary for the President on behalf of the government to provide transparent and accountable counter-measures while protecting the state, people, and legitimate government.

The cases of state emergency induced imminent threats to the existence of a state. Generally, the state emergency creates the necessity to empower the President to take extraordinary measures. The President in such an emergency situation is the state commander in chief and the first man to respond. The President as the commander in chief should act extraconstitutionally in a very urgent and limited period even before other branches can meet and decide further response measures. With the constitutional power as the state commander in chief, the President has the power to take extraordinary measures. As the top military general of the armed forces, the capacity cannot be substituted in broad presidential autonomy to command a standing army and navy. The capacity would also allow the President to respond directly to emergency situations as needed.

\footnotetext{
${ }^{738}$ According to the explanation of the Law No. 17/2011: The threats are either physical threat or non-physical threat, conventional or non-conventional, global or local, immediately or upcoming, potential or actual, military or non-military, direct or indirect, domestic or international, with or without violence. The threats against the security include economic security, food, health, environment, personal, community, and politic. The threats against the public security and public order include the ordinary crimes and the organized crimes and trans-national crimes. The threats against the state security are including the separatism, terrorism, espionagse, sabotage, political violence, conflict, War against information, cyber war, and national economy. The threats against the state defense include the unlimited war, limited war, border conflicts and territorial violence.
} 
A threat to public safety potentially will be an extraordinary situation when the threat impacts significantly upon the national security. An extraordinary situation would be overcome with an extra-ordinary measure. According to Farell, one of the privileges (or burdens) of the office of the executive is that the incumbent can be involved in any issues he desires, greatly influence the decision-making process by setting the stage and determining who will play what role. Even a time of emergency gives the president a rare opportunity to truly lead and implement or ignore organizational routines established to facilitate policy implementation where he wishes to keep his distance and allow the establishment of procedures to be followed. He may even be drawn into the fray by forces beyond his control. ${ }^{739}$ In acting in the name of national security, the President may be allowed by the Constitution to invoke his power to protect national security and the state interest against any threats. In terms of the national security, there are at least two things to deal with. The first is the physical element, and the second is a value element. Physical elements include the physical security of people or events that threaten the national infrastructure (legal, political, economic) and threats that may emerge from non-traditional sources, such as an economic crisis, diseases, and climate change; while the values elements include constitutional values and the rule of law. ${ }^{740}$ With regard to those threats, the need of state intelligence is also very important to prevent the attacks. Accordingly, the state intelligence is on the executive domain. It is timely and reliable intelligence which forms the first line of defense against any attacks. Activities that can be undertaken by intelligence agents include the surveillance of terrorist suspects, the infiltration of terrorist movements, the development of informer networks, the design and implementation of contingency systems to respond to terrorist threats, the collection, storage, and analysis of information, and direct counter-terrorist warfare. ${ }^{741}$

The exercise of state emergency power is mostly done by the Government regulation in lieu of legislation (PERPU) or the emergency law. The emergency law is a presidential directive

\footnotetext{
${ }^{739}$ David Cole and James X. Dempsey, Terrorism and the Constitution: Sacrificing Civil Liberties in The Name of National Security, the New York Press, 2002, pp. 124.

${ }^{740}$ Id. at pp. 21.

${ }^{741}$ Id. at pp. 135.
} 
Rosa Ristawati: Modelling Executive Powers in the Indonesian Constitution: A comparative Study

to overcome an extraordinary state emergency. It establishes policy, reorganizes the state administration and affects how the legislation is interpreted and implemented in the duration of the state of emergency. In practice, the emergency law is very important and has profound consequences for state practice. With the emergency law, the President declares of state emergency. The President's actions in emergency can authorize a broad range of unilateral actions and expand the executive responsibilities within the state emergency. It potentially expands the executive institutionalization and potentially creates increased power over policy implementation and administration. Such authority also potentially allows the President to make many substantive decisions within the duration of the state emergency and may impact on the situation after the emergency. With the emergency law, the President can make significant policy choices. ${ }^{742}$

In an emergency situation, it is assumed that the constitution obliges the president with the primary responsibility and therefore the power to ensure the security of the state in the situation of grave and unforeseen emergencies. Another basis offered to the granted power is not the Constitution or laws, but the doctrine of "state necessity". ${ }^{743}$ The doctrine of necessity is addressed to maintain public safety and to respond to the emergency situation as a result of terror. In this situation of terror, the executive is called upon to act on behalf of the state to restore national stability and protect the people. The doctrine of necessity gives the authority to the president to create the declaration of a stte of emergency. Thus, in the name of legitimate emergency, the people demand the president to act.

The president's actions are constitutionally permissible if the DPRmaintains its authority to ultimately oversee the actions of the president. In this way, there is a tradition of constitutional interpretation that has resulted in so-called implied powers, which may be invoked in order to respond to an emergency situation. Furthermore, the executive has

\footnotetext{
${ }^{742}$ Kenneth R. Mayer, "Executive Orders and Presidential Power", The Journal of Politics, Vol. 61, No. 2 (May, 1999), pp. 445-466, Cambridge University Press on behalf of the Southern Political Science Association, available online at: http://www.jstor.org/stable/2647511, accessed: 26/06/2010, pp. 463.

${ }^{743}$ Michael. A. Genovese, "The Roots and Development of Executive Prerogative in the United States", Paper prepared for presentation at the 2009 annual meeting of the American Political Science Association, Toronto, Canada, p.8.
} 
Rosa Ristawati: Modelling Executive Powers in the Indonesian Constitution: A comparative Study

occasionally taken an emergency action which it assumed to be constitutionally permissible. ${ }^{744}$ However, there are at least four aspects of an emergency condition: the first is its temporal character: an emergency is sudden, unforeseen, and of unknown duration; the second is its potential gravity: an emergency is dangerous and threatening to life and well-being; the third, in terms of government's role and authority, is the matter of perception of who discerns the phenomenon. Lastly, there is an element of response, as by definition, an emergency requires immediate action, but is, as well, unanticipated and, therefore, as Corwin notes, cannot always be "dealt with according to rule". From these simple factors arise the dynamics of national emergency powers. $^{745}$

Table 4.10 Examples of Emergency Law in Indonesia

\begin{tabular}{|c|c|}
\hline $\begin{array}{l}\text { Emergency Law } \\
\text { (PERPU) }\end{array}$ & On \\
\hline $1 / 2000$ & Free trade zone and free port \\
\hline $1 / 2002$ & The eradication measures on terrorism \\
\hline $1 / 2005$ & The Suspension from the enactment of the Law No. $2 / 2004$ on the dispute settlement on industrial relation \\
\hline 1/ 2006 & $\begin{array}{l}\text { The second amendment of the Law No } 12 / 2003 \text { on the general election of the members of the DPR, the DPD, } \\
\text { and the DPRD }\end{array}$ \\
\hline $1 / 2007$ & $\begin{array}{l}\text { The amendment of the Law No. } 36 / 2000 \text { on the Decision of the emergency law No. } 1 / 2000 \text { on the free trade } \\
\text { area and the free port after the transformation of such law to be Legislation }\end{array}$ \\
\hline $1 / 2008$ & The amendment of the Law No. $21 / 2001$ on the special autonomy for the province of Papua \\
\hline $1 / 2009$ & $\begin{array}{l}\text { The amendment of the Law No. 10/2008 on the general election of the members of the DPR, the DPD, and the } \\
\text { DPRD }\end{array}$ \\
\hline $2 / 2000$ & The free trade zone and the free port Sabang \\
\hline $2 / 2002$ & $\begin{array}{l}\text { The enactment of the emergency law against the emergency Law No. 1/2002 on the terrorism (response to the } \\
\text { terrorism attack in Bali, } 12 \text { October 2002) }\end{array}$ \\
\hline 2/2005 & $\begin{array}{l}\text { The zone rehabilitation and reconstruction agency and society in the province of Nanggroe Aceh Darussalam } \\
\text { and the Island of Nias in the Province of North Sumatra }\end{array}$ \\
\hline $2 / 2006$ & $\begin{array}{l}\text { The suspension of the implementation of duties and functions of the fisheries court as mentioned in Article } 71 \\
\text { section } 5 \text { of the Law No. } 31 / 2004 \text { on the Fisheries }\end{array}$ \\
\hline $2 / 2007$ & $\begin{array}{l}\text { The countermeasures of legal problem in order the implementation of rehabilitation and reconstruction area } \\
\text { and the society in the Province of Nanggroe Aceh Darussalam and the Islands of Nias in the Province of North } \\
\text { Sumatra }\end{array}$ \\
\hline $2 / 2008$ & The second amendment if the Law No. $23 / 1999$ on the BANK INDONESIA \\
\hline $2 / 2009$ & The amendment in the Law No. $13 / 2008$ on the Hajj arrangement \\
\hline $3 / 2000$ & $\begin{array}{l}\text { The amendment of the Law No. 11/1998 on the Amendment of the enactment of the legislation No. 25/1997 } \\
\text { on the Labor }\end{array}$ \\
\hline $3 / 2005$ & The amendment of the Law No. 32/2004 on the local government \\
\hline $3 / 2008$ & The amendment of the Law No. $24 / 2004$ on the deposit guarantor institution \\
\hline $3 / 2009$ & The amendment of the Law No. 9/1992 in the immigration \\
\hline $\begin{array}{l}4 / 2008 \\
4 / 2009 \\
5 / 2008 \\
1 / 2004 \\
2 / 2004\end{array}$ & $\begin{array}{l}\text { The financial safety system } \\
\text { The amendment of the Law No. 30/2002 on the Commission of the eradication of Corruption } \\
\text { The fourth amendment of the Law No. 6/1983 on the general provisions and the tax procedural } \\
\text { The amendment of the Law No. } 41 / 1999 \text { on the Forestry } \\
\text { The amendment of the Law No. 12/2003 on the general election of the members of the DPR, DPD, and the }\end{array}$ \\
\hline
\end{tabular}

\footnotetext{
${ }^{744}$ CRS Report for Congress, National Emergency Powers, Congressional Research Service, 2007, pp. 5.

${ }^{745}$ Id. at p. 7
} 


\section{f. Military Power}

The Constitution explicitly grants the power as Commander in chief to the President. Article 10 of the Amended Constitution stipulates that the President holds the highest power of Army, Navy, and Air Force. This article implies that the President is the supreme commander/ commander in chief of those three military forces. To this extent, the President automatically has the military powers. The Military powers of the President consist of the presidential war power, the power of the President in conducting military operations, the power of the President to be the Commander in Chief empowering the President to take control of the military organization, direct the mobilization of the military and command other authorization with regards to the military. Chapter XII on State defense and security of the constitution emphasizes that the military forces exist in order to protect and maintain state integrity and sovereignty. ${ }^{746}$ The military forces are one of the state instruments in order to support the Presidential duties in protecting the state and its people and preserving and maintaining the state sovereignty and integrity, as the President is appropriately the supreme chief of the military forces.

\section{- The presidential duties to protect}

The Presidential duties laid down in the Constitution as the constitutional oath and commitment are delivered as the President has been elected democratically. Article 9 of the Constitution contains the oath and entails that the President has the duty to faithfully execute the Constitution and the Laws. The Constitution in the Preamble basically mentions that the establishment of the Republic of Indonesia has four basic constitutional purposes of (1) protecting all the people of Indonesia, the independence, and the land; (2) improving public welfare; (3) educating the life of the people of Indonesia; and (4) participating in the world order based on freedom, peace, and social justice. Referring to the four constitutional purposes

\footnotetext{
${ }^{746}$ Article 30 section (3) of the Amendment Constitution stipulates that the TNI (the "Tentara Nasional Indonesia": the Indonesian National Military), consists of the Army, Navy, and Air Force, as the state instrument, has duties to defend, protect, and maintain the state sovereignty and integrity.
} 
of the establishment of the Republic of Indonesia, it is the duty of the President to faithfully protect them. To this extent, the duties of the President cover the areas including those in domestic affairs and foreign affairs, domestic and international. The constitutional existence of the TNI is significant as a constitutional instrument to support the President's constitutional and institutional effort and actualize the constitutional duties of the President.

- The Presidential Military Power: the TNI's roles in supporting the state government

The military power of the President is derived from the Constitutional Commander in Chief Clause in Article 10. Further, Article 11 of the Amended Constitution refers to the Presidential power in declaring war and making peace with other states. This clause affirms the military power of the President. In declaring war, the President may also call for the use of military force; whereas in making peace, the President may recall the use of military forces. Those Presidential actions are related to the power of the President as the Commander in Chief. In commanding, the President is vertically directing and guiding the Military actions. Military actions are not only about the use of military forces in the battle fields but also about mobilizing military forces outside the battle field. In the military organization, the President also has the power to control the organization of the TNI by nominating, appointing and dismissing the Chief of the Military, high rank officers, and other senior officers. In addition, the President also has the power to approve the promotion to the rank of military officer. ${ }^{747}$

The Military power of the President is manifested by the role of the President in a military operation. It is confirmed by Article 3 of the Law No. 34/2004 section 1 and section 2 . The Article stipulates that in terms of the mobilization and the utilization of the military force, the TNI is under the President. However, in terms of policy and defense strategy and the administration, the TNI is under the coordination of the Ministry of Defense. The article implies the vertical relationship between the President and the TNI. The TNI is only responsible and accountable to the President, and the Minister of Defense only has a coordination function. Article 19 of the Law 34/2004 emphasizes that all military actions fall within the responsibility of the President. In this case, the Chief of TNI should be directly accountable to the President.

\footnotetext{
${ }^{747}$ Article 33 and Article 43 of the Law 34/2004.
} 
Rosa Ristawati: Modelling Executive Powers in the Indonesian Constitution: A comparative Study

The article implies that any military action by the TNI is controlled and coordinated by the President. The President has the power to directly control the TNI.

Moreover, Article 5 of the Law No. 34/2004 on the TNI (Tentara Nasional Indonesia: Indonesian National Military) stipulates that the TNI has a role as a state instrument of defense and exercises the duties based on the policy and state political decision. The political decision in this case is the state political policy and decision that is delivered by joint session of the president and the DPR in the mechanism of the government-DPR relationship of consultation meeting and other joint sessions. ${ }^{748}$

The main duties of the TNI are in accordance with the President's constitutional duties based on the preamble of the Constitution. As the main state defense instrument, the TNI has the duties in upholding state sovereignty, maintaining the state territory of the NKRI, protecting the people of Indonesia and actively participating in the world order of peace. ${ }^{749}$ These duties are exercised under the vertical direction of the President. In practice, the TNI was widely recognized since there was no Indonesian President who could run the state without the tacit approval and assistance of the TNI. ${ }^{750}$ The TNI has key points in politics supporting the President elected not only for being the primary means of defense and protecting the state sovereignty but also for maintaining the dignity and legitimacy of the representative government. As the main state instrument, TNI supports the Presidential duties in domestic and international areas. In home affairs, the TNI functions primary for restoring the internal state security; whereas, in government international affairs, the TNI has a function in supporting the foreign affairs polices.

\footnotetext{
${ }^{748}$ The explanation of Article 5 the Law No. 34/2004.

${ }^{749}$ The explanation of Article 7 of the Law No. 34/2004 determines that the main duties of the TNI in maintaining the integrity of state sovereignty are by faithfully guarding the state power and the establishment of the state government from any threats; maintaining the integrity of state territory including the land, sea, and air; and protecting the life, liberty and property of the Indonesian people.

${ }^{750}$ See: Damien Kingsbury, Power Politic and the Indonesian Military, RoutledgeCurzon, London, 2003, p. 68. “It was known that the TNI had actively worked to destabilize the first two post-Suharto presidencies, insofar as it was able quite successfully to capitalize on the respective presidential foibles, in fomenting trouble in East Timor under Habibie, and in Maluku and Kalimantan under Abdurrahman Wahid".
} 
Rosa Ristawati: Modelling Executive Powers in the Indonesian Constitution: A comparative Study

The TNI, in running its military forces and conducting military operations, has to be accountable and responsible to the President. As the President is constitutionally a commander in chief, all the military operations and the use of military forces must be under the supervision of the President. According to the state experiences, the Indonesian President mostly has a military background and thus, significant experiencein consolidating control over the TNI. The state practice has shown that the issue of democratic civilian control of the military is somewhat more complicated than a matter of an elected president's ability to reshuffle the high command; Suharto thoroughly dominated the military during his long reign. ${ }^{751}$ During the administration of President Wahid, who was a non-military person who strived to consolidate his authority over the military, the military at the time appeared to distinguish between loyalty to the President and loyalty to the Constitution. ${ }^{752}$ There is an assumption if the President has a military background then he will have a strong military power to command the military forces.

Table 4.11 The Indonesian Presidential Military Power The Military Power of the President

\begin{tabular}{|c|c|}
\hline Constitutional power & $\begin{array}{l}\text { - } \quad \text { Commanding in chief of the army, navy and the air force } \\
\text { - } \quad \text { Declaring war (call out the Military forces) and Making peace (pull out the Military forces) } \\
\text { - } \quad \text { Emergency power in a emergency Military situation }\end{array}$ \\
\hline Legal power & $\begin{array}{l}\text { - Ordering and commandeering the Use of Military Forces of three purposes of war military } \\
\text { operation, non-war military operation, and military operation for international obligation of peace } \\
\text { keeping military operation } \\
\text { - } \text { Commanding the Military operation of War and other non-war military operation } \\
\text { - } \text { Mobilizing the military TNI forces } \\
\text { - } \quad \text { Dupervision the Military operations } \\
\text { - } \quad \text { Controlling the military organization } \\
\text { - } \\
\text { - } \\
\text { - } \\
\text { Appominating the chief of TNI }\end{array}$ \\
\hline
\end{tabular}

Table 4.12 Military operation in Indonesia conducted under the Indonesian President

\begin{tabular}{|c|c|}
\hline Aggression Military operation & Non-aggression Military Operation \\
\hline $\begin{array}{l}\text { 1. The military operation on the war; against other states } \\
\text { military operation; the international aggression; the } \\
\text { international armed conflict; or any others invasion that } \\
\text { declared as war within the International armed conflict law. } \\
\text { 2. Military operation on any threats and disturbances threats }\end{array}$ & $\begin{array}{l}\text { 1. the military operation on the armed separatist, } \\
\text { 2. military operation on the internal armed conflict, } \\
\text { 3. the military operation on terrorism, } \\
\text { 4. the military operation in order to preserve the state } \\
\text { territorial borders, }\end{array}$ \\
\hline
\end{tabular}

\footnotetext{
${ }^{751}$ Angel Rabasa and Peter Chalk, Indonesia's Transformation and the Stability of Southeast Asia, Rand, 2001, p. 61.

${ }^{752}$ Id. at p. 69: "It was said that the army leaders reportedly refused to support a bid by Wahid to declare a state of emergency in February 2001, at the time when the parliament was debating the motion of censure."
} 
the integrity of state sovereignty, namely; (1) aggression of the use of forces by other states against the integrity state sovereignty, state territorial and strike out people of Indonesia; (2) Invasion of the use of military forces; bombardment of the use of armed forces; (3) blockades of port, coast, air space or the whole Republic of Indonesia territorial; (4) armed attack by other states against the land, sea, and air space; (5) the military operation and the use of armed forces within the Republic of Indonesia territorial that contradict to the legal order or the agreement; (6) action that taken by other states in order to allow the use of its territorial to other states in order to conduct an armed attack, aggression or invasion against the Indonesia; (7) the sending of armed group or the mercenary army to conduct violation and disturbances in the Republic of Indonesia territorial; (8) other threats determined by the President

3. Territorial violation by other states

4. The armed conflict against the legitimate government

5. Sabotages to devastate the strategic installation and national vital objects

6. Spionase by other states in order to seek and obtain any enclosed state and military information

7. Any kinds of international terrorism or other domestic and regional terrorism

8. Threats against the Indonesian national jurisdiction in the sea or air space territorial; such as, international piracy, smuggling of weapons, ammunition, and explosives or other materials that endangered the safety of the nation, illegal fishery or marine thievery
5. the military operation to preserve the national vital and strategic properties,

6. the military operation for exercising duties for world peace on the basis of the political foreign policies,

7. military operation in securing the President and the Vice President and all their families,

8. military operation for pre-emptive action of the defense system by empowering the defense territorial and supporting power,

9. the military operation for supporting the local government under the Unitary state of Republic of Indonesia,

10. the military operation for supporting the Republic of Indonesia Police in order the security duties and public order,

11. the Military operation for guarantee the state visitor of other head of state and other state representative,

12. Military operation in anticipating and countermeasure action of the natural disaster, evacuation, and other humanitarian actions,

13. military operation for search and rescue action accident,

14. military operation for supporting the government in order to secure shipping and aviation against the piracy and smuggling and other illegal actions.

15. Military operation on the communal conflict between the society groups that endangered the national security and integrity of state sovereignty

\section{g. The Presidential Pardoning Power}

\section{The Pardoning power in the Constitution: a judiciary power for President?}

Article 14 section 1 of the Amended Constitution vests the power to give clemency and rehabilitation to the President. Moreover, the power must be exercised with the Supreme Court's consideration. The Article implies that the President should consult the Supreme Court since actually the power may contradict a judicial decision. Furthermore, Article 14 section 2 of the Constitution gives the President the power to give amnesty and abolition with the consideration of the DPR. According to Howard, the presidential pardon power can be categorized into three areas of pardon. The first one is full pardon, a typical pardonused to remedy acts by individuals against ordinary laws, pardon to terminate sentences and restore civil rights, pardon to restore civil rights, and conditional pardon. The second is the pardon determined by amnesties on condition that they are usually granted to groups rather than individuals. The third is the pardon categorized as commutation, including reprieve, commutation, commutation on condition and remission of fines and forfeitures, which is 
pardoning used to modify the terms of an individual's already established punishment. ${ }^{753}$ According to Article 14 section 1 and 2, the Presidential pardoning power can be one of the mechanisms of giving clemency, rehabilitation, amnesty or abolition.

From the three categories, Article 14 section 1 can be determined as the first category of Presidential power of full pardon and the third category of commutation. It is because such Presidential power has the effect to relieve a person from any potential, pending or assigned punishment related to a criminal offence. However, this power could be invoked by a reduction of the punishment that should be accompanied by the consideration from the Supreme Court. On the other hand, section 2 could be determined as the pardoning power included in the second categories in which the issue is merely a political issue. Therefore, this power should be accompanied by consideration from the DPR.

The argument of giving the President the pardoning power is firstly because the President is a personification of the state and that the state gives the pardon after the judicial process has been done. However, the power of the President is not intended to intervene and undermine the judicial power. The presidential power for clemency is also stipulated in the KUHP (the wet boek van straftrecht/ the Criminal Code) in Article 33a. Besides that, according to Article 1 section 1 Law No. 22/2002 on Clemency, Clemency (Grasi) is defined as pardoning in the form of change, commutation, remission, or the punishment abolition by the President. In the explanation of the Law 2002, the argument of the presidential pardoning power is not about technical matters within the criminal justicesystem and not about assessing the Court's decisions. It is not about the intervention of the President in judicial affairs. Therefore, it cannot be said that the President has part of the judicial power by his pardoning power. It is a matter of the prerogative rights of the President as the head of the state. The scope of the President in the exercise of his pardoning power is determined by Article 4 of the Law. Section 1 of the Article stipulates that the President has the right to grant or reject the clemency application by the convicted after the President obtains the consideration from the Supreme Court. Section 2

\footnotetext{
${ }^{753}$ Mark Howard Morris, Presidential Pardon Power: Discretion, Disuse, and Mass Media Coverage, Dissertation for the degree of Doctor of Philosophy, Department of Political Science, Miami University, Oxford, Ohio, 2004, p. 5.
} 
Rosa Ristawati: Modelling Executive Powers in the Indonesian Constitution: A comparative Study

of the Article gives the form of the President in giving pardon; it can be given by one of the three measures of commutation or change of types of punishment, remission of punishment, or the abolition of punishment.

However, the pardoning power of the President is limited in Article 2. The President can only give pardon to a convict after a court's decision that is legally binding and has been final. The Court decision that can be filed for the Presidential pardoning power is a decision about the death penalty, life imprisonment, and minimum 2 years imprisonment. The submission for the presidential pardoning can only be filed once.

On the other hand, after a decade of Constitutional amendments, still there is no Laws concerning the Presidential pardoning power in terms of amnesty and abolition. The Emergency Law No. 11/1954 is mentioned in Article 1 that the President, in the name of the State, can give amnesty and abolition to a person who has committed crimes. The President gives the amnesty and abolition after receiving the Supreme Court's written consideration as requested by the Ministry of Law. The granting of amnesty and abolition specified to persons who committed crimes as a consequence of the conflict between the Republic of Indonesia (Yogyakarta) and the Kingdom of the Netherlands. The amnesty has the meaning to abolish all the legal consequences, while the abolition has the meaning that the prosecution is dispensed with. The terms of amnesty are addressed to political crimes such as, self-determination movement or other acts against the legitimate government.

In the current period, the term Amnesty was found in the Law No. 27/2004 (the Law has been annulled by the Constitutional Court). The amnesty based on the annulled Law is the Presidential pardon for serious violation of human rights. The President in giving the amnesty is with the consideration of the DPR. ${ }^{754}$ It is given by a Presidential Decree. ${ }^{755}$

\footnotetext{
${ }^{754}$ The Law No. 27/2004 before it is annulled by the Constitutional Court, Decision of the Constitutional Court No. 006/PUU/IV/2006.

${ }^{755}$ By the Presidential Decision No. 22/2005, President SBY granted the amnesty and abolition to all persons involved in the GAM (The Aceh Independence Movement). The amnesty and abolition is based on the DPR's consideration as delivered in the Decision of the Chief of DPR No. 09/PIMP/I/2005 - 2006 on the Consideration of the DPR to grant amnesty and abolition for all persons involved in the Aceh Independence Movement. Previously, President Wahid by the Presidential Decision No. 91/2000 has granted amnesty to 5 persons and abolition to 4 persons for the tragedy of the flag "Bintang Kejora" raised in Papua. President Wahid had also given the abolition
} 
Rosa Ristawati: Modelling Executive Powers in the Indonesian Constitution: A comparative Study

After the annulment of the Law, there is no legal term concerning the Presidential pardoning power on amnesty and abolition. The abolition is mentioned as the power of the President to cancel the prosecution against the accused before the Court decision or it is defined as the power of the head of state to abort the prosecution rights in prosecuting and abort the legal consequences with regard to the prosecution. ${ }^{756}$

\subsection{Checks and balances over the executive powers of the President:}

"Checks and balances" are associated with the theory of separation of power. ${ }^{757}$ In Indonesia, the theory of separation of power is explicitly reflected in the provisions of the Constitution. The power of the Indonesian president is subjected to the checks and balancesof other constitutional institutions.

\section{c. Who and how checks and/ or constrain the president power}

\section{MPR}

Based on the characters, the MPR could be determined as a constitutional assembly in Indonesia. The MPR is the "Majelis Permusyawaratan Rakyat" (Majlis of people's deliberation). The constitutional composition of the MPR is the members of the DPR and members of the DPD

against R. Sawito Kartowibowo in the case of subversion by the Presidential Decision No. 93/2000. The Presidential Decision in granting the abolition is based on the DPR's written consideration No. PW.001/4112/-DPR-RI/1999 on 15 November 1999 and the written consideration from the Supreme Court No.KMA/1217/ XII/ 1999 on 31 December 1999 and the Minister of Law and Legislation with his written consideration No. M.PW.07.03-11 on 11 May 2000. President Soeharto by the Presidential Decision No. 1/A/1969 granted the amnesty and abolition to persons who were involved in the tragedy of "awom", tragedy of "mandacan" and tragedy of "wagete-enaratoli" in West Papua. In this Presidential Decision, the following up measure should be taken by the Ministry of Defense. President Soekarno by the Presidential Decision No. 303/1959 granted the amnesty and abolition to persons who were involved in the rebellion movement of DI/TII Kahar Muzakar in South Sulawesi. President Soekarno by the Presidential Decision No. 568/1961 had also granted amnesty and abolition to the rebel group that had already unconditionally. The consideration was come from the Supreme Authorize subsidiary war body and the Cabinet.

${ }^{756}$ Kompas, Mungkinkah Presiden gunakan hak abolisi?, November 23, 2009, accessed online at: http://nasional.kompas.com/read/2009/11/23/19475194/Mungkinkah.Presiden.Gunakan.Hak.Abolisi (last accessed 12/11/2014): In the case of the Commission of Eradication of Corruption, Bibit and Candra, the President was able to use his power to stop the prosecution against both the chief of commission as public expectation.

${ }^{757}$ M.J.C. Vile, Constitutionalism and Separation of Powers, Liberty Fund, Inc, $2^{\text {nd }}$ edition, 1998, p. 2: "The doctrine of the separation of powers, standing alone as a theory of government, has uniformly failed to provide an adequate basis for an effective, stable political system. It has therefore been combined with other political ideas, the theory of mixed government, the idea of balance, the concept of checks and balances, to form the complex constitutional theories that provided the basis of modern Western political systems". 
who are elected through a general election. ${ }^{758}$ The main constitutional powers of the MPR according to Article 3 of the Constitution are to change and to enact the Constitution; to formally induct the President and the Vice President; and to formally impeach according to the Constitution the President and/or the Vice President in office. ${ }^{759}$ The three Constitutional powers of the MPR are elaborated into six duties and authorities on Law No. 27/2009 in article 4: (1) change and enact the Constitution, except the Preamble of the Constitution; (2) induct the President and the Vice President as a result of a general election; (3) decide the DPR's motion to dismiss the President and/or the Vice President after the Constitutional Court decides that the President and/or the Vice President has evidently conducted unlawful acts of state betrayal, corruption, bribery, or other serious criminal acts or despicable acts (misdemenour) and/or proven that the President and/or Vice President is no longer eligible as a President and/or the Vice President; (4) induct the Vice President as the President if the President died, was dismissed, or can't exercise his office; (5) select the Vice President from 2 candidates proposed by the President in the case of a vacancy in the Vice Presidency office; (6) appoint the President and the Vice President after the previous election, in the case that both have died, resigned, have all been dismissed, or can't execute their duties within the office.

The MPR consists of two institutions generated from the general election. As the election is established by a direct mechanism, in which members are directly choseneach of the DPR and DPD, the MPR automatically has the popular sovereignty and represents the people. To this extent, the MPR is the institution representing people as a whole. According to the main constitutional power of the MPR, it has the basic powers that are generally relevant to the Constitution, as the higher Law which will delegate powers to other branches and the key powers in state government and administration. With regard to the oversight function of the state administration and governmental affairs, there is no provision in the Constitution granting the MPR with the power of scrutiny and oversight of the Executive. However, Article 2 of the Constitution, which stipulates the constitutional composition of the MPR, may be a

\footnotetext{
${ }^{758}$ Article 2 of the Amended Constitution of Indonesia.

${ }^{759}$ Article 3 of the Amended Constitution of Indonesia.
} 
constitutional basis for the MPR to have an indirect oversight function. In terms of the power to amend the Constitution, the MPR is conceivably to have the power to grant and control the power to other branches. In such case, the MPR holds the power not only to determine but also to limit those powers. By determining and limiting the executive power in the process of constitutional amendment, the MPR can be said to have the ex-ante oversight function in the state administration and governmental affairs. On the other hand, the power to decide the DPR's motion to dismiss the President and/or the Vice President after the Constitutional Court decision can be determined as the ex-post function to oversee the Executive, the President.

\section{The DPR}

The legislature is generally determined as the branch which has the primary law-making power. The Constitution in Article 20 section (1) explicitly grants the power to make Law to the DPR. To this extent, it is constitutional that the DPR is the legislature in Indonesia. The DPR (the "Dewan Perwakilan Rakyat) is the Council of the people's representatives. There are three constitutional functions of the DPR that are explicitly mentioned in Article 20A section (1) of the Constitution: legislating, budgeting, and oversight. In order to exercise its constitutional functions, the DPR is empowered by constitutional mechanisms as mentioned in Article $20 \mathrm{~A}$ section (2), inter alia: interpellation, enquette, and opinion. According to Article $20 \mathrm{~A}$ section (3), each of the DPR's members also has the constitutional right to inquire, to vote and argue, enjoy immunity, and the right to propose a Bill (Article 21 of the Constitution). All the constitutional functions of the DPR are emphasized on the Law No 27/2009. According to Article 60 section (2) of the Law, in exercising those three functions, the DPR is representing the people. As a consequence, in every action for exercising the three constitutional functions, the DPR is acting on behalf of the people. The people's representation by the DPR is exercised through the framework of public participation, transparency of the DPR's work, and the responsibility of the DPR to the people. ${ }^{760}$

\footnotetext{
${ }^{760}$ The explanation of Article 69 section 2 of the Legislation NO. 27/2009.
} 
Rosa Ristawati: Modelling Executive Powers in the Indonesian Constitution: A comparative Study

The legislative function is legally attached to the DPR as a manifestation that the DPR constitutionally holds the power to make Law. ${ }^{761}$ The budgetary function is given in order to have checks and balances mechanism against the power of the President in proposing the state budget. This function is given to the DPR by giving the DPR the legal authority to discuss and approve or reject the state budget proposed by the President. ${ }^{762}$ On the other hand, the function of oversight is legally attached to the DPR in order to exercise scrutiny of the execution of the Law and the state budget. ${ }^{763}$

Table 4.13 Duties of the DPR

\begin{tabular}{|c|c|c|c|}
\hline Functions & Duties & & Legal basis \\
\hline Legislative & $\begin{array}{l}\text { a. } \\
\text { b. } \\
\text { c. }\end{array}$ & $\begin{array}{l}\text { make legislations in the joint approval session with the President; } \\
\text { approve or reject the Government Rules in lieu the Legislation proposed by the } \\
\text { President become the Law } \\
\text { accept the draft of Legislation proposed by the DPD that relevant to the subject of: local } \\
\text { autonomy, the relationship between the central government and local government, the } \\
\text { establishment and expansion and the provinces merger, the exploration and the } \\
\text { governance of the natural resources, economic resources and others, and subject } \\
\text { relevant to the budget equality between the central and local government } \\
\text { discuss in a joint session with the President and the DPR the draft of Legislation } \\
\text { proposed by the DPD before continueing to the joint approval with the President } \\
\text { discuss the draft of Legislation proposed by the President or the DPR that relevant to } \\
\text { the subject of local autonomy, the relationship between the central and local } \\
\text { government, the establishment and expansion and the local government merger, the } \\
\text { exploration and the governance of the natural resources, economic resources and } \\
\text { others, and subject relevant to the budget equality between the central and local } \\
\text { government. The DPD should be engaged in the discussion before it is continued to the } \\
\text { joint approval session by the DPR and the President } \\
\text { observing the DPD's consideration on the bill concerning on the state budget and other } \\
\text { draft of legislations subject to the tax, education, and religion } \\
\text { discuss in the joint discussion with the President and observe the DPD's consideration } \\
\text { and give approval to the draft of legislation concerning on the state budget proposed by } \\
\text { the President }\end{array}$ & $\begin{array}{l}\text { Article } 71 \text { Law } \\
\text { No. 27/2009 }\end{array}$ \\
\hline Budgeting & & discuss and approve or reject the state budget proposed by the President & $\begin{array}{l}\text { Article } 7 \text { Law No. } \\
27 / 2009\end{array}$ \\
\hline Oversight & $\begin{array}{l}\text { a. } \\
\text { b. }\end{array}$ & $\begin{array}{l}\text { scrutiny on the laws and the state budget } \\
\text { discuss and follow up the scrutiny by the DPD on the application of the Law concerning } \\
\text { on the local autonomy, the establishment, expansion and the local government } \\
\text { merging, the central-local government relationship, the state budget application, tax, } \\
\text { education, and religion } \\
\text { give approval to the President concerning on: declaring the war, peace-making and } \\
\text { treaty-making with other states, and treaty-making that significant to the people and } \\
\text { potentially impact to the state financial and/or entails the changes or new law-making } \\
\text { give consideration to the President concerning on the presidential clemency power of } \\
\text { the amnesty and abolition } \\
\text { give consideration to the President concerning on the presidential diplomacy power of } \\
\text { the state ambassador appointment and other state ambassadors reception and } \\
\text { placement }\end{array}$ & $\begin{array}{l}\text { Article } 71 \text { Law No. } \\
27 / 2009\end{array}$ \\
\hline
\end{tabular}

${ }^{761}$ Article 70 Legislation No. 27/2009.

${ }^{762}$ Article 70 section (2) Legislation No. 27/2009.

${ }^{763}$ Article 70 section (3) Law No. 27/2009. 


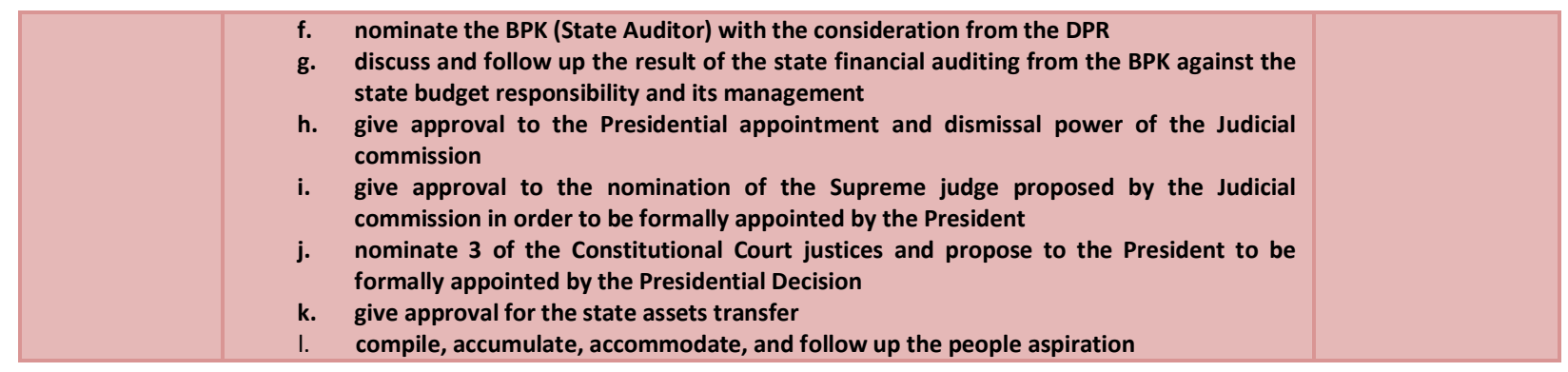

The DPR exercises a role of checks and balances against the President. It has three functions: legislative, budgetary, and oversight. These three functions are constitutionally and legally expected as an effective protection against any abuse of power by the President. In practice, those three functions are applied in varying mechanisms such as the constitutional DPR's legislative power, and in the mechanism of giving recommendation, consideration, opinion, and approval or rejection. With regard to the Constitutional DPR's legislative power, the DPR has a role to put legal limits on the Presidential power through legislation. On the other hand, by giving its approval/rejection, recommendation, consideration, and opinion, the DPR is acting as a cross-examiner in order to avoid the abuse of power by the President. On the other hand, by the joint-session and joint approval session in the state budget process, the DPR is representing the people, justifying the President in running and exercising state administration and governmental affairs. Such a mechanism could be accounted as ex-ante oversight functions by the DPR. On the other hand, the ex-post oversight by the DPR can be invoked by the constitutional mechanism of interpellation, the enquette, and right to argue. These are the mechanisms of ex-post oversight: the DPR's scrutiny after the Presidential or the government action, policy, and/or decisions have been taken.

The DPR's Code of Conduct stipulates that the DPR should invoke its function of oversight of the power of the President. Article 159 Section (2) of the DPR's Code of Conduct emphasizes the DPR's function to oversee the implementation of laws, the state budgetary spending, and the government policy. Article 160 Section (3) of the DPR's Code of Conduct mentions that the DPR can invoke its oversight function through (1) the discussion of the report of the state budgetary which has been audited by the BPK; (2) the result of the BPK's report 
each semester of the government spending on the state budgetary; (3) the follow-up measure of the BPK's auditing; (4) the BPK's result of auditing with a special purpose; (5) the DPD's report of scrutiny; (6) public complaints. In exercising the oversight function, the DPR can consult with other state institutions. ${ }^{764}$ The DPR functions can be exercised by invoking the DPR's constitutional rights of procedure in Chapter IX of the DPR's Code of Conduct. ${ }^{765}$ The mechanisms to exercise its power, rights, and functions are mentioned in Article 72 Law 27/2009. According to the Article, the DPR could invoke mechanisms as follows:

- The DPR has the authority and rights to ask state officials, state governments, the legal corporations, or Indonesian citizens to give the information on matters that need to be anticipated for the sake of state interest

- With regard to the DPR's authority, the state official, the government official and the legal corporation will be obliged to fulfill the DPR's request in order to invoke its authority and rights

- In order to invoke its authority and rights, the DPR can enforce the "calling enforcement" to the state official, the government official, legal corporation and citizen In case the "calling enforcement" is waived, the DPR can detain a person for 15 days. However, if the terms of the detention expire, the hostage must be released in the name of law.

\footnotetext{
${ }^{764}$ Article 160 section (4) of the DPR's Code of Conduct of Conduct.

${ }^{765}$ Article 160 section (1) of the DPR's Code of Conduct of Conduct.
} 


\section{Rosa Ristawati: Modelling Executive Powers in the Indonesian Constitution: A comparative Study}

Table 4.14 the DPR vis a vis the executive power

\begin{tabular}{|c|c|c|}
\hline $\begin{array}{l}\text { Constitutional } \\
\text { mechanism }\end{array}$ & Subject of oversight & Procedures \\
\hline Interpellation & 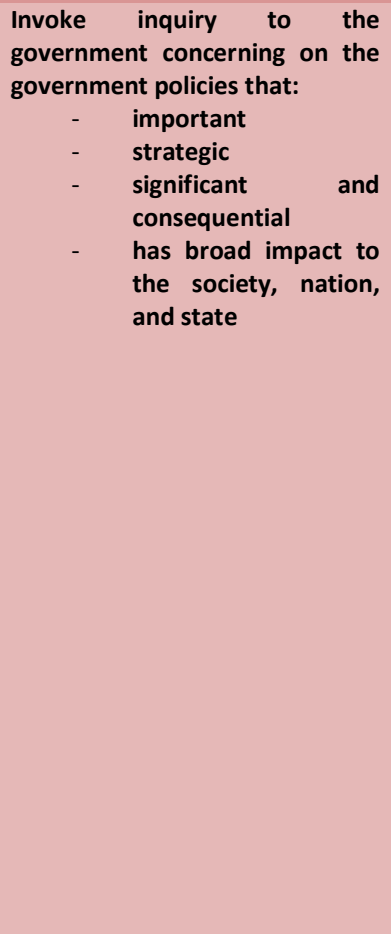 & $\begin{array}{l}\text { (1) proposed by minimum } 25 \text { members of the DPR and more than } 1 \text { fraction } \\
\text { (2) should be documented by at least: the substance of the government policy and/or its } \\
\text { implementation, reasoning the interpellation } \\
\text { (3) should be approved by the plenary session in which attended by } 1 / 2 \text { members of the DPR. The } \\
\text { decision has been made by approval from } 1 / 2 \text { of the attended members } \\
\text { Article } 174 \\
\text { (1) in case that interpellation has been approved by the plenary session, the President may attend } \\
\text { (2) if the President can't attend and give written explanation, the President could assign the } \\
\text { minister or the relevant officer as his representative } \\
\text { the DPR decides to accept or reject the President's explanation and answer } \\
\text { (1) } \\
\text { (2) in any case that the DPR accept the explanation and answer, the interpellation could be } \\
\text { avowed finish and the substance of the interpellation can't not be submitted for the } \\
\text { (3) In any case that the DPR rejects the explanation and the answer, the DPR can invoke } \\
\text { other mechanisms } \\
\text { (4) The decision to accept or reject the explanation and answer should be approved by the } \\
\text { approval from more that } 1 / 2 \text { attendance. }\end{array}$ \\
\hline Enquettee & $\begin{array}{l}\text { Investigation against the } \\
\text { implementation and/or the } \\
\text { government policy in which } \\
\text { allegedly contradicts to the laws } \\
\text { that: } \\
\text { - important } \\
\text { - } \text { strategic } \\
\text { broadly impact to the } \\
\text { society, nation, and } \\
\text { state policy could be } \\
\text { such polich that exercise } \\
\text { policy the } \\
\text { by the President, the } \\
\text { Vice President, the } \\
\text { state ministry, the } \\
\text { Chief of the TNI, the } \\
\text { chief of Police, the } \\
\text { Supreme prosecutor, } \\
\text { or the chief of non- } \\
\text { ministerial } \\
\text { government } \\
\text { institution }\end{array}$ & $\begin{array}{l}\text { Article } 177 \\
\text { (1) proposed by minimal } 25 \text { members of the DPR and more than } 1 \text { fraction } \\
\text { the proposal of enquette must be completed with the document mentioning the } \\
\text { substance of the policy and/or the implementation of the Law which investigated and } \\
\text { the reason of conducting the investigation } \\
\text { (3) If the proposal is approved in the plenary session, attended by } 1 / 2 \text { the DPR's members } \\
\text { and voted by } 1 / 2 \text { attendance, the enquettee will be continued } \\
\text { Article } 178 \\
\text { (1) The DPR decides to accept or reject the enquettee } \\
\text { (2) In any case that the DPR has accepted the enquettee, the special committee for } \\
\text { enquettee is established by the DPR's decision; contains of all fraction in the DPR. } \\
\text { (3) In any case that the DPR rejects the enquettee, the proposal could not be submitted for } \\
\text { the second time } \\
\text { Article 179 } \\
\text { The special enquettee committee besides asking for the explanation to the government, may also } \\
\text { require explanation from the evidence, expert, professional organization, and/or affiliation parties } \\
\text { Any citizen or non-citizen who resided in Indonesia can be called for an enquettee by the special } \\
\text { enquettee committee. They have legal obligation to come up. If they ignore the committee's } \\
\text { formal warrant three times, the committee could, by coordinating with the police, issue a call } \\
\text { warrant. }\end{array}$ \\
\hline
\end{tabular}




\section{Rosa Ristawati: Modelling Executive Powers in the Indonesian Constitution: A comparative Study}

\begin{tabular}{|c|c|c|c|}
\hline & & \multicolumn{2}{|r|}{$\begin{array}{l}\text { (1) If the DPR's plenary session decides the implementation of the Legislation or government policy } \\
\text { relevant to the important, strategic, broadly impacts to the society, nation, and state against the } \\
\text { laws, the DPR could invoke the right to express opinion to the government } \\
\text { (2) However, if the DPR's plenary session decides that such matters does not against the laws, the } \\
\text { enquettee will be concluded and will not be proposed in the next session } \\
\text { (3) Both decisions to decide against or not against should be approved by the DPR's plenary } \\
\text { session of } 1 / 2 \text { attendances. }\end{array}$} \\
\hline Opinion & $\begin{array}{l}\text { The right to intervene the } \\
\text { governmental affairs by } \\
\text { expressing the opinion against: } \\
\text { - the government } \\
\text { policy or the extra- } \\
\text { ordinary in Indonesia } \\
\text { or internationally } \\
\text { following up action of } \\
\text { the interpellation and } \\
\text { enquettee } \\
\text { the allegation that } \\
\text { the President and/or } \\
\text { the Vice President } \\
\text { conduct unlawful } \\
\text { action of the state } \\
\text { betrayal, corruption, } \\
\text { other serious crimes, } \\
\text { inmoral act, and/or } \\
\text { the President and/or } \\
\text { the Vice President are } \\
\text { no longer eligible }\end{array}$ & $\begin{array}{l}\text { (1) } \\
\text { (2) } \\
\text { (3) } \\
\text { (1) } \\
\text { (2) } \\
\text { (1) } \\
\text { (2) }\end{array}$ & 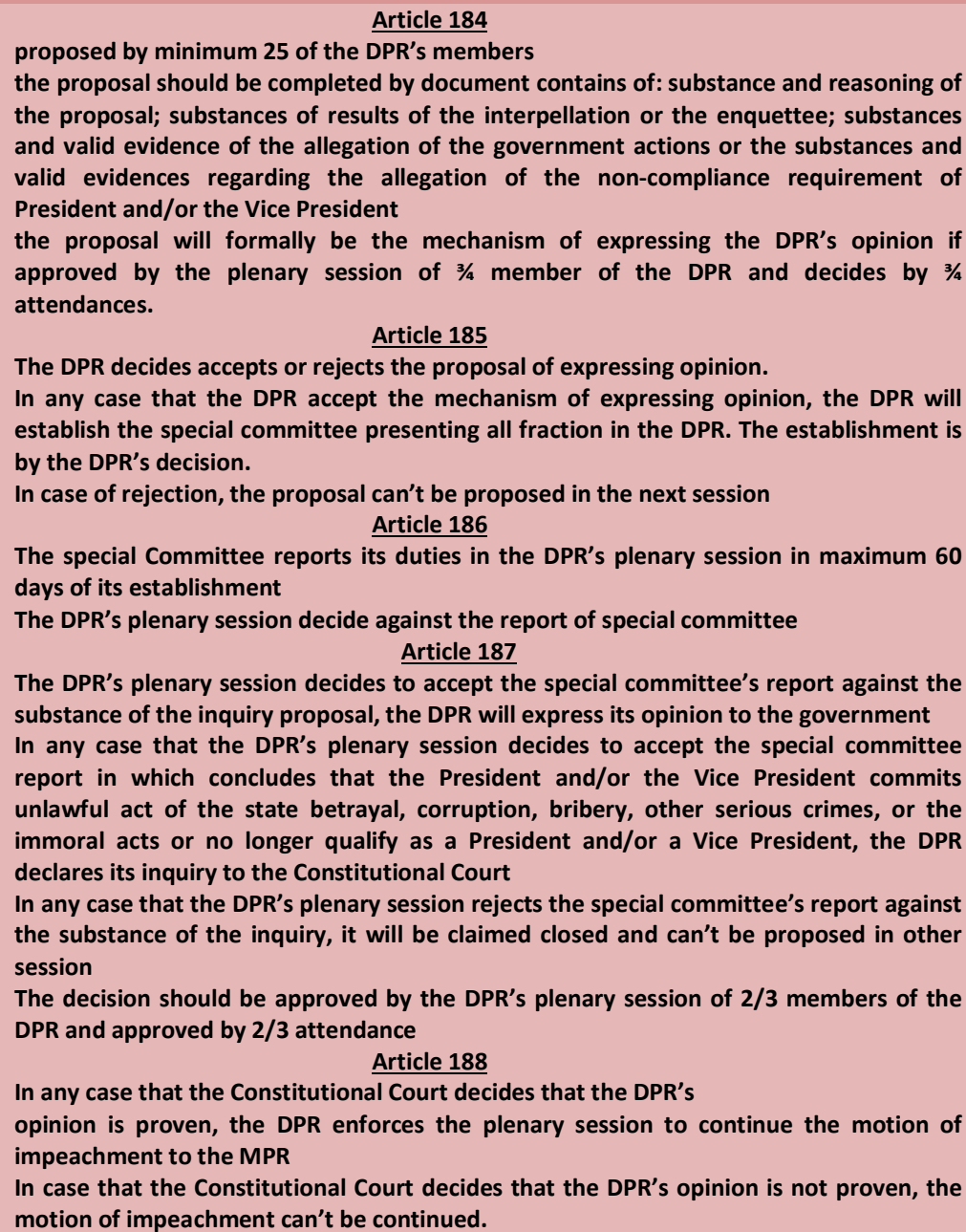 \\
\hline $\begin{array}{l}\text { Individual } \\
\text { mechanism }\end{array}$ & $\begin{array}{l}\text { - Individual inquiry } \\
\text { - Individual opinion } \\
\text { - Individual immunity } \\
\text { within office capacity }\end{array}$ & $\begin{array}{l}\text { In any cas } \\
\text { clearly an } \\
\text { individual } \\
\text { the Presic } \\
\text { answer sh } \\
\text { or other s }\end{array}$ & $\begin{array}{l}\text { Article } 191 \text { and Article } 192 \\
\text { se that the inquiry is subject to the President, the inquiry should be written shortly and } \\
\text { id be delivered to the Chief of the DPR. The chief of the DPR could ask explanation to the } \\
\text { I proposed inquiry. The chief of the DPR will forward the inquiry to the President and ask } \\
\text { dent to provide answers. Before it is forwarded, the inquiry can't be published. The } \\
\text { hould be by written or orally replied by the President. It can be mandated to the minister } \\
\text { tate officer. }\end{array}$ \\
\hline
\end{tabular}




\section{The DPD}

The existence of the DPD was the result of a Constitutional amendment. The DPD (the Dewan Perwakilan Daerah) is the Council of the province's representative. Members of the DPD like MPR and DPR's are elected directly from each of the provinces in Indonesia. According to Article 22D section (1) of the Constitution, the DPD can propose to the DPR the Bills that are relevant to the local autonomy, the relationship between the central and local government, the establishment and expansion and the merger of the provinces, the exploration and maintenance of natural resources and other economic resources, and Bills that are relevant to the state financial equality between the central and local government. Furthermore, in section (2), the Constitution gives the DPD constitutional status as the co-legislator and it has the power to discuss particular Bills regarding the local autonomy, the relationship between the central and local government, the establishment, expansion, and provinces merger, the exploration and management of natural resources and other economic resources, and the budget equality between the central and local government, and giving consideration to the DPR of the Bill of state budget and Bills relevant to tax, education and religion. As the nature of the DPD is also to function as people representatives, the DPD has also the function to oversee the state administration and governmental affairs with particular scopes. Article 22D section (3) enumerates that the DPD can exercise the oversight function of the execution of the Legislation subject to the local autonomy, establishment, expansion and the province merger, the relationship between central and local government, the natural resources and other economic resources exploration and maintenance, the application of the state budget, tax, education, and religion. With regard to the DPD's function of oversight, the DPD should submit the report from its oversight to the DPR for the consideration to be followed up. To this extent, the oversight function of the DPD is not as strong as the DPR. It can be concluded that to do the oversight, the DPD depends mainly on the DPR. The DPR only makes a report in its scrutiny without being empowered by any mechanisms to counter against the state administration and governmental affairs. 


\section{The Constitutional Court and the Supreme Court}

The Judicial power is constitutionally instituted in Article 24 of the Constitution. After the Third Amendment Constitution, the judicial power in Indonesia has become a dualist model of Judiciary in which, there are two institutions holding judicial power. However, the two institutions have different powers subject to their constitutional competence. Article 24 section (2) enumerates that the judicial power is exercised by a Supreme Court and its lower courts; and the Constitutional Court. There is no hierarchy relationship between the Supreme Court and the Constitutional Court. The constitution grants the competence of the Supreme Court in Article 24A of the Constitution to adjudicate cassation; to do a judicial review of the laws under the Legislation and other authorities given by the statutes. On the other hand, the Constitutional Court is granted the judicial power by article 24C of the Constitution. There are 2 main constitutional competences that the Constitutional Court has in accordance with its judicial power:

(1) Adjudication in the first and final stage with the final decision for judicial review of the Legislation vis a vis the Constitution; Adjudicate the conflict of authority between state institutions whose authority is granted by the Constitution. Adjudicate the dissolution of political parties, and conflicts about the general election

(2) Decides the DPR's opinion on the allegation of unconstitutional action by the President and/or the Vice President.

Besides judicial competences, both of the institutions have other powers to check the Presidential power. The Supreme Court, by article 24C section (3) has the power to nominate 3 out of 9 Constitutional judge candidates to the President. Also it has the constitutional power to balance the Presidential pardoning power by which the Court is giving consideration of clemency and rehabilitation. However, in terms of executive power, the Court has the power to oversee government affairs by judicial review of all kinds of Laws that are hierarchically under the Legislation. The laws subjected to the judicial review by the Supreme Court include the Government Rules, the Presidential Rules, and the other rules in the scope of government. Legally, the judicial review by the Supreme Court is part of the checks and balances mechanism 
of the executive power. The Court has the power to check the Presidential power in lawmaking.

\section{d. Check and balance of the Presidential power: constraint, limitation, control of government?}

- The Legislative checks and balances power constraints to the Presidential treaty power

In the treaty making domain, there are at least three roles which the DPR can conceivably play; first, it has the key decision making with its approval to authorize the exercise of the President's treaty power; secondly, the DPR has the role to verify and confirm the President's intention to conclude a treaty; and third, it has the role as public voice concerning certain treaties and the likely implications for Indonesia. ${ }^{766}$ Article 11 Section (1) of the Amended Constitution implies that the real and actual treaty power is vested in the DPR by its approval.The treaty power of the President is only a formal and dependent power. To exercise the power, the President depends on the DPR's approval. The main power rests in the DPR while the President gets the residual power to represent the state in the negotiations and conclusion process. Nevertheless, this would not mean that the President plays no important role in treaty power. The process of negotiation encourages the President to have significant power to come up with his independent perspective.

As the treaty power of the President is not a collaborative power but merely a dependent power, it potentially makes the DPR stronger and gives it bargaining power. Although the DPR does not need to sit in the treaty negotiation process, its approval is the key for the treaty making. If the President does not ask the DPR for approval, the exercise of the treaty power would be unconstitutional. Moreover, Article 20A section (1) of the UUD NRI 1945 mentions three constitutional functions of the DPR namely, the legislative function, budget function, and the oversight function against the executive power in governing the state. ${ }^{767}$ The Law No. 27/2009 in Article 69 Section (1) strengthens such constitutional functions of the DPR.

\footnotetext{
${ }^{766}$ Hikmahanto Juwana, Treaty Making: Indonesian Practice, Paper presented at the Seminar on the Parliamentary Oversight of Treaties Republic of Indonesia and Australia, Jakarta, 15-16/07/2005

${ }^{767}$ Article 20A (1) of the Amended Constitution of Indonesia (Appendix 5).
} 
The DPR may invoke those functions by the constitutional mechanism of interpellation rights, rights to investigation (right of enquette), or rights to question. Functions to check against the President's treaty making power may be invoked by the DPR at an early stage by giving approval (for both oversight function and budgeting function). On the treaty transformation stage, the DPR has the legislation function to approve and give domestic legal effect to the treaty and oversight function for the implementation of the treaty transformation law. ${ }^{768}$ Moreover, if the international agreements are potentially a threat to the national interest, the DPR can require the annulment of the international agreement. ${ }^{769}$ Accordingly, such a mechanism can be imposed by invoking interpellation and enquette right and followed by the issuing of the DPR's decision to require the President to withdraw from the international agreement. However, in practice, it will not be easy for the President to withdraw from the treaty that already has been concluded. In practice, the constitutional mechanism to invoke interpellation, right of enquette, right to question or even the mechanism of joint approval (in the law-making process) for the treaty transformation are still not effective for the DPR to constrain the President's treaty power. It is because there are no explicit constitutional duties requiring the President to answer the DPR's rights. The President is still in his safe zone as there are always loop holes to counter-balance the DPR's mechanisms.

\section{- The Judiciary and the treaty making power}

Article 24 section (2) the Amended Constitution stipulates that "The judicial power shall be implemented by a Supreme Court and judicial bodies underneath it; namely, Public courts, Sha'riah courts, Military Courts, and State administrative courts, and by a Constitutional Court". Accordingly, the constitution explicitly grants the judicial power to a Supreme Court and a Constitutional Court. As mentioned in the Amended Constitution Article 24A Section (1), the Supreme Court has the power to review laws which are hierarchically inferior to the Legislation.

\footnotetext{
${ }^{768}$ On the DPR's oversight function, the explanation of article 11 section (2) Law No. 24/2000(Appendix 5). In this case, the DPR can invoke responsibilities and an explanation from the governments (the executive) on the basis that the international agreement affects the state budget.

${ }^{769}$ The Explanation of article 11 section (2) Law No. 24/2000.
} 
On the other hand, based on Article 24C Section (1) of the Constitution, the Constitutional Court has constitutional power for a judicial review of Legislation against the Constitution.

The Constitution does not say anything about the role of the judicial power vis a vis treaties. Unlike in the US constitution which states explicitly the role of the Supreme Court, ${ }^{770}$ the Indonesian Constitution does not clarify any roles for either the Supreme Court or the Constitutional Court. However, as both of the Courts have the power to interpret the laws, the Courts might have the power to interpret the treaties after transformation. Unfortunately, the Constitution does not mention any provision about the status of treaties in the domestic legal framework. In Indonesia, as the Constitution does not apply treaties as the law of the land, the Courts seem to have less power compared to the treaty process.This is different from the US. Under Article IV of the US Constitution, treaty is also the law of the land; thus, the Supreme Court can apply the judicial review to any of treaties ${ }^{771}$.

\section{Are treaties subject to Judicial Review?}

The Court has the competence to conduct a judicial review to challenge executive action and legislation. The Amended Constitution explicitly recognizes judicial review by both Supreme Court and Constitutional Court. Presumably, with the power given by the Constitution, the Courts have the authority to declare any treaty to be incompatible with the Constitution or Legislation. As the Constitution does not say anything about the status and position of any international treaties in the Indonesian legal framework, treaties and other international agreements cannot be subject to judicial review as such. However, as Indonesia adopts a dualist model, judicial review may be performed for a treaty or international agreements that have already been transformed into domestic law. Such judicial review can only be performed for the

\footnotetext{
${ }^{770}$ In the US, article III of the constitution explicitly granted the Court with the competences to decide cases arising under the Constitution, laws and treaties, and other designated cases or controversies, and the courts are monitoring and calibrating the constitutional system.

${ }^{771}$ Louis Henkin, Op. Cit., p. 70: "Many a case coming to court because it arises under the Constitution, laws, and treaties of the United States and many another case or controversy within the judicial power impinge on the foreign affairs of the United States. In the course of their decisions, courts scrutinize the constitutional validity of acts of Congress or of actions of the executive branch that affect United States foreign relations, interpret such acts of Congress or treaties of the United States, and determine and apply international law (also known as the law of nations); at times, the courts even make some law related to foreign affairs on their own authority".
} 
legislation or Presidential rule as the legal form of treaty transformation. However, the Court may only challenge the formality issue regarding the transformation mechanism but not for substantial issues on the original draft of treaties or other international agreements.

In practice, a current case of judicial review is the review of the Legislation on the ASEAN Charter transformation. ${ }^{772}$ In this case, the Court rejected the case and came to the conclusion that the Court has no power to review a treaty. The Court seems to have chosen a safety position with its decision. In general, the Court could always review any legislation including legislation on the treaty transformation. However, it should be taken into account that the substance to be reviewed is not the substance of the International treaty as such. In this context, review by the domestic court will not affect the original international treaty (nor the validity of this treaty internationally) instead it only affects the substance of the legislation transforming the treaty into the legislation. It clearly shows that there is a demarcation between the International and domestic legal system. By judicial review, if the courts revoke the provision of a treaty that has been transformed into the Law or the Presidential Rules, the provision would only have a domestic legal effect. The annulment by domestic courts does not have any effect on a treaty internationally. It couldn't stop the state fulfilling the International obligations derived from the treaty. The state is still bound by the treaty or international agreement and thus, the President, as the state representative, is still responsible to ensure the international obligations. Therefore, to anticipate the international law violation, the President and his government should ensure the international obligation and anticipate a solution to harmonize domestic affairs and international obligations.

\section{- The DPR's Consideration for diplomatic powers}

The word "consideration" in the Constitution may be similar to the word "opinion". It does not imply a veto or an approval. In contrast to an approval to exercise treaty making powers, a consideration from the DPR is non-binding for the President. Textually in the

\footnotetext{
${ }^{772}$ Case No. 33/PUU-IX/2011 reviewing the Law No. 38/2008 concerning on the Ratification of Charter Of The Association Of Southeast Asian Nations. The Decision is about whether or not the Constitutional Court has the authority to review treaties and International agreements. It decided that the Constitutional Court has the authority to review treaties and International agreements which have been transformed into the National Legislation. The Decision did not say anything about a dualist system in Indonesia.
} 
Rosa Ristawati: Modelling Executive Powers in the Indonesian Constitution: A comparative Study

Constitution, Article 13 requires the President to take into account the DPR's consideration for ambassadors and consuls appointments. It may be interpreted that the DPR's role in diplomatic powers is not really as strong as the treaty making power. The President can exercise the power independently without seeking authorization from the DPR. In practice, there are at least three possibilities for the DPR in giving consideration to the President; first, by giving recommendation; second, by giving a conditional recommendation: giving a recommendation to the candidate but not for the recipient state; and third, by giving dissuasion in subtle ways and rejecting the recipient state.

As the word "consideration" has a non-binding meaning compared to an approval, the President may waive the DPR's consideration, recommendation and opinion. However, in practice, although a consideration is not binding, the DPR always has strong intervention on the exercise of diplomacy power. A constitutional practice showed that on August 2011, the President proposed 34 ambassador candidates. ${ }^{773}$ According to the fit and proper test, one candidate was rejected by the DPR. The President had no choice to waive the DPR's consideration instead of choosing to abide by the DPR on the grounds that the DPR has full power over the state budget. The fact that the DPR has the power of the purse has made its position superior to the President. ${ }^{774}$ The DPR has the power to approve a state budget and the allocation of the budget for the establishment of state representation offices in other countries. To give consideration, the DPR is involved in the diplomatic nomination process by conducting a fit and proper test. The consideration may also be given on the grounds of a political point of view or may be based merely onthe state allocation budget.

\footnotetext{
${ }^{773}$ Salman Al Farisi for Uni Emirat Arab, Ahmad Niam Salim for Aljazair, Nurul Qomar for Kazakstan, Letjen Mar Safzen Nurdin for Irak, Prayono for Azerbaijan, Lutfi Rauf for Thailand, Trie Edi Mulyani for Kolombia, Prianti Gagarin for Venezuela, Andrajati for Senegal, Retno Lestari for Belanda. Deddy Saiful Hadi for Qatar, Mayerfas for Vietnam, Teiseran Cornelis for Kuba, Desra Percaya for PTRI New York, Komjen Pol Nurfaizi for Mesir, Ellias Ginting for Denmark, Artanto Wargadinata for Bahrain, Harbangan Napitupulu for Mozambik, Djauhari Oratmangun for Rusia, Sukanto for Oman, Sunu Soemarno for Kenya, Dwi Ayu Arimami for Panama. Saut Maruli Gultom for Ekuador, Prof Muh Prakosa for Italia, Subijaksono Suyono for Bosnia, Andri Hadi for Singapura, Bunyan Saptomo for Bulgaria, Dewa Made Sastrawan for Swedia, Dian Wirengjurit for Iran, Budiarman Bahar for Vatikan, Agustinus Sumartono for Namibi.

${ }^{774}$ MataNews, the DPR's threat for the Republic Indonesia in Switzerland, April 24, 2011, accessed online at: http://matanews.com/2011/04/24/ancaman-dpr-untuk-dubes-swiss/ (last accessed on 12/05/2014).
} 
After getting the DPR's consideration, the President will continue to the next stages of formal appointment. Since the DPR's consideration is not only about the result of a fit and proper test but may also be on the grounds of the budget, the President must take into account the DPR's consideration.To conclude, although the text says that the President is given an independent power to exercise diplomatic powers, the President is constrained to abide by the DPR's consideration. At this point, it could be said that in the diplomatic powers, the President seems to have a formal power with no discretion.

In practice, under the Amended Constitution, President SBY exercised diplomatic power by determining a million friends diplomacy. ${ }^{775}$ The SBY diplomatic policy as part of exercising the diplomacy power was challenged when Indonesia faced some diplomatic relationship problems with Malaysia (in the case of the Bintan incident) ${ }^{776}$, Australia (in the case of tapping) ${ }^{777}$, and Singapore (in a case of over naming an Indonesian navy ship after two Indonesian marines who took part in the 1965 bombing on Orchard Road) ${ }^{778}$. The DPR can only question the President's policy.

\footnotetext{
${ }^{775}$ SBY's Inaugural Speech: The Text 2009, availabale online at: http://www.thejakartaglobe.com/archive/sbysinaugural-speech-the-text/ see also: Siswo Pramono, A Million Friends Diplomacy, Jakarta Post, 13 June 2010, available online at: http://www.thejakartapost.com/news/2010/06/13/\%E2\%80\%98a-million-friends\%E2\%80\%99diplomacy.html (last accessed on 12/05/2015).

${ }^{776}$ Antara News, Million friends zero enemies policy vs Bintan incident, accessed online at: http://www.antaranews.com/en/news/1282830376/million-friends-zero-enemies-policy-vs-bintan-incident (last accessed on 12/05/2015).

${ }^{777}$ Antaranews, Indonesia freezes joint military training with Australia as a response of wire tapping activities by Australia to President SBY and his wife, accessed online at:

http://www.antaranews.com/en/news/91512/indonesia-freezes-joint-military-training-with-australia-militarycommander (last accessed on 12/05/2015).

${ }^{778}$ Singapore concerned over naming Indonesian navy ship, available online at: http://www.straitstimes.com/breaking-news/singapore/story/singapore-registers-concerns-over-indonesian-navyship-20140206 (last accessed 12/05/2015).
} 
Rosa Ristawati: Modelling Executive Powers in the Indonesian Constitution: A comparative Study

Figure 5 The DPR Consideration for the Ambassador's nomination based on Article 196 of the DPR's Rules of Procedures

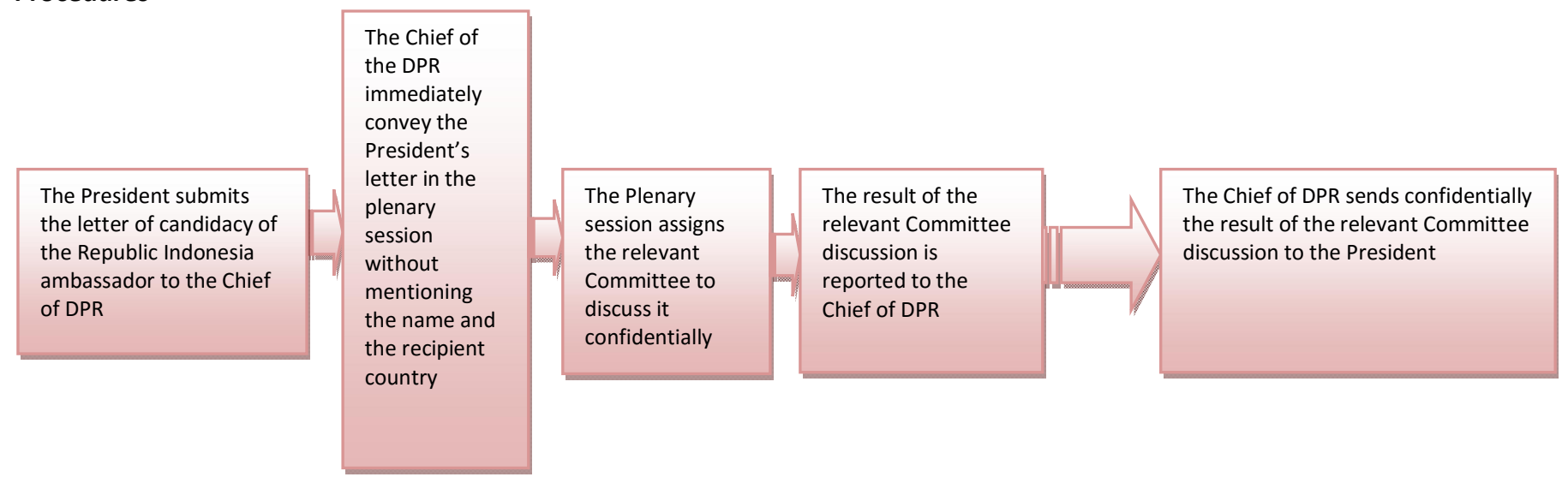

Figure 6 The DPR consideration of the prospective ambassador from foreign countries to Republic Indonesia (during the session) based on Article 194 of the DPR's Rules of Procedures

The nomination letter of
the foreign state
ambassadors for Republic
Indonesia is submitted by
the President to the Chief
of the DPR
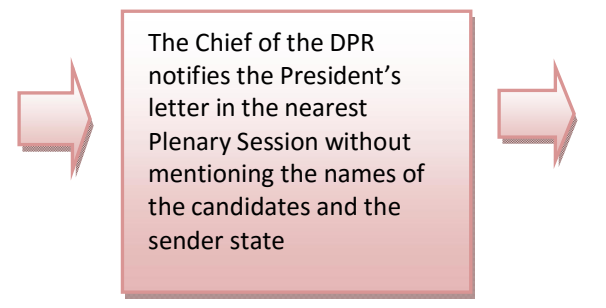

The letter of candidacy is
discussed secretly in the
consultative forum
between the Chief of the
DPR, the relevant
Committee and the Chief
of faction

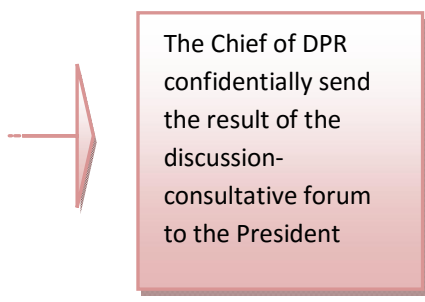

Figure 7 The DPR's consideration for the prospective ambassadors from foreign countries to Republic Indonesia (during the recess) based on Article 195 of the DPR's Rules of Procedures

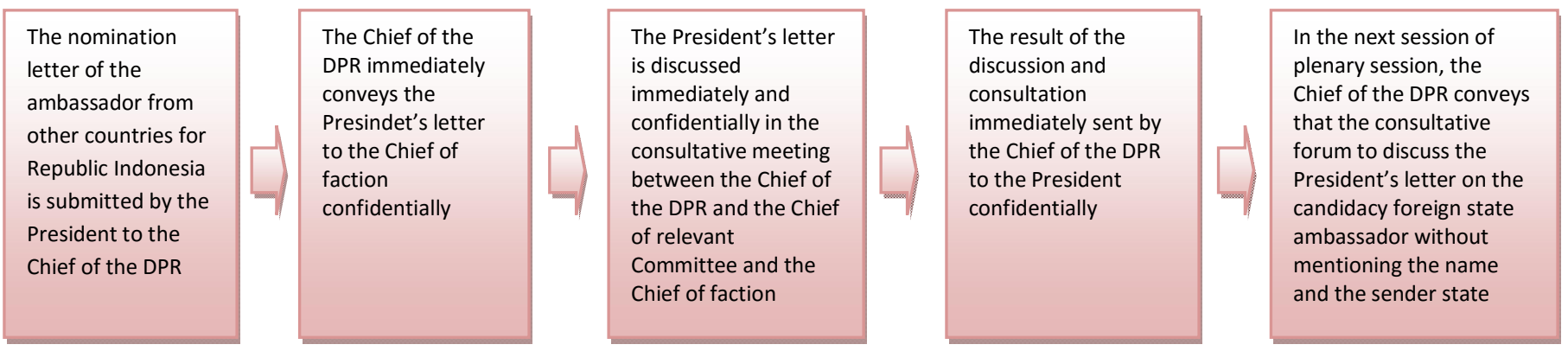

\section{- Checks and balances against the President's administration: Legislative Scrutiny (Oversight)}

Theoretically, the legislative branch, as its function is to represent public opinion, has the power to pursue legitimate government and the political system, law-making and scrutiny 
against the executive and the administration of the state. ${ }^{779}$ In modern ways, to conduct oversight functions over all the executive actions, there are mechanisms that the legislature can use, namely, the right to question, direct queries to ministers by oral or written questions, and interpellations, an alternative form of investigation by substantive form of question followed by a short debate and a vote on whether the government's response is deemed acceptable, emergency debates and confidence votes by which the legislature calls the government to account. In some countries this mechanism could bring down a minister and committee investigations as the key of legislature oversight. ${ }^{780}$

The DPR's oversight function may be followed by the right to invoke information, confirmation, explanation, and clarification against government affairs. Moreover, the DPR also has the right to invoke interpellation, enquette, resolution, and confirmation. However, the Constitution does not oblige the President to counteract and satisfy the DPR's rights. The DPR may invoke its oversight functions to public policy making, public policy execution, budgetary, budgetary implementation, any government actions, and the political appointment of public officials. $^{781}$

On the establishment of the agencies, commission, and other non-department agencies, the DPR as legislature can be directlyinvolved by setting a framework through Legislation or by overseeing the running of executive agencies. It can have a key role by giving approval for the budgets that are proposed by the President. If the DPR does not confirm the establishment of an agency, the budget for the agency establishment will never be approved and the President cannot fund the agency.

In terms of the appointment of executive officers, the legislature has the access to oversee the appointment. The DPR can either give approval or confirmation in the nomination and selection process and also by its mechanisms of scrutiny can monitor the work of executive officers.

\section{- The Legislature and the Presidential Law-Making Power}

\footnotetext{
${ }^{779}$ Kenneth Newton and Jan W. Van Deth, Op. Cit., p. 106

${ }^{780}$ Rod Hague and Martin Harrop, Comparative Government and Politics: An Introduction, $6{ }^{\text {th }}$ edition, Palgrave Macmillan, 2004, p. 258

${ }^{781}$ Jimly Asshiddiqie, Op. Cit., p. 36.
} 
The DPR as the state legislature has the power to make Law. Moreover, the Constitution stipulates that the implementation of the Law is by a delegated law (Government Directive) to have the more technical issue. ${ }^{782}$ The Government Directives, or the Executive Directives, are made by the President as ordered by the Legislation. In such process, the President will be responsible to issue the Government Directive to implement the Law on behalf of the Government. According to the DPR's function of oversight, the DPR has the competence to oversee the implementation of the Law. It means that the DPR also has the authority to oversee the government directive. In case there is a contradiction between the Law and the government rules, the DPR can invoke its right of question, interpellation and enquette as a result of the issuance of the Government Directive.

On the Emergency Law, the DPR can onlycheck the law after the constitutional limit has already been exhausted. Unlike a legislation process, the Emergency Law has a 1 year time limit or after the emergency situation has been restored. The DPR has no power to be involved in the early process. The emergency law allows the President to exercise full discretion to overrule Laws in order to overcome the situation. The Law can be checked by the Constitutional Court when it is still enacted as an Emergency Law or has been transformed to be Legislation. According to Article 52 Law 12/2011, to be transformed into Legislation, an Emergency Law should be submitted to the DPR in the next session or the DPR's first session after the issuance of the Emergency Law. According to Article 52 section 4 Law 12/2011, the DPR may give approval or rejection to the Emergency Law. ${ }^{783}$ At this point, the DPR can only act after the emergency law has been enacted. Against the emergency Law, the DPR has the power to invoke the ex-post mechanism of legislative review over the emergency law. On the other hand, the DPR's oversight function can only be invoked as anex-post mechanism after the emergency law has been enacted and the emergency situation has been overcome.

\section{- The Court and the Presidential Law-Making Power}

\footnotetext{
${ }^{782}$ The Law No. 12/2011 defines the Government Rules as the law that is set by the President to implement the Legislation as appropriate.

${ }^{783}$ Article 52 Section 4 and section 5 the Law No. 12/2011 (Appendix 5).
} 
According to Article 24A Section 1 of the Constitution, the Supreme Court has the power to review any laws under the Legislation, whereas, the Constitutional court has the power to conduct a judicial review of the constitutionality of the emergency law only after the emergency law has been approved to be Legislation by the DPR. The argument that the Constitutional Court should not have the power to review an Emergency Law before it is approved to be a Bill by the DPR, is actually in accordance with the argument that the law is about the emergency situation and by such law, the government needs to take urgent and necessary action to deal with the emergency situation. During the state of emergency, the President as the head of state and the commander in chief is given a broad discretion to protect the state and maintain the sovereignty of the state. The influence and the involvement of the Constitutional Court during the state of emergency would risk undermining an urgent measure taken by the President in his effort to exercise his constitutional duties to protect the state.

The judicial reviews conducted by the Supreme Court and the Constitutional Court are strictly distinguished by the Law No. $12 / 2011 .{ }^{784}$ The Supreme Court has the power to review the legality of any Government Directives (Peraturan Pemerintah), any Presidential Regulations and any other Regulations (such as the Minister Regulations) made in the area of the executive branches. The power of both Courts to review the constitutionality and the legality of laws made by the President in the area of the executive is such an ex-post mechanism of checks on the Presidential law-making power.

\section{- Legislative check on the Presidential pardoning power}

The DPR has the power to indirectly limit the President's pardoning power by Law No. 22/2002 on the Clemency. This Law has been revised by the Law No. 5/2010. In the Legislation, the Presidential pardoning power is even more limited than before. The DPR has given strict limitations to the exercise of the pardoning power. However, it is not actually focused on how the President himself decides in giving clemency, but the limitation is focused on the

\footnotetext{
${ }^{784}$ Article 9 of the Law No. 12/2011 distinguishes the competence of both Courts in Judicial Review. According to the Article, the Constitutional Court has the power to hold the session on the judicial review of the constitutionality of Law; whereas, the Supreme Court has the competence to hold a Judicial review about the legality of the other laws.
} 
Rosa Ristawati: Modelling Executive Powers in the Indonesian Constitution: A comparative Study

procedures of submission of clemency to the President. In practice, the President still has full powers to give clemency. ${ }^{785}$

With regard to the amnesty and abolition, as it has been clearly expressed in the Constitution, the DPR has also the function to balance the presidential pardoning power in giving amnesty and abolition by giving consideration. This is also in accordance with Article 71 (k) of the Law No. 27/2009. The Law stipulates that the DPR has such duties and responsibilities. In experience, in seeking the DPR's consideration before giving amnesty and abolition to the members of the Aceh Independence Movement (GAM), the President sent a written Decision to the DPR. ${ }^{786}$ In that case, the DPR may only act positively and avoid conflicts since the DPR has always concured with the President on giving amnesty and abolition. A political conflict may arise when the DPR with its consideration goes against the President. However, as the word consideration does not force the President to be bound to the DPR's consideration; the final decision would be in the hands of the President.

\section{- Judicial check against the Presidential pardoning power}

Article 14 section (1) of the Amended Constitution expressly stipulates the competence of the Supreme Court in giving consideration to the President in exercising a pardoning power.

\footnotetext{
${ }^{785}$ Detik News, Pemberian Grasi Sudah diperketat di UU yang Baru disahkan DPR, 21/08/2010, archived at: http://us.news.detik.com/read/2010/08/21/143943/1424856/10/pemberian-grasi-sudah-diperketat-di-uu-yangbaru-disahkan-dpr, accessed on 03/04/2012: "The procedure of clemency is given through the strict process in the Ministry of Law and Human rights by a special department and will process transparency with the scrutiny by the DPR. Compared to the previous Legislation (the Law No. 3/1950) that leaves more than 2000 cases of clemency application, the new Legislation is expected to give more clarity and effectiveness in the Presidential pardoning power implementation. Before the Law 2010, the President was directly considering and getting less feedback from the Ministry that has direct connection with the penitentiary. With the new Legislation, the DPR has set more strict limitations to the exercise of the Presidential pardoning power. It should be based on the principle of precautionary, principle of justice and principle of humanity. It is also purposed to balance the judicial power in applying justice and the rule of law and does not mean to intervene in judicial independence."

${ }^{786}$ In exercising the Presidential pardoning power, giving amnesty and abolition, the President had written a letter to the DPR: the Presidential's Letter No. B-11/Pres/8/2005 asking for the DPR's consideration to give amnesty and abolition to all persons involved in the Aceh Independece Movement (GAM). The DPR had internally discussed the Presidential letter and decided the arguments of giving the amnesty and abolition are considered based on the MoU between the Republic of Indonesia and the GAM, consider that people should have freedom of expression without fear of their freedom, people can only be prosecuted based on crimes and not on their political beliefs and activities, the DPR through the Commission III asks the government whenit grants the amnesty to the members of GAM, they must include the statement from all members of GAM who are given amnesty that they will be loyal to the Republic of Indonesia. The amnesty is given to avoid horizontal conflict, the MoU on peace which involved all the figures of GAM.
} 
Rosa Ristawati: Modelling Executive Powers in the Indonesian Constitution: A comparative Study

The Law No. 3/2009 on the second amendment of the Law No. 14/1985 on the Supreme Court Article 35 emphasizes that the Supreme Court gives legal consideration to the President in giving clemency and rehabilitation. Article 9 of the Law 2002 stipulates that within 20 days after the reception of the copy of the clemency application, the Court of first stage sends the copy of the clemency application to the Supreme Court. Furthermore, Article 10 of the Law 2012 clarifies that within 30 days after the reception by the Supreme Court, the Supreme Court will send the written consideration to the President. According to Article 11 of the Law 2002, after receiving the Supreme Court's written consideration, within a maximum of 3 months, the President decides whether to grant or reject it based on the Supreme Court's consideration.

- The legislative check on the Presidential Military Power: the DPR function in constraining the President's military power

When the military command is about a military operation, the DPR must be informed and has the right to give its recommendation and advice. The DPR's recommendation and advice is a political decision. The role of the DPR in military operations led by the President and conducted by the TNI can be implied in article 7 section (3) of the Law No. 34/2004. The Article confirms that all the military operations determined in the Legislation must be based on the policies and state political decision. The policies and political decision are delivered from a consultative session between the President and the DPR.

The legislative checks on the presidential military power can be observed from the approval given by the DPR. As the President has the constitutional power as commander in chief of the army, navy and air force, the president has also the power to command and control the military organization. In this respect, the President is granted the power to nominate, appoint, and dismiss the chief of TNI within the TNI's structural organization. Accordingly, Article 13 section (2) of the Law No. 34/2004 stipulates that the President appoints and dismisses the chief of TNI. However, to exercise the power, the President must seek approval from the DPR. The approval of the DPR may relate to the morality and track record of the nominee ${ }^{787}$ According to the legal procedures, the President appoints and dismisses the Chief

\footnotetext{
${ }^{787}$ The explanation of Article 13 section (2) of the Law No. 34/2004.
} 
of TNI on the basis of the organizational TNI's interest, and nominates one candidate for approval from the DPR. ${ }^{788}$ The DPR can give its approval or disapproval for a candidate of the Chief of the TNI nominated by the President. The approval is given by the DPR at least within 20 days (not including the recess period) after which the DPR's approval is administratively granted. ${ }^{789}$ On the other hand, if the nomination is rejected, the President can nominate other names. The DPR however must give a written reasoning letter to deliver its disapproval. ${ }^{790}$ However, as already indicated, in case the DPR does not respond within 20 days, the DPR is considered to have given its approval, so that the President has the power to appoint the new chief of the TNI and dismiss the previous chief. ${ }^{791}$ One of the roles of the chief of the TNI is to advise the Minister of state defense in relation to the state defense policy. ${ }^{792}$ However, in daily managing the TNI, exercising the state defense policy, conducting the military strategy and military operations, developing the TNI doctrine, establishing the use of military forces by the military force, the Chief of the TNI is responsible directly to the President. ${ }^{793}$

The President has the power to mobilize the military forces. The President is also responsible for the use of military forces. ${ }^{794}$ However, in doing so, the President must seek approval from the DPR. ${ }^{795}$ In the case of a state of emergency situation, the President can exercise his emergency power and could directly mobilize the Military power without previously seeking the DPR's approval. According to Article 18 section (1), the state is in an emergency when the state encounters military or armed threats. These emergency situations potentially inflict security chaos and massive state deprivation. If the situation fits the emergency conditions, the President is justified in unilaterally acting to mobilize the use of military forces, acting on behalf of the state interest. However, within $2 \times 24$ hours after the

\footnotetext{
${ }^{788}$ Article 13 section (3) and section (5) of the Law No. 34/2004.

${ }^{789}$ Article 13 section (6) of the Law No. 34/2004.

${ }^{790}$ Article 13 section (7) and section (8) of the Law No. 34/2004.

${ }^{791}$ Article 13 section (9) of the Law No. 34/2004.

792 Article 14 of the Law No. 34/2004.

${ }^{793}$ Article 15 of the Law No. 34/2004.

${ }^{794}$ Article 17 section (1) Law 34/2004.

${ }^{795}$ Article 17 section (2) Law 34/2004.
} 
President implements his Presidential Decision, the President must notify the DPR. ${ }^{796}$ Furthermore, to counter the President's notification for the use of military forces, the DPR can give its rejection. When that happens, the President must recall the military force. ${ }^{797}$ According to the provisions of the Law, the Presidential military power is not fully at the President's discretion. The military power of the President depends on the DPR. The DPR has an important role since the military power will not be exercised without DPR approval. But this seems to contradict the Constitutional military clause. However, from the original interpretation of Article 10 of the Constitution that "the President is the Commander in chief of the Army, Navy and Air force"; the President is the operational Commander and thus, has the power to operationally control the use of military force, mobilize the military forces for a particular military operation, and to manage the military organization for state defense purposes.

To sum up, the Presidential military power may be exercised after seeking the DPR's approval. The President depends on the DPR's approval to commandthe use of the military forces and the DPR can block the military use of force and other kinds of military operations by its rejection.

In terms of the military budget, Article 66 of the Law stipulates that the TNI is financed by the state budgeting through the Ministry of state defense. ${ }^{798}$ However, the state budget is not the only financial source for the TNI, because the military gains financial benefits from its commercial activities and foundations. ${ }^{799}$ Legally speaking, the TNI can invoke financial support from the DPR through the budget of the Minister of state defense. In special emergency military operations, the financial support can be invoked through the contingency state budget. However, the Ministry of state defense must invoke the budget to seek the DPR approval. ${ }^{800}$ To this extent, the Constitution and the Statute have given a great significant role to the DPR to

\footnotetext{
${ }^{796}$ Article 18 section (2) Law 34/2004.

${ }^{797}$ Article 18 section (3) Law 34/2004.

${ }^{798}$ Article 66 of the Law 34/2004.

${ }^{799}$ Angel Rabasa and Peter Chalk, Op. Cit., p. 59: "According to press reports, a military foundation like Kartikas Eka Paksi controls companies and the army's Cooperative Center, Inkopad. In private discussions, Indonesian military leaders deplore the military's reliance on commercial activities for funding, but argue that in order to pay the salaries and maintain the standard of living of the troops there is no alternative as long as insufficient funds are allocated to the armed forces in the state budget".

${ }^{800}$ Article 67 Legislation 34/2004.
} 
constrain the military power of the President. The DPR has the power to authorize the President to exercise his military power and mobilize any military operations determined in the Legislation. The DPR also checks over the Presidential military power in terms of controlling and managing the Military organization by its approval or rejection in nominating the Chief of Military. In terms of the state budgetary over the military activities, the DPR is the decision maker for part of the financial support for the Military organization and operations. Moreover in emergency situations, although the President can directly exercise his military power, the President cannot eschew from the DPR; since he should notify the DPR.

\section{- Legislative, the budgetary and expenditure power}

Unlike the law-making process, the process for state budgetary law has different stages and the bill has unique characters different from other laws. The differences are specially because the draft of state budget law is always proposed by the President and enacted annually. The proposed draft of the Law is not necessarily accompanied with the academic draft review. The bill is annually submitted to the DPR. The bill should only be accompanied by the explanation of the subject matters and substances. ${ }^{801}$ The DPR has to be involvedat an early stage of the process, in the governmentwork and the discussion. ${ }^{802}$ The DPR then is actively involved in and even dominating the process. ${ }^{803}$ The DPR will be the final decision maker by giving approval to the budget and it will be legalized as Law. The approval will include the allocation, and implementation of the budget. To this extent, the DPR has the power of the purse while the President will have the power of expenditure after the budget is approved. Beside the power of the purse, the DPR has the power to oversee the implementation of the state budget. The President on behalf of the government must deliver its accountability in implementing the state budget legislation and the spending of the money. ${ }^{804}$ In conclusion, on the budgetarypower, the DPR has the power to approve, oversee, evaluate, and audit the presidential budget and spending power. With regard to the expenditure power of the

\footnotetext{
${ }^{801}$ The Legislation 12/2011 on the Law-Making, Article 43 section 5.

${ }^{802}$ Article 152 and Article 153 the DPR's Code of Conduct.

${ }^{803}$ See Article 153 to Article 157 the DPR's Code of Conduct.

${ }^{804}$ Article 158 the DPR's Code of Conduct.
} 
Rosa Ristawati: Modelling Executive Powers in the Indonesian Constitution: A comparative Study

President, the DPR on checking the power depends on the BPK (a constitutional institution for state financial audit). The BPK will audit the government expenditure. While in return, the Constitution obligates the DPR to take action to follow up the BPK's audit on the state budget report. $^{805}$

In delivering the accountability of expenditure power, According to Article 30 Legislation 17/2003, the President submits the draft of the state budget accountability to the DPR. The draft consists of a financial report that has already been audited by the BPK at least 6 months after the period of the annual budget. The article shows that the DPR is the actual branch which has the power of the purse. For that reason, the DPR has the right to ask for accountability from the President. In general, the presidential state budgetary power and expenditure power is very limited only for proposing and spending the budget. The power to spend money is controlled by the DPR. The President constitutionally cannot hinder the DPR in spending the budget.

In more technical matters, the Law No. 1/2004 on the state treasurer points out that the DPR has the power to limit the power of state budget management. Article 45 section2 specifies that the transfer of state property by selling, exchanging, granting, or investing as a government share should be by approval of the DPR. The transfer of state assets and property must be approved by the DPR (Article 46 of the Law). ${ }^{806}$ In section 2 of the Article, the transfer of state property for more than 100 Billion Rupiah should be directly approved bythe President. In terms of responsibility and accountability of the state spending authority, the minister of finances as the state treasurer is directly accountable to the President. ${ }^{807}$

The DPR's power of the purse makes the presidential spending power categorized as a permissible and dependent power. ${ }^{808}$ The President may spend the state budget only by the

\footnotetext{
${ }^{805}$ Article 23E the Amendment Constitution of Indonesia gives the authority to the BPK to audit the state budget and spending. The report of the audit is reported to the DPR. Furthermore, in section 3 of the Article, the Constitution put forward obligation to the representative state bodies (the parliament) or agency to follow up the result of the BPK's report.

${ }^{806}$ Article 46 Law No. 1/2004 (Appendix 5).

${ }^{807}$ Article 53 section (3) of the Law No. 1/2004.

${ }^{808}$ According to Article 159 Law No. 12/2011, the President proposes the draft bill of the state budget Law with the financial bill and other supporting documents to the DPR in August a year before the budgeting year. The DPR will discuss and the DPR may propose any suggestion which results the changes of revenues and expenditures in the draft of the budgeting Law. The DPR should decide at least 2 months before the budgeting term. The DPR
} 
DPR's permission. ${ }^{809}$ It puts the obligation on the President to spend the money according to the budget approved. In the end of the budgeting term, according to Article 163 the Law No. 12/2011, the President should deliver the bill of the legislation draft for the accountability of the state budget to the DPR in the form of a financial report (including the budgeting realization, budgeting scale, the cash flows, and the financial notes with the attachment of ministries' financial repots) that havebeen audited by the BPK not more than 6 months after the term of budgeting has finished.

\section{- Judicial review on the state budget and spending power}

The state budget and its accountability must be in the form of legislation. According to the Constitution, it is the power of the Constitutional Court to exercise a judicial review of the state budget Law. As the legislation is subject to judicial review by the Constitutional Court, the Court has the power to overrule the state budget Legislation. ${ }^{810}$ According to Court Decision No. 012/PUU-II/2005 19 October 2005 dealing with a petitioner of Law No. 36/2004 in the 2005 , State budget onthe basis that the Law did not provide the $20 \%$ education budget as mandated in the Constitution, and the Court decided that the case is niet ontvankelijk verklaard

approved the budget against unit of organization, functions, programs, activities, and type of expenditures. However, in any case that the DPR refuses the draft of state budget Law, the previous state budget Law will be applied.

${ }^{809}$ Article 155 Law No. 12/2011 (Appendix 5).

${ }^{810}$ The Constitutional Court decided some of the cases that dealt with the state budget Law;in some of its decisions, the Court has the function to balance the power of the DPR and the President by influencing and coercing to conform to its decision. Some of the Court's judgments are as follows: 1 . the Decision No. 13/PUU$\mathrm{VI} / 2008$ on the Constitutional Court's Decision against the judicial review of Law No. 16/2008 on the Amendment of the Law No. 45/2007 concerning on the State Budget 2008; 2.The Decision No. 012/PUU-III/2005 on the Constitutional Court's Decision against the judicial review of the Law No. 36/2004 on the State Budget 2005; 3. The Decision No. 24/PUU-V/2007 on the Constitutional Court's Decision against the judicial review of the Law No. 20/2003 on the National Education System and the Law No. 18/2006 on the state budget 2007; 4 . The Decision No. 026/PUU-III/2005 on the Constitutional Court's Decision against the judicial review of the Law No. 13/2005 on the State budget 2006; 5. The Decision No. 026/PUU-IV/2006 on the Constitutional Court's Decision against the judicial review of the Law No. 18/2006 on the state budget 2007; 6. the Decision No. 57/PUU-VIII/2010 on the Constitutional Court's Decision against the judicial review of the Law No. 2/2010 on the Amendment of the Law No. 47/2010 on the state budget 2010; Decision No. 60/PUU-IX/2011 on the Constitutional Court's Decision against review on the Law No. 10/2010 on the State Budget 2011 and the Law No. 11/2011 on the Amendment of the Law No. 10/2010 on the State budget 2011. 
Rosa Ristawati: Modelling Executive Powers in the Indonesian Constitution: A comparative Study

(is inadmissible). ${ }^{811} \mathrm{~A}$ recent issue of judicial review on the state budget was the review on Law No. $10 / 2010$ on the state budget and state expenditure $2011 .{ }^{812}$ In other previous cases, according to the Court decision, the Court seems to have vague positions against the President and the DPR. The Court was trying to oblige the government and the DPR to conform to its decision and impose the decision in the next budgeting term; on the other hand, it declared that the Legislation is not annulled and still legally binding. ${ }^{813}$

In other Decisions, the Court refused an application in its Decision No. 60/PUUIX/2011. ${ }^{814}$ The Court argued that the President and the DPR had not fulfilled their obligation

\footnotetext{
${ }^{811}$ The Court implied on its consideration that the rights of education put an obligation to result to the state by maximum exploiation of natural resources with the good will and progressive realization. However, Article 31 section (4) the Constitution which has mandated at least $20 \%$ state budget for education has shifted from an obligation to result to be stronger as obligation to conduct. By this argument, the Court indicated that the state has an obligation to allocate a $20 \%$ education budget in every annual state budget. Violation of the $20 \%$ budget for education is stated by the Court to be unconstitutional and violates Article 31 section (4) the Constitution. However, the Court said that though it violates the Constitution, based on Article 23 section (3) Constitution, if the Court acceded to the application, the government should impose the previous state budget Legislation (state budget Law 2005), and that will potentially impact on the chaotic situation and governmental disaster in the financial administration of the state. The Court said that this situation will lead to legal uncertainty (rechtsonzekerheid) and the situation will be worse if the educational budget in the previous state budget Law is less than in the Law 2005. On the other hand, the two judges delivered their dissenting opinions, arguing that the situation of backwardness and the commitment of the Government and the DPR are the main reasons to decide that the educational budget in the state budget Law 2005 (that has not fulfilled the 20\% mentioned in the Constitution) does not unconstitutionally violate Article 31 section (4) the Constitution. The judges also considered that the state budget Legislation has a different character from other Legislation. The differences are including that the state budget Legislation is more as the result of the DPR's budgeting function rather than the DPR's Legislating function. The Legislation has a character of "eenmalig" as mentioned in Article 23 section 1 of the Constitution. Another character is mentioned in Article 23 section (2) of the Constitution that the power to propose the bill of the Legislation is in the hands of the President. Any amendments against such kind of Legislation will significantly influence other budgets in other sectors, in fact, it will affect the stagnation of the state government. By this argument both judges argued that the state budget Law No. 36/2004 on the State Budget 2005 has no conflict with the Constitution.

${ }^{812}$ The judicial review of the Law 10/2010 on the state budget and the Law No. 11/2011 on the amendment of the Law No. 10/2012 against the health budget was proposed as a violation against the Law No. 36/2009 on Health and Article 28D section (1) of the Constitution.

${ }^{813}$ Decision No. 13/PUU-VI/2008 on the Constitutional Court's Decision on the judicial review of Law No. 16/2008 on the Amendment of the Law No. 45/2007 concerning the State Budget 2008, vide: Decision, p. 32

${ }^{814}$ In the Court Decision of 2011, The dissenting opinion, one of the judges (Justice Sodiki) argued that the state budget Legislation has undermined public expectation, and impacted on public disobedience against the Law, increased the public lack of cohession, and did not guarantee public security, provoked legal uncertainty, unpredictability, and legal calculability; brought about legal inconsistency. While on the other hand, the morality and legislative obedience against what has been made (the legislation) did not reflect the morality of honesty. Judges Soliki referred to the empirical facts that many poor patients were rejected in the public hospital when they required health facilities and other cases reflected the basic violation against human rights.
} 
Rosa Ristawati: Modelling Executive Powers in the Indonesian Constitution: A comparative Study

based on the Law that they had made previously. In the decision, the Court seems to affirm the power of the President and the DPR in the budgeting and spending power by rejecting the case.

The Court held a judicial review on the case against the state budget legislation 2012. The petition was about the substance of Article 7 section 6 of the budget (APBN) Law which mentioned that the fuel oil subsidy price would not rise. ${ }^{815}$ However, section $6 a$ of the Article enables the government to adjust the price if there is a rise or reduction of at least $15 \%$ from the average crude oil in Indonesia throughout 6 months. Consistently, the Court should reject the case and be consistent with the Court's previous decision regarding the judicial review of the state budget Law 2011. To be consistent, the Court should not come up with its alternative procedures of the State Budget (APBN) Law. The Court had overstepped the mark to come up as a rival to both the President and the DPR to decide about the state budget, which belongs to the area of executive power. The Court should not act beyond its competences, acting as the rival to the DPR and the President by coming up with its alternative. It should only decide whether or not the budget law is constitutional or unconstitutional. However, in its decision, the Court admitted that from the perspective of the process, the 2012 state budget that was already legalized by the Law 2012 has shown that there were checks and balances between the DPR and the President, while, the process was already in accordance to the legislative procedures.

On other issues concerning the state budget, the Constitutional Court reviewed a case about a dispute between the President and both the DPR and the BPK. The Court was challenged by the question on the constitutionality of the fact that the finance minister on behalf of the government has the authority of state budget. ${ }^{816}$ From the President's

\footnotetext{
${ }^{815}$ The Jakarta Post, Fuel Price Compromise Faces Constitutional Challenge, April 3, 2012, accessed online at: http://www.thejakartapost.com/news/2012/04/03/fuel-price-compromise-faces-constitutional-challenge.html (last accessed 12/09/2014).

${ }^{816}$ In the case of dispute between state institutions, the President and the BPK, the President, the financial minister on behalf on the government argues that the government has its authority to decide to buy the Newmont shares without any approval from the DPR. This argument is believed to be in accordance to the Legislation that determines the power for government to spend the money for economic and social purposes. On the other hand, the BPK is opposed, arguing that the government in spending the money (since the money is from the state budget) for purchasing the Newmont shares should have approval from the DPR. The BPK argued so on the basis of its financial report. It is argued that the government should constitutionally comply with the BPK's report and
} 
perspective, the power to spend the state budget is in the hands of the minister on behalf of the President. ${ }^{817}$ The Court considered that with regard to the Presidential spending power, the President should only be bound by the DPR approval as delivered in the state budget Legislation. The President may only have discretion in the budget implementation after the budget is approved by the DPR. However, any discretion could only be made after being approved by the DPR. This is in line with the Constitution that gives the actual power of the purse to the DPR. In terms of the BPK, as the state auditor, the only constitutional competence of the BPK is to make a financial report and submit the report to the DPR. The BPK recommendation is only a recommendation even though it is constitutionally final. The recommendation from the BPK's financial report impacts upon the President only if the DPR follows up its recommendation. Article 23E section (2) and (3) makes clear that the BPK cannot directly impose its recommendation on the President. Based on Article 23E section (2), the BPK submits the state financial report to the DPR. However, it is the duty of the DPR to follow up the report. At this point, the following measure may be realized by invoking the right of questioning to the President regarding the government spending plan. In the case of the Newmont shares purchase, the DPR invoked its right of question and then continued with the exercise of giving approval or disapproval. ${ }^{818}$

The Court decision is final and legally binding for the DPR and the President. It is one of the institutions performing checks and balances. However, the Court decisions were an ultimatum for the DPR and the President to comply with the Constitution to fulfill the $20 \%$ constitutional educational budget in the State Budget Legislation. ${ }^{819}$ The Court decision on the

recommendation based on Article 23E section 3 stipulates that the financial report by the BPK is final and should be followed up by all relevant institutions (including the President).

${ }^{817}$ Law No. 1/2009 on the State treasury grants the authority to the finance minister to manage state funds and manage investment. It also allows the government to make long term investment for economic and social benefits. ${ }^{818}$ The Jakarta Post, BPK calls government compliance on Newmoon, April 4, 2012, accessed online at: http://www.thejakartapost.com/news/2012/04/04/bpk-calls-govt-compliance-newmont.html (last accessed 05/09/2015).

${ }^{819}$ Hukumonline, MK Ultimatum DPR dan Pemerintah, August 14, 2008, accessed online at: http://www.hukumonline.com/berita/baca/hol19919/mk-ultimatum-dpr-dan-pemerintah- (last accessed on 05/09/2015). 
Rosa Ristawati: Modelling Executive Powers in the Indonesian Constitution: A comparative Study

State budget Law 2008 contained an extreme warning for the government and the DPR and the President. $^{820}$

\subsection{The presidential impeachment in Indonesia}

According to the Constitution, the President could be impeached if evidently committing an unlawful act. The DPR in this case has the constitutional competence in gaining proof, to set up an investigation by previously invoking its enquette rights. After a comprehensive investigation, the DPR will submit its opinion to the Constitutional Court. The Court will come to its decision whether it concurs or not with the DPR's opinion that the President has committed a crime or is no longer qualified to be a President. As the impeachment is on the basis of the rule of law, the process will be followed by the DPR's plenary session to discuss the application of the Presidential impeachment. The application of the Presidential impeachment will be submitted to the MPR and the MPR as a representative body, representing the people in deciding to impeach the President. There is no explicit mechanism that the President can use to counter the process; except that the President is given the opportunity to express his argument before the MPR's plenary session of impeachment.

The process of impeachment is basically a consequence of the oath of the President. In the Presidential oath, the President declares to fulfill constitutional duties in executing the laws. As a consequence of the President's oath, the President should faithfully fulfill his obligation to make sureof the implementation of the laws. However, if the President commits unlawful acts, this is not only a breach of the oath but can also be a constitutional failure. The impeachment grounds of unlawful act can also be regarded in case that the President is acting unconstitutionally or illegally either in an official or private capacity. There should be a

\footnotetext{
${ }^{820}$ Kompas, Putusan MK Peringatan Keras Untuk Pmerintah, August 13, 2008, accessed online at: http://female.kompas.com/read/2008/08/13/13194986/putusan.mk.peringatan.keras.untuk.pemerinta h (last accessed on 05/09/2015): The Court has its method in calculating the percentages of the educational budget in the state budget legislation 2008. The Court has also criticised the method on how the government calculates the educational budget in which the government calculated based on the total budget minus the energy subsidy and the debts interest payment and not based on the total state budget as a whole. It is said that if the government used its method the calculation has resulted in $21.8 \%$ for the educational budget (152.2 Billion) from the total of 707.6 Billion of the state budget (after deductions). However, the Court argued that from the total of the state budget of 989.5 billion, the allocation for the education budget is only $15.6 \%$.
} 
Rosa Ristawati: Modelling Executive Powers in the Indonesian Constitution: A comparative Study

distinction between acting unconstitutionally and/ or illegally since there might be a justification for the President acting illegally in a state of emergency situation. The scope of unlawful act can be read as either unconstitutional or illegal acts. An unconstitutional act could be broadly interpreted that the President in using his Presidential power is against the Constitution. This act is difficult to use as a basis of impeachment.

Constitutionally, the ground to impeach the President is criminal acts. Legally speaking, there is no specific indicator to determine Presidential criminal acts. The Law No. 24/2003 on the Constitutional Court can be a legal basis to determine the scope of the Presidential criminal acts. Article 10 section (3) of the Legislation defines that:

a. Treason against the state is a crime against the state secrets as stipulated in laws. ${ }^{821}$ Treason as grounds of impeachment could be included internal treason (acts to totally change the state government which is unconstitutional) and external treason (giving access for other states in order to invite foreign states to conduct an armed attack that endangered the state security). ${ }^{822}$

b. Corruption is the corruption ${ }^{823}$ act or bribery ${ }^{824}$ as stipulated in laws

\footnotetext{
${ }^{821}$ State treason is a crime against state secrets. The acts against state secrets could be determined as follows: giving state secrets to a state that is known to be havea confrontation with Indonesia, leaking state secrets for private gain and endangering state and public interests. Other acts defined as state betrayal include having been involved in a separatism movement as well as acting unconstitutionally in order betray the state's purposes and state ideology.

${ }^{822}$ Mahkamah Konstitusi, Mekanisme Impeachment dan Hukum Acara Mahkamah Konstitusi, Pusat Penlitian dan Pengkajian Sekretariat Jenderal dan Kepaniteraan Mahkamah Konstitusi Republik Indonesia and Konrad Adenauer Stiftung, 2005, p. 65.

${ }^{823}$ Corruption is presumably to be one of the failures in the presidentialism. With regard to corruption, Indonesia has a package of legal instruments in order to suppress the systematic corruption in the governmental system. The Law No. 31/1999 concerning on the corruption eradication. However, the Legislation and other Laws amending the Legislation does not specify and explicitly address the executive branch; the President, instead of giving a general specification of person as subject of the laws of anti-corruption. According to Article 1 Law No. 31/1999 there are 5 scopes of public officials: a. public officials defined in the Legislation concerning the Public officials; b. the public officials defined in the Wet boek van Straftrecht (the KUHP, the Indonesian penal code); c. person who gets paid from the state or province budget, $d$. person who gets paid from a corporation which receives financial aid from state or province; or e. person who gets paid from other corporations which is using the state/public capital or state asset. Law No. 28/1999 on the Establishment of state administration in its article 1 defines the state administrator as the state official who is responsible to exercise duties and functions as executive, legislative and judiciary or other officials functions and mainly exercised in establishing the state administration. Furthermore, in article 2 of the Legislation, it legally provides the list of the state officials, namely: (1) the state official in the highest state institution (it was for the state officials within the MPR organization; however, after the amendment
} 
Rosa Ristawati: Modelling Executive Powers in the Indonesian Constitution: A comparative Study

C. Other serious crimes are crimes which have a minimum 5 years punishment

d. Misdemeanors or immoral acts are an act of degrading morality and dignity of the President and or the vice president. The acts refer to acts against the religious norm, ethics and morality norm, and customary norms. ${ }^{825}$ Such acts cause moral harm and loss of dignity of the President and or the vice president.

e. No longer qualifies as a President and/or Vice President is defined that the President and or the Vice President no longer meets the constitutional qualification as mentioned in Article 6 of the Constitution ${ }^{826}$

of the Constitution, there is no higher state institution); (2) the state official in the state institution, (3) the ministers; (4) Governor, (5) judges, (6) other state officials who have strategic functions on the establishment of state administration. By the Law No. 7/2006, Indonesia has transformed the UN Convention against Corruption 2003 to the Indonesian legal system. The Law No. 7/2006 is clearly mentioned that the three branches as subject to the laws against Corruption. Article 2(a) of the annex of the Law No. 7/2006 defines public official into three categories. The First category implies that the public official subject to the law is any person holding a legislative, executive, administrative or judicial office, whether appointed or elected, whether permanent or temporary, whether paid or unpaid irrespective of that person's seniority. Accordingly, the President as the executive is subject to the anti-corruption Law. The anti corruption law could be imposed when the President in office is alleged to have committed in the corruption scandal. However, the President in office can't directly proceed and prosecuted through the ordinary court. In this term, the constitutional mechanism of impeachment could be invoked by the DPR, after being allegedlyaccused of corruption by the Constitutional Court, the President could be laid off by the MPR and brought to the ordinary court for prosecution.

${ }^{824}$ With respect to bribery, Article 5 section (2) the Law 20/2001 on the amendment of the Law No. 31/1999 on eradication of corruption stipulates that the act of bribery is punishable by the state administrator who receives any gifts and promises that were given for the purpose of cheating against his/her official duties. Moreover, Article 11, Article 12, Article 12 B Law No. 20/2001 is addressed to the state administrator including the President as the state administrator.

${ }^{825}$ Article 5 Law 42/2008 (i) determines that the misdemeanors are (perbuatan tercela or moral turpitude and disgraceful act) against religious norms, morality norms, and customary norms. The acts could be as follows: gambling, drinking too much, drug addicts, sexual affairs.

${ }^{826}$ The constitutional qualification of an Indonesian President is mentioned in Article 6 of the Constitution. It is mentioned that a President should be a citizen of Indonesia since birth and never had other citizenship from other states by which because of his/her intention, s/he will never betray the state, and is mentally and physically qualified to exercise the duties as a President. Legally speaking, the qualifications as a President that a candidate President should be met are stipulated in Article 5 of the Law No. 42/2008 (on the President and Vice President's General Election. 
Rosa Ristawati: Modelling Executive Powers in the Indonesian Constitution: A comparative Study

Scheme 8. The Impeachment: the constitutional process based on Article 7B of the Constitution

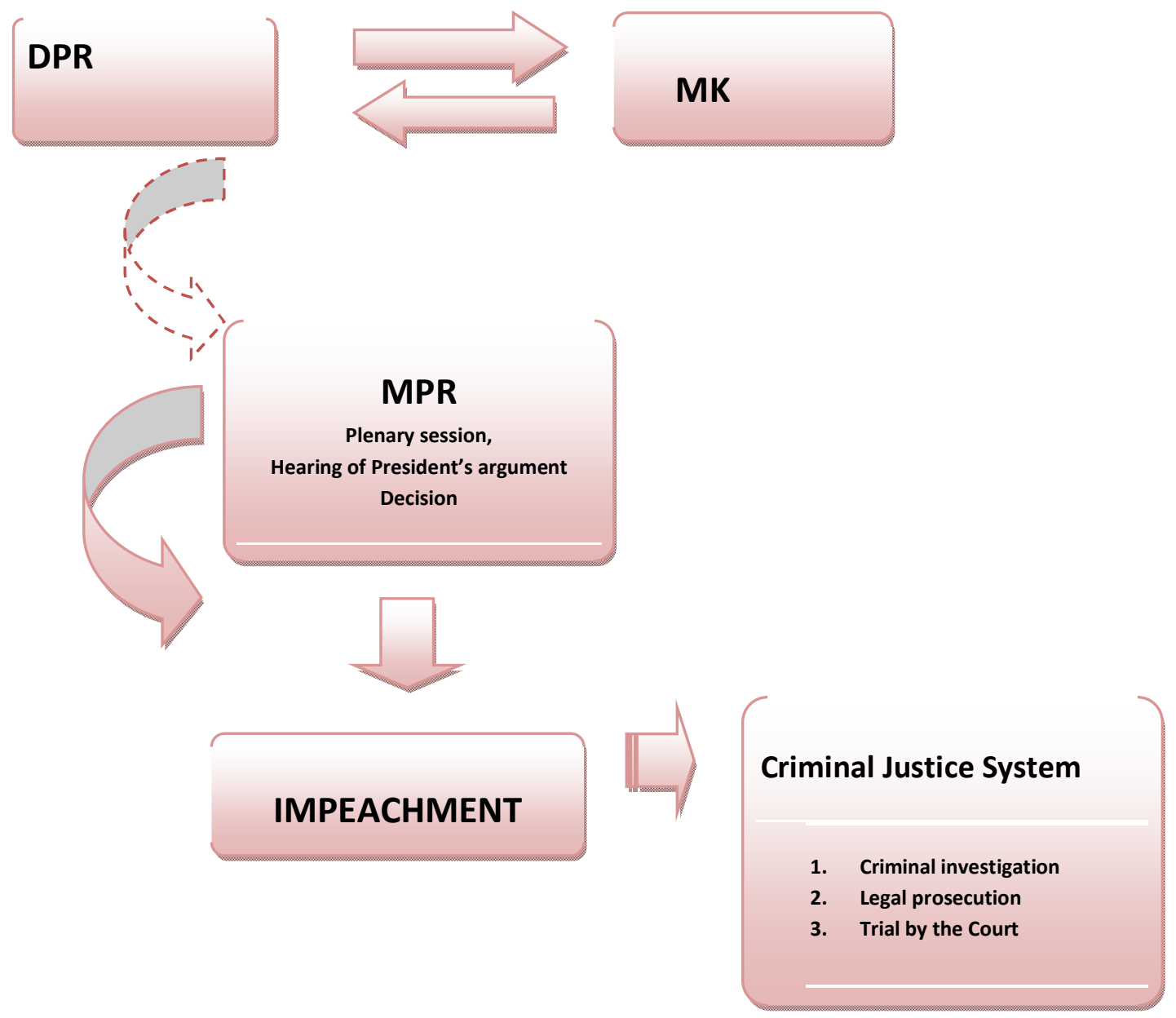

1. The DPR's request for the impeachment proposal (on the grounds of crimes and/or disqualification) shall only be invoked by at least $2 / 3$ of the DPR's members in the plenary session which was attended by at least 2/3 of the DPR's members

2. DPR, on behalf of oversight function, invokes its opinion to the Constitutional Court (MK) that the President and/or the Vice President commits crimes or is no longer qualified as a President and/or Vice President; the opinion is by asking the Constitutional Court to verify, adjudicate, decide that the President and/or the Vice President commits crimes or is no longer qualified based on the DPR's opinion.

3. The Mahkamah Konstitusi (Constitutional Court) must verify, adjudicate, decide impartially against the DPR's opinion at least 90 days after the DPR's opinion is accepted by the MK

4. If the MK decides that the President and/or the Vice President evidently commits crimes and/or evidently is no longer qualified as a President and/or Vice President, the DPR should arrange a plenary session to continue the proposal of impeachment to the MPR

5. The DPR submits the proposal of impeachment to the MPR, MPR must hold the session to decide the DPR's proposal at least 30 days after MPR accepted the proposals

6. The MPR's decision against the DPR's proposal of impeachment shall be decided at the plenary session attended by $3 / 4$ of the MPR's members and approved by at least $2 / 3$ of the attendaees, after the President and/or Vice President is given the opportunity to deliver his/her argument in the MPR's plenary session 


\subsection{The 2014 Presidential Election}

The 2014 Presidential election was the third direct presidential election under the period of the Amended Constitution. Following the Legislative Election which was held on 9 April 2014, the Presidential election was held on 9 July 2014. As a result of the Legislative election, none of the political parties were eligible for the $25 \%$ presidential threshold in order to propose a presidential candidate. ${ }^{827}$ Therefore, the 12 political parties which participated in the 2014 Legislative election agreed to establish a coalition to nominate a presidential candidate. As a result, there were two coalitions proposing presidential candidates. There were two pairs of presidential candidates, the first pair of the joint Presidential candidates was proposed by 6 political parties (most of them gained significant votes in the 2014 legislative election); while, the Second pair was proposed by 4 political parties (the PDIP, which gained the highest votes in the 2014 legislative election and three other political parties which gained minority votes in the 2014 legislative election). The result of the presidential election was officially announced by the General Election Committee on $22^{\text {nd }}$ July 2014 . Accordingly, it was the second pair of Presidential candidates, Joko Widodo (the Jakarta Governor, well-known as Mr. Jokowi) who won the election and became the $7^{\text {th }}$ Indonesian President. ${ }^{828}$

However, the 2014 Indonesian Presidential election was full of intrigues. The victory of the 2014 President elected, Joko Widodo, was not that smooth. There were some controversial reactions following his victory including the withdrawal speech from his rival (Prabowo Subianto). Prabowo Subianto (the former Commander of the Army Special Command Troops; known as KOPASUSS), who was Joko Widodo's rival claimed his victory for the 2014 election. Following the reaction, he used his constitutional right to challenge before the Constitutional Court the 2014 election's result. In his petition, he asked the Court to cancel the 2014 election result and requested the Court to order a new presidential election on the basis that there

\footnotetext{
${ }^{827}$ According to the Indonesian presidential election Law 2008, the Presidential candidates may only be proposed by political parties or coalitions (so called as joint presidential candidates) which gained $25 \%$ votes in the legislative election.

${ }^{828}$ See: Kompas, The official result of the 2014 Indonesia Presidential Election, July 22, 2014, accessed online: http://indonesiasatu.kompas.com/read/2014/07/22/20574751/ini.hasil.resmi.rekapitulasi.suara.pilpres.2014 Also available on the official website of the General Election Committee (KPU) on http://www.kpu.go.id/
} 
were many unfair mechanisms and massive fraud during the 2014 election. ${ }^{829}$ The Constitutional Court concluded its decision on the Presidential election dispute on $21^{\text {st }}$ August $2014 .^{830}$

The President's inauguration took place in October 2014 and the new Indonesian President took over the administration. In the meantime, after the official announcement of the General election Committee, the elected 2014 Indonesian President, Joko Widodo had taken some specific efforts to prepare his administration. He had decided to establish a House of transition for the specific purpose to prepare a transitional regime from the SBY'S administration to his administration. ${ }^{831}$ The house of transition raised much criticism as it had also the duty to propose and prepare Jokowi's cabinet, proposed the candidateministers to Jokowi, and prepare strategies for the implementation of the elected President's vision and missions including the setting of the 2015 state budget. Furthermore, there were also many questions about the credibility of Jokowi's transitional team and the significant intervention of the team to the Jokowi's administration. However, on every occasion Jokowi promised that the cabinet of ministers would be established as a professional cabinet. He would use his full power to choose and appoint a minister on the basis of his/her expertise and ignore the party coalition commitment. In contrast, Jokowi not only established a house of transition but also appointed 4 senior figures to be the advisors for the cabinet establishment and ministerial appointments. ${ }^{832}$

\subsection{Insights into President Jokowi's administration: a brief remark on the Executive powers during one year of President Jokowi}

\footnotetext{
${ }^{829}$ Reuter, Indonesia's Prabowo claims 'massive' fraud in presidential election, accessed online at: http://uk.reuters.com/article/2014/08/06/uk-indonesia-politics-idUKKBN0G60CV20140806 (last accessed 19/10/2014).

${ }^{830}$ The Constitutional Court delivered its decision to reject all the challenges of Prabowo and officially declared Jokowi as the winner of the 2014 Indonesian Presidential election. See more on: www.indonesiainvestment.com/news/todays-headlines/indonesian-constitutional-court-rejects-prabowo-subianto-s-electionchallenge/item2341, "Indonesian Constitutional Court Rejcets Prabowo Subianto's Election Challenge.

${ }^{831}$ The House of transition consists of some political party actors, members of the coalitions who proposed Jokowi in the 2014 election.

832 BBC, Polemik Hendropriyono, accessed online on 19/10/2014 at: http://www.bbc.co.uk/indonesia/berita indonesia/2014/08/140811 polemik hendropriyono.shtml : Jokowi appointed 4 senior figures to be the advisor of the transition team. It raised criticism against the appointment.
} 
Rosa Ristawati: Modelling Executive Powers in the Indonesian Constitution: A comparative Study

There were some challenges during the first year of President Jokowi's administration. The constitutional challenges would be as to whether Jokowi could use the executive powers under the current constitutional structure by the ambiguities of the constitutional powers or whether there has to be a constitutional amendment that would empower him as the 20142019 Indonesian President. On the other hand, the political challenges might be as whether or not he could smoothly use his power without any political conflicts with parliament and whether or not he could survive to override the parliament's pressure when using his executive powers. This is because his presidency would only be supported by less than $50 \%$ of the political parties sitting in the parliament. The situation may potentially trigger executive-legislative conflicts.

In general, President Jokowi came to the presidency and used the executive powers in a different way from the former presidents. According to Jokowi's vision and missions that he had delivered during the 2014 election campaign, he would rather use the executive powers mostly for the purpose of domestic reform agenda as his main concerns were the sovereignty and independence of the state and maritime issues. Jokowi introduced the fundamental future national policy that he would like to implement during his administration. The fundamental national policy is called TRISAKTI. It consists of three fundamental issues: (1) political sovereignty, (2) economic independency, (3) the cultural character. ${ }^{833}$

Table 4.15 the Jokowi's visions

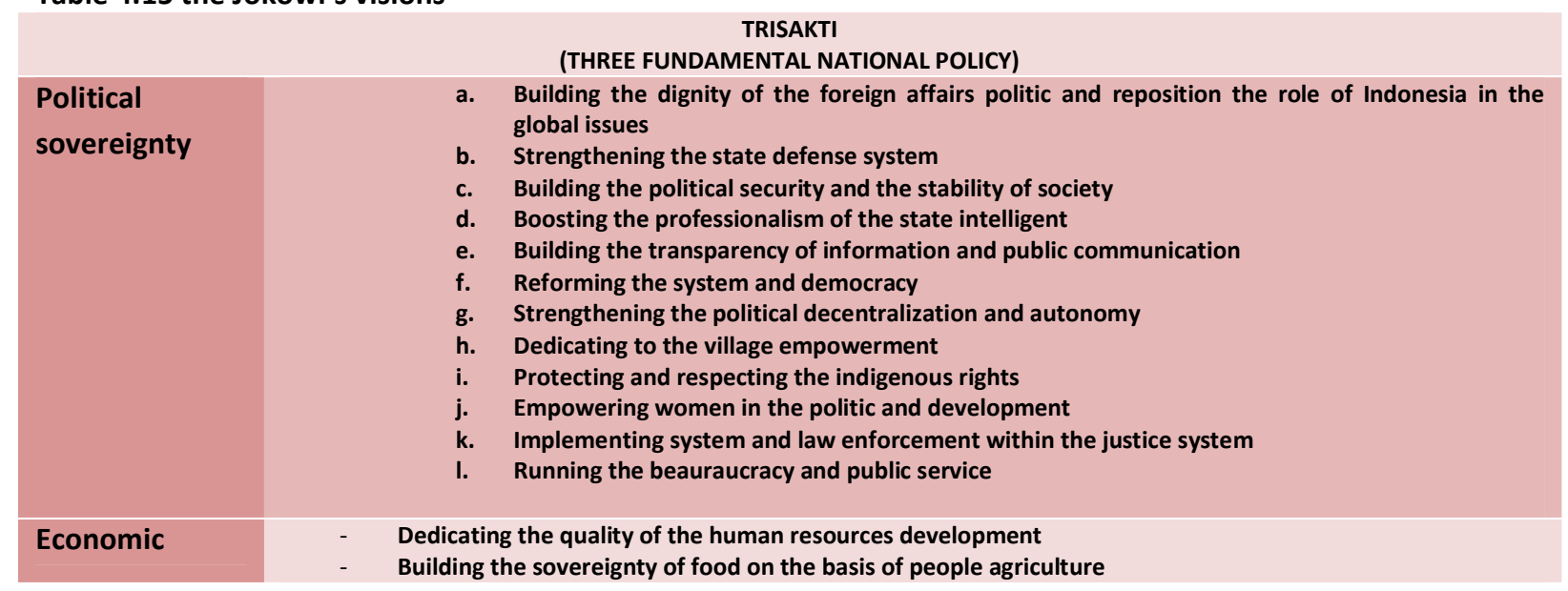

\footnotetext{
${ }^{833}$ See Table 4.15 .
} 


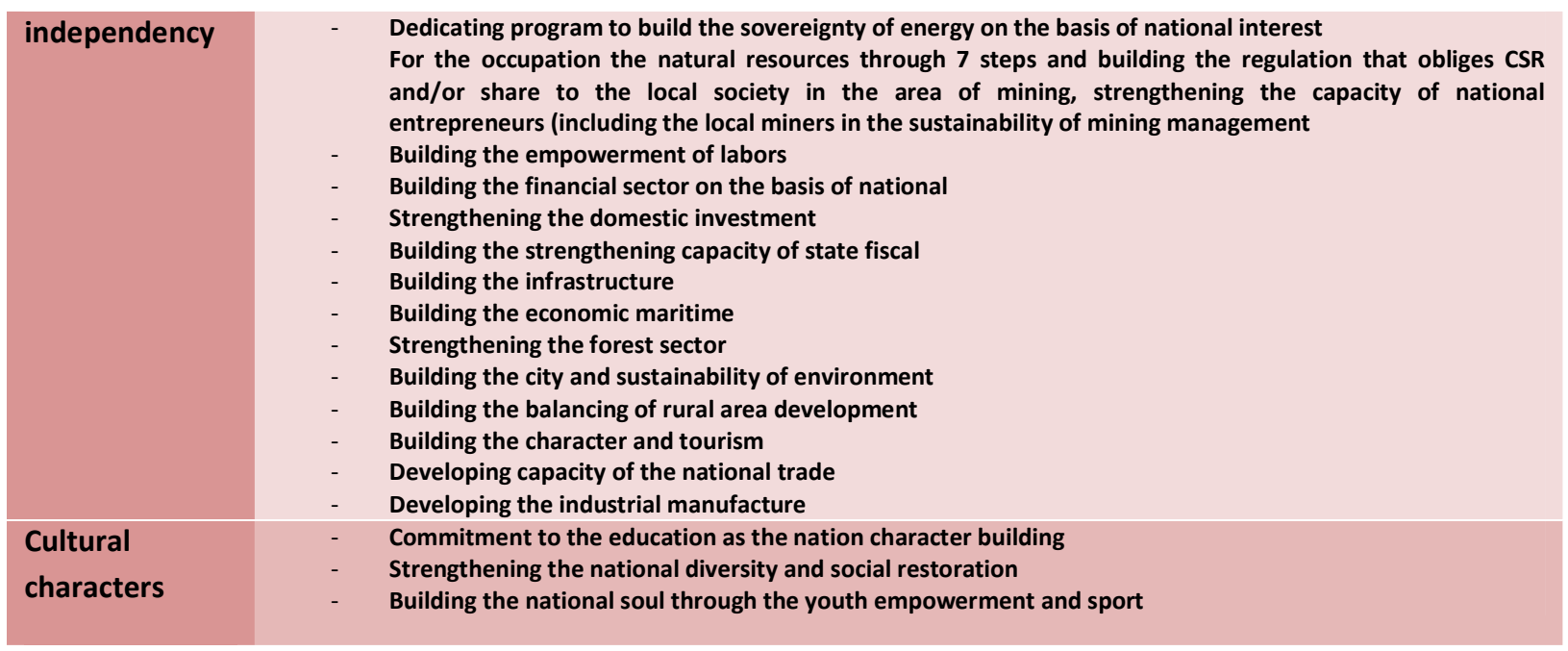

In addition, Jokowi also introduced some prior agendas which are called NAWACITA, and consist of 9 prior working agendas. ${ }^{834}$ In order to implement the three fundamental national issues, Jokowi sets his plans to use the presidential power in specific priority programs in politics, economy, and culture. ${ }^{835}$

\section{Table 4.16 the Jokowi's NAWACITA missions}

\begin{tabular}{|c|c|}
\hline Agenda & \\
\hline- & $\begin{array}{l}\text { Representing the state to protect the nation and guarantee the security of all the Indonesian citizens through the } \\
\text { free-active foreign affairs politic, trusted national security, and the development of state defense based on the } \\
\text { three integrated matra for the state interest and strengtening the state identity as the maritime state }\end{array}$ \\
\hline- & $\begin{array}{l}\text { Guranteeing that the government would not be absent to build the good governance government, clean, effective, } \\
\text { democratic, and trust by giving the priority to the effort to recover the public trust agains the democratic } \\
\text { institution and continue the democratic consolidation through the political parties system reform, election and } \\
\text { the public representation institution }\end{array}$ \\
\hline- & $\begin{array}{l}\text { Building Indonesia from the rural area through the empowerment areas and villages within the unitary state of } \\
\text { Indonesia }\end{array}$ \\
\hline- & $\begin{array}{l}\text { Rejecting the weak state through the reformation of the law enforcement system free from corruption, dignity } \\
\text { and trusted }\end{array}$ \\
\hline- & $\begin{array}{l}\text { Increasing the quality of life by increasing the educational quality and the training program of smart Indonesia; } \\
\text { and the incresing of the public welfare with the program of working Indonesia and the Indonesia welfare by } \\
\text { supporting the land reform and the land owned program of } 9 \text { hectar, the village housing program or the cheap } \\
\text { subsidy housing progam and the social secure program for the people in } 2019\end{array}$ \\
\hline- & Developing people productivity and competitive capacity in international market \\
\hline- & Implementing the economic independency through running the strategic sectors of domestic economy \\
\hline - & $\begin{array}{l}\text { Encouraging the revolution of national characters throught the rearrange the national education curricula policy } \\
\text { that make the priority of the citizenship educational aspect, proportionally insert the educational aspects for } \\
\text { example the nation building history, patriotic values, and the state defense sipirit and the humanc character } \\
\text { development in educational system in Indonesia }\end{array}$ \\
\hline- & $\begin{array}{l}\text { Strengthening the diversity and strengthening the social restoration through the policy of strenthening the } \\
\text { diversity of Bhinneka and creating the dialogue among people in Indonesia }\end{array}$ \\
\hline
\end{tabular}

Table 4.17 the Jokowi's agendas

- Political issue agendas:

\footnotetext{
${ }^{834}$ See Table 4.16 .

${ }^{835}$ See Table 4.17 .
} 


\title{
Rosa Ristawati: Modelling Executive Powers in the Indonesian Constitution: A comparative Study
}

\author{
Building the dignity of foreign politic policy and repost the role of Indonesia in the global issues \\ Empowering the State Defense system \\ Building the public peace and security politic \\ Building the state intelligent professionalism \\ Building the transparency of information and public communication in the information policy and public communication \\ Reforming the system and democracy institution \\ Committing to the empowerment of the decentralization politic and local autonomy \\ Dedicating the empowerment of villages and rural areas \\ Committing to protect the indigenous rights \\ Committing to the women empowerment in politic and national development \\ Committing to the system and the law enforcement on the frame of justice \\ Committing to the bureaucracy reformation and public services
}

\section{- Economy issue agendas:}

a. Dedicating the quality of human resources development through the Law on Complementary Education 12 years. The implementation of this Law would be followed by the free tuition fee and other fees in all over schools in Indonesia

b. Building food sovereignty on the basis of people agriculture-business through the import-control policy for food, the elimination of import-mafia and developing agricultural export; the anticipation of poverty and support of re-generation of farmer; implementing agrarian reforma; and agri-business development on the basis of people through the special bank development for agriculture, small enterprises, and Cooperation

c. Dedicating programs for energy sovereignty on the basis of national interest

d. Committing to natural resources occupation through the intensify the amount of national mining entrepreneur, the intensify direct benefit for local people in the mining area, the empowerment of coordination of mining governance under the minister of coordination, the gradual intensify of the state income from mining,

e. Committing to build the labor empowering

f. Committing to build the financial sector empowering on national basis

g. Committing to empower the domestic investment

h. Committing to build the fiscal capacity empowerment

i. Committing to the infrastructure empowerment

j. Committing on the economy-maritime development

k. Committing on forest sector empowerment

I. Building the sustainable environment

m. Committing on building the development balances of areas

n. Committing on character building and tourism

o. Committing on capacity development of national trade Committing on manufacture industry development

\section{Cultural focus agendas:}

1. Committing on make the education for the nation character building as it is mentioned in the Constitution

2. Preserving the national diversity in Indonesia and empowering social restoration

3. Building the soul of nation through the youth empowerment and sport

Shortly after he took office, Jokowi's first priority was to set up a ministerial cabinet. On the ministerial appointment, he definitely employed the right to use his power to appoint and fill most of the ministerial posts with his confidents and loyal aides to the PDIP (the Party which had been campaigning for Jokowi). The appointment of ministers in October 2014 raised positive and negative views from people in Indonesia. Jokowi introduced some new ministeries that had never existed in previous administrations. ${ }^{836}$ He named his ministerial cabinet as the

\footnotetext{
${ }^{836}$ Jokowi splits the Ministry of Education for the basic, primary, and secondary education; and the Ministry of Research and Technology for the research and higher education.
} 
Rosa Ristawati: Modelling Executive Powers in the Indonesian Constitution: A comparative Study

"Kabinet Kerja" (the Working Cabinet). Jokowi also changed the name of some of ministeries and added ministerial coordination. ${ }^{837}$

The ministers appointed consisted of some figures with a professional background, proposed by parties which had supported Jokowi during the 2014 election (the PDI-P, PKB, NasDem, and Hanura); the coalition in the government after the 2014 election (PPP), and the succession team of Jokowi. The appointment of the ministers had been done in a closed selection process. Jokowi also consulted and considered the KPK's (Anti-Corruption Commission) recommendation. Before coming to the final appointment, he revised some names of the ministers' nominees based on the KPK's recommendation. As a result of the appointment process, Jokowi appointed 4 coordinating ministers and 30 ministers. ${ }^{838}$ On the other appointment powers, Jokowi's nomination of General Budi Gunawan as the chief of national police raised a counter-reaction from the anti-corruption commission (KPK). A few days after

\footnotetext{
${ }^{837}$ Jokowi introduced 4 coordinating ministries, namely: (1) the coordinating ministry of maritime affairs for encouraging the development and preserving the state sovereignty, and in order to be consistent with the NAWACITA in which Jokowi promotes Indonesia as a maritime state. (2) The coordinating ministry of human development and culture, in order to coordinate the character development on the basis of national culture; (3) the coordinating ministry of culture and primary and middle education that is separated from the higher education; (4) the ministry of tourism that is separated from the ministry of economy-creative.

${ }^{838}$ Coordinating Minister for politic, law, and security affairs, Coordinating Minister for Economy affairs,Coordinating Minister for Maritime and Resources affairs, Coordinating Minister for Human Development and Culture affairs, Minister of Secretary of the State, Minister of home affairs, Minister of foreign affairs, Minister of Defence, Minister of Law and Human Rights, Minister of Finance, Minister of Energy and Mineral Resources,Minister of Industry,Minister of trade,Minister of Agriculture, Minister of Environment and Forest, Minister of transportation, Minister of Sea and Fishery, Minister of Worker affairs, Minister of village, the undeveloped area, and transmigration, Minister of general affairs and housing, Minister of health, Minister of Education and Culture, Minister of Research, Technology, and Higher Education, Minister of Social affairs, Minister of Religion affairs, Minister of Tourism, Minister of Communication and information, Minister of Koperasi and small-middle entrepreneurship, Minister of the Empowerment of Women and child protection, Minister of the empowerment of the state apparatus and reformation bureaucracy, Minister of Planning and National Development/Chief of the Planning and National Development Body,Minister of Land and Landscape/ Chief of the National Land affairs, Minister of State-owned company, Minister for Young and sport affairs. Jokowi also appointed state official officers equal to Minister: State Prosecutor, the Chief of National Army, the Chief of State police, Secretary of Cabinet and the Chief of the non-ministerial department: Chief of State Intelligent Body, Chief of Coordination and Capital investment body, Chief of economy creative body, and the chief of non-structural body: Chief of Presidential office. Jokowi also appointed two of the Vice-Ministers: Vice Minister of foreign affairs and Vice-Minister of Finance affairs.
} 
Rosa Ristawati: Modelling Executive Powers in the Indonesian Constitution: A comparative Study

the nomination, Budi Gunawan was declared as a graft suspect by the KPK. ${ }^{839}$ Following the KPK's declaration, Jokowi withdrew the nomination and announced General Badrodin Haiti as the new candidate of the chief of national police. Through a series of fit and proper tests conducted by the DPR, General Badrodin Haiti was inaugurated by President Jokowi to be the Indonesian chief of national police. The appointment process of the chief national police shows that in exercising the appointment power, there was a tough challenge checking the President. The President's decision in nominating, assigning and appointing state officials is not a final decision but could be possibly criticized or even withdrawn. The other appointment cases raised criticism against the President Jokowi's decision for appointing a number of ministers for specific countries in order to accelerate investment projects and to be liaison officers between Indonesia and its major trading partners. ${ }^{840}$

In early 2015, as Jokowi had set in Trisakti dan Nawacita, some giant Indonesian projects ${ }^{841}$ were started under Jokowi's administration. ${ }^{842}$ However, in the enthusiasm of the giant infrastructure projects, President Jokowi has decided to cancel some of the infrastructure projects which may have diplomatic consequences. At around September 2015, Jokowi declined bids from Japan and China for high-speed railway projects. ${ }^{843}$ In accordance with the execution of the projects, Jokowi used his administration powers to significantly reform the

\footnotetext{
${ }^{839}$ The Straits Times, Jokowi's police chief picks Budi Gunawan sworn in as deputy chief after graft row, April 22, 2015, www.straitstimes.com/asia/se-asia/jokowis-police-chief-pick-budi-gunawan-sworn-in-as-deputy-chief-aftergraft-row (last accessed 19/10/2015).

${ }^{840}$ Tama Salim on The Jakarta Post, Jokowi criticized for assigning ministers for specific countries, Jakarta: November 26, 2015, accessed online at: www.thejakartapost.com/amp/news/2015/11/26/jokowi-critizedassigning-ministers-specific-countries.html (last accessed 19/10/2015).

${ }^{841}$ See Table 4.18

${ }^{842}$ Tabita Diela on Jakarta Globe, Project Inaugurated by President Joko Widodo in H1, Jakarta: August 3 2015, accessed online on 19/10/2015 at: www.jakartaglobe.id/economy/projects-inaugurated-president-joko-widodoh1/ "Project Inaugurated by President Joko Widodo in H1": Some major infrastructure projects as part of the Jokowi administration's effort to stimulate the economy including the projects that have been started during January $28^{\text {th }}$ to August $2^{\text {nd }}$.

${ }^{843}$ Ian Marlow, It was brave for Indonesia's President to decline bids from Japan and China, Sept 10, 2015 accessed online on 19/10/2015 at: www.theglobeandmail.com/opinion/it-was-brave-for-indonesias-president-to-declinebids-from-japan-and-china/article26321657/?arc404=true

The Globe and Mail, Sept 10, 2015: Jokowi is expected to focus foreign policy on boosting the domestic economy, but it still took more courage to decline the project and risk the ire of prominent regional actors such as China and Japan than to approve it".
} 
Rosa Ristawati: Modelling Executive Powers in the Indonesian Constitution: A comparative Study

bureaucracy by pushing for a selection process to find officials in order to deliver the projects on time. ${ }^{844}$

Table 4.18. Example of Projects signed under Jokowi's administration

\begin{tabular}{|c|c|c|}
\hline No. & $\begin{array}{l}\text { Starting } \\
\text { date } \\
(2015)\end{array}$ & Infrastructure projects \\
\hline 1. & January 28 & $\begin{array}{l}\text { a } 4.99 \text { trillion Rupiah project of Kuala Tanjung Port in North Sumatera that is developed by state-port operator } \\
\text { Pelindo I, in cooperation with the state-owned infrastructure companies Waskita Karya and PP; 1,6 trillion Rupiah of } \\
\text { Medan-Binjay Highway, and a } 2 \text { billion US aluminium producer Inalum in Kuala Tanjung }\end{array}$ \\
\hline 2. & February 9 & the 54 Kilometer of Ciawi-Sukabumi toll road which costs 7.7 trillion in investment \\
\hline 3. & $\begin{array}{l}\text { February } \\
23\end{array}$ & the 80 Kilometer of Serang-Panimbang toll road in Banten which costs $\$ 385$ million \\
\hline 4. & March 9 & a $\$ 750$ million project of Arun LNG Storage in Aceh \\
\hline 5. & March 9 & a 1.7 million Rupiah project of Krueng Keureto Dam in Pay Bakong, North Aceh \\
\hline 6. & April 30 & The trans Sumatera toll road construction of 2.818 Kilometer which will connect Aceh-Lampung and costs 300 trillion \\
\hline 7. & April 30 & Solo-Ngawi and Ngawi-Kertosono toll roads which costs 625 million \\
\hline 8. & May 4 & Three power plant projects: Jatigede (West Java), Takalar (South Sulawesi) and Pangkalan Susu (North Sumatera). \\
\hline 9. & May 4 & $\begin{array}{l}\text { Jokowi also signed a power Purchase Agreement (PPA) in Samas Yogyakarta and Kendari Southeast Sulawesi, a Heads } \\
\text { of Agreement (HoA) in Sidrap South Sulawesi, and an Engineering, Procurement, and Construction (EPC) in Grati East } \\
\text { Java. Those projects are part of the } 1.100 \text { trillion Rupiah of } 35.000 \text { megawatt electricity project. }\end{array}$ \\
\hline 10. & May 19 & Broadband Fiber Optic Sulawesi Maluku Papua Cable System ( SMPCS) which costs 3.6 million \\
\hline 11. & May 22 & Multipurpose Terminal at Teluk Lamong Port in Surabaya, East Java which cost 23.4 million \\
\hline 12. & May 28 & $\begin{array}{l}\text { Integrated smelter project in Morowali, Central Sulawesi (a smelter which is owned by Sulawesi Mining Investment, a } \\
\text { joint venture of Chinese stainless steel producer Dingxin Group and local conglomerate Bintang Delapan. The total } \\
\text { cost is up to } \$ 2.5 \text { billion (there are three stage of developments: } \$ 635 \text { million, } \$ 1.04 \text { billion, and } \$ 820 \text { million) }\end{array}$ \\
\hline 13. & June 12 & The 130 Kilometer highway of Gempol-Pandaan in East Java toll road which costs 1.47 trillion Rupiah \\
\hline 14. & June 20 & $\begin{array}{l}\text { Cikopo-Palimanan highway and Tanjung Batu Port which costs } 13.7 \text { trillion Rupiah (the project is a continuing project } \\
\text { during the SBY administration) }\end{array}$ \\
\hline 15. & July 19 & $\begin{array}{l}\text { Holtekamp Bridge in Papua which the President Jokowi signed a contract to build the } 433 \text { meter bridge that costs } \\
856.72 \text { billion Rupiah by a consortium o state-owned construction companies }\end{array}$ \\
\hline 16. & July 26 & The Solo-Kertosono toll road \\
\hline 17. & August 2 & $\begin{array}{l}\text { A slew of energy-related projects costs billions of dollars in Banggai, Central Sulawesi. Some of it includes a } \$ 1.2 \\
\text { million Central Processing Plant operated by Joint Operating Body Pertamina Medco Tomori Sulawesi and } \$ 830 \\
\text { million ammonia plant owned by Panca Amara Utama in Central Sulawesi }\end{array}$ \\
\hline
\end{tabular}

During his first year of presidency, Jokowi was also challenged by global economic problems that urged him to use his power to revitalize his economic strategy, team and agenda in order to boost the economic market. ${ }^{845}$ In order to bolster the economy and currency,

\begin{abstract}
${ }^{844}$ Nicholas Owen on Reuters, "Indonesia's Widodo seeks to tame bureaucrats blocking infrastructure drive", July 23 2015, available online at: www.reuters.com/article/uk-indonesia-widodo-bureaucrats/indonesias-widodoseeks-to-tame-bureaucrats-blocking-infrastructure-drive-idUKKCNOPYOOL200150724 accessed on 19/10/2015 at: www.reuters.com : Widodo wants to cut to three weeks the time the panels take for appointments. Widodo wants to spend about $\$ 20$ billion this year on new ports, roads, and other projects, but the bureaucracy has so far disbursed only around a tenth of the capital spending budget. Side-lining them might make it smpler to fill long vacant posts with officials who can sign off on spending decisions.
\end{abstract}

${ }^{845}$ William Pesek, "Indonesian President Joko Widodo aims to revitalize his team \&agenda to restore confidence in economy", The Economic Times, Oct $6^{\text {th }} 2015$ : In mid of 2015, Jokowi named former central banker Darmin Nasution as his new minister of economy and brought former finance czar Rizal Ramli into the cabinet. 
Rosa Ristawati: Modelling Executive Powers in the Indonesian Constitution: A comparative Study

President Jokowi decided to make adjustments for 89 regulations to simplify doing business and cut irrelevant regulations which have hampered the competitiveness of national industry. ${ }^{846}$

In conducting his cabinet, Jokowi has shown flashes of great courage by slashing budgetbusting energy subsidies and increasing the transparency at government ministries. In August 2015, during his 10 months administration, Jokowi used the power to reshuffle the cabinet by replacing five of his ministers (including 3 of the coordinating ministers and the secretary of the cabinet). ${ }^{847} \mathrm{He}$ expects by reshuffling and appointing ministers with international experience and an external focus, to address concerns that his government too readily resorts to protectionism and is not wholly committed to nurturing foreign investment. ${ }^{848}$ However, some say that he needs to go further to use the power to reverse policies endorsing protectionist laws against mining and technology companies, stop doling out cash to inefficient state enterprises and increase regulatory certainty. ${ }^{849}$

On his four-and a half months administration, Jokowi shows to the world his consistency in the war against illegal drugs. Raising diplomatic tensions from many states, Jokowi used his

\footnotetext{
${ }^{846} \mathrm{ABC}$ News, "Indonesian President Joko Widodo unveils series of stimulus measures to bolster economy, currency", Sept 10, 2015, accessed at: www.abc.net.au/news/2015-09-10/indonesia-unveils-stimulus-to-bolstereconomy-currency/6763596: Policies announced to help the poor included the provision of cheaper fuel to fishermen, more funding to villages and the strengthening of a program to provide cheap rice. To help the currency (Rupiah), the stimulus is including the improvement of the management of foreign exchange flows. Other stimulus is including helping exporters with financing and making it easier for frequent foreign visitors to Indonesia to open bank accounts. Jokowi had also pledged to kick start growth by creating new jobs for the young, starting a flurry of infrastructure projects and boosting the manufacturing sector. He had also announced tax breaks for some industries and replaced key economic ministers in a cabinet reshuffle in August 2015.

${ }^{847}$ Hidayat Setiaji and Gayatri Suroyo on Reuters, "Indonesia's President reshuffles economy team as growth sags", August 12, 2015, accessed online on 19/10/2015 at: www.reuters.com/article/amp/idUSKCN0QH06Y20150812 : "Indonesia's President reshuffles economy team as growth sags", August 12, 2015: Jokowi put two experienced technocrats into economic management posts in a cabinet reshuffle designed to reassure investors worried about a policy drift that has allowed growth to slip to a six-year low. Some of the new ministers posted as a result of the reshuffle cabinet include Darmin Nasution as the Coordinating Minister for economy, Thomas T. Lembong as the Minister of trade, Luhut Pandjaitan as the Coordinating Minister for security and political affairs, Pramono Anung as the Secretary of the Cabinet, and Rizal Ramli as the Coordinating Minister for Maritime affairs".

${ }^{848}$ Id. However, Jokowi has been dogged by severe public criticsm over his perceived failure to stand up to vested interests and the political elite that backed him during the election and during his administration. Both Pramono Anung and Rizal Ramli are close to Megawati as the Chief of the party that backed Jokowi.

${ }^{849}$ William Pesek, The Economic Times, "Indonesian President Joko Widodo, aims to revitalize his team \&agenda to restore confidence in economy", Oct $6^{\text {th }} 2015$.
} 
Rosa Ristawati: Modelling Executive Powers in the Indonesian Constitution: A comparative Study

pardoning power to reject the pardoning pleas of drug traffickers. ${ }^{850}$ On the other hand, in a different situation, Jokowi as the President used the diplomatic power to protect an Indonesian citizen and negotiate on behalfof the Indonesian who faced the death penalty abroad. ${ }^{851}$ On the foreign policy, President Jokowi shows his interest to initiate bilateral and international agreements. ${ }^{852}$ Jokowi also made some official visits to increase and strengthen cooperation between countries. $^{853}$

It is not easy for Jokowi to run his administration. There are many challenges, mainly from the political aspects that have to be faced by Jokowi. Right after the election, the political parties who lost in the 2014 election, established an alliance of coalition parties opposed to the ruling party supporting Jokowi's administration. The opposition parties named the "Koalisi Merah Putih" consists of Gerindra, GOLKAR, PKS, and PAN are now the majority in the DPR. It has significant consequences for Jokowi's administration since it makes it more difficult for Jokowi, as the President, to execute the executive powers. They (the alliance of coalition parties opposed to Jokowi's partiy alliance) tend to counter every policy and decision that Jokowi introduced. After all, some of the parties opposed to Jokowi's administration (PAN and

\footnotetext{
${ }^{850}$ Aljazeera, "Joko Widodo: A strong message to drug smugglers", 7 March 2015, accessed online on 19/10/2015 at: $\quad$ www.aljazeera.com/programmes/talktojazeera/2015/03/joko-widodo-strong-message-drugsmugglers-150305131413414.html : "Widodo remains steadfast in his decision to carry out the death sentences of 11 convicts including two Australian nationals from the Bali nine drug smuggling ring due to be executed".

${ }^{851}$ Id., "As a head of state of course I'm going to try to save my citizens from execution. That's my obligation as a president, as a head of state. To protect my citizens who are facing the death penalty but on the other hand we have to respect other countries that apply capital punishment, the constitution and the existing law still allows the death penalty. But if the Indonesian people want to change it in the future, then it's possible."

852 "Three agreements will be signed between Indonesia and Singapore and some MoU will be initiated": President Joko Widodo to visit Singapore, Channel News Asia, 27 July 2015, 19.51, www.channelnewsasia.com/news/singapore (last accessed on 19/10/2015).

${ }^{853}$ On October 2015, President Jokowi makes his first official visit to the United States to discuss the future of the partnership between the countries and issues of common concern such as climate change, countering violent extremism and ASEAN related issues (from the Jakarta Post, President Jokowi to visit Obama in October, September 23, 2015, accessed online on 19/10/2015 at: www.thejakartapost.com/amp/news/2015/09/23/president-jokowi-visit-obama-october.html.
} 
Rosa Ristawati: Modelling Executive Powers in the Indonesian Constitution: A comparative Study

GOLKAR) turned to support Jokowi's administration. ${ }^{854}$ This situation is expected to counterweigh and support Jokowi in executing his executive powers and administration. Also, such a situation is expected to contribute to a strong government as there would be more political party alliance to the President.

In practice, President Jokowi tends to have less power than has been provided by the Constitution. The imminent challenges for President Jokowi to perform the executive powers would be from the majority alliance of opposition parties in the DPR. Also, the background that he is not the leader in his party made him an underdog vis a vis the party leader. This situation has significant consequences for President Jokowi whenever he executes and invokes executive powers. It may be because the leader of the PDIP would still hold the real executive powers as well as she would still have an overarching influence on a possible Jokowi presidency. ${ }^{855}$ Therefore, though Jokowi's popularity as a personal figureimproved and came up as the President in the 2014 election, indeed he needs majority support from the parties in the DPR in running the administration. President Jokowi has to fight to gain more sympathy or even more political support from the majority parties opposed to his parties alliance (the Indonesia Hebat) in the government. This is to make Jokowi to smoothly execute and invoke his executive powers, implement his "NAWACITA" agendas and avoid more legislative-executive conflict in the government process. It is not enough to only rely on the political back up from the alliance political parties which were reflected in Jokowi's ministers and other high-ranking

\footnotetext{
${ }^{854}$ Abraham Utama on CNN Indonesia, "Koalisi Indonesia Hebat Berubah Nama Jadi Koalisi Pemerintah", Jakarta: November 17, 2015, accessed online at: www.cnnindonesia.com/poliik/20151117194200-32-92312/koalisiindonesia-hebat-berubah-nama-jadi-koalisi-pemerintah/ (accessed 18/03/2016): The alliance parties supporting the President Jokowi is proposed to be renamed as the "Koalisi Pemerintah".

${ }^{855}$ RSIS Policy Report, "With Jokowi Finally in, what;s next?", Policy Report, S. Rajaratnam School of International Studies, Graduate School of Nanyang Technological University, p. 5: Megawati's imprint will nonetheless be present in every aspect of Jokowi's presidential bid as well as in his administration in the future. Selection of a potential vice-presidency for Jokowi would have to come under the aegis of Megawati's consent. This would include ministers in Jokowi's cabinet. In turn, Megawati herself relied largerly on an inner circle of confidents including senior party members Tjahjp Kumolo, Sabam Sirait, and Hasto Kristanto. Jokowi is also likely to seek Megawati's consent when it comes to select his ministers. While it is still too early to speculate, there will be suspicions whether Jokowi can be independent of Megawati's overweening influence.
} 
appointments. ${ }^{856}$ President Jokowi needs to do more to invite cooperation with the majority opposition parties in the DPR.

\subsection{The assessment of the Indonesian executive powers under the Amended Constitution}

\section{Problems in presidential power as a result of the Amendment}

\section{a. Law-making powers}

Under the Amended Constitution, the system of government in Indonesia is undoubtedly a presidential system. One of the purposes of the Amendment Constitution was to curb the President's law-making power. For this purpose, Article 5 of the Constitution was changed by the First Amendment Constitution:

4.19. The legislative power of the Indonesian President: problem before and after the Amended Constitution

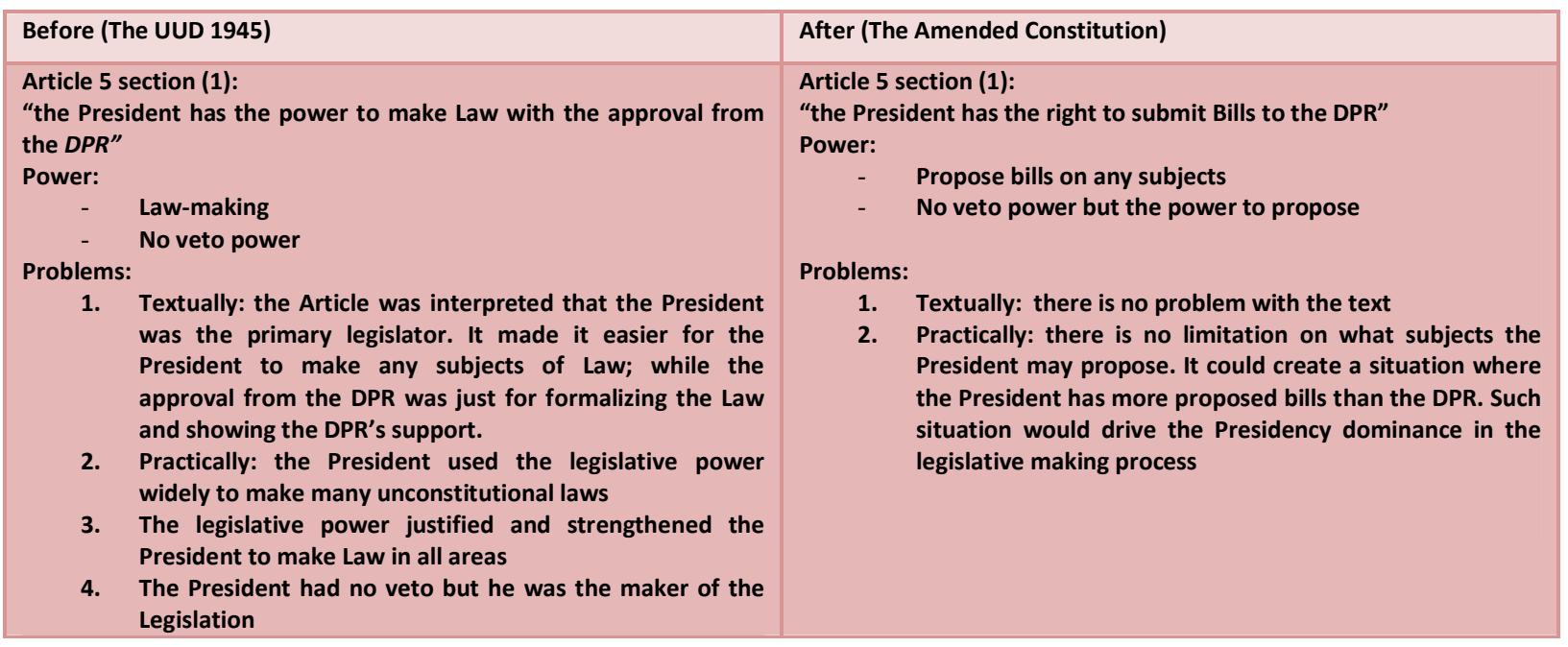

Although the Clauses had been amended, the legislative clauses have similar meaning. The clauses allow the President to initiate Bills. Article 5 Section (1) of the UUD 1945 (before the First Amendment) stated that "the President shall hold the power to make Law with the approval from the $D P R^{\prime \prime}$. It expressed that the President has the power to initiate, make the

\footnotetext{
${ }^{856}$ Yenni Kwok on Time, Indonesia's Jokowi marks 100 days of presidency with scandal, falling support, Jan. 28 , 2015, accessed online 19/10/2015 at: www.timeinc/time/3685421/indonesia-joko-widodo-100-days-ofpresidency/\%3fsource=dam : .."Nearly half of his ministers are members of the political parties supporting him -Megawati's daughter holds a senior Cabinet position -and his choices for Attorney General and police chief are linked with political patrons or their parties."
} 
Rosa Ristawati: Modelling Executive Powers in the Indonesian Constitution: A comparative Study

Law and submit it to the DPR for an approval. On the other hand, Article 5 of the Amended Constitution straightforward says that the President has the right to propose bills. The Amended Article has the meaning that the President can always still have the right to propose any kind of bills but no longer has the power to unilaterally dominate the legislative making process.

If we compare Article 5 before and after the First Amendment, both articles show that the main difference is on the approval. Before the Amendment, a democratic mechanism was never reflected in the legislative process since the approval only came from the DPR; on the other hand, the new Article promotes a democratic mechanism in the legislative process by setting an equal position between the President and the DPR on a joint legislative approval. Problems may occur since the Amended Constitution still gives the President the right to initiate bills on the one hand, and significant powers to discuss and approve the bill in the joint discussion and joint approval session on the other hand. At this point, actually there is no different notion about the president's legislative power. The difference may only be about the idea of shifting the legislative approval, from the DPR's unilateral approvalto a joint approval by the DPR and the President and make the President's position equal to the DPR in the legislative process.

In the situation before the Amendment, aPresident with lack of support from the DPR might get more disadvantages when proposing a bill. This might happen if the President had no majority party in the DPR. Intense lobbying should be done and it would be hard work for the President to build cooperation while Laws are urgently made. However, after the Amendment Constitution, such a situation would occur less frequently since the Constitution gives an equal bargaining position to the President in a joint session.

Furthermore, Article 20 of the First Amendment emphasizes that the DPR has the lawmaking power. All the bills have to be jointly discussed by the DPR and the President to get joint-approval. ${ }^{857}$ The Article implies that a democratic process and a mutual compromise between the DPR and the President during the legislative making are needed. If either the DPR

\footnotetext{
${ }^{857}$ Article 20 section (2) the First Amendment of Indonesian Constitution.
} 
Rosa Ristawati: Modelling Executive Powers in the Indonesian Constitution: A comparative Study

or the President rejects a bill, the bill will never be a Law and can't be proposed in the DPR session during that period. ${ }^{858}$ However, the new Article 20 seems contradictory to the spirit of reducing the president's power in the legislative process. It even makes the President's power stronger and makes the President equal as the co-partner to the DPR in a legislative process. The President has the power to come up with his rejection.

In a formal term, the President has the power to validate by signing a jointly approved bill and promulgate the Law. ${ }^{859}$ However, if the President does not give his signature within 30 days, the bill will be automatically enacted as a Law. On this point, the President signature is only a formality; while the most important thing is the approval.

Table 4.20. Problems occurred as a result of Article 20 before and after the Amendment Constitution

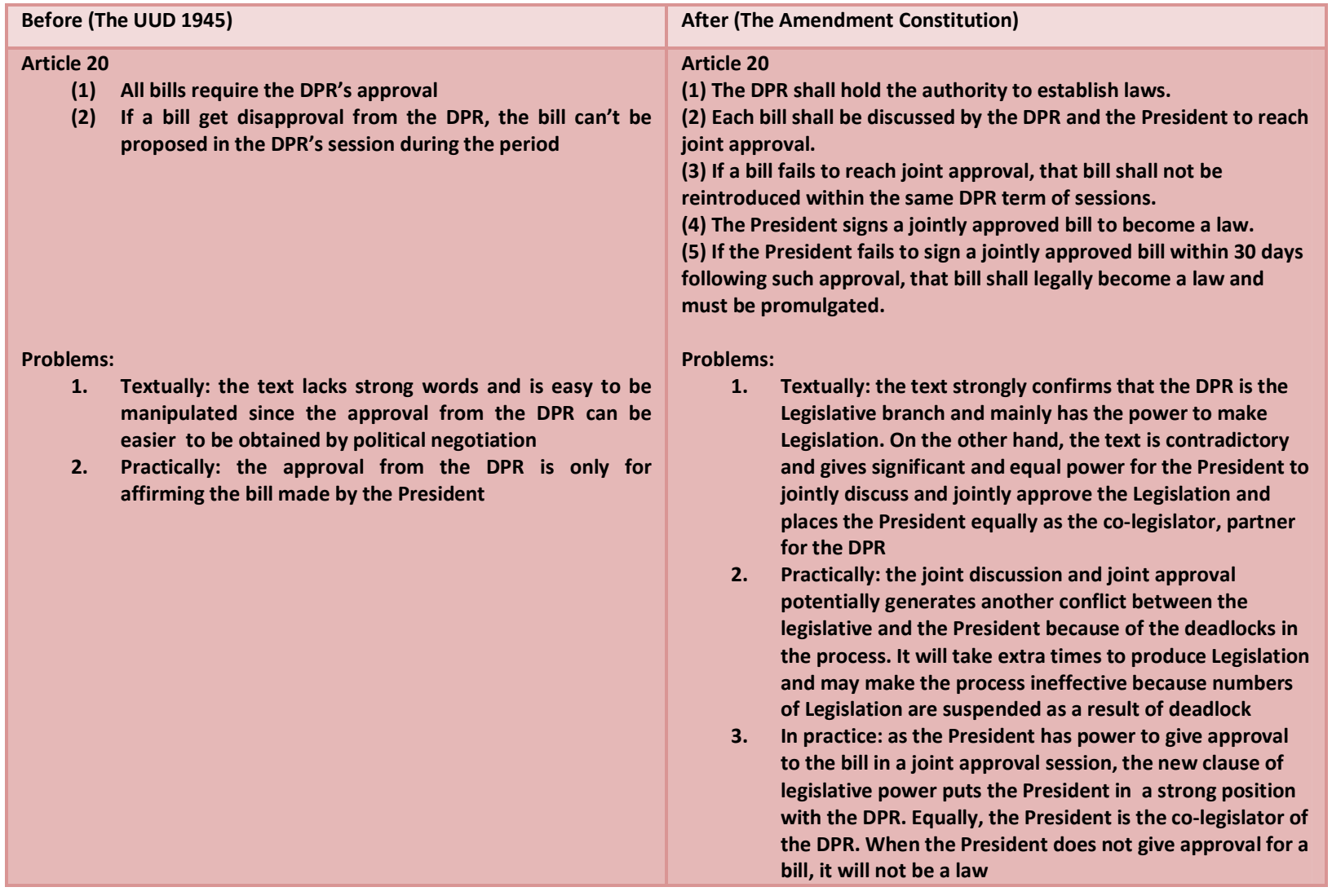

\footnotetext{
${ }^{858}$ Article 20 section (3) the First Amendment of Indonesia Constitution.

${ }^{859}$ Article 20 section (4) the First Amendment of Indonesia Constitution.
} 
Textually, the two articles before and after the Amendment have different interpretations. One of the differences is that before the Amendment, the DPR is the key point to give approval to a bill; while on the other hand, after the Amendment, the joint approval from the DPR and the President is the key point in the legislative process. However, Article 20 of the Amended Constitution may potentially generate a new problem of legislative deadlock. The deadlock may occur if a bill gets rejection from either the DPR or the President. Such a problem will make the process longer and may cause inefficiency of state budget. The deadlock in a legislation process may also contribute to another problem for the state since the annual national program will fail and the target on the NationalLegislation program that should be achieved will be unsolved. The other problems will come because the unsuccessful legislation agenda means that the DPR's program fails. The situation will also directly give impact to the state administration performance as the legislation is the instrument for government.

Compared to some problems that might occur even more as a result of the Amended Constitution, problems were less under the Articles before the Amended Constitution since it was only the DPR who decided by its unilateral approval. Article 20 before the Amendment confirmed that the last word in the legislative process was the DPR.

Overall, according to a comprehensive reading of Article 5 and Article 20 of the Amended Constitution, the President, in a legislative process may have a stronger role than it was under the old articles. The joint discussion and joint approval make the President one of the key parties in a legislative process. It shows that actually the Amended Constitution is only addressed to strengthen the checks and balances and promote a democraticmechanism in the legislative process but has failed to limit the presidential legislative power.

\section{b. Foreign affairs power}

In the area of foreign affairs power, the treaty clause in the Amended Constitution has been drafted in an even more complicated manner than before. It was written with a strong intention to hinder the President in exercising unilateral foreign policy making in the treaty process.

4.21. Problems of foreign affairs power of the Indonesian President before and after the Amendment Constitution 


\begin{tabular}{|c|c|}
\hline Before (The UUD 1945) & After (The Amended Constitution) \\
\hline $\begin{array}{l}\text { Article 11: } \\
\text { The President with the approval of the DPR may declare war, make } \\
\text { peaceand conclude treaties with other countries. }\end{array}$ & $\begin{array}{l}\text { Article } 11 \text { section (1): } \\
\text { The President with the approval of the DPR may declare war, make } \\
\text { peace and conclude treaties with other countries. } \\
\text { Section (2): } \\
\text { The President in making other international agreements that will } \\
\text { produce an extensive and fundamental impact on the lives of the } \\
\text { people which is linked to the state financial burden, and/or that will } \\
\text { require an amendment to or the enactment of a law, shall obtain } \\
\text { the approval of the DPR. } \\
\text { Section (3): } \\
\text { Further provisions concerning international agreement shall be } \\
\text { regulated by law }\end{array}$ \\
\hline $\begin{array}{l}\text { Problems: } \\
\text { 1. Textually: the text was too general } \\
\text { 2. Practically: the approval from the DPR was easy to be } \\
\text { skipped by the President }\end{array}$ & $\begin{array}{l}\text { Problems: } \\
\text { 1. Textually: the text is too complicated and vague. } \\
\text { 2. Practically: the approval from the DPR still can be skipped } \\
\text { by the President }\end{array}$ \\
\hline
\end{tabular}

With regard to treaty power, Article 11, in general, reflects that the intention of the drafters is to make a distinction between a treaty and other (special and significant) international agreements. A comprehensive reading of Article 11 (section 1 and section 2) may imply that all treaties (which have and do not have significant impact) and other international agreements (only in a particular condition: which has potential, extensive and fundamental impact on the people and is relevant to the state finance or a treaty that needs Law or amendment of law), need to be approved by the DPR. The Article may produce some technical problems. On the one hand, it implies that all treaties (substantial and technical) should be with the DPR's approval. While on the other hand, in practice, the President as the head of the state and also head of government must be given freedom to conclude a treaty with other states. ${ }^{860}$ The approval of the new article may contribute to the ineffectiveness of the state performance vis a vis the international community, other states or international organizations. The DPR approval implies that the real treaty power is in the hands of the DPR and the President only has a nominal treaty power for just formally representing the state. The words treaty and other international agreements should be clearly defined. Firstly, it is not easy to differentiate

\footnotetext{
${ }^{860}$ On 27 May 2013, President SBY concluded a treaty on mutual legal assistance on crime, the MoU on extradition, and MoU on agriculture with Vietnam in Hanoi. If strictly based on the Third Amendment, President SBY should seek approval from the DPR in any condition of the treaty and all international agreements whether or not it needs to be ratified.
} 
Rosa Ristawati: Modelling Executive Powers in the Indonesian Constitution: A comparative Study

between substantial and technical issues in a treaty. Secondly, there are many kinds of international agreements including the executive agreement (the Memorandum of Understanding, etc) which can be made by a President. The words "other international agreements" donot give a clear description of treaty and international agreements; while in fact, there are plenty of agreements which can be made by a President on behalf of the state. All agreements, joint statements, etc (such as investment agreements, trade agreements, and other technical agreements) may also potentially have disadvantages for the people and state as a whole.

In terms of the treaty transformation into the domestic legal system, the Constitution did not specify how International treaties and other international agreements are transformed into domestic law; except that in practice, a treaty may be transformed into domestic law either through the legislation process or unilaterally transformed by the Presidential decision. In general, the Treaty Clauses in the Amended Constitution lack descriptions of terms of ratification, transformation and legalization of any international treaty and international agreement into domestic law. Meanwhile, the approval for the treaty clauses is often misinterpreted as the transformation process of a treaty into a domestic legal instrument.

\section{c. Emergency powers}

In terms of the presidential emergency power, the Third Amendment changed Article 12. The Article specifies that the emergency power of the President can be exercised without DPR approval, while the conditions and all consequences resulting from the Presidential declaration should be set by the Law.

Table 4.22. Problems of Emergency power before and after the Amended Constitution

\begin{tabular}{|l|l|}
\hline Before (UUD 1945) & After (Amended Constitution) \\
\hline $\begin{array}{l}\text { Article } 12 \\
\text { The President, with the DPR approval, declares the state emergency. }\end{array}$ & $\begin{array}{l}\text { Article 12 } \\
\text { The President may declare a state of emergency. The conditions for } \\
\text { such a declaration and the subsequent measures regarding a state of } \\
\text { emergency shall be regulated by law. }\end{array}$ \\
$\begin{array}{l}\text { Problems: } \\
\begin{array}{l}\text { 1. Textually: the text was too general } \\
\text { 2. Practically: there was no clear legal basis about the }\end{array}\end{array}$ & $\begin{array}{l}\text { Problems: } \\
\text { limitation of emergency power. }\end{array}$ \\
\end{tabular}


The Third Amendment implies that the President may act unilaterally but that it should be on the basis of law. The absence of DPR's approval may potentially contribute to an abuse of emergency power by the President. The term "emergency" has a wide scope. The scope of emergency that is set by the Laws may become out of date since the term emergency is rapidly expanded by practice. On the other hand, the President's action in times of emergency may only be reviewed through an ex-post mechanism by the Courts. The Amended Constitution does not provide any provisions mentioning who has the power of checks and balances on the President's actions in times of emergency. It seems that the Constitution respects the emergency power of the president as a prerogative right on the one side but does not consider the development of the term "emergency" on the other side. In a modern democracy and constitutionalism era (in order to respect human rights and the rule of law), even during the time of emergency, the accountability of presidential actions is very important. In a chaotic situation, abuse of emergency power may potentially exist. Therefore, a framework that allows the Courts and the DPR to counter-balance the President's emergency power is necessary to guarantee that the executive acts constitutionally.

\section{d. Pardoning, accessories, and administrative powers}

In terms of the pardoning powers, the Amended Constitution has set a firm framework that allows the Court and the DPR to counterweigh the President's decision. The President can't exercise the pardoning power unilaterally as it was before the Amendment of Constitution. To grant a pardon, the President must seek the Supreme Court's opinion; while giving the amnesty and abolition, the President must seek consideration from the DPR. At this point, the Amended Constitution reflects a strong intention to limit the presidential pardoning power. The President can't go alone but must consult other branches; even though the final word would be on the President. The consideration from the Court and the DPR may reflect the people's legitimacy over the President's pardoning decision. Such a framework may be ideal. The Pardoning Clause in the First Amendment still gives the President the real power as the President has the final word to grant pardon, restoration, amnesty and abolition; while, the DPR and the Court can give their perspective as an alternative point of view. 
Rosa Ristawati: Modelling Executive Powers in the Indonesian Constitution: A comparative Study

The framework is similar to the president's power to grant titles and honours. According to Article 15 of the First Amendment, the power should be exercised according to the Law. Compared to the situation before the First Amendment, the President could unilaterally grant title and honour to any persons. However, in experience, the power to grant honour was only used for a President's personal interest and given to those to whom the President was personally indebted. ${ }^{861}$ The honour raised controversial debates where public connected to the previous practice when President Soeharto granted his wife an honour. ${ }^{862}$ The Law (Law No. 20/2009), which has been set according to the First Amendment constitution, orders that in granting an honorary title, the President should get consideration from the Honorary Council (Article 15 Law No. 20/2009). The Council is under, appointed by and removed by the President. It has the role to give consideration to the President under certain conditions and procedures that are set by the Law. However, the President truly has the final word in granting honorary titles. To this extent, the President still has the real power and may, with his personal discretion, nominate a person to be granted an honorary title.

Table 4.23. Problems of pardoning, accessories, and administrative power before and after the Amended Constitution

Pardoning power: pardons and restoration of rights (with advice by the Supreme Court); amnesty and abolitions (with advice of the Legislature) as provided by law.

\footnotetext{
${ }^{861}$ Under the First Amendment of Indonesian Constitution, President SBY gave honorary title to his wife (Kristiani Herrawati Yudhoyono) on 12 August 2011. (From Kompas, Ketika Presiden Memberi Penghargaan untuk Istrinya, accessed online on 12/05/2013 at: http://sejarah.kompasiana.com/2011/08/12/ketika-presiden-memberipenghargaan-untuk-istrinya-387650.html).

${ }^{862}$ President SBY also granted honorary titles (Bintang Mahaputera Adipradana) to 9 of his loyal ministers when the public viewed that they were incapable and just only personal logrolling. The Public viewed that the honour given by the President is not based on the outstanding performance of those 9 ministers (From Indonesia Media Online, http://www.shnews.co/detile-23423-sembilan-menteri-tak-pantas-dapat-bintang-jasa.html): Presiden Yudhoyono kemarin menyematkan Bintang Mahaputera kepada 11 tokoh, delapan di antaranya adalah para menteri dalam kabinetnya sendiri dan satu mantan ketua lembaga. Sembilan menteri tersebut ialah Menteri Koordinator Perekonomian Hatta Rajasa, Menteri Agama Suryadharma Ali, Menteri Pertahanan Purnomo Yusgiantoro, Menteri Pekerjaan Umum Djoko Kirmanto, Menteri Pariwisata dan Ekonomi Kreatif Mari Elka Pangestu, Menteri Pendidikan Muhammad Nuh, Menteri ESDM Jero Wacik, dan Menteri Sekretaris Negara Sudi Silalahi. Satu penghargaan diberikan kepada mantan Ketua Mahkamah Konstitusi Mahfud MD. Sementara dua lagi diberikan kepada almarhumah Hj Rahman El Yunusiah dan Almarhum Abdul Rahman Baswedan.
} 


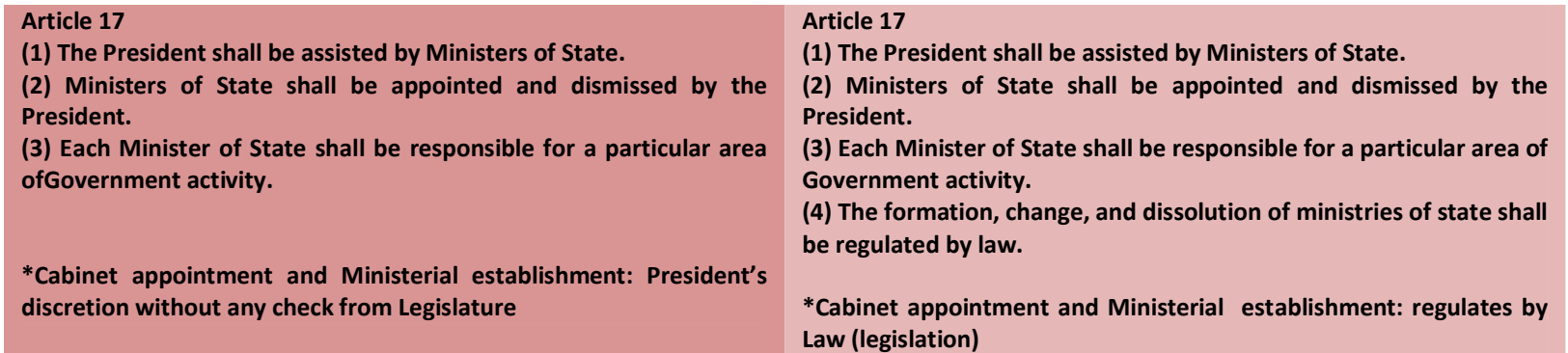

With regard to the administrative power, a presidential cabinet is under the President. In line with it, the Third Amendment does not change the constitutional position of ministers as the President's assistants. The President has the power to appoint the ministers. He also has the power to remove the ministers. However, the amendment makes limitation to the president'scabinet establishment power by adding section 4. The Third Amendment stipulates that the formation, change, and dissolution of a ministry are set by Law. Procedurally, according to the Third Amendment, the President cannot freely establish, change, or dissolve a ministry department according to his prerogative right but should exercise it according to the Law. Although the establishment of a ministerial department would be more accountable since it is based on the Law, problems may arise when the decision to establish and reshuffle a ministry is urgent. Meanwhile, the fact that the President is bound by political parties makes the establishment procedure more complicated. The Presidentalso has to copewith political pressures. In the experience, the reshuffle of the cabinet during President SBY' time was always a moment of high political tension. Sometimes the President has to make a deal with the political parties and the establishment of a ministerial department is just a political matter and not about the government's necessity.

In a presidential system, a minister in a cabinet is one of the instruments to support the President's vision and mission. Once it is limited, even by laws or political pressure; it may contribute to the failure of the government's performance.

\section{Electoral bargaining and the Indonesian Presidential election}

The election system has no connection with the executive power per se but indirectly relates to the exercise of executive power. In the current period, the coalition parties sitting in 
Rosa Ristawati: Modelling Executive Powers in the Indonesian Constitution: A comparative Study

the DPR are significant enough to influence the exercise of the executive powers. It is because the executive powers of the President mostly depend on, or are mostly shared with, the DPR. The multi party system in Indonesia combined with the presidential election system in Indonesia has driven the electoral bargaining for proposing a presidential candidate. This situation pushes a presidential candidate to have political commitment from the parties that have supported him for a nomination. In return, a majority support from parties sitting in the DPR may make it easier for the President to exercise executive power, and vice versa, if the support from the DPR is weak, it would hinder the President in the exercise of his powers.

According to the electoral system in the Indonesian presidency before the third Amended Constitution, there was only one general election to elect the political parties sitting in the parliament. Furthermore, the President was not (indirectly) elected by the people but based on the majority votes in the MPR's session with the focuson the political party. ${ }^{863}$ After the third amendment, there are two mechanisms of election: the general election for political parties sitting in the Parliament, and the Presidential election. The President and the Parliament are directly elected by the people with a majority election system. Under the system, the most qualified and popular presidential candidate is expected to be elected directly by the people and will directly represent the people. Article 6A section (1) of the Third Amendment stipulates that "The President and Vice President are directly elected by the people in one pair." Section (2) of the Article defined that "A pair of president and vice president candidates is proposed by the political party or consolidated political parties as the participant in the general election before the presidential election." Furthermore, section (3) of the Article emphasizes that the voting system is as follows: "the president and vice president in pair who have more than 50 percent votes from the total votes with at least 20 percent of the votes in each province of more than half out of the total provinces in Indonesia will be appointed as the President and Vice President." ${ }^{\prime 864}$

\footnotetext{
${ }^{863}$ The Constitution before the Third Amendment in 9 November 2001 stated that: "the President and vice president are elected by the MPR by a majority vote."

${ }^{864}$ Article $6 \mathrm{~A}$ of the Third Amendment of the Indonesian Constitution (9 November 2001).
} 
Rosa Ristawati: Modelling Executive Powers in the Indonesian Constitution: A comparative Study

After the Third Amendment, there are 2 legislations concerning the presidential election: Law No. 23/2003 and Law No. 42/2008. Both Laws set the details of procedures and system for the presidential election and the mechanism of candidacy. According to the Law, there is a threshold to be gained for political parties in nominating the President and Vice President as a pair. According to the Law No. 23/2003, the threshold that must be gained by a political party to nominate the president was 15 percent from the total of seats in the DPR, or 20 percent validity of national votes in the parliamentary election. This threshold was implemented in the presidential election of 2004. However, the threshold was up graded to be $5 \%$ more by Law No. $42 / 2008$. According to the Law, the threshold that should be gained by the political parties in order to nominate a presidential candidate is now 20 percent from the total seats in the DPR or 25 percent from the valid national votes in the parliamentary election. To gain the threshold, parties may deal with other parties for a coalition to nominate the presidential candidate. ${ }^{865}$ Such a mechanism pushes a presidential candidate to have political commitments. In the end if he could win the election and become a President, he is bound by the commitment and may be under the shadow of the coalition parties or his party when he exercises his power.

Table 4.24. Problems of the presidential election before and after the Amendment

\begin{tabular}{ll}
\hline Before (UUD 1945) & $\begin{array}{l}\text { After (Amended Constitution) } \\
\text { Article } 6\end{array}$ \\
$\begin{array}{l}\text { The President and Vice President are elected by the MPR by a } \\
\text { majority voting }\end{array}$ & $\begin{array}{l}\text { Article } 6 \text { A } \\
\text { (1) The President and Vice-President shall be elected as a pair } \\
\text { directly by the people. } \\
\text { (2) The pairs of candidates for President and Vice-President shall be } \\
\text { proposed prior to the holding of general elections by political parties } \\
\text { or coalitions of political parties which are participants in the general } \\
\text { elections. }\end{array}$ \\
$\begin{array}{l}\text { (3) The Presidential and Vice-Presidential candidate pair which polls } \\
\text { a vote of more than fifty percent of the total number of votes during } \\
\text { the general election and in addition polls at least twenty percent of } \\
\text { the votes in more than half of the total number of provinces in } \\
\text { Indonesia shall be declared elected as the President and Vice- } \\
\text { President. } \\
\text { (4) In the event that no Presidential and Vice Presidential candidate } \\
\text { pair is elected, the people shall directly choose between the two } \\
\text { candidate pairs that received the most number of votes in the } \\
\text { general elections, and the pair that receives the highest number of } \\
\text { votes shall be appointed President and Vice President. }\end{array}$
\end{tabular}

\footnotetext{
${ }^{865}$ The threshold for proposing presidential candidates is currently challenged. It has a tendency that in the future, the threshold for proposing presidential candidates will be eliminated. The Constitutional Court on 23 January 2014 ruled one voting day or a simoultaneous electionfor the DPR and presidential election.
} 
The Amended Constitution sets a more complicated mechanism for the Presidential election. The presidential nomination should be by a political party or party coalition. The Amended Constitution does not accommodate an individual presidential candidate. This mechanism may have disadvantages on one side, that is, the candidate has to belong to a political party which proposed the President in the election. Until now, there are still debates against an independent presidential candidate. Support for the independent candidate view may be related to the need to accommodate an individual right as it is mentioned in Article 6 section (1) the Third Amendment, which says that: "Any candidate for President or VicePresident shall be a citizen of Indonesia since birth, shall never have acquired another citizenship by his/her own will, shall never have committed an act of treason against the State, and shall be mentally and physically capable of implementing the duties and obligations of President or Vice-President. On the other hand, section (2) of the Article stipulates that "The requirements to become President or Vice-President shall be further regulated by law." Textually reading, Article 6 of the Third Amendment seems to contradictArticle 6 A section 2 which conditionally requires that the candidacy should be through a political party. It has the meaning that a candidate can't simply come from any Indonesian as has been mentioned in Article 6. On such an issue, the Constitutional Court had said in its Decision No. 56/PUU$\mathrm{VI} / 2008$, that the Court rejected independent candidates since it said that could be unconstitutional.

Furthermore, in terms of a voting system, according to Article 6A section (3) of the Third Amendment, the requirement of votes would bemore difficult to be obtained by the candidates. ${ }^{866}$ Section (3) of the Article clearly states that a candidate must have more than 50 percent votes from the total votes consisting at least 20 percent votes in each province out of

\footnotetext{
${ }^{866}$ Article 6A Section (3) the Amended Indonesian Constitution: The Presidential and Vice-Presidential candidate pair which polls a vote of more than fifty percent of the total number of votes during the general election and in addition polls at least twenty percent of the votes in more than half of the total number of provinces in Indonesia shall be declared elected as the President and Vice-President.
} 
more than half from the total provinces in Indonesia. By this article, if now the total provinces in Indonesia are 33, then, a candidate to be the President should have 20 percent of the votes in at least 18 provinces and a total of 20 percent votes; but these votes, should be more than 50 percent among other candidates. This voting system is complicated and not easy to be achieved.

The Fourth Amendment also added a first past the post system for the second round of the presidential election to anticipate a deadlock: "In case none of the candidates obtains the requirement of the votes, the two pairs of candidate who have the highest percentage of votes in the first and second place at the first election round, shall be directly elected by the people and by a simple majority vote, the President and vice president shall be elected. ${ }^{867}$

Practice shows that although the presidential candidates are proposed by a political party and are not independent candidates, an individual figure may emerge as a strong candidate for President. Article 12 Law No. 42/2008 stated that the political parties may declare their presidential candidate in the parliamentary election campaign. In 2 experiences of the Indonesian presidential elections (2004 and 2009), the individual figure was a magnet for the voters; and therefore, a strong figure with high popularity may potentially influence the performance of the party. The phenomenon of the 2014 presidential election, the electability and the popularity of an individual figure began to be the most attractive aspect rather than the political party allegiance. This tendency may show that the electability of a political party is subordinate to the electability of an individual candidate.

In conclusion, the Constitution designed the political party as the key in the Indonesian presidential election since the candidates can only be proposed by a political party or an alliance of political parties. However, practice shows that the first direct election in 2004 indicated that actually the entire community focused on the individual figure rather than the

\footnotetext{
${ }^{867}$ Article 6A Section (4) the Amendment of the Indonesian Constitution: In the event that no Presidential and Vice Presidential candidate pair is elected, the people shall directly choose between the two candidate pairs that received the most number of votes in the general elections, and the pair that receives the highest number of votes shall be appointed President and Vice President".
} 
Rosa Ristawati: Modelling Executive Powers in the Indonesian Constitution: A comparative Study

partisan figure. Experiences showed that SBY (the 2004's elected President) was proposed by small percentages of coalition political parties. It implied that the centrist model of representation was the key in the presidential election rather than the partisan figure. However, after the election, reflected from the public policy, the tendency of the partisan modelof representation is shown. Most of the public policy-making process reflects theparty interest rather than the entire nation's interest. The President should make much effort to compromise with the public and other left and right groups.

\section{Presidential immunity}

The Amended Constitution is silent on presidential immunity even though it is implied from Article $7 \mathrm{~B} .{ }^{868}$ The absence or the obscurity of the presidential immunity concept in the Indonesian Constitution would potentially cause mis-interpretation, other political conflicts, or constitutional problems. In practice, there are many doubts about whether or not a President can be entangled in a legal process. ${ }^{869}$ When a President is given an unconditional immunity, he may exercise the power unimpeded without interruption by legal prosecution.

The term "immunity" has different meanings. The term immunity in constitutional law refers to the immunity from prosecution that is mostly expressed in the Constitution. The purpose of granting immunity to public officers is to assure the performance and independence of the branches. ${ }^{870}$ There are two basic types of immunity that can be distinguished, namely, a

\footnotetext{
${ }^{868}$ According to the Article, the President may be impeached when he allegedly violated laws, committed crimes; treason, corruption, bribery, or other crimes. The proposal for impeachment is submitted by the DPR (after intense investigation) to the Constitutional Court to get a confirmation motion. Furthermore, the MPR will conduct a special session to formally impeach the President in office. At this point, it implies that the President in office can't be prosecuted during his office. The legal process would be held after the impeachment process. The impeachment article may indirectly confirm that a President in office has absolute immunity from legal prosecution. The legal process may only be held after he is no longer in office.

${ }^{869}$ The experiences when president Soeharto was involved in some of corruption cases during his regime or when there were allegations that the former President was indirectly related to some scandals such as Centurygate, $\mathrm{BLBI}$, and Hambalang.

${ }^{870}$ A summary of a publication that was produced for review and funded by the United States Agency for International Development in February 2006, Parliamentary Immunity Brief: a Summary of Case Studies of Armenia, Ukraine and Guatemala, Development Alternatives Inc., USAID, August 2006: "The legitimate purpose of immunity is to allow legislators to freely express themselves and adopt policy positions without fear of politically
} 
narrow scope of immunity and a broad scope of immunity. ${ }^{871}$ To this extent, the purpose of granting immunity to the President is rational in order to ensure the independent performance of the President in exercising power, functions, and duties to administer the state and establish a legitimate government. The rationale of granting immunity to the President is also because the President is the symbol of the state (head of the state). It is also connected with the separation of power that the President in the area of the executive is the unique branch; the President has the executive power, is the head of state and the commander in chief; so, the rationale of granting the Presidential immunity is expected to effectively establish state governance in the state administration and on the basis of the public policy perspective, it is expected to meet the need of strong state administration and effective government. ${ }^{872}$ The distinction between official capacity and private capacity is also important to determine the scope of presidential immunity. An official capacity treats the President as an institution within the executive branch and acting officially as the head of the state and the head of government. On the other hand, the President is viewed as acting in his own private capacity when the President represents himself as a person in a civil action.

The doctrine ofimmunity of the head of state and high rank state official has been developed within International law. ${ }^{873}$ According to Article 31 VCDR 1961, the head of state

motivated retribution. However, protection from criminal and/or civil prosecution can allow some legislators to engage in corrupt or illicit behavior with impunity; alternately, an overly-politicized legislature and/or executive and judicial branches of government can override the legitimate protection that immunity is supposed to provide."

${ }^{871}$ Id, Some countries, like the United States, adopt a narrow scope of immunity, restricting protection to actions and statements that the legislator undertakes directly in his or her capacity as a politically elected representative and lawmaker. If the legislator engages in illegal activity outside his or her legitimate role as a representative, he or she is subject to investigation, prosecution, trial, and potentially punishment like any other citizen. Similarly, the British model provides legislators with protection from civil actions (e.g. charges of slander and libel) that transpire in the execution of their duties. The Continental model of the French system provides deputies with a broad scope of immunity, including protection from both civil and criminal prosecution, within and outside of their roles as parliamentarians. The majority of developing democracies have embraced a broad scope of immunity, presumably to protect against the authoritarian abuses of the past.

872 Enoch Chang, "Presidential Immunity; A Survey of United States Cases", Taiwan International Studies Quarterly, Vol. 3, No. 1, pp. 149-70, Spring 2007, pp. 150.

${ }^{873}$ The Vienna Convention on Diplomatic Relations (the VCDR) of 18 April 1961 mentionsin its preamble that the purpose of diplomatic privileges and immunities is not to benefit individuals but to ensure the efficient performance of the functions of diplomatic missions as representing States. Therefore, with regard to the 
should enjoy immunity from criminal jurisdiction of the receiving state and also enjoy immunity from its civil and administrative jurisdiction in certain areas. ${ }^{874}$ The rationale for granting immunity to the state official representing the state besides diplomatic reasons is also because of respect for the sovereignty of the state. In general theory, International law distinguishes two types of immunity that can be granted to the President as the head of state; namely, the functional immunity and the personal immunity. ${ }^{875}$ However, such immunity in International law may be derogated, waived, renounced, or removed for certain reasons according to Article 32 VCDR $1961 .{ }^{876}$ Borrowing from the legal concept of immunity in International law, within the state territory, the President represents the sovereignty of the state and a legitimate government. The concept of presidential immunity may be either generally articulated in a provision or implied from the impeachment provision in the Constitution. To this extent, there is no explicit provision of presidential immunity in the Indonesia Constitution. The concept of immunity may be linked to presidential impeachment. ${ }^{877}$ Within the state and according to the Constitution, the President can enjoy either absolute immunity or qualified immunity. Absolute immunity is granted with the intention to accommodate effective decision making and discretionary action by the President. While, qualified immunity is addressed to provide effective measures in protecting the constitutional rights of the citizens. ${ }^{878}$ Qualified immunity

immunity, in the international sphere, the rationale to grant the head of state with the immunity is to ensure the efficient performance of the head of state (the President) in representing his state.

${ }^{874}$ Article 31 VCDR 1961.

${ }^{875}$ Sarah Williams and Lena Sherif, "The Arrest Warrant for President Al-Bashir: Immunities of Incumbent Heads of State and the International Criminal Court", Journal of Conflict \& Security Law,Vol. 14, No. 1, pp. 71-92, Oxford University Press, 2009, p. 74: Functional immunity (ratione materiae) attaches to the acts of officials while they are in office. This type of immunity is limited, in that it only applies to those official acts carried out during the period of office. Officials may still be the subject of legal proceedings in respect of acts committed in a personal capacity, even where such acts were committed before or after their appointment. However, immunity "ratione materiae" will survive the cessation of office and, thus, may be claimed by former state officials. The second type of immunity enjoyed by state officials is known as personal immunity (ratione personae). It protects the office holder in the exercise of their representative functionsand is intended to facilitate the conduct of international relations.

${ }^{876}$ Article 32 VCDR 1961.

${ }^{877}$ Id. at p. 6., The silence of the Constitution on the President's exposure to judicial process, in this light, is not neutral, but allows the inference that impeachment is the sole form of official action against a President in office, to the exclusion of judicial process.

${ }^{878}$ Michael T. Matraia, "Running for Cover Behind Presidential Immunity: the Oval Office as Safe Haven Civil Suits", Suffolk University Law Review, Vol. XXIX, 1995, pp. 195 - 231, p. 230, accessed on 29/04/2012). 
Rosa Ristawati: Modelling Executive Powers in the Indonesian Constitution: A comparative Study

protects against constitutional tort suits in a manner similar to absolute immunity but does so in an individualized, case-specific basis. It turns on the objective reasonableness of the official's conduct in the light of existing constitutional doctrine. ${ }^{879}$ In another argument, qualified immunity is an immunity that protects government officers from liability for violating constitutional rights; it is a doctrine that precludes damages unless the officer violated constitutional rights. ${ }^{880}$

In common practice, presidential immunity is understood as immunity from the judicial process. ${ }^{881}$ It is actually an immunity of legal prosecution of criminal acts or civil private suits during the presidential office term. The argument of giving the President immunity is mainly to respect the President as the head of state, the symbol of the state. On the other hand, the need to grant the President immunity is for the purpose of assuring the independence, accountability to fulfill the President's constitutional duties in administering state administration and executing the laws. An absolute presidential immunity can be granted to the President, in the sense that the President cannot be brought to a legal prosecution or civil case before the Court during the president's office in a private capacity. Such immunity exempts the President from civil actions liability for his/her official acts. Generally, the immunity also relates to the presidential privilege.

With regard to Indonesia, the executive immunity concept may be important to be constructed in the Constitution since it would help to distinguish between private conduct andofficial conduct. It would, in the end, avoid abuse of executive power. A qualified executive immunity may help to restrain presidential powers. On the one side, giving a very limited immunity would be for respecting the President as the personification of the State; while on the

\footnotetext{
${ }^{879}$ See more: Alan K.Chen, "The Facts about the Qualified Immunity", Emory Law Journal, Vol. 55, No. 2, 2006, pp. 229-278, p. 235: " the absolute immunity and qualified immunity operates differently, the absolute immunity is rigid and rule like. Once a court determines that an official being sued for the performance of a function for which absolute immunity is recognized, the suit is over and visa versa on the theory of qualified immunity.

${ }^{880}$ John C. Jeffries, Jr," What's Wrong With Qualified Immunity?", Florida Law Review, Vol. 62, No. 4, September, 2010, p.2, accessed at http://ssrn.com/abstract=1619997.

${ }^{881}$ Joseph Isenbergh, "Impeachment and Presidential Immunity from Judicial Process", Chicago Public Law and Legal Theory Working Paper, No. 2, accessed on 24/04/2012 from The Social Science Research Network Electronic Paper Collection: http://papers.ssrn.com/paper.taf?abstract id=193849, p. 1
} 
other hand, enhancing the executive responsibility would contribute to a more responsible President.

\section{The Constitution and the Presidential Immunity}

The impeachment provisions are not enough to give guidance on how a legal mechanism to prosecute the President in office should be. The President in office is not subject to investigation and prosecution within the criminal justice system. The President in office could not be directly impeded by arrest, subpoena, detention, indictment, or other civil action.

In proving that the President commits unlawful acts, it is not the competence of the public prosecutor but the DPR with its constitutional rights and mechanism of "enquette"which has the constitutional competences to question and can set an investigation to gather the facts that the President committed an unlawful act. This mechanism is beyond a criminal justice system. It is a matter of constitutional and political process within an impeachment process. This has as a consequence that the President is a privileged citizen during his/her office. However, a general legal prosecution within a criminal justice system can be set up after a constitutional process of impeachment is completed and the President has stepped down.

In his official capacity as the head of government, the President is subject to the administrative courts. Before the Court, the President can be institutionally sued by a citizen. The presidential immunity in this case could belimited only for the official capacity as the head of government in establishing state administration. However, since the suit is not addressed directly to the President but to the state official within the state administration, the President cannot be responsible as a private person.

\subsection{Closing remarks}

In general, the ambiguities of the Indonesian Amended Constitution texts are revisible in some articles. While some articles are ambigous in creating power balances, the others reflect a bias ambition to cut down and weaken the president's power. The texts on the treaty power are one of the examples that reduce the President's room for manouvre as the executive in a presidential system. They are even more complicated. The ambiguity of the texts is relating to 
the obscurity of the term "treaty" and "other international agreement". ${ }^{882}$ It leaves loopholes for the President to conclude an international agreement (that does not have significant impact on a certain situation mentioned on the Article) without any checks and balances from the DPR. Furthermore, some articles actually are inconsistent with the spirit of curbing the President's power. They even give more excessive powers to the President. For example, the legislative power clauses, which actually give the Presidentequal power as the DPR.

Institutionally, the Amended Constitution has not yet provided a definitive clarification of each of institutional functions. However, in order to anticipate a conflict of powers among the state institutions, it is important to provide a clear institutional governance framework. Under a future Indonesian Amendment of the Constitution, it is important to give a strong clarification to the institutional roles and functions of the state institutions. The DPR should be the parliament, and the legislative branch, while, the "MPR", should be in the futureexplicitly a constitutional assembly (since it has the main duty to amend the Constitution). The Courts, as the judicial branch, should have functions mentioned by the Constitution, and the President should be the executive.

\footnotetext{
${ }^{882}$ Article 11 section (1) and Article 11 section (2) of the Fourth Amended of Indonesian Constitution (Appendix 4).
} 


\section{CHAPTER 5: THE INDONESIAN PRESIDENCY: THE IDEAS AND THE PROPOSAL}

\section{Introduction: From President Soekarno to President Jokowi}

This chapter will in particular be concerned with the general conclusions on relevant issues in this dissertation and alternative solutions for a constitutional improvement. The previous chapters have explored the theory, history, development, and current specific issues of Indonesian executive power under different constitutional regimes. It shows in chapter 3 that the Indonesian executive powers had been performed differently under different constitutional regimes. Under the First Indonesian Constitution (UUD 1945), the Executive emerged as a revolutionary branch with strong anddominant powers to deal with revolutionary situations, the struggle for Indonesian independence, and International recognition. After experiencing the revolutionary executive powers, Indonesia moved on to the authoritarian regime. Under the authoritarian Soeharto regimes, the Indonesian Constitution was used as an authoritarian constitution, justifying the dominance of the executive branch and strengthening the authoritative executive powers of the President. The fall of the Soeharto administration in 1998 brought a transitional government under the Habibie administration. ${ }^{883}$ During his one year administration, Habibie made a noteworthy decision which had significant impact on both foreign and domestic affairs by giving a referendum to Timor-Timur. ${ }^{884} \mathrm{He}$ performed a unilateral presidential decision on a referendum for Timor Timur which was urgently made after an informal consultation with some Ministers and was validated by the MPR's decision. Another new Indonesian President, President Wahid, was elected in 1999 by the parliament (the MPR). During the Wahid administration, the process of the Indonesian Amended Constitution was started by a special commission of the MPR. President Wahid performed his executive power under the First Amendment of the Constitution as he wished and in his own way. Moving on to

\footnotetext{
${ }^{883}$ On May 1998, the massive people and student's demonstration all over Indonesia and specifically in Jakarta successfully brought down the Soeharto's administration. The demonstration was mainly provoked by the monetery crisis in Indonesia.

${ }^{884}$ Merdeka.com, "Benarkah lepasnya Timor-Timur Karena Kesalahan Habibie?", Jakarta: June 132013 , accessed online 19/10/2015 at: http://www.merdeka.com/peristiwa/benarkah-lepasnya-timor-timur-karenakesalahan-habibie.html : The Prime Minister John Howard urged Habibie to overcome the situation in Timor Timur by giving a referendum.
} 
Rosa Ristawati: Modelling Executive Powers in the Indonesian Constitution: A comparative Study

Megawati's administration, the executive power was partly performed under the III Amended Constitution (2001 - 2002) and the IV Amended Constitution (2002 - 2004). During her administration, Megawati was more prudent in using the executive powers. After a series of constitutional Amendments, the Amended Constitution introduced a new model for the Indonesian presidential system. The system was designed to stifle the executive powers of the President. The Constitution was made to be more protective of the executive power. The checks and balances of the executive power of the President became even more stringent. In 2004, theadministration turned to President Susilo Bambang Yudoyono (SBY) as a result of the first democratic direct presidential election according to the Amended Constitution. In the two terms of SBY's office (the first office term was 2004-2009, the second office term was 20092014), the executive powers have been exercised under the Amended Constitution with some vagueness and obscurity of concepts in most of its provisions as has been discussed in chapter 4. Since 2014, in the new era of the Jokowi administration, the executive powers of the President are also performed under the Amended Constitution. However, it is performed in a very different style with more pressure from the parliament.

2. Indonesian presidency and the executive powers: idea for the future executive powers in Indonesia

This section will present ideas for redesigning the Constitution, in particular, to redesign the Articles which concern the executive powers. The main issues in this part will be more about the future of the Indonesian presidency and what and how the executive powers should be given in order to improve the presidency. First, it will be an elaboration of the executive powers that should be given to the President, how the President should be given the executive powers, and how the mechanism of counter-balance from other branches should be regulated. Second, by combining local and international values, reflecting aspects of the 6 Constitutions (the US Constitution, the Philippines Constitution, German Constitution, South African Constitution, French Constitution, and Polish Constitution), and imitating some constitutional concepts, the proposal on how the executive power of The Indonesian President should be given will be drawn. 
Rosa Ristawati: Modelling Executive Powers in the Indonesian Constitution: A comparative Study

a. A choice of presidency: from a high level of presidential system to an original style of presidential system

A presidential system is still the best choice for Indonesia. Firstly, because it would not be easy to switch to other types of government systemsand the process would very complicated if the system is changed. The mechanism of changing to a new system will take more time to set up and install a new framework, while it would not be easy to adapt to such a new mechanism. Secondly, each government system has its advantages and disadvantages. After almost two decades, Indonesia has gained benefits from experience of the presidential system and has successfully passed through transitional periods of presidential systems. The advantages and disadvantages of the system have helped the Indonesian government system to develop. However, the system needs improvement in order to encourage its effectiveness.

According to the development, there are some models of presidential system: the US style presidential system, a high level of presidential system (hyper-presidential system) and a low level presidential system (passive-presidential system). ${ }^{885} \mathrm{It}$ is considered that a hyperpresidential system is a presidential system which provides more/strict checks on the presidential power, while a passive-presidential system is a presidential system which provides fewer/weak checks on the presidential power. Whilst, an original presidential system is a presidential system which is based on the original idea of the US Constitutional framers where the President was intended to be an independent branch, a strong institution, but had few substantial portions of executive powers, undefined executive power can only be exercised with and by the power of other branches. ${ }^{886}$ However, some states built a presidential system

\footnotetext{
${ }^{885}$ Read: Susan Rose Ackerman, "Hyper-Presidentialism: Separation of Powers without Checks and Balances in Argentina and the Philippines", 2011, Faculty Scholarship Series, Paper 4155, accessed online via www.digitlcommons.law.yale.edu/fss papers/4155 . Susan Rose-Ackerman used the hyper-presidential term to explain how the presidential system in the Philippines and Argentina is adopted. However, she used the terms differently. She determined the term hyper-presidential as the system where the President has more unilateral power.

${ }^{886}$ Eric A Posner and Adrian Vemeule, "Tyrannophobia”, in: Tom Ginsburg, Comparative Constitutional Design, Cambridge Universiy Press, 2012, p. 325: "The veto power might be understood just to mean the right to veto unconstitutional legislation, not legislation that the president rejected on policy grounds, the commander in chief power could refer only to tactical control, not military strategy and foreign policy in general, the power to receive ambassadors could refer to a ceremonial role, not the power to recognize states and governments".
} 
by vesting wide substantial powers and leaving the powers independently to the President. While other states proportionally allocated the executive powers to the President, some states are simply inspired by a parliamentary system, establishing a presidency by only giving the President formal power for the executive affairs.

According to Indonesian history, Indonesia was established as a republic. The Founding fathers established a presidency within the Indonesian government system. Although the Constitution does not strictly say that the Indonesian system is a presidential system, in practice, the President is the head of state and head of government. Before the Amendment, the Indonesian parliament was the key of the government. It could impeach the president and appoint the president. ${ }^{887}$ Under such a framework, practice became more confusing when conflicts happened between the President and the parliament since the Constitution did not provide appropriate solutions. At this point, it is important to strongly confirm that a presidential system is still a plausible system to be adopted in Indonesia.

To redesign a more appropriate presidential system for Indonesia, firstly, it is important to reflect on US presidential history. Not only because the US Constitution is the world's first written Constitution introducing the presidential system, but also because the US constitutional system has historically set the standard on how executive powers could be exercised under a presidency. Accordingly, the framers of the US Constitution intended to have an independent executive branch assigned to the US President with substantivelimitations of executive powers. The framers of the US Constitution gave the US Congress more powers than the powers that were attached to the US President. However, the US President was assigned with some powers that are relevant to his roles and functions. Although the US President is considered as the key point of the government, in exercising the power, the US President has to share his executive powers with either the Congress or the Senate.

The original idea of a presidency has been developed and applied in various ways. In practice, the tendency to over limit and put too much limitation to the executive power may

\footnotetext{
${ }^{887}$ The first Constitution indicated that Indonesia was a parliamentary system. The Constitution assigned the MPR as the key where the President was dependent on it, being elected and responsible to the MPR. This is a little bit contradictory with what the framers actually wanted for a government system.
} 
Rosa Ristawati: Modelling Executive Powers in the Indonesian Constitution: A comparative Study

appear as a phenomenon of weak executive power. Such a tendency indicates hyperpresidential (less executive power, more checks and balances) since there are hyperactive checks and balances over the executive power and the President as the executive branch. In this situation, the executive power is over limited and over controlled. Too much intervention is given from other branches; the parliament and the courts. The President is given only formal and limited executive powers. The President is conceived to have weak executive power or even only artificial executive powers while the real powers are vested in other institutions. In such a framework, the executive branch may be the weakest branch among others. On the other hand, another presidential model shows the tendency of unilateral executive powers which are vested in an independent executive branch. Such a model may appear in a situation where passive checks and balances over the executive are exercised. The tendency may indicate a passive presidency where the executive power is given broadly with fewer checks and balances from other institutions. In a framework where the President is given dominant and unilateral executive power, most of the executive powers may be exercised according to the personal discretion of the President. The President does not need to seek any authorization before he executes the powers and most of the powers are not to be shared with other institutions.

Under the Amended Constitution, the executive powers of Indonesian presidents are mostly weak. The Constitution has made an over-limitation of the executive powers, while, in performing the power, the President is not only constrained by the Constitution but also has to deal with "political limitations" from parliament. From the period of the First Indonesian Constitution to the period of 1998 , before the process of the Amendment, Indonesia was familiar with a passive-presidential model. The executive powers of the President were strong and dominant. A powerful president exercised the executive powers with very small checks from other branches or went even unchecked. As Indonesia has experienced both hyper and passive presidentialism, the more plausible plan is to redesign the Indonesian system with an original model of presidentialism as in the US. A system which gives proportional checks and provides balancing power between three branches (the executive, the legislature, and the 
judiciary). It may be realized by bringing back the powers of the President. The President must be given significant executive powers that are relevant to the duties and roles while proportional checks and balances must be performed by the parliament and the courts. A proportional framework of checks and balances is that other branches will act proportionally to equalize the executive powers. The Legislature would notoverstep constraint and dominate the executive powers of the President, but rather be working as a mutual partner. On the other hand, the Courts would not intervene but act as truly constitutional interpreters. The President should remain the key figure of government, vested with significant executive powers that are relevant to his roles and duties. The power of other institutions should be encouraged to be more advisory rather than extremely contentious. To strengthen the institutional checks and balance from the legislative to the executive, the legislative should not direct the executive but be a counterpart to the executive. The President, vice versa, should also be given the power to counter-balance the Legislature. It would also be reasonable to empower the Constitutional Court with the power to offer passive advisory opinions, that is, an advisory competence that may be given by the Court when any branch requires constitutional advice. In some areas, the President should be given real powers. For example in some of appointment powers, the President should be given nominal powers, rather than just formal powers, to nominate, select and appoint the ministers without any political pressure from others. While in other areas, such as the pardoning power, the president should share the power with other branches. This, inter alia, is merely to respect the judicial process and not make it too easy for the President to contradict the Court's decisions. On the emergency power, the Constitution should accommodate "an extra-ordinary" situation where the President is mostly expected to takeurgent and substantial action by still respecting mutual and equal relations between the three branches. By still preserving the "natural conflict" between the executive and the legislative, the Constitution must provide a clear framework to solve the conflicts.

\section{b. Model of checks and balances of the executive powers for Indonesia}


In the development of constitutional theory, there are some mechanisms to be applied to constrain the executive powers, such as the classic mechanism of checks and balances from the Legislature by a real mechanism for control, oversight, and judicial review of the Legislature. Moreover, some scholars argue that the mechanisms of impeachment and removal are also effective to check one particular type of abuse of power by the executive, namely, corruption. $^{888}$ Meanwhile, some constitutional doctrines, such as executive immunity may be relevant to limit executive powers and enhance executive accountability. To be applied effectively and in co-existence with the constitutional system, the Constitution should clarify the application of such a doctrine including its limits.

The executive powers should rely on checks and balances mechanisms, such as legislative control, legislative oversight, and other institutional functions. According to Posner and Vermeule, the legal checks, either the requirement that the executive should obtain the consent of other government officials (legislator) before acting; or the requirement that the executive submit to periodic popular elections is the mechanism in order to avoid unchecked executive power and prevent dictatorship in the presidency. ${ }^{889}$ On the other hand, citing from a parliamentary system, parliamentary control of the executive is important to anticipate the greatexpansion of power in the global modern era. ${ }^{890}$ However, there are other checks and balances that may potentially create gridlock and make it difficult to pass necessary reforms; such as the elaboration of veto gates (bi-cameralism and a committee system); legislative and judicial oversight of executive action; and other checks and balances, all with a view to minimizing the risk of executive dictatorship. ${ }^{891}$ The mechanism of checks and balances to

\footnotetext{
${ }^{888}$ See: “Checking Executive power: Presidential Impeachment in Comparative Perspective" Edited by Jody C. Baumgartner and Naoko Kada, Praeger Publishers, USA, 2003, p. 133.

${ }^{889}$ Eric A.Posner and Adrian Vemeule, Op. Cit., p. 319: The fewer the checks, the more plausible the "dictator" label becomes.

${ }^{890}$ Anthony W. Bradley and Cesare Pinelly, Op. Cit., p. 668, In general, parliamentary control of the executive is perceived as being particularly needed given the great expansion in the importance of international organizations and in government activities connected with the adhesion to supranational organizations.

${ }^{891}$ Eric A.Posner and Adrian Vermeule, Op. Cit., p. 338.
} 
Rosa Ristawati: Modelling Executive Powers in the Indonesian Constitution: A comparative Study

check the executive may potentially have a risk of becoming tyranical when it is an independent institution such as in the oversight bodies. ${ }^{892}$

In common practice of a presidential system, the oversight function of the Legislature is more significant when the government is backed-up by a majority. ${ }^{893}$ However, the Constitution should provide more specific mechanisms to make Legislative branch functions more applicable. To make Legislature control more effective, the mechanism of questions and the interpellation mechanism can be borrowed and adopted from the mechanism of parliamentary control in parliamentary states. Such a mechanism will allow the Legislature to invoke questions and interpellation; it may be followed by a short debate and a vote whether the executive's response is acceptable. But however, most importantly, since the system is a presidential system, the vote should not end with a vote of no confidence but should end with a Legislature recommendation that will oblige the executive to take the recommended actions.

The following table offers the model of checks and balances of the executive power of the Indonesian President:

Table 5.1 Model for Indonesian executive power

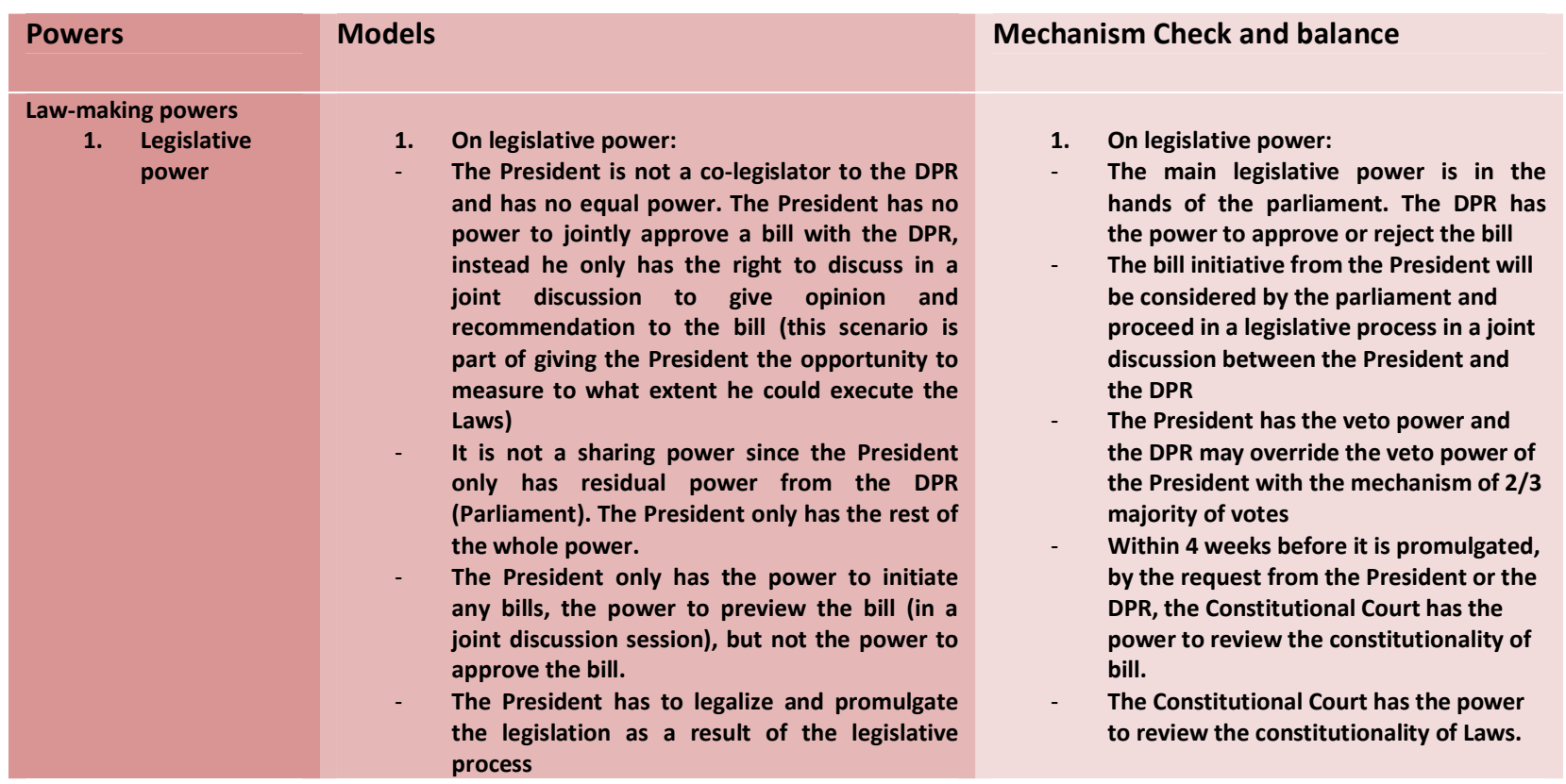

\footnotetext{
${ }^{892}$ Id. at p. 339.

${ }^{893}$ Anthony W. Bradley and Cesare Pinelli, Op. Cit., p. 667.
} 


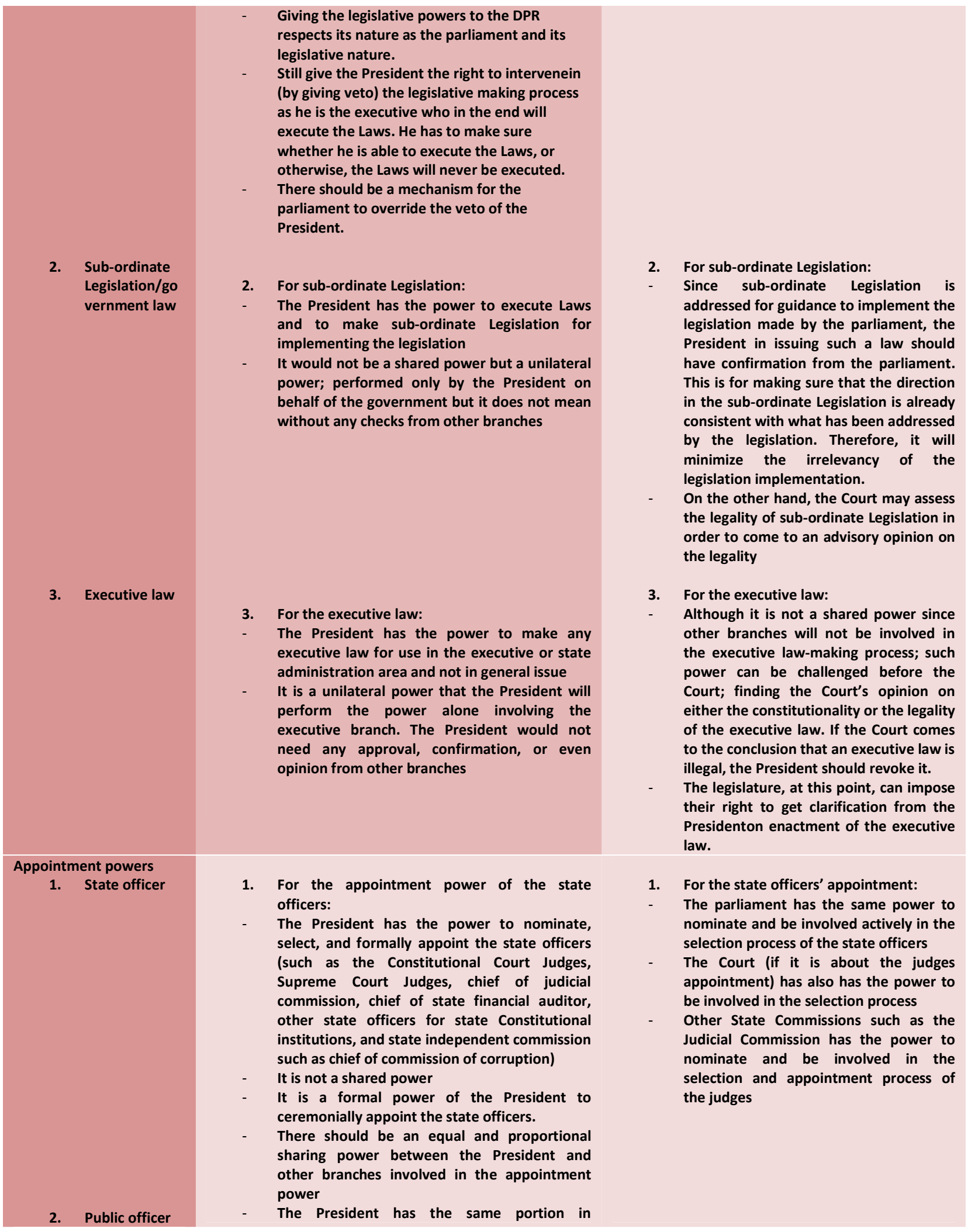




\section{Rosa Ristawati: Modelling Executive Powers in the Indonesian Constitution: A comparative Study}

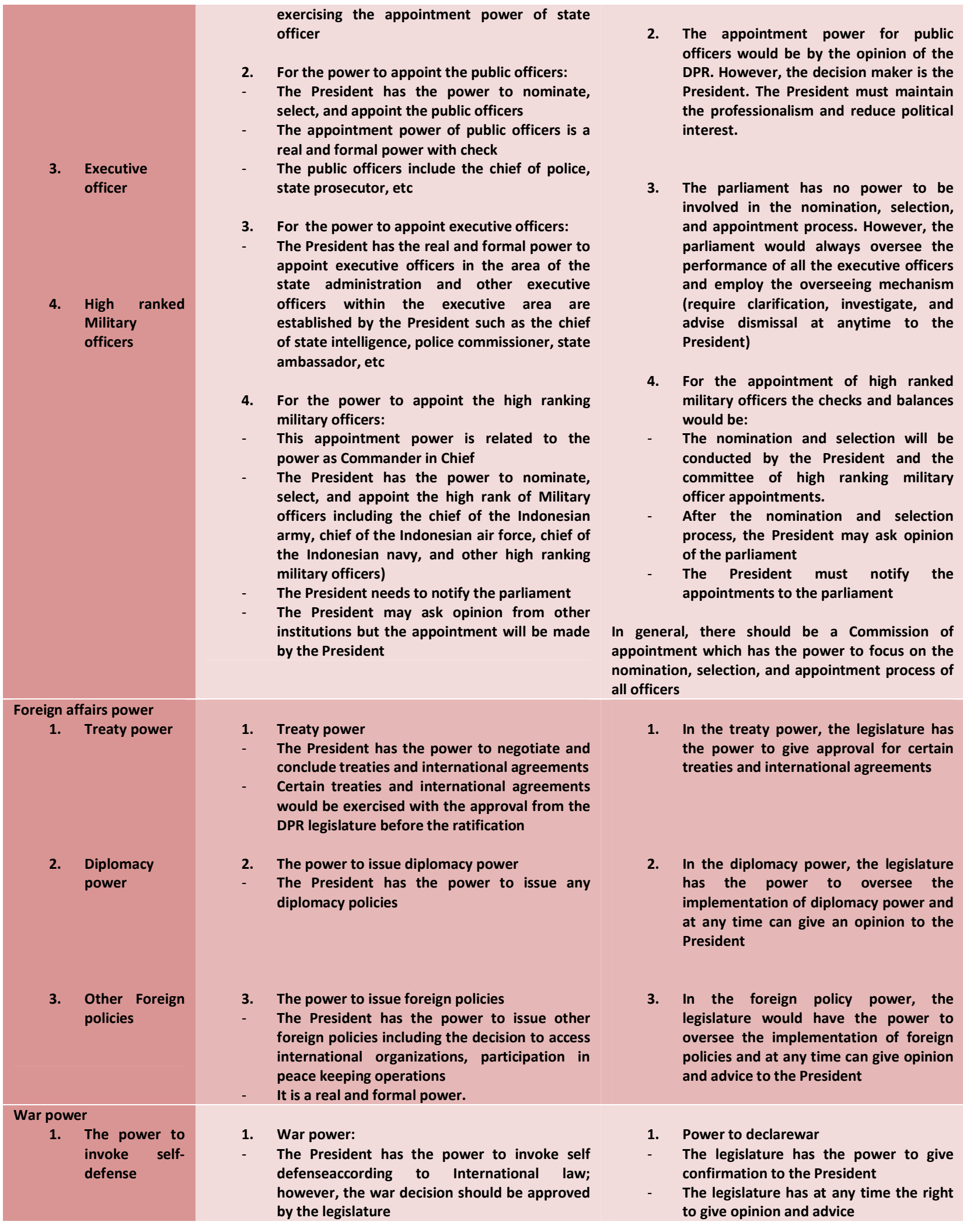




\begin{tabular}{|c|c|c|c|c|c|}
\hline 2. & $\begin{array}{l}\text { The use of } \\
\text { force power }\end{array}$ & $\begin{array}{l}2 . \\
- \\
-\end{array}$ & $\begin{array}{l}\text { It is the power of the President but the power } \\
\text { should get approval from the legislature } \\
\text { The power to use force } \\
\text { The President has the power to use force with } \\
\text { the approval from the DPR } \\
\text { The President has the power to mobilize the } \\
\text { use of force abroad for the purpose of } \\
\text { supporting international intervention with } \\
\text { confirmation from the DPR }\end{array}$ & $\begin{array}{l}2 . \\
- \\
-\end{array}$ & $\begin{array}{l}\text { The power to use force } \\
\text { The DPR has the key power to approve } \\
\text { or reject the use of force } \\
\text { The DPR has the power to confirm the } \\
\text { use of force abroad for international } \\
\text { intervention }\end{array}$ \\
\hline $\begin{array}{c}\text { Budgeta } \\
1 .\end{array}$ & $\begin{array}{l}\text { power } \\
\text { Initiate budget }\end{array}$ & - & $\begin{array}{l}\text { The power to initiate a budget: } \\
\text { The President has the power to initiate and } \\
\text { discuss the state budget. However, the } \\
\text { legislature has the power to approve the state } \\
\text { budget } \\
\text { It is the power with approval from the } \\
\text { legislature } \\
\text { It is not a shared power since the President } \\
\text { only has the power to discuss and negotiate } \\
\text { while the approval is made by the DPR }\end{array}$ & $\begin{array}{l}1 . \\
- \\
-\end{array}$ & $\begin{array}{l}\text { The power to initiate budget: } \\
\text { The legislature has the power to approve } \\
\text { the state budget } \\
\text { The constitutional court has the power } \\
\text { to review the state budget and come to } \\
\text { its opinion and advice }\end{array}$ \\
\hline 2. & $\begin{array}{l}\text { Expenditure } \\
\text { power }\end{array}$ & $\begin{array}{l}2 . \\
- \\
- \\
-\end{array}$ & $\begin{array}{l}\text { Expenditure power: } \\
\text { The President has the spending power } \\
\text { It is not a shared power since the President } \\
\text { spends from the approved budget } \\
\text { To perform the expenditure power, the } \\
\text { President does not need any approval, } \\
\text { confirmation or consideration from the } \\
\text { legislature }\end{array}$ & $\begin{array}{l}2 . \\
- \\
- \\
-\end{array}$ & $\begin{array}{l}\text { Expenditure power: } \\
\text { Although the legislature would not be } \\
\text { confirmed, it can always oversee } \\
\text { presidential spending } \\
\text { The legislature can always at any time } \\
\text { require the clarification, investigation or } \\
\text { cut the budget } \\
\text { The state auditor has the authority to } \\
\text { oversee, make report, and audit the } \\
\text { spending budget }\end{array}$ \\
\hline Pardonir & power & For the $p$ & rdoning power: & & \\
\hline 1. & $\begin{array}{l}\text { The power to } \\
\text { grant pardon }\end{array}$ & 1. & $\begin{array}{l}\text { In giving the pardon, the President shall have } \\
\text { recommendation and advice from the } \\
\text { commission on the prerogative of pardon. In } \\
\text { giving the amnesty, the President shall have } \\
\text { advice from the DPR. }\end{array}$ & 1. & $\begin{array}{l}\text { The power to give pardon and amnesty } \\
\text { should be by and with advice from the } \\
\text { commission on the prerogative of } \\
\text { pardon established by the President } \\
\text { including the Supreme Court, the judicial } \\
\text { commission, the president's advisor, } \\
\text { state prosecutor, the minister of justice } \\
\text { and human rights } \\
\text { The recommendation and advice from } \\
\text { the Court is in order to respect the } \\
\text { judicial process. A unilateral pardoning } \\
\text { power without the Court's involvement } \\
\text { is likely to undermine the court's } \\
\text { decisions }\end{array}$ \\
\hline The eme & gency power & Model fo & the emergency power would be: & & \\
\hline 1. & $\begin{array}{l}\text { The power to } \\
\text { decide } \\
\text { emergency in } \\
\text { part or the } \\
\text { whole state } \\
\text { territories }\end{array}$ & 1. & $\begin{array}{l}\text { The President has the power to declarea state } \\
\text { emergency without any approval from other } \\
\text { branches. In an emergency situation where the } \\
\text { state under real threat (such as terrorist attack, } \\
\text { natural disaster, economic collapse, political } \\
\text { chaos) or military attack that undermine } \\
\text { national peace and security, the President has } \\
\text { unilateral power to take any action to } \\
\text { overcome the situation } \\
\text { However, apart from the real threat or military } \\
\text { attack, the President has the power to take any } \\
\text { action with the approval from the DPR }\end{array}$ & $\begin{array}{l}2 . \\
- \\
-\end{array}$ & $\begin{array}{l}\text { There should be an ad-hoc commission } \\
\text { established by the Parliament to observe } \\
\text { any measures and actions of the } \\
\text { President during the state emergency. } \\
\text { The court has the power to review any } \\
\text { legal consequences that result from any } \\
\text { legal measure taken by the President } \\
\text { For the emergency law: } \\
\text { The legislature can always oversee the } \\
\text { implementation of the emergency law } \\
\text { that is enacted in times of emergency } \\
\text { and always has the power to get } \\
\text { clarification from the President } \\
\text { The legislature can always ask the }\end{array}$ \\
\hline
\end{tabular}




\section{Rosa Ristawati: Modelling Executive Powers in the Indonesian Constitution: A comparative Study}

\begin{tabular}{|c|c|c|c|c|c|}
\hline 3. & $\begin{array}{l}\text { The power to } \\
\text { issue } \\
\text { emergency law } \\
\text { and establish } \\
\text { ad-hoc } \\
\text { institution to } \\
\text { overcome the } \\
\text { emergency } \\
\text { situation }\end{array}$ & 3. & $\begin{array}{l}\text { The President has the power to issue } \\
\text { emergency law in a time of state emergency or } \\
\text { other emergency situation where there is no } \\
\text { legislation. } \\
\text { The President has the power to establish ad- } \\
\text { hoc institutions relevant to the emergency } \\
\text { situation }\end{array}$ & & $\begin{array}{l}\text { President to revoke the emergency law } \\
\text { after the adoption of the legislation on } \\
\text { the emergency issue } \\
\text { The Court has always the power to } \\
\text { review the constitutionality and the } \\
\text { legality of the emergency law and has } \\
\text { the power to come to the conclusion } \\
\text { that the emergency law should be } \\
\text { revoked. }\end{array}$ \\
\hline \multicolumn{2}{|c|}{ Administrative power } & \multirow{2}{*}{\multicolumn{2}{|c|}{$\begin{array}{l}\text { In administrative power: } \\
\text { 1. the establishment of cabinet of ministers } \\
\text { - The President has the power to establish } \\
\text { cabinet of ministers according to the } \\
\text { President's vision, mission, and programs. } \\
\text { The President has the power to establish, set, } \\
\text { reshuffle, and dissolve a ministerial } \\
\text { department. } \\
\text { The President has the power to nominate, } \\
\text { select and appoint ministers } \\
\text { The President shall notify the establishment of } \\
\text { ministerial departments and appointment of } \\
\text { ministers }\end{array}$}} & \multirow{2}{*}{\multicolumn{2}{|c|}{$\begin{array}{l}\text { In administrative power: } \\
\text { 1. The legislature has the power of control } \\
\text { over the budget of the establishment of } \\
\text { a ministerial department and the } \\
\text { appointment of ministers. The state } \\
\text { auditor has the power to audit the } \\
\text { ministerial budget }\end{array}$}} \\
\hline 1. & $\begin{array}{l}\text { The power to } \\
\text { establish the } \\
\text { ministerial } \\
\text { department } \\
\text { and any other } \\
\text { extra } \\
\text { ministerial } \\
\text { department } \\
\text { (independent } \\
\text { department) }\end{array}$ & & & & \\
\hline 2. & $\begin{array}{l}\text { The power to } \\
\text { control over } \\
\text { the cabinet }\end{array}$ & 2. & $\begin{array}{l}\text { The President has the power to directly lead } \\
\text { the cabinet and give direct command to the } \\
\text { ministers }\end{array}$ & 2. & $\begin{array}{l}\text { The legislature can at anytime have } \\
\text { oversight by requesting clarification and } \\
\text { explanation from the minister through } \\
\text { the President }\end{array}$ \\
\hline 3. & $\begin{array}{l}\text { The power to } \\
\text { issue the } \\
\text { executive law }\end{array}$ & 3. & $\begin{array}{l}\text { The President has the power to issue } \\
\text { government regulations in order to regulate }\end{array}$ & 3. & $\begin{array}{l}\text { Supreme court has the power to decide } \\
\text { the legality of the executive law }\end{array}$ \\
\hline 4. & $\begin{array}{l}\text { The power to } \\
\text { establish } \\
\text { executive } \\
\text { commissions, } \\
\text { agencies, other } \\
\text { executive } \\
\text { bodies }\end{array}$ & 4. & $\begin{array}{l}\text { state administration } \\
\text { The President, when it is needed, has the } \\
\text { power to establish executive commissions, } \\
\text { agencies, or other executive bodies. The } \\
\text { President shall notify the Parliament. The } \\
\text { President has also the power to set, reshuffle, } \\
\text { or dismiss the executive commissions, }\end{array}$ & 4. & $\begin{array}{l}\text { The legislature has the oversight power. } \\
\text { the state auditor has the power to audit } \\
\text { the budget }\end{array}$ \\
\hline 5. & $\begin{array}{l}\text { The power to } \\
\text { establish any } \\
\text { executive } \\
\text { auxiliary } \\
\text { bodies or any } \\
\text { institution } \\
\text { supporting } \\
\text { state } \\
\text { administration }\end{array}$ & 5. & $\begin{array}{l}\text { executive agencies, or other executive bodies } \\
\text { In running the state administration, the } \\
\text { President for any reason has the power to } \\
\text { establish executive auxiliary bodies with the } \\
\text { approval from the legislature }\end{array}$ & 5. & $\begin{array}{l}\text { The legislature: Constraint of the budget } \\
\text { agencies establishment, oversight of the } \\
\text { agencies' performance }\end{array}$ \\
\hline 6. & $\begin{array}{l}\text { The power to } \\
\text { supervise the } \\
\text { local } \\
\text { government } \\
\text { and } \\
\text { autonomous } \\
\text { provinces }\end{array}$ & 6. & $\begin{array}{l}\text { The President has the power to supervise the } \\
\text { local government and autonomous province } \\
\text { government. Such power is as a consequence } \\
\text { of the presidential Unitarian model }\end{array}$ & 6. & The legislature: oversight function \\
\hline 7. & 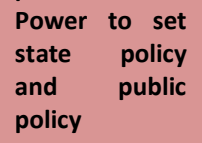 & 7. & $\begin{array}{l}\text { The President has the power to set state policy } \\
\text { and public policy }\end{array}$ & 7. & The legislature: oversight function \\
\hline \multicolumn{2}{|c|}{$\begin{array}{l}\text { The extraordinary power } \\
\text { The power to call } \\
\text { referendum in the } \\
\text { situation needed }\end{array}$} & \multicolumn{2}{|c|}{$\begin{array}{l}\text { According to the Indonesian experience with the province } \\
\text { of Timor-Timur (which is now Timor Leste), the idea of } \\
\text { giving the President the power to call a referendum would } \\
\text { have a constitutional basis; so, any action taken as a result }\end{array}$} & \multicolumn{2}{|c|}{$\begin{array}{l}\text { The power is a dependent power that can only be } \\
\text { exercised with the approval from both chambers in } \\
\text { the MPR }\end{array}$} \\
\hline
\end{tabular}




\begin{tabular}{|c|c|c|c|c|}
\hline & & $\begin{array}{l}\text { of the referendum will be easier to be checked by other } \\
\text { branches } \\
\text { It will be a sharing power between the president and the } \\
\text { legislature. To perform the power, the President should } \\
\text { get approval from the legislature }\end{array}$ & & \\
\hline \multicolumn{2}{|c|}{ The military power } & \multicolumn{3}{|l|}{ For the military power: } \\
\hline & $\begin{array}{l}\text { The } \\
\text { Commander in } \\
\text { chief of army, } \\
\text { navy and air } \\
\text { force }\end{array}$ & $\begin{array}{l}\text { 1. The President is the Commander in chief of } \\
\text { army, navy, and air force. As a result, the } \\
\text { military organization is under the President }\end{array}$ & 1. & $\begin{array}{l}\text { With regard to the Commander chief } \\
\text { power, the DPR has the oversight power } \\
\text { to oversee budget of the military } \\
\text { organization }\end{array}$ \\
\hline & $\begin{array}{l}\text { The power to } \\
\text { maintain } \\
\text { national peace } \\
\text { and security }\end{array}$ & $\begin{array}{l}\text { 2. As the Commander in chief, the President has } \\
\text { the power and duty to maintain national peace } \\
\text { and security }\end{array}$ & 2. & $\begin{array}{l}\text { The DPR has the power to check over the } \\
\text { power of national peace and security by } \\
\text { law. }\end{array}$ \\
\hline \multirow{2}{*}{\multicolumn{2}{|c|}{$\begin{array}{l}\text { 3. The power to } \\
\text { directly } \\
\text { command the } \\
\text { military force }\end{array}$}} & $\begin{array}{l}\text { 3. The President has the power to directly } \\
\text { command the military force. In commanding } \\
\text { the military force, except during a military } \\
\text { operation, the President shall have }\end{array}$ & 3. & \multirow{3}{*}{$\begin{array}{l}\text { Confirmation from the DPR is only } \\
\text { needed when there is no urgent } \\
\text { situation. However, in some situations } \\
\text { such as during a military operation, the } \\
\text { President is permitted to directly } \\
\text { command military forces without } \\
\text { confirmationfrom the DPR } \\
\text { The DPR check over the organization by } \\
\text { the budget }\end{array}$} \\
\hline & & $\begin{array}{l}\text { confirmation from the DPR } \\
\text { 4. The President has the power of full }\end{array}$ & & \\
\hline & $\begin{array}{l}\text { over the } \\
\text { military } \\
\text { organization }\end{array}$ & $\begin{array}{l}\text { intervention over the military organization } \\
\text { including the power to reorganize the military } \\
\text { organization }\end{array}$ & 4. & \\
\hline \multicolumn{2}{|c|}{ Accessories power } & $\begin{array}{l}\text { The accessories power is a consequence of the role of the } \\
\text { President as the head of the state }\end{array}$ & \multirow[b]{2}{*}{1.} & \multirow[b]{2}{*}{$\begin{array}{l}\text { The legislature has the power to be } \\
\text { notified about all the foreign policy that } \\
\text { the president has made }\end{array}$} \\
\hline 1. & $\begin{array}{l}\text { Power to make } \\
\text { sure that the } \\
\text { state's } \\
\text { compliance to } \\
\text { the } \\
\text { International } \\
\text { obligation that } \\
\text { Indonesia has } \\
\text { already a party }\end{array}$ & $\begin{array}{l}\text { 1. The President, as the head of the state, } \\
\text { according to the development of international } \\
\text { criminal law is the subject to the international } \\
\text { criminal court. At this point, the constitution } \\
\text { should provide the anticipation and establish a } \\
\text { mechanism to avoid and facilitate if there is a } \\
\text { case regarding international law. The } \\
\text { Constitution should accommodate such } \\
\text { international developments }\end{array}$ & & \\
\hline 2. & $\begin{array}{l}\text { Power to grant } \\
\text { honorary titles }\end{array}$ & $\begin{array}{l}\text { 2. The power to grant honorary titles is a } \\
\text { consequence of the President being the head of } \\
\text { state. In exercising such power, the President } \\
\text { has to establish a council of honorary awards } \\
\text { to give recommendations and opinions }\end{array}$ & 2. & $\begin{array}{l}\text { The legislature has to be notified and has } \\
\text { the right to clarify, to challenge and to } \\
\text { give opinion to the President }\end{array}$ \\
\hline
\end{tabular}

\section{c. Design constitutional text for future Indonesia executive power}

This section is about the proposal of design for the executive power in Indonesia. With the assumption that the government system is a presidential system, the executive power would be vested in the hands of the President. The powers include law-making power, budgetary and expenditure power, appointment power, foreign affairs power, administrative power, power to invoke self-defense replacing the classic concept of war power, military power, emergency power, pardoning power, accessories and symbolic powers, and extra ordinary powers. The allocation of powers should be based on the principles of proportionality 
Rosa Ristawati: Modelling Executive Powers in the Indonesian Constitution: A comparative Study

and the necessity. In general, proportionality concerns the quantities and substances of the power that relates to the role of the President in a presidential system. This is to avoid any disproportionate allocation of powersthat may cause the domination of power by one of branches. Meanwhile, it is necessary to consider the reasons and priority level of the power which is given to the President. There must be a legitimate and reasonable purpose in giving the power to the President.

To this extent, there are three models of the allocation of executive powers that have been developed in practice and may be adopted in Indonesia.Model 1 is a shared power. The idea is addressed to the power which has widespread impact on the state and public interest; while actually the power is not in the area of the executive. Such power must be exercised jointly by the President and the DPR. In this model, the executive power is not only enjoyed by the President alone but also enjoyed by the DPR. The President equally has the same power and role. A shared power is commonly actualized by joint approval; the President and other branches produce joint approval. The power would not be exercised if one party does not approve. Model 2 is a dependent power. The idea is that the President can exercise executive power only when the DPR gives approval. The model would be addressed for thepower that potentially may be abused by the President. For example in a diplomacy power, when the President has the real power to conduct a special humanitarian mission; the DPR on the other hand, has the power of the purse, and therefore, it has the power to decide whether or not the mission may be called. The power should then be exercised dependent on the approval of the DPR that is expressed in the budget approval. Model 3 is an independent power. ${ }^{894}$ The idea is that the President can exercise executive power independently while on the other hand, other branches may check by giving consideration, opinion, advice, or recommendation. However, the final decision is independently made by the President.

\footnotetext{
${ }^{894}$ The independent power could be addressed to solve the situation that under the Indonesian Constitution (Amended) the President is mostly a weak branch among others. Therefore, to make a balance against other dominant branches and to make sure of the president's survival vis a vis other branches, the independent power is assumed to be a plausible solution to maintain a good balance between the Legislative and the President, between democracy and efficiency and rule of law. This is also considering that the experiences of presidency the under the Amended Constitution as well as in the present situation creates an ineffective president and does too little to spur the Legislature into acttion and does too little to balance the powers of the Legislature.
} 
On the law-making power, the President should be given limited substantial powers in the legislative process. In order to accommodate the spirit of the 1999 amendment which was reducing the president's power, it would be more rational not to give the President equal poweras as the DPR with regard to the approval in a legislative process. However, the President still should be given the power to initiate bills; but the framework would not place the President as a co-legislator who has the power to sit in a joint approval session with the DPR. The articles of the Constitution may be written as follows:

"The DPR holds the Legislative power"

"All the bills are initiated by the DPR or the President"

"The DPR has the power to amend, reject, or approve bills"

"The President or the DPR, before the promulgation, may refer to the Constitutional Court to review its constitutionality.

"The President has the veto power ofa bill"

"The DPR may override the veto power of the President with 2/3 of the votes cast"

"The President signs and promulgates the Law"

In the legislative process, the President should be still given significant power to initiate bills. Furthermore, the President should be given veto power. To counter-balance the President's veto, the DPR could override the veto. However, the President may veto bills. On the other hand, the role of the Court must be strengthened as a counter-weight. The most important thing is that the process should reflect a democratic mechanism on the basis of equality among branches. It is rational not to give the President an equal power in joint approval with the DPR because the experiences of joint approval commonly raise conflicts between the President and legislature. It mostly will generate an ineffectivegovernment. On the other hand, it would take longer for the legislative process because of a legislative deadlock.

Other law-making power should be vested to the President. To this extent, the President would have the authority to make rules and regulations. Those powers are including the power to make sub-ordinate Legislation, the power to make executive law, the power to make Presidential law, and the power to make emergency law. The power to make sub-ordinate Legislation is related to the President's duties to implement the Law. At this point, the sub- 
Rosa Ristawati: Modelling Executive Powers in the Indonesian Constitution: A comparative Study

ordinate legislation should be based on the Laws. The sub-ordinate law is mainly about the President's direction and guidance to implement Legislation.

On the other hand, the presidential law is the law made by the President in order to overcome a legal vacuum when there is no Legislation concerning particular issues and it is immediately required by the public. The Presidential law is a temporary and ad-hoc law, has time limits and is only enacted within 1 year. If it is needed, after the time limit of 1 year, the President has to submit the presidential Law to be jointly discussed as a bill and approved by the DPR to become Law. The presidential law is relatively different from the emergency law. It is not as unchecked power since the Constitutional Court has the power to review the constitutionality of the law during the enactment. Alternatively, to check and constrain the presidential law and in order to compete and overcome the legal vacuum, the DPR may be given the power to make ad-hoc legislation.

The design for the law-making power besides the power to initiate bills would be as follows:

"The President has the power to makeexecutive laws and to set rules and regulations in the area of the administration"

"The President has the power to execute laws and to make sub-ordinate legislation. In order to make subordinate Legislation, the President should get consideration from the DPR"

On the budgetary power, the design for the constitutional provision would be as follows:

The President has the exclusive power to submit the budget bills to the DPR for its consideration and approval After the budget bill has been approved by the DPR, the President has the spending power

The DPR has the power to oversee the spending of the state budget and ensure the transparency and accountability of the expenditure

With regard to the war power, the term war is out of date and does not specifically refer to particular cases since nowdays, war is broadly defined, not only covering hostilities between states but also encompassing any kinds of threats to the state. The term "use of force"may be appropriate in the context of global development and more up to date compared to the term "war".The term "use of force" is based on Article 2(4) UN Charter which requires states to refrain from the use of force against the territorial integrity or political independence of 
another state. ${ }^{895}$ Furthermore, Article 51 UN Charter gives states the right to individual selfdefence and collective self defence. This allows states to use force against armed attack and imminent threat. Accordingly, there are some concepts that are relevant to the concept of war, namely: the use of force, the armed attack, individual self defence, collective self defence, preemptive self defence and imminent threat. The German Constitution in Article 115a has used the term "state defence" instead of war. ${ }^{896}$ Whereas, the South African Constitution uses the words "state of national defence" and attaches the power to declare a state of national defence to the President. ${ }^{897}$ To this extent, it would be rational to refer to the German concept of state defence and the South African concept that allows the President to have the power to declare a state of national defence.

The power to invoke self defence and call the use of military forces clause would be written as follows:

The President has the power to invoke the state of self defence with approval from the DPR The President has the power to invoke the use of force and declare a state of national defence with the approval from the DPR

The power to invoke self defence as well as the power of use of force is a shared power between the President and the DPR. The purpose to put such power in the hands of the President and the DPR is to strengthen and make accountable the President's decision. The DPR's approval reflects support from the people. The use of force would be the use of military force either at home or abroad. It also includes any purposes for humanitarian intervention and for peace-keeping operations.

In practice, there are different issues faced by the Indonesian President and the US President concerning the war power. The US frequently deals with the use of force abroad against international armed conflict. In practice, how Obama interpreted the US Constitution regarding to war power in his presidential campaign statement of 2007 was better than what the facts had shown:

\footnotetext{
${ }^{895}$ Article 2(4) UN Charter.

${ }^{896}$ Article 115a (1) German Constitution and Article 115a (5) German Constitution.

${ }^{897}$ Article 203 of the South African Constitution on State of national defence.
} 


\begin{abstract}
"As a presidential candidate in 2007, Obama agreed: "The President does not have power under the Constitution to unilaterally authorize a military attack in a situation that does not involve stopping an actual or imminent threat to the nation." Fast forward four years. In announcing the intervention in Libya, Mr. Obama told Congress that he was acting "pursuant to my constitutional authority to conduct U.S. foreign relations and as commander in chief and chief executive." 898
\end{abstract}

The US practice may not be the case for Indonesia. Whereas the US is familiar with the use of military forces abroad for international armed conflicts, Indonesia has never been involved in such acts. However, internal armed conflict and other kinds of domestic threat may be a potential threat for Indonesia. Nevertheless, in experience, Indonesia has dealt with some territorial conflicts that sometimes trigger the use of military force. The fact that Indonesia has many islands makes Indonesia familiar with border conflicts and other cases of territorial conflict with Malaysia, the Philippines, Singapore, the New Guinea, East Timor, Australia and other countries. ${ }^{899}$ Such a situation may be a threat to Indonesian peace and security. When such a situation has to be dealt with, the President is constitutionally responsible to take any action including the mobilization and the use of military action abroad in order to preserve the territories.

In the other area, the power as the Commander in chief is strongly associated with the use of force, military mobility, and the highest military decision making. As the Commander in chief it should be clear that the President has the highest power in military administration and military organization. Furthermore, the President would have the power to command the military action in the battle field and have the power to direct any military operation authorized by the parliament. To formulate a Commander in Chief clause, the South African Constitution may provide a good model of a constitutional basis for the military power of the President. Article 202 of the South African Constitution does not just stipulate that the President is the

\footnotetext{
${ }^{898}$ Foxnews, Constitution Allows Obama to strike Syria Without Congressional approval, accessed online at: http://www.foxnews.com/opinion/2013/08/30/constitution-allows-obama-to-strike-syria-without-congressionalapproval/

${ }^{899}$ Kompas, Indonesia vs Malayasia Fenomena Perbatasan Negara Berdaulat, accessed online at: http://hankam.kompasiana.com/2011/04/13/indonesia-vs-malaysia-fenomena-perbatasan-negara-berdaulat355153.html: The territorial conflicts between Indonesia and other countries may happen because of special interest (claiming the natural resources or territorial expansion), and people illegally intrudingacross the border. The conflicts sometimes also provoke military action in frontier areas.
} 
Rosa Ristawati: Modelling Executive Powers in the Indonesian Constitution: A comparative Study

Commander in Chief of the defence forces but also clarifies the consequences of the constitutionality of the President's office as the Commander in Chief. ${ }^{900}$ The Article clarifies that as the Commander in Chief, the President must appoint the Military Commander of the defence force. Moreover, the Constitution also clarifies that the President has the power to authorize the use of defence force in three circumstances of cooperation with the policeservices, in defence of the Republic, or in fulfillment of an international obligation. ${ }^{901}$

Furthermore, the power to decide the mobilization of military force abroad for the purpose of International intervention should be given to the President. The concept of armed forces intervention abroadcould be taken from the French Constitution Article $35 .{ }^{902}$ In such power, the President would have the power to mobilize the armed forces for a particular purpose of international intervention. Such power would be an independent power but may be confirmed by the DPR.

The proposal for the Commander in Chief would be as follows:

The President of the state shall be the Commander in Chief of the military armed forces including the army, navy, and the air force.

As the commander in chief, the President has the power to maintain national peace and security, maintain national independence, territorial integrity, and the proper functioning of the public authorities and the continuity of the State

The President has the power to command and mobilize the armed forces

For the purposes of an international intervention, the President has the power to mobilize the armed forces, by and with the approval of the DPR

As terrorism and other internal disturbances are potential threats to Indonesia, it would be important to consider the intelligence clause of the South African Constitution to be adopted by the Indonesian Constitution. ${ }^{903}$ The design for the intelligence power for the President would be as follows:

The President has the power to direct, and control any intelligence services within the legal framework established by Law;

The President has the power to appoint the Chief of the secret intelligence service and other senior members

\footnotetext{
${ }^{900}$ Article 202 Command of defence force of the South African Constitution.

${ }^{901}$ Article 201 of the South African Constitution.

${ }^{902}$ Article35 of the French Constitution.

${ }^{903}$ Article 209 of the South African Constitution on the Establishment and control of intelligence services.
} 
Rosa Ristawati: Modelling Executive Powers in the Indonesian Constitution: A comparative Study

With regard to the emergency power, the most important thing is setting a firm definition that would include the scope ofthe emergency situation. In general, state emergency refers to several situations where there is an armed attack such as invasion, aggression, rebellion, or non-armed attack such as terrorism, natural disaster, economic and public order chaos that results in real or imminent threat to the national peace and security. At this point, any urgent measures and actions are needed to overcome the situation. Furthermore, the important thing of the emergency power is about measuring the threat to the national peace and security. According to the international law development, the UN Security Council has broadly defined the term threat to international peace and security. Similar to the common practices, the threat to international peace and security is not only about a military attack but also including other threats such as terrorism, economic and political deterioration, natural disaster, disease, poverty, human rights abuses, etc.

With regard to the emergency powers of the President, it would be rational to refer to the term of "threat to international peace and security" that the UN Security Council has defined. Similar to the threats against International peace and security, the threats against national peace and security include armed attacks and non-armed attacks that potentially put the state in chaotic situations, total breakdown of the law and public order, or political and economic deterioration. In a modern and democratic era, the emergency power is given in a limited term and exercised with control from other institutions on the basis of the rule of law and human rights values. The emergency power of the President would be for a limited period and could not be prolonged indefinitely for the life of the regime.

When the attack or other threat is real, and when there is a conflict that should be ended, the President would be given a unilateral emergency power and may use his discretion to override the administrative and legal framework. In some of tangible threats that are relevant to the state and emergency situation, the need for formal approval from the parliament wouldinhibit the urgent action. The President at this moment should benefit from his position as the Commander in chief and act as the highest authorization to protect the state and the people. However, if the attack is imminent and not a potential threat that immediately 
needs a response, the approval from the legislature must be required. This is intended to obtain legitimate action approved by the legislature as representative of the people.

With regard to the articulation of the emergency power in the Constitution, it is important to refer to the power of the President to take any measures according to Article 16 of the French Constitution as part of the emergency power. ${ }^{904}$ To this extent, the President has the emergency power to take any measures in an emergency situation that intimidates state independence, the integrity of the state territory, or the fulfillment of international commitments under serious and immediate threat, or the situation where the proper functions of the constitutional public authorities are interrupted. The power and any measures taken by the President should be the subject of consultion with the DPR, the DPD, the Supreme Court, the Constitutional Court and other institutions.

The other significant emergency power that may be given to the President is the power to make emergency law. The Law mostly relates to martial law and the power is given as a consequence of the President being the Commander in chief.The emergency law is commonly issued when the state is under the real armed attack. Similar to the presidential law, the emergency law is not power without check. The Court has the power to review the constitutionality of the law.

The design for the emergency power constitutional provision would be as follows:

The President has the emergency power.

The emergency power is exercised in circumstances of any attacks or disasters that will undermine the state, and political and economic stability.

The emergency power of the President shall not exceed6 months. This period may only be extended with the DPR's approval.

In the context of an emergency situation, the President must take all measures necessary. The emergency measures taken by the President are put before the DPR for approval

The Constitutional Court has the power to review the constitutionality of any emergency meaures taken by the President

With regard to the responsibility for foreign affairs, the first point should be clarifying the scopes of foreign affairs. It is also to clarify in which area the President is needsto be given the substantive power and in what area the President is given the formal power which should

\footnotetext{
${ }^{904}$ Article 16 the French Constitution.
} 
be shared by other institutions. To clarify the foreign affairs (especially that has significant and relevant impact to the people and state as a whole), the scope of power should also be clearly mentioned in the Constitution. This is because such power may be potentially abused while the negative impact and disadvantage can endanger people as awhole and the existence of the state. It is also important to classify certain powers, such as the power to conclude an important and substantive treaty, into powers that should be shared along with the DPR. In general, the foreign affairs powers should include the treaty power, the diplomatic power, and the foreign policy making power.

On the treaty power, it is important to distinguish between treaty and international agreements according to their impact and scope. For this purpose, the concept of the treaties classification according to Article 53 of the French Constitution provides an example of clarity of the classification. According to the Article, there are 3 sorts of treaties: peace treaties, trade agreements, treaties or agreements relating to international organizations. ${ }^{905}$ Moreover, those three sorts of treaty should be ratified or approved by an Act of Parliament if: they commit the finances of the State, if they modify provisions which are the preserve of statute law, if they relate to the status of persons, and if they involve the ceding, and exchanging or acquiring of territory.

In the case of Indonesia, the design would be as follows:

The President makes and unmakes treaties. To make peace treaties, trade agreements, treaties or agreements relating to international organizations, the President needs the approval of the DPR determined by Laws.

The Constitutional Court may review the constitutionality of any treaties or international agreements challenged by either the President or the DPR before becoming a party (to the treaty or the international agreements

To have domestic effect, all treaties or international agreementsshall be transformed into Law

In terms of the diplomacy power, the area of diplomacy is mostly the domain of the President. It is because that the President is the head of the state and head of government. The diplomacy is part of running the state administration externally. To this extent, the power

\footnotetext{
${ }^{905}$ Article 53 the French Constitution.
} 
Rosa Ristawati: Modelling Executive Powers in the Indonesian Constitution: A comparative Study

should be independently exercised by the President without intervention from other branches. The clause would be as follows:

The President has the power to give diplomatic accreditation by issuing a letter of credence. The President has the power to verifydiplomatic letters from other states

In some other certain diplomatic affairs related to foreign policy, the President must also be given a more substantive and independent power to determine, decide and deliver his view. This is because foreign policy making is part of the area of the executive. On 10 September 2013, President SBY delivered a letter to the UN Security Council about Syria. In his letter, the President addressed his disagreement with the US President's plan to launch a military force against Syria. In the G20 Meeting, the President delivered his personal view about the possibility not to use military force, but instead a peaceful operation under the UN and engage the political process with the people of Syria. The President SBY also offered Indonesian participation in the peacekeeping operation for Syria. At this point, the President had his personal point of view in which he does not have to consult the parliament. The clause would be as follows:

The President is incharge offoreign affairs. The DPR must be consulted in a commencement, termination of the diplomatic relation and major policy issues, to be detemined by law.

The President has the power to decide ona participation in any international activities, such as the peacekeeping operations after due consultation with the DPR

The President ensures state compliance with International law including treaties and other international law instruments.

On the pardoning power, the power should be given as an independent power where the President has the more substantial power to decide the final word. However, the power will always be exercised by and with advice. In some arguments, such power is classified as a judicial power of the President. However, for some reasons it may be inappropriate to say that the pardoning power of the president is a judicial power of the President. It is because judicial affairs are not under the area of executive affairs. The executive affairs are only for implementing the laws made by the Legislature but also including the implementation of the Court's decision. The pardoning power of the President is always exercised after the judicial 
process is finished. It is usually exercised after the court decision has been finalised. After the final court decision, the process will turn to the executive area as part of the law enforcement in order to implement the court decision. At this point, communication between the President and the Court would be needed. This is to respect the Court's decision and the judicial process that has already been finished. By involving the Court, the pardoning power of the President would not undermine the judicial process.

In general, it is argued that even though the pardoning power is a prerogative of the President, the power should be exercised after advice. For this matter, with the assumption that the President is the head of the state, there should be a commission on the Prerogative of pardoning established by the President. ${ }^{906}$ The commission's main duty is to give recommendations to the President. The Constitution also has to provide the limitation of the pardoning power of the President. In this point, the US Constitution may give a good reference as it gives the President the pardoning power except in cases of impeachment. ${ }^{907}$ In addition, the Philippines Constitution may give a good reference for the articulation of amnesty. ${ }^{908}$ Referring to the Philippines Constitution where the President has the concurrence votesof the Congress, the Indonesian Constitution should articulate that the amnesty granted by the Indonesian President should be with the advice of the DPR. It is because the President should still be given discretion, though it is limited, to determine the final decision on amnesty.

The design for the pardoning power clause would be as follows:

The President may grant pardon, except, in cases of impeachment, only upon advicefrom the commission of pardoning.

The President may grant amnesty but only upon the advice of the DPR

The following is the appointment and the state administration power. The appointment power is the most potential for the abuse of power. For the appointment power, the provision

\footnotetext{
${ }^{906}$ The composition of the Commission may refer to the composition of Switzerland's commission on the Prerogative of pardoning, consisting of the President's advisory council, the state prosecutor, the minister of justice and human rights, and from the Supreme Court.

${ }^{907}$ Article Il section 2 of the US Constitution.

${ }^{908}$ Article VII Section 19 the Philippines Constitution.
} 
Rosa Ristawati: Modelling Executive Powers in the Indonesian Constitution: A comparative Study

should articulate the categories of the appointment, namely: the judicial appointment, state officer appointment (members of state institutions mentioned in the Constitution), public officer appointment (including the members of the independent agencies, state prosecutor, Chief of police, etc), executive officers appointment (ministers and other executiveofficers for the presidential office and the state ambassador), and military appointments (including high ranked military officers of army, navy, and air force). The appointment power may include the power to nominate, select and formally appoint. For the appointment power, the Philippines Constitution may provide a good reference in particular on the existence of a commission of appointment. As for Indonesia, there shoud be an independent advisory commission of appointment consisting of the DPR, DPD, Supreme Court, the Judicial Commission and other state institutions to advise the President.

The President has the appointment powerto appoint public officers determined by Laws, upon advice from an independent advisory commissionof appointment and upon the opinion of the DPR

The appointment of the senior member of the state officers and the Judges are made by a joint approval from the DPR, the President, and other state institutions. On the appointment of the Constitutional Court Judges, the joint approval is from the President, the DPR, and the Supreme Court; and on the appointment of the Supreme Court judges, the joint approval is from the DPR, the President and the Judicial Commision.

In running the state administration, the President nominates, selects, and appoints ministers. The Ministers are under the executive department headed by the President.

The President has the power to determine and establish ministerial departments and extra ministerial departmenst and has the power to coordinate and direct control over ministerial departments and other extra ministerial departments.

The President appoints state ambassadors and other executive officers within the executive areas determined by law

The President has the power to establish presidential office, executive commission, agency, or other executive auxiliary bodies to assist in particular area of the executive determined by laws

The President has the power to supervise and coordinate local government and autonomous provincial government as a consequence of the unitary model of the state.

The President makes and implements national policy and public policy for the purpose of state administration

The President has the power to take any measure in accordance with anti-corruption measures

The appointment powers have great potential for abuse of power. Therefore, it should be given in different ways. In addition to anticipating the abuse of power, however, the design 
should still give room for the President to independently perform certain appointment powers. On the judicial appointment, the President would appropriately be given the power to formally appoint while the real appointment power would be attached to a joint approval. For the state ambassadors appointment, public officer appointment, military appointment, the model would be that the President has to act upon the advice of an independent advisory commission of appointment and the opinion of the DPR. For executive appointments that mostly have an executive function including ministers, chiefs of executive non-ministerial department, other chiefs of executive agencies under the executive branch, and the executive officers within the presidential office, the President should be given independent power with his own discretion but in order to maintain a proportional power,the DPR should be notified about the appointments and at any time should have the right to give its opinion to the President.

With respect to the administrative power, since it is the main power for the President, Article 85 of the South African Constitution may provide a good example to explicitly determine the administrative powers of the President. ${ }^{909}$ It clearly shows the main purpose of the executive function as the executor of national legislation, developer and executor of national policy, coordinator of the functions of state departments and administrations and the branch which performs any other executive functions provided for in the Constitution. Referring to the South Africa Constitution, the articulation of the provision should clearly specify the administrative power of the President. The design of the administrative power would cover the power to:

1. exercise executive authority

2. implement national legislation

3. establish ministerial departments and any other extra ministerial departments (independent departments) ;

4. coordinate and controlover the cabinet;

5. issue government regulations;

6. establish executive commissions, agencies, other executive bodies;

7. establish other executive departments (such as executive auxiliary bodies or any institutions supporting state administration);

8. supervise the local government and autonomous provinces;

9. set and implement national policy and public policy

${ }^{909}$ Article 85 of the South African Constitution. 
10. set executive law

The President has the power to establish a cabinet of ministers according to the vision, mission, and program of the President. He has also the power to reshuffle, or dissolve a ministerial department, the power to appoint, change, and dismiss the ministers. The administrative power of the President would be mostly an independent power where the President is the main decision maker and given the opportunity to independently decide but the President still has to notify the DPR.

The Constitution has to make clear that ministers are the assistants of the President. It should provide the mechanism for the ministers to support the President's constitutional duties, state administration and daily governmental activities. The President should appoint ministers based on their expertise and professionalism. Ministerial appointments on the basis on professionalism and expertise would help to avoid abuse of ministerial authority and anticipate ministers acting ultra vires; in fact in ministerial policy making, conflictswith the group interests of political parties were always involved and the policies in thesematters are usually just a matter of bargaining. ${ }^{910}$ To this extent, it will be important to clarify that the ministers are under the executive department which is headed by the President as the head of government. The term executive department may refer to the US Constitution.

Moreover, the administrative powers of the President should be mostly given as an independent power. The Parliament may only use its power to invoke the oversight function and the Court may review the constitutionality of any of the government's legal products. The administrative power would be more about executive affairs and they fall under the presidentas the head of government. The check over such power would be appropriately conducted by observing the running of the state administration. This is merely to maintain the independency of state administration. However, in certain powers such as the power to establish an executive commission, agency, or other executive auxiliary bodies, the power would also be given as an independent power but must be performed following consideration from the DPR. The consideration should be only on the grounds of the budget instead of

\footnotetext{
${ }^{910}$ Herbert Feith, Op. Cit., p. 172.
} 
political grounds. In addition, it would also be important to give and specify in details about the power of the President as the unitary executive branch to supervise and intervene in certain purposes and particular issues of the local government. To this extent, the South African Constitution may give a good example to consider providing a constitutional basis for the President's powers that is related to local government.According to Article 100 of the South African Constitution, the President as the head of the national executive has the power to intervene and take some measures when a local government does not fulfill an executive obligation in terms of the Constitution or legislation. ${ }^{911}$ Moreover, it is also important to refer to the Philippines Constitution Article $\mathrm{X}$ section 4 for the real power of the President to supervise the local governments.

In addition, there should be an additional power namely the extraordinary power for the President. The power may be needed for extraordinary circumstances when a fundamental decision is required or when the state's sovereignty is under threat, such as a constitutional issue concerning self-determination. This is according to the Indonesian experience when the referendum to give the right of self-determination for the province of Timor-Timor (which is now Timor Leste) in 1999 had no constitutional basis. The referendum that was conducted during the Habibie administration was said to be unconstitutional since it had no constitutional basis; on the other hand, the referendum had brought a major substantial decision for the Timor Leste secession. In the future, to deal with similar issues, the Constitution needs to provide an extraordinary power for the President.

The power of referendum would be given for a very few and special circumstances, under high pressure, and in a situation when there is an issue concerning state sovereignty and territory. The parliament is the key point for such power. An extraordinary power should be a dependent power. It depends only on the approval from the both chambers in the MPR (the DPR and the DPD) and also the Constitutional Court.

The clause of the referendum power would be as follows:

\footnotetext{
${ }^{911}$ Article 100 of the South African Constitution.
} 
Rosa Ristawati: Modelling Executive Powers in the Indonesian Constitution: A comparative Study

The President by and with the consent from the MPR, has the power to call a referendum in a situation when the state sovereignty requires it or in urgent situations when there is a fundamental and essential state question. The Constitutional Court may give a decision on the constitutionality of a referendum to be held upon request by the MPR, the President, the DPR, or the DPD. 


\section{CHAPTER 6: CONCLUSION AND GENERAL REMARKS}

The Fifth Amendment of the Indonesian Constitution must be put on the agenda. It must be an agenda to reduce the ambiguity and obscurity in most of the Articles in the Amended Constitution. To be consistent with the democratic sphere, the process of amendment must accommodate public participation. It does not only reflect the proper theory, but also reconciles local and global international developments. This is intended to anticipate global challenges faced by Indonesia.

Since experiment with other features of government system would be more precarious, the presidential system still needs to be preserved in Indonesia. It is not only because its original reason, which relates to the Indonesian founding father's intention of the first Republic of Indonesia, but also due to the idea of preserving the Indonesian presidency as the original Indonesian government. Although the system has often been practised along with some irregularities, the presidential system has for a longperiodsurvived inIndonesia. Changing to another system would be ineffective and inefficient for Indonesia. It would take another transitional period. Experimenting with a new regime will not only push Indonesia to adjust with the new institutional framework, but also to deal with other legal and political complexities that could be even more problematic. Another factor that makes the presidential system worth preserving is because Indonesia has to deal with the complexity of political institutions. The presidential system would help, at least, to reduce the complexity by providing a simple institution with its feature of a single executive. Furthermore, according to theory, the system provides checks and balances and adheres to the doctrine of the separation of powers. By the separation of powers and checks and balances, it is expected that conflicts of power between branches as well as abuse of powers can be minimized.

However, having regard to all the considerations to keep the presidential system, it does not mean that Indonesia has been satisfied with the existing presidential system. The process of finding the best model of a presidential system in Indonesia should continue. Indonesia must decide and clarify in what way the presidential system would be adapted, what presidential model would be chosen (whether a system that gives limited executive powers to the 
Rosa Ristawati: Modelling Executive Powers in the Indonesian Constitution: A comparative Study

president, a system that gives wide and excessive substance of executive powers to the president, or a system that gives proportional executive power to the president).

There are no perfect or best practice government systems in the world; however, it would be good to have the framework for the executive power which is enriched with the adoption and combination of some good elements that have been well practised by other states. With all challenges and problems faced, the original US presidential system model which allocates a proportional power to the Presidentis the main model for a presidential system; a system which empowers the President with substantive powers without being over protective to the President.It is a system that views the executive as not only the executive, but also as the sole branch that has roles as the head of government and head of state and as the organ that can immediately react to any kinds of challenges and can deal with modern international developments. On the other hand, some states such as France, Germany, Poland, and other states which have adopted other frameworks for the executive powers should also be considered as giving a good model for the executive power.

In general, the Indonesian president should be still given at least some essential powers as follows:

1. law-making powers, including the power to initiate Laws together with the DPR, and other kinds of rules and regulations;

2. the budgetary and spending power, including the budget proposal and control over budget expenditure;

3. the emergency power, including the power to determine and declare state emergency, issue emergency law, and take any measure to overcome and restore the situation;

4. the self-defense power, including the power to invoke the use of military force;

5. the military power including the power to lead the armed forces organization, the power to ensure the national security and state sovereignty, the power to command and mobilize military forces, and the power to take any decision to participate in an international intervention or military operation; 
6. the foreign affairs power including the treaty power, the diplomatic power, and other foreign policy powers including the power to ensure state compliance with International obligations;

7. the pardoning power;

8. the appointment power, consisting of the appointment of state officers including the judicial appointment; the public officers including the military appointment, the chief of police appointment, the state prosecutor, etc; the executive officers including the ministers, state ambassadors, and other executive officers;

9. the administrative power, including the power that is relevant to the state administration and local government administration, and the additional symbolic power to take any measure in accordance with anti-corruption measures; and

10. the power to call a referendum that may be applied in an extra-ordinary situation when a fundamental issue arises.

The exercise of executive power doesnot only depend on the Constitution and Laws but also on other factors such as the presidential election system, political bargaining, legislature's support; some factors like the presidential nomination and election process may have direct or indirect influences. This work does not recommend how the election system should be and what is the best presidential election system which should be adopted for the Indonesian presidential system. That is another area of future research.However, to be consistent with a presidential model, it is necessary to preserve a direct presidential election in Indonesia. It is also important to encourage a strong figure whom represents an entire nation rather than party interest. In fact, the party coalition in the parliament and the parliamentary majority vote is also significant to the executive power and its exercise. The more support the President gain from the legislature, the more legitimate the executive power exercised by the President.

In order to promote executive accountability in Indonesia, it is important to formulate a provision about executive immunity and privilege in the Constitution. ${ }^{912}$ This is not only for a

\footnotetext{
${ }^{912}$ The executive immunity is part of guaranteeing the balancing power among the three branches of government. By explicitly adopting executive immunity in the Constitution, it will give constitutional certainty to the problems
} 
clarification of in what way and what limits the immunity and privilege should be given to the President, but also to maintain the accountability of the executive power performance. At this point, a qualified immunity may be plausibly adopted by the Indonesian Constitution. A qualified immunity should be given in order to give the President limited immunity in certain official issues. It has to be given by clearly expressing an immunity clause in the Constitution. This is in order to prevent abuse of power by the President in the area of his private capacity by still legally shielding the President on the area of official capacity.

As the present Indonesian Constitution gives limited portions of the executive powers to the President and this removal of some substantial executive power from the President will provide over-checks and over- control for the exercise of power. The situation will treat the President as an underdog vis a vis the Legislature. In fact, it contributes to the disadvantage of the Indonesian constitutional system as a whole, provoking unsolved institutional conflicts, and preventingthe President from quickly dealing with imminent challenges and problems. Moreover, the unsolved conflicts between the Legislative and the President have put more tension in their relationship. The Legislatureand the President are more often fighting for fighting for their institutional powers, for example on the appointment power,currently the appointment power of the President is not real but only just a formal power. The Legislative mostly dominates the appointment power; they intervene too often for political reasons. This, in fact, frequently obstructs the President's actions. The Legislative actually already has enough tools to constrain the presidential power in this area. They can use the scrutiny and budgetary power to counter-balance the Presidential powers. Moreover, they can also invoke any kind of constitutional mechanism such as the right of question, the right of interpellation or right of investigation to counter-balance the appointment power of the President. Too many Legislature interventions in the appointment process, about what actually the process should

which arise on the special issue of the institutional conflict or power conflict. An explicit executive immunity clause would also help to make effective the roles of the President in office, which would benefit fromprotection for any controversial action that must be taken during the office. However, the immunity proposed in this thesis would not an absolute immunity, but a limited immunity which is commonly defined as a qualified immunity. 
be on the area of the President, will bepresenting more political interest rather than useful debate.

The Constitution must enable the President to exercise the executive power as well as enhancing the executive accountability in order to tackle emergency situations and take any action when a quick response is needed. Moreover, the Constitution should clarify which power should be shared, which power needs to rely on another branches' approval, and which power may be independently exercised by the executive. To be more adaptive to global developments, the President as the executive branch must be able to ensure state compliance with International obligations and enable the President to take any measures to react against any International challenges.

The Constitution should clarify whether the executive power is a shared power which can only be exercised jointly with other branches, a dependence power which may only be exercised after the approval or consent by other branches, or a virtually substantivepower of the President which can be independently exercised by the President. At this point, the Legislature and the Court play the role to counter-balance the executive branch. On the other hand, it is important to enhance the Court's independency and roles.

With regards to the Legislative power, the power should remain in the handsof the Legislative branch as a whole. It is not only to avoid excessive overlap of the presidential power, with the theory that the Legislature is a branch which holds the power to make law, but also to prevent any inefficient deadlocks and conflict between the legislature and the executive. In Indonesia, while preserving the legislative power in the Legislature, the President should still be involved in the legislative process. However, the President should not be the co-legislator who equally has the same power as the Legislature but the partner-observer in the legislative process. The President may initiate the bill, jointly discuss but not jointly approve the bill. In the joint discussion, the President would better to have the right of executive preview over the legislation by submitting the bill to the constitutional court in order to test the constitutionality of the bill. Sucha mechanism can be found in the Polish Constitution of Article 122 stating that the President may refer to the Constitutional Court for the constitutionality of the bills. 
Rosa Ristawati: Modelling Executive Powers in the Indonesian Constitution: A comparative Study

However, the process from the executive preview to the judicial preview of the legislation should be conducted within a limited time and should not delay the legislation process. It should be limited within 14 days, after which the Legislative may still go to the next stage of approval.

Furthermore, the President should be given the power to make rules and regulations. In general, it would be plausible to look at the Polish Constitution as it provides a good model for the law-making power of the President. It clarifies that the President has the power to make regulations, executive orders, the power to issue decisions within the scope of his authority, and has the power according to Article 144 to issue official acts in particular formal matters.

On the appointment power, it is important to make a clear distinction of appointment, particularly the state officer appointment (members of the state institutions established by the Constitution) including judicial appointment, public officers appointment including military appointments, the chief of police appointment, the state prosecutor, etc; and the executive appointment including the ministers, state ambassador, and other executive officers in the area of the executive. On the state officer appointment (the appointment of the members of the state institutions), the President should be merely acting as a branch running checks and balances vis a vis other branches. In such powers, the President should share the power with the Legislature; he has the right to nominate but the appointment should be jointly made by the DPR and other state institutions. On the judicial appointment, the President may have the formal power to formalize the appointment but the real judicial appointment would be with the joint approval of the DPR, the President, and other state institutions. ${ }^{913}$ On the executive officer appointment in particularly the cabinet appointment, the President should be given independent powers to establish ministries, appoint, reshuffle, and dismiss the ministers. Moreover, for the other executive officers appointment, such as the appointment of the state

\footnotetext{
${ }^{913}$ In some cases of the appointment of the Constitutional Court's Judges, the President SBY had unilaterally appointed a Constitutional Court Judge without considering the transparency principle. The case on the appointment of Judge Patrialis Akbar had raised a question before the Administrative Court (PTUN); however, the Court came to its decision to revoke the Presidential Decision 87/2013 on the appointment of Judge Patrialis Akbar on 23 December 2013 (accessed on: http://www.merdeka.com/peristiwa/adnan-buyung-gembira-atasputusan-patrialis-sebut-sby-otoriter.html, 24/12/2013).
} 
Rosa Ristawati: Modelling Executive Powers in the Indonesian Constitution: A comparative Study

ambassador, the member of executive agency or other executive officers within the presidential office, the President should be given more actual and substantive power instead of only formal appointment power. For this matter, the Philippines Constitution may provide a fair enough power in its Constitution. There should be a Committee of appointment (CA) that would formally work along with the president in the selection and nomination process of the executive officers, but the President would be the final decision maker. Therefore, the appointment power in particular areas of the executive would remain in the hands of the President as the executive. The legislature could oversee the performance and daily work of the executive officer and would have the power to criticise, give opinion, or even dismissal advice.

As the nature of the executive is for running the state administration, the President should be seen as an independent branch in running the daily state administration. It would be necessary to clarify the ministerial departments as the executive department in the Constitution to strongly confirm that the ministers are under the President as the head of government. The use of the term "the executive department" would be like in the US Constitution (Section 2 of Article II). As a unitary state, the President should have the power to supervise, develop, and control the local government including autonomous government in Indonesia. The President should have the power to coordinate all the local government affairs including the decision for expanding or merging the local government territories. At this point, the Philippines may provide an appropriate model for consideration. Article $\mathrm{X}$ section 4 of the Philippines Constitution firmly states that the President has the power to exercise general supervision over local governments. The need to have the supervision power over the local government written in the Constitution is not only for confirming that Indonesia is a unitary state, but also to provide a constitutional basis for the President to react immediately whenever it is needed. The power would enable the President to manage his daily administration, direct and control the institution in his branch while the parliament is doing its function, scrutiny and oversight of the administration. Additionally, it is also important to expressly determine the President's power to intervene in the local government on the President's administrative power on the grounds that he is the head of the national executive. 
The foreign affairs power should be mainly vested in the hands of the President. However, the exercise of such power would be exercised in consultation by and with the DPR. On the treaty making power, the President should have the main power to make a treaty by and with the advice from the DPR. The DPR may challenge the constitutionality of the draft of the treaty by submitting the draft of the treaty to the constitutional court. As a result, the President may only ratify the treaty after the Constitutional Court has confirmed that the treaty is compatible with the Constitution or the Constitution has been reconciled with the subject of the treaty. At this point, the mechanism of treaty power in the Polish Constitution is a good example to consider. According to Article 133 section (2) of the Polish Constitution, the President may refer to the Constitutional Court for the conformity of the treaty to the Constitution. ${ }^{914}$ For the treaty classification, the French Constitution may help. Article 53 French Constitution expressly provides the classification of treaty and determines which treaty should be ratified or approved by the Law. ${ }^{915}$ On the other foreign affairs power or the diplomacy power, again, Article 133 section (1) of the Polish Constitution may be appropriate to be adopted. It clearly defines the diplomatic power of the President. ${ }^{916}$

In a global development of the international law, it would be important to give the power to take any action in order to ensure state compliance with the international obligation and the power to make sure that the implementation of international law depends on the President. The reason is not only because the President as the executive is the only branchwhich could take any direct response but also because it is commonly recommended by International law that the President is the representative of the state in the international community. Moreover, in international law perspective, the President as the executive has to be legally responsible before the International adjudication to represent his state. To this extent, the President should be given the power to take any measure in order to ensure state compliance with the International obligation.

\footnotetext{
${ }^{914}$ Article 133 Section 2 Polish Constitution.

${ }^{915}$ Article 53 French Constitution.

${ }^{916}$ Article 133 Section 1 the Polish Constitution.
} 
Rosa Ristawati: Modelling Executive Powers in the Indonesian Constitution: A comparative Study

Furthermore, as the modern international practices have rapidly developed, the term war has been defined broadly but seems old-fashioned. In this context, the German Constitution has used a modern concept of the state of defence instead of using the term war power in Article 115(a). The German term of state defence may be adopted to replace war power on the Indonesian Constitution. Moreover, the concept of a state of national defence, as mentioned in the South African Constitution, would be fit to replace the concept of war. In common practice, such power is a dependent power to be performed upon the DPR's approval.

The clarity of the determination of the term emergency would be very important. In this context, the German Constitution provides the determination of the term as imminent threat and immediate attack. The President would only exercise the emergency power on particular issues. The emergency power of the President would only be exercised for actual and immediate threats. Other than that, the President should confirm and seek approval from the DPR. The emergency clause in the French Constitution would also be reasonable to be adopted. It provides clear definition of the emergency situations.On the other hand, the Constitution should guarantee the power of the President to command over the military forces in times of peace and in times of armed conflict. At this point, the model of Supreme Commander in Chief by the Polish Constitution in Article 134 and Article 136 combined with the Commander in Chief model written in the South African Constitution may be a good model to be adopted.

In addition, based on the Indonesian experience of a fundamental and crucial question about the seccession of the province of Timor-Timur (which is now Timor-Leste) there should be an anticipatory power that might be invoked by the President. For a very fundamental state question, such as the issue relating to secession, right of self-determination, or state accession to (what is now being designed)a union model of the AEC (ASEAN Economic Community)or any union models similar to the EU model, it is important to empower the President with the power to call a referendum. However, such power would only be exercised by and with approval from the two chambers of the MPR (the DPR and the DPD). The inspiration of such a referendum power is from the Polish Constitution (Article 125) which gives the possibility for the President to invoke a referendum in respect of matters of particular importance to the State. 
Rosa Ristawati: Modelling Executive Powers in the Indonesian Constitution: A comparative Study

Furthermore, the President is given the power to initiate the budget while the real power of approval is with the DPR. After the budget is approved, the President should be given the power to spend the budget independently. The DPR at this point could always monitor and oversee the exercise of spending power of the President. This model is similar to what happens in the US.

For the pardoning power, it is worth referring to the US and the Philippines. According to the US pardoning clause, it is important to clearly express the limitation of pardoning power; that the pardoning power does not apply in the impeachment case. While in general, the scopes of pardoning power would be rationally defined as what is written in the Philippines.

It is important to consider setting a constitutional basis for the power of the President that relates to the establishment and control of state intelligence services. This would be not only in order to maintain the accountability of intelligence operations but also providing a constitutional check over any intelligence operations conducted in a secret way by the President. To this extent, Article 209 of the South African Constitution may provide a model for the intelligence power of the President.

Lastly, as corruption is one of the greatest enemies for Indonesia and in order to enhance the anticipation and support on the anti-corruption commitment, a symbolic constitutional power, namely the anti-corruption power for the President may also be considered. ${ }^{917}$ The reason for giving the anti-corruption power to the President is because the President, as the head of the executive has to deal with the bureaucracy within the state administration. The President should ensure control over the bureaucracy and the executive

\footnotetext{
${ }^{917}$ Such anti-corruption power had been introduced in the Venezuela constitutional system when President Nicolas Maduro seeks the national legislature to enhance his constitutional power. He seeks fast-track legislative powers to enable him enacting the laws by decree without the parliament in order to help his government to fight against corruption (see: Ezequiel Minaya: Venezuelan Leaders Seeks to Boost His Power, the Wall Street Journal, August 13 , 2013, available online

on

http://online.wsj.com/news/articles/SB10001424127887324769704579009772676705350, last accessed 12/10/2013). The Venezuelan requirement for enhancing the Presidential power was approved by the Venezuelan national legislature by giving a special power to the President the decree powers to fight corruption and economic war (see: Ryan Mallett-Outtrim: Venezuela's Legislature Gives Maduro Decree Powers to fight against Corruption and Economic War, Venezuelananalysis.com, November 20, 2013, available online on http://venezuelanalysis.com/news/10178, last accessed 12/10/2013.
} 
Rosa Ristawati: Modelling Executive Powers in the Indonesian Constitution: A comparative Study

department under the executive branch, includingmaking sure the application of anticorruption policy on the entirety of all institutions under his branch. It is rational to give to the President since the President has a direct access to the cabinet, state institution, executive agencies, local government, and other state agencies. 
Summary

\section{Modelling Executive Powers in the Indonesian Constitution A comparative study of Constitutions}

This PhD dissertation on "Modellling Executive Powers in the Indonesian Constitution: A Comparative study of Constitutions" generally proposes a presidency model for Indonesia. It mainly addresses to seek and find an appropriate constitutional framework for giving executive powers to the President. The issue is crucial for the proper and effective functioning of the Presidency as one of the important constitutional branches. This dissertation proposes a design framework of constitutional provisions on the specific issue of the executive powers of the President.

This dissertation has the main method of observing theory and comparing other Constitutions to draw a general conclusion on how should the Executive be established in different countries. By comparing the Constitutions and analysing the constitutional provisions, concerning the Executive and its powers, this dissertation identifies the constitutional standards on how executive powers should be given to the President in the Indonesian presidential system. Another method used in this dissertation is to referring back to the constitutional history in Indonesia, in which the executive powers have evolved under different Constitutions, different regimes, and different models of government systems.

In general, the arguments in this dissertation include the Executive and its powers provided by different model of Constitutions, thus encompassing the general executive mode and the modes of the executive powers. The findings presented in this dissertation are based on the normative method of analysis. The Constitutions are the normative basis of analysis in this dissertation, which, along with the Laws and Judicial decisions, allow us not only to determine the content of certain constitutional structures of government, but also to identify constitutional practices which do not come directly from the constitutional provisions. Limiting the scope of analysis to the constitutional provisions was intentional, as the Constitution is the main key to creating a constitutional and legal framework for the system of government, a presidential system, in Indonesia. 


\section{Rosa Ristawati: Modelling Executive Powers in the Indonesian Constitution: A comparative Study}

There are two major issues which presented themselves as the research questions in this dissertation. The first issue deals with the description of the existing constitutional framework for the executive powers in the Indonesian Constitution and the effect of the Amendment on the Constitution and its implications for the executive powers of the Indonesian President. The other is the assessment of the Indonesian executive powers and the idea for an alternative constitutional design of the Indonesian executive powers that may be developed in order to improve the Indonesian presidency, reduce unsolved power conflicts between branches, prevent abuse power and corruption, and adapt to International challenges.

The dissertation consists of six chapters. While the first chapter is an introductory chapter, the second chapter is devoted to issues related to defining the theory and the depiction of other Constitutions to seek to find constitutional regularity standards for the Executive branch and how the Constitutions allocate the executive powers to the executive branch. In this chapter, an attempt is made to classify the constitutional standards and constitutional frameworks. Moreover, the relations between constitutional frameworks and other frameworks that make up the group of constitutional rules defining the powers of the Executive in the government systems are compared and described. The third chapter is focussed on the historical issue related to the development of the executive and its powers in Indonesia. It depicts the constitutional practices within different regimes of the Indonesian Presidents. The fourth chapter is focused on the matters related to the Executive and the executive powers under the Amended Constitution. There is an attempt to present the current constitutional conditions concerning the interpretation of the constitutional provisions. It is also essentially to identify all common features of the Indonesian presidential system. The constitutional provisions of the current Amended Constitution and identification of the vagueness, ambiguities, irregularities and inconsistencies in particular issues of the Executive and its powers mentioned in the Constitution, are also being reviewed in this chapter. The reviews are concentrated to identify the vagueness and ambiguity of the constitutional provision concerning the Executive and its power. In this chapter, the analysis and descriptions are outlined to find problems of what is happening with the system of government in Indonesia generally, and in particular, problems with the Presidency and its powers. Finally, the solutions of problems identified in this chapter are offered. The next chapter is devoted to proposing a design of constitutional framework on the particular issue of the Executive and the executive powers. The design is based on the constitutional regularity features and common characters 
Rosa Ristawati: Modelling Executive Powers in the Indonesian Constitution: A comparative Study

of system of governments under some Constitutions. The design being made is addressed to prevent abuse of powers but still preserving the normal roles of the Executive in a presidential system. Such design may be introduced in order to propose the fifth amendment to the Constitution in Indonesia.

The result of the research in this dissertation confirms that the executive powers in Indonesia have been evolved, starting from the revolutionary strong character of the executive powers to the authoritarian strong character and coming to the weak character of the executive powers. Following the fall of the regime of President Soeharto in Indonesia, the amendment to the Constitution had been proposed to curb the executive powers of the President. The Amended Indonesian Constitution had successfully introduced a limited presidency under a presidential system by setting limits and interventions to the executive powers of the President. The Legislature mostly dominated the Executive; it made too many political interventions into the executive powers. This, in fact, frequently prevented the President from, acting genuinely as what it should be.

Furthermore, it contributed to the increasing disadvantages of the Indonesian constitutional system as a whole, the unsolved institutional conflicts and over-restrained the President from quickly reacting to deal with imminent challenges and problems. The conclusion of this dissertation generally affirms that the Constitutional provisions establish the key elements of the system of government in Indonesia. Therefore, the framework of the Constitution, which elaborated from the articles, has to be fixed in order to improve the performance of the Indonesian presidency. Furthermore, this dissertation indicates that a presidential system is the system where the President has to be given some substantial executive powers, in order to support the president's functions and roles, but has to be checked and balanced by other institutions.

Key words: the Constitution, the Executive, the executive powers, presidential system, the Indonesian President, Amendment Constitution 
Rosa Ristawati: Modelling Executive Powers in the Indonesian Constitution: A comparative Study 
Ringkasan (Bahasa)

\section{Modelling Executive Powers in the Indonesian Constitution A comparative study of Constitutions Pemodelan Kekuasaan Eksekutif dalam Konstitusi Indonesia: Studi Perbandingan Konstitusi}

Disertasi yang berjudul "Modelling Executive Powers in the Indonesian Constitution: A Comparative Study of Constitutions" ini bertujuan untuk menghasilkan pemikiran sebuah model sistem presidensial untuk Indonesia. Disertasi ini mencoba untuk mencari dan menemukan sebuah kerangka konstitusional yang cocok dalam memberikan kekuasaan eksekutif kepada Presiden. Isu tersebut krusial untuk ketepatan dan fungsi yang efektif kelembagaan Presiden sebagai salah satu institusi konstitutional yang penting. Disertasi ini mengajukan proposal sebuah desain kerangka konstitusional Pasal-Pasal Konstitusi tentang isu-isu khusus terkait kekuasaan eksekutif Presiden. Salah satu metode yang digunakan dalam disertasi ini adalah dengan mengacu kembali pada sejarah konstitusional Indonesia, dimana kekuasaan eksekutif telah hidup dan berevolusi dalam beberapa konstitusi yang berbeda yang berlaku di Indonesia, dalam rezim pemerintahan yang berbeda, dan dalam model sistem pemerintahan yang berbeda.

Disertasi ini mempunyai metode utama mengobservasi teori dan membandingkan konstitusi untuk menarik gambaran umum tentang bagaimana seharusnya institusi Eksekutif dibangun di beberapa negara. Dengan melakukan perbandingan beberapa Konstitusi, dan menganalisa pasal-pasal Konstitusi terkait dengan Eksekutif dan kekuasaan eksekutif, disertasi ini mengidentifikasi standar konstitutional terkait bagaimana seharusnya kekuasaan eksekutif harus diberikan kepada presiden dalam sebuah sistem presidensial.

Secara umum, argumen-argumen dalam disertasi ini meliputi eksekutif dan kekuasaan eksekutif dalam model konstitusi yang berbeda, sehingga, menggambarkan model eksekutif dan kekuasaan eksekutif secara umum. Penemuan yang dihasilkan dalam disertasi ini didasarkan dari analisa dengan menggunakan metode normatif. Pasal-Pasal dalam Konstitusi-Konstitusi merupakan dasar norma hukum yang di analisa secara normatif dalam disertasi ini, yang bersamaan dengan Undang-Undang dan putusan-putusan pengadilan tidak hanya memastikan isi dari struktur konstitusional tertentu, tetapi juga mengidentifikasi praktek konstitutional yang tidak secara langsung berasal dari pasal-pasal dalam Konstitusi. Membatasi area analisis normatif hanya pada pasal-pasal dalam Konstitusi adalah sebuah tujuan dalam disertasi ini, karena Konstitusi merupakan kunci utama untuk membuat kerangka konstitusional dan kerangka hukum untuk sebuah sistem pemerintahan, sistem presidensial di Indonesia.

Dalam disertasi ini terdapat dua isu utama yang keduanya diformulasikan dalam rumusan masalah. Isu pertama adalah deskripsi pasal-pasal konstitusi yang berlaku dan ada dalam kerangka Konstitusi 
Rosa Ristawati: Modelling Executive Powers in the Indonesian Constitution: A comparative Study

Indonesia yang merujuk pada kekuasaan eksekutif dalam Konstitusi Indonesia dan efek Amandemen Konstitusi beserta implikasinya terhadap kekuasaan eksekutif. Isu kedua adalah analisa kekuasaan eksekutif di Indonesia dan ide alternatif desain konstitusional untuk kekuasaan eksekutif di Indonesia yang mungkin dapat dibangun untuk memperbaiki kepresidenan di Indonesia, mengurangi konflik kekuasaan antar cabang kekuasaan yang tidak terselesaikan, mengantisipasi penyalahgunaan kekuasaan dan korupsi, dan mengadaptasi tantangan-tantangan internasional.

Disertasi ini terdiri dari enam bab. Bab pertama adalah pendahuluan, bab kedua merupakan teori dan penggambaran Konstitusi-Konstitusi negara lain untuk mencari dan menemukan standart umum konstitutional untuk cabang eksekutif dan bagaimana konstitusi-konstitusi tersebut mengalokasikan kekuasaan eksekutif untuk cabang kekuasaan eksekutifnya. Dalam bab ini, dicoba untuk membuat sebuat pengklasifikasian standart konstitusional dan kerangka konstitusi. lebih lanjut, hubungan antara kerangka konstitusi dan kerangka lainnya yang mengelompokkan norma-norma konstitutional yang mengatur kekuasaan eksekutif dalam sistem pemerintahan yang berbeda diperbandingkan dan dideskripsikan. Bab ketiga difokuskan pada isu historis yang berkaitan dengan perkembangan eksekutif dan kekuasaannya di Indonesia. Bab tersebut menggambarkan praktek konstitusional dalam rezim kepresidenan yang berbeda di Indonesia. Bab empat difokuskan terkait dengan eksekutif dan kekuasaan eksekutif yang diatur dalam Konstitusi Indonesia setelah amandemen. Dalam bab ini diulas tentang kondisi konstitutional terkini dibawah rezim konstitusi amandemen Indonesia melalui interpretasi pasalpasalnya. Dalam bab ini juga dipandang perlu untuk mengidentifikasikan fitur umum sistem presidensial di Indonesia. Pasal-pasal dalam Konstitusi Indonesia setelah amandemen dan identifikasi ketidakjelasan, keambiguan, ketidakwajaran, dan ketidakkonsistenan terutama dalam isu eksekutif dan kekuasaan eksekutif yang diatur dalam Konstitusi akan dianalisa dalam bab ini. Analisa akan dikonsentrasikan untuk menidetifikasi ketidakjelasan dan keambiguan pasal-pasal konstitusi terkait dengan eksekutid dan kekuasaannya. Dalam bab ini, analisa dan deskripsi diuraikan untuk mencari masalah-masalah yang terjadi dalam sistem presidensial Indonesia secara umum, dan khususnya, masalah-masalah yang terkait dengan kepresidenan dan kekuasaannya. Pada akhirnya, solusi-solusi terhadap masalah-masalah yang telah diidentifikasikan dalam bab ini diberikan. Bab selanjutnya dikhususkan untuk mengidekan sebuah desain kerangka konstitusional terkait isu eksekutif dan kekuasaannya. Desain ini didasarkan pada fitur konstitusional dan karakter-karakter yang pada umumnya terdapat pada sistem pemerintahan dibawah konstitusi-konstitusi yang berbeda. Desain yang dibuat ditujukan untuk mengantisipasi penyalahgunaan kekuasaaan dengan tetap mempertahankan fungsi eksekutif yang sebenarnya dalam sebuah sistem presidensial. Desain tersebut diharapkan dapat diintrodusir dalam proses amandemen konstitusi kelima di Indonesia.

Hasil penelitian dalam disertasi ini menegaskan bahwa kekuasaan eksekutif di Indonesia telah berkembang secara berevolusi, dimulai dari karakter revolusioner kuat kekuasaan eksekutif berkembang menjadi kekuasaan eksekutif yang berkarakter otoriter kuat, dan beralih menjadi kekuasaan eksekutif yang mempunyai karakter lemah. Setelah jatuhnya rezim Soeharto di Indonesia, amandemen terhadap Konstitusi di Indonesia telah memangkas kekuasaan eksekutif presiden Indonesia. Amandemen 
Rosa Ristawati: Modelling Executive Powers in the Indonesian Constitution: A comparative Study

terhadap Konstitusi di Indonesia telah berhasil mengintrodusir kepresidenan yang berbatas dalam sebuah sistem presidensial dengan memberikan batasan-batasan dan intervensi-intervensi terhadap kekuasaan eksekutif presiden. Legislatur bertendensi dominan terhadap eksekutif dengan terlalu banyak memberikan intervensi politik terhadap kekuasaan eksekutif. Hal ini, dalam faktanya, telah berulang kali menghalangi presiden untuk melakukan hal yang seharusnya dilakukan oleh presiden. Lebih lanjut, hal tersebut berkontribusi untuk meningkatkan kerugian-kerugian sistem konstitusional Indonesia secara menyeluruh, memprovokasi konflik institutional yang tidak terselesaikan, dan pengekangan berlebihan terhadap presiden untuk secara cepat berreaksi menghadapi tantangan nyata dan permasalahanpermasalahan.

Kesimpulan dalam disertasi ini secara umum mengafirmasi bahwa pasal-pasal konstitusi membangun elemen-elemen kunci sistem pemerintahan di Indonesia. Sehingga, kerangka konstitutional yang dijabarkan dalam pasal-pasal konstitusi harus direvisi untuk meningkatkan kinerja kepresidenan di Indonesia. Disertasi ini juga memberi indikasi bahwa sistem presidensial adalah sistem dimana presiden harus diberikan beberapa substansial kekuasaan eksekutif yang mendukung fungsi dan perannya, tetapi kekuasaan tersebut tetap harus diimbangi dengan mekanisme cek dari cabang kekuasaan yang lainnya.

Kata kunci: Konstitusi, Eksekutif, Kekuasaan Eksekutif, Sistem President, Presiden Indonesia, Amandemen Konstitusi. 


\section{Bibliography}

Books:

\section{Ackerman 2006}

Ackerman, Bruce, Before the Next Attack: Preserving Civil Liberties in an Age of Terrorism, New Haven: Yale University Press, 2006.

\section{Ackerman 2010}

Ackerman, Bruce, the Decline and Fall of the American Republic, the Belknap Press of Harvard University Press, 2010.

\section{Adler 1986}

Adler, David Gray, the Constitution and the Termination of Treaties, New York \& London: Garland Publishing, Inc, 1986.

\section{Asshiddiqie 2005}

Asshiddiqie, Jimly, Konstitusi dan Konstitusionalisme, Jakarta: Konstitusi Press, 2005.

\section{Asshiddiqie 2005}

Asshiddiqie, Jimly, Hukum Tata Negara dan Pilar-Pilar Demokrasi, Jakarta: Konstitusi Press, 2005.

\section{Asshiddiqie 2006}

Asshiddiqie, Jimly, Perihal Undang-Undang, Jakarta: Konstitusi Press, 2006.

\section{Asshiddiqie 2006}

Asshidiqie, Jimly, Pengantar IImu Hukum Tata Negara Jilid II, Jakarta: Mahkamah Konstitusi Republik Indonesia, 2006.

\section{Asshiddiqie 2006}

Asshiddiqie, Jimly, Perkembangan dan Konsolidasi Lembaga Negara Pasca Reformasi, Jakarta: Sekretariat Jenderal dan Kepaniteraan Mahkamah Konstitusi RI, 2006.

\section{Baumgartner and Kada 2003}

Baumgartner, Jody C., Kada, Naoko, Introduction: Comparative Presidential Impeachment on Checking Executive power: Presidential Impeachment in Comparative Perspective, USA: Praeger Publishers, 2003.

\section{Bockenforde et al 2011}

Bockenforde, Markus, Hedling, Nora et al, A Practical Guide to Constitution Building, Sweden: International IDEA resources on Constitution Building, 2011.

\section{Brandt 2011}

Brandt, Michele, Jill Cottrell et al, Constitution-making and Reform:

Options for the Process, Switzerland: Interpeace, 2011.

\section{Brown 2003}


Rosa Ristawati: Modelling Executive Powers in the Indonesian Constitution: A comparative Study

Brown, Colin, a Short History of Indonesia: the Unlikely Nation?, Australia: Allen and Unwin, 2003.

\section{Buckley 2006}

Buckley, Stephen, the Prime Minister and Cabinet, Edinburgh University Press, 2006.

\section{Cameron 2000}

Cameron, Charles M, Veto Bargaining: Presidents and the Politics of Negative Power, Cambridge

University Press, 2000.

\section{Cheibub 2007}

Cheibub, Jose Antonio, Presidentialism, Parliamentarism, and Democracy, Cambridge: Cambridge University Press, 2007.

\section{Claes 2006}

Claes, Monica, The National Court's Mandate in the European Constitution, Oregon: Hart Publishing Oxford and Portland, 2006.

\section{Cole 2002}

Cole, David, Dempsey, James X., Terrorism and the Constitution: Sacrificing Civil Liberties in The Name of National Security, New York: the New York Press, 2002.

\section{Corwin 1940}

Corwin, Edward S., The President Office and Powers: History and Analysis of Practice and Opinion, New York: New York University Press, 1940.

\section{Cruz 1999}

Cruz, Peter de, Comparative Law in a Changing World, London: Cavendish Publishing Limited, $2^{\text {nd }}$ Edition, 1999.

\section{Diehl et al 2009}

Diehl, Katharina, Mantel, Johanna et al, Max Planck Manuals on Constitutional Building: Structures and Principles of a Constitution $2^{\text {nd }}$ Edition, Heidelberg: Max Planck Institute for Comparative Public Law and International Law, 2009.

\section{Dorsen 2010}

Dorsen, Norman, et al, Comparative Constitutionalism: Cases and Materials, $2^{\text {nd }}$ Edition, USA: Thomson Reuters, 2010.

\section{Drakeley 2005}

Drakeley, Steven, The History of Indonesia, Westport, Conn: Greenwood Press, 2005.

\section{Elgie 2004}

Elgie, Robert, Comparative European Politics: Semi-Presidentialism in Europe, New York: Oxford University Press, 2004.

Elgie and Moestrup 2007 
Elgie, Robert, Moestrup, Sophie, Semi-Presidentialism Outside Europe: A Comparative Study, New York: Routledge, 2007.

\section{Elgie 2011}

Elgie, Robert, Semi-Presidentialism: Sub Types and Democratic Performance, New York: Oxford University Press, 2011.

\section{Feith 2007}

Feith, Herbert, The Decline of Constitutional Democracy in Indonesia, Jakarta: Equinox Publishing, $1^{\text {st }}$ Edition, 2007.

\section{Fisher 2007}

Fisher, Louis, Constitutional Conflicts between Congress and the President, $5^{\text {th }}$ Edition Revised, University Press of Kansas, 2007.

\section{Freeman 2003}

Freeman, Michael, Freedom or Security: The Consequences for the Democracies Using Emergency Powers to Fight Terror, Praeger Publisher, 2003.

\section{Ginsberg 2011}

Ginsberg, Benjamin, et al, We the People: an introduction to American Politics (W.W. Norton \&Company, Eight Essential Edition, 2011).

\section{Ginsburg et al 2011}

Ginsburg, Tom, Dixon, Rosalind, Research Handbook in Comparative Constitutional Law, Edward Elgar Publishing Limited, 2011.

\section{Ginsburg 2012}

Ginsburg, Tom, Comparative Constitutional Design, New York: Cambridge University Press, 2012.

\section{Goldman 2008}

Goldman, Lawrence, The Federalist Papers/ Alexander Hamilton, James Madison, and John Jay, edited with an introduction and notes by Lawrence Goldman, Oxford University Press, 2008.

\section{Hague 2004}

Hague, Rod, and Martin Harrop, Comparative Government and Politics: An Introduction, $6^{\text {th }}$ edition, Palgrave Macmillan, 2004.

\section{Henkin 1990}

Henkin, Louis, Constitutionalism, Democracy, and Foreign Affairs, New York: Columbia University Press, 1990.

Henkin 1997 
Henkin, Louis, Foreign Affairs and the United States Constitution, Clarendon Press, Oxford University Press, $2^{\text {nd }}$ edition, 1997.

\section{Heringa 2012}

Heringa, Aalt Willem, Kiiver, Philipp, Constitutions Compared: An Introduction to Comparative Constitutional Law, $3^{\text {rd }}$ Edition, UK: Intersentia, 2012.

\section{Iskandar 2004}

Iskandar, Muhaimin, Gus Dur yang Saya Kenal: Catatan Transisi Demokrasi Kita, Yogyakarta: LKis, 2004.

\section{Jones 2005}

Jones, Charles O, The Presidency in a Separated System, Washington DC: Brookings Institution Press, $2^{\text {nd }}$ edition, 2005.

\section{Jenning 1969}

Jennings, Sir Ivor, Cabinet Government, Cambridge University Press, $3^{\text {rd }}$ edition, 1969.

\section{Knapp and Wright 2001}

Knapp, Andrew, Wright, Vincent, the Government and Politics of France, $4^{\text {th }}$ Edition, Routledge, London, 2001.

\section{Kingsbury 2003}

Kingsbury, Damien, Power Politic and the Indonesian Military, London: RoutledgeCurzon, 2003.

\section{Kiiver 2010}

Kiiver, Philipp and N. Kornet, eds, the Maastricht Collection: Selected National European and International Provisions from Public and Private Law, Second Edition, Groningen: Europa Law Publishing, 2010.

\section{Koppel 2003}

Koppel, Jonathan G.S., The Politics of Quasi-Government: Hybrid Organizations and Dynamics of Bureaucracy Control, Cambridge: Cambridge University Press, 2003.

\section{Laslett 2012}

Laslett, Peter, The Founders' Constitution Volume 1, Chapter 10, Document 3, the University of Chicago Press, John Locke: Second Treatise, New York: Mentor Books, New American Library, 1965 accessed on http://press-pubs.uchicago.edu/founders/documents/v1ch10s3.html, at 12/12/2012.

\section{Levinson 2006}

Levinson, Sanford, Our Undemocratic Constitution, Oxford University Press, 2006.

\section{Lewis 2003}

Lewis, David E, Presidents and the politics of agency design: political insulation in the United States government Bureaucracy, 1946 - 1997, Stanford California: Stanford University Press, 2003. 
Rosa Ristawati: Modelling Executive Powers in the Indonesian Constitution: A comparative Study

Lutz 2006

Lutz, Donald S., Principles of Constitutional Design, Cambridge University Press, 2006.

Manan 2004

Manan, Bagir, Teori dan Politik Konstitusi, Yogyakarta: FH UII Press, Cet. Kedua, 2004.

\section{Mietzner 2006}

Mietzner, Marcus, the Politics of Military Reform in Post-Suharto Indonesia: Elite Conflict, Nationalism, and Institutional Resistance, Washington: the East-West Center, 2006.

\section{Moestrup 2011}

Moestrup, Sophie, Semi Presidentialism and Democracy, Edited by Elgie, R., Wu, Y., Palgrave Macmillan UK, 2011.

\section{Mulyosudarmo 2004}

Mulyosudarmo, Soewoto, Pembaharuan Ketatanegaraan Melalui Perubahan Konstitusi, Malang: Asosiasi Pengajar HTN-HAM Jatim-Intrans, 2004.

\section{Newton 2005}

Newton, Ken, Deth, Jan W. Van, Foundations of Comparative Politics: Democracies of the Modern World, Cambridge: Cambridge University Press, 2005.

O'Rourke 2002

O’Rourke, Kevin, Reformasi: The Struggle for Power in Post Soeharto Indonesia, Allen\&Unwin, 2002.

\section{Poguntke 2005}

Poguntke, Thomas, Webb, Paul, The Presidentialization of Politics: A Comparative Study of Modern Democracies, Oxford University Press, 2005.

\section{Provost 2009}

Provost, Colin, Teske, Paul, President George W. Bush's influence over Bureaucracy and Policy: Extraordinary Times, Extraordinary Powers, New York: $1^{\text {st }}$ Edition, Palgrave Macmillan, 2009.

\section{Rabasa 2001}

Rabasa, Angel, Chalk, Peter, Indonesia's Transformation and the Stability of Southeast Asia, Rand, 2001.

\section{Ricklefs 2001}

Ricklefs, Merle Calvin, A History of Modern Indonesia since c.1200, $3^{\text {rd }}$ Edition, Palgrave Macmillan, 2001.

\section{Rudalevige 2005}

Rudalevige, Andrew, The New Imperial Presidency: Renewing Presidential Power after Watergate, the University of Michigan Press, 2005.

Ruland et al 2005 
Ruland, Jurgen, Clemen Jurgenmeyer, et al, Parliaments and Political Change in Asia, Singapore: Institute of Southeast Asian Studies, 2005.

\section{Sajo 1999}

Sajo, Andraz, Limiting Government: An Introduction to Constitutionalism, English Translation, Budapest: Central European University Press, 1999.

\section{Sanford 2002}

Sanford, George, Democratic Government in Poland, Palgrave Macmillan, 2002.

\section{Schwarz et al 2007}

Schwarz Jr., Frederick A.O., et al, Unchecked and Unbalanced: Presidential Power in a Time of Terror, New York: The New Press, 2007.

\section{Singh 2003}

Singh, Robert, American Government and Politics: a Concise Introduction, Sage Publication, $1^{\text {ST }}$ publishing, 2003.

\section{Smith 1999}

Smith, Jeffrey A., War and Press Freedom: The Problem of Prerogative Power, Oxford University Press, 1999.

\section{Storey 2007}

Storey, William, US Government and Politics, Edinburgh: Edinburgh University Press, 2007.

\section{Strong 1963}

Strong, C.F., Modern Political Constitutions: An Introduction to the Comparative Study of Their History and Existing Form, London: Sidgwick \& Jackson Limited, Sixth edition, 1963.

\section{Suni 1986}

Suni, Ismail, Pergeseran Kekuasaan Eksekutif, Jakarta: Aksara Baru 1986.

\section{Rosenfield et all 2012}

Rosenfield, Michael, Sajo, Andras, The Oxford Handbook of Comparative Constitutional Law 1st Edition, Oxford University, 2012.

\section{Vile 1998}

Vile, M.J.C., Constitutionalism and Separation of Powers, Indianapolis: Liberty Fund, Inc, $2^{\text {nd }}$ edition, 1998.

\section{Watts 2003}

Watts, Duncan, Understanding US/UK Government and Politics: a Comparative Guide, Manchester University Press, 2003.

\section{Watts 2006}

Watts, Duncan, British Government and Politics: a Comparative Guide, Edinburgh University Press, 2006. 


\section{Wagner 2007}

Wagner, Heather Lehr, the Presidency: the US Government How It Works, USA: Chelsea House Publisher, 2007.

\section{Weinberger 2009}

Weinberger, Seth, Restoring the balance: war powers in an age of terror, Greenwood Publishing Group, 2009.

\section{Books Contributions:}

\section{Bradley 2012}

Bradley, Anthony W., Cesare Pinelli, Parliamentarism, in: the Oxford Handbook of Comparative Constitutional Law edited by Michel Rosenfeld and Andras Sajo, Oxford University Press, 2012.

\section{Ferejohn 2012}

Ferejohn, John, Pasquale Pasquino, Emergency Power, in: the Oxford Handbook of Political Theory by John S. Dryzek, Bonnie Honig, and Anne Phillips, Printed from Oxford Handbooks Online (www.oxfordhandbooks.com), Oxford University Press, 2012, accessed online from Maastricht University Library Online on 30 January 2013.

\section{Fisher 2006}

Fisher, Louis, From Presidential Wars to American Hegemony: the Constitution: the Constitution After 9/11" in: The Presidency and the Challenge of Democracy edited by Michael A. Genovese and Lori Cox Han, Palgrave Macmillan, 2006.

\section{Fix-Fierro 2012}

Fix-Fierro, Hector, Salazar-Ugarte, Pedro, Presidentialism, in: The Oxford Handbook of Comparative Constitutional Law edited by Michel Rosenfeld and Andras Sajo, Oxford University Press, 2012.

\section{Genovese 2006}

Genovese, Michael A., Is the Presidency Dangerous to Democracy?, in: The Presidency and the challenge of Democracy edited by Michael A. Genovese and Lori Cox Han, Palgrave Macmillan, 2006.

\section{Hasebe 2012}

Hasebe, Yasuo, War Power, in: The Oxford Handbook of Comparative Constitutional Law edited by Michel Rosenfeld and Andras Sajo, Oxford University Press, 2012.

\section{Kassop 2006}

Kassop, Nancy, The Constitutional Checks and Balances that Neither Check nor Balance, in: the Presidency and the challenge of Democracy edited by Michael A. Genovese and Lori Cox Han, Palgrave Macmillan, 2006.

\section{Pasquino 2007}


Pasquino, G., The Advantages and Disadvantages of Semi-Presidentialism: A West European Perspective, in Elgie, R. And Moestrup, S. (eds) Semi-Presidentialism Outside Europe: A Comparative Study, London: Routledge, 2007.

\section{Posner and Vemeule 2012}

Posner, Eric A, Vemeule, Adrian, Tyrannophobia, in: Tom Ginsburg, Comparative Constitutional Design, Cambridge Universiy Press, 2012.

\section{Protsyk 2011}

Protsyk, Oleh, Semi-Presidentialism under Post-Communism, in: Semi-Presidentialism and Democracy Edited by Robert Elgie, Sophia Moestrup and Yu-Shan Wu, Palgrave Macmillan, 2011.

\section{Institutional Books}

Mahkamah Konstitusi RI 2005

Mahkamah Konstitusi RI, Mekanisme Impeachment dan Hukum Acara Mahkamah Konstitusi, Jakarta: Pusat Penelitian dan Pengkajian Sekretariat Jenderal dan Kepaniteraan Mahkamah Konstitusi Republik Indonesia and Konrad Adenauer Stiftung, 2005.

\section{Mahkamah Konstitusi RI 2012}

Mahkamah Konstitusi RI, Naskah Komprehensif Perubahan Undang-Undang Dasar Republik Indonesia Tahun 1945, Buku 1: Latar Belakang, Proses dan Hasil Perubahan UUD 1945, Edisi Revisi, Jakarta: Sekretariat Jenderal dan Kepaniteraan Mahkamah Konstitusi, 2012.

\section{The Public International Law and Policy Group 2007}

The Public International Law and Policy Group, Post-Conflict Constitution Drafter's Handbook, 2007, available online at www.publicinternationallaw.org

\section{Journals:}

\section{Ackerman 2004}

Ackerman, Bruce, "The Emergency Constitution", 113 the Yale Law Journal (2004), 1029 - 1091.

\section{Angelo 1950}

Angelo, Homer G., "Transfer of Sovereignty Over Indonesia", 44 the American Journal of International Law 3 (July 1950), $569-572$.

\section{Bahro et al 1998}

Bahro, Horst, Bayerlein, Bernhard H., et all, “Duverger's concept: Semi-presidential government revisited", 34 European Journal of Political Research 2 (October 1998), 201-224.

\section{Baumgartner and Morris 2001}

Baumgartner, Jody C., Morris, Mark H., “Presidential Power Unbound: A Comparative Look at Presidential Pardon Power", 29 Politics and Policy 2 (June 2001), 206-236.

\section{Bradley and Flaherty 2004}


Rosa Ristawati: Modelling Executive Powers in the Indonesian Constitution: A comparative Study

Bradley, Curtis A., Flaherty, Martin S., "Executive Power Essentialism and Foreign Affairs", 102 Michigan Law Review 4 (February 2004), 545-688.

\section{Bullard Jr 1983}

Bullard Jr, Lyman G., "Absolute Presidential Immunity from Civil Damage Liability: Nixon v. Fitzgerald", 24 Boston College Law Review 3 (1983), 737-769. (accessed online from:

http://lawdigitalcommons.bc.edu/bclr/vol24/iss $3 / 5$

\section{Chang 1997}

Chang, Enoch, "Presidential Immunity; A Survey of United State Cases", 3 Taiwan International Studies Quarterly 1 (1997), 149-70.

\section{Chen 2006}

Chen, Alan K., "The Facts about the Qualified Immunity", 55 Emory Law Journal 2 (2006), 229-278.

\section{Cheney 1949}

Cheney, Charles, "The Status of the Republic of Indonesia in International Law", 49 Colombia Law Review 7 (November 1949), 955 - 966.

\section{Croner 2009}

Croner, Andrew, "Morrison, Edmond, and the Power of Appointments", 77 the George Washington Law Review, (2009), $1002-1014$.

\section{Cole 1998}

Cole, David H., "Poland's 1997 Constitution in Its Historical Context", 1 Saint Louis- Warsaw Transatlantic Law Journal (1998), 1-43. accessed via www.repository.law.indiana.edu/facpub/589

\section{Francis et al 2005}

Francis, Fukuyama, Dressel, Bjorn et all, "Facing the Perils of Presidentialism?: Challenge and Change in East Asia", 16 The Johns Hopkins University Press Journal of Democracy, 2 (April 2005), 102116.

\section{Green 1965}

Green, L.C., "Indonesia, the United Nations and Malaysia", 6 Journal of Southeast Asian History 2 (September, 1965), pp. 71-86.

\section{Harvard Law Review 2007}

Harvard Law Review, "Congressional Restrictions on the President's Appointment Power and the Role of Longstanding Practice in Constitutional Interpretation", 120 The Harvard Law Association 7 (2007) 1914 - 1935. (available online at www.harvardlawreview.org/issues/volume-120-issue-7/)

\section{Hein 2008}

Hein, Patrick, "In Defense of Broad Recess appointment power: the Effectiveness of Political Counterweights", 96 California Law Review 1(2008), 235 - 282. (Accessed from: http://scholarship.law.berkeley.edu/californialawreview/vol96/iss1/5)

\section{Hunter 2011}


Hunter, Matthew, "Legislating Around the Appointments Clause", 91 Boston University Law Review (2011), $753-788$.

\section{Jackson 2010}

Jackson, Vicky C., "Methodological Challenges in Comparative Constitutional Law", 28 Penn State International Law Review (2010), 319- 326. (Accessed from http://ssrn.com/abstract=1739756, 28/07/2011)

\section{Jeffries Jr 2010}

Jeffries Jr, John C., "What's Wrong With Qualified Immunity?", 62 Florida Law Review 4 (September 2010), 851- 869. (Accessed at http://ssrn.com/abstract=1619997)

\section{Jorgensen 1993}

Jorgensen, James N., "Clemency and Pardons Note", 27 University of Richmond Law Review (1993), 345

- 370. (Accessed online from heinOnline http://heinonline.org on 01/04/2012)

\section{Kroef 2012}

Kroef, Justus M. van der, " Guided Democracy in Indonesia”, XXVI Far Eastern Survey 8 (August 1957), $113-124$.

\section{Kumar 2009}

Kumar, Parul, "the Executive Power to Pardon", 2 NUJS Law Review 9 (2009), 9-30.

\section{Linz 1990}

Linz, Juan J., "The Perils of Presidentialism", 1 The John Hopkins University Press Journal of Democracy No. 1 (Winter 1990), 51-69.

\section{Lobel 1989}

Lobel, Jules, "Emergency Power and the Decline of Liberalism", 98 the Yale Law Journal 7 (May 1989), 1385 - 1433. (Accessed online athttp://www.jstor.org/stable/796748 on 20/03/2012)

\section{Luebke 2010}

Luebke, Christian von, "the Politic of Reform: Political Scandals, Elite Resistance, and Presidential Leadership in Indonesia", 1 Journal of Current Southeast Asian Affairs (2010), 79-94. (Accessed online at www.CurrentSoutheastAsianAffairs.org)

\section{Maga 2012}

Maga,Timothy P., "The New Frontier vs Guided Democracy: JFK, Sukarno, and Indonesia, 1961 - 1963", 20 Presidential Studies Quarterly 1 (Winter 1990), 91-102.

\section{Malley 1998}

Malley, Michael, "the $7^{\text {th }}$ Development Cabinet: Loyal to a Fault?, Indonesia", 65 Southeast Asia Program Publications at Cornell University (April 1998), 155-178.

\section{Martinez 2006}


Martinez, Jenny S., "Inherent Executive Power: a Comparative Perspective", 115 the Yale Law Journal 9 (September 2006), 2480-2511.

\section{Matraia 1995}

Matraia, Michael T., "Presidential Immunity: Running For Cover Behind Presidential Immunity: the Oval Office as Safe Heaven From Civil Suits", XXIX Suffolk University Law Review (1995) 195-231.

(accessed online from http://heinonline.org , 29/04/2012)

\section{Mayer 1999}

Mayer, Kenneth R., "Executive Orders and Presidential Power", 61 The Journal of Politics 2 (May, 1999), 445-466. Cambridge University Press on behalf of the Southern Political Science Association, available online at: http://www.jstor.org/stable/2647511, accessed: 26/06/2010

\section{Menitove 2009}

Menitove, Jonathan T., "The Problematic Presidential Pardon: A Proposal for Reforming Federal Clemency", 3 Harvard Law and Policy Review (2009), 447 - 460.

\section{McCarty 1999}

McCarty, Nolan, Razaghian, Rose, “Advice and Consent: Senate Responses to Executive Branch Nominations 1885- 1996”, 43 American Journal of Political Science 4 (Oct., 1999), 1122-1143.

\section{Pereira 2005}

Pereira, Carlos, Timothy J. Power, Lucio Renno, "Under What Condition Do the Presidents Resort to Decree Power? Theory and Evidence from the Brazilian Case", 67 The Journal of Politics 1 (February 2005), 178-200.

\section{Prakash 2008}

Prakash, Saikrishna Bangalore, "A Taxonomy of Presidential Powers", 88 Boston University Law Review (2008), 327- 340. (Accessed via Heinonline (http://heinonline.org, Citation 88 B.U. L. Rev. 327 2008) on $11 / 03 / 2010)$

\section{Prakash and Ramsay 2001}

Prakash, Saikrishna Bangalore, Ramsay, Michael D., "the Executive Power over Foreign Affairs", 111 the Yale Law Journal 231 (2001), 236 - 355.

\section{Rosenkranz 2005}

Rosenkranz, Nicholas Quinn, “Executing the Treaty Power", 118 Harvard Law Review 6 (April 2005), 1867-1938.

\section{Samberg 2010}

Samberg, Matthew A., "Established by Law: Saving Statutory Limitations on Presidential Appointments from Unconstitutionality", 85 New York University Law Review (November 2010), 1735 -1765.

\section{Sherlock 2001}

Sherlock, Stephen, “Indonesia's New Government: Stability at Last?”, Department of the Parliamentary 
Library: Current Issues Brief No. 4 (2001)02, Australia. (accessed at: http://www.aph.gov.au/library on 23/10/2011)

\section{Smith 1998}

Smith, Peter Wesley, "Executive Order and the Basic Law, Law Lectures for Practitioner", Hong Kong Law Journal Limited (1998), 187-209.

\section{Stepan and Skach 1993}

Stepan, Alfred and Skach, Cindy, "Constitutional Frameworks and Democratic Consolidation: Parliamentarianism versus Presidentialism", 46 World Politics 1 (October 1993), 1-22, Published by Cambridge University Press, accessed online via: (http://www.jstor.org/stable/2950664on 12/08/2010)

\section{Turley 2013}

Turley, Jonathan, “Constitutional Adverse Possession: Recess Appointments and the Role of Historical Practice in Constitutional Interpretation", Winconsin Law Review (2013), 965 - 1037.

\section{Turley 2013}

Turley, Jonathan, "Recess Appointment in the Age of Regulation", 93 Boston University Law Review (2013), 1523-1604.

\section{Voloks 2008}

Volokh, Hannah Metchis, "The Two Appointments Clauses: Statutory Qualifications for Federal Officers", 10 Journal of Constitutional Law May (2008), 745 - 789.

\section{Weatherbee 2002}

Weatherbee, Donald E., "Indonesia: Political Drift and State Decay", IX The Brown Journal of World Affairs 1 (Spring 2002), 23-33.

\section{Wyrzykowski and Ciele 2006}

Wyrzykowski, Miroslaw, Ciele, Agnieszka Ciele, "Presidential Elements in Government Poland semipresidentialism or rationalized parliamentarism?", 2 European Constitutional Law Review (2006), 253 - 267. (Accessed online athttp://journals.cambridge.org on 09/11/2011)

\section{Williams 2009}

Williams, Sarah, Sherif, Lena, "The Arrest Warrant for President Al-Bashir: Immunities of Incumbent Heads of State and the International Criminal Court", 14 Journal of Conflict \& Security 1 (2009), pp. 7192.

\section{Theses and Dissertations}

Harvey, Cole J, The Double-Headed Eagle: Semi- Presidentialism and Democracy in France and Russia, Bachelor of Philosophy Thesis, Submitted to the Dean of the University Honors College, University of Pittsburgh, Defended on 14 July 2008.

Indrayana, Deny, Indonesian Constitutional Reform 1999-2002: an Evaluation of Constitution- Making in 
Rosa Ristawati: Modelling Executive Powers in the Indonesian Constitution: A comparative Study

Transition, PhD Dissertation Centre for Comparative Constitutional Studies and the Asian Law, University of Melbourne, Kompas Book Publishing, Jakarta, 2008.

King,Blair Andrew, Empowering the Presidency: Interest and Perceptions in Indonesia's Constitutional Reforms 1999-2002, Dissertation in Political Science, the Ohio State University, 2004.

Morris, Mark Howard, Presidential Pardon Power: Discretion, Disuse, and Mass Media Coverage, Dissertation for the degree of Doctor of Philosophy, Department of Political Science, Miami University, Oxford, Ohio, 2004.

Wildhaber, Luzius, Treaty-Making Power and Constitution: an International and Comparative Study, Schriftenreihe des Instituts fur Internationales Recht und Internationale Beziehungen, Helbig and Lichtenhahn, Basel und Stuttgart, 1971.

\section{Research papers, report, working papers, and others:}

Ackerman, Susan rose, "Hyper-Presidentialism: Separation of Powers without Checks and Balances in Argentina and the Philippines" Faculty Scholarship Series, Paper 4155, 2011. (Accessed online via www.digitlcommons.law.yale.edu/fss papers/4155)

Albert, Richard, "The Fusion of Presidentialism and Parliamentarism", Research Paper 190, March 1 (2010) Boston College Law School, Legal Studies Research Paper Series, available online at: (http://ssrn.com/abstract=1424084)

Burrows, Vanessa K., "An Overview of the Presidential Pardoning Power", Congressional Research Service (2009), available online at www.crs.gov

Candland, Christhopher, and Sity Nurjanah, "Indonesia after Wahid: the New Authoritarianism”, The Royal Institute of International Affairs, Briefing Paper No. 28, London: December 2001, available online at: https://www.chatamhouse.org/Asia

Cheibub, Jose Antonio, "Reforming Presidential and Semi-Presidential Democracies", Instituto de Investigaciones Juridicas de la UNAM, March 3, 2013, available online at: www.juridicas.unam.mx

CRS Report for Congress, National Emergency Powers, Congressional Research Service (2007)

Elkins, Zachary, Ginsburg, Tom et all, “Constitutional Constraint on Executive Law Making”, available online at https://netfiles.uiuc.edu/melton/Files/melkinsburg executivepower.pdf

Garvey, Todd, Carpenter, David H., "The Recess Appointment Power after Noel Canning v. NLRB: Constitutional Implication", the CRS Report for Congress, March 27 (2013) 14, available online at www.crs.gov 
Genovese, Michael. A., "The Roots and Development of Executive Prerogative in the United States", Paper prepared for presentation at the 2009 annual meeting of the American Political Science Association, Toronto, Canada.

ICG International Crisis Group, “Indonesia's Presidential Crisis”, ICG Asia Briefing Paper, Jakarta-Brussels, 21 February 2011.

Isenbergh, Joseph, "Impeachment and Presidential Immunity from Judicial Process", Chicago Public Law and Legal Theory Working Paper, No. 2, accessed on 24/04/2012 from The Social Science Research Network Electronic Paper Collection:

http://papers.ssrn.com/paper.taf?abstract id=193849

Juwana, Hikmahanto, "Treaty Making: Indonesian Practice", Paper presented at the Seminar on the Parliamentary Oversight of Treaties Republic of Indonesia and Australia, Jakarta, 15-16/07/2005.

Koh, Harold Hongju, "The Treaty Power", Faculty Scholarship Series Paper 2066, Yale Law School Faculty Scholarship, http://digitalcommons.law.yale.edu/fss papers/2066

Maddex, Robert L., "Constitution of the World", $3^{\text {rd }}$ Edition, Congressional Quarterly (CQ) Press, Washington D.C., 2008.

Neyfakh, Leon, "The Untapped Power of Pardons", Boston Globe, March, 17, 2013.

Ndulo, Muna, "Presidentialism in the Southern African States and Constitutional Restraint on Presidential Power", Cornell Law Faculty Publications paper 62 (2002), available online at: http://scholarship.law.cornell.edu/facpub/62

Development Alternatives, Inc, Parliamentary Immunity Brief: "a Summary of Case Studies of Armenia, Ukraine and Guatemala", Report and Case/Countries Studies, United States Agency for International Development (USAID), August 2006.

Relyea,Harold C., National Emergency Powers. CRS Report for Congress, Congressional Research Service, 2007, available online at https://fas.org/sgp/crs/natsec

RSIS Policy Report, "With Jokowi Finally in, what's next?", Policy Report, S. Rajaratnam School of International Studies, Graduate School of Nanyang Technological University, April 4, 2014, available online at: www.rsis.edu.sg/rsis-publication/idss/200-with-jokowi-finally-in-whats/\#.Wb4xA1GlbqA

Ruckman Jr, P.S., "Federal Executive Clemency in the Administration of George W. Bush (2001-2009): A Pardon Power Report", Available online at: www.pardonpower.com

Sherlock, Stephen, Indonesia's New Government: Stability at Last?, Department of the Parliamentary Library: Current Issues Brief No. 4 2001-02, Australia, available online at: http://www.aph.gov.au/library

Yuda, Hanta, "Evaluating the First Year of the SBY Administration's Performance", V The Indonesian Update, the Indonesian Institute 7, 2010. 


\section{Other sources: Media, newspapers, and internet:}

ABC News, "Indonesian President Joko Widodo unveils series of stimulus measures to bolster economy, Currency", Sept 10, 2015 available online at: www.abc.net.au/news/2015-09-10/indonesia-unveilsstimulus-to-bolster-economy-currency/6763596

AntaraNews, "Indonesia freezes joint military training with Australia as a response of wire tapping activities by Australia to President SBY and his wife", available online at: http://www.antaranews.com/en/news/91512/indonesia-freezes-joint-military-training-with-australiamilitary-commander

Antaranews, "Million friends zero enemies policy vs Bintan incident", available online at: http://www.antaranews.com/en/news/1282830376/million-friends-zero-enemies-policy-vs-bintanincident

Aljazeera, "Joko Widodo: A strong message to drug smugglers", 7 March 2015, available online at: www.aljazeera.com/programmes/talktojazeera/2015/03/joko-widodo-strong-message-drug-smugglers$\underline{150305131413414 . \mathrm{html}}$

BBC, “Polemik Hendropriyono", August 14, 2014, available online at: http://www.bbc.co.uk/indonesia/berita indonesia/2014/08/140811 polemik hendropriyono.shtml

BBC, Philippine clashes: President warns Muslim rebels in Zamboanga, September 3, 2013, available online at: $\underline{\text { http://www.bbc.com/news/world-asia-24082614 }}$

Braun, Sebastian K, "Indonesia's Presidential Democracy in Comparison with Malaysia's System", Friedrich Naumann Foundation, September 2008, avaliable online at: http://www.fnfasia.org

Channel News Asia, "President Joko Widodo to visit Singapore", July 27, 2015, available online at: www.channelnewsasia.com/news/singapore

Detik, "Pemberian Grasi Sudah diperketat di UU yang Baru disahkan DPR", August 21, 2010, available online at: http://us.news.detik.com/read/2010/08/21/143943/1424856/10/pemberian-grasi-sudahdiperketat-di-uu-yang-baru-disahkan-dpr

Diela, Tabita on Jakarta Globe, "Project Inaugurated by President Joko Widodo in H1", Jakarta: August 3

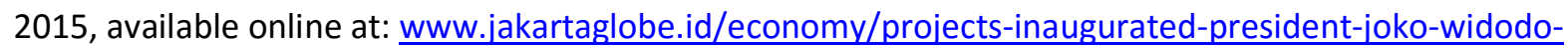
$\underline{\mathrm{h} 1 /}$

Ezequiel Minaya, "Venezuelan Leaders Seeks to Boost His Power", the Wall Street Journal, August 13, 2013, available online at http://online.wsj.com/news/articles/SB10001424127887324769704579009772676705350

Fas.org, "The Executive Order 12333: the US Intelligence Activities (as amended)", available online at: www.fas.org/irp/offdocs/eo/eo-12333-2008.pdf- 
Rosa Ristawati: Modelling Executive Powers in the Indonesian Constitution: A comparative Study

Fox News, "Constitution Allows Obama to Strike Syria Without Conggresional Approval", August 8, 2013, available online at: http://www.foxnews.com/opinion/2013/08/30/constitution-allows-obama-to-strikesyria-without-congressional-approval/

Hukumonline, "MK ultimatum DPR dan Pemerintah", Jakarta: August 14, 2008, available online at: http://www.hukumonline.com/berita/baca/hol19919/mk-ultimatum-dpr-dan-pemerintah-

Indonesia Media Online, "Sembilan Menteri Tak Pantas Dapat Bintang Jasa", August 15, 2013, available online at: http://www.shnews.co/detile-23423-sembilan-menteri-tak-pantas-dapat-bintang-jasa.html:

Inquirer.net, "The Court of Appeals junks Arroyo "midnight appointments", September 6, 2013, available online at: http://newsinfo.inquirer.net/482351/ca-junks-arroyo-midnight-appointments

Kompas, "Putusan MK Peringatan Keras Untuk Pemerintah", Jakarta: August 13 2008, available online at:

http://female.kompas.com/read/2008/08/13/13194986/putusan.mk.peringatan.keras.untuk.pemerinta $\underline{h}$

Kompas, "Mungkinkah Presiden gunakan hak abolisi?", November 23, 2009, available online at: http://nasional.kompas.com/read/2009/11/23/19475194/Mungkinkah.Presiden.Gunakan.Hak.Abolisi

Kompas, "Ketika Presiden Memberi Penghargaan untuk Istrinya", Jakarta: August 12, 2011, available online at: http://sejarah.kompasiana.com/2011/08/12/ketika-presiden-memberi-penghargaan-untukistrinya-387650.html

Kompas, "Indonesia vs Malaysia Fenomena Perbatasan Negara Berdaulat", Jakarta: April 4, 2013, available online at: http://hankam.kompasiana.com/2011/04/13/indonesia-vs-malaysia-fenomenaperbatasan-negara-berdaulat-355153.html

Kompas, "Ini Hasil Resmi Rekapitulasi Suara Pilpres 2014", Jakarta: July 22, 2014, available online at: http://indonesiasatu.kompas.com/read/2014/07/22/20574751/ini.hasil.resmi.rekapitulasi.suara.pilpres. $\underline{2014}$

Kwok, Yenny on Time, "Indonesia's Jokowi marks 100 days of presidency with scandal, falling support", January 28, 2015, available online at: www.timeinc/time/3685421/indonesia-joko-widodo-100-days-ofpresidency/\%3fsource $=$ dam

Lingao, Ed, on Philippine Center for Investigative Journalism, "Day after P-Noy Proclaimed President Arroyo made 13 midnight appointments on June 10", Manila, July 11, 2010, available online on: http://pcij.org/stories/arroyo-made-13-\%E2\%80\%98midnight-appointments\%E2\%80\%99-on-june-10/

MataNews, "The DPR's threat for the Republic Indonesia ambassador in the Switzerland", April 24, 2011, available online at: http://matanews.com/2011/04/24/ancaman-dpr-untuk-dubes-swiss/

Mallett-Outtrim, Ryan, "Venezuela's Legislature Gives Maduro Decree Powers to fight against Corruption and Economic War", Venezuelananalysis.com, November 20, 2013, available online on 
Rosa Ristawati: Modelling Executive Powers in the Indonesian Constitution: A comparative Study

\section{http://venezuelanalysis.com/news/10178}

Marlow, Ian for The Globe and Mail, "It was brave for Indonesia's President to decline bids from Japan and China", Sept 10, 2015 available online at: www.theglobeandmail.com/opinion/it-was-brave-for-indonesiaspresident-to-decline-bids-from-japan-and-china/article26321657/?arc404=true

Merdeka.com, “Benarkah lepasnya Timor-Timur Karena Kesalahan Habibie?”, Jakarta: June 132013, available online at: http://www.merdeka.com/peristiwa/benarkah-lepasnya-timor-timur-karenakesalahan-habibie.html

Merdeka, "Adnan Buyung Gembira Atas Putusan Patrialis Sebut SBY Otoriter", December 24, 2013, available online at: http://www.merdeka.com/peristiwa/adnan-buyung-gembira-atas-putusan-patrialissebut-sby-otoriter.html

Mietzner, Marcus on indoupdate, "SBY's mixed legacy”, available online at: www.indoupdate.com

Owen, Nicholas on Reuters, "Indonesia's Widodo seeks to tame bureaucrats blocking infrastructure drive", July 23 2015, available online at: www.reuters.com/article/uk-indonesia-widodobureaucrats/indonesias-widodo-seeks-to-tame-bureaucrats-blocking-infrastructure-driveidUKKCNOPYOOL200150724

Reuters, “Indonesia's Prabowo claims 'massive' fraud in presidential election”, August 6, 2014, available online at:

http://uk.reuters.com/article/2014/08/06/uk-indonesia-politics-idUKKBN0G60CV20140806

Rufo, Aries, on abs-cbnNews.com, "Arroyo issues midnight madness of appointments", June, 3 2010, available online at: http://www.abs-cbnnews.com/nation/06/03/10/arroyo-issues-midnight-madnessappointments

Salim, Tama on The Jakarta Post, "Jokowi criticized for assigning ministers for specific countries", Jakarta: November 26, 2015, available online at:

www.thejakartapost.com/amp/news/2015/11/26/jokowi-critized-assigning-ministers-specificcountries.html

Salim, Tama on The Jakarta Post, "President Jokowi to visit Obama in October", Jakara: September 23, 2015, available online at www.thejakartapost.com/amp/news/2015/09/23/president-jokowi-visitobama-october.html

Schneier, Edward, "The Role of Constitution-Building Processes in Democratization: Case Study Indonesia, International IDEA Democracy- building and Conflict Management (DCM)", Sweden, 2005, available online at: http://www.idea.int/conflict

Setiaji, Hidayat, Suroyo Gayatri on Reuters, "Indonesia's President reshuffles economy team as growth sags", August 12, 2015, available online at: www.reuters.com/article/amp/idUSKCNOQH06Y20150812

Straits Times, "Singapore concerned over naming Indonesian navy ship", available online at: 
Rosa Ristawati: Modelling Executive Powers in the Indonesian Constitution: A comparative Study

http://www.straitstimes.com/breaking-news/singapore/story/singapore-registers-concerns-overindonesian-navy-ship-20140206

The Jakarta Globe, SBY's Inaugural Speech: The Text 2009, available online at: http://www.thejakartaglobe.com/archive/sbys-inaugural-speech-the-text/

The Jakarta Post, "Million Friends Diplomacy", Jakarta, 13 June 2010, available online at: http://www.thejakartapost.com/news/2010/06/13/\%E2\%80\%98a-million-friends\%E2\%80\%99diplomacy.html

The Jakarta Post, "Analyst says health minister's resignation proves flaw in Cabinet selection", Jakarta Post, April 26, 2012, available online at: http://www.thejakartapost.com/news/2012/04/26/analystsays-health-minister-s-resignation-proves-flaw-cabinet-selection.html

The Jakarta Post, "Fuel's price compromise faces constitutional challenge", Jakarta: April 3, 2012, available online at: http://www.thejakartapost.com/news/2012/04/03/fuel-price-compromise-facesconstitutional-challenge.html

The Jakarta Post, "BPK calls government compliance on Newmont", Jakarta: April 4, 2012, available online at: http://www.thejakartapost.com/news/2012/04/04/bpk-calls-govt-compliance-newmont.html

The Jakarta Post, "State budget should not be reviewed", Jakarta: April 5, 2012, available online at: http://www.thejakartapost.com/news/2012/04/05/state-budget-should-not-be-reviewed.html

The Jakarta post, "Analyst says health minister's resignation proves flaw in Cabinet selection", Jakarta Post, Thursday, 04/26/2012, available online at:

http://www.thejakartapost.com/news/2012/04/26/analyst-says-health-minister-s-resignation-proves$\underline{\text { flaw-cabinet-selection.html }}$

The Straits Times, "Jokowi's police chief pick Budi Gunawan sworn in as deputy chief afterr graft row", April 22, 2015, available online at: www.straitstimes.com/asia/se-asia/jokowis-police-chief-pick-budigunawan-sworn-in-as-deputy-chief-after-graft-row

US State Government Website, The US National security act 1947 available online at www.state.gov/www/about state/history/intel/intro6.html

Utama, Abraham on CNN Indonesia, "Koalisi Indonesia Hebat Berubah Nama Jadi Koalisi Pemerintah", Jakarta: November 17, 2015, available online at: www.cnnindonesia.com/poliik/20151117194200-3292312/koalisi-indonesia-hebat-berubah-nama-jadi-koalisi-pemerintah/

William Pesek, The Economic Times, "Indonesian President Joko Widodo aims to revitalize his team \&agenda to restore confidence in economy", Oct $6^{\text {th }} 2015$

Yusuf, Aly, "Evaluasi Pemerintahan SBY - KALLA, Policy Assessment", The Indonesian Institute, Juni 12 2005, available online at: www.theindonesianinstitute.com/evaluasi-pemerintahan-sby-kalla/ 


\section{Constitutions:}

German Constitution, Deutscher Bundestag, Basic Law for the Federal Republic of Germany, Translated by Christian Tomuschat and David P. Currie, Donald P. Kommers in cooperation with the Language Service of the German Bundestag, Printed version at November 2012.

South Africa's Constitution of 1996 with Amendments through 2012, generated from excerpts of texts from the repository of the Comparatice Constitutions Project and accessed at www.constituteproject.org

The United State of America's Constitution of 1789 with Amendments through 1992, generated from excerpts of texts from the repository of the Comparative Constitutions Project, accessed at www.constituteproject.org

Philippines's Constitution of 1987, generated from excerpt of texts from the repository of the Comparative Constitutions Project, accessed at www.constituteprojects.org

France's Constitution of 1958 with Amendments through 2008, generated from excerpts of texts from the repository of the Comparative Constitutions Project, accessed at www.constituteproject.org

Poland's Constitution of 1997 with Amendments through 2009, generated from excerpts of texts from the repository of the Comparative Constitutions Projects, accessed at www.constituteproject.org

Indonesia's Constitution of 1945, Reinstated in 1959, with Amendments through 2002, Constitute, accessed at www.constituteproject.org

Naskah Komprehensif Perubahan Undang-Undang Dasar Republik Indonesia Tahun 1945, Buku 1: Latar Belakang, Proses dan Hasil Perubahan UUD 1945, Edisi Revisi, Sekretariat Jenderal dan Kepaniteraan Mahkamah Konstitusi, 2012 
Rosa Ristawati: Modelling Executive Powers in the Indonesian Constitution: A comparative Study

\section{Appendix 1}

Excerpts from The First Indonesian 1945 Constitution (the UUD 194518 August 1945)

Source: Naskah Komprehensif Perubahan UUD 1945, Edisi Revisi, Sekretariat Jenderal dan Kepaniteraan Mahkamah Konstitusi, 2012 (translation by the author)

\begin{tabular}{|c|c|}
\hline Articles & \\
\hline $\begin{array}{l}\text { Provision III of the } \\
\text { Transitional Provision }\end{array}$ & $\begin{array}{l}\text { At the first time the Republic of Indonesia is established, the President and the Vice President shall be elected by } \\
\text { the Preparatory Committee for Indonesia's Independence }\end{array}$ \\
\hline $\begin{array}{l}\text { Provision IV of the } \\
\text { Transitional provision }\end{array}$ & $\begin{array}{l}\text { Prior to the formation of the MPR, the DPR, and the DPA in accordance with this Constitution, all their powers } \\
\text { shall be exercised by the President assisted by a a national committee }\end{array}$ \\
\hline Article 3 & The MPR has the power to enact the Constitution and the GBHN (the guidelines of the state policy) \\
\hline Article 5 section (1) & The President shall hold the power to make Laws with the DPR's approval \\
\hline Article 5 section (2) & The President shall make the government regulationsas the directives to the Laws \\
\hline Article 10 & The President is the Supreme Commander of the Army, the Navy, and the Air Force. \\
\hline Article 11 & $\begin{array}{l}\text { With the approval from the DPR, the President declares war, makes peace and concludes treaties with other } \\
\text { states }\end{array}$ \\
\hline Article 12 & $\begin{array}{l}\text { The President declares the state of emergency. The conditions for such a declaration and the measures to deal } \\
\text { with the emergency shall be set by law. }\end{array}$ \\
\hline Article 13 section (1) & The President appoints ambassadors and consuls \\
\hline Article 13 section (2) & The President receives the credentials of foreign ambassadors \\
\hline Article 14 & The President grants mercy, amnesty, pardon, and restoration of rights \\
\hline Article 15 & The President grants titles, decorations, and other distinctions of honors \\
\hline Article 17 Section (1) & The President shall be assisted by the Ministers of State. \\
\hline Article 17 Section (2) & The ministers are appointed and dismissed by the President \\
\hline Article 17 Section (3) & The Ministers shall head the government departments \\
\hline Article 22 Section (1) & $\begin{array}{l}\text { In case of a compelling emergency, the President has the right to issue government regulations in lieu of laws } \\
\text { (the emergency laws) }\end{array}$ \\
\hline Article 22 Section (2) & Such regulations shall have the consent from the DPR during its subsequent sessions \\
\hline Article 22 Section (3) & Where the approval of the DPR is not obtained, the government regulation shall be revoked \\
\hline $\begin{array}{l}\text { Chapter VII on State } \\
\text { Finance, Article } 23 \\
\text { section (1) }\end{array}$ & $\begin{array}{l}\text { The annual state budgetary shall be set by law. In case of the DPR rejects the draft of budget, the government } \\
\text { shall adopt the budget of the preceding year }\end{array}$ \\
\hline Article 23 section (5) & $\begin{array}{l}\text { In order to examine the accountability of the state finances, a State Auditor shall be established by law. The audit } \\
\text { report of the state auditor shall be reported to the DPR. }\end{array}$ \\
\hline $\begin{array}{l}\text { Transitional Provision } \\
\text { Clause IV }\end{array}$ & $\begin{array}{l}\text { Prior to the formation of the MPR, the DPR, the DPA (Supreme Advisory Council) in accordance with this } \\
\text { Constitution, all their powers shall be exercised by the President assisted by a national committee. }\end{array}$ \\
\hline $\begin{array}{l}\text { Chapter VII paragraph } \\
2-4\end{array}$ & $\begin{array}{l}\text { The President in exercising his powers has to take into consideration of the DPR's opinion. The President cannot } \\
\text { dissolve the DPR. The members of the DPR are also members of the MPR. The DPR is acting as counterbalance to } \\
\text { the President. It functioned to oversee that the President's has to act in accordance with the guidelines of the } \\
\text { state policy which been set by the MPR. In any reasons that the DPR is in opinion that the President has acted in } \\
\text { contrarary to the state policy as laid down in the Constitution and the state guidelines that had set by the MPR, } \\
\text { the MPR can call for a special session and request for the president's accountability }\end{array}$ \\
\hline $\begin{array}{l}\text { Article } 22 \text { of the } \\
\text { constitutional } \\
\text { explanation }\end{array}$ & $\begin{array}{l}\text { Article } 22 \text { of the Constitution concerns the emergency rights (noodverordeningsrect) of the President. The } \\
\text { necessity to have the article } 22 \text { is that the article will give constitutional basis for the government to guarantee } \\
\text { the safety of the country by taking prompt and appropriate action. However, by the article, the government } \\
\text { cannot eschew from the DPR's control. The DPR mayput intervention to the president's emergency power by } \\
\text { approving the emergency law issued by the President on behalf of government. }\end{array}$ \\
\hline $\begin{array}{l}\text { The annotation to the } \\
\text { constitutional provision } \\
23\end{array}$ & $\begin{array}{l}\text { Besides the DPR represents the peoples and whereas the people has the right to participate in determining the } \\
\text { state income and expenses, how the government spends the money (approved by the DPR) }\end{array}$ \\
\hline Annotation IV & $\begin{array}{l}\text { "Under the People's Consultative Assembly, the President is the highest government executive. In running the } \\
\text { administration, the power and the responsibility are restedin the President. }\end{array}$ \\
\hline
\end{tabular}


Rosa Ristawati: Modelling Executive Powers in the Indonesian Constitution: A comparative Study

\section{Appendix 2}

Excerpts from The Federal Republic Indonesia Constitution 1949 (KRIS 1949)

Translation by the author

\begin{tabular}{|c|c|}
\hline Articles & \\
\hline Chapter III & $\begin{array}{l}\text { The state institutions are the President, the ministers, the senate, the people representative (the DPR), the } \\
\text { Indonesia Supreme Court, and the Council of state financial auditor. }\end{array}$ \\
\hline Article 68 Section (1) & The President and the ministers altogether are the government of the State. \\
\hline Article 68 Section (2) & $\begin{array}{l}\text { As the state government, the President and a minister or some or all the ministers, have special responsibility or } \\
\text { general responsibility. The government of the State has to be in Jakarta and in case of the state of emergency, the } \\
\text { government has the power to decide other places to be the head quarter of the state }\end{array}$ \\
\hline Article 85 Section (1) & The President has the power to appoint the Chief of Senate according to the advice of the Senate. \\
\hline Article 117 (2) & $\begin{array}{l}\text { The government has the power to establish the Indonesia state welfare and specially to maintain the Constitution, } \\
\text { the Federal Law, and other rules that are applied in Indonesia }\end{array}$ \\
\hline Article 120 section (2) & $\begin{array}{l}\text { The Ministers have to give written or oral explanation to the DPR as they required, as long as it is not against the } \\
\text { public interest of the Republic Federal of Indonesia }\end{array}$ \\
\hline Article 123 & $\begin{array}{l}\text { Section (1) The government takes notice to the Senate only if it deemed to be necessary. } \\
\text { Section (3) The Senate is to be considered about the important and special affairs regarding some or all states or } \\
\text { part of the states or a special relationship between the Republic Federal of Indonesia and the states. The rule is } \\
\text { excluded in any urgent and emergency situation that needed to be taken of an emergency action while the Senate } \\
\text { is in recess. } \\
\text { Section (4) The Senate is considered instead of the bill of the emergency law } \\
\text { Section (5) The Government shall have to notify the Senate all the decisions that the Senate has the right to be } \\
\text { considered } \\
\text { Section (6) In accordance that the Senate is considered, it is mentioned in the head of the Decision Letter }\end{array}$ \\
\hline Article 128 section(1) & $\begin{array}{l}\text { The proposal from the Government on the Legislation is delivered to the DPR through the Presidential message and } \\
\text { will be sent to the Senate to be noted. }\end{array}$ \\
\hline Article 128 section (2) & $\begin{array}{l}\text { The Senate has the right to propose the bill of legislation to the DPR on particular issues regarding to Article 127a. } \\
\text { The Senate uses the rights by notifyng the copy of bill proposal to the President. }\end{array}$ \\
\hline Article 128 section (3) & The DPR has the right to propose the bill of the Legislation to the Government. \\
\hline Article 139 section (1) & $\begin{array}{l}\text { The Government has the right to authorize and responsible to enact the emergency law, to adjust to the } \\
\text { establishment of the Federal administration in time of emergency that needs to be taken in action. }\end{array}$ \\
\hline $\begin{array}{l}\text { Article } 139 \text { Section } \\
\text { (2) }\end{array}$ & The emergency lawsare the Federal Law without prejudice \\
\hline Article 140 section (2) & If the emergency law is rejected by the DPR, the law $\mathrm{i}$ \\
\hline $\begin{array}{l}\text { Article } 140 \text { Section } \\
\text { (3) }\end{array}$ & If the emergency law is no longer valid and it is not being amended, the Federal law shall take action on it. \\
\hline $\begin{array}{l}\text { Article } 140 \text { Section } \\
\text { (4) }\end{array}$ & $\begin{array}{l}\text { If the rules determined in the emergency law is changed and enacted as the federal laws, all the consequences shall } \\
\text { be adjusted to the laws. }\end{array}$ \\
\hline $\begin{array}{l}\text { Article } 141 \text { Section } \\
\text { (1) }\end{array}$ & $\begin{array}{l}\text { The government regulations as directive to the Legislation are made by the government and have the functions to } \\
\text { implement the legislation }\end{array}$ \\
\hline $\begin{array}{l}\text { Article } 141 \text { Section } \\
\text { (2) }\end{array}$ & The government regulationscan be completed with the sanctions. The sanction is limited by the Federal laws. \\
\hline (1) & $\begin{array}{l}\text { The President shall have the right to give pardon. The pardon shall be given after the advice from the Supreme } \\
\text { Court, and given by the Federal law without asking other Courts to give the advice. }\end{array}$ \\
\hline $\begin{array}{l}\text { Article } 160 \text { Section } \\
\text { (2) }\end{array}$ & $\begin{array}{l}\text { If the capital punishment is determined by the Court, it shall not be executed before the President decided to give } \\
\text { or reject the pardon }\end{array}$ \\
\hline $\begin{array}{l}\text { Article } 160 \text { Section } \\
\text { (3) }\end{array}$ & $\begin{array}{l}\text { The Amnesty shall only be given by the Federal Law or according to the authorization of the Federal Law by the } \\
\text { President after asking for the advice from the Supreme Court }\end{array}$ \\
\hline Article 176 & $\begin{array}{l}\text { According to the treaty and agreements that determined by Article } 175 \text {, the Government shall decide to participate } \\
\text { in the International organizations }\end{array}$ \\
\hline
\end{tabular}


Rosa Ristawati: Modelling Executive Powers in the Indonesian Constitution: A comparative Study

\begin{tabular}{|c|c|}
\hline Article 178 & $\begin{array}{l}\text { The President appoints the Republic Federal of Indonesia's representatives for other states and accepts other } \\
\text { states representatives }\end{array}$ \\
\hline Article 181 (1) & The Government has the power of state defense affairs \\
\hline $\begin{array}{l}\text { Article } 18 \\
\text { (3) }\end{array}$ & $\begin{array}{l}\text { The officers of the state defense are appointed, promoted, and dismissed on behalf of the President and according } \\
\text { to the Federal Law }\end{array}$ \\
\hline Article 184 section (1) & $\begin{array}{l}\text { According to the Federal Law, the Government declares the Republic Federal of Indonesia or part of the state is } \\
\text { under the war or under the emergency war when it is necessary and urgent for the national interest and } \\
\text { international security }\end{array}$ \\
\hline Article 184 section (2) & $\begin{array}{l}\text { The Federal Law regulates the consequences of the declaration of the state of emergency and stipulates that the } \\
\text { civil power according to the Constitution, the public order, and the policy, can be transferred to other civil powers } \\
\text { or military powers. Whereas, civil authority can be subjected to the military powers. }\end{array}$ \\
\hline Article 186 & $\begin{array}{l}\text { The "Konstituante" (the Committee of Constitution), together with the Government shallimmediately set the } \\
\text { Constitution of Republic of Federal Indonesia replacing the temporary Constitution }\end{array}$ \\
\hline $\begin{array}{l}\text { Article } 187 \text { Section } \\
\text { (1) }\end{array}$ & $\begin{array}{l}\text { The draft of the Constitution is made by the Government with the presidential mandate to the Konstituante to be } \\
\text { discussed in a session }\end{array}$ \\
\hline $\begin{array}{l}\text { Article } 187 \text { Section } \\
\text { (2) }\end{array}$ & $\begin{array}{l}\text { The Government shall ensure that the draft of the Constitution is according to the development of the Republic of } \\
\text { the Federal Indonesia, the people's will and democracy in article } 43 \text { and } 46\end{array}$ \\
\hline Article 1 & $\begin{array}{l}\text { The "Konstituante" consists of all members of the DPR that has been elected according to Article 111, the new } \\
\text { Senate that has been elected according to Article } 97 \text { and the ad-hoc members. }\end{array}$ \\
\hline Article 189 & $\begin{array}{l}\text { (1) the "Konstituante" cannot held session and decide the draft of the New Constitution if the session is not held by } \\
\text { at least } 2 / 3 \text { of the members } \\
\text { (2) the Konstituante has the right to change the draft of the Constitution. The new Constitution is enacted if the } \\
\text { draft of the Constitution is accepted by at least } 2 / 3 \text { of the present members and will be validated by the } \\
\text { Government } \\
\text { (3) If the draft of the Constitution has been accepted by the Konstituante, it will be sent to the President to be } \\
\text { validated by the Government. The Government shall validate the draft of the Constitution immediately and shall } \\
\text { publish the Constitution } \\
\text { (4) Each of the states is given the opportunity to accept the Constitution. In term that the State does not accept the } \\
\text { Constitution, the Federal State has the right to discuss on a special relationship of the Republic Federal of Indonesia } \\
\text { and the Kingdom of the Netherlands }\end{array}$ \\
\hline Article 196 & $\begin{array}{l}\text { After the Constitution is enacted, the Government order a committee that is appointed to run its duties as the } \\
\text { direction, work and make sure that the rules that are needed by the Constitution is set, and all the Laws is set and } \\
\text { adjusted according to the Constitution }\end{array}$ \\
\hline
\end{tabular}


Rosa Ristawati: Modelling Executive Powers in the Indonesian Constitution: A comparative Study

\section{Appendix 3}

Excerpts from The Temporary Constitution 1950 of Indonesia (the UUDS 1950)

Translation by the author

\begin{tabular}{|c|c|}
\hline Articles & \\
\hline Article 45 & $\begin{array}{l}\text { 1. the President is the head of the state. } \\
\text { 2. in exercising his duties, the President is assisted by a Vice President } \\
\text { 3. the President and the Vice President is elected according to the Law } \\
\text { 4. For the first time, the Vice President is appointed by the President with the advice by the DPR }\end{array}$ \\
\hline Article 46 & $\begin{array}{l}\text { 1. The President and the vice president hold the position in the government office } \\
\text { 2. The government is based in Jakarta. In term of emergency, the government has the right to decide others }\end{array}$ \\
\hline Article 48 & $\begin{array}{l}\text { If the President died, resign, or cannot run his duties in his office period, he can be replaced by his vice president until the } \\
\text { office term is finished }\end{array}$ \\
\hline Article 50 & The President establishes the ministries. \\
\hline Article 52 & $\begin{array}{l}\text { 1. In a joint discussion session to discusspublic interests of the Republic of Indonesia, the Ministers hold the Council } \\
\text { Minister session which are chaired by the Prime minister or if the Prime minister is in absence, by the Minister who is } \\
\text { appointed by the Council of the Minister } \\
\text { 2. The Council of the Minister always informs all the important affairs to the President and the Vice President. A minister } \\
\text { has the duties to do so in terms of the special affairs that are belongs to his duty }\end{array}$ \\
\hline Article 55 & $\begin{array}{l}\text { 1. the president, vice president, and ministersare prohibited tohave double offices, neither in Indonesia nor abroad } \\
\text { 2.the President, the vice President and ministers are prohibited to directly or indirectly involved in a corporation according } \\
\text { to the agreement to have profits or benefits, neither with the Republic of Indonesia nor with one of the autonomy } \\
\text { provinces in Indonesia } \\
\text { 3. They cannot have any claims on behalf of the Republic of Indonesia except for general state obligations } \\
\text { 4. The prohibitions are also valid for the period three years after the office is finished }\end{array}$ \\
\hline Article 79 & $\begin{array}{l}\text { 1. The chief, the vice-chief and the Supreme Court members are appointed according to the laws. The appointment is for } \\
\text { the whole life } \\
\text { 2. The Legislation decides that the Chief, the vice-chief, or the members of the Supreme Court, to be dismissed in certain } \\
\text { ages } \\
\text { 3. They can be dismissed or fired according to the procedures set by the laws } \\
\text { 4. They can be dismissed by the President or by their proposal }\end{array}$ \\
\hline Article 81 & $\begin{array}{l}\text { 1. The chief or the vice chief or the members of the state auditoris appointed according to the laws. The appointment is for } \\
\text { the whole life. } \\
\text { 2. The Legislation decides that the chief, the vice chief, or the members of the state auditor is dismissed in certain ages } \\
\text { 3. They can be removed or dismissed according to the laws } \\
\text { 4. The can be dismissed by the President }\end{array}$ \\
\hline $\begin{array}{l}\text { Article } 83 \\
\text { section } 1 \\
\end{array}$ & The President and the Vice President are inviolability \\
\hline $\begin{array}{l}\text { Article } 83 \\
\text { Section (2) }\end{array}$ & The Ministers are responsible for all the government policy either jointly or individually \\
\hline Article 84 & $\begin{array}{l}\text { The President has the rights to dissolve the DPR. A presidential decision declares the dissolution and orders to set the new } \\
\text { DPR's election within } 30 \text { days }\end{array}$ \\
\hline Article 85 & $\begin{array}{l}\text { All the Presidential decrees including those concerning the performance of presidential military powers military powers } \\
\text { shall be countersigned by the ministers; except for the decree concerning on the appointment of the vice president (upon } \\
\text { the recommendations submitted by the House of representative in article } 45 \text { paragraph } 4 \text { ) and decree concerning the } \\
\text { appointment of the cabinet committee and of ministers in accordance to the recommendation of the cabinet committee } \\
\text { (article } 52 \text { paragraph 4). }\end{array}$ \\
\hline Article 87 & the President gives the honorable titles according to the laws \\
\hline Article 90 & $\begin{array}{l}\text { 1. The government's proposal on the bill of the legislation is delivered to the DPR by the presidential message } \\
\text { 2. The DPR has the right to propose the bill of legislation to the government }\end{array}$ \\
\hline Article 91 & the DPR has the right to change the proposal of Legislation that is proposed by the Government \\
\hline Article 92 & $\begin{array}{l}\text { 1. If the DPR accepts the proposal of legislation either with or without any changes, the proposal is sent with the } \\
\text { notification to the President } \\
\text { 2. If the DPR rejects the proposal of legislation from the government, it shall be notified to the President }\end{array}$ \\
\hline Article 93 & $\begin{array}{l}\text { if the DPR decides to process the proposal of Legislation, they will send the proposal to be validated by the government to } \\
\text { the President }\end{array}$ \\
\hline Article 94 & $\begin{array}{l}\text { 1. As long as the proposal of Legislation has not been accepted by the DPR according to the law, the proposal can } \\
\text { be withdrawn by the government } \\
\text { 2. The Government shall validate the proposal of Legislation that has been accepted except if within one month, it } \\
\text { is being challenged. } \\
\text { 3. The validation by the government or the government's objection as mentioned in previous article will be notified }\end{array}$ \\
\hline
\end{tabular}


Rosa Ristawati: Modelling Executive Powers in the Indonesian Constitution: A comparative Study

\begin{tabular}{|c|c|}
\hline & by the DPR \\
\hline Article 96 & $\begin{array}{l}\text { Section 1. The government has the right of authority and responsibility to set the emergency law that determined the state } \\
\text { administration and the government affairs because of the urgent situation that shall need to be immediately anticipated. } \\
\text { Section } 2 \text { of the Article stipulates that the emergency law has the power and the degree as legislation. }\end{array}$ \\
\hline Article 97 & $\begin{array}{l}\text { 1. The rules which are determined in the emergency law, after they are set, shall be delivered to the DPR at least in the next } \\
\text { session. The DPR will discuss the law according to the procedures } \\
\text { 2. If the emergency law is rejected, the law is invalid. } \\
\text { 3. If the emergency law is invalid and does not determine the consequences, either the situation can be recovered or not, it } \\
\text { shall have to be determined the action in anticipating the result and consequences. } \\
\text { 4. If the substance on the emergency law is changed and the emergency law is set as legislation, the results and its } \\
\text { consequences shall be determined according to the law }\end{array}$ \\
\hline Article 98 & $\begin{array}{l}\text { 1. The rules establish legislation is set by the Government. It is called by the government rules } \\
\text { 2. The government rules can have criminal sanctions against the violation. The sanction is limited by the legislation }\end{array}$ \\
\hline $\begin{array}{l}\text { Article } 99 \\
\text { Section (1) }\end{array}$ & $\begin{array}{l}\text { the Legislation and the government rules can order other state institutions to regulate certain subjects which are } \\
\text { determined in the laws }\end{array}$ \\
\hline $\begin{array}{l}\text { Article } 106 \\
\text { Section (1) }\end{array}$ & $\begin{array}{l}\text { the President, the vice president, the ministers, the chief and the vice chief and the members of the DPR, the chief, the vice } \\
\text { chief and the members of the Supreme Court, state prosecutor in the Supreme Court, the chief, the vice chief, and the } \\
\text { members of the council of the state financial supervisor, the President of the bank, the members of the highest institutions } \\
\text { and other state officers who are appointed by the legislation, are prosecuted in the first and highest Supreme Court after } \\
\text { their resignation. The prosecution can be held because of the crimes and official violation and other crimes and other } \\
\text { violations that are determined by the legislation and acted within their office }\end{array}$ \\
\hline Article 107 & $\begin{array}{l}\text { 1. The President has the right to give pardoning. The pardoning is given after asking the advice from the Supreme } \\
\text { Court } \\
\text { 2. In case of death penalty, it cannot be executed before the President decides to give or not to give the pardoning } \\
\text { 3. The Amnesty and abolition is only be given by law or on behalf of the law, by the President after asking the } \\
\text { advice to the Supreme Court }\end{array}$ \\
\hline $\begin{array}{l}\text { Article } 109 \\
\text { Section } 4\end{array}$ & Valid payment tools are diffused by the government of the Republic of Indonesia or the bank. \\
\hline $\begin{array}{l}\text { Article } 111 \\
\text { Section } 1\end{array}$ & The government holds the financial general affairs. The state financial is managed and responsible according to the law \\
\hline $\begin{array}{l}\text { Article } 112 \\
\text { Section } 1\end{array}$ & $\begin{array}{l}\text { The state auditor shall audit the state financial. Furthermore, section } 2 \text { of the Article stated that the report of the } \\
\text { auditingare submitted to the DPR }\end{array}$ \\
\hline Article 114 & $\begin{array}{l}\text { 1. The proposal ofthe state budget legislation is proposed to the DPR bu the government in early of the year that shall not } \\
\text { within } 2 \text { years } \\
\text { 2. The proposal to amend the state budget legislation is proposed to the DPR by the government }\end{array}$ \\
\hline Article 116 & the state expenses and the state incomes of the Republic of Indonesia are being responsible to the DPR \\
\hline Article 117 & $\begin{array}{l}\text { The government shall not collect tax, customs for the benefit of the state instead of according to the Law or authorized by } \\
\text { the laws }\end{array}$ \\
\hline $\begin{array}{l}\text { Article } 120 \\
\text { Section } 1\end{array}$ & $\begin{array}{l}\text { the President makes and ratifies treaty and other agreements between other states. Instead of contradictory to the laws, } \\
\text { the treaty or other agreements shall not be ratified. They shall be approved by the Legislation". }\end{array}$ \\
\hline $\begin{array}{l}\text { Article } 120 \\
\text { Section } 2 \\
\end{array}$ & The President concludes and decidestreaty and other agreements by the Laws" \\
\hline $\begin{array}{l}\text { Article } 127 \\
\text { Section } 1 \text { - } \\
\text { Section } 3\end{array}$ & $\begin{array}{l}\text { 1. the President has the highest power in the army of the Republic of Indonesia. } \\
\text { 2. the government assigns the army under a commander in chief. The President has the power to appoint and } \\
\text { dismiss the army officers. } \\
\text { 3. the army officers are appointed and dismissed by and on behalf of the President according to the laws". }\end{array}$ \\
\hline Article 128 & the President shall not declare war instead of by the approval from the DPR. \\
\hline $\begin{array}{l}\text { Article } 129 \\
\text { Section } 1\end{array}$ & $\begin{array}{l}\text { According to the laws, the President can declare the Republic of Indonesia or part of the Republic of Indonesia is under } \\
\text { dangerous situationson the basis of state security, public interest and international security }\end{array}$ \\
\hline
\end{tabular}


Rosa Ristawati: Modelling Executive Powers in the Indonesian Constitution: A comparative Study

\section{Appendix 4}

Excerpts from The Amended Constitution of Indonesia (the "UUDNRI 1945")

Source: Indonesia's Constitution of 1945, Reinstated in 1959, with Amendments through 2002, Constitute, accessed at www.constituteproject.org

\begin{tabular}{|c|c|}
\hline Articles & \\
\hline Article 11 Section (1) & $\begin{array}{l}\text { "The President with the approval from the DPR declares war, makes peace and concludes treaty with other } \\
\text { countries". }\end{array}$ \\
\hline Article 11 Section (2) & $\begin{array}{l}\text { "The President in making other international agreements, whichpotentially create an extensive and fundamental } \\
\text { impact on the people,influence the state financial burden, and/or require an amendment to or the enactment of a } \\
\text { law, shall obtain the approval from the DPR". }\end{array}$ \\
\hline Article 13 Section (1) & The President appoints ambassadors and consuls. \\
\hline Article 13 Section (2) & In the appointment of ambassadors, the President takes into account the consideration of the DPR \\
\hline Article 13 Section (3) & $\begin{array}{l}\text { The President receives the accreditation of ambassadors of foreign nations by taking into account the consideration } \\
\text { of the DPR }\end{array}$ \\
\hline Article 16 & $\begin{array}{l}\text { The President establishes an Advisory Council which has the duty to give advice and consideration to the President. } \\
\text { Furthermore, the establishment shall be regulated by Law }\end{array}$ \\
\hline Article 17 Section (1) & the Ministers are the President's assistant \\
\hline $\begin{array}{l}\text { Article 20A Section } \\
\text { (1) }\end{array}$ & The DPR shall hold legislative, budgeting and oversight functions \\
\hline Article 22 & $\begin{array}{l}\text { Section 1: In time of urgent and emergency situation, the President has the power to issue the government rule in } \\
\text { lieu the Legislation/ the emergency law } \\
\text { Section 2: Such law shall have approval from the DPR in the next session. However, if the DPR rejects, it shall be } \\
\text { revoked }\end{array}$ \\
\hline $\begin{array}{l}\text { Article 24A Section } \\
\text { (3) }\end{array}$ & $\begin{array}{l}\text { The candidates of the Supreme Court judges are proposed to the judicial commission to the DPR to have its } \\
\text { approval. They will be formally appointed as the Supreme Court judges by the President. }\end{array}$ \\
\hline $\begin{array}{l}\text { Article 24C Section } \\
\text { (3) }\end{array}$ & $\begin{array}{l}\text { The Constitutional Court has } 9 \text { judges that formally appointed by the President. The candidates are proposed by } \\
\text { each } 3 \text { judges from the Supreme Court, } 3 \text { judges form the DPR, and the three Judges from the President }\end{array}$ \\
\hline Article 30 Section (3) & $\begin{array}{l}\text { The TNI (the "Tentara Nasional Indonesia": the Indonesian National Military) consists of the Army, Navy, and Air } \\
\text { Force, as the state instrument, has duties to defend, protect, and maintain the state sovereignty and integrity }\end{array}$ \\
\hline
\end{tabular}


Rosa Ristawati: Modelling Executive Powers in the Indonesian Constitution: A comparative Study

\section{Appendix 5}

Excerpts from the National Legislations

Source: the Indonesian Laws, translation by the author

\begin{tabular}{|c|c|}
\hline Articles & \\
\hline & Law No. 37/1999 on Foreign Relations \\
\hline $\begin{array}{l}\text { Article } 6 \text { Section (1) } \\
\text { Law No. } 37 / 1999\end{array}$ & $\begin{array}{l}\text { The power to establish the International relation and to apply political foreign policy is in the hand of the President. } \\
\text { Whereas, the power to declare war, make peace, and the agreements with other states needs approval from the DPR }\end{array}$ \\
\hline $\begin{array}{l}\text { Article } 6 \text { Section (2) } \\
\text { Law No. 37/1999 }\end{array}$ & $\begin{array}{l}\text { The President delegates the power to establish the International relation and to apply the Republic of Indonesia } \\
\text { political foreign policy to the Minister }\end{array}$ \\
\hline $\begin{array}{l}\text { Article } 7 \text { Section (1) } \\
\text { Law No. 37/1999 }\end{array}$ & $\begin{array}{l}\text { The President appoints the state official in addition to the foreign affairs minister, the government official, or others } \\
\text { in order to establish foreign affairs relation in a particular field }\end{array}$ \\
\hline $\begin{array}{l}\text { Article } 9 \text { Section (1) } \\
\text { Law No. } 37 / 1999\end{array}$ & $\begin{array}{l}\text { The establishment and the termination of the diplomatic or consular with other states and the membership and the } \\
\text { membership termination from the international organization shall be decided by the President with the consideration } \\
\text { from the DPR. }\end{array}$ \\
\hline $\begin{array}{l}\text { Article } 9 \text { Section (2) } \\
\text { Law No. 37/1999 }\end{array}$ & $\begin{array}{l}\text { To establish and shutdown the diplomatic or consular representative office in other countries or the representative } \\
\text { office of Indonesian government in the international organization, the President shall make Presidential Decision. }\end{array}$ \\
\hline $\begin{array}{l}\text { Article } 10 \text { Law No. } \\
37 / 1999\end{array}$ & To send the troops or the peace keeping mission are decided by the President with the consideration from the DPR" \\
\hline $\begin{array}{l}\text { Article } 22 \text { Law No. } \\
37 / 1999\end{array}$ & $\begin{array}{l}\text { In terms of war or the termination of the diplomatic relation with other countries, the minister or the state officer } \\
\text { assigned by the President, coordinates effort for secure and protect national interest including the citizen. }\end{array}$ \\
\hline $\begin{array}{l}\text { Article } 25 \text { Law No. } \\
37 / 1999\end{array}$ & $\begin{array}{l}\text { Section 1: "the Authority to grant asylum for foreigner is in the hand of the President with the consideration from the } \\
\text { minister"; } \\
\text { Section (2): further shall be regulated by a presidential decision" }\end{array}$ \\
\hline $\begin{array}{l}\text { Article } 27 \text { Section } \\
\text { (1) Law No. } \\
37 / 1999\end{array}$ & $\begin{array}{l}\text { The President decides the policy against the refugees from outside countries with the consideration from the } \\
\text { minister; in section (2), the main policies shall be regulated by the Presidential decision. }\end{array}$ \\
\hline & Law No. $24 / 2000$ on International Agreements \\
\hline $\begin{array}{l}\text { Article } 2 \text { Law } \\
24 / 2000\end{array}$ & $\begin{array}{l}\text { The Foreign Minister has the competence to give the political consideration and take any actions against the treaty } \\
\text { making and its ratification. However, the Competences shall be consulted with the DPR }\end{array}$ \\
\hline $\begin{array}{l}\text { Article } 5 \text { Section (1) } \\
\text { Law No. 24/2000 }\end{array}$ & $\begin{array}{l}\text { The state institutions and the government institutions, whether it is a department or a non- department, in the } \\
\text { national level and local level, that has an initiative to make international agreements,shall consult and coordinate } \\
\text { with the minister. }\end{array}$ \\
\hline $\begin{array}{l}\text { The explanation off } \\
\text { Article } 11 \text { Section } \\
\text { (2) Law No. } \\
\text { 24/2000 }\end{array}$ & $\begin{array}{l}\text { Although the President does not need to ask for the DPR's approval, the DPR can oversee the government in terms of } \\
\text { treaty implementation, by monitoring the implementation the Laws (which transform a treaty or an agreement). }\end{array}$ \\
\hline & Law No. 2/2002 on the State Police of the Republic Indonesia \\
\hline $\begin{array}{l}\text { Article } 11 \text { Law No. } \\
2 / 2002\end{array}$ & $\begin{array}{l}\text { Within } 20 \text { days of work after the Presidential letter, the DPR shall give approval or disapproval. However, in case that } \\
\text { the DPR does not give any decisions, the candidate of the chief of police is assumed to be approved by the DPR. In } \\
\text { any urgent case, the Presidenttemporary dismisses the chief of police and appoint a temporary chief and ask the } \\
\text { DPR's approval. }\end{array}$ \\
\hline & Law No. 34/2004 on the National Army of Indonesia \\
\hline $\begin{array}{l}\text { Article } 13 \text { Law } \\
34 / 2004\end{array}$ & $\begin{array}{l}\text { The President proposes one name of the candidate chief of military to have the DPR's approval. The approval from } \\
\text { the DPR on the candidate of the chief military shall be given at least } 20 \text { days work after the proposal is received. In } \\
\text { case that the DPR rejects; the President shall propose other candidates. However, in case there is no response from } \\
\text { the DPR, the DPR is assumed to be agreed with the President's nominee }\end{array}$ \\
\hline & Law No. 16/2004 on the State Prosecutor \\
\hline $\begin{array}{l}\text { Article } 37 \text { Law } \\
16 / 2004\end{array}$ & The state prosecutor shall accountably make a report and shall submit it to the President and the DPR. \\
\hline & Law No. 1/2004 on the State Treasury \\
\hline $\begin{array}{l}\text { Article } 41 \text { Law } \\
1 / 2004\end{array}$ & $\begin{array}{l}\text { The government makes long-term investment to have economic, social, or other benefits. It can be in the form of } \\
\text { shares, obligations, and direct investments. The government encloses its shares to the state company, local } \\
\text { government company, or private company. }\end{array}$ \\
\hline $\begin{array}{l}\text { Article } 46 \text { Law } \\
1 / 2004\end{array}$ & $\begin{array}{l}\text { The DPR's approval shall be needed for transferring assets, property of land,building, and state property more than } 1 \\
\text { Billion Rupiah. }\end{array}$ \\
\hline $\begin{array}{l}\text { Article } 58 \text { Section } \\
\text { (1) Law } 1 / 2004\end{array}$ & $\begin{array}{l}\text { For the improvement of the government performance, the transparency and the accountability of the state finances } \\
\text { management, the President as the head of the government, has the power to comprehensively direct and establish } \\
\text { the system of the internal government control. }\end{array}$ \\
\hline
\end{tabular}


Rosa Ristawati: Modelling Executive Powers in the Indonesian Constitution: A comparative Study

\begin{tabular}{|c|c|}
\hline & Law. No. $39 / 2008$ on the State Ministry \\
\hline $\begin{array}{l}\text { Article } 14 \text { Law } \\
39 / 2008\end{array}$ & $\begin{array}{l}\text { For the purpose of synchronization and coordination among the ministerial affairs, the President may establish a } \\
\text { ministry of coordination". }\end{array}$ \\
\hline $\begin{array}{l}\text { Article } 22 \text { Law } \\
39 / 2008\end{array}$ & $\begin{array}{l}\text { The requirements to be appointed as minister are as follows:Indonesia citizenship, loyal to God, loyal to the } \\
\text { "Pancasila" as the state ideology, devoted to the UUD NRI } 1945 \text { as the Indonesia constitution,devoted to the aims of } \\
\text { the proclamation of independence, physically and mentally health, having high integrity and good personality and } \\
\text { never been sentenced to prison under the court decisions for committing serious crimes }\end{array}$ \\
\hline \multirow[t]{2}{*}{$\begin{array}{l}\text { Article } 20 \text { Law No. } \\
39 / 2008\end{array}$} & $\begin{array}{l}\text { The liquidation of a ministry (education, culture, health, social, labor, industry, trade, mining, energy, public work, } \\
\text { transmigration, transportation, information, communication, agriculture, plantation, forestry, animal husbandry, } \\
\text { marine and fisheries, national development planning, state apparatus, state secretariat, state company, land, } \\
\text { population, environment, science, technology, investment, cooperation, small and medium enterprises, tourism, } \\
\text { woman empowering, sports, housing and construction area or disadvantages area) shall have with the DPR } \\
\text { consideration. The DPR consideration shall also be asked by the President in terms of the liquidation of the ministry } \\
\text { of religion, Justice, finance, and defense. }\end{array}$ \\
\hline & $\begin{array}{l}\text { Law No. } 27 / 2009 \text { on the People Assemby, the People Representative Council, the Local } \\
\text { Representative Council, and the Local People Representative Council }\end{array}$ \\
\hline \multirow[t]{2}{*}{$\begin{array}{l}\text { Article } 265 \text { Law No. } \\
27 / 2009\end{array}$} & $\begin{array}{l}\text { Section 2: A member of the DPD shall not be prosecute and accused before the Court for the statement, question, } \\
\text { and/or opinion which delivered either written or unwritten within the DPD's session or outside the DPD's session } \\
\text { that related to the functions, duties and authorities of the DPD. } \\
\text { Section 3: A member of the DPD shall not be removed because of the statement, questions, and/or the opinion that } \\
\text { deliver within the session or outside session that related to the function, duties and authority of the DPD. }\end{array}$ \\
\hline & Law No. 12/2011 on The Law Making \\
\hline $\begin{array}{l}\text { Article } 8 \text { Section (2) } \\
\text { LawNo.12/2011 }\end{array}$ & The Ministerial Rules, as long as ordered by the higher law are regarded as law and have legal binding \\
\hline $\begin{array}{l}\text { The explanation of } \\
\text { Article } 8 \text { Law No. } \\
\text { 12/2011 }\end{array}$ & The Ministerial Rules are rules which set by a Minister in order to particular government affairs \\
\hline $\begin{array}{l}\text { Article } 52 \text { Law No. } \\
12 / 2011\end{array}$ & $\begin{array}{l}\text { Section 4: In case that the DPR gives approval to an emergency law, such law shall be set as the Legislation. } \\
\text { Section } 5 \text { : In case that the DPR disapproves the emergency law, the emergency law shall be revoked and shall be } \\
\text { declared invalid by Law. }\end{array}$ \\
\hline \multirow[t]{2}{*}{$\begin{array}{l}\text { Article } 155 \text { Law No. } \\
12 / 2011\end{array}$} & $\begin{array}{l}\text { The making of budgetary framework is based on the work plans of the government in order to implement the state's } \\
\text { purposes. The government's work plansaremade by the Government to be discussed and jointly agreed with the DPR. } \\
\text { The Government work plans which have been discussed and jointly agreed are the guideline to arrange the state } \\
\text { budget and shall be set as the state budget by a Presidential Decision }\end{array}$ \\
\hline & Law No. 17/2011 on State Intelligence \\
\hline $\begin{array}{l}\text { Article } 41 \text { Law } \\
17 / 2011\end{array}$ & The state intelligence activities cost are funded by the state budget \\
\hline $\begin{array}{l}\text { Article } 36 \text { Law } \\
17 / 2011\end{array}$ & $\begin{array}{l}\text { The DPR's consideration against the candidate of the Chief of the state intelligence is given at least within } 20 \text { working } \\
\text { daysafter the request of a consideration is received by the DPR }\end{array}$ \\
\hline
\end{tabular}


Rosa Ristawati: Modelling Executive Powers in the Indonesian Constitution: A comparative Study

\section{Appendix 6}

\section{Excerpts from The US Constitution}

Source: the United State of America's Constitution of 1789 with Amendments through 1992, generated from excerpts of texts from the repository of the Comparative Constitutions Project, accessed at www.constituteproject.org

\begin{tabular}{|c|c|}
\hline $\begin{array}{l}\text { Article II } \\
\text { Section } 1\end{array}$ & 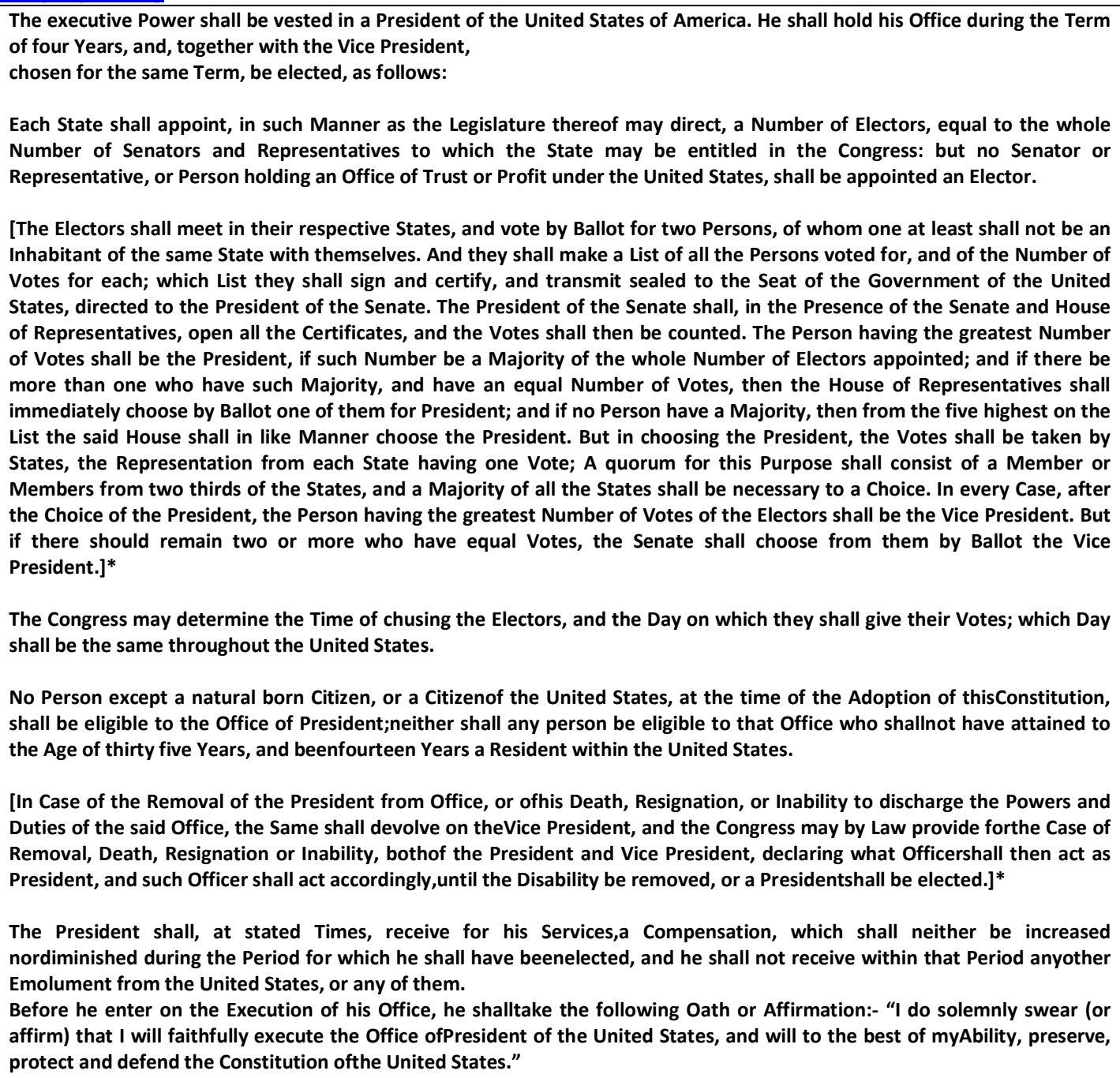 \\
\hline & $\begin{array}{l}\text { The President shall be Commander in Chief of the Army and Navy of the United States, and of the Militia of the several } \\
\text { States, when called into the actual Service of the United States; he may require the Opinion, in writing, of the principal } \\
\text { Officer in each of the executive Departments, upon any Subject relating to the Duties of their respective Offices, and he } \\
\text { shall have Power to grant Reprieves and Pardons for Offenses against the United States, except in Cases of Impeachment. } \\
\text { He shall have Power, by and with the Advice and Consent of the Senate, to make Treaties, provided two thirds of the } \\
\text { Senators present concur; and he shall nominate, and by and with the Advice and Consent of the Senate, shall appoint } \\
\text { Ambassadors, other public Ministers and Consuls, Judges of the supreme Court, and all other Officers of the United States, } \\
\text { whose Appointments are not herein otherwise provided for, and which shall be established by Law: but the Congress may } \\
\text { by Law vest the Appointment of such inferior Officers, as they think proper, in the President alone, in the Courts of Law, or } \\
\text { in the Heads of Departments. } \\
\text { The President shall have Power to fi II up all Vacancies that may happen during the Recess of the Senate, by granting } \\
\text { Commissions which shall expire at the End of their next Session. }\end{array}$ \\
\hline
\end{tabular}


Rosa Ristawati: Modelling Executive Powers in the Indonesian Constitution: A comparative Study

\begin{tabular}{|l|l|}
\hline $\begin{array}{l}\text { Article II } \\
\text { Section } 3\end{array}$ & $\begin{array}{l}\text { He shall from time to time give to the Congress Information of the State of the Union, and recommend to their } \\
\text { Consideration such Measures as he shall judge necessary and expedient; he may, on extraordinary Occasions, convene both } \\
\text { Houses, or either of them, and in Case of Disagreement between them, with Respect to the Time of Adjournment, he may } \\
\text { adjourn them to such Time as he shall think proper; he shall receive Ambassadors and other public Ministers; he shall take } \\
\text { Care that the Laws be faithfully executed, and shall Commission all the Officers of the United States. }\end{array}$ \\
\hline $\begin{array}{l}\text { Article II } \\
\text { Section } 4\end{array}$ & $\begin{array}{l}\text { The President, Vice President and all civil Officers of the United States, shall be removed from Office on Impeachment for, } \\
\text { and Conviction of, Treason, Bribery, or other high Crimes and Misdemeanors. }\end{array}$ \\
\hline
\end{tabular}




\section{Appendix 7}

\section{Excerpts from The Philippines Constitution}

Source: Philippines's Constitution of 1987, generated from excerpt of texts from repository of the Comparative Constitutions Project, accessed at www.constituteprojects.org

\begin{tabular}{|c|c|}
\hline $\begin{array}{l}\text { Article I on } \\
\text { National Territory }\end{array}$ & $\begin{array}{l}\text { The national territory comprises the Philippine archipelago, with all the islands and waters embraced therein, and all } \\
\text { other territories over which the Philippines has sovereignty or jurisdiction, consisting of its terrestrial, fluvial and } \\
\text { aerial domains, including its territorial sea, the seabed, the subsoil, the insular shelves, and other submarine areas. } \\
\text { The waters around, between, and connecting the islands of the archipelago, regardless of their breadth and } \\
\text { dimensions, form part of the internal waters of the Philippines. }\end{array}$ \\
\hline $\begin{array}{l}\text { Article II on } \\
\text { Declaration of } \\
\text { Principles and } \\
\text { State Policies } \\
\text { Principles Section } 2\end{array}$ & $\begin{array}{l}\text { The Philippines renounces war as an instrument of national policy, adopts the generally accepted principles of } \\
\text { international law as part of the law of the land and adheres to the policy of peace, equality, justice, freedom, } \\
\text { cooperation, and amity with all nations. }\end{array}$ \\
\hline Article VII Section 1 & The executive power shall be vested in the President of the Philippines. \\
\hline Article VII Section 2 & $\begin{array}{l}\text { No person may be elected President unless he is a natural-born citizen of the Philippines, a registered voter, able to } \\
\text { read and write, at least forty years of age on the day of the election, and a resident of the Philippines for at least ten } \\
\text { years immediately preceding such election. }\end{array}$ \\
\hline Article VII Section 3 & $\begin{array}{l}\text { There shall be a Vice-President who shall have the same qualifications and term of office and be elected with, and in } \\
\text { the same manner, as the President. He may be removed from office in the same manner as the President. } \\
\text { The Vice-President may be appointed as a Member of the Cabinet. Such appointment requires no confirmation. }\end{array}$ \\
\hline Article VII Section 4 & $\begin{array}{l}\text { The President and the Vice-President shall be elected by direct vote of the people for a term of six years which shall } \\
\text { begin at noon on the thirtieth day of June next following the day of the election and shall end at noon of the same } \\
\text { date, six years thereafter. The President shall not be eligible for any re-election. No person who has succeeded as } \\
\text { President and has served as such for more than four years shall be qualified for election to the same office at any } \\
\text { time. } \\
\text { No Vice-President shall serve for more than two successive terms. Voluntary renunciation of the office for any length } \\
\text { of time shall not be considered as an interruption in the continuity of the service for the full term for which he was } \\
\text { elected. Unless otherwise provided by law, the regular election for President and Vice-President shall be held on the } \\
\text { second Monday of May. } \\
\text { The returns of every election for President and Vice-President, duly certified by the board of canvassers of each } \\
\text { province or city, shall be transmitted to the Congress, directed to the President of the Senate. Upon receipt of the } \\
\text { certificates of canvass, the President of the Senate shall, not later than thirty days after the day of the election, open } \\
\text { all the certificates in the presence of the Senate and the House of Representatives in joint public session, and the } \\
\text { Congress, upon determination of the authenticity and due execution thereof in the manner provided by law, canvass } \\
\text { the votes. } \\
\text { The person having the highest number of votes shall be proclaimed elected, but in case two or more shall have an } \\
\text { equal and highest number of votes, one of them shall forthwith be chosen by the vote of a majority of all the } \\
\text { Members of both Houses of the Congress, voting separately. } \\
\text { The Congress shall promulgate its rules for the canvassing of the certificates. } \\
\text { The Supreme Court, sitting en banc, shall be the sole judge of all contests relating to the election, returns, and } \\
\text { qualifications of the President or Vice-President, and may promulgate its rules for the purpose. }\end{array}$ \\
\hline Article VII Section 5 & $\begin{array}{l}\text { Before they enter on the execution of their office, the President, the Vice-President, or the Acting President shall take } \\
\text { the following oath or affirmation: } \\
\text { "I do solemnly swear [or affirm] that I will faithfully and conscientiously fulfill my duties as President [or Vice- } \\
\text { President or Acting President] of the Philippines, preserve and defend its Constitution, execute its laws, do justice to } \\
\text { every man, and consecrate myself to the service of the Nation. So help me God." } \\
\text { [In case of affirmation, last sentence will be omitted]. }\end{array}$ \\
\hline Article VII Section 6 & $\begin{array}{l}\text { The President shall have an official residence. The salaries of the President and Vice-President shall be determined by } \\
\text { law and shall not be decreased during their tenure. No increase in said compensation shall take effect until after the } \\
\text { expiration of the term of the incumbent during which such increase was approved. They shall not receive during their } \\
\text { tenure any other emolument from the Government or any other source. }\end{array}$ \\
\hline Article VII Section 7 & $\begin{array}{l}\text { The President-elect and the Vice President-elect shall assume office at the beginning of their terms. } \\
\text { If the President-elect fails to qualify, the Vice President-elect shall act as President until the President-elect shall have } \\
\text { qualified. } \\
\text { If a President shall not have been chosen, the Vice President-elect shall act as President until a President shall have } \\
\text { been chosen and qualified. }\end{array}$ \\
\hline
\end{tabular}




\begin{tabular}{|c|c|}
\hline & $\begin{array}{l}\text { If at the beginning of the term of the President, the President-elect shall have died or shall have become permanently } \\
\text { disabled, the Vice President-elect shall become President. } \\
\text { Where no President and Vice-President shall have been chosen or shall have qualified, or where both shall have died } \\
\text { or become permanently disabled, the President of the Senate or, in case of his inability, the Speaker of the House of } \\
\text { Representatives, shall act as President until a President or a Vice-President shall have been chosen and qualified. } \\
\text { The Congress shall, by law, provide for the manner in which one who is to act as President shall be selected until a } \\
\text { President or a Vice-President shall have qualified, in case of death, permanent disability, or inability of the officials } \\
\text { mentioned in the next preceding paragraph. }\end{array}$ \\
\hline Article VII Section 8 & $\begin{array}{l}\text { In case of death, permanent disability, removal from office, or resignation of the President, the Vice-President shall } \\
\text { become the President to serve the unexpired term. In case of death, permanent disability, removal from office, or } \\
\text { resignation of both the President and Vice-President, the President of the Senate or, in case of his inability, the } \\
\text { Speaker of the House of Representatives, shall then act as President until the President or Vice-President shall have } \\
\text { been elected and qualified. } \\
\text { The Congress shall, by law, provide who shall serve as President in case of death, permanent disability, or resignation } \\
\text { of the Acting President. He shall serve until the President or the Vice-President shall have been elected and qualified, } \\
\text { and be subject to the same restrictions of powers and disqualifications as the Acting President. }\end{array}$ \\
\hline Article VII Section 9 & $\begin{array}{l}\text { Whenever there is a vacancy in the Office of the Vice-President during the term for which he was elected, the } \\
\text { President shall nominate a Vice-President from among the Members of the Senate and the House of Representatives } \\
\text { who shall assume office upon confirmation by a majority vote of all the Members of both Houses of the Congress, } \\
\text { voting separately. }\end{array}$ \\
\hline $\begin{array}{l}\text { Article VII Section } \\
10\end{array}$ & $\begin{array}{l}\text { The Congress shall, at ten o'clock in the morning of the third day after the vacancy in the offices of the President and } \\
\text { Vice-President occurs, convene in accordance with its rules without need of a call and within seven days, enact a law } \\
\text { calling for a special election to elect a President and a Vice-President to be held not earlier than forty-five days nor } \\
\text { later than sixty days from the time of such call. The bill calling such special election shall be deemed certified under } \\
\text { paragraph 2, Section 26, Article V1 of this Constitution and shall become law upon its approval on third reading by } \\
\text { the Congress. Appropriations for the special election shall be charged against any current appropriations and shall be } \\
\text { exempt from the requirements of paragraph 4, Section } 25 \text {, Article V1 of this Constitution. The convening of the } \\
\text { Congress cannot be suspended nor the special election postponed. No special election shall be called if the vacancy } \\
\text { occurs within eighteen months before the date of the next presidential election. }\end{array}$ \\
\hline $\begin{array}{l}\text { Article VII Section } \\
11\end{array}$ & $\begin{array}{l}\text { Whenever the President transmits to the President of the Senate and the Speaker of the House of Representatives his } \\
\text { written declaration that he is unable to discharge the powers and duties of his office, and until he transmits to them a } \\
\text { written declaration to the contrary, such powers and duties shall be discharged by the Vice- President as Acting } \\
\text { President. } \\
\text { Whenever a majority of all the Members of the Cabinet transmit to the President of the Senate and to the Speaker of } \\
\text { the House of Representatives their written declaration that the President is unable to discharge the powers and } \\
\text { duties of his office, the Vice- President shall immediately assume the powers and duties of the office as Acting } \\
\text { President. } \\
\text { Thereafter, when the President transmits to the President of the Senate and to the Speaker of the House of } \\
\text { Representatives his written declaration that no inability exists, he shall reassume the powers and duties of his office. } \\
\text { Meanwhile, should a majority of all the Members of the Cabinet transmit within five days to the President of the } \\
\text { Senate and to the Speaker of the House of Representatives, their written declaration that the President is unable to } \\
\text { discharge the powers and duties of his office, the Congress shall decide the issue. For that purpose, the Congress shall } \\
\text { convene, if it is not in session, within forty-eight hours, in accordance with its rules and without need of call. } \\
\text { If the Congress, within ten days after receipt of the last written declaration, or, if not in session, within twelve days } \\
\text { after it is required to assemble, determines by a two-thirds vote of both Houses, voting separately, that the President } \\
\text { is unable to discharge the powers and duties of his office, the Vice-President shall act as President; otherwise, the } \\
\text { President shall continue exercising the powers and duties of his office. }\end{array}$ \\
\hline $\begin{array}{l}\text { Article VII Section } \\
12\end{array}$ & $\begin{array}{l}\text { In case of serious illness of the President, the public shall be informed of the state of his health. The members of the } \\
\text { Cabinet in charge of national security and foreign relations and the Chief of Staff of the Armed Forces of the } \\
\text { Philippines shall not be denied access to the President during such illness. }\end{array}$ \\
\hline $\begin{array}{l}\text { Article VII Section } \\
13\end{array}$ & $\begin{array}{l}\text { The President, Vice-President, the Members of the Cabinet, and their deputies or assistants shall not, unless } \\
\text { otherwise provided in this Constitution, hold any other office or employment during their tenure. They shall not, } \\
\text { during said tenure, directly or indirectly, practice any other profession, participate in any business, or be financially } \\
\text { interested in any contract with, or in any franchise, or special privilege granted by the Government or any } \\
\text { subdivision, agency, or instrumentality thereof, including government-owned or controlled corporations or their } \\
\text { subsidiaries. They shall strictly avoid conflict of interest in the conduct of their office. } \\
\text { The spouse and relatives by consanguinity or affinity within the fourth civil degree of the President shall not, during }\end{array}$ \\
\hline
\end{tabular}




\begin{tabular}{|c|c|}
\hline & $\begin{array}{l}\text { his tenure, be appointed as Members of the Constitutional Commissions, or the Office of the Ombudsman, or as } \\
\text { Secretaries, Undersecretaries, chairmen or heads of bureaus or offices, including government-owned or controlled } \\
\text { corporations and their subsidiaries. }\end{array}$ \\
\hline & $\begin{array}{l}\text { Appointments extended by an Acting President shall remain effective, unless revoked by the elected President, } \\
\text { within ninety days from his assumption or re-assumption of office. }\end{array}$ \\
\hline $\begin{array}{l}\text { Article VII Section } \\
15\end{array}$ & $\begin{array}{l}\text { Two months immediately before the next presidential elections and up to the end of his term, a President or Acting } \\
\text { President shall not make appointments, except temporary appointments to executive positions when continued } \\
\text { vacancies therein will prejudice public service or endanger public safety. }\end{array}$ \\
\hline $\begin{array}{l}\text { Article VII Section } \\
16\end{array}$ & $\begin{array}{l}\text { The President shall nominate and, with the consent of the Commission on Appointments, appoint the heads of the } \\
\text { executive departments, ambassadors, other public ministers and consuls, or officers of the armed forces from the } \\
\text { rank of colonel or naval captain, and other officers whose appointments are vested in him in this Constitution. He } \\
\text { shall also appoint all other officers of the Government whose appointments are not otherwise provided for by law, } \\
\text { and those whom he may be authorized by law to appoint. The Congress may, by law, vest the appointment of other } \\
\text { officers lower in rank in the President alone, in the courts, or in the heads of departments, agencies, commissions, or } \\
\text { boards. } \\
\text { The President shall have the power to make appointments during the recess of the Congress, whether voluntary or } \\
\text { compulsory, but such appointments shall be effective only until disapproved by the Commission on Appointments or } \\
\text { until the next adjournment of the Congress. }\end{array}$ \\
\hline $\begin{array}{l}\text { Article VII Section } \\
17\end{array}$ & $\begin{array}{l}\text { The President shall have control of all the executive departments, bureaus, and offices. He shall ensure that the laws } \\
\text { be faithfully executed. }\end{array}$ \\
\hline $\begin{array}{l}\text { Article VII Section } \\
18\end{array}$ & $\begin{array}{l}\text { The President shall be the Commander-in-Chief of all armed forces of the Philippines and whenever it becomes } \\
\text { necessary, he may call out such armed forces to prevent or suppress lawless violence, invasion or rebellion. In case of } \\
\text { invasion or rebellion, when the public safety requires it, he may, for a period not exceeding sixty days, suspend the } \\
\text { privilege of the writ of habeas corpus or place the Philippines or any } \\
\text { part thereof under martial law. Within forty-eight hours from the proclamation of martial law or the suspension of } \\
\text { the privilege of the writ of habeas corpus, the President shall submit a report in person or in writing to the Congress. } \\
\text { The Congress, voting jointly, by a vote of at least a majority of all its Members in regular or special session, may } \\
\text { revoke such proclamation or suspension, which revocation shall not be set aside by the President. Upon the initiative } \\
\text { of the President, the Congress may, in the same manner, extend such proclamation or suspension for a period to be } \\
\text { determined by the Congress, if the invasion or rebellion shall persist and public safety requires it. } \\
\text { The Congress, if not in session, shall, within twenty-four hours following such proclamation or suspension, convene in } \\
\text { accordance with its rules without need of a call. } \\
\text { The Supreme Court may review, in an appropriate proceeding filed by any citizen, the sufficiency of the factual basis } \\
\text { of the proclamation of martial law or the suspension of the privilege of the writ of habeas corpus or the extension } \\
\text { thereof, and must promulgate its decision thereon within thirty days from its filing. } \\
\text { A state of martial law does not suspend the operation of the Constitution, nor supplant the functioning of the civil } \\
\text { courts or legislative assemblies, nor authorize the conferment of jurisdiction on military courts and agencies over } \\
\text { civilians where civil courts are able to function, nor automatically suspend the privilege of the writ of habeas corpus. } \\
\text { The suspension of the privilege of the writ of habeas corpus shall apply only to persons judicially charged for rebellion } \\
\text { or offenses inherent in, or directly connected with, invasion. } \\
\text { During the suspension of the privilege of the writ of habeas corpus, any person thus arrested or detained shall be } \\
\text { judicially charged within three days, otherwise he shall be released. }\end{array}$ \\
\hline $\begin{array}{l}\text { Article VII Section } \\
19\end{array}$ & $\begin{array}{l}\text { Except in cases of impeachment, or as otherwise provided in this Constitution, the President may grant reprieves, } \\
\text { commutations, and pardons, and remit fines and forfeitures, after conviction by final judgment. } \\
\text { He shall also have the power to grant amnesty with the concurrence of a majority of all the Members of the Congress. }\end{array}$ \\
\hline $\begin{array}{l}\text { Article VII Section } \\
20\end{array}$ & $\begin{array}{l}\text { The President may contract or guarantee foreign loans on behalf of the Republic of the Philippines with the prior } \\
\text { concurrence of the Monetary Board, and subject to such limitations as may be provided by law. The Monetary Board } \\
\text { shall, within thirty days from the end of every quarter of the calendar year, submit to the Congress a complete report } \\
\text { of its decision on applications for loans to be contracted or guaranteed by the Government or government-owned } \\
\text { and controlled corporations which would have the effect of increasing the foreign debt, and containing other matters } \\
\text { as may be provided by law. }\end{array}$ \\
\hline $\begin{array}{l}\text { Article VII Section } \\
21\end{array}$ & $\begin{array}{l}\text { No treaty or international agreement shall be valid and effective unless concurred in by at least two-thirds of all the } \\
\text { Members of the Senate. }\end{array}$ \\
\hline $\begin{array}{l}\text { Article VII Section } \\
22\end{array}$ & $\begin{array}{l}\text { The President shall submit to the Congress, within thirty days from the opening of every regular session as the basis } \\
\text { of the general appropriations bill, a budget of expenditures and sources of financing, including receipts from existing } \\
\text { and proposed revenue measures. }\end{array}$ \\
\hline $\begin{array}{l}\text { Article VII Section } \\
23\end{array}$ & $\begin{array}{l}\text { The President shall address the Congress at the opening of its regular session. He may also appear before it at any } \\
\text { other time. }\end{array}$ \\
\hline $\begin{array}{l}\text { Article IX B on the } \\
\text { Civil Service }\end{array}$ & $\begin{array}{l}\text { The Chairman and the Commissioners shall be appointed by the President with the consent of the Commission on } \\
\text { Appointments for a term of seven years without reappointment. Of those first appointed, the Chairman shall hold }\end{array}$ \\
\hline
\end{tabular}




\begin{tabular}{|c|c|}
\hline $\begin{array}{l}\text { Commission } \\
\text { Section } 1(2)\end{array}$ & $\begin{array}{l}\text { ffice for seven years, a Commissioner for five years, and another Commissioner for three years, without } \\
\text { eappointment. Appointment to any vacancy shall be only for the unexpired term of the predecessor. In no case shall } \\
\text { ny Member be appointed or designated in a temporary or acting capacity. }\end{array}$ \\
\hline $\begin{array}{l}\text { Article IX C on the } \\
\text { Commission on } \\
\text { Elections Section } 1 \\
\text { (2) }\end{array}$ & $\begin{array}{l}\text { The Chairman and the Commissioners shall be appointed by the President with the consent of the Commission on } \\
\text { Appointments for a term of seven years without reappointment. Of those first appointed, three Members shall hold } \\
\text { office for seven years, two Members for five years, and the last Members for three years, without reappointment. } \\
\text { Appointment to any vacancy shall be only for the unexpired term of the predecessor. In no case shall any Member be } \\
\text { appointed or designated in a temporary or acting capacity. }\end{array}$ \\
\hline $\begin{array}{l}\text { Article IX C on the } \\
\text { Commission on } \\
\text { Elections Section } 5\end{array}$ & $\begin{array}{l}\text { No pardon, amnesty, parole, or suspension of sentence for violation of election laws, rules, and regulations shall be } \\
\text { granted by the President without the favorable recommendation of the Commission. }\end{array}$ \\
\hline $\begin{array}{l}\text { Article IX D on the } \\
\text { Commission on } \\
\text { Audit Section } 1(2)\end{array}$ & $\begin{array}{l}\text { The Chairman and the Commissioners shall be appointed by the President with the consent of the Commission on } \\
\text { Appointments for a term of seven years without reappointment. Of those first appointed, the Chairman shall hold } \\
\text { office for seven years, one Commissioner for five years, and the other Commissioner for three years, without } \\
\text { reappointment. Appointment to any vacancy shall be only for the unexpired portion of the term of the predecessor. } \\
\text { In no case shall any Member be appointed or designated in a temporary or acting capacity. }\end{array}$ \\
\hline $\begin{array}{l}\text { Article } X \text { on Local } \\
\text { Government } \\
\text { Section } 4\end{array}$ & $\begin{array}{l}\text { The President of the Philippines shall exercise general supervision over local governments. Provinces with respect to } \\
\text { component cities and municipalities, and cities and municipalities with respect to component barangays, shall ensure } \\
\text { that the acts of their component units are within the scope of their prescribed powers and functions. }\end{array}$ \\
\hline $\begin{array}{l}\text { Article } \mathrm{X} \text { on Local } \\
\text { Government } \\
\text { Section } 14\end{array}$ & $\begin{array}{l}\text { The President shall provide for regional development councils or other similar bodies composed of local government } \\
\text { officials, regional heads of departments and other government offices, and representatives from non-governmental } \\
\text { organizations within the regions for purposes of administrative decentralization to strengthen the autonomy of the } \\
\text { units therein and to accelerate the economic and social growth and development of the units in the region. }\end{array}$ \\
\hline $\begin{array}{l}\text { Article } \mathrm{X} \text { on Local } \\
\text { Government } \\
\text { Section } 16\end{array}$ & The President shall exercise general supervision over autonomous regions to ensure that laws are faithfully executed. \\
\hline $\begin{array}{l}\text { Article XI } \quad \text { on } \\
\text { Accountability } \text { of } \\
\text { Public Officers } \\
\text { Section } 2\end{array}$ & $\begin{array}{l}\text { The President, the Vice-President, the Members of the Supreme Court, the Members of the Constitutional } \\
\text { Commissions, and the Ombudsman may be removed from office on impeachment for, and conviction of, culpable } \\
\text { violation of the Constitution, treason, bribery, graft and corruption, other high crimes, or betrayal of public trust. All } \\
\text { other public officers and employees may be removed from office as provided by law, but not by impeachment. }\end{array}$ \\
\hline Article XI Section 9 & $\begin{array}{l}\text { The Ombudsman and his Deputies shall be appointed by the President from a list of at least six nominees prepared by } \\
\text { the Judicial and Bar Council, and from a list of three nominees for every vacancy thereafter. Such appointments shall } \\
\text { require no confirmation. All vacancies shall be filled within three months after they occur. }\end{array}$ \\
\hline $\begin{array}{l}\text { Article XI Section } \\
16\end{array}$ & $\begin{array}{l}\text { No loan, guaranty, or other form of financial accommodation for any business purpose may be granted, directly or } \\
\text { indirectly, by any government-owned or controlled bank or financial institution to the President, the Vice-President, } \\
\text { the Members of the Cabinet, the Congress, the Supreme Court, and the Constitutional Commissions, the } \\
\text { Ombudsman, or to any firm or entity in which they have controlling interest, during their tenure. }\end{array}$ \\
\hline $\begin{array}{lr}\text { Article } & \text { XII on } \\
\text { National } & \text { Economy } \\
\text { and } & \text { Patrimony } \\
\text { Section } & \quad 2 \\
\text { paragraph } 4\end{array}$ & $\begin{array}{l}\text { The President may enter into agreements with foreign-owned corporations involving either technical or financial } \\
\text { assistance for large-scale exploration, development, and utilization of minerals, petroleum, and other mineral oils } \\
\text { according to the general terms and conditions provided by law, based on real contributions to the economic growth } \\
\text { and general welfare of the country. In such agreements, the State shall promote the development and use of local } \\
\text { scientific and technical resources. } \\
\text { The President shall notify the Congress of every contract entered into in accordance with this provision, within thirty } \\
\text { days from its execution. }\end{array}$ \\
\hline $\begin{array}{l}\text { Article XII on } \\
\text { National Economy } \\
\text { and Patrimony } \\
\text { Section } 17\end{array}$ & $\begin{array}{l}\text { In times of national emergency, when the public interest so requires, the State may, during the emergency and under } \\
\text { reasonable terms prescribed by it, temporarily take over or direct the operation of any privately-owned public utility } \\
\text { or business affected with public interest. }\end{array}$ \\
\hline $\begin{array}{l}\text { Article XVIII on } \\
\text { Transitory } \\
\text { Provisions Section } \\
4\end{array}$ & $\begin{array}{l}\text { All existing treaties or international agreements which have not been ratified shall not be renewed or extended } \\
\text { without the concurrence of at least two-thirds of all the Members of the Senate. }\end{array}$ \\
\hline $\begin{array}{l}\text { Article XVII on } \\
\text { Transitory } \\
\text { Provision Section } 6\end{array}$ & oent president snali continue to exercise iegisiative powers untin the irst congress is conv \\
\hline $\begin{array}{l}\text { Article XVII on } \\
\text { Transitory } \\
\text { Provision Section } 7\end{array}$ & $\begin{array}{l}\text { Until a law is passed, the President may fill by appointment from a list ofnominees by the respective sectors, the } \\
\text { seats reserved for sectoral representation in paragraph (2), Section } 5 \text { of Article V1 of this Constitution. }\end{array}$ \\
\hline $\begin{array}{l}\text { Article XVII on } \\
\text { Transitory } \\
\text { Provision Section } 8\end{array}$ & $\begin{array}{l}\text { Until otherwise provided by the Congress, the President may constitute the Metropolitan Manila Authority to be } \\
\text { composed of the heads of all local government units comprising the Metropolitan Manila area. }\end{array}$ \\
\hline
\end{tabular}




\section{Appendix 8}

\section{Excerpts from The German Basic Law}

Source: German Constitution, Deutscher Bundestag, Basic Law for the Federal Republic of Germany, translated by Christian Tomuschat and David P. Curie, Donald P. Kommers in cooperation with the Language Service of the German Bundestad, Printed version at November 2012

\begin{tabular}{|c|c|}
\hline $\begin{array}{ll}\text { Article } 25 & \text { on } \\
\text { Primacy } & \text { of } \\
\text { International } & \\
\text { Law } & \end{array}$ & $\begin{array}{l}\text { The general rules of international law shall be an integral part of federal law. They shall take precedence over the laws } \\
\text { and directly create rights and duties for the inhabitants of the federal territory. }\end{array}$ \\
\hline Article 55 & $\begin{array}{l}\text { 1) The Federal President may not be a member of the government or of a legislative body of the Federation or of a } \\
\text { Land. }\end{array}$ \\
\hline Article 58 & $\begin{array}{l}\text { Orders and directions of the Federal President shall require for their validity the countersignature of the Federal } \\
\text { Chancellor or of the competent Federal Minister. This provision shall not apply to the appointment or dismissal of the } \\
\text { Federal Chancellor, the dissolution of the Bundestag under Article 63, or a request made under paragraph (3) of Article } \\
\text { 69. }\end{array}$ \\
\hline $\begin{array}{l}\text { Article 59on } \\
\text { Representation } \\
\text { of the Federation } \\
\text { for the purposes } \\
\text { of international } \\
\text { law }\end{array}$ & $\begin{array}{l}\text { (1) The Federal President shall represent the Federation for the purposes of international law. He shall conclude } \\
\text { treaties with foreign states on behalf of the Federation. He shall accredit and receive envoys. } \\
\text { (2) Treaties that regulate the political relations of the Federation or relate to subjects of federal legislation shall require } \\
\text { the consent or participation, in the form of a federal law, of the bodies responsible in such a case for the enactment of } \\
\text { federal law. In the case of executive agreements the provisions concerning the federal administration shall apply } \\
\text { mutatis mutandis. }\end{array}$ \\
\hline $\begin{array}{l}\text { Article } 60 \text { on } \\
\text { Appointment of } \\
\text { civil servants - } \\
\text { Pardon - } \\
\text { Immunity }\end{array}$ & $\begin{array}{l}\text { (1) The Federal President shall appoint and dismiss federal judges, federal civil servants, and commissioned and } \\
\text { noncommissioned officers of the Armed Forces, except as may otherwise be provided by a law. } \\
\text { (2) He shall exercise the power to pardon individual offenders on behalf of the Federation. } \\
\text { (3) He may delegate these powers to other authorities. } \\
\text { (4) Paragraphs (2) to (4) of Article } 46 \text { shall apply to the Federal President mutatis mutandis. }\end{array}$ \\
\hline $\begin{array}{l}\text { Article } 61 \text { on } \\
\text { Impeachment } \\
\text { before the } \\
\text { Federal } \\
\text { Constitutional } \\
\text { Court }\end{array}$ & $\begin{array}{l}\text { (1) The Bundestag or the Bundesrat may impeach the Federal President before the Federal Constitutional Court for } \\
\text { wilful violation of this Basic Law or of any other federal law. The motion of impeachment must be supported by at least } \\
\text { one quarter of the Members of the Bundestag or one quarter of the votes of the Bundesrat. The decision to impeach } \\
\text { shall require a majority of two thirds of the Members of the Bundestag or of two thirds of the votes of the Bundesrat. } \\
\text { The case for impeachment shall be presented before the Federal Constitutional Court by a person commissioned by the } \\
\text { impeaching body. } \\
\text { (2) If the Federal Constitutional Court finds the Federal President guilty of a willful violation of this Basic Law or of any } \\
\text { other federal law, it may declare that he has forfeited his office. After the Federal President has been impeached, the } \\
\text { Court may issue an interim order preventing him from exercising his functions. }\end{array}$ \\
\hline Article 62 & The Federal Government shall consist of the Federal Chancellor and the Federal Ministers. \\
\hline Article 63 & $\begin{array}{l}\text { Election of the Federal Chancellor } \\
\text { (1) The Federal Chancellor shall be elected by the Bundestag without debate on the proposal of the Federal President. } \\
\text { (2) The person who receives the votes of a majority of the Members of the Bundestag shall be elected. The person } \\
\text { elected shall be appointed by the Federal President. } \\
\text { (3) If the person proposed by the Federal President is not elected, the Bundestag may elect a Federal Chancellor within } \\
\text { fourteen days after the ballot by the votes of more than one half of its Members. } \\
\text { (4) If no Federal Chancellor is elected within this period, a new election shall take place without delay, in which the } \\
\text { person who receives the largest number of votes shall be elected. If the person elected receives the votes of a majority } \\
\text { of the Members of the Bundestag, the Federal President must appoint him within seven days after the election. If the } \\
\text { person elected does not receive such a majority, then within seven days the Federal President shall either appoint him } \\
\text { or dissolve the Bundestag. }\end{array}$ \\
\hline Article 65 & $\begin{array}{l}\text { Power to determine policy guidelines - Department and collegiate responsibility } \\
\text { The Federal Chancellor shall determine and be responsible for the general guidelines of policy. Within these limits each } \\
\text { Federal Minister shall conduct the affairs of his department independently and on his own responsibility. The Federal } \\
\text { Government shall resolve differences of opinion between Federal Ministers. The Federal Chancellor shall conduct the } \\
\text { proceedings of the Federal Government in accordance with rules of procedure adopted by the Government and }\end{array}$ \\
\hline
\end{tabular}


Rosa Ristawati: Modelling Executive Powers in the Indonesian Constitution: A comparative Study

\begin{tabular}{|c|c|}
\hline & approved by the Federal President. \\
\hline Article 65a & $\begin{array}{l}\text { Article 65a Command of the Armed Forces } \\
\text { (1) Command of the Armed Forces shall be vested in the Federal Minister of Defense. }\end{array}$ \\
\hline Article 67 & $\begin{array}{l}\text { Vote of no confidence } \\
\text { (1) The Bundestag may express its lack of confidence in the Federal Chancellor only by electing a successor by the vote } \\
\text { of a majority of its Members and requesting the Federal President to dismiss the Federal Chancellor. The Federal } \\
\text { President must comply with the request and appoint the person elected. } \\
\text { (2) Forty-eight hours shall elapse between the motion and the election. }\end{array}$ \\
\hline Article 68 & $\begin{array}{l}\text { Vote of confidence } \\
\text { (1) If a motion of the Federal Chancellor for a vote of confidence is not supported by the majority of the Members of } \\
\text { the Bundestag, the Federal President, upon the proposal of the Federal Chancellor, may dissolve the Bundestag within } \\
\text { twenty-one days. The right of dissolution shall lapse as soon as the Bundestag elects another Federal Chancellor by the } \\
\text { vote of a majority of its Members. } \\
\text { (2) Forty-eight hours shall elapse between the motion and the vote. }\end{array}$ \\
\hline Article 69 & $\begin{array}{l}\text { Deputy Federal Chancellor - Term of office } \\
\text { (1) The Federal Chancellor shall appoint a Federal Minister as his deputy. } \\
\text { (2) The tenure of office of the Federal Chancellor or of a Federal Minister shall end in any event when a new Bundestag } \\
\text { convenes; the tenure of office of a Federal Minister shall also end on any other occasion on which the Federal } \\
\text { Chancellor ceases to hold office. } \\
\text { (3) At the request of the Federal President the Federal Chancellor, or at the request of the Federal Chancellor or of the } \\
\text { Federal President a Federal Minister, shall be obliged to continue to manage the affairs of his office until a successor is } \\
\text { appointed. }\end{array}$ \\
\hline Article 76 & $\begin{array}{l}\text { Bills } \\
\text { (1) Bills may be introduced in the Bundestag by the Federal Government, by the Bundesrat, or from the fl oor of the } \\
\text { Bundestag. } \\
\text { (2) Federal Government bills shall first be submitted to the Bundesrat. The Bundesrat shall be entitled to comment on } \\
\text { such bills within six weeks. If for important reasons, especially with respect to the scope of the bill, the Bundesrat } \\
\text { demands an extension, the period shall be increased to nine weeks. If in exceptional circumstances the Federal } \\
\text { Government on submitting a bill to the Bundesrat declares it to be particularly urgent, it may submit the bill to the } \\
\text { Bundestag after three weeks or, if the Bundesrat has demanded an extension pursuant to the third sentence of this } \\
\text { paragraph, after six weeks, even if it has not yet received the Bundesrat's comments; upon receiving such comments, it } \\
\text { shall transmit them to the Bundestag without delay. In the case of bills to amend this Basic Law or to transfer sovereign } \\
\text { powers pursuant to Article } 23 \text { or } 24 \text { the comment period shall be nine weeks; the fourth sentence of this paragraph } \\
\text { shall not apply. }\end{array}$ \\
\hline Article 81 & $\begin{array}{l}\text { Legislative emergency } \\
\text { (1) If, in the circumstances described in Article } 68 \text {, the Bundestag is not dissolved, the Federal President, at the request } \\
\text { of the Federal Government and with the consent of the Bundesrat, may declare a state of legislative emergency with } \\
\text { respect to a bill, if the Bundestag rejects the bill although the Federal Government has declared it to be urgent. The } \\
\text { same shall apply if a bill has been rejected although the Federal Chancellor had combined it with a motion under Article } \\
68 \text {. } \\
\text { (2) If, after a state of legislative emergency has been declared, the Bundestag again rejects the bill or adopts it in a } \\
\text { version the Federal Government declares unacceptable, the bill shall be deemed to have become law to the extent that } \\
\text { it receives the consent of the Bundesrat. The same shall apply if the Bundestag does not pass the bill within four weeks } \\
\text { after it is reintroduced. } \\
\text { (3) During the term of office of a Federal Chancellor, any other bill rejected by the Bundestag may become law in } \\
\text { accordance with paragraphs (1) and (2) of this Article within a period of six months after the first declaration of a state } \\
\text { of legislative emergency. After the expiration of this period, no further declaration of a state of legislative emergency } \\
\text { may be made during the term of office of the same Federal Chancellor. } \\
\text { (4) This Basic Law may neither be amended nor abrogated nor suspended in whole or in part by a law enacted pursuant } \\
\text { to paragraph (2) of this Article. }\end{array}$ \\
\hline Article 82 & $\begin{array}{l}\text { Certification - Promulgation - Entry into force } \\
\text { (1) Laws enacted in accordance with the provisions of this Basic Law shall, after countersignature, be certified by the } \\
\text { Federal President and promulgated in the Federal Law Gazette. Statutory instruments shall be certified by the agency } \\
\text { that issues them and, unless a law otherwise provides, shall be promulgated in the Federal Law Gazette. }\end{array}$ \\
\hline Article 84 & $\begin{array}{l}\text { (2) The Federal Government, with the consent of the Bundesrat, may issue general administrative rules. } \\
\text { (3) The Federal Government shall exercise oversight to ensure that the Länder execute federal laws in accordance with } \\
\text { the law. For this purpose the Federal Government may send commissioners to the highest Land authorities and, with }\end{array}$ \\
\hline
\end{tabular}




\begin{tabular}{|c|c|}
\hline & $\begin{array}{l}\text { their consent or, where such consent is refused, with the consent of the Bundesrat, also to subordinate authorities. } \\
\text { (4) Should any deficiencies that the Federal Government has identified in the execution of federal laws in the Länder } \\
\text { not be corrected, the Bundesrat, on application of the Federal Government or of the Land concerned, shall decide } \\
\text { whether that Land has violated the law. The decision of the Bundesrat may be challenged in the Federal Constitutional } \\
\text { Court. } \\
\text { (5) With a view to the execution of federal laws, the Federal Government may be authorized by a federal law requiring } \\
\text { the consent of the Bundesrat to issue instructions in particular cases. They shall be addressed to the highest Land } \\
\text { authorities unless the Federal Government considers the matter urgent. }\end{array}$ \\
\hline Article 85 & $\begin{array}{l}\text { (2) The Federal Government, with the consent of the Bundesrat, may issue general administrative rules. It may provide } \\
\text { for the uniform training of civil servants and other salaried public employees. The heads of intermediate authorities } \\
\text { shall be appointed with its approval. }\end{array}$ \\
\hline Article 86 & $\begin{array}{l}\text { Federal administration } \\
\text { Where the Federation executes laws through its own administrative authorities or through federal corporations or } \\
\text { institutions established under public law, the Federal Government shall, insofar as the law in question contains no } \\
\text { special provision, issue general administrative rules. The Federal Government shall provide for the establishment } \\
\text { of the authorities insofar as the law in question does not otherwise provide. }\end{array}$ \\
\hline Article 87 & $\begin{array}{l}\text { Matters } \\
\text { (1) The foreign service, the federal financial administration, and, in accordance with the provisions of Article 89, the } \\
\text { administration of federal waterways and shipping shall be conducted by federal administrative authorities with their } \\
\text { own administrative substructures. A federal law may establish Federal Border Police authorities and central offices for } \\
\text { police information and communications, for the criminal police, and for the compilation of data for purposes of } \\
\text { protection of the constitution and of protection against activities within the federal territory which, through the use of } \\
\text { force or acts preparatory to the use of force, endanger the external interests of the Federal Republic of Germany. }\end{array}$ \\
\hline Article 87a & $\begin{array}{l}\text { Armed Forces } \\
\text { (1) The Federation shall establish Armed Forces for purposes of defense. Their numerical strength and general } \\
\text { organizational structure must be shown in the budget. } \\
\text { (2) Apart from defense, the Armed Forces may be employed only to the extent expressly permitted by this Basic Law. } \\
\text { (3) During a state of defense or a state of tension the Armed Forces shall have the power to protect civilian property } \\
\text { and to perform traffic control functions to the extent necessary to accomplish their defense mission. Moreover, during } \\
\text { a state of defense or a state of tension, the Armed Forces may also be authorized to support police measures for the } \\
\text { protection of civilian property; in this event the Armed Forces shall cooperate with the competent authorities. } \\
\text { (4) In order to avert an imminent danger to the existence or free democratic basic order of the Federation or of a Land, } \\
\text { the Federal Government, if the conditions referred to in paragraph (2) of Article } 91 \text { obtain and the police forces and the } \\
\text { Federal Border Police prove inadequate, may employ the Armed Forces to support the police and the Federal Border } \\
\text { Police in protecting civilian property and in combating organized armed insurgents. Any such employment of the Armed } \\
\text { Forces shall be discontinued if the Bundestag or the Bundesrat so demands. }\end{array}$ \\
\hline Article 87b & $\begin{array}{l}\text { Federal Defense Administration } \\
\text { (1) The Federal Defense Administration shall be conducted as a federal administrative authority with its own } \\
\text { administrative substructure. It shall have jurisdiction for personnel matters and direct responsibility for satisfaction of } \\
\text { the procurement needs of the Armed Forces. Responsibilities connected with pensions for injured persons or with } \\
\text { construction work may be assigned to the Federal Defense Administration only by a federal law requiring the consent } \\
\text { of the Bundesrat. Such consent shall also be required for any laws to the extent that they empower the Federal Defense } \\
\text { Administration to interfere with rights of third parties; this requirement, however, shall not apply in the case of laws } \\
\text { regarding personnel matters. } \\
\text { (2) In addition, federal laws concerning defense, including recruitment for military service and protection of the civilian } \\
\text { population, may, with the consent of the Bundesrat, provide that they shall be executed, wholly or in part, either by } \\
\text { federal administrative authorities with their own administrative substructures or by the Länder on federal commission. } \\
\text { If such laws are executed by the Länder on federal commission, they may, with the consent of the Bundesrat, provide } \\
\text { that the powers vested in the Federal Government or in the competent highest federal authorities pursuant to Article } \\
85 \text { be transferred wholly or in part to federal higher authorities; in this event the law may provide that such authorities } \\
\text { shall not require the consent of the Bundesrat in issuing general administrative rules pursuant to the first sentence of } \\
\text { paragraph (2) of Article } 85 \text {. }\end{array}$ \\
\hline Article 91 & $\begin{array}{l}\text { Internal emergency } \\
\text { (1) In order to avert an imminent danger to the existence or free democratic basic order of the Federation or of a Land, } \\
\text { a Land may call upon police forces of other Länder, or upon personnel and facilities of other administrative authorities } \\
\text { and of the Federal Border Police. } \\
\text { (2) If the Land where such danger is imminent is not itself willing or able to combat the danger, the Federal Government } \\
\text { may place the police in that Land and the police forces of other Länder under its own orders and deploy units of the } \\
\text { Federal Border Police. Any such order shall be rescinded once the danger is removed, or at any time on the demand of }\end{array}$ \\
\hline
\end{tabular}




\begin{tabular}{|c|c|}
\hline & $\begin{array}{l}\text { the Bundesrat. If the danger extends beyond the territory of a single Land, the Federal Government, insofar as is } \\
\text { necessary to combat such danger, may issue instructions to the Land governments; the first and second sentences of } \\
\text { this paragraph shall not be affected by this provision. }\end{array}$ \\
\hline Article 115a & $\begin{array}{l}\text { Declaration of state of defence } \\
\text { (1) Any determination that the federal territory is under attack by armed force or imminently threatened with such an } \\
\text { attack (state of defence) shall be made by the Bundestag with the consent of the Bundesrat. Such determination shall } \\
\text { be made on application of the Federal Government and shall require a two-thirds majority of the votes cast, which shall } \\
\text { include at least a majority of the Members of the Bundestag. } \\
\text { (2) If the situation imperatively calls for immediate action, and if insurmountable obstacles prevent the timely } \\
\text { convening of the Bundestag or the Bundestag cannot muster a quorum, the Joint Committee shall make this } \\
\text { determination by a two-thirds majority of the votes cast, which shall include at least a majority of its members. } \\
\text { (3) The determination shall be promulgated by the Federal President in the Federal Law Gazette pursuant to Article } 82 \text {. } \\
\text { If this cannot be done in time, promulgation shall be effected in another manner; the determination shall be printed in } \\
\text { the Federal Law Gazette as soon as circumstances permit. } \\
\text { (4) If the federal territory is under attack by armed force, and if the competent federal authorities are not in a position } \\
\text { at once to make the determination provided for in the first sentence of paragraph (1) of this Article, the determination } \\
\text { shall be deemed to have been made and promulgated at the time the attack began. The Federal President shall } \\
\text { announce that time as soon as circumstances permit. } \\
\text { (5) If the determination of a state of defense has been promulgated, and if the federal territory is under attack by } \\
\text { armed force, the Federal President, with the consent of the Bundestag, may issue declarations under international law } \\
\text { regarding the existence of the state of defense. Under the conditions specified in paragraph (2) of this Article, the Joint } \\
\text { Committee shall act in place of the Bundestag. }\end{array}$ \\
\hline Article 115b & $\begin{array}{l}\text { Power of command of the Federal Chancellor } \\
\text { Upon the promulgation of a state of defense the power of command over the Armed Forces shall pass to the Federal } \\
\text { Chancellor. }\end{array}$ \\
\hline Article 115d & $\begin{array}{l}\text { Urgent bills } \\
\text { (1) During a state of defense the federal legislative process shall be governed by the provisions of paragraphs (2) } \\
\text { and (3) of this Article without regard to the provisions of paragraph (2) of Article 76, the second sentence of } \\
\text { paragraph (1) and paragraphs (2) to (4) of Article } 77 \text {, Article 78, and paragraph (1) of Article } 82 \text {. } \\
\text { (2) Federal Government bills that the Government designates as urgent shall be forwarded to the Bundesrat at the } \\
\text { same time as they are submitted to the Bundestag. The Bundestag and the Bundesrat shall debate such bills in joint } \\
\text { session without delay. Insofar as the consent of the Bundesrat is necessary for any such bill to become law, a majority } \\
\text { of its votes shall be required. Details shall be regulated by rules of procedure adopted by the Bundestag and requiring } \\
\text { the consent of the Bundesrat. } \\
\text { (3) The second sentence of paragraph (3) of Article 115a shall apply to the promulgation of such laws mutatis mutandis. }\end{array}$ \\
\hline Article 115f & $\begin{array}{l}\text { Use of Federal Border Police - Extended powers of instruction } \\
\text { (1) During a state of defense the Federal Government, to the extent circumstances require, may: } \\
\text { 1. employ the Federal Border Police throughout the federal territory; } \\
\text { 2. issue instructions not only to federal administrative authorities but also to Land governments and, if it deems the } \\
\text { matter urgent, to Land authorities, and may delegate this power to members of Land governments designated by } \\
\text { it. } \\
\text { (2) The Bundestag, the Bundesrat and the Joint Committee shall be informed without delay of the measures taken in } \\
\text { accordance with paragraph (1) of this Article. }\end{array}$ \\
\hline
\end{tabular}




\section{Appendix 9}

\section{Excerpts fromThe South African Constitution}

Source: South Africa's Constitution of 1996 wih Amendments through 2012, generated from excerpts of texts from the repository of the Comparative Constitutions Project and accessed at www.constitutionproject.org

\begin{tabular}{|c|c|}
\hline Article 83 & $\begin{array}{l}\text { The President } \\
\text { The President- } \\
\text { (a) is the Head of State and head of the national executive; } \\
\text { (b) must uphold, defend and respect the Constitution as the supreme law of the Republic; and } \\
\text { (c) promotes the unity of the nation and that which will advance the Republic. }\end{array}$ \\
\hline Article 84 & $\begin{array}{l}\text { Powers and functions of President } \\
\text { (1) The President has the powers entrusted by the Constitution and legislation, including those necessary to perform the } \\
\text { functions of Head of State and head of the national executive. } \\
\text { (2) The President is responsible for- } \\
\text { (a) assenting to and signing Bills; } \\
\text { (b) referring a Bill back to the National Assembly for reconsideration of the Bill's constitutionality; } \\
\text { (c) referring a Bill to the Constitutional Court for a decision on the Bill's constitutionality; } \\
\text { (d) summoning the National Assembly, the National Council of Provinces or Parliament to an } \\
\text { extraordinary sitting to conduct special business; } \\
\text { (e) making any appointments that the Constitution or legislation requires the President to make, other } \\
\text { than as head of the national executive; } \\
\text { (f) appointing commissions of inquiry; } \\
\text { (g) calling a national referendum in terms of an Act of Parliament; } \\
\text { (h) receiving and recognizing foreign diplomatic and consular representatives; } \\
\text { (i) appointing ambassadors, plenipotentiaries, and diplomatic and consular representatives; } \\
\text { (j) pardoning or reprieving offenders and remitting any fines, penalties or forfeitures; and } \\
\text { (k) conferring honors }\end{array}$ \\
\hline Article 85 & $\begin{array}{l}\text { Executive authority of the Republic } \\
\text { (1) The executive authority of the Republic is vested in the President. } \\
\text { (2) The President exercises the executive authority, together with the other members of the Cabinet, by- } \\
\text { (a) implementing national legislation except where the Constitution or an Act of Parliament provides } \\
\text { otherwise; } \\
\text { (b) developing and implementing national policy; } \\
\text { (c) co-ordinating the functions of state departments and administrations; } \\
\text { (d) preparing and initiating legislation; and } \\
\text { (e) performing any other executive function provided for in the Constitution or in national legislation. }\end{array}$ \\
\hline Article 86 & $\begin{array}{l}\text { Election of President } \\
\text { (1) At its first sitting after its election, and whenever necessary to fill a vacancy, the National Assembly must elect a woman or } \\
\text { a man from among its members to be the President. } \\
\text { (2) The Chief Justice must preside over the election of the President, or designate another judge to do so. The procedure set } \\
\text { out in Part A of Schedule } 3 \text { applies to the election of the President. } \\
\text { [Sub-s. (2) substituted by s. } 6 \text { of the Constitution Sixth Amendment Act of 2001.] } \\
\text { (3) An election to fill a vacancy in the office of President must be held at a time and on a date determined by the Chief Justice, } \\
\text { but not more than } 30 \text { days after the vacancy occurs. } \\
\text { [Sub-s. (3) substituted by s. } 6 \text { of the Constitution Sixth Amendment Act of 2001.] }\end{array}$ \\
\hline Article 87 & $\begin{array}{l}\text { Assumption of office by President } \\
\text { When elected President, a person ceases to be a member of the National Assembly and, within five days, } \\
\text { must assume office by swearing or affirming faithfulness to the Republic and obedience to the } \\
\text { Constitution, in accordance with Schedule } 2 \text {. }\end{array}$ \\
\hline Article 88 & $\begin{array}{l}\text { Term of office of President } \\
\text { (1) The President's term of office begins on assuming office and ends upon a vacancy occurring or when the person next } \\
\text { elected President assumes office. } \\
\text { (2) No person may hold office as President for more than two terms, but when a person is elected to fill a } \\
\text { vacancy in the office of President, the period between that election and the next election of a President } \\
\text { is not regarded as a term. }\end{array}$ \\
\hline $\begin{array}{l}\text { Article } 89 \\
\text { Removal } \\
\text { of } \\
\text { President }\end{array}$ & $\begin{array}{l}\text { (1) The National Assembly, by a resolution adopted with a supporting vote of at least two thirds of its members, may remove } \\
\text { the President from office only on the grounds of- } \\
\text { (a) a serious violation of the Constitution or the law; } \\
\text { (b) serious misconduct; or } \\
\text { (c) in-ability to perform the functions of office. } \\
\text { (2) Anyone who has been removed from the office of President in terms of subsection (1) (a) or (b) may } \\
\text { not receive any benefits of that office, and may not serve in any public office. }\end{array}$ \\
\hline
\end{tabular}




\section{Rosa Ristawati: Modelling Executive Powers in the Indonesian Constitution: A comparative Study}

\begin{tabular}{|c|c|}
\hline Article 90 & $\begin{array}{l}\text { Acting President } \\
\text { (1) When the President is absent from the Republic or otherwise unable to fulfill the duties of President, or during a vacancy } \\
\text { in the office of President, an office-bearer in the order below acts as President: } \\
\text { (a) The Deputy President. } \\
\text { (b) A Minister designated by the President. } \\
\text { (c) A Minister designated by the other members of the Cabinet. } \\
\text { (d) The Speaker, until the National Assembly designates one of its other members. } \\
\text { (2) An Acting President has the responsibilities, powers and functions of the President. } \\
\text { (3) Before assuming the responsibilities, powers and functions of the President, the Acting President must swear or affirm } \\
\text { faithfulness to the Republic and obedience to the Constitution, in accordance with Schedule } 2 \text {. } \\
\text { (4) A person who as Acting President has sworn or affirmed faithfulness to the Republic need not repeat the swearing or } \\
\text { affirming procedure for any subsequent term as acting President during the period ending when the person next elected } \\
\text { President assumes office. } \\
\text { [Sub-s. (4) added by s. } 1 \text { of the Constitution First Amendment Act of 1997.] }\end{array}$ \\
\hline Article 91 & $\begin{array}{l}\text { Cabinet } \\
\text { (1) The Cabinet consists of the President, as head of the Cabinet, a Deputy President and Ministers. } \\
\text { (2) The President appoints the Deputy President and Ministers, assigns their powers and functions, and may dismiss them. } \\
\text { (3) The President- } \\
\text { (a) must select the Deputy President from among the members of the National Assembly; } \\
\text { (b) may select any number of Ministers from among the members of the National Assembly; and } \\
\text { (c) may select no more than two Ministers from outside the Assembly. } \\
\text { (4) The President must appoint a member of the Cabinet to be the leader of government business in the National Assembly. } \\
\text { (5) The Deputy President must assist the President in the execution of the functions of government. }\end{array}$ \\
\hline Article 92 & $\begin{array}{l}\text { Accountability and responsibilities } \\
\text { (1) The Deputy President and Ministers are responsible for the powers and functions of the executive assigned to them by the } \\
\text { President. } \\
\text { (2) Members of the Cabinet are accountable collectively and individually to Parliament for the exercise of their powers and } \\
\text { the performance of their functions. } \\
\text { (3) Members of the Cabinet must- } \\
\text { (a) act in accordance with the Constitution; and } \\
\text { (b) provide Parliament with full and regular reports concerning matters under their control. }\end{array}$ \\
\hline Article 93 & $\begin{array}{l}\text { Deputy Ministers } \\
\text { (1) The President may appoint- } \\
\text { (a) any number of Deputy Ministers from among the members of the National Assembly; and } \\
\text { (b) no more than two Deputy Ministers from outside the Assembly, } \\
\text { to assist the members of the Cabinet, and may dismiss them. } \\
\text { (2) Deputy Ministers appointed in terms of subsection (1) (b) are accountable to Parliament for the exercise of their powers } \\
\text { and the performance of their functions. } \\
\text { [S. } 93 \text { substituted by s. } 7 \text { of the Constitution Sixth Amendment Act of 2001.] }\end{array}$ \\
\hline Article 97 & $\begin{array}{l}\text { Transfer of functions } \\
\text { The President by proclamation may transfer to a member of the Cabinet- } \\
\text { (a) the administration of any legislation entrusted to another member; or } \\
\text { (b) any power or function entrusted by legislation to another member. }\end{array}$ \\
\hline Article 98 & $\begin{array}{l}\text { Temporary assignment of functions } \\
\text { The President may assign to a Cabinet member any power or function of another member who is absent } \\
\text { from office or is unable to exercise that power or perform that function. }\end{array}$ \\
\hline Article 100 & $\begin{array}{l}\text { National intervention in provincial administration } \\
\text { (1) When a province cannot or does not fulfill an executive obligation in terms of the Constitution or legislation, the national } \\
\text { executive may intervene by taking any appropriate steps to ensure fulfillment of that obligation, including- } \\
\text { (a) issuing a directive to the provincial executive, describing the extent of the failure to fulfill its } \\
\text { obligations and stating any steps required to meet its obligations; and } \\
\text { (b) assuming responsibility for the relevant obligation in that province to the extent necessary to- } \\
\text { (i) maintain essential national standards or meet established minimum standards for the rendering of a } \\
\text { service; } \\
\text { (ii) maintain economic unity; } \\
\text { (iii) maintain national security; or } \\
\text { (iv) prevent that province from taking unreasonable action that is prejudicial to the interests of another } \\
\text { provinces or to the country as a whole. } \\
\text { [Sub-s. (1) amended by s. } 2 \text { (b) of the Constitution Eleventh Amendment Act of } 2003 . \text {.] } \\
\text { (2) If the national executive intervenes in a province in terms of subsection (1) (b)- } \\
\text { (a) it must submit a written notice of the intervention to the National Council of Provinces within } 14 \text { days } \\
\text { after the intervention began; } \\
\text { (b) the intervention must end if the Council disapproves the intervention within } 180 \text { days after the }\end{array}$ \\
\hline
\end{tabular}




\begin{tabular}{|c|c|}
\hline & $\begin{array}{l}\text { intervention began or by the end of that period has not approved the intervention; and } \\
\text { (c) the Council must, while the intervention continues, review the intervention regularly and may make } \\
\text { any appropriate recommendations to the national executive. } \\
\text { [Sub-s. (2) substituted by s. } 2 \text { (c) of the Constitution Eleventh Amendment Act of 2003.] } \\
\text { (3) National legislation may regulate the process established by this section. } \\
\text { [S. } 100 \text { amended by s. } 2 \text { (a) of the Constitution Eleventh Amendment Act of 2003.] }\end{array}$ \\
\hline Article 101 & $\begin{array}{l}\text { Executive decisions } \\
\text { (1) A decision by the President must be in writing if it- } \\
\text { (a) is taken in terms of legislation; or } \\
\text { (b) has legal consequences. } \\
\text { (2) A written decision by the President must be countersigned by another Cabinet member if that decision concerns a function } \\
\text { assigned to that other Cabinet member. } \\
\text { (3) Proclamations, regulations and other instruments of subordinate legislation must be accessible to the public. } \\
\text { (4) National legislation may specify the manner in which, and the extent to which, instruments mentioned in subsection (3) } \\
\text { must be- } \\
\text { (a) tabled in Parliament; and } \\
\text { (b) approved by Parliament }\end{array}$ \\
\hline Article 102 & $\begin{array}{l}\text { Motions of no confidence } \\
\text { (1) If the National Assembly, by a vote supported by a majority of its members, passes a motion of no confidence in the } \\
\text { Cabinet excluding the President, the President must reconstitute the Cabinet. } \\
\text { (2) If the National Assembly, by a vote supported by a majority of its members, passes a motion of no } \\
\text { confidence in the President, the President and the other members of the Cabinet and any Deputy } \\
\text { Ministers must resign. }\end{array}$ \\
\hline Article 174 & 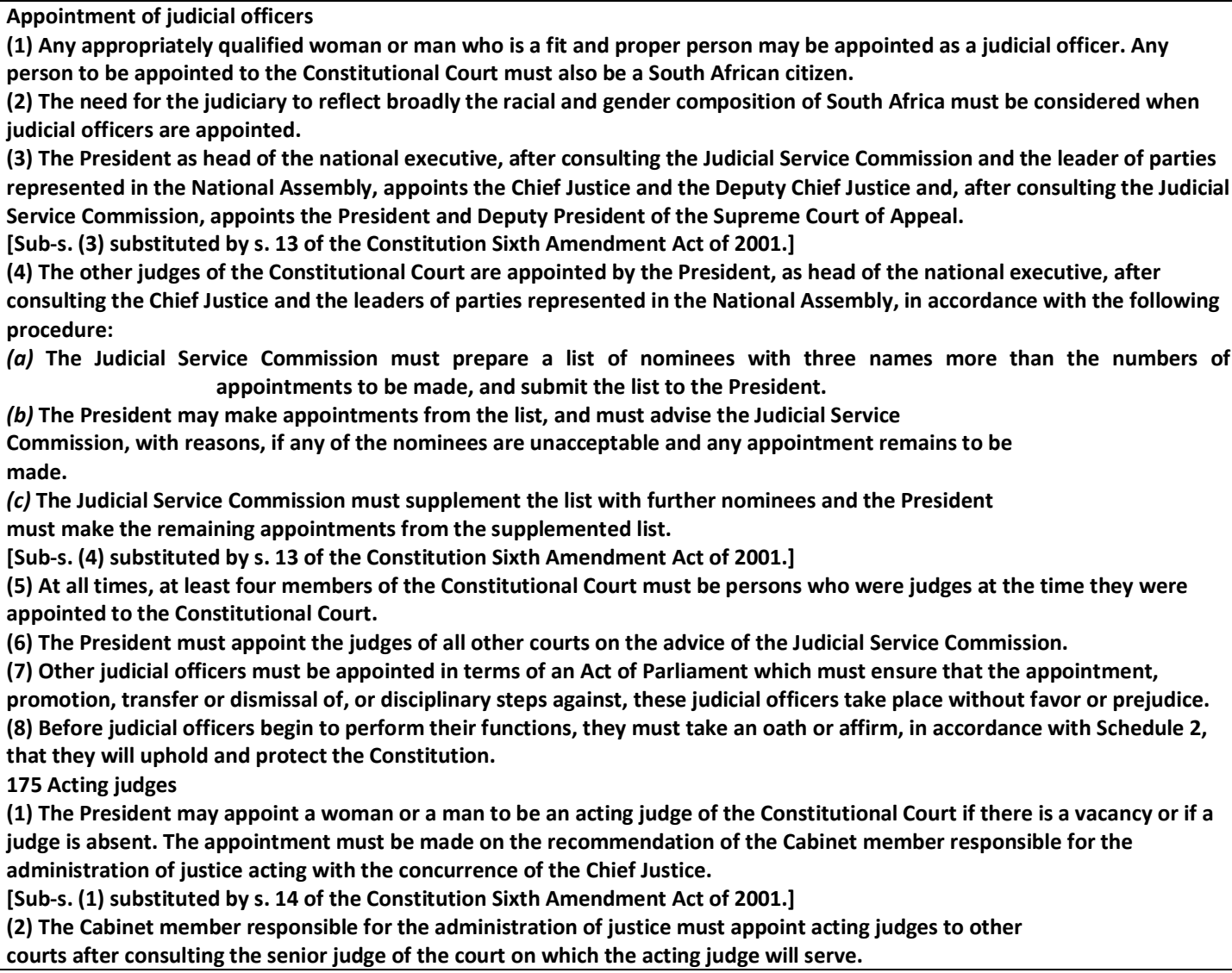 \\
\hline Article 177 & $\begin{array}{l}\text { Removal } \\
\text { (1) A judge may be removed from office only if-(a) the Judicial Service Commission funds that the judge } \\
\text { suffers from an incapacity, is grossly incompetent or is guilty of gross misconduct; and } \\
\text { (b) the National Assembly calls for that judge to be removed, by a resolution adopted with a supporting } \\
\text { vote of at least two thirds of its members. } \\
\text { (2) The President must remove a judge from office upon adoption of a resolution calling for that judge to be removed. }\end{array}$ \\
\hline
\end{tabular}




\begin{tabular}{|c|c|}
\hline & $\begin{array}{l}\text { (3) The President, on the advice of the Judicial Service Commission, may suspend a judge who is the } \\
\text { subject of a procedure in terms of subsection (1). }\end{array}$ \\
\hline Article 179 & $\begin{array}{l}\text { Prosecuting authority } \\
\text { (1) There is a single national prosecuting authority in the Republic, structured in terms of an Act of Parliament, and consisting } \\
\text { of- } \\
\text { (a) a National Director of Public Prosecutions, who is the head of the prosecuting authority, and is } \\
\text { appointed by the President, as head of the national executive; and } \\
\text { (b) Directors of Public Prosecutions and prosecutors as determined by an Act of Parliament. }\end{array}$ \\
\hline Article 193 & $\begin{array}{l}\text { Appointments } \\
\text { (1) The Public Protector and the members of any Commission established by this Chapter must be women or men who- } \\
\text { (a) are South African citizens; } \\
\text { (b) are fit and proper persons to hold the particular office; and } \\
\text { (c) are complied with any other requirements prescribed by national legislation. } \\
\text { (2) The need for a Commission established by this Chapter to reflect broadly the race and gender composition of South Africa } \\
\text { must be considered when members are appointed. } \\
\text { (3) The Auditor-General must be a woman or a man who is a South African citizen and a fit and proper person to hold that } \\
\text { office. Specialised knowledge of, or experience in, auditing, state finances and public administration must be given due regard } \\
\text { in appointing the Auditor-General. } \\
\text { (4) The President, on the recommendation of the National Assembly, must appoint the Public Protector, the Auditor-General } \\
\text { and the members of- } \\
\text { (a) the South African Human Rights Commission; } \\
\text { [Para. (a) amended by s. } 4 \text { of the Constitution Second Amendment Act of 1998.] } \\
\text { (b) the Commission for Gender Equality; and } \\
\text { (c) the Electoral Commission. } \\
\text { (5) The National Assembly must recommend persons- } \\
\text { (a) nominated by a committee of the Assembly proportionally composed of members of all parties } \\
\text { represented in the Assembly; and(b) approved by the Assembly by a resolution adopted with a } \\
\text { supporting vote- } \\
\text { (i) of at least } 60 \text { per cent of the members of the Assembly, if the recommendation concerns the } \\
\text { appointment of the Public Protector or the Auditor-General; or } \\
\text { (ii) of a majority of the members of the Assembly, if the recommendation concerns the appointment of a } \\
\text { member of a Commission. } \\
\text { (6) The involvement of civil society in the recommendation process may be provided for as envisaged in } \\
\text { section } 59 \text { (1) (a). }\end{array}$ \\
\hline Article 194 & $\begin{array}{l}\text { Removal from office } \\
\text { (1) The Public Protector, the Auditor-General or a member of a Commission established by this Chapter may be removed from } \\
\text { office only on- } \\
\text { (a) the ground of misconduct, incapacity or incompetence; } \\
\text { (b) a finding to that effect by a committee of the National Assembly; and } \\
\text { (c) the adoption by the Assembly of a resolution calling for that person's removal from office } \\
\text { (2) A resolution of the National Assembly concerning the removal from office of- } \\
\text { (a) the Public Protector or the Auditor-General must be adopted with a supporting vote of at least two thirds of the members } \\
\text { (b) a member of a Commission must be adopted with a supporting vote of a majority of the members of the Assembly. } \\
\text { (3) The President- } \\
\text { (a) may suspend a person from office at any time after the start of the proceedings of a committee of the National Assembly } \\
\text { (b) must remove a person from office upon adoption by the Assembly of the resolution calling for that person's removal. }\end{array}$ \\
\hline Article 198 & $\begin{array}{l}\text { CHAPTER } 11 \text { SECURITY SERVICES (ss 198-210) } \\
\text { Governing principles } \\
\text { The following principles govern national security in the Republic: } \\
\text { (a) National security must reflect the resolve of South Africans, as individuals and as a nation, to live as } \\
\text { equals, to live in peace and harmony, to be free from fear and want and to seek a better life. } \\
\text { (b) The resolve to live in peace and harmony precludes any South African citizen from participating in } \\
\text { armed conflict, nationally or internationally, except as provided for in terms of the Constitution or } \\
\text { national legislation. } \\
\text { (c) National security must be pursued in compliance with the law, including international law. } \\
\text { (d) National security is subject to the authority of Parliament and the national executive. }\end{array}$ \\
\hline Article 199 & $\begin{array}{l}\text { Establishment, structuring and conduct of security services } \\
\text { (1) The security services of the Republic consist of a single defense force, a single police service and any intelligence services } \\
\text { established in terms of the Constitution. } \\
\text { (2) The defense force is the only lawful military force in the Republic. } \\
\text { (3) Other than the security services established in terms of the Constitution, armed organizations or services may be }\end{array}$ \\
\hline
\end{tabular}




\begin{tabular}{|c|c|}
\hline & $\begin{array}{l}\text { established only in terms of national legislation. } \\
\text { (4) The security services must be structured and regulated by national legislation. } \\
\text { (5) The security services must act, and must teach and require their members to act, in accordance with the Constitution and } \\
\text { the law, including customary international Copyright Juta \& Company Limitedlaw and international agreements binding on } \\
\text { the Republic. } \\
\text { (6) No member of any security service may obey a manifestly illegal order. } \\
\text { (7) Neither the security services, nor any of their members, may, in the performance of their functions- } \\
\text { (a) prejudice a political party interest that is legitimate in terms of the Constitution; or } \\
\text { (b) further, in a partisan manner, any interest of a political party. } \\
\text { (8) To give effect to the principles of transparency and accountability, multi-party parliamentary committees, have oversight } \\
\text { of all security services in a manner determined by national legislation or the rules and orders of Parliament. }\end{array}$ \\
\hline Article 201 & $\begin{array}{l}\text { Political responsibility } \\
\text { (1) A member of the Cabinet must be responsible for defense. } \\
\text { (2) Only the President, as head of the national executive, may authorize the employment of the defense force- } \\
\text { (a) in co-operation with the police service; } \\
\text { (b) in defense of the Republic; or } \\
\text { (c) in fulfillment an international obligation. } \\
\text { (3) When the defense force is employed for any purpose mentioned in subsection (2), the President must inform Parliament, } \\
\text { promptly and in appropriate detail, of- } \\
\text { (a) the reasons for the employment of the defence force; } \\
\text { (b) any place where the force is being employed; } \\
\text { (c) the number of people involved; and } \\
\text { (d) the period for which the force is expected to be employed. } \\
\text { (4) If Parliament does not sit during the first seven days after the defence force is employed as envisaged in subsection (2), the } \\
\text { President must provide the information required in subsection (3) to the appropriate oversight committee. }\end{array}$ \\
\hline Article 201 & $\begin{array}{l}\text { Command of defence force } \\
\text { (1) The President as head of the national executive is Commander-in-Chief of the defence force, and must appoint the Military } \\
\text { Command of the defence force. } \\
\text { (2) Command of the defence force must be exercised in accordance with the directions of the Cabinet } \\
\text { member responsible for defence, under the authority of the President. }\end{array}$ \\
\hline Article 203 & $\begin{array}{l}\text { State of national defence } \\
\text { (1) The President as head of the national executive may declare a state of national defence, and must inform Parliament } \\
\text { promptly and in appropriate detail of- } \\
\text { (a) the reasons for the declaration; } \\
\text { (b) any place where the defence force is being employed; and } \\
\text { (c) the number of people involved. } \\
\text { (2) If Parliament is not sitting when a state of national defence is declared, thePresident must summon Parliament to an } \\
\text { extraordinary sitting within seven days of the declaration. } \\
\text { (3) A declaration of a state of national defence lapses unless it is approved by Parliament within seven } \\
\text { days of the declaration. }\end{array}$ \\
\hline Article 207 & $\begin{array}{l}\text { Control of police service } \\
\text { (1) The President as head of the national executive must appoint a woman or a man as the National } \\
\text { Commissioner of the police service, to control and manage the police service. }\end{array}$ \\
\hline Article 209 & $\begin{array}{l}\text { Establishment and control of intelligence services } \\
\text { (1) Any intelligence service, other than any intelligence division of the defence force or police services, may be established } \\
\text { only by the President, as head of the national executive, and only in terms of national legislation. } \\
\text { (2) The President as head of the national executive must appoint a woman or a man as head of each } \\
\text { intelligence service established in terms of subsection (1), and must either assume political responsibility } \\
\text { for the control and direction of any of those services, or designate a member of the Cabinet to assume } \\
\text { that responsibility. }\end{array}$ \\
\hline Article 210 & $\begin{array}{l}\text { Powers, functions and monitoring } \\
\text { National legislation must regulate the objects, powers and functions of the intelligence services, including any intelligence } \\
\text { division of the defence force or police service, and must provide for- } \\
\text { (a) the co-ordination of all intelligence services; and } \\
\text { (b) civilian monitoring of the activities of those services by an inspector appointed by the President, as } \\
\text { head of the national executive, and approved by a resolution adopted by the National Assembly with a } \\
\text { supporting vote of at least two thirds of its members. }\end{array}$ \\
\hline Article 220 & $\begin{array}{l}\text { Financial and Fiscal Commission (ss 220-222) } \\
\text { Establishment and functions } \\
\text { (1) There is a Financial and Fiscal Commission for the Republic which makes recommendations envisaged in this Chapter, or in } \\
\text { national legislation, to Parliament, provincial legislatures and any other authorities determined by national legislation. } \\
\text { (2) The Commission is independent and subject only to the Constitution and the law, and must be impartial. }\end{array}$ \\
\hline
\end{tabular}




\begin{tabular}{|c|c|}
\hline & $\begin{array}{l}\text { (3) The Commission must function in terms of an Act of Parliament and, in performing its functions, must consider all relevant } \\
\text { factors, including those listed in section } 214 \text { (2). } \\
221 \text { Appointment and tenure of members } \\
\text { (1) The Commission consists of the following women and men appointed by the President, as head of the national executive: } \\
\text { (a) A chairperson and deputy chairperson; } \\
\text { (b) three persons selected, after consulting the Premiers, from a list compiled in accordance with a } \\
\text { process prescribed by national legislation; } \\
\text { (c) two persons selected, after consulting organized local government, from a list compiled in accordance } \\
\text { with a process prescribed by national legislation; and } \\
\text { (d) two other persons. } \\
\text { [Sub-s. (1) substituted by s. } 7 \text { (a) of the Constitution Seventh Amendment Act of 2001.] } \\
\text { (1A) National legislation referred to in subsection (1) must provide for the participation of- } \\
\text { (a) the Premiers in the compilation of a list envisaged in subsection (1) (b); and } \\
\text { (b) organized local government in the compilation of a list envisaged in subsection (1) (c). } \\
\text { [Sub-s. (1A) inserted by } 7 \text { (b) of the Constitution Seventh Amendment Act of 2001.] } \\
\text { (2) Members of the Commission must have appropriate expertise. } \\
\text { (3) Members serve for a term established in terms of national legislation. The President may remove a } \\
\text { member from office on the ground of misconduct, incapacity or incompetence. }\end{array}$ \\
\hline Article 231 & $\begin{array}{l}\text { International agreements } \\
\text { (1) The negotiating and signing of all international agreements is the responsibility of the national executive. } \\
\text { (2) An international agreement binds the Republic only after it has been approved by resolution in both the National } \\
\text { Assembly and the National Council of Provinces, unless it is an agreement referred to in subsection (3). } \\
\text { (3) An international agreement of a technical, administrative or executive nature, or an agreement which does not require } \\
\text { either ratification or accession, entered into by the national executive, binds the Republic without approval by the National } \\
\text { Assembly and the National Council of Provinces, but must be tabled in the Assembly and the Council within a reasonable time. } \\
\text { (4) Any international agreement becomes law in the Republic when it is enacted into law by national legislation; but a self- } \\
\text { executing provision of an agreement that has been approved by Parliament is law in the Republic unless it is inconsistent with } \\
\text { the Constitution or an Act of Parliament. } \\
\text { (5) The Republic is bound by international agreements which were binding on the Republic when this Constitution took effect. }\end{array}$ \\
\hline Article 232 & $\begin{array}{l}\text { Customary international law } \\
\text { Customary international law is law in the Republic unless it is inconsistent with the Constitution or an Act of Parliament. }\end{array}$ \\
\hline Article 233 & $\begin{array}{l}\text { Application of international law } \\
\text { When interpreting any legislation, every court must prefer any reasonable interpretation of the } \\
\text { legislation that is consistent with international law over any alternative interpretation that is } \\
\text { inconsistent with international law. }\end{array}$ \\
\hline \multirow[t]{2}{*}{ Article 238} & $\begin{array}{l}\text { Agency and delegation } \\
\text { An executive organ of state in any sphere of government may- } \\
\text { (a) delegate any power or function that is to be exercised or performed in terms of legislation to any } \\
\text { other executive organ of state, provided the delegation is consistent with the legislation in terms of } \\
\text { which the power is exercised or the function is performed; or } \\
\text { (b) exercise any power or perform any function for any other executive organ of state on an agency or } \\
\text { delegation basis. }\end{array}$ \\
\hline & $\begin{array}{l}\text { ANNEXURE B GOVERNMENT OF NATIONAL UNITY: NATIONAL SPHERE } \\
\text { 1. Section } 84 \text { of the new Constitution is deemed to contain the following additional subsection: } \\
\text { '(3) The President must consult the Executive Deputy Presidents- } \\
\text { (a) in the development and execution of the policies of the national government; } \\
\text { (b) in all matters relating to the management of the Cabinet and the performance of Cabinet business; } \\
\text { (c) in the assignment of functions to the Executive Deputy Presidents; } \\
\text { (d) before making any appointment under the Constitution or any legislation, including the appointment } \\
\text { of ambassadors or other diplomatic representatives; } \\
\text { (e) before appointing commissions of inquiry; } \\
\text { (f) before calling a referendum; and } \\
\text { (g) before pardoning or reprieving offenders.'. } \\
2 \text {. Section } 89 \text { of the new Constitution is deemed to contain the following additional subsection: } \\
\text { '(3) Subsections (1) and ( } 2 \text { ) apply also to an Executive Deputy President.' } \\
\text { 3. Paragraph (a) of section } 90 \text { (1) of the new Constitution is deemed to read as follows. } \\
\text { '(a) an Executive Deputy President designated by the President;' } \\
4 \text {. Section } 91 \text { of the new Constitution is deemed to read as follows: } \\
\text { 'Cabinet } \\
\text { Section } 91 \text { (1) The Cabinet consists of the President, the Executive Deputy Presidents and- } \\
\text { (a) not more than } 27 \text { Ministers who are members of the National Assembly and appointed in terms of } \\
\text { subsections (8) to ( } 12 \text { ); and } \\
\text { (b) not more than one Minister who is not a member of the National Assembly and appointed in terms of }\end{array}$ \\
\hline
\end{tabular}


subsection (13), provided the President, acting in consultation with the Executive Deputy Presidents and the leaders of the participating parties, deems the appointment of such a Minister expedient.

(2) Each party holding at least 80 seats in the National Assembly is entitled to designate an Executive Deputy President from among the members of the Assembly.

(3) If no party or only one party holds $\mathbf{8 0}$ or more seats in the Assembly, the party holding the largest number of seats and the party holding the second largest number of seats are each entitled to designate one Executive Deputy President from among the members of the Assembly.

(4) On being designated, an Executive Deputy President may elect to remain or cease to be a member of the Assembly.

(5) An Executive Deputy President may exercise the powers and must perform the functions vested in the office of Executive Deputy President by the Constitution or assigned to that office by the President.

(6) An Executive Deputy President holds office-

(a) until 30 April 1999 unless replaced or recalled by the party entitled to make the designation in terms of subsections (2) and (3); or

(b) until the person elected President after any election of the National Assembly held before 30 April 1999, assumes office.

(7) A vacancy in the office of an Executive Deputy President may be filled by the party which designated that Deputy President.

(8) A party holding at least $\mathbf{2 0}$ seats in the National Assembly and which has decided to participate in the government of national unity, is entitled to be allocated one or more of the Cabinet portfolios in respect of which Ministers referred to in subsection (1) (a) are to be appointed, in proportion to the number of seats held by it in the National Assembly relative to the number of seats held by the other participating parties.

(9) Cabinet portfolios must be allocated to the respective participating parties in accordance with the following formula:

(a) A quota of seats per portfolio must be determined by dividing the total number of seats in the National Assembly held jointly by the participating parties by the number of portfolios in respect of which Ministers referred to in subsection (1) (a) are to be appointed, plus one.

(b) The result, disregarding third and subsequent decimals, if any, is the quota of seats per portfolio. (c) The number of portfolios to be allocated to a participating party is determined by dividing the total number of seats held by that party in the National Assembly by the quota referred to in paragraph (b). (d) The result, subject to paragraph (e), indicates the number of portfolios to be allocated to that party. (e) Where the application of the above formula yields a surplus not absorbed by the number of portfolios allocated to a party, the surplus competes with other similar surpluses accruing to another party or parties, and any portfolio or portfolios which remain unallocated must be allocated to the party or parties concerned in sequence of the highest surplus.

(10) The President after consultation with the Executive Deputy Presidents and the leaders of the participating parties must-

(a) determine the specific portfolios to be allocated to the respective participating parties in accordance with the number of portfolios allocated to them in terms of subsection (9);

(b) appoint in respect of each such portfolio a member of the National Assembly who is a member of the party to which that portfolio was allocated under paragraph (a), as the Minister responsible for that portfolio;

(c) if it becomes necessary for the purposes of the Constitution or in the interest of good government, vary any determination under paragraph $(a)$, subject to subsection (9);

(d) terminate any appointment under paragraph (b)-

(i) if the President is requested to do so by the leader of the party of which the Minister in question is a member; or

(ii) if it becomes necessary for the purposes of the Constitution or in the interest of good government; or (e) fill, when necessary, subject to paragraph (b), a vacancy in the office of Minister.

(11) Subsection (10) must be implemented in the spirit embodied in the concept of a government of national unity, and the President and the other functionaries concerned must in the implementation of that subsection seek to achieve consensus at all times: Provided that if consensus cannot be achieved on-

(a) the exercise of a power referred to in paragraph (a), (c) or (d) (ii) of that subsection, the President's decision prevails;

(b) the exercise of a power referred to in paragraph (b), (d) (i) or (e) of that subsection affecting a person who is not a member of the President's party, the decision of the leader of the party of which that person is a member prevails; and

(c) the exercise of a power referred to in paragraph (b) or (e) of that subsection affecting a person who is a member of the President's party, the President's decision prevails.

(12) If any determination of portfolio allocations is varied under subsection (10) (c), the affected

Ministers must vacate their portfolios but are eligible, where applicable, for reappointment to other 
portfolios allocated to their respective parties in terms of the varied determination.

(13) The President-

(a) in consultation with the Executive Deputy Presidents and the leaders of the participating parties, must-

(i) determine a specific portfolio for a Minister referred to in subsection (1) (b) should it become

necessary pursuant to a decision of the President under that subsection;

(ii) appoint in respect of that portfolio a person who is not a member of the National Assembly, as the

Minister responsible for that portfolio; and

(iii) fill, if necessary, a vacancy in respect of that portfolio; or

(b) after consultation with the Executive Deputy Presidents and the leaders of the participating parties, must terminate any appointment under paragraph (a) if it becomes necessary for the purposes of the Constitution or in the interest of good government.

(14) Meetings of the Cabinet must be presided over by the President, or, if the President so instructs, by an Executive Deputy President: Provided that the Executive Deputy Presidents preside over meetings of the Cabinet in turn unless the exigencies of government and the spirit embodied in the concept of the government of national unity otherwise demand.

(15) The Cabinet must function in a manner which gives consideration to the consensus-seeking spirit embodied in the concept of a government of national unity as well as the need for effective government.'

5. Section 93 of the new Constitution is deemed to read as follows:

'Appointment of Deputy Ministers

93 (1) The President may, after consultation with the Executive Deputy Presidents and the leaders of the parties participating in the Cabinet, establish deputy ministerial posts.

(2) A party is entitled to be allocated one or more of the deputy ministerial posts in the same proportion and according to the same formula that portfolios in the Cabinet are allocated.

(3) The provisions of section 91 (10) to (12) apply, with the necessary changes, in respect of Deputy Ministers, and in such application a reference in that section to a Minister or a portfolio must be read as a reference to a Deputy Minister or a deputy ministerial post, respectively.

(4) If a person is appointed as the Deputy Minister of any portfolio entrusted to a Minister-

(a) that Deputy Minister must exercise and perform on behalf of the relevant Minister any of the powers and functions assigned to that Minister in terms of any legislation or otherwise which may, subject to the directions of the President, be assigned to that Deputy Minister by that Minister; and

(b) any reference in any legislation to that Minister must be construed as including a reference to the Deputy Minister acting in terms of an assignment under paragraph (a) by the Minister for whom that Deputy Minister acts.

(5) Whenever a Deputy Minister is absent or for any reason unable to exercise or perform any of the powers or functions of office, the President may appoint any other Deputy Minister or any other person to act in the said Deputy Minister's stead, either generally or in the exercise or performance of any specific power or function.'.

6. Section 96 of the new Constitution is deemed to contain the following additional subsections: '(3) Ministers are accountable individually to the President and to the National Assembly for the administration of their portfolios, and all members of the Cabinet are correspondingly accountable collectively for the performance of the functions of the national government and for its policies.

(4) Ministers must administer their portfolios in accordance with the policy determined by the Cabinet.

(5) If a Minister fails to administer the portfolio in accordance with the policy of the Cabinet, the President may require the Minister concerned to bring the administration of the portfolio into conformity with that policy.

(6) If the Minister concerned fails to comply with a requirement of the President under subsection (5), the President may remove the Minister from office-

(a) if it is a Minister referred to in section 91 (1) (a), after consultation with the Minister and, if the Minister is not a member of the President's party or is not the leader of a participating party, also after consultation with the leader of that Minister's party; or

(b) if it is a Minister referred to in section 91 (1) (b), after consultation with the Executive Deputy Presidents and the leaders of the participating parties.'. 
Rosa Ristawati: Modelling Executive Powers in the Indonesian Constitution: A comparative Study

Appendix 10

Excerpts from The French Constitution

Source: France's Constitution of 1958 with Amendments through 2008, generated from excerpt of texts from the repository of the Comparative Constitutions Project, accessed at www.constituteproject.org

\begin{tabular}{|c|c|}
\hline Article 5 & $\begin{array}{l}\text { The President of the Republic shall ensure due respect for the Constitution. He shall ensure, by his arbitration, the proper } \\
\text { functioning of the public authorities and the continuity of the State. } \\
\text { He shall be the guarantor of national independence, territorial integrity and due respect for Treaties. }\end{array}$ \\
\hline Article 6 & $\begin{array}{l}\text { The President of the Republic shall be elected for a term of five years by direct universal suffrage. } \\
\text { No one may hold office for more than two consecutive terms. } \\
\text { The manner of implementation of this article shall be determined by an Institutional Act. }\end{array}$ \\
\hline Article 7 & 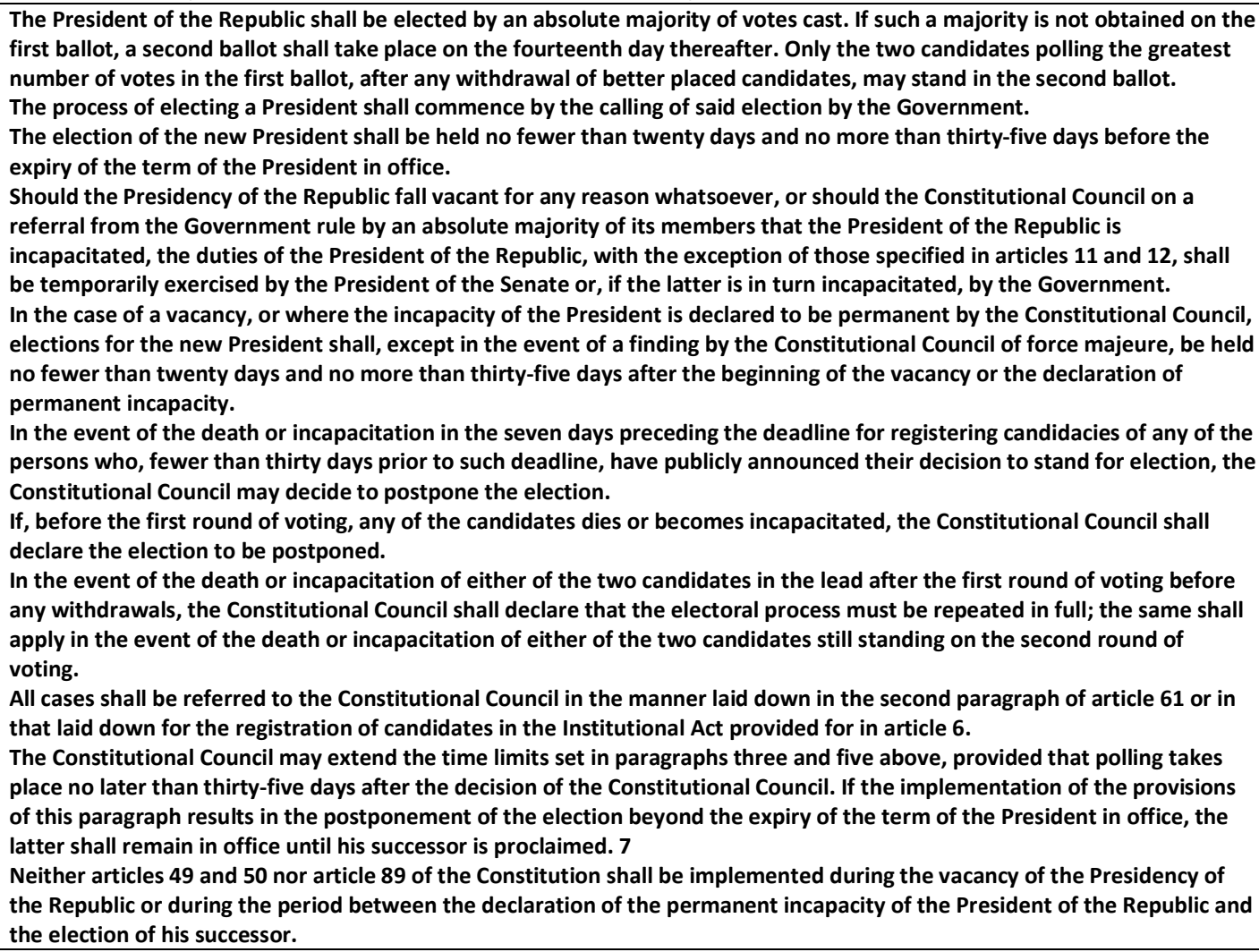 \\
\hline Article 8 & $\begin{array}{l}\text { The President of the Republic shall appoint the Prime Minister. He shall terminate the appointment of the Prime Minister } \\
\text { when the latter tenders the resignation of the Government. } \\
\text { On the recommendation of the Prime Minister, he shall appoint the other members of the Government and terminate their } \\
\text { appointments. }\end{array}$ \\
\hline Article 9 & The President of the Republic shall preside over the Council of Ministers. \\
\hline Article 10 & $\begin{array}{l}\text { The President of the Republic shall promulgate Acts of Parliament within fifteen days following the final passage of an Act } \\
\text { and its transmission to the Government. } \\
\text { He may, before the expiry of this time limit, ask Parliament to reopen debate on the Act or any sections thereof. Such } \\
\text { reopening of debate shall not be refused. }\end{array}$ \\
\hline Article 11 & $\begin{array}{l}\text { The President of the Republic may, on a recommendation from the Government when Parliament is in session, or on a joint } \\
\text { motion of the two Houses, published in the Journal Officiel, submit to a referendum any Government Bill which deals with } \\
\text { the organization of the public authorities, or with reforms relating to the economic or social policy of the Nation, and to the } \\
\text { public services contributing thereto, or which provides for authorization to ratify a treaty which, although not contrary to } \\
\text { the Constitution, would affect the functioning of the institutions. } \\
\text { Where the referendum is held on the recommendation of the Government, the latter shall make a statement before each } \\
\text { House and the same shall be followed by a debate. }\end{array}$ \\
\hline Article 11(1) & $\begin{array}{l}\text { The President of the Republic may, on a recommendation from the Government when Parliament is in session, or on a joint } \\
\text { motion of the two Houses, published in the Journal Officiel, submit to a referendum any Government Bill which deals with } \\
\text { the organization of the public authorities, or with reforms relating to the economic, social or environmental policy of the }\end{array}$ \\
\hline
\end{tabular}




\begin{tabular}{|c|c|}
\hline & $\begin{array}{l}\text { Nation, and to the public services contributing thereto, or which provides for authorization to ratify a treaty which, } \\
\text { although not contrary to the Constitution, would affect the functioning of the institutions. } \\
\text { Where the referendum is held on the recommendation of the Government, the latter shall make a statement before each } \\
\text { House and the same shall be followed by a debate. } \\
\text { A referendum concerning a subject mentioned in the first paragraph may be held upon the initiative of one fifth of the } \\
\text { Members of Parliament, supported by one tenth of the voters enrolled on the electoral register. This initiative shall take the } \\
\text { form of a Private Member's Bill and shall not be applied to the repeal of a statutory provision promulgated for less than one } \\
\text { year. } \\
\text { The conditions by which it is introduced and those according to which the Constitutional Council monitors the respect of the } \\
\text { provisions of the previous paragraph, are set down by an Institutional Act. } \\
\text { If the Private Member's Bill has not been considered by the two Houses within a period set by the Institutional Act, the } \\
\text { President of the Republic shall submit it to a referendum. } \\
\text { Where the decision of the French people in the referendum is not favourable to the Private Member's Bill, no new } \\
\text { referendum proposal on the same subject may be submitted before the end of a period of two years following the date of } \\
\text { the vote. } \\
\text { Where the outcome of the referendum is favourable to the Government Bill or to the Private Member's Bill, the President } \\
\text { of the Republic shall promulgate the resulting statute within fifteen days following the proclamation of the results of the } \\
\text { vote. }\end{array}$ \\
\hline Article 12 & $\begin{array}{l}\text { The President of the Republic may, after consulting the Prime Minister and the Presidents of the Houses of Parliament, } \\
\text { declare the National Assembly dissolved. } \\
\text { A general election shall take place no fewer than twenty days and no more than forty days after the dissolution. } \\
\text { The National Assembly shall sit as of right on the second Thursday following its election. Should this sitting fall outside the } \\
\text { period prescribed for the ordinary session, a session shall be convened by right for a fifteen-day period. } \\
\text { No further dissolution shall take place within a year following said election. }\end{array}$ \\
\hline Article 13 & $\begin{array}{l}\text { The President of the Republic shall sign the Ordinances and Decrees deliberated upon in the Council of Ministers. } \\
\text { He shall make appointments to the civil and military posts of the State. Conseillers d'État, the Grand Chancelier de la Légion } \\
\text { d'Honneur, Ambassadors and Envoys Extraordinary, Conseillers Maîtres of the Cour des Comptes, Prefects, State } \\
\text { representatives in the overseas communities to which article } 74 \text { applies and in New Caledonia, highest-ranking Military } \\
\text { Officers, Recteurs des Académies and Directors of Central Government Departments shall be appointed in the Council of } \\
\text { Ministers. } \\
\text { An Institutional Act shall determine the other posts to be filled at meetings of the Council of Ministers and the manner in } \\
\text { which the power of the President of the Republic to make appointments may be delegated by him to be exercised on his } \\
\text { behalf. } \\
\text { An Institutional Act shall determine the posts or positions, other than those mentioned in the third paragraph, concerning } \\
\text { which, on account of their importance in the guaranteeing of the rights and freedoms or the economic and social life of the } \\
\text { Nation, the power of appointment vested in the President of the Republic shall be exercised after public consultation with } \\
\text { the relevant standing committee in each House. The President of the Republic shall not make an appointment when the } \\
\text { sum of the negative votes in each committee represents at least three fifths of the votes cast by the two committees. } \\
\text { Statutes shall determine the relevant standing committees according to the posts or positions concerned. }\end{array}$ \\
\hline Article 14 & $\begin{array}{l}\text { The President of the Republic shall accredit ambassadors and envoys extraordinary to foreign powers; foreign ambassadors } \\
\text { and envoys extraordinary shall be accredited to him. }\end{array}$ \\
\hline Article 15 & $\begin{array}{l}\text { The President of the Republic shall be Commander-in-Chief of the Armed Forces. He shall preside over the higher national } \\
\text { defence councils and committees. }\end{array}$ \\
\hline Article 16 & $\begin{array}{l}\text { Where the institutions of the Republic, the independence of the Nation, the integrity of its territory or the fulfillment of its } \\
\text { international commitments are under serious and immediate threat, and where the proper functioning of the constitutional } \\
\text { public authorities is interrupted, the President of the Republic shall take measures required by these circumstances, after } \\
\text { formally consulting the Prime Minister, the Presidents of the Houses of Parliament and the Constitutional Council. } \\
\text { He shall address the Nation and inform it of such measures. } \\
\text { The measures shall be designed to provide the constitutional public authorities as swiftly as possible, with the means to } \\
\text { carry out their duties. The Constitutional Council shall be consulted with regard to such measures. } \\
\text { Parliament shall sit as of right. } \\
\text { The National Assembly shall not be dissolved during the exercise of such emergency powers. } \\
\text { After thirty days of the exercise of such emergency powers, the matter may be referred to the Constitutional Council by the } \\
\text { President of the National Assembly, the President of the Senate, sixty Members of the National Assembly or sixty Senators, } \\
\text { so as to decide if the conditions laid down in paragraph one still apply. The Council shall make its decision publicly as soon } \\
\text { as possible. It shall, as of right, carry out such an examination and shall make its decision in the same manner after sixty } \\
\text { days of the exercise of emergency powers or at any moment thereafter. }\end{array}$ \\
\hline Article 17 & The President of the Republic is vested with the power to grant individual pardons. \\
\hline Article 18 & $\begin{array}{l}\text { The President of the Republic shall communicate with the two Houses of Parliament by messages which he shall cause to be } \\
\text { read aloud and which shall not give rise to any debate. } \\
\text { He may take the floor before Parliament convened in Congress for this purpose. His statement may give rise, in his absence, } \\
\text { to a debate without vote. }\end{array}$ \\
\hline
\end{tabular}


Rosa Ristawati: Modelling Executive Powers in the Indonesian Constitution: A comparative Study

\begin{tabular}{|c|c|}
\hline & hen not in session, the Houses of Parliament shall be convened especially for this purpose. \\
\hline Article 19 & $\begin{array}{l}\text { Instruments of the President of the Republic, other than those provided for under articles } 8 \text { (paragraph one), 11, 12, 16, 18, } \\
54,56 \text { and } 61 \text {, shall be countersigned by the Prime Minister and, where required, by the ministers concerned. }\end{array}$ \\
\hline Article 20 & $\begin{array}{l}\text { The Government shall determine and conduct the policy of the Nation. } \\
\text { It shall have at its disposal the civil service and the armed forces. } \\
\text { It shall be accountable to Parliament in accordance with the terms and procedures set out in articles } 49 \text { and } 50 \text {. }\end{array}$ \\
\hline Article 21 & $\begin{array}{l}\text { The Prime Minister shall direct the actions of the Government. He shall be responsible for national defence. He shall ensure } \\
\text { the implementation of legislation. Subject to article } 13 \text {, he shall have power to make regulations and shall make } \\
\text { appointments to civil and military posts. } \\
\text { He may delegate certain of his powers to Ministers. } \\
\text { He shall deputize, if the case arises, for the President of the Republic as chairman of the councils and committees referred } \\
\text { to in article } 15 . \\
\text { He may, in exceptional cases, deputize for him as chairman of a meeting of the Council of Ministers by virtue of an express } \\
\text { delegation of powers for a specific agenda. }\end{array}$ \\
\hline Article 22 & $\begin{array}{l}\text { Instruments of the Prime Minister shall be countersigned, where required, by the ministers responsible for their } \\
\text { implementation. }\end{array}$ \\
\hline Article 23 & $\begin{array}{l}\text { Membership of the Government shall be incompatible with the holding of any Parliamentary office, any position of } \\
\text { professional representation at national level, any public employment or any professional activity. } \\
\text { An Institutional Act shall determine the manner in which the holders of such offices, positions or employment shall be } \\
\text { replaced. } \\
\text { The replacement of Members of Parliament shall take place in accordance with the provisions of article } 25 \text {. }\end{array}$ \\
\hline Article 24 & $\begin{array}{l}\text { Parliament shall pass statutes. It shall monitor the action of the Government. It shall assess public policies. } \\
\text { It shall comprise the National Assembly and the Senate. } \\
\text { Members of the National Assembly, whose number shall not exceed five hundred and seventy-seven, shall be elected by } \\
\text { direct suffrage. } \\
\text { The Senate, whose members shall not exceed three hundred and forty-eight, shall be elected by indirect suffrage. The } \\
\text { Senate shall ensure the representation of the territorial communities of the Republic. }\end{array}$ \\
\hline Article 34 & 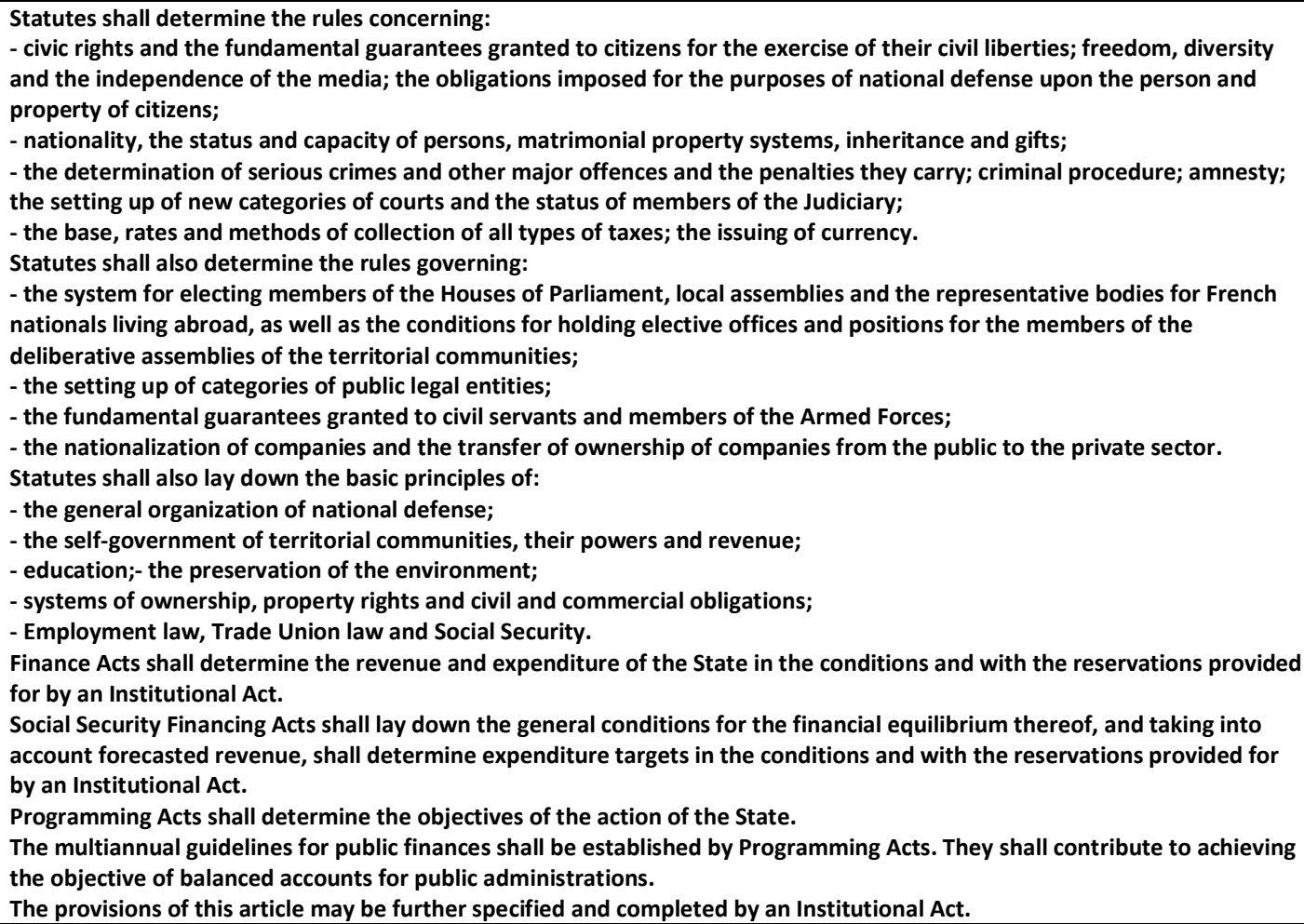 \\
\hline Article 35 & $\begin{array}{l}\text { A declaration of war shall be authorized by Parliament. } \\
\text { The Government shall inform Parliament of its decision to have the armed forces intervene abroad, at the latest three days } \\
\text { after the beginning of said intervention. It shall detail the objectives of the said intervention. This information may give rise } \\
\text { to a debate, which shall not be followed by a vote. } \\
\text { Where the said intervention shall exceed four months, the Government shall submit the extension to Parliament for }\end{array}$ \\
\hline
\end{tabular}




\begin{tabular}{|c|c|}
\hline & $\begin{array}{l}\text { authorization. It may ask the National Assembly to make the final decision. } \\
\text { If Parliament is not sitting at the end of the four-month period, it shall express its decision at the opening of the following } \\
\text { session. }\end{array}$ \\
\hline Article 36 & $\begin{array}{l}\text { A state of siege shall be decreed in the Council of Ministers. } \\
\text { The extension thereof after a period of twelve days may be authorized solely by Parliament. }\end{array}$ \\
\hline Article 37 & 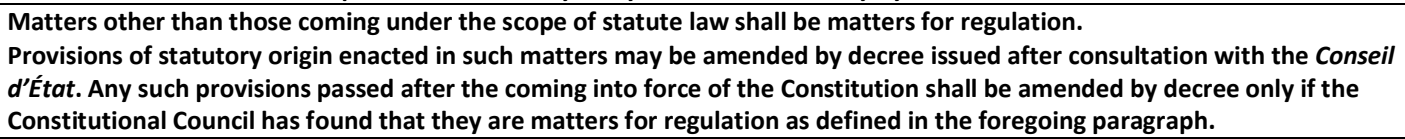 \\
\hline Article 37-1 & Statutes and regulations may contain provisions enacted on an experimental basis for limited purposes and duration. \\
\hline Article 38 & $\begin{array}{l}\text { In order to implement its program, the Government may ask Parliament for authorization, for a limited period, to take } \\
\text { measures by Ordinance that are normally the preserve of statute law. } \\
\text { Ordinances shall be issued in the Council of Ministers, after consultation with the Conseil d'État. They shall come into force } \\
\text { upon publication, but shall lapse in the event of failure to table before Parliament the Bill to ratify them by the date set by } \\
\text { the Enabling Act. They may only be ratified in explicit terms. } \\
\text { At the end of the period referred to in the first paragraph hereinabove Ordinances may be amended solely by an Act of } \\
\text { Parliament in those areas governed by statute law. }\end{array}$ \\
\hline Article 39 & $\begin{array}{l}\text { Both the Prime Minister and Members of Parliament shall have the right to initiate legislation. } \\
\text { Government Bills shall be discussed in the Council of Ministers after consultation with the Conseil d'Étatand shall be tabled } \\
\text { in one or other of the two Houses. Finance Bills and Social Security Financing Bills shall be tabled first before the National } \\
\text { Assembly. Without prejudice to the first paragraph of article 44, Bills primarily dealing with the organization of territorial } \\
\text { communities shall be tabled first in the Senate. } \\
\text { The tabling of Government Bills before the National Assembly or the Senate, shall comply with the conditions determined } \\
\text { by an Institutional Act. } \\
\text { Government Bills may not be included on the agenda if the Conference of Presidents of the first House to which the Bill has } \\
\text { been referred, declares that the rules determined by the Institutional Act have not been complied with. In the case of } \\
\text { disagreement between the Conference of Presidents and the Government, the President of the relevant House or the Prime } \\
\text { Minister may refer the matter to the Constitutional Council, which shall rule within a period of eight days. } \\
\text { Within the conditions provided for by statute, the President of either House may submit a Private Member's Bill tabled by a } \\
\text { Member of the said House, before it is considered in committee, to the Conseil d'État for its opinion, unless the Member } \\
\text { who tabled it disagrees. }\end{array}$ \\
\hline Article 40 & $\begin{array}{l}\text { Private Members' Bills and amendments introduced by Members of Parliament shall not be admissible where their } \\
\text { enactment would result in either a diminution of public revenue or the creation or increase of any public expenditure. }\end{array}$ \\
\hline Article 41 & $\begin{array}{l}\text { If, during the legislative process, it appears that a Private Member's Bill or amendment is not a matter for statute or is } \\
\text { contrary to a delegation granted under article 38, the Government or the President of the House concerned, may argue that } \\
\text { it is inadmissible. } \\
\text { In the event of disagreement between the Government and the President of the House concerned, the Constitutional } \\
\text { Council, at the request of one or the other, shall give its ruling within eight days. }\end{array}$ \\
\hline Article 42 & $\begin{array}{l}\text { The discussion of Government and Private Members' Bills shall, in plenary sitting, concern the text passed by the committee } \\
\text { to which the Bill has been referred, in accordance with article } 43 \text {, or failing that, the text which has been referred to the } \\
\text { House. } \\
\text { Notwithstanding the foregoing, the plenary discussion of Constitutional Revision Bills, Finance Bills and Social Security } \\
\text { Financing Bills, shall concern, during the first reading before the House to which the Bill has been referred in the first } \\
\text { instance, the text presented by the Government, and during the subsequent readings, the text transmitted by the other } \\
\text { House. } \\
\text { The plenary discussion at first reading of a Government or Private Members' Bill may only occur before the first House to } \\
\text { which it is referred, at the end of a period of six weeks after it has been tabled. It may only occur, before the second House } \\
\text { to which it is referred, at the end of a period of four weeks, from the date of transmission. } \\
\text { The previous paragraph shall not apply if the accelerated procedure has been implemented according to the conditions } \\
\text { provided for in article } 45 \text {. Neither shall it apply to Finance Bills, Social Security Financing Bills, or to Bills concerning a state } \\
\text { of emergency. }\end{array}$ \\
\hline Article 43 & $\begin{array}{l}\text { Government and Private Members' Bills shall be referred to one of the standing committees, the number of which shall not } \\
\text { exceed eight in each House. } \\
\text { At the request of the Government or of the House before which such a bill has been tabled, Government and Private } \\
\text { Members' Bills shall be referred for consideration to a committee specially set up for this purpose. }\end{array}$ \\
\hline Article 44 & $\begin{array}{l}\text { Members of Parliament and the Government shall have the right of amendment. This right may be used in plenary sitting or } \\
\text { in committee under the conditions set down by the Rules of Procedure of the Houses, according to the framework } \\
\text { determined by an Institutional Act. } \\
\text { Once debate has begun, the Government may object to the consideration of any amendment which has not previously been }\end{array}$ \\
\hline
\end{tabular}




\begin{tabular}{|c|c|}
\hline & $\begin{array}{l}\text { referred to committee. } \\
\text { If the Government so requests, the House before which the Bill is tabled shall proceed to a single vote on all or part of the } \\
\text { text under debate, on the sole basis of the amendments proposed or accepted by the Government. }\end{array}$ \\
\hline Article 45 & $\begin{array}{l}\text { Every Government or Private Member's Bill shall be considered successively in the two Houses of Parliament with a view to } \\
\text { the passing of an identical text. Without prejudice to the application of articles } 40 \text { and } 41 \text {, all amendments which have a } \\
\text { link, even an indirect one, with the text that was tabled or transmitted, shall be admissible on first reading. } \\
\text { If, as a result of a failure to agree by the two Houses, it has proved impossible to pass a Government or Private Member's } \\
\text { Bill after two readings by each House or, if the Government has decided to apply the accelerated procedure without the two } \\
\text { Conferences of Presidents being jointly opposed, after a single reading of such a Bill by each House, the Prime Minister, or in } \\
\text { the case of a Private Members' Bill, the Presidents of the two Houses acting jointly, may convene a joint committee, } \\
\text { composed of an equal number of members from each House, to propose a text on the provisions still under debate. } \\
\text { The text drafted by the joint committee may be submitted by the Government to both Houses for approval. No amendment } \\
\text { shall be admissible without the consent of the Government. } \\
\text { If the joint committee fails to agree on a common text, or if the text is not passed as provided in the foregoing paragraph, } \\
\text { the Government may, after a further reading by the National Assembly and by the Senate, ask the National Assembly to } \\
\text { reach a final decision. In such an event, the National Assembly may reconsider either the text drafted by the joint } \\
\text { committee, or the last text passed by itself, as modified, as the case may be, by any amendment(s) passed by the Senate. }\end{array}$ \\
\hline Article 49 & $\begin{array}{l}\text { The Prime Minister, after deliberation by the Council of Ministers, may make the Government's program or possibly a } \\
\text { general policy statement an issue of a vote of confidence before the National Assembly. } \\
\text { The National Assembly may call the Government to account by passing a resolution of no-confidence. Such a resolution } \\
\text { shall not be admissible unless it is signed by at least one tenth of the Members of the National Assembly. Voting may not } \\
\text { take place within forty-eight hours after the resolution has been tabled. Solely votes cast in favour of the no-confidence } \\
\text { resolution shall be counted and the latter shall not be passed unless it secures a majority of the Members of the House. } \\
\text { Except as provided for in the following paragraph, no Member shall sign more than three resolutions of no-confidence } \\
\text { during a single ordinary session and no more than one during a single extraordinary session. } \\
\text { The Prime Minister may, after deliberation by the Council of Ministers, make the passing of a Finance Bill or Social Security } \\
\text { Financing Bill an issue of a vote of confidence before the National Assembly. In that event, the Bill shall be considered } \\
\text { passed unless a resolution of no-confidence, tabled within the subsequent twenty-four hours, is carried as provided for in } \\
\text { the foregoing paragraph. In addition, the Prime Minister may use the said procedure for one other Government or Private } \\
\text { Members' Bill per session. } \\
\text { The Prime Minister may ask the Senate to approve a statement of general policy. }\end{array}$ \\
\hline Article 50 & $\begin{array}{l}\text { When the National Assembly passes a resolution of no-confidence, or when it fails to endorse the Government program or } \\
\text { general policy statement, the Prime Minister shall tender the resignation of the Government to the President of the } \\
\text { Republic. }\end{array}$ \\
\hline Article 52 & $\begin{array}{l}\text { The President of the Republic shall negotiate and ratify treaties. } \\
\text { He shall be informed of any negotiations for the conclusion of an international agreement not subject to ratification. }\end{array}$ \\
\hline Article 53 & $\begin{array}{l}\text { Peace Treaties, Trade agreements, treaties or agreements relating to international organization, those committing the } \\
\text { finances of the State, those modifying provisions which are the preserve of statute law, those relating to the status of } \\
\text { persons, and those involving the ceding, exchanging or acquiring of territory, may be ratified or approved only by an Act of } \\
\text { Parliament. } \\
\text { They shall not take effect until such ratification or approval has been secured. } \\
\text { No ceding, exchanging or acquiring of territory shall be valid without the consent of the population concerned. }\end{array}$ \\
\hline Article 53-1 & $\begin{array}{l}\text { The Republic may enter into agreements with European States which are bound by undertakings identical with its own in } \\
\text { matters of asylum and the protection of human rights and fundamental freedoms, for the purpose of determining their } \\
\text { respective jurisdiction as regards requests for asylum submitted to them. } \\
\text { However, even if the request does not fall within their jurisdiction under the terms of such agreements, the authorities of } \\
\text { the Republic shall remain empowered to grant asylum to any foreigner who is persecuted for his action in pursuit of } \\
\text { freedom or who seeks the protection of France on other grounds. }\end{array}$ \\
\hline Article 53-2 & $\begin{array}{l}\text { The Republic may recognize the jurisdiction of the International Criminal Court as provided for by the Treaty signed on } 18 \\
\text { July } 1998 .\end{array}$ \\
\hline Article 54 & $\begin{array}{l}\text { If the Constitutional Council, on a referral from the President of the Republic, from the Prime Minister, from the President } \\
\text { of one or the other Houses, or from sixty Members of the National Assembly or sixty Senators, has held that an } \\
\text { international undertaking contains a clause contrary to the Constitution, authorization to ratify or approve the international } \\
\text { undertaking involved may be given only after amending the Constitution. }\end{array}$ \\
\hline Article 55 & $\begin{array}{l}\text { Treaties or agreements duly ratified or approved shall, upon publication, prevail over Acts of Parliament, subject, with } \\
\text { respect to each agreement or treaty, to its application by the other party. }\end{array}$ \\
\hline Article 64 & $\begin{array}{l}\text { The President of the Republic shall be the guarantor of the independence of the Judicial Authority. } \\
\text { He shall be assisted by the High Council of the Judiciary. } \\
\text { An Institutional Act shall determine the status of members of the Judiciary. } \\
\text { Judges shall be irremovable from office. }\end{array}$ \\
\hline Article 65 & The High Council of the Judiciary shall be presided over by the President of the Republic. The Minister of Justice shall be \\
\hline
\end{tabular}




\begin{tabular}{|c|c|}
\hline & $\begin{array}{l}\text { ex officio Vice-president. He may deputize for the President of the Republic. } \\
\text { The High Council of the Judiciary shall consist of two sections, one with jurisdiction over judges, theother over public } \\
\text { prosecutors. } \\
\text { The section with jurisdiction over judges shall comprise, in addition to the President of the Republic and the Minister of } \\
\text { Justice, five judges and one public prosecutor, one Conseiller d'Étatappointed by the Conseil d'État, and three prominent } \\
\text { citizens who are not members either of Parliament or of the Judiciary, appointed respectively by the President of the } \\
\text { Republic, the President of the National Assembly and the President of the Senate. } \\
\text { The section with jurisdiction over public prosecutors shall comprise, in addition to the President of the Republic and the } \\
\text { Minister of Justice, five public prosecutors and one judge, and the Conseiller d'Étattogether with the three prominent } \\
\text { citizens referred to in the preceding paragraph. } \\
\text { The section of the High Council of the Judiciary with jurisdiction over judges shall make recommendations for the } \\
\text { appointment of judges to the Cour de cassation, the Chief Presidents of Courts of Appeal and the Presidents of the } \\
\text { Tribunaux de grande instance. Other judges shall be appointed after consultation with this section. } \\
\text { This section shall act as disciplinary tribunal for judges. When acting in such capacity, it shall be presided over by the Chief } \\
\text { President of the Cour de cassation. } \\
\text { The section of the High Council of the Judiciary with jurisdiction over public prosecutors shall give its opinion on the } \\
\text { appointment of public prosecutors, with the exception of posts to be filled at meetings of the Council of Ministers. } \\
\text { It shall give its opinion on disciplinary measures regarding public prosecutors. When acting in such capacity, it shall be } \\
\text { presided over by the Chief Public Prosecutor at the Cour de cassation. } \\
\text { An Institutional Act shall determine the manner in which this article is to be implemented. }\end{array}$ \\
\hline (1) & 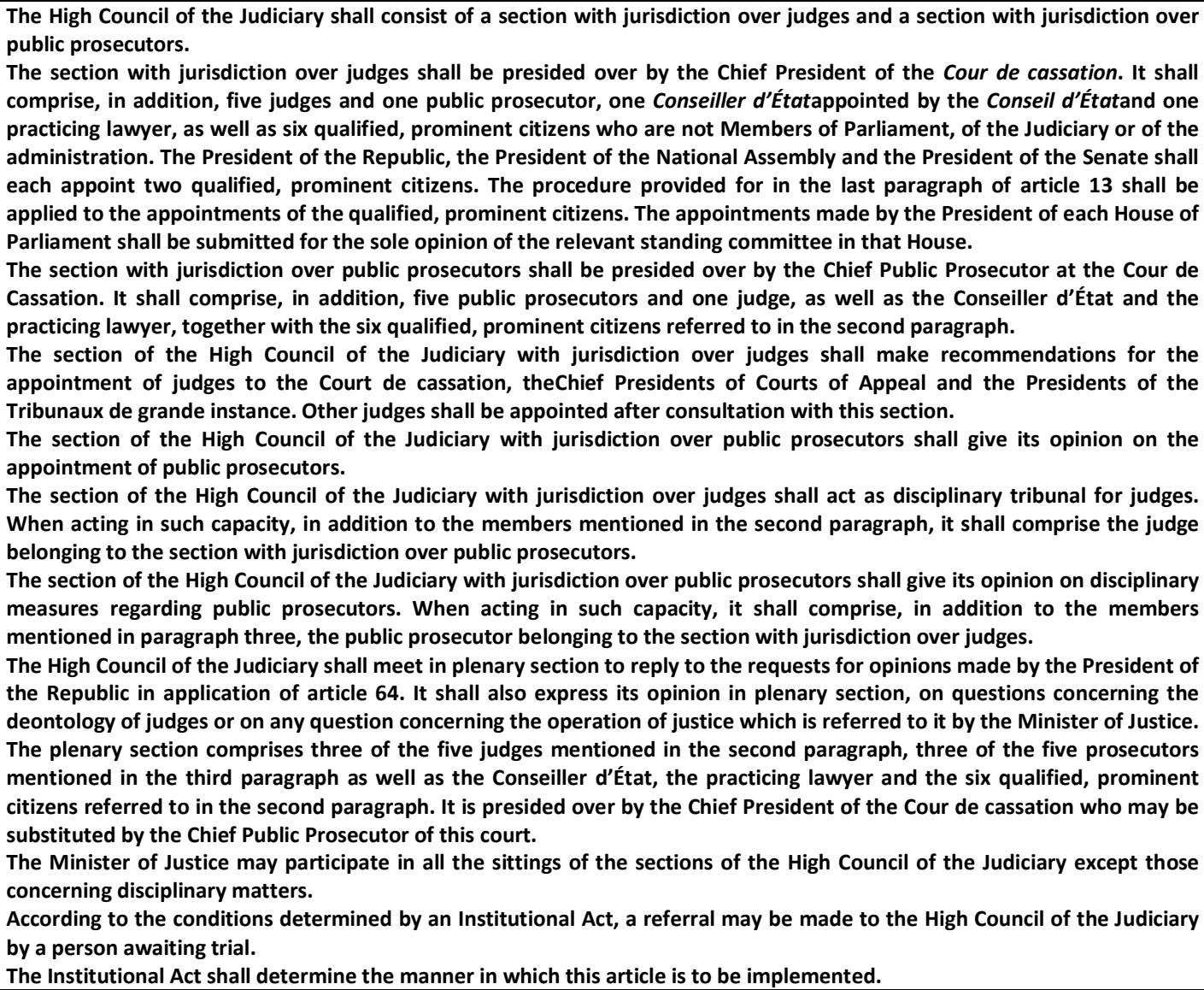 \\
\hline Article 67 & $\begin{array}{l}\text { The President of the Republic shall incur no liability by reason of acts carried out in his official capacity, subject to the } \\
\text { provisions of Articles } 53-2 \text { and } 68 \text { hereof. } \\
\text { Throughout his term of office the President shall not be required to testify before any French Court of law or Administrative } \\
\text { authority and shall not be the object of any civil proceedings, nor of any preferring of charges, prosecution or investigatory } \\
\text { measures. All limitation periods shall be suspended for the duration of said term of office. } \\
\text { All actions and proceedings thus stayed may be reactivated or brought against the President one month after the end of his } \\
\text { term of office. }\end{array}$ \\
\hline Article 68 & The President of the Republic shall not be removed from office during the term thereof on any grounds other than a breach \\
\hline
\end{tabular}


Rosa Ristawati: Modelling Executive Powers in the Indonesian Constitution: A comparative Study

\begin{tabular}{|c|c|}
\hline & $\begin{array}{l}\text { of his duties patently incompatible with his continuing in office. Such removal from office shall be proclaimed by Parliament } \\
\text { sitting as the High Court. } \\
\text { The proposal to convene the High Court adopted by one or other of the Houses of Parliament shall be immediately } \\
\text { transmitted to the other House which shall make its decision known within fifteen days of receipt thereof. } \\
\text { The High Court shall be presided over by the President of the National Assembly. It shall give its ruling as to the removal } \\
\text { from office of the President, by secret ballot, within one month. Its decision shall have immediate effect. } \\
\text { Rulings given hereunder shall require a majority of two thirds of the members of the House involved or of the High Court. } \\
\text { No proxy voting shall be allowed. Only votes in favor of the removal from office or the convening of the High Court shall be } \\
\text { counted. } \\
\text { An Institutional Act shall determine the conditions for the application hereof. }\end{array}$ \\
\hline Article 72-4 & $\begin{array}{l}\text { No change of status as provided for by articles } 73 \text { and } 74 \text { with respect to the whole or part of any one of the communities to } \\
\text { which the second paragraph of article } 72-3 \text { applies, shall take place without the prior consent of voters in the relevant } \\
\text { community or part of a community being sought in the manner provided for by the paragraph below. Such change of status } \\
\text { shall be made by an Institutional Act. } \\
\text { The President of the Republic may, on a recommendation from the Government when Parliament is in session or on a joint } \\
\text { motion of the two Houses, published in either case in the Journal Officiel, decide to consult voters in an overseas territorial } \\
\text { community on a question relating to its organization, its powers or its legislative system. Where the referendum concerns a } \\
\text { change of status as provided for by the foregoing paragraph and is held in response to a recommendation by the } \\
\text { Government, the Government shall make a statement before each House which shall be followed by debate. }\end{array}$ \\
\hline Arti & $\begin{array}{l}\text { The President of the Republic, on the recommendation of the Prime Minister, and Members of Parliament alike shall have } \\
\text { the right to initiate amendments to the Constitution. } \\
\text { A Government or a Private Member's Bill to amend the Constitution must be considered within the time limits set down in } \\
\text { the third paragraph of article } 42 \text { and be passed by the two Houses in identical terms. The amendment shall take effect after } \\
\text { approval by referendum. } \\
\text { However, a Government Bill to amend the Constitution shall not be submitted to referendum where the President of the } \\
\text { Republic decides to submit it to Parliament convened in Congress; the Government Bill to amend the Constitution shall then } \\
\text { be approved only if it is passed by a three-fifths majority of the votes cast. The Bureau of the Congress shall be that of the } \\
\text { National Assembly. } \\
\text { No amendment procedure shall be commenced or continued where the integrity of national territory is placed in jeopardy. } \\
\text { The republican form of government shall not be the object of any amendment. }\end{array}$ \\
\hline
\end{tabular}


Rosa Ristawati: Modelling Executive Powers in the Indonesian Constitution: A comparative Study

Appendix 11

Excerpts from The Polish Constitution

Source: Poland's Constitution of 1997 with Amendments thorugh 2009, generated from excerpt of texts from the repository of the Comparative Constitutions Projects, accessed at www.constituteproject.org

\begin{tabular}{|c|c|}
\hline Article 126 & $\begin{array}{l}\text { The President of the Republic of Poland shall be the supreme representative of the Republic of Poland and the guarantor of } \\
\text { the continuity of State authority. } \\
\text { The President of the Republic shall ensure observance of the Constitution, safeguard the sovereignty and security of the } \\
\text { State as well as the inviolability and integrity of its territory. } \\
\text { The President shall exercise his duties within the scope of and in accordance with the principles specified in the Constitution } \\
\text { and statutes. }\end{array}$ \\
\hline $\begin{array}{l}\text { Article } 127 \\
\text { (1) }\end{array}$ & $\begin{array}{l}\text { The President of the Republic shall be elected by the Nation, in universal, equal and direct elections, conducted by secret } \\
\text { ballot. } \\
\text { The President of the Republic shall be elected for a } 5 \text {-year term of office and may be re-elected only for one more term. } \\
\text { Only a Polish citizen who, no later than the day of the elections, has attained } 35 \text { years of age and has a full electoral } \\
\text { franchise in elections to the Sejm, may be elected President of the Republic. Any such candidature shall be supported by the } \\
\text { signatures of at least } 100,000 \text { citizens having the right to vote in elections to the Sejm. } \\
\text { A candidate who has received more than half of the valid votes shall be considered elected President of the Republic. If } \\
\text { none of the candidates has received the required majority of votes, then a repeat ballot shall be held on the } 14 \text { th day after } \\
\text { the first vote. } \\
\text { The two candidates who have received the largest number of votes in the first ballot shall participate in a repeat ballot. If } \\
\text { one of the two such candidates withdraws his consent to candidacy, forfeits his electoral rights or dies, he shall be replaced } \\
\text { in the repeat ballot by the candidate who received the next highest consecutive number of votes in the first ballot. In such } \\
\text { case, the date of the repeat ballot shall be extended by a further } 14 \text { days. } \\
\text { The candidate who receives the higher number of votes in the repeat ballot shall be elected President of the Republic. } \\
\text { The principles of and procedure for nominating candidates and conducting the elections, as well as the requirements for } \\
\text { validity of the election of the President of the Republic, shall be specified by statute. }\end{array}$ \\
\hline Article 128 & $\begin{array}{l}\text { (1) The term of office of the President of the Republic shall commence on the date of his assuming such office. } \\
\text { (2) The election of the President of the Republic shall be ordered by the Marshal of the Sejm to be held on a day no } \\
\text { sooner than } 100 \text { days and no later than } 75 \text { days before expiry of the term of office of the serving President of the } \\
\text { Republic, and in the event of the office of President of the Republic falling vacant - no later than the 14th day } \\
\text { thereafter, specifying the date of the election which shall be on a non-working day and within a period of } 60 \text { days } \\
\text { of the day of ordering the election. }\end{array}$ \\
\hline & $\begin{array}{l}\text { The Supreme Court shall adjudicate upon the validity of the election of the President of the Republic. } \\
\text { A voter shall have the right to submit a complaint to the Supreme Court concerning the validity of the election of the } \\
\text { President of the Republic in accordance with principles specified by statute. } \\
\text { In the event of the election of the President of the Republic being judged invalid, a new election shall be held in accordance } \\
\text { with the principles prescribed in Article 128, para. } 2 \text { in relation to a vacancy in the office of President of the Republic. }\end{array}$ \\
\hline Article 130 & $\begin{array}{l}\text { The President of the Republic shall assume office upon taking the following oath in the presence of the National Assembly: } \\
\text { "Assuming, by the will of the Nation, the office of President of the Republic of Poland, I do solemnly swear to be faithful to } \\
\text { the provisions of the Constitution; I pledge that I shall steadfastly safeguard the dignity of the Nation, the independence } \\
\text { and security of the State, and also that the good of the Homeland and the prosperity of its citizens shall forever remain my } \\
\text { supreme obligation." The oath may also be taken with the additional sentence "So help me, God." }\end{array}$ \\
\hline $\begin{array}{l}\text { Article } 131 \\
\text { (1) }\end{array}$ & $\begin{array}{l}\text { If the President of the Republic is temporarily unable to discharge the duties of his office, he shall communicate this fact to } \\
\text { the Marshal of the Sejm, who shall temporarily assume the duties of the President of the Republic. If the President of the } \\
\text { Republic is not in a position to inform the Marshal of the Sejm of his incapacity to discharge the duties of the office, then } \\
\text { the Constitutional Tribunal shall, on request of the Marshal of the Sejm, determine whether or not there exists an } \\
\text { impediment to the exercise of the office by the President of the Republic. If the Constitutional Tribunal so finds, it shall } \\
\text { require the Marshal of the Sejm to temporarily perform the duties of the President of the Republic. } \\
\text { The Marshal of the Sejm shall, until the time of election of a new President of the Republic, temporarily discharge the duties } \\
\text { of the President of the Republic in the following instances: } \\
\text { 1) the death of the President of the Republic; } \\
\text { 2) the President's resignation from office; } \\
\text { 3) judicial declaration of the invalidity of the election to the Presidency or other reasons for not assuming office following } \\
\text { the election; } \\
\text { 4) a declaration by the National Assembly of the President's permanent incapacity to exercise his duties due to the state of } \\
\text { his health; such declaration shall require a resolution adopted by a majority vote of at least two-thirds of the statutory } \\
\text { number of members of the National Assembly; } \\
\text { 5) dismissal of the President of the Republic from office by a judgment of the Tribunal of State. } \\
\text { 6) If the Marshal of the Sejm is unable to discharge the duties of the President of the Republic, such duties shall be } \\
\text { discharged by the Marshal of the Senate. }\end{array}$ \\
\hline
\end{tabular}


Rosa Ristawati: Modelling Executive Powers in the Indonesian Constitution: A comparative Study

\begin{tabular}{|c|c|}
\hline & charging the duties of the President of the Republic shall not shorten the term of \\
\hline Article 132 & $\begin{array}{l}\text { The President of the Republic shall hold no other offices nor discharge any public functions, with the exception of those } \\
\text { connected with the duties of his office. }\end{array}$ \\
\hline $\begin{array}{l}\text { Article } 133 \\
\text { (1) }\end{array}$ & $\begin{array}{l}\text { The President of the Republic, as representative of the State in foreign affairs, shall: } \\
\text { 1) ratify and renounce international agreements, and shall notify the Sejm and the Senate thereof; } \\
\text { 2) appoint and recall the plenipotentiary representatives of the Republic of Poland to other states and to international } \\
\text { organizations; } \\
\text { 3) receive the Letters of Credence and recall of diplomatic representatives of other states and international organizations } \\
\text { accredited to him. } \\
\text { 4) The President of the Republic, before ratifying an international agreement may refer it to the Constitutional Tribunal with } \\
\text { a request to adjudicate upon its conformity to the Constitution. } \\
\text { 5) The President of the Republic shall cooperate with the Prime Minister and the appropriate minister in respect of foreign } \\
\text { policy. }\end{array}$ \\
\hline Article 134 & $\begin{array}{l}\text { 1. The President of the Republic shall be the Supreme Commander of the Armed Forces of the Republic of Poland. } \\
\text { 2. The President of the Republic, in times of peace, shall exercise command over the Armed Forces through the } \\
\text { Minister of National Defense. } \\
\text { 3. The President of the Republic shall appoint, for a specified period of time, the Chief of the General Staff and } \\
\text { commanders of branches of the Armed Forces. The duration of their term of office, the procedure for and terms } \\
\text { of their dismissal before the end thereof, shall be specified by statute. } \\
\text { The President of the Republic, for a period of war, shall appoint the Commander-in-Chief of the Armed Forces on } \\
\text { request of the Prime Minister. } \\
\text { He may dismiss the Commander-in-Chief of the Armed Forces in accordance with the same procedure. The authority of the } \\
\text { Commander-in-Chief of the Armed Forces, as well as the principle of his subordination to the constitutional organs of the } \\
\text { Republic of Poland, shall be specified by statute. } \\
\text { The President of the Republic, on request of the Minister of National Defense, shall confer military ranks as } \\
\text { specified by statute. } \\
\text { 6. The authority of the President of the Republic, regarding his supreme command of the Armed Forces, shall be } \\
\text { specified in detail by statute. }\end{array}$ \\
\hline Article 135 & $\begin{array}{l}\text { The advisory organ to the President of the Republic regarding internal and external security of the State shall be the } \\
\text { National Security Council. }\end{array}$ \\
\hline Article 136 & $\begin{array}{l}\text { In the event of a direct external threat to the State, the President of the Republic shall, on request of the Prime Minister, } \\
\text { order a general or partial mobilization and deployment of the Armed Forces in defense of the Republic of Poland. }\end{array}$ \\
\hline Article 137 & The President of the Republic shall grant Polish citizenship and shall give consent for $r$ \\
\hline Article 138 & The \\
\hline Article 139 & $\begin{array}{l}\text { The President of the Republic shall have the power of pardon. The power of pardon may not be extended to ind } \\
\text { convicted by the Tribunal of State. }\end{array}$ \\
\hline Article 140 & $\begin{array}{l}\text { The President of the Republic may deliver a Message to the Sejm, to the Senate or to the National Assembly. Such Message } \\
\text { shall not be a subject of debate. }\end{array}$ \\
\hline $\begin{array}{l}\text { Article } 141 \\
\text { (1) }\end{array}$ & $\begin{array}{l}\text { The President of the Republic may, regarding particular matters, convene the Cabinet Council. The Cabinet Council shall be } \\
\text { composed of the Council of Ministers whose debates shall be presided over by the President of the Republic. } \\
\text { The Cabinet Council shall not possess the competence of the Council of Ministers. }\end{array}$ \\
\hline Article 142 & $\begin{array}{l}\text { 1. The President of the Republic shall issue regulations and executive orders in accordance with the principles } \\
\text { specified in Articles } 92 \text { and } 93 \text {. } \\
\text { 2. The President of the Republic shall issue decisions within the scope of discharge of his other authorities. }\end{array}$ \\
\hline Article 143 & $\begin{array}{l}\text { The Presidential Chancellery shall be the organ of assistance to the President of the Republic. The President of the Republic } \\
\text { shall establish the statute of the Presidential Chancellery and shall appoint and dismiss its Chief. }\end{array}$ \\
\hline $\begin{array}{l}\text { Article } 144 \\
\text { (1) }\end{array}$ & $\begin{array}{l}\text { The President of the Republic, exercising his constitutional and statutory authority, shall issue Official Acts. } \\
\text { Official Acts of the President shall require, for their validity, the signature of the Prime Minister who, by such signature, } \\
\text { accepts responsibility therefor to the Sejm. } \\
\text { The provisions of para. } 2 \text { above shall not relate to: } \\
\text { 1) proclaiming elections to the Sejm and to the Senate; } \\
\text { 2) summoning the first sitting of a newly elected Sejm and Senate; } \\
\text { 3) shortening of the term of office of the Sejm in the instances specified in the Constitution; } \\
\text { 4) introducing legislation; } \\
\text { 5) proclaiming the holding of a nationwide referendum; } \\
\text { 6) signing or refusing to sign a bill; } \\
\text { 7) ordering the promulgation of a statute or an international agreement in the Journal of Laws of the Republic of Poland } \\
\text { (Dziennik Ustaw); } \\
\text { 8) delivering a Message to the Sejm, to the Senate or to the National Assembly; } \\
\text { 9) making a referral to the Constitutional Tribunal; } \\
\text { 10) requesting the Supreme Chamber of Control to carry out an audit; } \\
\text { 11) nominating and appointing the Prime Minister; }\end{array}$ \\
\hline
\end{tabular}




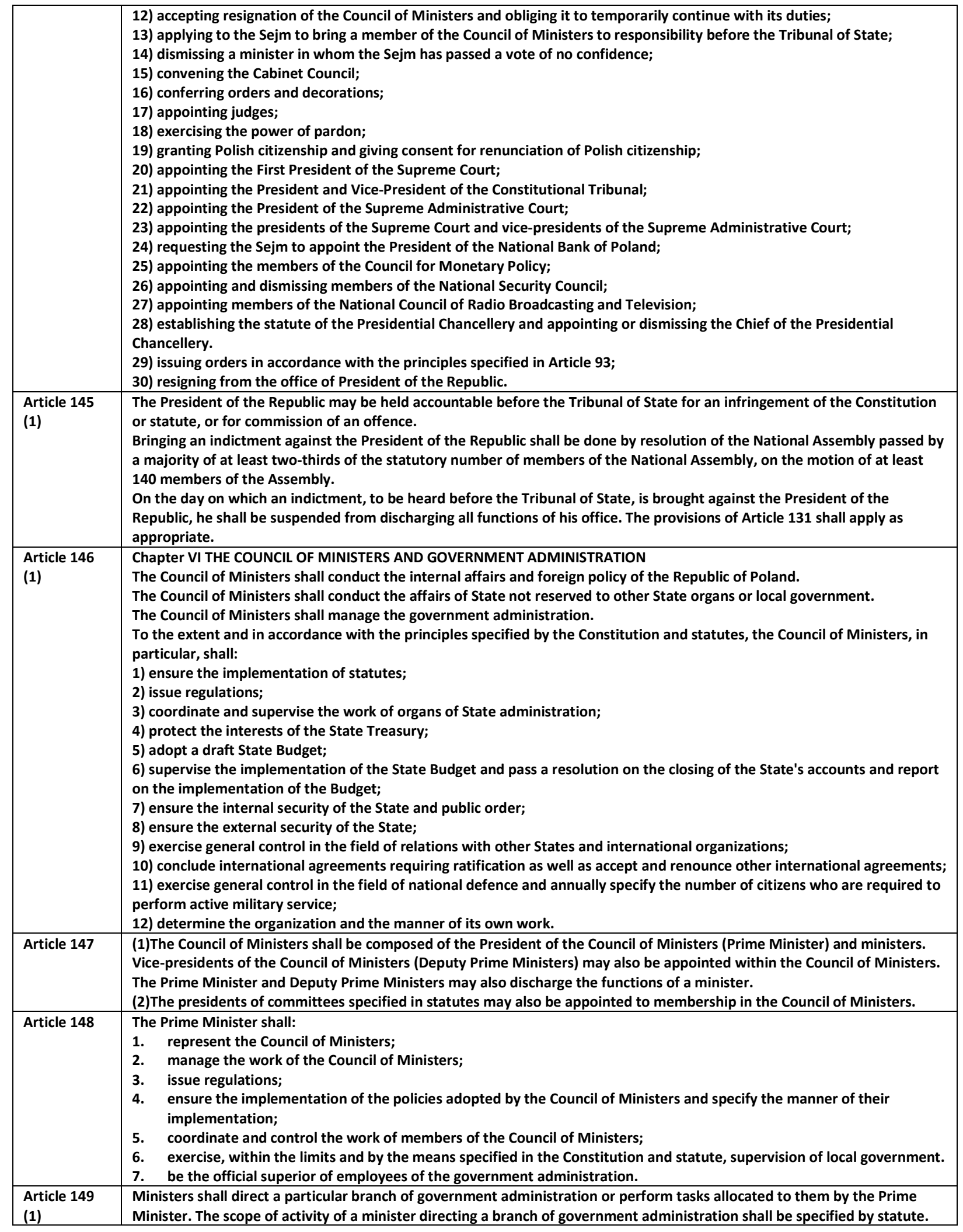




\begin{tabular}{|c|c|}
\hline & $\begin{array}{l}\text { A minister directing a branch of government administration shall issue regulations. The Council of Ministers, on the request } \\
\text { of the Prime Minister, may repeal a regulation or order of a minister. } \\
\text { The provisions applicable to a minister directing a branch of government administration shall apply, as appropriate, to } \\
\text { presidents of the committees referred to in Article 147, para. } 4 \text {. }\end{array}$ \\
\hline Article 150 & A member of the Council of Ministers shall not perform any activity inconsistent with his public duties. \\
\hline Article 151 & $\begin{array}{l}\text { The Prime Minister, Deputy Prime Ministers and ministers shall take the following oath in the presence of the President of } \\
\text { the Republic: } \\
\text { "Assuming this office of Prime Minister (Deputy Prime Minister, minister) I do solemnly swear to be faithful to the } \\
\text { provisions of the Constitution and other laws of the Republic of Poland, and that the good of the Homeland and the } \\
\text { prosperity of its citizens shall forever remain my supreme obligation." } \\
\text { The oath may also be taken with the additional sentence "So help me, God." }\end{array}$ \\
\hline $\begin{array}{l}\text { Article } 152 \\
\text { (1) }\end{array}$ & $\begin{array}{l}\text { The voivod shall be the representative of the Council of Ministers in a voivodship. } \\
\text { The procedure for appointment and dismissal, as well as the scope of activity, of a voivod shall be specified by statute. }\end{array}$ \\
\hline Article 153 & $\begin{array}{l}\text { A corps of civil servants shall operate in the organs of government administration in order to ensure a professional, diligent, } \\
\text { impartial and politically neutral discharge of the State's obligations. } \\
\text { The Prime Minister shall be the superior of such corps of civil servants. }\end{array}$ \\
\hline Article 154 & $\begin{array}{l}\text { The President of the Republic shall nominate a Prime Minister who shall propose the composition of a Council of Ministers. } \\
\text { The President of the Republic shall, within } 14 \text { days of the first sitting of the Sejm or acceptance of the resignation of the } \\
\text { previous Council of Ministers, appoint a Prime Minister together with other members of a Council of Ministers and accept } \\
\text { the oaths of office of members of such newly appointed Council of Ministers. } \\
\text { The Prime Minister shall, within } 14 \text { days following the day of his appointment by the President of the Republic, submit a } \\
\text { program of activity of the Council of Ministers to the Sejm, together with a motion requiring a vote of confidence. The Sejm } \\
\text { shall pass such vote of confidence by an absolute majority of votes in the presence of at least half of the statutory number } \\
\text { of Deputies. } \\
\text { In the event that a Council of Ministers has not been appointed pursuant to para.1 above or has failed to obtain a vote of } \\
\text { confidence in accordance with para. } 2 \text { above, the Sejm, within } 14 \text { days of the end of the time periods specified in paras } 1 \\
\text { and } 2 \text {, shall choose a Prime Minister as well as members of the Council of Ministers as proposed by him, by an absolute } \\
\text { majority of votes in the presence of at least half of the statutory number of Deputies. The President of the Republic shall } \\
\text { appoint the Council of Ministers so chosen and accept the oaths of office of its members. }\end{array}$ \\
\hline Article 155 & $\begin{array}{l}\text { In the event that a Council of Ministers has not been appointed pursuant to the provisions of Article 154, para. 3, the } \\
\text { President of the Republic shall, within a period of } 14 \text { days, appoint a Prime Minister and, on his application, other members } \\
\text { of the Council of Ministers. The Sejm, within } 14 \text { days following the appointment of the Council of Ministers by the President } \\
\text { of the Republic, shall hold, in the presence of at least half of the statutory number of Deputies, a vote of confidence } \\
\text { thereto. } \\
\text { In the event that a vote of confidence has not been granted to the Council of Ministers pursuant to para. 1, the President of } \\
\text { the Republic shall shorten the term of office of the Sejm and order elections to be held. }\end{array}$ \\
\hline Article 156 & $\begin{array}{l}\text { The members of the Council of Ministers shall be accountable to the Tribunal of State for an infringement of the } \\
\text { Constitution or statutes, as well as for the commission of an offence connected with the duties of his office. } \\
\text { On the motion of the President of the Republic or at least } 115 \text { Deputies, resolution to bring a member of the Council of } \\
\text { Ministers to account before the Tribunal of State shall be passed by the Sejm by a majority of three-fifths of the statutory } \\
\text { number of Deputies. }\end{array}$ \\
\hline Article 157 & $\begin{array}{l}\text { The members of the Council of Ministers shall be collectively responsible to the Sejm for the activities of the Council of } \\
\text { Ministers. } \\
\text { The members of the Council of Ministers shall be individually responsible to the Sejm for those matters falling within their } \\
\text { competence or assigned to them by the Prime Minister. }\end{array}$ \\
\hline Article 158 & $\begin{array}{l}\text { The Sejm shall pass a vote of no confidence in the Council of Ministers by a majority of votes of the statutory number of } \\
\text { Deputies, on a motion moved by at least } 46 \text { Deputies and which shall specify the name of a candidate for Prime Minister. If } \\
\text { such a resolution has been passed by the Sejm, the President of the Republic shall accept the resignation of the Council of } \\
\text { Ministers and appoint a new Prime Minister as chosen by the Sejm, and, on his application, the other members of the } \\
\text { Council of Ministers and accept their oath of office. } \\
\text { A motion to pass a resolution referred to in para. } 1 \text { above, may be put to a vote no sooner than } 7 \text { days after it has been } \\
\text { submitted. A subsequent motion of a like kind may be submitted no sooner than after the end of } 3 \text { months from the day the } \\
\text { previous motion was submitted. A subsequent motion may be submitted before the end of } 3 \text { months if such motion is } \\
\text { submitted by at least } 115 \text { Deputies. }\end{array}$ \\
\hline Article 159 & $\begin{array}{l}\text { The Sejm may pass a vote of no confidence in an individual minister. A motion to pass such a vote of no confidence may be } \\
\text { submitted by at least } 69 \text { Deputies. The provisions of Article } 158, \text { para. } 2 \text { shall apply as appropriate. } \\
\text { The President of the Republic shall recall a minister in whom a vote of no confidence has been passed by the Sejm by a } \\
\text { majority of votes of the statutory number of Deputies. }\end{array}$ \\
\hline Article 160 & $\begin{array}{l}\text { The Prime Minister may submit to the Sejm a motion requiring a vote of confidence in the Council of Ministers. A vote of } \\
\text { confidence in the Council of Ministers shall be granted by a majority of votes in the presence of at least half of the statutory } \\
\text { number of Deputies. }\end{array}$ \\
\hline
\end{tabular}


Rosa Ristawati: Modelling Executive Powers in the Indonesian Constitution: A comparative Study

\begin{tabular}{|l|l|}
\hline Article 161 & $\begin{array}{l}\text { The President of the Republic shall, on the application of the Prime Minister, effect changes in the composition of the } \\
\text { Council of Ministers. }\end{array}$ \\
\hline Article 224 & $\begin{array}{l}\text { The President of the Republic shall sign the Budget or interim Budget submitted to him by the Marshal of the Sejm within } 7 \\
\text { days of receipt thereof, and orders its promulgation in the Journal of Laws of the Republic of Poland (Dziennik Ustaw). The } \\
\text { provisions of Article 122, para. } 5 \text { shall not apply to the Budget or any interim budget. } \\
\text { If the President of the Republic has made reference to the Constitutional Tribunal for an adjudication upon the conformity } \\
\text { to the Constitution of the Budget or interim budget before signing it, the Tribunal shall adjudicate such matter no later than } \\
\text { within a period of } 2 \text { months from the day of submission of such reference to the Tribunal. }\end{array}$ \\
\hline Article 231 & $\begin{array}{l}\text { The President of the Republic shall submit the regulation on the introduction of martial law or a state of emergency to the } \\
\text { Sejm within 48 hours of signing such regulation. The Sejm shall immediately consider the regulation of the President. The } \\
\text { Sejm, by an absolute majority of votes taken in the presence of at least half the statutory number of Deputies, may annul } \\
\text { the regulation of the President. }\end{array}$ \\
\hline Article 232 & $\begin{array}{l}\text { In order to prevent or remove the consequences of a natural catastrophe or a technological accident exhibiting } \\
\text { characteristics of a natural disaster, the Council of Ministers may introduce, for a definite period no longer than } 30 \text { days, a } \\
\text { state of natural disaster in a part of or upon the whole territory of the State. An extension of a state of natural disaster may } \\
\text { be made with the consent of the Sejm. }\end{array}$ \\
\hline
\end{tabular}




\section{CURRICULUM VITAE}

Rosa Ristawati (February 17, 1979) holds a Bachelor degree in Laws (SH) (Airlangga University, Indonesia, 2002). Her Bachelor thesis was "The Principle of Proportionality in Contract Law: a Case Study on Private Construction Contract". In 2004, she got a Masters degree in Bussiness Law (MH) from Surabaya University, Indonesia. Her master thesis was "The Implementation of Good Corporate Governance on the Banking System in Indonesia". In 2010, Rosa got an LLM in International Law and the Law of International organizations from University of Groningen (Rijksuniversiteit Groningen) the Netherlands. Her LLM thesis was "Presidential Powers in Time of Terror: Comparative Study of the US and Indonesia".

Rosa started her academic career in 2003 as she joined the Catholic University of Widya Mandala in Surabaya, Indonesia. She taught Law and Psychology at the Faculty of Psychology. On April 2006, Rosa started working as lecturer at the Faculty of Law, Airlangga University. During the time, she taught Indonesian Constitutional Law and comparative constitutional law. Her research interests are including Constitutional Law, Comparative Constitutional Law, Constitutional design, and the Law of International organizations.

In 2009, she was granted the University of Groningen Talent Grant, a scholarship by the University of Groningen. She got an opportunity to study Master of Laws programmes (the LLM programme in International Law and the Law of International Organizations) at the Faculty of Law, Groningen University, the Netherlands (September 1, 2009- 31 August 2010).

In September 2011, Rosa started her PhD project at Maastricht University, the Netherlands. The project was the three years PhD project under the Indonesian Ministry of Education. Her research focusses on the constitutional law and the comparative constitutional law. During the $\mathrm{PhD}$ program, she also joined the ius commune research school where she gained workshops, $\mathrm{PhD}$ trainings, and $\mathrm{PhD}$ conferences. She complished the ius commune $\mathrm{PhD}$ training program within three years and got the certificate as researcher from the ius commune research school on 2013.

In her second year of PhD program, she was granted the 2012 SUN scholarship, a summer school scholarship by the Central European University where she got an opportunity attending summer school program on comparative regionalism at CEU, Budapest. In October 2012, she got an opportunity to be a visiting scholar at CEU, Budapest. Her PhD thesis at Maastricht University on "Modelling Executive Powers in the Indonesian Constitution: A Comparative Study of Constitutions" was approved on Summer 2017 and defended on Winter 2017. 